\title{
A RESPONSABILIDADE INTERNACIONAL DO ESTADO POR VIOLAÇÕES A NORMAS PROTETORAS DE DIREITOS HUMANOS
}

A possibilidade de aplicação de contramedidas por Estados "não diretamente lesados"

Tese de Doutorado

Orientador: Professor Associado Umberto Celli Júnior

Tese apresentada à Comissão de Pós Graduação da Faculdade de Direito da Universidade de São Paulo, com requisito parcial à obtenção do título de doutor.

Faculdade de Direito da Universidade de São Paulo 
DANIELLE CANDIDO DE OLIVEIRA

A RESPONSABILIDADE INTERNACIONAL DO ESTADO POR VIOLAÇÕES A NORMAS PROTETORAS DE DIREITOS HUMANOS

\section{BANCA EXAMINADORA}

SÃO PAULO

2011 


\section{RESUMO}

Trata-se de tese de doutorado que analisa a possibilidade da adoção de contramedidas por Estados não diretamente lesados por um ato ilícito internacional diante da violação de uma norma protetora de direitos humanos. Partindo do estudo sobre a responsabilidade internacional dos Estados, analisam-se as consequências jurídicas advindas desta responsabilidade, dentre elas, o direito de outros Estados de adotarem contramedidas contra o Estado violador do Direito Internacional. Com base em pesquisa documental, jurisprudencial e bibliográfica, averigua-se a legalidade da adoção de contramedidas por Estados não diretamente lesados, levando-se em conta o trabalho da Comissão de Direito Internacional da ONU, a jurisprudência, a doutrina e a prática dos Estados nesta matéria. Argumenta-se que a existência de uma norma consuetudinária garante o direito dos Estados recorrerem a contramedidas mesmo quando estes não tenham sido diretamente lesados pelo ato internacionalmente ilícito, nos casos em que a obrigação violada é devida à comunidade internacional como um todo. Estuda-se também a necessidade da adoção das contramedidas em resposta a violações graves a normas de proteção de direitos humanos fundamentais, tendo em vista o sistema global de proteção destes direitos. Conclui-se que, diante da eficácia limitada dos mecanismos de proteção global dos direitos humanos do Direito Internacional atual, as contramedidas adotadas por Estados não diretamente lesados são não somente legais, mas necessárias à garantia da mais ampla proteção aos direitos humanos fundamentais.

Palavras-chave: Responsabilidade Internacional. Contramedidas. Direitos Humanos. 


\begin{abstract}
This work is a doctoral thesis that analyzes the possibility of the resort to countermeasures by non directly injured States in light of the violation of a norm protecting human rights. Starting from a study of the international responsibility, the legal consequences of this responsibility are analyzed, among them, the right of other States to adopt countermeasures against the State violating the International Law. Based on a documental, jurisprudential and bibliographic research, the legality of the adoption of countermeasures by non directly injured States is verified taking in account the work of the International Law Commission of the UN, the jurisprudence, and the State practice in the subject. It is argued that the existence of a customary norm guarantees the right of States to resort to countermeasures even when they are not directly injured by the internationally unlawful act, in the cases where the violated obligation is due to the international community as a whole. The necessity of the resort to countermeasures in light of serious violations of norms protecting fundamental human rights in view of the global system for protection of these rights. It is concluded that in view of the limited efficacy of the global mechanisms for the protection of human rights in the current International Law, the countermeasures adopted by non directly injured States are not only legal, but also necessary to the guarantee of the broadest protection of fundamental human rights.
\end{abstract}

Keywords: International Responsibility. Countermeasures. Human Rights 


\section{RESUMEN}

El presente trabajo, es la tesis de doctorado que analiza la posibilidad de adoptar contramedidas por los Estados no directamente lesionados por un hecho ilícito internacional, consecuencia de la violación de una norma protectora de los derechos humanos. Basándose en el estudio sobre la responsabilidad Internacional de los Estados, se analizan las consecuencias jurídicas venideras de esta responsabilidad, y en detalle, el derecho de otros Estados en adoptar contramedidas contra el Estado violador del Derecho Internacional. Con base en la investigación documental, jurisprudencial y bibliográfica, se presenta la legalidad en la adopción de contramedidas por los Estados directamente no perjudicados, considerando, el trabajo de la Comisión de Derecho Internacional de la ONU, la Jurisprudencia, la doctrina y la práctica de los Estados en esta Materia. Se argumenta que la existencia de una norma consuetudinaria garantiza el derecho a los Estados a recurrir a contramedidas, incluso en situaciones o casos, donde no hayan sido directamente lesionados por el hecho internacionalmente ilícito, responsabilizando la práctica de la obligación violada, a toda la comunidad Internacional en su conjunto. Se estudia la necesidad de tomar contramedidas, en respuesta a las violaciones graves de las normas de protección de Derechos Humanos fundamentales, considerando en el presente el sistema global de Protección de estos Derechos.

Se concluye que, en función de la eficacia limitada de los mecanismos globales de protección de los derechos humanos del Derecho Internacional actual, las contramedidas adoptadas por los Estados no directamente lesionados, son, no solamente legales, sino necesarias para garantizar la máxima protección a los derechos humanos fundamentales.

Palabras-clave: Responsabilidad Internacional. Contramedidas. Derechos Humanos. 


\section{LISTA DE ABREVIATURAS}

ACP - African, Caribbean and Pacific Countries

AG - Assembleia Geral da Organização das Nações Unidas

CAT - Convenção contra a tortura e outros tratamentos ou penas cruéis, desumanos ou degradantes

CDH - Conselho de Direitos Humanos da Organização das Nações Unidas

CDI - Comissão de Direito Internacional da Organização das Nações Unidas

CEDAW - Convenção sobre a eliminação de todas as formas de discriminação contra as mulheres

$\mathrm{CIDH}$ - Corte Interamericana de Direitos Humanos

CIJ - Corte Internacional de Justiça

CPED - Convenção sobre a proteção de todas as pessoas dos desaparecimentos forçados

CPJI - Corte Permanente de Justiça Internacional

CRC - Convenção sobre os direitos da criança

CRPD - Convenção sobre o direito das pessoas portadoras de deficiência

GATT - Acordo geral sobre tarifas aduaneiras e comércio de 1947

ICCPR - Pacto internacional sobre direitos civis e políticos

ICERD - Convenção sobre a eliminação de todas as formas de discriminação racial

ICESCR - Pacto internacional sobre direitos econômicos, sociais e culturais

ICRMW - Convenção sobre a proteção dos direitos de todos os trabalhadores migrantes e suas famílias

ILM - International Legal Materials

Keesing's - Keesing's Contemporary Archives

OJ - Official Journal of the European Community

OEA - Organização dos Estados Americanos

ONU - Organização das Nações Unidas

OUA - Organização da União Africana

UE - União Europeia

UNRIAA - United Nations Reports of International Arbitral Awards.

UNTS - United Nations Treaty Series

UNYB - United Nations Yearbook

US - United States 


\section{Sumário}

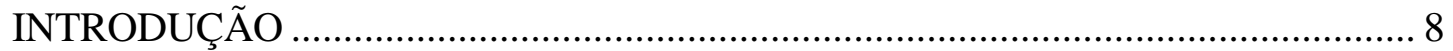

PARTE I: A RESPONSABILIDADE INTERNACIONAL E AS NORMAS

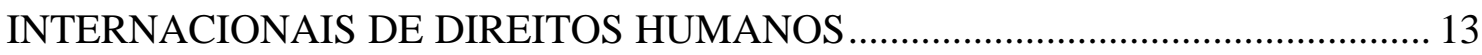

CAPITULO I: RESPONSABIIDADE INTERNACIONAL ..................................... 13

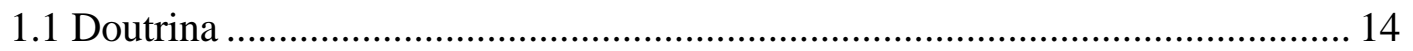

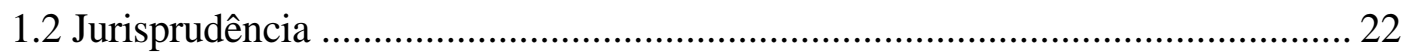

1.3 Trabalhos da CDI (Comissão de Direito Internacional da ONU) sobre a

Responsabilidade dos Estados .......................................................................... 26

CAPITULO II: NORMAS INTERNACIONAIS DE DIREITOS HUMANOS ...... 185

2.1. Fatores que levaram à internacionalização das normas de Direitos Humanos

185

2.2 A Natureza das Normas de Direito Humanos............................................... 189

PARTE II: A APLICAÇÃO DE CONTRAMEDIDAS POR ESTADOS NÃO DIRETAMENTE LESADOS DIANTE DE VIOLAÇÃO ÀS NORMAS DE DIREITOS

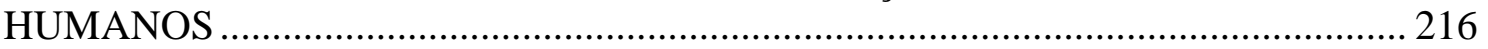

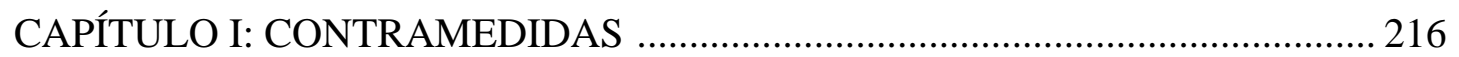

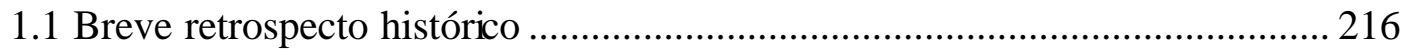

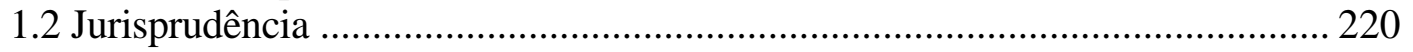

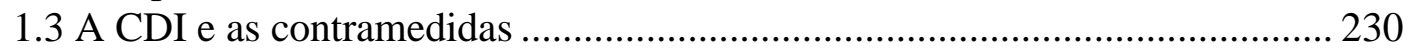

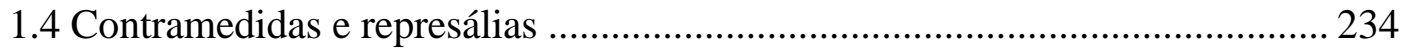

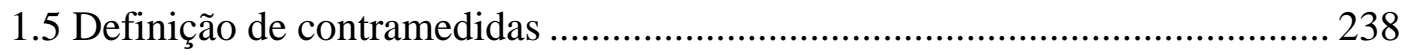

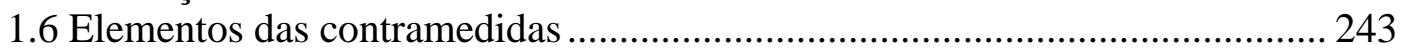

1.7 Funções das contramedidas ....................................................................... 245

1.8 Condições procedimentais para a adoção de contramedidas ......................... 249

1.9 Condições de validade das contramedidas ............................................... 251

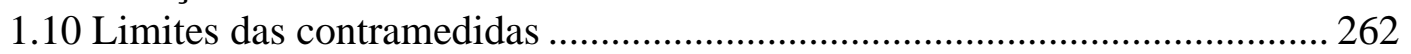

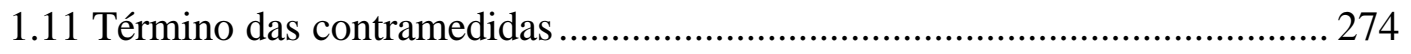

CAPITULO II: A LEGALIDADE DAS CONTRAMEDIDAS ADOTADAS POR ESTADOS NÃO DIRETAMENTE LESADOS DIANTE DE VIOLAÇÃO ÀS NORMAS PROTETORAS DE DIREITOS HUMANOS..................................... 276

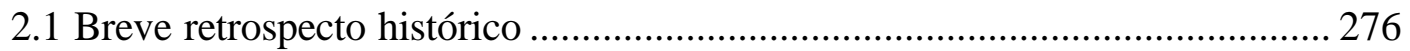

2.2 A legalidade das contramedidas, segundo o anteprojeto de artigos da CDI sobre

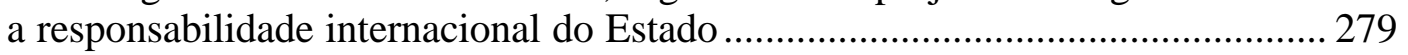

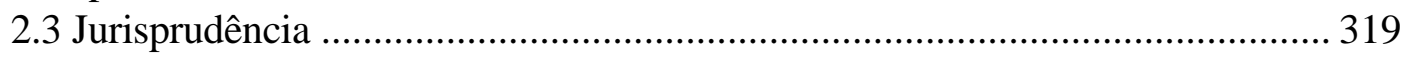

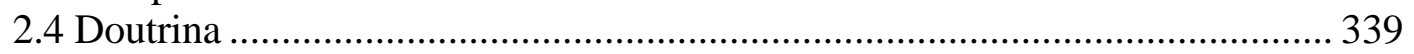

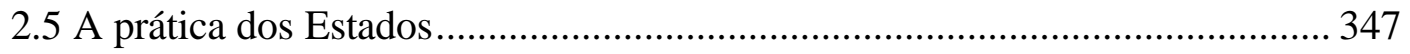

2.6 A configuração de uma norma consuetudinária reconhecendo a legalidade das contramedidas adotadas por violação a normas protetoras de direitos humanos . 377

CAPITULO III: A NECESSIDADE DAS CONTRAMEDIDAS ADOTADAS POR ESTADOS NÃO DIRETAMENTE LESADOS DIANTE DE VIOLAÇÃO ÀS NORMAS PROTETORAS DE DIREITOS HUMANOS....................................... 385

3.1 O sistema da ONU de proteção dos direitos humanos .................................. 385

3.2 O Princípio Pro Homine ................................................................................. 418

3.3 A necessidade das contramedidas adotadas por estados não diretamente lesados por violação a normas protetoras de direitos humanos ...................................... 422

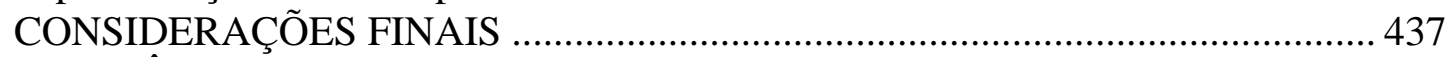

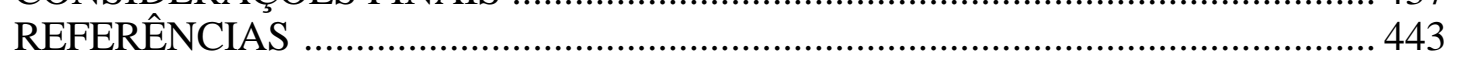




\section{INTRODUÇÃO}

A destruição e os massacres ocorridos na Segunda Guerra Mundial levaram a sociedade internacional a duas importantes conclusões. A primeira, que a paz duradoura só seria conseguida através da cooperação dos Estados e do desenvolvimento de meios pacíficos para a solução das controvérsias. A segunda, que a proteção dos direitos humanos não poderia ser deixada exclusivamente a cargo do direito interno dos Estados.

A crescente interdependência dos Estados fez com que novos ramos surgissem no Direito das Gentes aumentando a complexidade deste.

Também, o banimento do direito ao uso da força fez com surgisse a necessidade de se desenvolver novas formas de implementação do Direito Internacional. Em qualquer sistema jurídico, a consolidação de regras regulando a atribuição de responsabilidade em razão de atos ilícitos é essencial para que as violações às normas de direito produzam consequências jurídicas. Assim, no ordenamento jurídico internacional, a responsabilidade internacional tem um papel de destaque na atribuição de efetividade do sistema como um todo.

A regulação desta responsabilidade, no entanto, não pode ocorrer sem levar em conta os aspectos próprios do Direito a que ela se aplica. E uma das principais características do Direito Internacional é a sua descentralização, com a ausência de uma instituição única, encarregada da criação e da aplicação das normas jurídicas

Portanto, a codificação da responsabilidade internacional do Estado, ao mesmo tempo em que visa sistematizar o Direito Internacional, levando-o a uma maior institucionalização, não pode deixar de considerar a necessidade ainda existente de mecanismos de autotutela, típicos de ordenamentos descentralizados. A inclusão das contramedidas no anteprojeto de artigos da responsabilidade internacional do Estado da Comissão de Direito Internacional da ONU é, então, o reflexo de um sistema jurídico em desenvolvimento.

Por outro lado, a internacionalização dos direitos humanos intensificada nas últimas décadas, vem aos poucos mudando o paradigma estabelecido a séculos no Direito Internacional. O sistema jurídico voltado a regular as relações entre Estados tem que se adaptar cada vez mais a influência de novos "sujeitos" nas relações internacionais. 
A consolidação do conceito de uma comunidade internacional, a conscientização da importância do ser humano e o advento das organizações internacionais têm alterado o papel predominante do Estado no Direito das Gentes.

Embora estes ainda sejam os principais legisladores e destinatários das normas internacionais, os interesses individuais dos Estados não são mais os únicos fatores a serem considerados. Eles podem mesmo ser sacrificados em nome de valores e interesses da comunidade internacional como um todo.

A consolidação destes valores e interesses tem dado origem a novos tipos de normas, consagradas tanto nos tratados e normas consuetudinárias, quanto na jurisprudência dos tribunais internacionais. $\mathrm{O}$ jus cogens e as obrigações erga omnes destacam-se das demais normas internacionais pela importância dos valores nelas consubstanciados.

Outra consequência dessa internacionalização da proteção dos direitos humanos é a criação de diversos mecanismos, tanto no âmbito global quanto no âmbito regional, de proteção a estes direitos. Formoutse uma complexa rede de tratados, órgãos e procedimentos voltada exclusivamente à promoção e proteção dos direitos humanos.

Entretanto, apesar dos esforços da comunidade internacional, graves violações aos direitos humanos continuam ocorrendo frequentemente. As perseguições políticas raciais e religiosas, entre outras, têm deslocado enormes contingentes de pessoas de seus lares. O termo genocídio, já foi utilizado mais de uma vez para descrever massacres ocorridos nas últimas décadas.

É diante deste quadro complexo, que alguns chamariam de verdadeira mudança paradigmática, que realizamos nosso estudo.

Nele pretendemos analisar a possibilidade de utilização de antigos instrumentos de implementação do Direito Internacional na proteção dos novos valores e interesses reconhecidos por este direito.

Assim, no âmbito da responsabilidade internacional dos Estados e do Direito Internacional dos Direitos Humanos, pretende-se analisar a tese da aplicabilidade de contramedidas por Estados não diretamente lesados diante de violações às normas protetoras de direitos humanos.

A verificação desta aplicabilidade se dará levando em conta dois parâmetros. O primeiro, a legalidade destas contramedidas segundo as normas do Direito Internacional. O segundo, a necessidade destas contramedidas para a proteção efetiva dos direitos humanos. 
Este estudo utilizará, para a verificação desta aplicabilidade, a pesquisa documental, analisando a documentação compilada dos Estados e organizações internacionais relevantes para o tema em consideração; a pesquisa jurisprudencial, baseada na jurisprudência dos tribunais internacionais; e a pesquisa bibliográfica, tanto de obras gerais de autores representando diferentes escolas do Direito Internacional, como obras específicas, voltadas à questão da responsabilidade internacional ou do instituto das contramedidas.

Com base nas pesquisas documental, jurisprudencial e bibliográfica, pretende-se utilizar o método indutivo, para aferir a validade da tese apresentada.

Assim, num primeiro momento, estudar-se-á a responsabilidade internacional, em especial os trabalhos realizados pela Comissão de Direito Internacional da ONU, durante mais de 40 anos, para a codificação da responsabilidade internacional do Estado. Os debates sobre estes trabalhos, que resultaram na elaboração de um anteprojeto que foi adotado por Resolução pela Assembleia Geral da ONU, não só refletem as diferentes correntes doutrinárias, com espelham a posição dos Estados em relação aos diversos aspectos da responsabilidade do Estado tratados.

Num segundo momento, a natureza das normas de direitos humanos será examinada, tendo em vista que as características diferenciadas destas normas podem resultar em consequências jurídicas diversas no caso de violações graves a elas.

Posteriormente, planeja-se analisar o instituto das contramedidas em geral, com base na jurisprudência, doutrina e no anteprojeto de artigos sobre a responsabilidade internacional do Estado da CDI.

Em seguida, iniciaremos o estudo sobre a legalidade das contramedidas adotadas por Estados não diretamente lesados diante de violações às normas protetoras de direitos humanos. A verificação desta legalidade se dará com base na pesquisa das disposições do anteprojeto sobre a responsabilidade internacional, da jurisprudência dos principais tribunais internacionais, da doutrina e da prática dos Estados. $\mathrm{Na}$ análise da prática dos Estados levar-se-á em conta tanto a prática efetiva dos Estados quanto os seus pronunciamentos públicos sobre a matéria, em especial nos debates da questão no seio das Nações Unidas.

Por fim, pretende-se analisar a necessidade destas contramedidas para a efetiva proteção dos direitos humanos. Nesta análise, considerar-se-á a efetividade dos sistemas tradicionais de proteção dos direitos humanos para estudar a necessidade de um mecanismo de proteção alternativo, levando-se em conta o princípio Pro Homine, ou 
seja, o princípio segundo o qual as normas de direitos humanos devem ser interpretadas e aplicadas visando sempre a maior efetividade da proteção destes direitos.

Ao final, devemos concluir se a aplicabilidade das contramedidas por Estados não diretamente lesados é uma tese válida ou não, justificando qualquer que seja a conclusão.

Embora existam estudos publicados em outros países tratando da legalidade da adoção das contramedidas por Estados não diretamente lesados, nenhum deles analisa a questão da perspectiva exclusiva da violação das obrigações de proteção dos direitos humanos. Este trabalho pretende, assim, examinar em profundidade uma questão que só foi discutida incidentalmente em outras obras.

Os mecanismos de proteção internacional dos direitos humanos se desenvolveram muito nas últimas décadas. Foram celebrados inúmeros tratados internacionais protegendo os mais variados direitos humanos. Alguns destes tratados criaram órgãos internacionais de monitoramento do cumprimento das suas disposições. Ainda, outros procedimentos se desenvolveram no âmbito da Organização das Nações Unidas, cujos órgãos passaram a ter uma conduta mais atuante na proteção dos direitos humanos.

Também no plano regional, diversas convenções foram ratificadas. Em especial, o sistema interamericano e o sistema europeu de proteção dos direitos humanos criaram tribunais especializados para julgar violações aos direitos reconhecidos nestas convenções regionais.

Apesar deste quadro legislativo e institucional complexo, violações graves de direitos humanos continuam ocorrendo. E embora este sistema consiga monitorar, investigar e determinar a existência destas violações, ele muitas vezes não possui os instrumentos adequados para evitá-las.

Como veremos neste trabalho, a ampla maioria dos mecanismos de proteção internacional não têm competência para editar decisões obrigatórias. Aqueles que têm, não têm competência para forçar o cumprimento destas decisões.

A única exceção é o Conselho de Segurança. Porém este órgão é de natureza política e sua função precípua não é a proteção dos direitos humanos, e sim a manutenção da paz e segurança mundiais.

A eficácia do sistema internacional coletivo de proteção aos direitos humanos se baseia, assim, de modo geral, na pressão política exercida pela comunidade internacional. 
Embora este tipo de pressão seja eficaz no caso de Estados com relações internacionais complexas e que tenham uma opinião pública interna atuante, o mesmo não pode ser dito em relação a Estados cujos Governos estão mais preocupados com a consolidação de seu poder interno do que com sua imagem internacional.

Assim, nos casos de violações graves e sistemáticas aos direitos humanos, quando esta pressão política é ineficaz, devem os Estados membros da comunidade internacional assistir impassíveis o massacre, a expulsão, a prisão arbitrária de milhares de seres humanos?

Pretendemos estudar neste trabalho se existe a possibilidade jurídica, quando falham os demais mecanismos de proteção internacional dos direitos humanos, dos Estados adotarem, individualmente ou em conjunto, medidas unilaterais coercitivas, contrárias as suas obrigações segundo o Direito Internacional, para proteger o interesse da comunidade internacional como um todo, i.e. proteger o interesse coletivo no respeito aos direitos humanos.

Os críticos das contramedidas afirmam que este é um instituto arcaico que privilegia os mais poderosos. Mas uma vez reconhecida a legalidade das contramedidas em geral, por que não utilizá-las para salvaguardar os valores mais importantes da comunidade internacional?

Enquanto não houver mecanismos de proteção internacional coletiva dos direitos humanos efetivos, qual será o valor mais importante? A preservação dos direitos de um Estado violador contumaz dos direitos humanos, ou a preservação dos direitos de toda a população afetada por estas violações? 


\title{
PARTE I: A RESPONSABILIDADE INTERNACIONAL E AS NORMAS INTERNACIONAIS DE DIREITOS HUMANOS
}

\section{CAPITULO I: RESPONSABIIDADE INTERNACIONAL}

A responsabilidade internacional é uma das questões mais relevantes do Direito das Gentes. Segundo Dupuy (1984, p. 21):

\begin{abstract}
A responsabilidade constitui o epicentro de um sistema jurídico. A natureza dos direitos, a estrutura das obrigações, a definição das sanções por sua violação, tudo converge e se entremeia nas relações lógicas e nas relações de estreita interdependência. Um direito se dita, reconhece seus fundamentos, trata de suas lacunas, demonstra sua eficácia e seu grau de integração através de seu sistema de responsabilidade. (tradução nossa) ${ }^{1}$
\end{abstract}

Já Grotius, um dos fundadores do Direito Internacional moderno, reconhecia o princípio de que um ato ilícito acarreta obrigações para seu autor. Em suas palavras (p. 713, 2004):

Chamamos aqui de delito toda falta, seja na ação, seja na inação, em oposição com que os homens devem fazer comumente ou em razão de uma qualidade determinada. De tal falta, se houve um prejuízo causado, surge naturalmente uma obrigação que tem por objeto a reparação.

Apesar da sua grande importância, a responsabilidade internacional do Estado continua, até os dias de hoje, regulada apenas por normas consuetudinárias. Mesmo o extenso trabalho realizado por mais de quarenta anos pela Comissão de Direito Internacional da ONU, que resultou no anteprojeto de artigos sobre a responsabilidade internacional do Estado, como veremos mais adiante, foi somente adotado pela Assembleia Geral da ONU por meio de Resolução, não tendo assim, caráter vinculante.

Portanto, diante de um instituto regulado principalmente por regras consuetudinárias, coube à doutrina a tarefa inicial de sistematização.

\footnotetext{
${ }^{1}$ La responsabilité constitue l'epicentre d'un système juridique. La nature des droits, la structure des obligations, la définition des sanctions de leur violation, tout y converge et s'entremêle en des rapports logiques et des relations détroite interdépendence. Un droit se dit, avoue ses fondements, trahit ses lacunes, démontre son efficacité et son degré d'intégration, à travers son système de responsabité.
} 


\subsection{Doutrina}

Anzilotti dedicou, no início do século XX, uma obra exclusiva à responsabilidade do Estado no Direito Internacional. Para este autor (p. 78, 1902): “A responsabilidade jurídica nas relações entre os estados surge, assim, como um efeito da violação do direito internacional."2 (tradução nossa)

Ainda, para este autor (p. 102, 1902):

A responsabilidade nasce da violação injusta do direito de outro e gera a obrigação de reparação uma vez que esteja conectada com um sujeito agente, que é imputável por esta, entendida a palavra imputabilidade no significado geral do termo, que une o fato ou a omissão ilícita ao autor. (tradução nossa)

Para Anzilotti, também (p. 102, 1902):

O dano, que a doutrina comum também considera como elemento necessário da responsabilidade, pode ser oportunamente deixado a parte, seja porque, como já foi observado também pelo direito interno, o dano diz respeito mais à obrigação de ressarcimento, que é efeito da responsabilidade, enquanto esta tem sua razão de ser somente da violação do direito, seja porque, e esta é uma razão especial do nosso campo, nas relações internacionais, devido à grande importância que tem o elemento moral da consideração, da estima, da honra, cada violação do direito representa por si mesma certamente um dano para o estado que foi vítima e faz sentir imediatamente a necessidade de reparação. ${ }^{4}$ (tradução nossa)

Assim, para Anzilotti, a responsabilidade internacional decorre da simples violação de um direito alheio estabelecido pelo Direito Internacional. Sua consequência direta é a obrigação de reparar.

Já Ago, em trabalho anterior ao cargo de Re lator Especial da CDI para o tema da responsabilidade do Estado estabeleceu os elementos do delito internacional. Seriam

\footnotetext{
${ }^{2}$ La responsabilità giuridica nei rapport fra gli stati sorge dunque come un effetto della violazione del diritto internazionale.

${ }^{3}$ La responsabilità nasce dall'ingiusta violazione del diritto altrui e genera l'obbligo della riparazione in quanto sia collegata con un soggetto agente, sia cioè imputabile a questo, presa la parola imputabilità nel significato generale di termine che unisce il fatto o l'omissione illecitaal l'autore.

${ }^{4}$ Il danno, che una dottrina comune considera pure come elementonecessario della responsabilità può essere qui opportunamente lasciato da parte,sia prechè, come fu già osservato anche per il diritto interno, il danno riguarda piuttosto l'obbligo del risarcimiento, che è l'effetto della responsabilità, mentre questa trae la sua ragion d'essere dalla sola violazione del diritto, sia perché,e questa è ragione speciale al campo nostro, nelle relazioni internazionali, attesa la grande importanza che ha l'elemento morale della considerazione, della stima, dell'onore, ogni violazione del diritto rappresenta di per sè e senz'altro un danno per lo stato che fu vittima e fa sentire immediatamente il bisogno della riparazione.
} 
eles (p. 441, 1939): "um elemento objetivo, normalmente representado por uma ação ou omissão, em uma palavra, por uma certa conduta; e um elemento subjetivo, resultando da imputabilidade desta conduta a um sujeito de direito" ". (tradução nossa)

Ainda em suas palavras (p. 441, 1939): "Em direito internacional - se disse anteriormente -, uma tal conduta é representada, em qualquer caso, por uma ação ou uma omissão contrastando com uma obrigação jurídica internacional." (tradução nossa)

Assim, para Ago, o delito internacional é composto de dois elementos, um elemento objetivo, a conduta contrária às obrigações internacionais por parte de um Estado e o elemento subjetivo, a imputabilidade desta conduta ao Estado.

Já para Oppenheim (p. 359, 1961):

É delito internacional todo dano ou prejuízo causado a outro Estado pelo chefe ou Governo de um Estado em violação a uma obrigação internacional de caráter jurídico. [...] A noção ampla de delito internacional compreende desde as violações correntes das obrigações contraídas por um tratado e que não requerem mais que uma indenização pecuniária, até as violações do Direito internacional equivalentes a um ato criminal no sentido geralmente aceito do termo. $^{7}$ (tradução nossa)

Segundo este autor (p. 373, 1961):

As principais consequências jurídicas do delito internacional são a reparação do dano moral e material causado. As circunstâncias e condições de cada caso em particular são tão distintas, entretanto, que o Direito internacional não pode precisar de uma maneira geral as consequências jurídicas do delito internacional. A única regra unanimemente reconhecida pela teoria e a prática é que do delito internacional nasce para o Estado prejudicado um direito de requerer ao Estado delinquente que execute aqueles atos necessários para a reparação do dano causado. ${ }^{8}$ (tradução nossa)

\footnotetext{
${ }^{5}$ Un élé ment subjectif, normalement représenté par une action ou une omission, en un mot par une certain conduite ; et un élément subjectif, 'resultant de l'imputabilité de cette conduite à un sujet de droit.

${ }^{6}$ En droit international - on l'a dit auparavant -, une telle conduit est représentée, en toute hypothèse, par une action ou par une omission contrastant avec une obligation juridique internationale ;

${ }^{7}$ Es delito internacional todo daño o perjuicio causado a otro Estado por el jefe o el Gobierno de un Estado en violación de una obligación internacional de carácter jurídico. [...] La noción amplia del delito internacional comprende desde las violaciones corrientes de las obligaciones contraídas por tratado y que no requieren más que una indemnización pecuniaria, hasta las violaciones del Derecho internacional equivalentes a un acto criminal en el sentido generalmente aceptado del término.

8 Las principales consecuencias jurídicas del delito internacional son la reparación del daño moral y material causado. Las circunstancias y condiciones de cada caso en particular son, sin embargo, tan distintas que el Derecho internacional no puede precisar de una manera general las consecuencias jurídicas del delito internacional. La única regla unánimemente reconocida por la teoría y la práctica es que del delito internacional nace para el Estado perjudicado un derecho de requerir al Estado delincuente para que ejecute aquellos actos necesarios para la reparación del daño causado.
} 
Oppenheim, ainda, reconhece a responsabilidade penal do Estado (p. 376, 1961):

O Estado e aqueles que atuam em seu nome contraem responsabilidade de caráter penal por aquelas violações da lei internacional que em razão da sua gravidade, crueldade e menosprezo pela vida humana constituem atos criminais tal como o entendem as leis dos países civilizados. ${ }^{9}$ (tradução nossa)

Este autor também reconhece a responsabilidade internacional por atos não ilícitos. Para ele (p. 366, 1961): “A responsabilidade internacional pode entrar em jogo como resultado do abuso de um direito reconhecido pelo Direito internacional."10 (tradução nossa)

Assim, para Oppenheim, um delito internacional é o dano ou prejuízo causado por um Estado a outro devido ao descumprimento de uma obrigação internacional. Deste decorre a responsabilidade internacional, que pode mesmo ser penal, dependendo da gravidade e do tipo da violação.

Já de acordo com Verdross (p. 297, 1967): "Segundo o DI [Direito Internacional] comum, um sujeito de DI que infringe uma norma jurídica internacional, comum ou particular, é responsável em relação ao sujeito prejudicado." ${ }^{11}$ (tradução nossa)

Ainda, para este autor (p. 299, 1967):

Em princípio, a responsabilidade jurídica internacional só se dá em relação aos Estados afetados de maneira imediata pelo comportamento antijurídico. Por isso, mesmo na violação de uma norma consuetudinária ou de um tratado coletivo, só podem intervir em princípio os Estados imediatamente prejudicados. O mero interesse ideal dos demais Estados de que se respeite o ordenamento jurídic o internacional não basta, por conseguinte, para fundamentar uma reclamação desta índole. ${ }^{12}$ (tradução nossa)

\footnotetext{
${ }^{9}$ El Estado y los que en su nombre actúan contraen responsabilidades de carácter penal por aquellas violaciones de la ley internacional que en razón de su gravedad, crueldad y menos precio por la vida humana constituyen actos criminales tal como lo entienden las leyes de los países civilizados.

${ }^{10} \mathrm{La}$ responsabilidad del Estado puede entrar en juego como resultado del abuso de un derecho reconocido por el Derecho internacional.

${ }^{11}$ Según el DI común, un sujeto de DI que infringe una norma jurídica internacional, común o particular, es responsable con respecto al sujeto perjudicado.

${ }^{12}$ En principio, la responsabilidad jurídico-internacional solo se da con respecto a los Estados afectados de manera inmediata por el comportamiento antijurídico. Por eso, aun en la violación de una norma consuetudinaria o de un tratado colectivo, solo pueden intervenir en principio los Estados inmediatamente perjudicados. El mero interés ideal de los demás Estados de que se respecte el ordenamiento jurídicointernacional no basta, por consiguiente para fundamentar una reclamación de esta índole.
} 
Assim, Verdross entende que a responsabilidade internacional tem um caráter bilateral, surgindo apenas entre o Estado infrator e o Estado diretamente lesado. Ele, entretanto, ao analisar a questão da possibilidade excepcional de um Estado não diretamente lesado atuar, após citar autores que reconhecem esta exceção, admite a possibilidade de advertência ao Estado antes que este cometa o ilícito, e de apoio ao Estado ofendido na satisfação de suas reclamações.

Ainda para este autor para que se configurar a responsabilidade internacional do Estado, deve se comprovar que este agiu com culpa. Em suas palavras (p. 302, 1967): "Estes exemplos são suficientes para fazer ver que tem que haver culpa de um órgão não só nas omissões, como também nas ações para atribuir o ato jurídico ao seu Estado."13 (tradução nossa)

Para Verdross, a culpa é elemento essencial da responsabilidade internacional, que só excepcionalmente pode ser objetiva.

Para Dupuy a responsabilidade pode ser vista segundo diversas facetas diferentes mais complementares. Em suas palavras (p. 25, 1984):

a) Ela é considerada normalmente como a consequência da violação de uma obrigação internacional. Ela é, assim, definida com relação ao caráter ilícito do seu fato gerador.

b) Muitos autores a designam também segundo seu conteúdo e o objeto que a concepção objetivista atribuiu a ela: eles dirão, assim, que a responsabilidade consiste na obrigação de reparar os danos causados por fatos apresentando certas características e declarados imputáveis à pessoa do Estado.

c) Alguns, enfim, preferem insistir na relação nova instituída entre o autor do fato gerador e os outros sujeitos de direito. ${ }^{14}$ (tradução nossa)

Já para Reuter (p. 245-246, 1983):

A responsabilidade internacional decorre da violação de uma obrigação internacional. $\mathrm{O}$ ilícito é o fundamento e o primeiro elemento da responsabilidade, ao qual se conectam todos os outros:

\footnotetext{
13 Estos ejemplos hacen ver suficientemente que tiene que haber culpa de un órgano no solo en las omisiones, sino también en las acciones, para atribuir el acto antijurídico a su Estado.

14 a) On l'envisage ordinairement comme la conséquence de la violation d'une obligation internationale. Elle est ainsi définie par rapport au caractère illicite de son fait générateur.

b) Beaucoup d'auteurs la désignent aussi d'après son contenu et l'objet que la conception positiviste classique lui a assignés : ils diront alors que la responsabilité consiste dans l'obligation de réparer les dommages causés par des faits présentant certains caractères et déclarés imputables à la personne de l'Etat.

c) Certains, enfin, préfèrent insister sur la relation nouvelle instituée entre l'auteur du fait générateur et d'autres sujets de droit.
} 
imputação do fato ilícito, prejuízo, reparação e eventualmente punição. ${ }^{15}$ (tradução nossa)

Este autor também reconhece diferentes tipos de fatos ilícitos. Em suas palavras (p. 271, 1983):

Distinguir-se-á o fato ilícito ordinário e o fato ilícito grave. Usando, como faz desde algum tempo a AG [Assembleia Geral] o termo 'crime' para qualificar uma tal violação, não somente se traduz uma reação emocional, mas se sugere a ideia de uma responsabilidade penal internacional dos Estados. ${ }^{16}$ (tradução nossa)

Para Reuter, ainda a reparação pode ter diversas modalidades. Dentre elas, (p. 268, 1983): “A restituição em natura implica tanto em reparações jurídicas, quanto em reparações materiais e nas duas ao mesmo tempo."17 (tradução nossa) Ela visa apagar as consequências do ato ilícito trazendo de volta o status quo ante.

Ainda segundo este autor (REUTER, p. 268, 1983): “A restituição por equivalente se efetua normalmente pelo pagamento de uma soma em dinheiro. Sua determinação se opera pelo recurso a um método de avaliação determinado, ou mesmo a vários métodos entre os quais se faz uma média [...]." ${ }^{18}$ (tradução nossa)

Também para Reuter (p. 268, 1983): “Um dano puramente moral pode ser reparado por 'satisfações' puramente morais. A mais simples é a declaração pelo juiz do caráter ilícito do comportamento de um Estado;" 19 (tradução nossa)

Assim, no pensamento deste francês, a responsabilidade internacional decorre da violação de uma obrigação internacional. Esta violação pode caracterizar um fato ilícito ordinário ou um fato ilícito grave, também chamado de "crime". Uma das consequências da responsabilidade internacional, a reparação, a seu ver, pode ser de diversos tipos. A restituição em natura, que visa o status quo ante, a restituição por

\footnotetext{
${ }^{15}$ La responsabilité internationale découle de la violation d'une obligation internationale. L'illicite est le fondement et l'élément premier de la responsabilité, celui auquel se rattachent tous les autres : imputation du fait illicite, préjudice, réparation et éventuellement punition.

${ }^{16}$ On distinguera le fait illicit ordinaire et le fait illicite grave. En usant, comme l'a fait depuis un certain temps l'AG. du terme 'crime' pour qualifier une telle violation, non seulement on traduit une réaction émotionnelle, mais on suggère l'idée d'une responsabilité pénale internationale des Etats.

${ }^{17} \mathrm{La}$ restitution en nature implique tantôt des réparations juridiques, tantôt des réparations matérielles, tantôt les deux en même temps.

${ }^{18}$ La restitution par équivalent s'effectue normalement par le paiement d'une somme d'argent. Sa détermination s'opère par le recours à une méthode déterminée, ou bien à plusiers méthodes entre lesquelles on fait une moyenne [...].

19 Un dommage purement moral peut être réparé par des 'sactisfactions' purement morales. La plus simple est la proclamation par le juge du caractère illicite du comportement d'un Etat ;
} 
equivalente, no qual uma indenização é paga pelo dano sofrido, e a satisfação, quando a reparação é meramente moral.

Para Nquyên e Dinh (p.733, 1999): “pode-se dizer que a responsabilidade internacional pode ocorrer depois que um descumprimento ao direito internacional é cometido e este descumprimento pode ser atribuído a um sujeito do direito internacional. ${ }^{, 20}$ (tradução nossa)

Ainda, para estes autores (p. 753, 1999): "A responsabilidade por descumprimento de uma regra de direito internacional permanece puramente teórica se o fato internacionalmente ilícito não causa nenhum prejuízo."21

Nquyên e Dinh fazem, ainda, uma diferenciação entre direito jurídico e interesse jurídico. Para eles (p. 754, 1999):

No domínio da responsabilidade, os sujeitos do direito internacional só podem invocar o fato ilícito para fundamentar sua ação se este fato prejudica a um direito juridicamente protegido, um direito do qual eles são titulares. Eles só têm um interesse ao respeito do direito internacional fora desta hipótese; este interesse não é suficiente em si para que seu recurso seja aceitável. ${ }^{22}$ (tradução nossa)

Também para estes autores as formas de reparação seriam a restitutio in integrum, que visa o restabelecimento do status quo ante, a reparação por equivalência, que prevê o pagamento de uma indenização, e a satisfação, quando a reparação é puramente moral (p. 768-769, 1999).

Sobre as consequências dos crimes internacionais, eles afirmam que há mais dúvidas e incertezas do que respostas. (p. 771, 1999)

Já para Brownlie (p. 433, 1995): "Hoje, pode-se considerar responsabilidade como um princípio geral do direito internacional, acompanhado de regras substantivas e da suposição de que atos e omissões podem ser categorizados como ilegais pela referência de regras estabelecendo direitos e deveres."23 (tradução nossa)

\footnotetext{
${ }^{20}$ L'on peut dire que la responsabilité internationale peut être engagée dès lors qu'un manquement au droit international a été commis et que ce manquement peut être attribué à un sujet du droit international.

${ }^{21} \mathrm{La}$ responsabilité pour manquement à une règle de droit international demeure purement théorique si le fait internationalement illicite n'a causé aucun préjudice.

${ }^{22}$ Dans le domaine de la responsabilité, les sujets du droit international ne peuvent invoquer un fait illicite pour fonder leur action que si ce fait a porté atteinte à un droit juridiquement protégé, un droit dont ils sont titulaires. Ils n'ont qu'un intérêt au respect du droit international, en dehors de cette hypothèse ; cet intérêt n'est pas suffisant en soi pour que leur recours soit recevable.

23 Today one can regard international responsibility as a general principle of international law, a concomitant of substantive rules and of the supposition that acts and omissions may be categorized as illegal by the reference to the rules establishing rights and duties.
} 
Ainda, para este autor (p. 437, 1995): "Tecnicamente, a responsabilidade objetiva prevalece sobre a doutrina do ato voluntário: desde que a ação e a conexão causal sejam estabelecidas, existe a violação de um dever pelo resultado somente."24

Também para Brownlie (p. 460, 1995):

Satisfação pode ser definida como qualquer medida que o autor da violação ao dever é obrigado a tomar segundo o direito consuetudinário ou segundo um acordo feito pelas partes de uma disputa, a parte da restituição ou compensação. Satisfação é um aspecto da reparação em termos amplos. ${ }^{25}$ (tradução nossa)

Assim, para Brownlie, a responsabilidade internacional é um princípio de direito internacional. Ela é objetiva, ocorrendo independente de culpa. Este autor também dá uma definição mais ampla de satisfação, que seria toda a forma de reparação de não a restituição ou compensação.

Também para Shaw (p. 694, 2005):

A responsabilidade estatal é um princípio fundamental do direito internacional, decorrente da natureza do sistema jurídico internacional e das doutrinas de soberania do Estado e igualdade entre os Estados. Ela prevê que sempre que um estado comete um ato internacionalmente ilícito contra um outro estado, a responsabilidade internacional é estabelecida entre os dois. A violação de uma obrigação internacional da origem a um requerimento de reparação. ${ }^{26}$ (tradução nossa)

Ainda segundo este autor (p. 696, 2005):

As características essenciais da responsabilidade dependem de certos fatores básicos: primeiro, a existência de uma obrigação internacional legal em vigor entre dois estados em particular; segundo, que tenha ocorrido um ato ou omissão que viola esta obrigação e que é

\footnotetext{
${ }^{24}$ Technically, objective responsibility rests on the doctrine of the voluntary act: provided that agency and causal connection are established, there is a breach of duty by result alone.

${ }^{25}$ Satisfaction may be defined as any measure which the author of the breach of duty is bound to take under customary law or under an agreement by the parties to a dispute, apart from restitution or compensation. Satisfaction is an aspect of reparation in the broad sense.

${ }^{26}$ State responsibility is a fundamental principle of international law, arising out of the nature of the international legal system and the doctrines of state sovereignty and equality of states. It provides that whenever one state commits an internationally unlawful act against another state, international responsibility is established between the two. A breach of an international obligation gives rise to a requirement for reparation.
} 
imputável ao estado responsável, e finamente, que perda ou dano tenham resultado do ato ou omissão ilícitos. ${ }^{27}$ (tradução nossa)

Assim, segundo Shaw, a responsabilidade internacional é um princípio de direito internacional. Dentre seus principais elementos estão a existência de uma obrigação internacional entre as partes, a violação desta obrigação internacional imputável a uma delas e o dano ocorrido em consequência desta violação.

Já para Ramos (p. 74, 2004):

Em essência, a responsabilidade internacional do Estado é uma reação jurídica, qualificada como sendo instituição, princípio geral de direito, obrigação jurídica ou mesmo situação jurídica pela doutrina e jurisprudência, na qual o Direito Internacional justamente reage às violações de suas normas, exigindo a preservação da ordem jurídica presente.

Ainda para este autor esta responsabilidade seria objetiva. Em suas palavras (p. 101, 2004): "Mas a caracterização do fato ilícito e sua imputação ao Estado, mesmo no caso de omissão, responde, como vimos, a critérios objetivos de causalidade $e$ constatação da violação da obrigação internacional."

Deste breve apanhado doutrinário, podemos concluir que a responsabilidade internacional pode ser definida de diversas formas, de açodo com a faceta que se queira ressaltar. Ela possui, entretanto, elementos comuns que são reconhecidos pela grande maioria dos autores.

A responsabilidade internacional pode ser considerada uma norma consuetudinária ou um princípio geral de Direito Internacional regulado por normas consuetudinárias. Ela pode ser uma relação bilateral, ou multilateral que surge de um ato internacionalmente ilícito. Mais, eleme ntos comuns a esta responsabilidade são o elemento objetivo, uma ação ou omissão de um Estado em violação a uma obrigação internacional para ele estabelecida; e o elemento subjetivo, a imputabilidade desta conduta ao Estado violador.

Outros elementos que podem ser considerados no âmbito da responsabilidade internacional são o dano e a culpa do agente. Ambos, no entanto, podem ser interpretados de formas diversas.

\footnotetext{
${ }^{27}$ The essential characteristics of responsibility hinge upon certain basic factors: first, the existence of an international legal obligation in force as between two particular states; secondly, that there has occurred an act or omission which violates that obligation and which is imputable to the state responsible, and finally, that loss or damage has resulted from the unlawful act or omission.
} 
Outro ponto em comum é que da responsabilidade internacional decorre um dever de reparação. Esta reparação pode se dar na forma da restitutio in integrum, de uma compensação pecuniária ou mesmo através de uma satisfação moral.

Também a natureza das obrigações violadas pode influenciar nas consequências jurídicas advindas da responsabilidade internacional. Seja através do conceito de crime internacional ou da ideia de um fato ilícito grave, o regime da responsabilidade internacional pode variar e novas consequências podem surgir.

É com base neste amplo quadro que a Comissão de Direito Internacional da ONU vai realizar seus trabalhos de codificação.

\subsection{Jurisprudência}

A responsabilidade internacional também foi, repetidas vezes, reconhecida pelos tribunais internacionais

\subsubsection{Corte Permanente de Justiça Internacional (CPJI)}

Já no caso Wimbledon, em que a Alemanha foi responsabilizada por impedir a passagem de navios no Canal de Kiev, julgado em 1923, a CPJI reconhece que o descumprimento de uma obrigação internacional, deve gerar um dever de reparação. Segundo esta Corte (CPJI, p. 30, 1923): “A Corte, tendo chegado à conclusão de que o respondente, Alemanha, ilicitamente recusou a passagem pelo Canal ao navio 'Wimbledon', este país é responsável pelo prejuízo causado por esta recusa, e deve compensar o Governo Francês, [...]”28 (tradução nossa)

Nos Julgamentos relativos a Fábrica Chorzów, onde se discutiu o direito da Polônia de expropriar propriedades de companhias alemãs a Corte mencionou reiteradamente o principio de que a violação de uma obrigação gera o dever de reparação. Em suas palavras (CPJI, p. 21, 1927):

\footnotetext{
${ }^{28}$ The Court having arrived at the conclusion that the respondent, Germany, wrongfully refused passage through the Canal to the vessels 'Wimbledon', that country is responsible for the loss occasioned by this refusal, and must compensate the French Government, [...]
} 
É um princípio de direito internacional que a violação de um compromisso envolve uma obrigação de fazer uma reparação em uma forma adequada. Reparação, assim, é um complemento indispensável à falha de aplicar uma convenção é não há necessidade que isto esteja estabelecido na própria convenção. Diferenças relacionadas à reparações, que podem ser devidas em razão da falha em aplicar a convenção, são consequentemente diferenças relativas à sua aplicação. ${ }^{29}$ (tradução nossa)

No julgamento do Caso Fosfatos em Marrocos, 1938, a Corte reconheceu que a violação de uma obrigação resulta na responsabilidade internacional. Estabelece a Corte (CPJI, p.28, 1938):

Sendo assim, é nesta decisão que nos devemos procurar a violação do direito internacional - um ato definitivo que iria, por si mesmo, diretamente envolver a responsabilidade internacional. Este ato sendo atribuível ao Estado e descrito como contrário ao direito convencional de outro Estado, a responsabilidade internacional seria imediatamente estabelecida entre os dois Estados. ${ }^{30}$ (tradução nossa)

Assim, não só a Corte reconhece que a violação do Direito Internacional acarreta a responsabilidade imediata do Estado violado, como ainda ela estabelece alguns requisitos para que se estabeleça esta responsabilidade. Primeiro, o ato deve ser atribuível a um Estado, e segundo ele deve ser contrário ao direito estabelecido em tratado de outro Estado.

\subsubsection{Corte Internacional de Justiça (CIJ)}

Também a Corte de Justiça se manifestou a respeito da responsabilidade internacional. No caso estreito de Corfu, de 1949, estabelece que a responsabilidade internacional também pode ocorrer por omissão (CIJ, p. 23, 1949): "De fato, nada foi

\footnotetext{
${ }^{29}$ It is a principle of international Law that the breach of an engagement involves an obligation to make reparation in an adequate form. Reparation therefore, is the indispensible complement of a failure to apply a convention and there is no necessity for this to be stated in the convention itself. Differences relating to reparations, which may be due by reason of failure to apply a convention, are consequently differences relating to its application.

${ }^{30}$ That being so, it is in this decision that we should look for the violation of international law - a definite act which would, by itself, directly involve international responsibility. This act being attributable to the State and described as contrary to the treaty right of another State, international responsibility would be established immediately as between the two States.
} 
tentado pelas autoridades da Albânia para prevenir o desastre. Essas graves omissões envolvem a responsabilidade internacional da Albânia."31 (tradução nossa)

No Parecer Consultivo sobre a reparação dos danos sofridos no serviço das Nações Unidas, a CIJ cita o já mencionado dito da CPJI no Julgamento sobre a Fábrica Chorzów (p. 184, 1949).

Também no Parecer Consultivo de 18 de julho de 1950, sobre os Tratados de paz entre Bulgária, Hungria e Romênia, a Corte declara (CIJ, p. 228, 1950): "é claro que uma recusa a cumprir uma obrigação de um tratado envolve responsabilidade internacional." $^{, 32}$ (tradução nossa)

\subsubsection{Tribunais Arbitrais}

No caso sobre os bens britânicos no Marrocos espanhol o Tribunal Arbitral estabelece (UNRIAA, p. 641, Vol. II, 1925):

1) A responsabilidade é um corolário necessário do direito. Todos os direitos de ordem internacional têm por consequência uma responsabilidade internacional. A responsabilidade tem como consequência a obrigação de dar uma reparação no caso onde a obrigação não poderá ser retomada. Resta examinar a natureza e a extensão desta reparação. [...]

3) O Estados cujo nacional estabelecido em outro Estado foi lesado em seus direitos, tem direito de intervir naquele estado se a lesão constitui uma violação do direito internacional. Também, o simples fato de que um dano foi causado, nem o fato que a indenização demandada ou a punição exigida pelo dano não forma obtidas, não justificam em si mesmos a intervenção diplomática: é necessário que um elemento particular ocorra que faça nascer uma responsabilidade $[\ldots]^{33}$ (tradução nossa)

\footnotetext{
31 In fact, nothing was attempted by the Albanian authorities to prevent the disaster. These grave omissions involve the international responsibility of Albania.

32 it is clear that refusal to fulfil a treaty obligation involves international responsibility

331 ) La responsabilité est le corollaire nécessaire du droit. Tous droits d'ordre international ont pour conséquence une responsabilité internationale. La responsabilité entraîne comme conséquence l'obligation d'accorder une réparation au cas où l'obligation n'aurait pas été remplie. Reste à examiner la nature et l'étendue de la réparation. [...]

3) L'Etat dont un ressortissant établi dans un autre État se trouve lésé dans ses droits, est en droit d'intervenir auprès de cet État si la lésion constitue une violation du droit international. D'autre part, le simple fait qu'un dommage a été causé, non plus que le fait que l'indemnité demandée ou la punition exigée par le damnifié n'ont pas été obtenues, ne justifient pas en eux-mêmes l'intervention diplomatique: il faut qu'un élément particulier survienne qui fasse naître une responsabilité, tel est le problème qui se pose en ce mo ment.
} 
Para este Tribunal, assim, a responsabilidade decorre do direito e tem como consequência a obrigação de reparar. Por outro lado, o simples dano não acarreta a responsabilidade. Ele deve derivar sempre de uma violação ao Direito Internacional para que ela ocorra.

No caso Dickson Car Wheel Company (UNRIAA, p. 678, Vol. IV, 1931), o Tribunal Arbitral estabelece:

Segundo o direito internacional, independente de qualquer convenção, para que um Estado incorre em responsabilidade, é necessário que um ato ilícito internacional seja imputado a ele, ou seja, que existe a violação de um dever imposto por uma regra jurídica internacional ${ }^{34}$ (tradução nossa)

Também no caso International Fisheries Company (UNRIAA, p. 701, Vol. IV, 1931) o Tribunal Arbitral declara: "Os Estados, de acordo com uma regra de direito internacional completamente estabelecida, são responsáveis apenas por aqueles danos que infligiram através de um ato que viola algum princípio de direito internacional.",35

Assim, para estes dois julgados, a violação do Direito Internacional também é uma condição para a ocorrência da responsabilidade.

No caso Armstrong Cork Company (UNRIAA, p. 163, Vol. XIV,1953) o Tribunal Arbitral discorre sobre o tema:

Deve-se considerar como ilícitas ações (como foi dito por Strupp Das Wolkerrechtliche Délit, 1920) produzindo a responsabilidade daqueles que realizam tais ações e permitindo ao Estado que sofreu ou àquele $s$ sujeitos que sofreram o dano demandar reparação, todas ações de um Estado que estão em contradição com qualquer regra que seja do direito internacional. [...]

A responsabilidade do Estado acarretaria a obrigação de reparar os danos sofridos na extensão de que tais danos são o resultado da inobservância da obrigação internacional. ${ }^{36}$ (tradução nossa)

\footnotetext{
${ }^{34}$ Under international law, apart from any convention, in order that a State may incur responsibility it is necessary that an unlawful international act be imputed to it, that is, that there exist a violation of a duty imposed by an international juridical standard.

35 States according to a thoroughly established rule of international law, are responsible only for those injuries which are inflicted through an act which violates some principle of international law.

${ }^{36}$ One must consider as illicit actions (as has been stated by Strupp Das Wolkerrechtliche Délit, 1920), producing the responsibility of those performing such actions and allowing the State which has suffered or whose subjects have suffered damage to demand reparation, all actions of a State which are in contradiction with any rule whatsoever of international law. [...]

The responsibility of the State would entail the obligation to repair the damages suffered to the extent that said damages are the result of the inobservance of the international obligation.
} 
Também neste caso, o Tribunal condiciona a responsabilidade à violação do Direito Internacional e reconhece que esta enseja um dever de reparação.

1.3 Trabalhos da CDI (Comissão de Direito Internacional da ONU) sobre a Responsabilidade dos Estados

\subsubsection{Antecedentes}

Dada a importância da questão da responsabilidade internacional, ocorreram algumas tentativas de sistematizar e mesmo codificar as regras de Direito Internacional sobre a responsabilidade dos Estados no plano internacional.

\subsubsection{Codificação sob os auspícios de órgão regionais}

\subsection{Codificação pelos Órgãos Interamericanos}

A responsabilidade internacional foi um dos temas tratados no âmbito das Conferências Interamericanas, que tiveram lugar no final do século XIX e primeira metade do século XX. Segundo Garcia Amador (ONU, p. 178, 1956):

Embora a decisão de fazer uma codificação completa sobre o tema só tenha sido tomada mais tarde, a Primeira Conferência Internacional dos Estados Americanos, e quase que todas as Conferências subsequentes, estudaram o problema da responsabilidade dos Estados e algumas delas adotaram resoluções ou convenções relacionadas ao tema. (tradução nossa) ${ }^{37}$

De fato, a Primeira Conferência Internacional dos Estados Americanos, ocorrida entre 1889 e 1890, adotou a recomendação relacionada a "reclamações e intervenção diplomática", que visava proteger os direitos civis dos estrangeiros, igualando-os aos dos seus nacionais ${ }^{38}$. Esta delimitava, ainda, a responsabilidade dos Estados em relação

\footnotetext{
${ }^{37}$ Although the decision to undertake a complete codification of the topic was not taken until later, the First International Conference of American States, and all the subsequent Conferences, studied the problem of State responsibility and some of them adopted resolutions or conventions relating to the subject.

38 (1) Foreigners are entitled to enjoy all the civil rights enjoyed by natives; and they shall be accorded all the benefits of said rights in all that is essential as well as in the form or procedure, and the legal remedies incident thereto, absolutely in like manner as said natives. (Recommendation concerning "Claims and
} 
a estes estrangeiros. Esta responsabilidade não seria maior do que a que este Estado teria em relação aos seus nacionais ${ }^{39}$.

Já a Segunda Conferência Internacional dos Estados Americanos, na Convenção relativa ao Direito dos Estrangeiros, assinada no México, em 1902, estabeleceu que:

[...] os Estados não são responsáveis por danos sofridos por estrangeiros através de atos de rebeldes e indivíduos, e em geral, por danos originados de causas fortuitas de qualquer tipo, considerando-se como tais, atos de guerra, tanto civil quanto nacional; exceto no caso de falha por parte das autoridades constituídas em cumprir com seus deveres. (tradução nossa) ${ }^{40}$

Esta Convenção também estabelecia que quaisquer reclamações de estrangeiros contra um Estado, deveriam ser apresentadas à Corte nacional competente, "exceto em casos onde deve ter ocorrido, por parte da Corte, uma manifesta denegação de justiça, uma demora ño usual, ou evidente violação aos princípios de Direito Internacional." (MÉXICO, 1902) (tradução nossa) ${ }^{41}$

Nestas primeiras conferências, a responsabilidade internacional surge ligada a questão da proteção aos estrangeiros e, consequentemente, ao instituto da proteção diplomática. Essa responsabilidade, ainda embrionária, era bastante limitada, ocorrendo somente em casos excepcionais.

É somente a partir da Sétima Conferência, ocorrida em Montevidéu, em 1933, que o tema da responsabilidade internacional em geral, será abordado. A Resolução sobre "Responsabilidade internacional do Estado", adotada por esta Conferência, recomenda que:

(...) o estudo de todo o problema relacionado à responsabilidade internacional do Estado, com referência especial à responsabilidade por manifesta denegação ou demora injustificada de justiça seja

Diplomatic Intervention" adopted at the First International American Conference apud ONU, Yearbook of the International Law Commission, p. 226, 1956)

39 A nation has not, nor recognizes in favor of foreigners, any other obligations or responsibilities than those which in favor of the natives are established, in like cases, by the constitutions and the laws. (ibid, p. 226, 1956)

40 [...] the States are not responsible for damages sustained by aliens through acts of rebels or individuals, and in general, for damages originating from fortuitous cases of any kind, considering as such the acts of war, whether civil or national; except in the case of failure on the part of the constituted authorities to comply with their duties. (Convention relative to the Rights of Aliens signed at the Second International Conference of American States, Mexico city, 1902 apud ONU, Yearbook of the International Law Commission, p. 226, 1956)

${ }^{41}[\ldots]$ except in the cases where there shall have been on the part of the Court, a manifest denial of justice, or unusual delay, or evident violation of the principles of International Law. (ibid, p. 226, 1956) 
efetuado pelas agencias de codificação, instituídas pela Conferência Internacional dos Estados Americanos, e que seus estudos sejam coordenados com o trabalho de codificação que está sendo feito sob os auspícios da Liga das Nações ${ }^{42}$. (tradução nossa) ${ }^{43}$

Esta Resolução também reafirma alguns princípios já estabelecidos pelas Conferências anteriores, sejam eles, o princípio da igualdade civil entre estrangeiros e nacionais de um Estado ${ }^{44}$ e o princípio da necessidade da exaustão dos recursos internos como requisito para a proteção diplomática ${ }^{45}$.

Nas duas Conferências seguintes a questão da responsabilidade internacional volta a ser relegada ao segundo plano. Já a Décima Conferência dos Estados Americanos, ocorrida em 1954, volta a tratar da matéria em resolução específica. Na Resolução sobre "Princípios do Direito Internacional regendo a Responsabilidade do Estado" a Conferência, tendo em vista a Resolução da Assembleia Geral da ONU, que encarrega a Comissão de Direito Internacional da ONU de proceder a codificação do tema ${ }^{46}$, ressaltou a importante contribuição feita pelo Continente Americano no desenvolvimento da matéria ${ }^{47}$, e recomendou ao Conselho de Juristas Interamericano um estudo ou relatório sobre esta contribuição ${ }^{48}$.

\footnotetext{
${ }^{42}$ Como veremos mais a frente, desde 1924, também a Liga das Nações vinha trabalhando no sentido de codificar matérias relevantes para o Direito Internacional, dentre eles, a responsabilidade internacional dos Estados.

${ }^{43}$ the study of the entire problem relating to the international responsibility of the state, with special reference to responsibility for manifest denial or unmotivated delay of justice be handed over to the agencies of codification instituted by the International Conferences of American States and that their studies be co-ordinated with the work of codification being done under the auspices of the League of Nations. (Resolution on "International Responsibility of the State" adopted at the Seventh International Conference of American states, Montevideo,1933, apud ONU, Yearbook of the International Law Commission, p. 226, 1956)

${ }^{44}$ 2. That, notwithstanding this, it reaffirms once more, as a principle of international law, the civil equality of the foreigner with the national as the maximum limit of protection to which he may aspire in the positive legislations of the states. (ibid, p. 226, 1956)

45 3. Reaffirms equally that diplomatic protection cannot be initiated in favor of foreigners unless they exhaust all legal measures established by the laws of the country before which the action is begun. (ibid, p. 226, 1956)

${ }_{46}$ The General Assembly of the United Nations, during its Eighth Session, requested the International Law Commission to proceed to the codification of the principles of international law that govern the responsibility of the State; (Resolution concerning "Principles of International Law governing the Responsibility of the State", OEA, Caracas, 1954, apud ONU, Yearbook of the International Law Commission, p. 179, 1956)

${ }^{47}$ The American Continent has made a notable contribution to the development and codification of the principles of international law that govern the responsibility of the State, (ibid, p. 179, 1956)

48 To recommend to the Inter-American Council of Jurists and its permanent committee, the Inter American Juridical Committee of Rio de Janeiro, the preparation of a study or report on the contribution the American Continent has made to the development and to the codification of the principles of international law that govern the re sponsibility of the State. (ibid, p. 179, 1956)
} 
Atendendo a recomendação feita pela Décima Conferência, o Conselho Interamericano de Juristas instruiu o Comitê Jurídico Interamericano a preparar um relatório com a contribuição do Continente Americano sobre a responsabilidade internacional dos Estados. O Comitê Jurídico Interamericano, por seu turno, decidiu delimitar os seus trabalhos à responsabilidade internacional dos Estados por danos causados aos estrangeiros, por considerar que foi nesta área que o Continente Americano teria produzido suas contribuições mais originais. Decidiu também se limitar à prática dos Estados Latino Americanos, pois, em sua opinião, a prática dos Estados Unidos não trazia nenhuma inovação (ONU, p. 129, 1969).

Com base nestas premissas, este Comitê adotou em $1961^{49}$ o relatório 'Principles of international law that govern the responsibility of the State in the opinion of Latin American countries", com 10 postulados retratando a posição dos Estados Americanos sobre o tema. Neste texto, este Comitê não se afastou da posição das primeiras Conferências dos Estados Americanos, prevendo em seu segundo postulado: "Um Estado não é responsável por atos ou omissões em relação a estrangeiros, exceto nos mesmos casos e condições em que, de acordo com suas próprias normas, ele tenha tal responsabilidade em relação aos seus próprios nacionais." ${ }^{50}$ (tradução nossa)

Este Comitê também entendia que: "Intervenção nos assuntos internos ou externos de um Estado não é admissível para impor a responsabilidade ao referido Estado. Pelo contrário, a intervenção estabelece a responsabilidade do Estado interveniente. ${ }^{51}$ (tradução nossa)

Esse postulado consubstanciava o princípio de não intervenção, defendido pelos Estados Latino-Americanos.

O texto também estabelecia a irresponsabilidade do Estado no caso de existência de uma cláusula Calvo ${ }^{52}$ (postulado IV) ${ }^{53}$, e desconsiderava a teoria do risco (postulado $\mathrm{VI})^{54}$

\footnotetext{
${ }^{49}$ Já em 1958 o Comitê havia apresentado um trabalho preliminar com 6 princípios, porém é o texto de 1961, mais completo que seria submetido ao Conselho Interamericano de Juristas.

${ }^{50}$ The State is not responsible for acts or omissions with respect to foreigners except in those same cases and conditions where, according to its own laws, it has such responsibility towards its own nationals. (Principles of international law that govern the responsibility of the State in the opinion of Latin American countries, OEA, Washington, 1962, apud ONU, Yearbook of the International Law Commission, p. 153, 1969)

51 Intervention in the internal or external affairs of a State is not admissible to enforce the responsibility of said State. On the contrary, intervention establishes the responsibility of the intervening State. (ibid, p. $153,1969)$

52 The Calvo Clause generally provides that the alien must rely upon local remedies for the adjustment of differences arising under the contract and may not invoke the diplomatic protection of his Government.
} 
O Relatório deste Comitê foi submetido ao Conselho Interamericano de Juristas em 1965 e considerourse que este representava a contribuição Latino Americana sobre a matéria. O Conselho também requereu a este Comitê que elaborasse um relatório suplementar sobre a contribuição dos Estados Unidos sobre o tema.

O Relatório "Principles of international law that govern the responsibility of the State in the opinion of the United States of America" foi apresentado em 1965. Em uma posição bem diferente da expressada pelos países da América Latina, a posição norteamericana, segundo este Comitê, estabelecia que: "Um Estado que falha em cumprir com o Direito Internacional aplicável, em relação à pessoa ou propriedades de estrangeiros em seu território, incorre em responsabilidade internacional e deve proceder a reparação na forma em que for apropriada. ${ }^{55}$ (tradução nossa)

O texto, ainda, estabelecia diversa hipóteses em que um Estado incorreria em responsabilidade internacional, dentre elas a adoção de legislação incompatível com suas obrigações internacionais e mesmo a omissão em adotar legislação necessária para implementar essas obrigações, nos casos em que essas ações ou omissões acarretassem danos a um estrangeiro. ${ }^{56}$

No seu postulado $\mathrm{X}$, o texto também estabelecia a invalidade da cláusula Calvo para precluir o direito de um Estado de endossar uma reclamação tendo em vista uma

(Principles of international law that govern the responsibility of the State in the opinion of the United States of America, OEA, Washington, 1965, apud ONU, Yearbook of the International Law Commission, p. 154, 1969)

53 A State is relieved of all international responsibility if the alien has, by contract, renounced the diplomatic protection of his government, or if domestic legislation subjects the contracting alien to the jurisdiction of the local courts, or if it places him in a similar status with nationals for all purposes of the contract. (Principles of international law that govern the responsibility of the State in the opinion of Latin American countries, OEA, Washington, 1962, apud ONU, Yearbook of the International Law Commission, p. 153, 1969)

54 The theory of risk as the basis for international responsibility is not admissible. (ibid, p. 153,1969)

55 A State that fails to comply with the applicable international law, as regards the person or property of foreigners in its territory, incurs international responsibility and must make reparation in such form as may be appropriate. (Principles of international law that govern the responsibility of the State in the opinion of the United States of America, OEA, Washington, 1965, apud ONU, Yearbook of the International Law Commission, p. 153, 1969)

56 Enactment of legislation of a constitutional or any other character incompatible with international customary law or the treaty rights of other States will, if enforced by the State to the injury of a foreigner, give rise to international responsibility.

Failure to enact legislation necessary for the purpose of implementing a treaty or other international obligation of the State makes the State responsible internationally, if an injury is caused thereby to a foreigner or his property.

Enacting legislation incompatible with the terms of concessions or contracts granted to or concluded with foreigners or of a nature internationally, if an injury is caused thereby to a foreigner or his property.

Similarly, the enactment of legislation infringing vested rights of foreigners and the repudiation of debts may form the basis for State responsibility for injuries caused thereby, since a State may not take property of aliens except for a public purpose and upon payment of just compensation. (ibid, p. 153-154, 1965) 
violação ao Direito Internacional, por outro Estado ${ }^{57}$, posição diametralmente oposta da adotada pelos Estados Latino Americanos, segundo o Comitê Jurídico Interamericano.

Bastante diferentes, as duas posições sobre a responsabilidade internacional por danos causados aos estrangeiros vão influenciar os esforços de codificação elaborados por entidades privadas, assim como o trabalho da Comissão de Direito Internacional da ONU, que os analisará em seus estudos sobre a matéria.

\subsection{Codificação pelos Países Africanos e Asiáticos}

O tema da responsabilidade internacional dos Estados também foi tratado pelo Comitê Consultivo Legal Asiático Africano ${ }^{58}$. Já em sua primeira sessão, em 1957, este Comitê tratou da responsabilidade internacional decorrente do tratamento dado aos estrangeiros, a exemplo do trabalho desenvolvido pelos órgãos interamericanos. $\mathrm{Na}$ sua segunda sessão, em Cairo, 1958, este Comitê encarregou o Secretariado de elaborar um relatório, na forma de um anteprojeto de artigos, sobre o tema. Na sua terceira sessão, em Colombo, 1960, este Comitê analisou o relatório apresentado pelo secretariado e decidiu dividir o tema, por sua amplitude, em dois itens. O primeiro, tratando da proteção diplomática e da responsabilidade internacional dos Estados teve sua discussão agendada para futuras sessões. O segundo, tratando de regras substantivas em relação ao status e ao tratamento de estrangeiros foi objeto da resolução Princípios relativos a admissão e tratamento dos estrangeiros ${ }^{59}$, contendo um anteprojeto de Convenção com 18 artigos (ONU, p. 130, 1969).

A contribuição mais relevante deste Comitê para a codificação da responsabilidade internacional, porém, advém, talvez, do seu reconhecimento incidental em outras matérias. Por exemplo, no trabalho desenvolvido sobre a legalidade dos testes nucleares, este Comitê, na resolução aprovada em 4 de março de 1964, afirma não só a

\footnotetext{
${ }^{57}$ Where an alien contracts with a national Government and agrees not to resort to the diplomatic or other protection of the Government of the State of which he is a national, in connection with the contract, his Government is not precluded from espousing a claim based on a violation of international law by the other Government. (ibid, p. 154, 1965)

${ }^{58}$ Criado em 15 de novembro de 1956, originalmente como um comitê não permanente por um prazo de 5 anos, o Comitê se constituía em um órgão de apoio, formado por Estados para auxiliá-los no campo do Direito Internacional e como um fórum de cooperação jurídica Asiático Africano. Adquiriu status permanente em 1981 e atualmente, sob o nome de Organização Consultiva Legal Asiática-Africana, é uma Organização Intergovernamental com 47 Estados Membros. Informações disponíveis em: http://www.aalco.int/. Acesso em 13 de ago. 2010.

${ }^{59}$ Texto disponível em ONU, Yearbook of International Law, p. 82, 1961.
} 
ilegalidade dos testes de armas nucleares ${ }^{60}$ como também a "absoluta responsabilidade" dos Estados por danos causado por estes testes ${ }^{61}$.

\subsubsection{Projetos desenvolvidos por entidades privadas}

Algumas entidades privadas, voltadas ao estudo do Direito Internacional, também se dedicaram ao estudo da responsabilidade internacional dos Estados. Dentre estas podemos destacar o Instituto Americano de Direito Internacional, que, a pedido da União Pan-Americana, em 1925, elaborou uma série de projetos sobre diversas matérias de Direito Internacional Público. Dois destes tem relação com o tema.

O projeto sobre a Responsabilidade dos Governos, composto apenas por 2 artigos, que desconsiderava a responsabilidade internacional dos Governos das Repúblicas Americanas por danos causados a estrangeiros, exceto nos casos de falha em manter a ordem interior, de negligência na supressão de atos que perturbem esta ordem ou se não foram tomadas as precauções devidas que teriam sido capazes de evitar a ocorrência de tais danos ${ }^{62}$.

E o projeto sobre Proteção Diplomática, com 11 artigos, que embora não trate da responsabilidade internacional em si, estabelece o direito de representação diplomática de um Estado em relação a seus nacionais nos casos em que estes não tem recurso legal contra as autoridades de outro Estado, tem a justiça denegada por estas, ou em casos de demora injustificada ou de princípios de Direito Internacional ${ }^{63}$. Estes dois projetos seguem a linha das Resoluções apresentadas pelas primeiras Conferências

\footnotetext{
603 . Having regard to its harmful effects, as shown by scientific data, a test explosion of nuclear weapons constitutes an international wrong. Even if such tests are carried out within the territory of the testing State, they are liable to be regarded as an abuse of rights (abus de droit). (Cairo, 1964, in ONU, Yearbook of the International Law Commission, p. 120, 1964)

61 4. The principle of absolute liability for harbouring dangerous substances or carrying on dangerous activities is recognized in international law. A State carrying out test explosions of nuclear weapons is therefore absolutely liable for the damage caused by such test explosions. (Ibid, p. 120, 1964)

${ }^{62}$ As a consequence of the rule formulated in the preceding article, the Governments of the American Republics are not responsible for damages suffered by foreigners, in their persons or in their property for any reason whatsoever, except when the said Governments have not maintained order in the interior, have been negligent in the suppression of acts disturbing this order, or, finally, have not taken precautions so far as they were able to prevent the occurrence of such damages or injuries. (Project no. 15: Responsibility of Governments apud ONU, Yearbook of the International Law Commission, p. 227, 1956)

${ }^{63}$ Every nation has the right to accord diplomatic protection to its nationals in an American Republic in cases in which they do not have legal recourse to the authorities of the country, or if it can be proved that there has been denial of justice by the said authorities, undue delay, or violation of the principles of international law. (Project no. 16: Diplomatic Protection apud ONU, Yearbook of the International Law Commission, p. 227, 1956)
} 
Internacionais dos Estados Americanos, e pelo texto apresentado pelo Comitê Jurídico Interamericano, retratando a posição da América Latina, mencionados anteriormente.

Em 1926 o ramo japonês da International Law Association e o Kokusaiho Gakkwai elaboraram, tendo em vista a Conferência de Codificação, um anteprojeto de Código de Direito Internacional. Este, em seu Capítulo II, tratava da responsabilidade internacional. O artigo 1 estabelecia: "Um Estado é responsável pelos danos sofridos por estrangeiros em seus territórios, na vida, pessoa ou propriedade, por ato intencional, omissão ou negligência das autoridades oficiais no cumprimento de suas funções oficiais, se tal ato, omissão ou negligência constitui uma violação de uma obrigação internacional recaindo sobre o Estado ao qual estas autoridades pertencem."64 (tradução nossa)

Além de adotar a teoria da culpa, o texto no seu artigo 5 adotava a primazia do direito internacional ${ }^{65}$, atribuindo a responsabilidade independente das disposições do direito interno do Estado.

Outra entidade com trabalhos na área é o Institut de Droit International ${ }^{66}$, cuja Resolução de 1927 sobre a "Responsabilidade Internacional dos Estados em razão dos danos causados em seu território às pessoas e aos bens estrangeiros", traz no seu bojo um anteprojeto de artigos sobre o tema. Composta por 12 artigos, a Resolução estabelece no seu artigo primeiro que: "O Estado é responsável pelos danos que causa aos estrangeiros por toda ação ou omissão contrária às suas obrigações internacionais, qualquer que seja a autoridade do Estado da qual ela proceda: constituinte, legislativa, governamental ou judiciária." 67

Ainda no seu artigo primeiro, a Resolução prevê:

\footnotetext{
64 A State is responsible for injuries suffered by aliens within its territories, in life, person or property through wilful act, default or negligence of the official authorities in the discharge of their official functions, if such act, default or negligence constitutes a violation of international duty resting upon the State to which the said authorities belong. (Draft code of international law, adopted by the Japanese branch of the International Law Association and the Kokusaiho Gakkwai 'International Law Association of Japan' Protection apud ONU, Yearbook of the International Law Commission, p. 141, 1969)

${ }^{65}$ A State cannot evade the responsibility established by the present Rules for reasons of its own constitutional law or practice. (ibid, p. 141, 1969)

${ }^{66}$ Associação científica fundada em 8 de setembro de 1873 na Bélgica. Ganhadora do prêmio Nobel da Paz em 1904. Informações disponíveis em: http://www.idi-iil.org/. Acesso em 11 de ago. 2010.

${ }^{67}$ L'Etat est responsable des dommages qu'il cause aux étrangers par toute action ou omission contraire à ses obligations internationales, quelle que soit l'autorité de l'Etat dont elle procède : constituante, législative, gouvernementale ou judiciaire. (INSTITUT DE DROIT INTERNATIONAL, Lausanne, 1927, disponível em : http://www.idi-iil.org/idiF/resolutionsF/1927 lau 05 fr.pdf, acesso em : 10, ago, 2010)
} 
Essa responsabilidade do Estado não existe se a inobservância da obrigação não é consequência de uma ação culposa por parte de seus órgãos, a menos que, nos casos em que se trata de uma regra convencional ou costumeira, especial em relação à matéria, se admita a responsabilidade sem culpa. ${ }^{68}$ (tradução nossa)

Segundo Garcia Amador, em seu curso na Academia de Haia sobre o tema ( p. 390-392, 1958), o texto do Instituto tenta conciliar duas escolas diferentes, a que defende a teoria da culpa na responsabilidade internacional, e a que defende a "responsabilidade absoluta". Para este autor, entretanto: "A proposta do instituto, por sua vez, além de ter substancialmente o mesmo defeito, não prevê os casos de 'responsabilidade sem culpa' que são mais frequentemente encontrados na prática."

O texto da Resolução também propõe que os Estados devem aplicar aos estrangeiros as mesmas medidas de proteção que aplica aos nacionais (artigo 4) e atribui responsabilidade ao Estado no caso de denegação de justiça (artigos 5 e 6).

Esta mesma entidade elaborou, ainda, mais 3 resoluções relevantes, tratando de pontos específicos da responsabilidade internacional. Em 1956, na Sessão de Grenada, a Resolução sobre a Regra de Exaustão dos Remédios Locais; em 1965, na Sessão de Varsóvia, a Resolução sobre o Caráter Nacional de uma Reclamação Internacional apresentada por um Estado por dano sofrido por um indivíduo; e a Resolução sobre obrigações erga omnes no Direito Internacional, adotada na sessão de Cracóvia, que trata da responsabilidade do Estado por violação a uma obrigação erga omnes, e que reconhece a possibilidade de aplicação de contramedidas por qualquer Estado em relação ao qual a obrigação é devida ${ }^{69}$, ou seja, no caso de uma obrigação erga omnes ${ }^{70}$, a qualquer Estado parte da Comunidade Internacional ou do tratado multilateral descumprido.

A Deutsche Gesellschaft fur Volkerrecht (Sociedade Alemã de Direito Internacional) também elaborou, em 1930, um anteprojeto específico sobre a

\footnotetext{
${ }^{68}$ Cette responsabilité de l'Etat n'existe pas si l'inobservation de l'obligation n'est pas la conséquence d'une faute de ses organes, à moins que, dans le cas dont il s'agit, une règle conventionnelle ou coutumière, spéciale à la matière, n'admette la responsabilité sans faute. (ibid, art. 1)

${ }^{69}$ Should a widely acknowledged grave breach of an erga omnes obligation occur, all the States to which the obligation is owed: (...)

(c) are entitled to take non-forcible counter-measures under conditions analogous to those applying to a State specially affected by the breach. (INSTITUT DE DROIT INTERNATIONAL, art.5, Krakow, 2005)

${ }^{70}$ For the purposes of the present articles, an obligation erga omnes is: (a) an obligation under general international law that a State owes in any given case to the international community, in view of its common values and its concern for compliance, so that a breach of that obligation enables all States to take action; or (b) an obligation under a multilateral treaty that a State party to the treaty owes in any given case to all the other States parties to the same treaty, in view of their common values and concern for compliance, so that a breach of that obligation enables all these States to take action. (ibid, art. 1)
} 
responsabilidade internacional dos Estados, composto por 18 artigos. O seu artigo 1 estabelece:

Todo Estado é responsável perante outros Estados pelo dano causado em seu território à pessoa ou propriedade de estrangeiros como consequência de uma violação por este Estado de uma de suas obrigações perante o outro Estado segundo as normas de Direito Internacional. ${ }^{71}$ (tradução nossa)

A responsabilidade internacional, para este instituto alemão, seria, então, devida exclusivamente a um Estado, e apenas por uma violação a uma obrigação que o estado responsabilizado tivesse diante deste.

Um ponto a se destacar neste projeto é o reconhecimento, no seu artigo $16^{72}$, da possibilidade de adoção de medidas de legítima defesa caso o Estado responsável se recusasse a participar dos procedimentos de solução de disputas. Essas medidas de legítima defesa deveriam respeitar os princípios da necessidade e da proporcionalidade.

A expressão "medidas de legítima defesa" é então utilizada para descrever medidas tomadas por um Estado, diante de um ato internacionalmente ilícito de outro Estado. Tendo em vista que este ato ilícito não constitui uma agressão armada, e sim o descumprimento de uma obrigação internacional que traga prejuízo a um estrangeiro, tais medidas não podem ser consideradas como legítima defesa, tal como o instituto é entendido atualmente (art. 51 da Carta da Nações Unidas ${ }^{73}$ ). Tais medidas seriam então, se lícitas: retorsões; e se ilícitas, caso não estivessem sendo tomadas em resposta a um outro ato ilícito: contramedidas, o objeto de estudo deste trabalho.

\footnotetext{
71 1. Every State is responsible to other States for injury caused in its territory to the person or property of aliens as a consequence of the violation by that State of any of its obligations towards the other State under international law. (Draft convention on the responsibility of States for injuries caused in their territory to the person or property of aliens, prepared by the Deutsche Gesellschaft fur Volkerrecht apud ONU, Yearbook of the International Law Commission, p. 149, 1969)

72 Article 16: 1. Unless otherwise provided in special agreements between individual States, such States undertake to refer any disputes concerning the interpretation and application of this Convention to commissions of inquiry, settlement boards, arbitral tribunals or the Permanent Court of International Justice, and to take measures of self-defence only if the other party refuses such a settlement of the disputes. 2. Measures of self-defence shall not exceed the bounds of necessity and shall not be disproportionate to the injury. In the event of disagreement on whether this is the case, the States shall endeavour to settle the disagreement by peaceful means. (ibid, p. 151, 1969)

73 Artigo 51: Nada na presente Carta prejudicará o direito inerente de legítima defesa individual ou coletiva no caso de ocorrer um ataque armado contra um Membro das Nações Unidas, até que o Conselho de Segurança tenha tomado as medidas necessárias para a manutenção da paz e da segurança internacionais. As medidas tomadas pelos Membros no exercício desse direito de legítima defesa serão comunicadas imediatamente ao Conselho de Segurança e não deverão, de modo algum, atingir a autoridade e a responsabilidade que a presente Carta atribui ao Conselho para levar a efeito, em qualquer tempo, a ação que julgar necessária à manutenção ou ao restabelecimento da paz e da segurança internacionais. (São Francisco, 1945)
} 
Devemos mencionar, ainda, o trabalho da Harvard Law School, que produziu dois anteprojetos de artigos sobre a responsabilidade internacional dos Estados. O primeiro anteprojeto, de 1929, foi elaborado tendo em vista a Conferência de Codificação, a ter lugar em Haia, em 1930. O texto, composto por 18 artigos, estabelece no seu artigo $1^{\circ}$ : "Um Estado é responsável, como o termo é utilizado nesta convenção, quando ele tem o dever de reparar a outro Estado pelo dano sofrido por este último, em consequência de um dano sofrido por um de seus nacionais. ${ }^{74}$ (tradução nossa)

Assim, neste primeiro anteprojeto de Harvard, a responsabilidade surge vinculada a reparação e o dano é um dos seus pressupostos.

O documento descreve, também, hipóteses em que o Estado seria considerado responsável e outras em que o Estado não seria considerado responsável. Dentre seus artigos, podemos destacar o 17, que determina:

Um Estado não é isento de responsabilidade por consequência de nenhuma provisão de sua própria lei ou de acordo com o estrangeiro que tente excluir essa responsabilidade ao tornar a decisão de suas cortes a decisão final; nem é o Estado isento de responsabilidade por qualquer renúncia feita pelo estrangeiro à proteção do Estado do qual ele é nacional. ${ }^{75}$ (tradução nossa)

Este artigo contém 3 pontos importantes. O primeiro, estabelece o princípio, que posteriormente seria consagrado na Convenção de Viena sobre o Direito dos Tratados de $1969^{76}$, segundo o qual um Estado não pode se escusar de suas obrigações internacionais com base em disposições do seu direito interno. Os outros dois dizem respeito à invalidade da cláusula Calvo para isentar um Estado de sua responsabilidade internacional.

Em 1956, a Comissão de Direito Internacional da ONU requereu à Harvard Law School que revisasse e atualizasse o anteprojeto de convenção apresentado em 1929. O resultado deste trabalho foi publicado em 1961, e segundo Ago (ONU, p. 128, 1969), vai além da simples revisão e atualização, constituindo na verdade, um novo anteprojeto.

\footnotetext{
${ }^{74} \mathrm{~A}$ state is responsible, as the term is used in this convention, when it has a duty to make reparation to another state for the injury sustained by the latter state as a consequence of an injury to its national. (HARVARD, p. 133, 1929)

${ }^{75}$ A state is not relieved of responsibility as a consequence of any provision in its own law or in an agreement with an alien which attempts to exclude responsibility by making the decisions of its own courts final; nor is it relieved of responsibility by any waiver by the alien of the protection of the State of which he is a national. (HARVARD, p. 135, 1929)

76 Artigo 27: Uma parte não pode invocar as disposições de seu direito interno para justificar o descumprimento de um tratado. Esta regra não prejudica o art. 46. (Viena, 1969)
} 
De fato, o novo documento continha 40 artigos, mais que o dobro dos 18 originais.

As diferenças entre os anteprojetos começam já no seu artigo 1, que pela nova versão disporia (HARVARD, p. 548, 1961):

Um Estado é internacionalmente responsável por um ato ou omissão os quais, segundo o Direito Internacional, é ilícita, é atribuível a este estado e causa um dano a um estrangeiro. O Estado que é responsável por tal ato ou omissão, tem o dever reparar ao estrangeiro prejudicado ou ao estrangeiro reclamando através dele, ou ao Estado que tem o direito de apresentar a reclamação em nome do reclamante individual. ${ }^{77}$ (tradução nossa)

Pelo novo texto, um ato, para ensejar a responsabilidade internacional teria que preencher 3 pressupostos: ser ilícito, atribuível ao Estado e causar um dano a um estrangeiro. A reparação passaria a ser uma consequência da responsabilidade e não um dos seus elementos. Ainda, no seu artigo 3, o texto de Harvard estabelecia as hipóteses em que um ato seria atribuível a um Estado ${ }^{78}$, dentre elas, quando este criasse um risco não razoável de dano através da ausência da devida diligência.

Outra inovação, o artigo $22^{79}$ estabelecia não só o direito do indivíduo reclamante de apresentar sua reclamação diretamente perante o Estado responsável (art. 22.1), mas também o direito deste indivíduo de apresentar diretamente, perante um tribunal internacional, a sua reclamação (art. 22.2). Por esta disposição, a responsabilidade internacional do Estado poderia ser invocada não apenas pelos Estados, mas também por indivíduos prejudicados, que teriam capacidade postulatória perante tribunais internacionais.

O anteprojeto de artigos publicado pela Harvard Law School foi estudado pelo Comitê Consultivo Legal Asiático Africano e pela Comissão de Direito Internacional da ONU, que o encomendou.

\footnotetext{
77 1. A State is internationally responsible for an act or omission which, under international law, is wrongful, is attributable to that State, and causes an injury to an alien. A State which is responsible for such an act or omission has a duty to make reparation therefor to the injured alien or an alien claiming through him, or to the State entitled to present a claim on behalf of the individual claimant.

78 1. An act or omission which is attributable to a State and causes an injury to an alien is "wrongful", as the term is used in this Convention: $(a)$ if, without sufficient justification, it is intended to cause, or to facilitate the causing of, injury; $(b)$ if, without sufficient justification, it creates an unreasonable risk of injury through a failure to exercise due care; (c) if it is an act or omission defined in Articles 5 to 12; or (d) if it violates a treaty. (HARVARD, p. 548-549, 1961)

79 1. A claimant is entitled to present his claim directly to the State alleged to be responsible.

2. A claimant is entitled to present his claim directly to a competent international tribunal if the State alleged to be responsible has conferred on that tribunal jurisdiction over such claim. (HARVARD, p. 578, 1961)
} 
Por último, podemos destacar o trabalho desenvolvido pelo III Congresso Hispano-Luso-Americano ${ }^{80}$, que em 1957, aprovou uma Resolução sobre a Responsabilidade do Estado por danos causados a estrangeiros, na qual recomendava a admissão da responsabilidade do Estado por danos causados a estrangeiros nos casos em que os direitos fundamentais dos estrangeiros sejam afetados; de denegação de justiça; ou se o dano provém de um ato contrário ao direito internacional. ${ }^{81}$

\subsubsection{Codificação sob os auspícios da Liga das Nações}

Também no âmbito da Liga das Nações, esforços foram feitos no sentido de codificar a responsabilidade internacional, sem que, no entanto, se conseguisse algum resultado.

A Assembleia da Liga das Nações adotou, em 22 de setembro de 1924, resolução na qual requeria ao Conselho a criação de um "comitê de especialistas" para elaborar uma lista provisória de temas do direito internacional, cuja regulação por meio de acordo internacional seria desejável.

O Comitê de especialistas para a Codificação Progressiva do Direito Internacional foi criado e na sua primeira sessão, em abril de 1925, estabeleceu uma lista provisória

\footnotetext{
${ }^{80}$ Congresso que antecedeu a formação do Instituto hispano-luso-americano. Mais informações em: http://www.ihladi.org. Acesso em: 14 de ago. 2010.

$811^{\circ}$. Recomendar que se admita la responsabilidad del Estado por daños y perjuicios causados a los extranjeros en su territorio, en los casos que a continuación se enumeran: a) Aquellos que afecten derechos fundamentales, entendiéndose por tales la discriminación con los extranjeros, es decir, el no reconocimiento de igualdad, con los nacionales para el goce y ejercicio de los derechos civiles, con las limitaciones previstas en la ley o en los tratados; si el daño causado a los extranjeros ha sido verificado por su especial condición de tales, o por ser nacionales de un Estado determinado; la negligencia por parte del Estado para prevenir o impedir un delito político contra un extranjero, o, si producido éste, sus autores resultan impunes por abandono de los deberes por parte del Estado. b) Si el extranjero que ha sufrido un perjuicio no encuentra amparo por parte del Estado debido a que le es rehusado el acceso a los tribunales para defender sus derechos, o si la decisión judicial definitiva resulta incompatible con las obligaciones que emanan de un tratado u otras obligaciones internacionales contraídas por el Estado. c) Si el daño sufrido por un extranjero proviene de un acto contrario al Derecho internacional, ya sea por acción u omisión del Estado, ya sea verificado por funcionario que ha actuado dentro de los límites de su competencia. (Resolution La Responsabilidad del Estado en los daños causados a extranjeros, Quito, 1957, disponível em: http://www.ihladi.org/resoluciones III.pdf. Acesso em 14 de ago. 2010.
} 
com 11 temas de direito internacional ${ }^{82}$, dentre eles a responsabilidade internacional do Estado por danos ao estrangeiro ${ }^{83}$. Para cada tema foi criado um subcomitê de trabalho. Na segunda Sessão, em Janeiro de 1926, o Comitê examinou o relatório dos subcomitês e selecionou 7 temas ${ }^{84}$, elaborando um questionário sobre cada um a ser circulado pelos Estados, membros ou não da Liga das Nações, para avaliar a opinião destes sobre a regulação internacional da matéria (Ago, p. 131, 1969). O questionário 4, que tratava da Responsabilidade Internacional do Estado por dano, em seu território, a pessoa ou a bens de estrangeiros continha a seguinte pergunta:

Se, e em quais termos seria possível elaborar uma convenção internacional por meio da qual fatos que possam envolver a responsabilidade internacional dos estados possam ser estabelecidos, e proibindo em tais casos recurso de medidas de coerção até que todos os meios possíveis de solução pacífica de disputas tenham sido exauridos. ${ }^{85}$ (tradução nossa)

Interessante notar que já no questionário preparatório da Convenção de Codificação a questão da possibilidade de adoção de medidas "coercitivas" aparece. Em seu Relatório, o Subcomitê sobre o tema ${ }^{86}$, afirma sobre o assunto: "Estados devem se comprometer a não recorrer no futuro a nenhuma medida de coerção até que todos os meios acima mencionados [de solução pacífica de disputas] tenham sido exauridos." 87 (tradução nossa)

\footnotetext{
${ }^{82}$ Nacionalidade, mar territorial, privilégios e imunidade diplomáticas, navios dos Estados empregados no comércio, extradição, responsabilidade do estado por danos causado em seu território a estrangeiros, regras sobre conferências internacionais e elaboração de tratados, pirataria, prescrição, exploração de produtos marinhos, e competência criminal dos Estados para crimes cometidos fora de seus territórios. (LIGA DA NAÇÕES, document C.275.192.V. In p. 14 American Journal of International Law, Special Supplement, Vol. 20, 1926)

${ }^{83}$ The Committee appoints a Sub-Committee to examine: 1) Whether, and in what cases, a state may be liable for injury caused in its territory to the person or property of foreigners; 2) Whether, and if so, in what terms, it would be possible to contemplate the conclusion of an international convention providing for the ascertainment of the facts which may involve the liability on the part of a state and forbidding in such cases recourses to measures of coercion before the means of pacific settlement have been exhausted. (ibid, p. 14,1926)

84 Nacionalidade; águas territoriais; privilégios e imunidades diplomáticas; responsabilidade internacional dos Estados por danos causados, em seu território, a pessoa ou propriedades de estrangeiros; procedimentos para conferência internacionais e para a conclusão e elaboração de tratados; pirataria; e exploração de produtos marítimos. (LIGA DAS NAÇÕES, document C.46.M.23.1926.V. In p. 19 American Journal of International Law, Special Supplement, Vol. 20, 1926)

${ }^{85}$ Whether and, if so, in what terms it would be possible to frame an international convention whereby facts which might involve the responsibility of States could be established, and prohibiting in such cases recourse to measures of coercion until all possible means of pacific settlement have been exhausted. (ibid, p. 177,1926$)$

${ }^{86}$ Composto pelo Sr. Gustav Guerreiro e pelo Sr. Wang Chung-Hui.

${ }^{87}$ States must formally undertake not to resort in the future to any measure of coercion until all the abovementioned means have been exhausted (ibid, p. 103,1926)
} 
Na terceira Sessão, de Março a Abril de 1927 o Comitê analisou as respostas dadas aos questionários.

Em relação ao questionário tratando da responsabilidade internacional, 25 Estados se expressaram em favor da codificação da matéria sem nenhuma reserva ${ }^{88}, 5$ responderam afirmativamente, mas com alguma reserva ${ }^{89}$ e apenas 4 Estados foram contra uma convenção regulando este tema ${ }^{90}$.

O Comitê, após esta terceira Sessão, recomendou ao Conselho a organização de uma ou mais conferências para a formulação de tratados contendo disposições sobre os 7 temas escolhidos, dentre eles a responsabilidade dos Estados.

Em setembro de 1927 a Assembleia da Liga das Nações decidiu que a primeira Conferência de Codificação deveria ser convocada para examinar, entre outros temas, a "Responsabilidade dos Estados por Dano ocorrido em seu Território a Pessoas ou Propriedade estrangeiras".

Foi estabelecido um Comitê Preparatório para a Conferência de Codificação que se reuniu por três vezes. Na primeira Sessão, em Fevereiro de 1928, foram elaborados requerimentos de informações aos Estados. Na segunda Sessão, em Janeiro de 1929, foram examinadas as respostas enviadas pelos Estados as questões do programa proposto para a Conferência e com base nestas respostas elaboradas as bases para discussão. Na terceira Sessão, em maio, de 1929, estas bases de discussão foram revistas e foram adotadas em sua forma final.

As bases de discussão elaboradas pelo Comitê Preparatório sobre a Responsabilidade Internacional do Estado por Danos a Pessoa ou Propriedades estrangeiras possuíam 31 itens, que tratavam de princípios gerais ${ }^{91}$, de questões mais específicas $^{92}$, das circunstâncias que eximiam os Estados de responsabilidade ${ }^{93}$, do caráter nacional da reclamação ${ }^{94}$, da compensação pelos danos ${ }^{95}$ e da jurisdição, que em

\footnotetext{
88 Alemanha, Argentina, Austrália, Bélgica, Brasil, Reino Unido, Bulgária, Chile, Espanha, Estônia, Estados Unidos da América, Finlândia, Grécia, Índia, Noruega, Polônia, Portugal, Romênia, Salvador, Reino dos sérvios, Croatas e Eslovênios, Suécia, Suíça, Tchecoslováquia e posteriormente, Nova Zelândia e Haiti (LIGA DAS NAÇÕES, document C.196.M.70.1927.V, in p. 15-21, American Journal of International Law, Special Supplement, Vol. 22, 1928)

89 Áustria, Cuba, Dinamarca e Itália (ibid, p. 20-21)

${ }^{90}$ França, Japão, Holanda e Venezuela (ibid, p. 21)

91 Bases de discussão n. 2, 5, 6, 7, 12, 13, 14, 15, 16, 23. (LIGA DAS NAÇOES, document C.75.M.69.1929.V. In ONU, Yearbook of International Law Commission, p. 223-225, 1956)

92 Como: concessões ou contratos, n. 3 e 8; débitos, n. 4 e 9; privação de liberdade, n. 11; proteção insuficiente, n. 10, 17, 18, 19, 20; danos resultando de insurreições, motins e outros distúrbios, n. 21, 22, 22a, 22b, 22c, 22d. (Ibid, p. 223-225, 1956)

${ }_{93}$ Bases de discussão n. 1, 24, 25, 26 e 27. (Ibid, p. 223-225, 1956)

${ }^{94}$ Base de discussão n. 28( Ibid, p. 223-225, 1956)
} 
caso que falha dos meios de solução amigáveis, ficaria a cargo da Corte Permanente de Justiça Internacional (base de discussão n. 30).

Sem delimitar nenhuma regra geral de atribuição de responsabilidade ou definir a responsabilidade internacional de forma específica, as bases de discussão simplesmente elencavam diversos casos em que tal responsabilidade poderia ser atribuída a um Estado, através de um ato ou omissão por parte deste. Destacam-se duas bases de discussão; A base de discussão n.1, que estabelece que: "Um Estado não pode escapar da sua responsabilidade de acordo com o Direito Internacional invocando as provisões do seu direito interno."96 (tradução nossa)

E a que estabelece que: "Um Estado não é responsável por dano causado a um estrangeiro se prova que agiu em circunstâncias justificando o exercício de represálias contra o Estado ao qual o estrangeiro pertence." ${ }^{97}$

Aqui, ainda que não se trate de utilização de contra-medida em razão da responsabilidade internacional do Estado, ao menos se reconhece a legalidade das mesmas, que seriam uma "excludente de ilicitude", eximindo o estado de responsabilidade na esfera internacional.

Após os trabalhos preparatórios, a Conferência para Codificação do Direito Internacional, teve lugar, finalmente, em Haia, de 13 de março a 12 de abril de 1930. Um de seus objetivos era regular a responsabilidade internacional (ACCIOLY, 1959, p. 356). Porém, devido à grave crise econômica que assolava a Europa e os Estados Unidos, além das dificuldades políticas da época (ROSENNE, 1998) a Conferência acabou por fracassar nessa tarefa. Segundo Brierly ( p. 80, 1963):

Três temas foram colocados perante a Conferência, o direito de nacionalidade, das águas territoriais, e da responsabilidade por dano sofrido no território de um estado a estrangeiros. O trabalho preparatório tinha sido bem sucedido e a Conferência começou com grandes esperanças. Foi um grande fracasso. Acordos foram concluídos em apenas poucos pontos de menor relevância do direito da nacionalidade, e mesmo esses foram ratificados posteriormente por poucos Estados. (tradução nossa) ${ }^{98}$

\footnotetext{
${ }^{95}$ Base de discussão n. 29(Ibid, p. 223-225, 1956)

96 A State cannot escape its responsibility under international law by invoking the provisions of its municipal law. (ibid, p. 224, 1956)

97 A State is not responsible for damage caused to a foreigner if it proves that it acted in circumstances justifying the exercise of reprisals against the State to which the foreigner belongs. (ibid, p. 224, 1956)

${ }^{98}$ Three subjects were before the Conference, the law of nationality, of territorial waters, and of responsibility for damage done in the territory of a state to foreigners. The preparatory work had been thorough, and the Conference was entered on with high hopes. It was a dismal failure. Agreements were
} 
O tema da responsabilidade internacional ficou a cargo do Terceiro Comitê, que embora tenha discutido a questão profundamente e tenha mesmo adotado, em uma primeira leitura, um texto composto por 10 artigos, não foi capaz de chegar a nenhuma conclusão definitiva sobre o tema. De acordo com o Relator, na minuta do seu relatório:

No curso das discussões, o Comitê foi obrigado a reconhecer que o tempo designado para seu trabalho não era suficiente para permitir que este chegasse a uma conclusão em seus estudos, a qual ele perseguiu com tanta assiduidade. Na verdade, devido à natureza compreensiva e à extrema complexidade dos problemas levantados, ele só foi capaz de discutir 10 das 31 bases submetidas a ele. O fato, além do mais, de que várias das questões eram interdependentes, cada qual estando subordinada às outras, impediu qualquer tentativa de chegar a um acordo parcial. [...] Ele, assim, decidiu abster-se de qualquer esforço para colocá-las em uma fórmula definitiva. ${ }^{99}$ (tradução nossa)

Apesar de não adotado oficialmente, o texto elaborado pelo Comitê, composto por 10 artigos, foi estudado por doutrinadores e pela Comissão de Direito Internacional da ONU. O seu artigo primeiro continha uma regra geral que estabelecia: "Um estado incorre em responsabilidade internacional se há alguma incapacidade por parte de seus órgãos de cumprir obrigações internacionais do estado que causem danos à pessoa ou a propriedade de estrangeiros no território deste Estado." ${ }^{100}$ (tradução nossa)

Tal responsabilidade internacional, resultava, ainda, num dever de reparação do dano (artigo $3^{101}$ ) e não poderia ser afastada pela invocação do seu direito interno (artigo $\left.5^{102}\right)$.

reached on only a few minor points on the law of nationality, and even these were ratified afterwards by very few states.

${ }^{99}$ In the course of its discussions, the Committee was obliged to recognize that the time assigned for its work was not sufficient to allow it to bring to a conclusion the studies which it had pursued with such assiduity. In point of fact, owing to the comprehensive nature and extreme complexity of the problems raised, it was only able to discuss ten out of the thirty-one bases submitted to it. The fact, moreover, that the various questions were closely interdependent, each being subordinated to the others, precluded any attempt to reach a partial settlement. The Committee accordingly, though in agreement as to certain fundamental principles, was unable, owing to lack of time, to determine the exact limits of their application. It therefore decided to refrain from any endeavour to embody them in definite formulae. (LIGA DAS NAÇÕES, document C.351(c)M.145(c).1930.V. apud ONU, Yearbook of International Law Commission, p. 178, 1956)

${ }^{100}$ International responsibility is incurred by a State if there is any failure on the part of its organs to carry out the international obligations of the State which causes damage to the person or property of a foreigner on the territory of the State. (ibid, p. 225, 1956)

101 The international responsibility of a State imports the duty to make reparation for the damage sustained in so far as it results from failure to comply with its international obligation. (ibid, p. 225, 1956) ${ }^{102}$ A State cannot avoid international responsibility by invoking (the state of) its municipal law. (ibid, p. $225,1956)$ 
Após a Conferência de Haia, a Liga das Nações não promoveu mais nenhum esforço no sentido de codificar a responsabilidade internacional do Estado.

1.3.2 $\mathrm{O}$ anteprojeto sobre a responsabilidade internacional do Estado da CDI

\subsubsection{A Comissão de Direito Internacional da ONU}

Com o advento da Segunda Guerra Mundial, a Liga das Nações deixou de funcionar, de fato. Após a Segunda Guerra ela foi substituída pela Organização das Nações Unidas, constituída pela Carta das Nações Unidas, assinada em São Francisco, em 26 de junho de 1945.

Esta Carta, no seu Artigo 13 estabelece:

Art.13

1. A Assembleia-Geral iniciará estudos e fará recomendações, destinados a:

a) promover cooperação internacional no terreno político e incentivar o desenvolvimento progressivo do direito internacional e a sua codificação. (SÃO FRANCISCO, 1945)

Visando o cumprimento deste artigo, a Assembleia-Geral da ONU criou, através da Resolução 174, de 21 de novembro de 1947, a Comissão de Direito Internacional, que tem como atribuições, de acordo com o Artigo $1^{\circ}$ do seu Estatuto:

Artigo $1^{\circ}$

1. A Comissão de Direito Internacional deve ter como objeto a promoção do desenvolvimento progressivo do direito internacional e a sua codificação.

2. A Comissão deve se preocupar primariamente com o direito público internacional, mas não está proibida de entrar no campo do direito internacional privado. ${ }^{103}$ (tradução nossa)

A Comissão é atualmente formada por 34 membros $^{104}$, eleitos pela Assembleia Geral da ONU, de uma lista apresentada pelos Estados Membros desta organização. A

\footnotetext{
${ }^{103}$ 1. The International Law Commission shall have for its object the promotion of the progressive development of international law and its codification.

2. The Commission shall concern itself primarily with public international law, but is not precluded from entering the field of private international law.
} 
composição deve obedecer a uma distribuição geográfica baseada em grupos regionais ${ }^{105}$ e os mandados são de 5 anos ${ }^{106}$, renováveis. ${ }^{107}$

Os métodos de trabalho da Comissão variaram ao longo da sua existência, porém sua estrutura principal continua a mesma. Para cada tema a ser estudado é designado um Relator Especial, encarregado de apresentar Relatórios que serão examinados pela CDI em suas sessões. Esses Relatórios, usualmente, contem propostas de artigos sobre o tema, que devem ser debatidos um a um pela CDI em suas reuniões. Durante as discussões, podem ser apresentadas propostas de alteração ou mesmo fórmulas alternativas para os artigos em pauta.

Depois das considerações sobre um determinado artigo, a Comissão, o encaminha, com as sugestões e propostas pertinentes, ao Comitê de Redação (Drafting Committee). O "Drafting Committee" é um Comitê encarregado de preparar o texto dos artigos propostos para serem considerados pela CDI. Este Comitê deve encontrar soluções não só sobre questões de redação ou terminologia, mas algumas vezes também sobre questões substanciais em relação às quais a Comissão não alcançou consenso em seus debates.

O texto dos artigos adotados pelo Drafting Committee é submetido a CDI, que os discute novamente, uma a um. Os artigos são postos a votação, e aqueles adotados são incluídos no Relatório da CDI à Assembleia Geral. Este Relatório é apresentado e debatido no âmbito do Sexto Comitê da Assembleia Geral da ONU, o principal fórum de discussão das questões legais da Assembleia Geral.

\footnotetext{
${ }^{104} \mathrm{O}$ número de membros originalmente estabelecido pela Resolução era de 15. O estatuto da CDI foi reformado inúmeras vezes alterando esta composição. A última alteração, feita pela Resolução 36/39 de 1981, determinou a composição atual.

${ }^{105}$ A distribuição geográfica foi inserido no Estatuto pela Resolução 36/39 de 1981.

${ }^{106}$ A duração do mandato originalmente era de 3 anos. O Estatuto foi alterado pela Resolução 985 (X) de 1955 para a duração atual.

${ }^{107}$ Resolução 174, artigos 2,3,9 e 10, conforme alterada posteriormente.. Mais informações em: http://www.un.org/law/ilc/. Acesso em 13 de ago. 2010.
} 
Quando os artigos de um anteprojeto preliminar são adotados pela Comissão, o anteprojeto é submetido à apreciação dos Estados, para que estes façam comentários. O texto também é discutido pelo Sexto Comitê da Assembleia Geral.

Após estes comentários, o anteprojeto volta a ser examinado pela CDI, à luz dos comentários feitos pelos governos e pelo Sexto Comitê. Os artigos são, mais uma vez, discutidos um a um. Quando, finalmente, um anteprojeto final de artigos é adotado pela CDI, esta o submete, com suas recomendações, à Assembleia Geral, que pode devolvêlos a Comissão ou aceitá-los como final e decidir o seu destino (CDI, p. 241-243, 1968). Mesmo adotando um procedimento longo e complexo, a CDI foi de grande importância para a codificação do Direito Internacional. Nas palavras de Soares (2002, p. 87-88):

\begin{abstract}
Não deixa de ser impressionante a lista das realizações da CDI [Comissão de Direito Internacional]. Foi ela responsável pela adoção das mais importantes convenções multilaterais da atualidade, como as quatro Convenções de Genebra de 1958 sobre alguns aspectos do Direito do Mar, as já citadas Convenções de Viena sobre Relações Diplomáticas e sobre Relações Consulares, respectivamente de 1961 e 1963, a de Viena sobre Direito dos Tratados de 1969, a Convenção sobre Missões Especiais de New York de 1969, o Estatuto do Tribunal Penal Internacional, [...]
\end{abstract}

\title{
1.3.2.2 Trabalhos preparatórios da Comissão de Direito Internacional da ONU ${ }^{108}$
}

A Comissão de Direito Internacional da ONU, (doravante denominada apenas CDI), retomou os trabalhos de codificação do Direito Internacional, deixados inacabados pela Liga das Nações. Já em sua primeira Sessão, em 1949, a CDI elaborou uma lista provisória com 14 tópicos cuja codificação seria desejável. Dentre eles, a responsabilidade internacional do Estado.

\footnotetext{
108 Tendo em vista o extensor trabalho realizado sobre a responsabilidade internacional do Estado pela $\mathrm{CDI}$, tratando de seus mais diversos aspectos, cabe aqui fazer um corte metodológico. O trabalho da CDI será analisado dando-se ênfase a definição de responsabilidade internacional em si, ao desenvolvimento do conceito de violações graves decorrentes de normas imperativas de direito internacional geral, tendo em vista a sua relação com violações a normas de direitos humanos, e ao tratamento do instituto das contramedidas, objeto principal deste trabalho. Os demais aspectos da responsabilidade internacional serão tratados apenas de forma geral, de modo a contextualizar os estudos realizados pela CDI.
} 
A Assembleia-Geral da ONU, por seu turno, em sua oitava Sessão, em 1953, aprovou a Resolução 799 (VIII), segundo a qual: "Requer que a Comissão de Direito Internacional, assim que esta considerar aconselhável, se encarregue da codificação dos princípios de direito internacional governando a responsabilidade do Estado." 109 (tradução nossa)

Tomando nota desta Resolução, a CDI, em sua sexta Sessão, em 1954, decide se encarregar do estudo dos princípios governando a responsabilidade dos Estados. Nesta mesma sessão o memorandum apresentado por Garcia Amador foi considerado, porém devido ao grande número de questões incluídos na sua agenda, o estudo da matéria não pode ser iniciado.

Já neste primeiro memorandum Garcia Amador (ONU p. 24, 1954), ao tratar do escopo do mandato dado pela Resolução da Assembleia Geral, apesar de reconhecer que este se referia apenas à "responsabilidade civil" do Estado, estando a "responsabilidade penal" excluída ${ }^{110}$, atestava a necessidade de estudar esta "responsabilidade penal", ainda que somente pelas consequências que esta poderia trazer em relação à "responsabilidade civil".

\subsection{Trabalho realizado pelo Relator Especial Garcia Amador (1956-1961)}

Na sua sétima Sessão, em 1955, a CDI apontou Garcia Amador como Relator Especial para o tema da responsabilidade do Estado.

O Relator apresentou seu relatório inicial durante a oitava Sessão da CDI, em 1956. Seguindo a linha do memorandum apresentado em 1954, o Relator mencionava dois tipos de responsabilidade internacional: a responsabilidade civil e a responsabilidade penal. Segundo este (ONU, p. 219,1956):

Atos e omissões que são meramente ilegais apenas comportam o dever de reparação stricto sensu, enquanto a responsabilidade por um ato punível implica em uma sanção, a saber, a punição da parte culpada, sem prejuízo da reparação do dano, onde aplicável. ${ }^{111}$ (tradução nossa)

\footnotetext{
109 Requests the International Law Commission, as soon as it considers it advisable, to undertake the codification of the principles of international law governing State responsibility.

${ }^{110}$ Los antecedentes de la resolution 799 (VIII), tanto como los debates en la Sexta Comision

durante el octavo periodo de sesiones de la Asamblea General, permiten suponer que la responsabilidad penal cae fuera del proposito de la petition de la Asamblea. (GARCIA AMADOR in Yearbook of International Law Comission, p. 24, 1954)

111 Acts or omissions which are merely unlawful only comport the duty to make reparation stricto sensu,
} 
Sobre a responsabilidade criminal do Estado Garcia Amador escreve (ONU p. $183,1956)$ :

Por outro lado, certas violações aos direito fundamentais dos estrangeiros (se a violação é tão séria que corresponde ou é análoga ao que é conhecido como 'crime contra a humanidade'), além de ser ilegal, agora envolve responsabilidade internacional de caráter criminal. $^{112}$ (tradução nossa)

Assim, segundo o Relator Especial, em seu primeiro relatório, a responsabilidade internacional do Estado estaria dividida em responsabilidade civil, quanto um ato é meramente ilegal em relação ao Direito Internacional, e responsabilidade penal, quando este responsabilidade é agravada, implicando em sanções internacionais. Exemplos de crimes internacionais seriam violações graves aos direitos fundamentais de estrangeiros.

Nessa linha, para Garcia Amador (ONU p. 220, 1956):

O propósito de reparação não é necessariamente somente a restituição ou compensação pelo dano material. Medidas de 'reparação' podem ter também uma função punitiva. Em tais casos, a medida em questão deve ser considerada como uma penalidade, aplicável a parte culpada do ato que deu lugar à responsabilidade. ${ }^{113}$ (tradução nossa)

Sobre as contramedidas ou represálias, a única menção do Relator seria para negar a estas a capacidade de exonerar um Estado da responsabilidade internacional (ONU, p. $208,1956)^{114}$.

Já em relação aos direitos humanos, o Relator menciona a existência de dois grandes princípios, o princípio da igualdade entre nacionais e estrangeiros (ONU, p. 201, 1956) e o princípio de um "padrão internacional de justiça" (ONU, p. 199-200, 1956).

\footnotetext{
whereas the responsibility for a punishable act implies a sanction, namely the punishment of the guilty party, without prejudice to the reparation of the injury, where applicable. (GARCIA AMADOR, in Yearbook of International Law Commission, p. 219, 1956)

112 On the other hand, certain violations of fundamental human rights of foreigners (if the violation is so serious that it corresponds or is analogous to what is now known as a "crime against humanity"), besides being wrongful, now involve international responsibility of a criminal character.

113 The purpose of reparation is not necessarily solely restitution or compensation for material damage.

"Reparation" measures may also have a punitive function. In such cases the measures in question should be regarded as a penalty, applicable to the party guilty of the act giving rise to responsibility.

${ }^{114}$ It will be seen how difficult it would be to accept today this view that reprisals may constitute grounds for exoneration from responsibility.
} 
Para o Relator, estes dois princípios, a primeira vista antagônicos, poderiam se reconciliar formando um novo princípio. Em suas palavras (ONU, p.203, 1956): “A base deste novo princípio seria 'o respeito universal por, e a observância dos direitos humanos e liberdades fundamentais' referidos na Carta das Nações Unidas e em outros instrumentos gerais, regionais e bilaterais." 115

Garcia Amador, ainda, reconhecia a capacidade ativa e passiva dos indivíduos de estarem sujeitos á responsabilidade internacional, e na condição de sujeitos passivos, a capacidade de fazer uma reclamação internacional pelos danos sofridos (ONU, p. 220, 1956).

Este Relatório foi discutido pela CDI nas reuniões n. 370 a 373 da sua $8^{\text {a }}$ Sessão. Apesar de devidamente apreciado, diversas diferenças de opinião surgiram em temas como a responsabilidade penal do Estado ${ }^{116}$ e a capacidade do indivíduo de possuir direitos internacionais subjetivos e de trazer reclamações em seu próprio nome perante os tribunais internacionais ${ }^{117}$. Reservas também foram feitas em relação à possibilidade de utilizar a violação a um direito humano fundamental como critério para estabelecer a responsabilidade internacional por dano a estrangeiros ${ }^{118}$. Outro ponto discutido foi questão da responsabilidade objetiva e da responsabilidade por culpa. Alguns membros da Comissão se posicionaram a favor de limitar o tema da responsabilidade internacional, tratando apenas da questão em relação aos danos causados a estrangeiro $^{119}$. Os debates, que haviam sido intensos, não chegaram a nenhuma conclusão definitiva sobre as bases de discussão propostas.

Em 1957, o Relator apresentou seu segundo Relatório sobre o tema. Tendo em vista as controvérsias levantadas pelo primeiro relatório, neste segundo, Garcia Amador se limitou a tratar do tema "Responsabilidade Internacional do Estado por Danos a Pessoa ou Propriedades estrangeiras". A questão da responsabilidade penal foi deixada de lado, assim como as questões de caráter procedimental (ONU, p. 105, 1957). O relatório foi apresentado na forma de um anteprojeto, composto por 12 artigos, acompanhado por comentários feitos pelo Relator. O seu artigo 1, estabelecia:

\footnotetext{
115 The basis of this new principle would be the " universal respect for, and observance of, human rights and fundamental freedom" referred to in the Charter of the United Nations and in other general, regional and bilateral instruments.

${ }^{116}$ Fitzmaurice, François, Scelle, Amado, Krylov, Sandstrom, contra; el-Khouri a favor (CDI, p. 228, et seq. 1956a).

${ }^{117}$ Spiropoulos, Salamanca, Pal, Zourek contra; Scelle a favor. (ibid p. 228, et seq. 1956a)

${ }^{118}$ El_Khouri, François, Fitzmaurice, Zourek contra. (ibid p. 228, et seq. 1956a).

${ }^{119}$ Fitzmaurice e Hsu (ibid p. 228, et seq. 1956a).
} 
Para os propósitos deste anteprojeto, a 'responsabilidade internacional de um Estado por danos causados em seu território à pessoa ou a propriedade de estrangeiros' envolve o dever de reparar tais danos, se esses são consequência da algum ato ou omissão por parte de seus órgãos ou oficiais que violam as obrigações internacionais do Estado. ${ }^{120}$ (tradução nossa)

Este primeiro artigo, embora lembrasse o artigo elaborado pela Harvard Law School em 1929, anteriormente citado, se diferenciava deste na media em que não equiparava a responsabilidade internacional simplesmente à obrigação de reparar, pois, nas palavras do Relator (ONU, p.105, 1957):

o direito internacional não justifica a assimilação da responsabilidade ao 'dever de reparar', pura e simples, porque existem certas obrigações de não observância as quais envolvem, além da responsabilidade civil no sentido estrito do termo, alguma responsabilidade criminal e a consequente punição do autor do dano. ${ }^{121}$ (tradução nossa)

Adotando, esta definição, Garcia Amador também evitava adentrar na questão das teorias da culpa e do risco, que haviam dado lugar a extensos debates na CDI (ONU, p. 106, 1957).

O capítulo III do anteprojeto, composto por 2 artigos, tratava da violação de direito humanos fundamentais. $\mathrm{O}$ artigo 5, parágrafo 1, prescrevia:

1. O Estado está sob o dever de assegurar aos estrangeiros o gozo dos mesmos direitos civis e de disponibilizar a eles as mesmas garantias que são asseguradas aos seus próprios nacionais. Estes direitos e garantias não podem, entretanto, em qualquer caso, serem menores que os 'direitos humanos fundamentais' reconhecidos e definidos nos instrumentos internacionais contemporâneos. ${ }^{122}$ (tradução nossa)

\footnotetext{
${ }^{120} 1$. For the purposes of this draft, the "international responsibility of the State for injuries caused in its territory to the person or property of aliens " involves the duty to make reparation for such injuries, if these are the consequence of some act or omission on the part of its organs or officials which contravenes the international obligations of the State.

${ }^{121}$ international law does not justify the assimilation of the notion of responsibility to the " duty to make reparation ", pure and simple, because there exist certain obligations the non-observance of which involves, besides civil responsibility in the strict sense of the term, some criminal responsibility and the consequent punishment of the author of the injury

${ }^{122}$ ARTICLE $5: 1$. The State is under a duty to ensure to aliens the enjoyment of the same civil rights, and to make available to them the same individual guarantees as are enjoyed by its own nationals. These rights and guarantees shall not, however, in any case be less than the " fundamental human rights " recognized and defined in contemporary international instruments.
} 
Este artigo incorporava em seu bojo os princípios de direitos humanos reconhecidos em seu Relatório anterior.

O primeiro, seria o da igualdade de tratamento entre nacionais e estrangeiros, reconhecido pelas Conferências Internacionais dos Estados Americanos, mencionadas, e pelos anteprojetos de codificações apresentados por diversas entidades privadas.

O segundo princípio seria a síntese do novo princípio de direitos humanos, mencionado por Garcia Amador no documento de 1956, reconhecendo a existência de padrões mínimos de direito humanos, tal como reconhecidos pelo direito internacional contemporâneo.

Tais padrões mínimos deveriam ser respeitados, tanto em relação aos estrangeiros quanto em relação aos seus nacionais. No entanto, somente o desrespeito a estes em relação aos estrangeiros é que ensejaria a responsabilidade internacional do Estado.

É o que estabelece o parágrafo 2 do artigo 5 (ONU, p. 113, 1957): "Em consequência, em caso de violação dos direitos civis, ou desconsideração das garantias individuais, com relação aos estrangeiros, a responsabilidade internacional será envolvida apenas se 'direitos humanos fundamentais' reconhecidos forem afetados." "123 (tradução nossa)

O artigo 6 deste capítulo (ONU, p. 113, 1957), possuía um rol, não exaustivo, destes direitos humanos fundamentais, dentre eles: o direito à vida, à liberdade, e à segurança pessoal; à privacidade, garantido pela inviolabilidade de sua casa e correspondência; o direito à honra e reputação; o direito à liberdade de pensamento, consciência e religião; o direito à propriedade; ao reconhecimento como pessoa perante à lei; o direito ao recurso à justiça; à audiência pública, e diversos direitos em matéria criminal, como a presunções à inocência, à irretroatividade da lei penal, e a um julgamento rápido $^{124}$.

\footnotetext{
${ }^{123} 2$. In consequence, in case of violation of civil rights, or disregard of individual guarantees, with respect to aliens, international responsibility will be involved only if internationally recognized " fundamental human rights " are affected.

${ }^{124}$ Article 6: 1. For the purposes of the foregoing article, the expression " fundamental human rights" includes, among other, the rights enumerated below: (a) The right to life, liberty and security of person; (b) The right of the person to the inviolability of his privacy, home and correspondence, and to respect for his honour and reputation; (c) The right to freedom of thought, conscience and religion; (d) The right to own property; $(e)$ The right of the person to recognition everywhere as a person before the law; (f) The right to apply to the courts of justice or to the competent organs of the State, by means of remedies and proceedings which offer adequate and effective redress for violations of the aforesaid rights and freedoms; $(g)$ The right to a public hearing, with proper safeguards, by the competent organs of the State, in the determination of any criminal charge or in the determination of rights and obligations under civil
} 
Segundo o Relator, nem todos os direitos humanos são relevantes para a codificação da responsabilidade internacional (ONU, p. 113, 1957). Somente os direitos fundamentais, ou seja, aqueles (ONU, p. 115, 1957) “direitos e liberdades cujo caráter essencial ou fundamental parece estar além de qualquer dúvida" ${ }^{25}$ (tradução nossa) devem ser considerados.

Nos capítulos seguintes, o Relator trata do não cumprimento das obrigações contratuais e da expropriação (capítulo IV) e dos atos de indivíduos e distúrbios internos (capítulo V).

O Relatório apresentado foi discutido nas reuniões 413 a 416 e 418 da CDI. Mais uma vez, diversos pontos de discordância surgiram. Dentre os principais destaca-se a relutância de alguns membros da CDI em inserir a normas referentes a proteção de direitos humanos no âmbito da codificação ${ }^{126}$, quer seja por se tratarem de normas substantivas e não meramente procedimentais, que pela dificuldade de reconhecer que uma violação a direito humanos pudesse dar origem à responsabilidade internacional do Estado.

De fato, a posição de Garcia Amador, atualmente amplamente aceita no Direito Internacional, era, para época, inovadora. Basta lembrar que o Pacto Internacional sobre Direitos Civis e Políticos e o Pacto Internacional sobre Direitos Econômicos, Sociais e Culturais só seriam elaborados em 1966. Até então, afora algumas convenções específicas, a Declaração Universal, considerada de caráter não vinculante, era o único grande instrumento internacional de Direitos Humanos.

Outro ponto controverso foi o corte metodológico escolhido, tratando o tema da responsabilidade internacional, sob a perspectiva de um setor específico e não de forma geral, numa tentativa de evitar os pontos controversos da matéria ${ }^{127}$. Para alguns membros da CDI, questões importantes, como a teoria da culpa e do risco, não poderiam deixar de ser consideradas pela Comissão em seus estudos. Assim, na visão de Ago (p. 134, 1969): “A tentativa de evitar as dificuldades inerentes aos problemas da responsabilidade em geral, limitando-se a codificação da responsabilidade por violação

\footnotetext{
law; $(h)$ In criminal matters, the right of the accused to be presumed innocent until proved guilty; the right to be informed of the charge made against him in a language which he understands; the right to speak in his defence or to be defended by a counsel of his choice; the right not to be convicted of any punishable offence on account of any act or omission which did not constitute an offence, under national or international law, at the time when it was committed; the right to be tried without delay or to be released. 125 rights and freedoms whose essential or fundamental character appears to be beyond all doubt.

${ }^{126}$ Amado, Ago, Matine -Daftary, Edmonds, Khoman, François, Fitzmaurice, Tunkin, Zourek, Spiropoulos, El -Erian contra; Hsu e Yokota a favor. (CDI, p. 154 et seq., 1957a)

${ }^{127}$ Nesse sentido, em especial, a posição de Ago e Verdross (ibid, p. 154 et seq., 1957a)
} 
a obrigações relativas ao tratamento de estrangeiro, foi, deste modo, ilusória." ${ }^{28}$ (tradução nossa)

Durante a discussão sobre a responsabilidade dos Estados, a questão das represálias foi abordada. Ago defendia a possibilidade de adoção represálias por Estados que teriam um caráter de sanção podendo ser consideradas como uma consequência penal do ato internacionalmente ilícito (ONU, p. 170, 1957a). Esta posição, rejeitada por El-Erian, foi apoiada por Bartos e por Fitzmaurice (ONU, p.171, 1957a), que acrescentou que na ausência de um mecanismo que obrigasse um Estado a aderir aos meios pacíficos de solução de controvérsias "o recurso a sanções pacíficas continuaria uma forma legítima de reação" ${ }^{\text {129 }}$ (tradução nossa)

Apesar dos debates, a CDI não chegou a nenhuma decisão definitiva sobre os temas tratados, acabando por adiar a discussão para a Sessão seguinte, em 1958 (ONU, p.181, 1957a).

Tendo em vista a ausência de conclusões nos debates da CDI, o Relator, no ano seguinte, apresentou seu terceiro Relatório, contendo a continuação do anteprojeto de artigos apresentado em 1957. Aos 12 artigos apresentados anteriormente se somaram mais 13, compondo um anteprojeto de 25 artigos. Os novos artigos versavam sobre: a exoneração da responsabilidade e circunstâncias agravantes e atenuantes (capítulo VI), a exaustão dos remédios locais (capítulo VII), a submissão da reclamação internacional (capítulo VIII) e caráter e medidas de reparação (capítulo IX);

Em relação às causas de exoneração de responsabilidade, Garcia Amador (ONU, p. 55, 1958) reconhece apenas o estado de necessidade, a força maior e a culpa por parte do estrangeiro. Sobre as represálias, seguindo a linha de seus Relatórios anteriores, este apenas a reconhece como circunstância exonerando a responsabilidade se esta puder ser justificada pelo estado de necessidade.

A maior inovação apresentada pelo anteprojeto, entretanto, seria a consubstanciação, no capítulo que trata da submissão das reclamações internacionais, do direito do estrangeiro prejudicado de apresentar uma reclamação internacional

\footnotetext{
${ }^{128}$ The attempt to evade the difficulties inherent in the problems of responsibility in general by limiting the attempt at codification to responsibility for the violation of obligations concerning the treatment of aliens was therefore seen to be illusory.

${ }^{129}$ recourse to peaceful sanctions remained a legitimate form of counter-action
} 
diretamente a um órgão internacional, cuja competência seria atribuída pela futura convenção (artigo 19) ${ }^{130}$.

O direito do indivíduo de apresentar diretamente reclamações internacionais, ou seja, o reconhecimento da capacidade processual do indivíduo no plano internacional, mesmo na atualidade, se encontra limitada a determinados mecanismos de proteção aos direitos humanos e tribunais especializados. A proposta apresentada por Garcia Amador em 1958, mais uma vez, poderia ser considerada a frente de seu tempo.

A CDI, na sua $10^{\mathrm{a}}$ Sessão, tendo em vista os outros assuntos incluídos na pauta, não teve tempo de analisar o Relatório apresentado (ONU, p. 106, 1958). Os debates sobre a responsabilidade internacional foram adiados para a Sessão seguinte.

Em 1959 o Relator apresentou seu quarto Relatório. Dando continuidade aos seus estudos, o Relatório tratava com maior profundidade das questões tratadas no capítulo IV do seu anteprojeto de artigos, ou seja, a responsabilidade internacional por consequência de descumprimento de obrigações contratuais e atos de expropriação.

Analisando as novas tendências surgidas no Direito Internacional depois da Segunda Guerra, o Relatório, composto de 3 capítulos, tratava em seu capítulo I da proteção internacional dos direitos adquiridos, da expropriação em geral no seu capítulo II, e dos direitos contratuais no seu capítulo III (ONU, p. 2, 1959).

Em sua $11^{\mathrm{a}}$ Sessão, a CDI mais uma vez não pode examinar nem o quarto Relatório apresentado por Garcia Amador, nem os seus Relatórios precedentes. Os debates realizados sobre o tema da responsabilidade internacional, giraram em torno do anteprojeto preliminar de artigos elaborado pela Harvard Law School, então apresentados pelos seus representantes, Professor Sohn e Professor Baxter. Este anteprojeto, já mencionado, possuía diversos pontos em comum com o anteprojeto apresentado pelo Relator Especial em 1957 e 1958.

Além de tratar da responsabilidade internacional sob a perspectiva dos danos causados aos estrangeiros, o anteprojeto apresentado por Harvard também consagrava o direito do indivíduo de apresentar diretamente uma reclamação internacional. No entanto, enquanto o anteprojeto de Harvard previa a possibilidade de apresentar essa reclamação perante os tribunais internacionais, o anteprojeto do Relator previa o

\footnotetext{
${ }^{130}$ Article 19: 1 . The alien may submit an international claim to obtain reparation for the injury suffered by him to the body in which competence for this purpose has been vested by an agreement between the respondent State and the alien's State of nationality or between the respondent State and the alien himself. 2. If the body mentioned in the previous paragraph was established by an agreement between the respondent State and the alien, the authorization of the State of nationality shall not be necessary for the purpose of submitting the international claim. (CDI, p. 61, 1958)
} 
estabelecimento de um órgão internacional através de um acordo entre o Estado e o estrangeiro (ONU, p. 63, 1958). Em seus comentários (ONU, p. 547, 1961), Harvard também faz menção a padrões mínimos de direito internacional no tratamento de estrangeiros ${ }^{131}$, padrão este que poderia se referir a direitos humanos fundamentais.

O anteprojeto apresentado por Harvard, apesar de apreciado, enfrentou resistências nas discussões da CDI. Para alguns membros da Comissão, certas ideias e princípios adotados não encontrariam respaldo no Direito Internacional existente (ONU, p. 135, 1969).

Em 1960 Garcia Amador apresentou seu sexto Relatório sobre a responsabilidade internacional. O documento, dividido em 3 partes tratava, primeiramente, da continuação do trabalho sobre direitos adquiridos, mais especificamente das medidas que afetavam estes direitos. A segunda parte versava sobre os elementos constituintes da responsabilidade internacional. Já a terceira parte do Relatório trazia em seu bojo emendas e adições ao anteprojeto de artigos, apresentado anteriormente, fruto das considerações surgidas através dos novos estudos elaborados.

Ao tratar dos elementos constituintes da responsabilidade internacional o Relator menciona uma questão importante, a responsabilidade internacional por abuso de direito.

Em sua análise sobre o tema, o Relator ponderava se existiria algum tipo de responsabilidade internacional que não adviria da violação de uma obrigação internacional (ONU, p. 58, 1960). A questão surgia, a seu ver, devido às "lacunas e incertezas que ainda podiam ser encontradas neste complexo de normas"132 (tradução nossa) que seria o Direito Internacional.

Após mencionar doutrina, jurisprudência e a prática estatal reconhecendo o princípio da proibição do abuso de direito no plano internacional (ONU, p. 58-60, 1960), o autor conclui que tal princípio poderia ser amplamente utilizado no campo da responsabilidade internacional do Estado ${ }^{133}$ (ONU, p. 60, 1960).

\footnotetext{
${ }^{131}$ The draft Convention is based on the principle that the treatment of aliens is to be governed by an international minimum standard (Article 2).

${ }^{132}[\ldots]$ the lacunae and uncertainties which are still to be found within its complex of rules $[\ldots]$.

133 it is necessarily true that the doctrine of the abuse of rights finds its widest application in the context of " unregulated matters", that is, matters which " are essentially within the domestic jurisdiction " of States. In fact, as has been pointed out, even the most forceful opponents of the doctrine admit the possibility of the abusive exercise of this category of State rights. And in any field in which States necessarily enjoy wide discretionary powers the applicable principles are precisely those "principles of international law which govern the responsibility of the State" for injuries caused in its territory to the person or property of aliens.
} 
Dentre as hipóteses de utilização deste princípio o Relator cita, além do direito de expulsão, exemplo mais típico dado, o abuso ao direito de restringir certos direitos humanos e liberdades fundamentais em determinada situações. Em suas palavras (ONU, p. 60, 1960):

o Estado possui o direito de tomar medidas restringindo direitos humanos e garantias fundamentais por razões de segurança interna, do bem-estar econômico da nação, para assegurar a ordem, para proteger a saúde e a moral, etc. Consequentemente, onde este direito não é regulado por regras explícitas e exatas, a responsabilidade internacional na qual um Estado pode incorrer pela violação de direito humanos e liberdades fundamentais, em tais casos, seria apenas imputável nos termos de um injustificado e arbitrário i.e. 'abusivo' exercício do poder discricionário. ${ }^{134}$

Garcia Amador também menciona a possibilidade de utilizar a doutrina do abuso de direito para lidar com a questão dos testes nucleares (ONU, p. 65, 1960), tendo em vista a falta de regulação sobre a matéria à época.

Como conclusão, o Relator na terceira parte do seu Relatório sugere alterar o artigo 1 do anteprojeto para inserir um parágrafo 2 bis que menciona explicitamente a proibição do abuso de direito e consequentemente o coloca como capaz de ensejar a responsabilidade internacional (ONU, p. 66, 1960). ${ }^{135}$

A CDI, mais uma vez não conseguiu discutir este e os outros Relatórios apresentados por Garcia Amador em sua 12 ${ }^{\mathrm{a}}$ Sessão. As discussões sobre a responsabilidade internacional, ocorridas nas reuniões 566 e 568, giraram em torno do discurso do Sr. Gomez Robledo, observador do Comitê Jurídico Interamericano, que, como mencionado, também foi encarregado pela $10^{\mathrm{a}}$ Conferência Internacional dos Estados Americanos de estudar a responsabilidade internacional dos Estados, sob a ótica dos países do Continente Americano; e do discurso do Professor Sohn, que apresentou a nova versão do anteprojeto de artigos da Harvard Law School.

\footnotetext{
134 the State possesses the right to take measures restricting human rights and fundamental freedoms for reasons of internal security, the economic well-being of the nation, to ensure order, to protect health and morals, etc. Consequently, where this right is not governed by explicit and exact rules, the international responsibility which may be incurred by the State through a violation of human rights and fundamental freedoms in such cases will only be imputable on the grounds of an unjustified and arbitrary, i.e. " abusive ", exercise of the discretionary power.

1352 bis. The expression ' international obligation of the State' shall also include the prohibition of 'abuse of rights', which shall be construed to mean any act or omission contrary to the conventional or general rules of international law governing the exercise of the rights of the State."
} 
O Sr. Robledo mencionou o trabalho elaborado e as dificuldades encontradas pelos juristas americanos na tarefa de estudar a responsabilidade internacional. Esclareceu que o Comitê Jurídico Interamericano teria se limitado ao estudo das reclamações e que mesmo neste setor específico, diversas questões geravam polêmica. Sobre a posição dos Estados Americanos, mencionou que a doutrina de um padrão mínimo de justiça não era aceita pelos países Latino-Americanos, que defendiam o princípio da igualdade entre nacionais e estrangeiros (ONU, p. 265, 1960a) ${ }^{136}$. Adicionou (ONU, p. 267, 1967a), entretanto, que a proteção internacional aos direitos humanos estaria avançando e que:

Um padrão internacional de justiça mínimo seria estabelecido para os seres humanos em geral; em caso de violação do padrão estabelecido, a pessoa afetada, seja estrangeiro ou nacional, poderia apelar ao órgão competente internacional. Quando este processo estiver completo, a proteção diplomática deixará de existir como uma instituição legal distinta. ${ }^{137}$ (tradução nossa)

O Professor Sohn, por sua vez, apresentou o anteprojeto preliminar de artigos da Harvard Law School, contendo algumas alterações fruto das discussões ocorridas na $11^{\mathrm{a}}$ Sessão da CDI, alterações que não importavam em grandes modificações de fundo, no projeto.

Os debates da CDI giraram, mais uma vez, sobre o anteprojeto de artigos de Harvard. As críticas feitas a este documento pelos membros da Comissão, diziam respeito, em geral, aos pontos em comum entre este anteprojeto e o anteprojeto apresentado pelo Relator Especial, ou seja, a possibilidade de indivíduos apresentaram diretamente uma reclamação internacional ${ }^{138}$ e o tratamento da matéria de forma específica e não da responsabilidade internacional em geral ${ }^{139}$. A CDI, como em suas reuniões anteriores sobre o tema, não chegou a nenhuma conclusão definitiva sobre o tema.

\footnotetext{
${ }^{136}$ So far as the position of aliens was concerned, the doctrine of an international minimum standard of justice had been uniformly opposed in the Latin American countries, which observed the principle of the equality of nationals and aliens

${ }^{137}$ An international minimum standard of justice would be laid down for human beings in general; in case of violation of the standard thus laid down, the person concerned, whether alien or national, could appeal to the competent international body. When that process was completed, diplomatic protection would cease to exist as a distinct legal institution.

${ }^{138}$ Contra: Fitzmaurice, Verdross, Ago e Pal. (CDI, p. 264 et seq., 1960a)

${ }^{139}$ Contra: Verdross, Ago, Tunkin.(ibid, p. 264 et seq., 1960a)
} 
A relativa inércia da CDI no campo da responsabilidade internacional não passou desapercebida pela Assembleia Geral da ONU. Em sua 15ª Sessão, em 1960, o tema da responsabilidade internacional foi mais uma vez discutido por este órgão durante a consideração do Relatório Anual apresentado pela CDI. Neste momento, representantes dos Estados manifestaram seu pesar com o fato de que a CDI não teria encontrado tempo para realizar um estudo mais aprofundado sobre o tema, embora tivesse recebido cinco Relatórios do Relator Especial. Criticou-se, também, a decisão de limitar o estudo da responsabilidade a um campo específico, o que seria contrário ao espírito da Resolução 799 (VIII), e a decisão tomada pelo Secretariado da CDI de encomendar uma revisão do anteprojeto de artigos de 1929 à Harvard Law School. Diversos oradores expressaram a esperança de que a CDI pudesse apresentar à Assembleia um anteprojeto preliminar sobre a matéria a ser analisado na já na próxima Sessão.

Por recomendação do Sexto Comitê, a Assembleia Geral adotou a Resolução $1505^{140}(\mathrm{XV})$ na qual incluía na agenda da $16^{\mathrm{a}}$ Sessão a questão dos futuros trabalhos na codificação e desenvolvimento do direito internacional e convidava os Estados a submeterem suas opiniões e sugestões sobre o assunto, tendo em vista considerar relevante rever se novos tópicos seriam suscetíveis à codificação e a prioridade dada aos tópicos incluídos na lista da Comissão, ou a abordagem dada a estes tópicos.

Em 1961 Garcia Amador apresentou o sexto e último Relatório sobre a Responsabilidade Internacional. O texto, consagrado ao estudo da reparação, era composto por 3 capítulo, dos quais o primeiro tratava do dever de reparação, em si. O segundo versava sobre o dano e as formas e funções da reparação em geral. $\mathrm{O}$ terceiro capítulo era sobre a reparação por danos causados a estrangeiros. O texto também possui um anexo com a versão final do seu anteprojeto de artigos, após as alterações feitas devido aos estudos posteriores a 1958.

\footnotetext{
${ }^{140}$ Resolution 1505 (XV): The General Assembly, [...] Considering that it is desirable to survey the present state of international law, with a view to ascertaining whether new topics susceptible of codification or conducive to progressive development have arisen, whether priority should be given to any of the topics already included in the Commission's list or whether a broader approach may be called for in the consideration of any of these topics, [...]

1. Decides to place the question entitled 'Future work in the field of the codification and progressive development of international law' on the provisional agenda of its sixteenth session in order to study and survey the whole field of international law and make necessary suggestions with the regard to the preparation of a new list of topics for codification and for the progressive development of international law. (ONU, 1960, disponível em: http://daccess-ddsny.un.org/doc/RESOLUTION/GEN/NR0/152/79/IMG/NR015279.pdf?OpenElement. Acesso em 23 ago. 2010)
} 
Segundo o Relator, em seu último estudo, a reparação lato sensu abrangeria tanto a reparação stricto sensu como a satisfação. A satisfação seria uma forma de compensar os danos políticos e morais causados pelo Es tado. Um exemplo seriam os "julgamentos declaratórios" nos quais embora se reconhecesse que nenhum dano objetivo ou material ocorreu ou pudesse ser provado, determinava-se que o ato ou omissão do Estado teria sido considerado ilegal. (ONU, p. 15, 1961)

Já a reparação stricto sensu, seria a reparação do dano através de duas principais formas: a restituição, através da qual se restaura a propriedade ou o direito do estrangeiro que teria sido afetado, e o pagamento de indenização pelo dano causado.

Do trabalho apresentado, destaca-se a posição do Relator que defende o caráter muitas vezes punitivo da reparação de um dano causado a um estrangeiro. Para Garcia Amador (p. 37, 1961): “O seu propósito - a dizer, punir ou ao menos reprovar o Estado por sua conduta - tanto explícita como implicitamente, e assim, tentar prevenir a repetição de tais atos no futuro, é de fato, o mais característico e distinto traço deste modo de reparação. ${ }^{141,}$

Como destacado nos debates da CDI, o caráter punitivo da reparação diferenciaria a responsabilidade "civil" da responsabilidade "penal" no plano internacional. Assim, em seu último Relatório, Garcia Amador ainda mantém, ainda que indiretamente, a posição adotada em seus Relatórios anteriores sobre a existência de uma responsabilidade penal internacional.

Estando ocupada com o tema das relações e imunidade diplomáticas, a CDI mais uma vez não conseguiu discutir os Relatórios apresentados na sua $13^{\mathrm{a}}$ Sessão. $\mathrm{O}$ tema da responsabilidade internacional só foi tratado durante a apresentação final, pelo Professor Sohn, do anteprojeto de artigos sobre a responsabilidade internacional da Harvard Law School e durante as discussões sobre o trabalho futuro da Comissão, tendo em vista a Resolução 1505 da Assembleia Geral.

Nos debates sobre o futuro trabalho, diversos membros mencionaram a importância de continuar estudando a responsabilidade internacional do Estado. Muitos deles, no entanto, destacaram a necessidade de se estudar a responsabilidade internacional em geral e não um setor específico. ${ }^{142} \mathrm{O}$ imenso volume de trabalho a ser

\footnotetext{
${ }^{141}$ Its purpose - namely, to punish or at least to reprove a State for its conduct - either explicitly or implicitly, and thereby to try to prevent a repetition of such acts in the future, is in fact the most characteristic and distinctive feature of this mode of reparation.

${ }^{142}$ A favor: Vedross, Amado, Edmonds, Ago, Zourek,Gros, Padilha Nervo, Tunkin. Contra: Liang, Secretário da Comissão. (CDI, p. 206 et seq, 1961a)
} 
realizado e o pouco tempo disponível deram origens a discussões sobre os métodos de trabalho da CDI, porém nada ficou decidido a respeito.

Tendo em vista a não reeleição de Garcia Amador como membro da CDI, o trabalho desenvolvido por este não teve continuidade. A nosso ver, rês principais fatores influenciaram para que a contribuição do Relator não fosse bem aceita pelos demais membros da CDI. Em primeiro lugar, a incorporação no anteprojeto de artigos de algumas ideias revolucionárias para a época. A questão da responsabilidade criminal do Estado, embora bastante discutida após o final da Segunda Guerra, ainda não era, como não o é até os dias de hoje, amplamente aceita quer pela doutrina, quer pela prática dos Estados.

Também o princípio proposto, estabelecendo um padrão mínimo de proteção aos direitos humanos, embora amplamente aceito atualmente, foi considerado demasiado precipitado naquele momento histórico. Em 1957 e 1958, quando os artigos foram propostos, o processo de internacionalização dos direitos humanos estava em seus estágios iniciais e o sistema de proteção internacional a estes direitos ainda não estava plenamente desenvolvido. Como já mencionado, somente em 1961 os Pactos sobre os Direitos Civis e Políticos e o sobre os Direitos Econômicos, Sociais e Culturais foram assinados. O Pacto de San José da Costa Rica também só seria firmado em 1969.

Outro ponto a ser destacado foi a inserção do indivíduo como sujeito passivo e ativo de direito internacional, tendo reconhecida inclusive sua capacidade processual ativa, algo que mesmo nos dias de hoje os doutrinadores conservadores ainda refutam.

Além das ideias inovadoras, o excesso de itens na agenda da CDI e a priorização de outros temas fizeram com que os Relatórios apresentados não fossem discutidos detalhadamente pelos membros da Comissão. O Relator teve que continuar o trabalho sem que instruções objetivas lhe fossem passadas e sem que pontos essenciais fossem definitivamente decididos.

O último fator foi a manutenção, seja direta ou indiretamente, pelo Relator, destes princípios e ideias, nos artigos propostos, mesmo após pesadas críticas dos demais membros da CDI, tanto nos debates sobre o seu trabalho, quanto nos debates sobre o anteprojeto da Harvard Law School, que possuía diversos pontos em comum.

Apesar de criticados e negligenciados, os estudos realizados por Garcia Amador tiveram influência no trabalho posterior da CDI. Ago, em seu primeiro Relatório, faz um extenso resumo do material produzido por Garcia Amador, e defende algumas de suas ideias, como a responsabilidade criminal do Estado. 
Se esta não é incorporada ao anteprojeto final de artigos, aprovado em 2001, influencia claramente o capítulo III sobre "violações graves de obrigações decorrentes de normas imperativas de direito internacional geral", que embora não faça refe rência a normas substantivas, não tratando diretamente dos direitos humanos, tem como um de seus objetivos principais a proteção destes direitos.

1.3.2.2.2 Trabalho realizado pelo Subcomitê sobre Responsabilidade do Estado (1962-1963)

Na sua $16^{\text {a }}$ Sessão a Assembleia Geral tratou da questão da codificação do Direito Internacional. A grande maioria dos oradores manifestou a necessidade de se priorizar dois temas: o direito dos tratados e a responsabilidade internacional. Mencionou-se também a necessidade de ampliar o escopo da codificação da responsabilidade internacional, tratando de setores além do dano causado a estrangeiros (ONU, p. 137, 1969). Ao final da discussão, a Assembleia Geral adotou a Resolução 1686 (XVI), que recomendava à CDI: “a) Continuar seu trabalho no campo do direito dos tratados e da responsabilidade do Estado e incluir na sua lista de prioridades o tema da sucessão dos Estados e Governos;", 143

Tendo em vista a Resolução 1686 (XVI) da Assembleia Geral, a CDI em sua $14^{\mathrm{a}}$ Sessão, em 1962, realizou extensos debates sobre o seu futuro programa de trabalho ${ }^{144}$.

Durante os debates, ficou estabelecido que o tema do direito dos tratados deveria ser o principal objeto dos esforços, sendo priorizado acima dos outros. A resolução 1686 (XVI), no entanto, não poderia ser ignorada, e a questão da responsabilidade internacional e da sucessão dos Estados não poderia ser deixada de lado.

Em relação à responsabilidade internacional, a grande maioria dos membros da Comissão era favorável a reiniciar o estudo da questão, deixando de lado o trabalho elaborado por Garcia Amador.

Três eram os principais fatores que contribuíram para esta posição. O primeiro, que o estudo elaborado se concentrava em um setor específico da responsabilidade internacional. Essa abordagem, inicialmente apoiada pela Comissão, sofreu diversas críticas nos debates ocorridos no seio da $6^{\text {a }}$ Comissão da Assembleia Geral, e agora

143 (a) To continue its work in the field of the law of treaties and of State responsibility and to include on its priority list the topic of succession of States and Governments;

144 (CDI, p. 2 a 45, 1962) 
diversos membros da CDI entendiam que o tema deveria ser tratado de forma mais geral.

O segundo ponto era que as posições adotadas pelo Relator Especial não se coadunavam com o pensamento da maioria dos membros da Comissão, como os debates iniciais sobre o tema já haviam deixado claro.

O terceiro ponto era a não reeleição do Relator Especial como membro da Comissão, o que aliado com a discordância dos demais membros da linha de trabalho tomada, dificultava a continuação do trabalho do ponto em que este se encontrava.

A questão da responsabilidade internacional, no entanto, era bastante complexa. Havia hesitações em se apontar um novo Relator Especial antes que alguns pontos principais estivessem definidos.

Esse impasse, aliado a pressão feita pela Assembleia Geral para a priorização de determinados tópicos, a dizer, o direito dos tratados, a responsabilidade internacional, e a sucessão de Estado e governos; e a limitada capacidade de trabalho da CDI, composta então por apenas 25 membros, fez com que a Comissão decidisse adotar novos métodos de trabalho.

Foram criados 2 subcomitês de trabalho para lidar com a Responsabilidade internacional; e a sucessão dos Estados e governos. O subcomitê sobre a Responsabilidade do Estado era composto por 10 membros: Ago, o presidente, Briggs, Grso, Jiménez de Aréchaga, Lachs, de Luna, Paredes, Tsuruoka, Tunkin e Yansseen. Este Comitê se reuniria em Janeiro de 1963, e trataria dos aspectos gerias da responsabilidade dos Estados. O objetivo era traçar linha mais específicas para instruir o trabalho de um futuro Relator Especial no tema, tendo em vista a amplitude a complexidade da matéria.

O Subcomitê se reúne pela primeira vez em junho de 1962 e em Relatório, estabelece as regras de trabalho para as reuniões que teria em janeiro de 1963.

A Assembleia Geral reconhece os esforços realizados pela CDI e na Resolução 1765 (XVII) recomenda a continuação do trabalho com base no Relatório do Subcomitê sobre responsabilidade do Estado. ${ }^{145}$

\footnotetext{
145 (b) continue its work on State responsibility, taking into account the views expressed at the seventeenth session of the General Assembly and the report of the Sub-Committee on State Responsibility and giving due consideration to the purposes and principles enshrined in the Charter of the United Nations (ONU, Resolution 1765 (XVII), disponível em: http://daccess-ddsny.un.org/doc/RESOLUTION/GEN/NR0/192/73/IMG/NR019273.pdf?OpenElement, acesso em: 25 de ago. 2010)
} 
O Subcomitê se reuniu por sete vezes em janeiro de 1963. No inicio dos debates ficou clara a divisão de posições. Enquanto alguns membros ${ }^{146}$ ainda defendiam o tratamento da responsabilidade internacional voltado a um determinado setor, a dizer, a responsabilidade decorrente de dano causado a estrangeiros, a maioria era a favor de uma abordagem mais geral sobre o tema. Após debates, foi adotada a posição da maioria sobre o tratamento da matéria. O Subcomitê, então, passou a tratar do programa de trabalho proposto pelo Presidente, Sr. Ago. Ao final dos trabalhos foi aprovado Relatório que continha os seguintes pontos, aprovados por unanimidade, a serem recomendados à Comissão (ONU, p. 227-228, 1963):

Ponto Preliminar: Definição do conceito de responsabilidade internacional do Estado.

Primeiro ponto: Origem da responsabilidade internacional.

1) Ato inte rnacionalmente ilícito: a violação por um Estado de um obrigação legal imposta a este pelo direito internacional qual seja a sua origem e a sua esfera.

2) Determinação das partes componentes do ato internacionalmente ilícito: a) Elemento objetivo: ato ou omissão objetivamente conflitando com uma obrigação internacional do Estado $[\ldots] ; b)$ Elemento subjetivo: imputabilidade a um sujeito de direito internacional de conduta contrária a uma obrigação internacional.[...]

3) Os vários tipos de violações às obrig ações internacionais: questões relacionadas ao escopo prático das distinções que podem ser feitas. [...]

4) Circunstâncias nas quais um ato não é ilícito: Consentimento da parte lesada. Problemas do consentimento presumido; Sanção legítima contra o autor de um ato internacionalmente ilícito; Legítima Defesa; Estado de necessidade.

Segundo ponto: As formas de responsabilidade internacional.

1) $O$ dever de reparação, e o direito de aplicar sanções ao Estado cometendo um ato ilícito, como consequência desta responsabilidade. [...]

2) Reparação. suas formas. Restitutio in integrum e reparação por equivalência ou compensação. [...]

3) Sanção. Sanções individuais previstas no direito internacional geral. Represálias e seu possível papel como sanção de um ato internacionalmente ilícito. Sanções coletivas. ${ }^{147}$ (tradução nossa)

\footnotetext{
146 Jiménesz Aréchaga, Tsuruoka e Briggs (p. 229 et seq, 1963)

147 Preliminary point: Definition of the concept of the international responsibility of the State 2

First point: Origin of international responsibility.
}

(1) International wrongful act: the breach by a State of a legal obligation imposed upon it by a rule of international law whatever its origin and in whatever sphere.

(2) Determination of the component parts of the international wrongful act:

(a) Objective element: act or omission objectively conflicting with an international legal obligation of the State.3 Problem of the abuse of right. Cases where the act or omission itself suffices to constitute the objective element of the wrongful act and cases where there must also be an extraneous event caused by the conduct. 
A abordagem geral do tema da responsabilidade incluía, não só o estudo da definição da responsabilidade internacional em si, seu conceito e seus elementos, como também das formas de reparação. Nestas formas de reparação podemos notar a inserção da questão de sanções ao ato internacionalmente ilícito.

Dentre estas sanções, se estudariam as represálias e "seu possível papel como sanção de um ato internacionalmente ilícito". As represálias também eram tidas como possíveis elementos de excludente de ilicitude. Tal posição diferia frontalmente a posição adotada pelo Relator Especial anterior, que não só não enxergava as represálias como vinculadas à sanção no direito internacional, como nem mesmo admitia sua capacidade de excluir a ilicitude de um ato internacional $^{148}$

Ao mencionar a sanção como consequência de um ato internacionalmente ilícito, o Subcomitê, indiretamente volta a tratar da responsabilidade penal internacional, que outrora havia sido tão criticada nos debates da CDI sobre o tema.

O trabalho do Subcomitê foi examinado pela CDI na sua $15^{\text {a }}$ Sessão, reunião 686, em 1963. O plano de trabalho proposto foi bem recebido, tendo sido aprovado unanimemente, tendo em vista se tratar somente de um programa de trabalho, que não prejudicava em nada a posição de algum membro relativa à substância dos pontos propostos (ONU, p. 79 et seq., 1963a). Ao final da reunião, Ago foi apontado como Relator Especial sobre a Responsabilidade do Estado.

O Relatório da CDI foi analisado pela Assembleia Geral da ONU na sua $18^{\mathrm{a}}$ Sessão. A grande maioria dos representantes dos Estados aprovou o enfoque dado pela

(b) Subjective element: imputability to a subject of international law of conduct contrary to an international obligation. Questions relating to imputation. Imputation of the wrongful act and of responsibility. Problem of indirect responsibility.

(3) The various kinds of violations of international obligations. Questions relating to the practical scope of the distinctions which can be made. [...]

(4) Circumstances in which an act is not wrongful

Consent of the injured party. Problem of presumed consent; Legitimate sanction against the author of an international wrongful act;

Self-defence;

State of necessity.

Second point: The forms of international responsibility

(1) The duty to make reparation, and the right to apply sanctions to a State committing a wrongful act, as consequences of responsibility. Question of the penalty in international law. Relationship between consequences giving rise to reparation and those giving rise to punitive action. Possible distinction between international wrongful acts involving merely a duty to make reparation and those involving the application of sanctions. Possible basis for such a distinction.

(2) Reparation. Its forms. Restitutio in integrum and reparation by equivalent or compensation. Extent of reparation. Reparation of indirect damage. Satisfaction and its forms.

(3) Sanction. Individual sanctions provided for in general international law. Reprisals and their possible role as a sanction for an international wrongful act. Collective sanctions.

148 Para Garcia Amador, como já mencionado, as represálias não teriam mais esta função no Direito Internacional. 
Comissão no tratamento do tema e ao final a Assembleia Geral aprovou a Resolução 1902 (XVIII), na qual instava a CDI a continuar seus trabalhos com base no Relatório apresentado pelo Subcomitê sobre Responsabilidade do Estado ${ }^{149}$.

\subsection{Trabalho realizado pelo Relator Especial Roberto Ago (1963-1979)}

Em 1964 o Secretariado apresentou à CDI dois trabalhos sobre a responsabilidade dos Estados, requeridos durante os debates da $15^{\text {a }}$ Sessão. O primeiro continha um sumário das discussões sobre a responsabilidade internacional nos diversos órgãos da ONU. O segundo, uma compilação das decisões dos tribunais internacionais sobre o tema.

No sumário sobre as discussões relativas à responsabilidade dos Estados nos demais órgão da ONU, vale destacar a discussão sobre a responsabilidade criminal internacional.

O tema surge nos debates da Convenção sobre punição e prevenção do crime de genocídio onde uma proposta apresentada pelo Reino Unido pretendia estabelecer, no artigo 5, a responsabilidade criminal do Estado por ato de genocídio ${ }^{150}$. Tal proposta, encontrado grandes resistência, foi retirada pelo patrocinador.

O tema também teria sido tratado pela CDI no estudo do anteprojeto sobre ofensas contra a paz e a segurança da humanidade, quando o Relator Especial Spiropoulos concluiu não ser adequado incluir esta responsabilidade naquele momento; e pelo Sexto Comitê da Assembleia Geral, na discussão dos princípios de Nuremberg na qual a responsabilidade criminal do Estado também foi rejeitada.

Já em relação à compilação das decisões internacionais sobre a responsabilidade internacional, ressaltam-se as decisões arbitrais que não reconhecem a possibilidade de aplicação de danos punitivos no Direito Internacional, a dizer, o Caso Lusitania de 1923 (ONU, p. 167, 1964), o Caso da Responsabilidade da Alemanha por atos cometidos

\footnotetext{
149 (b) Continue its work on State resp onsibility, taking into account the views expressed at the eighteenth session of the General Assembly and the report of the Sub-Committee on State Responsibility and giving due consideration to the purposes and principles enshrined in the Charter of the United Nations. (Resolution 1902 (XVIII) disponível em: http://daccess-dds-ny.un.org/doc/RESOLUTION/GEN/NR0/185/77/IMG/NR018577.pdf?OpenElement. Acesso em 25 ago. 2010)

${ }^{150}$ Criminal responsibility for any act of genocide as specified in articles II and IV shall extend not only to all private persons or associations, but also to States, governments, or organs or authorities of the State or government, by whom such acts are committed. Such acts committed by or on behalf of States or governments constitute a breach of the present Convention (in document A/C.6/236, apud, CDI, p. 127, 1964)
} 
depois de 14 de julho de 1914 e antes de Portugal entrar na guerra, de 1930 (CDI, p. 168, 1964) e o Caso Torrey de 1903 (ONU, p. 169, 1964).

A CDI, no entanto, tendo em vista o final do mandato de seus membros, que terminaria em 1966, decidiu dedicar as Sessões de 1964, 1965 e 1966 à conclusão dos trabalhos sobre o direito dos tratados e missões especiais, deixando de lado a questão da responsabilidade internacional.

A Assembleia Geral, embora aprovando a decisão na Resolução 2045 (XX), de 1965, recomendou que a CDI continuasse, quando possível, o trabalho sobre a responsabilidade do Estado.

Em 1967 o Relator Especial, tendo em vista a nova composição da CDI, apresentou nota na qual resumia os trabalhos realizados pelo Subcomitê sobre responsabilidade do Estado, e requeria à nova composição da CDI que se manifestasse sobre o programa de trabalho proposto.

Nos debates sobre o tema, ocorridos nas reuniões 934 e 935 da $19^{\text {a }}$ Sessão, o programa de trabalho foi novamente aprovado e Ago foi reconfirmado como Relator Especial para o tema. Este se comprometeu a apresentar um relatório pormenorizado em 1969, na 20ª Sessão da CDI.

Em 1967 a Assembleia Geral aprovou a Resolução 2272 (XXII), na qual requeria que a CDI "acelerasse seu estudo no tema da responsabilidade do Estado."151

Em sua Sessão de 1968 a CDI decidiu realizar uma consideração substantiva sobre o tema da responsabilidade internacional na Sessão seguinte, em 1969, e dar prioridade ao tema na Sessão de 1970 (ONU, p. 224, 1968).

A Assembleia Geral, por seu lado, editou a Resolução 2400 (XXIII) em 1968 instando a CDI a:

Realizar todos os esforços para começar um trabalho substantivo sobre a responsabilidade dos Estados na sua próxima sessão, levando em conta as opiniões e considerações referidas pela Assembleia Geral nas resoluções 1765 (XVII) e 1902 (XVIII) ${ }^{152}$. (tradução nossa)

\footnotetext{
$151 \quad$ Disponível em: $\quad \underline{\text { http://daccess-dds- }}$ ny.un.org/doc/RESOLUTION/GEN/NR0/236/07/IMG/NR023607.pdf?OpenElement. Acesso em 25 ago. 2010

152 (c) Make every effort to begin substantive work on State responsibility as from its next session, taking into account the views and considerations referred to in General Assembly resolutions 1765 (XVII) and 1902 (XVIIT), (Resolution $2400 \quad$ (XXIII). Disponível em: $\underline{\text { http://daccess-dds- }}$ ny.un.org/doc/RESOLUTION/GEN/NR0/243/60/IMG/NR024360.pdf?OpenElement. Acesso em: 25 ago. 2010.
} 
Em 1969, o Relator Especial Ago, apresentou seu primeiro Relatório sobre a responsabilidade do Estado. O Relatório continha um detalhado resumo dos esforços de codificação realizado por entidades privadas, por órgãos regionais e pela Liga das Nações. Continha também um resumo dos trabalhos realizados no seis da CDI sobre o tema até então.

O tema da responsabilidade do Estado foi tratado pela CDI na sua $21^{\text {a }}$ Sessão, nas reuniões 1011 a 1013. O trabalho histórico apresentado pelo Relator foi parabenizado e a abordagem do tema, tratando da responsabilidade de forma geral, foi aprovada pela maioria. Algumas questões, porém, como o tratamento de questões substantivas no estudo, e a responsabilidade criminal do Estado mostraram opiniões divergentes.

Em 1970, Ago apresenta seu segundo Relatório à CDI. Neste documento, o Relator delimitava o estudo a ser realizado sobre o tema, de acordo com o estabelecido pela CDI.

A responsabilidade internacional seria tratada da perspectiva dos Estados, não incluindo à responsabilidade dos outros sujeitos de direito internacional. Ainda, s restringiria à responsabilidade resultante de atos internacionalmente ilícitos, sendo a responsabilidade por ato lícitos tratada separadamente. O trabalho também se concentraria nas regras secundárias da responsabilidade internacional, se abstendo de tratar das normas primárias, que estabeleceriam as obrigações internacionais cuja violação ensejariam nesta responsabilidade.

Delimitado o objeto de estudo, o método a ser empregado seria dividir o trabalho em duas fases. Na primeira, se trataria da origem da responsabilidade internacional; na segunda se analisaria o conteúdo desta responsabilidade (ONU, p. 177-178, 1970).

A tratar da origem da responsabilidade internacional o Relator menciona princípio, amplamente reconhecido de que (ONU, p. 180, 1970): “atos internacionalmente ilícitos de Estados criam novas relações jurídicas internacionais que se caracterizam como situações jurídicas subjetivas distintas daquelas que existiam antes que o ato ocorresse." (tradução nossa) ${ }^{153}$

Em relação à natureza desta nova relação jurídica, Ago menciona a existência de 3 correntes. A primeira entende que essa relação seria uma relação obrigatória bilateral, estabelecida entre o Estado que cometeu o ilícito e o Estado que foi prejudicado (ONU, p. $180-181,1970)$.

\footnotetext{
153 Internationally wrongful acts by States create new international legal relations characterized by subjective legal situations distinct from those which existed before the acts took place
} 
A segunda corrente, por entender que toda ordem jurídica é uma ordem coercitiva, entende que a reparação é apenas um dever subsidiário, e a consequência de um ato ilícito implicaria numa sanção. Assim (ONU, p. 182, 1970): “o direito internacional geral não consideraria que o ato ilícito cria qualquer relação obrigatória entre o Estado ofensor e o Estado prejudicado, mas autorizaria o último a reagir ao ato ilícito do

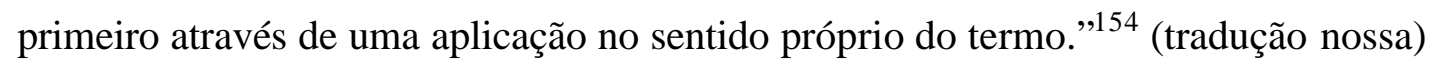

A terceira corrente adotaria uma posição intermediária, segundo a qual (ONU, p. 182, 1970): “em qualquer sistema de direito, um ato ilícito poderia dar origem não a um único tipo de relação internacional, mas a uma relação dual, cada forma sendo caracterizada pelas situações legais diferentes dos sujeitos envolvidos". ${ }^{155}$

Para Ago, embora o conceito de comunidade internacional não estivesse ainda plenamente personificado no Direito Internacional, a ponto de se reconhecer que o ato internacionalmente ilícito crie uma relação entre o Estado lesado e a "comunidade internacional', o desenvolvimento recente deste ramo do Direito, em especial o advento das organizações internacionais como a ONU, permite considerar que (ONU, p. 184, 1970):

um Estado cometendo um ato ilícito internacional de uma certa importância possa ser colocado em uma nova relação não apenas com o Estado prejudicado, mas também com a Organização. Ele pode, assim, estar sujeito à faculdade ou mesmo ao dever da Organização e seus membros, de reagir contra a conduta internacionalmente ilícita através da aplicação de sanções coletivas decididas. ${ }^{156}$ (tradução nossa)

O Relator cita também o julgado da Corte Internacional de Justiça (CIJ) no caso Barcelona Traction, de 1970, que reconhece a existência de obrigações erga omnes, ou seja, obrigações que dizem respeito a toda comunidade internacional. Levando em conta esses novos fatores, Ago entende que (ONU, p. 184, 1970): “é possível gradualmente

\footnotetext{
${ }^{154}$ general international law would not regard the wrongful act as creating any obligatory relationship between the offending State and the injured State, but would authorize the latter to react to the wrongful act of the former by applying to it a sanction in the proper sense of the term.

${ }^{155}$ in any system of law a wrongful act may give rise, not to a single type of legal relationship, but to a dual form of relationship, each form being characterized by the different legal situations of the subjects involved.

${ }^{156}[\ldots]$ a State committing an internationally wrongful act of a certain kind and of a certain importance might be placed in a new legal relationship not only with the in jured State, but also with the Organization. It might thus be subject to the faculty or even the duty of the Organization and its members to react against the internationally wrongful conduct by applying sanctions collectively decided upon.
} 
delinear um conceito de 'crime' no direito internacional, dentro do contexto geral do ato internacionalmente ilícito."

O segundo Relator Especial sobre a responsabilidade do Estado, assim como o primeiro, Garcia Amador, também defendia a responsabilidade criminal internacional. Ago, no entanto, numa posição, mais flexível, opta por não incorporar esta visão nos artigos apresentados neste segundo Relatório. Ao invés disso ele propõe (ONU, p. 185, 1970):

\begin{abstract}
A Comissão pode assinalar que esta utilizando o termo 'responsabilidade internacional' para significar, globalmente e sem adotar nenhuma posição, todas as formas de novas relações que podem ser estabelecidas no direito internacional pelo ato ilícito do Estado - independentemente se elas estão limitadas à uma relação entre o Estado que cometeu o ilícito internacional e o Estado diretamente prejudicado, ou se estende-se a outros sujeito de direito internacional também. ${ }^{157}$
\end{abstract}

Essa posição seria consubstanciada no artigo primeiro proposto, que estabeleceria (ONU, p. 187, 1970): “Artigo I: O ato internacionalmente ilícito como fonte da responsabilidade. Todo ato internacionalmente ilícito de um Estado dá origem a uma responsabilidade internacional." 158

Após haver estabelecido a regra básica sobre a origem da responsabilidade internacional, o Relator passa a tratar dos elementos que comporiam um ato internacionalmente ilícito. Segundo Ago, para caracterizar um ato internacionalmente ilícito, dois elementos deveriam estar presentes (ONU, p. 187, 1970):

a) Um elemento geralmente chamado elemento subjetivo, consistindo de uma conduta que possa ser atribuível, não a um indivíduo ou a um conjunto de indivíduos, os quais estiveram efetivamente engajados na mesma, mas ao Estado como sujeito de direito internacional. Isto é o que se quer dizer com conduta ou comportamento imputável a um Estado.

b) Um elemento usualmente chamado elemento objetivo: o Estado ao qual a conduta em questão foi legalmente imputada, deve, por aquela

\footnotetext{
157 the Commission might well point out that it is using the term "international responsibility" to mean, globally and without taking a position, all the forms of new legal relationship which may be established in international law by a State's wrongful act-irrespective of whether they are limited to a relationship between the State which commits the wrongful act and the State directly injured, or extend to other subjects of international law as well,

${ }^{158}$ Article I The internationally wrongful act as a source of responsibility

Every internationally wrongful act by a State gives rise to international responsibility.
} 
conduta, ter falhado em cumprir com uma obrigação internacional que a ele cabia. ${ }^{159}$ (tradução nossa)

Em relação ao primeiro elemento, "uma conduta atribuível a um Estado", o Relator ressalta que tal conduta pode ser tanto positiva (ação), quanto negativa (omissão) (ONU, p, 188, 1970).

A conduta também deve ser "atribuível" ou "imputável”, ao Estado. Para Ago (ONU, p. 190, 1970): "Falar em imputação a um Estado, assim, meramente indica que a ordem jurídica internacional deve ser capaz de considerar a ação ou omissão considerada como um ato do Estado."160 (tradução nossa)

Tendo em vista que o Estado, como uma entidade legal, é incapaz fisicamente de realizar qualquer conduta, a conduta referida seria o ato ou omissão de um indivíduo ou um grupo de indivíduos. Mas para que esta conduta seja considerada como uma conduta do Estado, 3 pontos devem ser considerados. Sobre o primeiro ponto, Ago, escreve (ONU, p. 190, 1970): “imputação a um Estado é necessariamente, por causa da natureza mesma do Estado, uma operação jurídica de conexão que não tem nada a ver com a ligação de causalidade natural." 161 (tradução nossa).

Para ele, também, a imputação ao Estado se dá em relação a este enquanto pessoa de Direito Internacional, não como pessoa de direito interno, e por último, a conduta do indivíduo só pode ser imputada ao Estado como um ato ilícito internacional pelo Direito Internacional, e não por qualquer outro sistema jurídico (ONU, p. 190, 1970).

O elemento objetivo do ato internacionalmente ilícito, o descumprimento de alguma obrigação internacional, não traz grandes dificuldades conceituais. Para o Relator, entretanto, dois pontos devem ser considerados. Para que uma conduta seja considerada ilícita, algumas vezes ela é suficiente por si mesma. Outras vezes, porém, é necessária a presença de um elemento adicional, de um evento externo. Esse evento externo deve ser decorrente direta ou indiretamente, da conduta ilícita do Estado. Segundo Ago (ONU, p. 195, 1970): "Em outras palavras, deve haver uma certa relação causal entre a conduta e o evento, que pode ser a causalidade natural, nos casos mais

\footnotetext{
159 (a) An element generally called a subjective element, consisting of conduct which must be attributable, not to the individual or group of individuals which has actually engaged in it, but to a State as a subject of international law. This is what is meant by conduct or behavior imputable to a State.

(b) An element usually called an objective element: the State to which the conduct in question has been legally imputed must, by that conduct, have failed to fulfil an international obligation incumbent on it.

${ }^{160}$ To speak of imputation to a State, therefore, merely indicates that the international legal order must be able to regard the action or omission concerned as an act of the State

161 imputation to the State is necessarily, because of the very nature of the State, a legal connecting operation which has nothing in common with a link of natural causality.
} 
simples, ou pode ser em outros casos uma causalidade normativa, na qual a ligação é estabelecida não pela natureza, mais por determinação legal [...]."162 (tradução nossa)

Esse evento externo seria, para alguns doutrinadores, o dano, ou seja, o prejuízo sofrido por algum Estado. Mas Ago tem uma noção diferente de dano. Para ele (ONU, p. 195, 1970): “Cada violação de uma obrigação frente a outro Estado e cada prejuízo de um direito subjetivo daquele Estado constitui, em si mesmo, um dano, material ou moral, aquele Estado."163

Assim, segundo o Relator (ONU, p. 195, 1970):

A extensão do dano material causado pode ser um fator decisivo para determinar o valor da reparação a ser feita. Mas não pode ser de nenhuma ajuda em estabelecer se o direito subjetivo de outro Estado foi prejudicado e assim, se um ato internacionalmente ilícito ocorreu. Parece, portanto, inapropriado levar o elemento do dano em consideração na definição da existência de um ato internacionalmente ilícito. ${ }^{164}$ (tradução nossa)

Após estas considerações o Relator propõe o seguinte artigo II (ONU, p. 195, 1970):

Artigo II Condições para a existência de um ato internacionalmente ilícito

Um ato internacionalmente ilícito existe quando:

a) Conduta consistindo em uma ação ou omissão é imputável a um Estado de acordo com o direito internacional;e

b) Tal conduta, em si mesma, ou como causa direta ou indireta de um evento externo, constitui em uma falha na execução de uma obrigação internacional do Estado. ${ }^{165}$ (tradução nossa)

\footnotetext{
${ }^{162}$ In other words, there must be a certain causal relationship between the conduct and the event, which may be natural causality, as in the simplest case, or may be in other cases a "normative" causality, in which the link is established not by nature but by a rule of law, as where the State has omitted to take the safety measures and precautions which could have prevented the occurrence of the external event (for example, an attack by private persons).

${ }^{163}$ Every breach of an engagement vis-à-vis another State and every impairment of a subjective right of that State in itself constitutes a damage, material or moral, to that State.

${ }^{164}$ The extent of the material damage caused may be a decisive factor in determining the amount of the reparation to be made. But it cannot be of any assistance in establishing whether a subjective right of another State has been impaired and so whether an internationally wrongful act has occured. It therefore seems inappropriate to take this element of damage into consideration in defining the conditions for the existence of an internationally wrongful act.

${ }^{165}$ Article II Conditions for the existence of an internationally wrongful act

An internationally wrongful act exists where:

(a) Conduct consisting of an action or omission is imputed to a State under international law; and

(b) Such conduct, in itself or as a direct or indirect cause of an external event, constitutes a failure to carry out an international obligation of the State.
} 
$\mathrm{Na}$ última parte o Relatório, Ago trata da capacidade do Estado para cometer um ato internacionalmente ilícito e propõe o seguinte artigo (ONU, p. 197, 1970):

Artigo III Capacidade de cometer atos internacionalmente ilícitos 1. Todo Estado possui a capacidade de cometer atos internacionalmente ilícios.

2. Esta capacidade pode ser excepcionalmente limitada, em situações particulares, pelo fato de que os órgãos de um Estado tenham sido substituídos, numa dada esfera de atividade, por aqueles de outro sujeito ou sujeitos de direito internacional agindo em seu território. ${ }^{166}$

Essa nova abordagem de Ago sobre a responsabilidade internacional foi considerada revolucionária (PELLET, p. 3, 2002). Os dois primeiros artigos propostos pelo Relator davam uma nova perspectiva ao trabalho da CDI sobre a responsabilidade do Estado.

Ao adotar um conceito amplo de responsabilidade internacional, entendendo esta como "todas as formas de novas relações que podem ser estabelecidas no direito internacional pelo ato ilícito do Estado" (ONU, p. 185, 1970, acima citado), o Relator se distanciava de todas as tentativas de codificação anteriores.

Porém, ainda mais inovador era seu artigo II, que não só consubstanciava a teoria objetiva da responsabilidade, eliminando qualquer menção a necessidade de culpa ou dolo no elemento subjetivo do ato internacionalmente ilícito, como também descartava o dano como um dos elementos constitutivos do ato internacionalmente ilícito.

Essa nova abordagem vai permear todo o trabalho futuro da CDI sobre o tema e os dois artigos propostos, com algumas alterações na forma, podem ser identificados nos primeiros artigos do anteprojeto de artigos aprovado pela CDI em 2001.

O Segundo Relatório de Ago foi examinado nas reuniões 1074, 1076 e 1079 a 1981 da 22 $2^{\mathrm{a}}$ Sessão da CDI. A metodologia empregada pelo Relator, tanto na abordagem geral do tema, quanto na forma de apresentação do Relatório foi bem aceita pelos demais membros. Algumas questões referentes à terminologia empregada foram levantadas, em especial o uso do termo "fait illicite" e "hecho ilícito' nas versões francesa e espanhola e a utilização do termo "imputação". Embora o Relator se mantivesse firme em relação ao primeiro ponto, não viu problemas em substituir o

\footnotetext{
${ }^{166}$ Article III Capacity to commit internationally wrongful acts

1. Every State possesses capacity to commit internationally wrongful acts.

2. This capacity may exceptionally be limited, in particular situations, by the fact that the organs of a State have been replaced, in a given sphere of activity, by those of another subject or subjects of international law acting on its territory.
} 
termo imputável por atribuível. Alguns membros também questionaram a referência feita no artigo II b, do termo "evento externo", que deixaria confusa a redação.

Críticas gerais foram feitas à redação do artigo III, que Ago concordou em revisar (ONU, p. 175 et seq., 1970a).

Apesar de algumas críticas, os principais pontos estabelecidos nos artigos foram mantidos, sem grandes discordâncias.

A Comissão aceitou a existência de dois elementos caracterizando o ato internacionalmente ilícito, o elemento subjetivo e o elemento objetivo. Em relação ao elemento subjetivo, as objeções levantadas disseram respeito mais à terminologia (atribuição ao invés de imputação), do que a substância, ou seja, a adoção da teoria da responsabilidade objetiva (ONU, p. 308, 1970).

A Comissão também reconheceu que o dano, ou "o elemento econômico do dano" não seria inerente a definição de ato internacionalmente ilícito (ONU, p. 308, 1970).

Em 1971 o Relator Especial apresentou seu terceiro Relatório. A exemplo do anterior, o Relatório continha propostas de artigos, precedidos de comentários e explicações. Neste documento, Ago apresentava os 3 primeiro artigos, anteriormente discutidos, com as alterações feitas segundo as sugestões aprovadas durante os debates. A nova redação dos artigos estabelecia (ONU, p. 214, 223,224, 226, 1971):

Artigo I. Princípio atribuindo responsabilidade a todo ato internacionalmente ilícito do Estado

Todo ato internacionalmente ilícito de um Estado envolve a responsabilidade internacional deste Estado.

Artigo II. Condições para a existência de um ato internacionalmente ilícito

Um ato internacionalmente ilícito existe quando:

a) Conduta consistindo de uma ação ou omissão é atribuível ao Estado em virtude do direito internacional; e

b) Tal conduta constitui uma falha em cumprir com uma obrigação internacional do Estado

Artigo III. Sujeitos que podem cometer atos internacionalmente ilícitos

Todo Estado pode ser considerado autor de um ato internacionalmente ilícito. ${ }^{167}$ (tradução nossa)

\footnotetext{
${ }^{167}$ Article 1. Principle attaching responsibility to every internationally wrongful act of the State Every internationally wrongful act of a State involves the international responsibility of that State. Article 2. Conditions for the existence of an internationally wrongful act An internationally wrongful act exists when:

(a) Conduct consisting of an action or omission is attributed to the State in virtue of international law; and (b) That conduct constitutes a failure to comply with an international obligation of the State. Article 3. Subjects which may commit internationally wrongful acts Every State may be considered the author of an internationally wrongful act
} 
Além destes 3 artigos, o Relatório trazia um quarto artigo relativo aos princípios gerais da responsabilidade internacional, consubstanciando o princípio da irrelevância do direito interno para caracterizar o ato internacionalmente ilícito ${ }^{168}$, e mais 5 artigos tratando da atribuição do ato ilícito ao Estado.

No artigo 5 o Relator desenvolve a noção de ato do Estado. O artigo estabelece (ONU, p. 243, 1971):

Artigo 5. Atribuição ao Estado sujeito de direito internacional, dos atos de seus órgãos

Para os propósitos destes artigos, a conduta de uma pessoa ou grupo de pessoas que, de acordo com a ordem interna de um Estado, possui o status de órgãos daquele Estado e estão agindo nesta capacidade no caso em questão, é considerada um ato do Estado do ponto de vista do direito internacional. ${ }^{169}$ (tradução nossa)

Os artigos seguintes tratam sobre a "irrelevância da posição de um órgão na distribuição de poderes e na hierarquia interna" (artigo 6); da atribuição ao Estado de atos de órgãos de instituições públicas separadas do Estado (artigo 7); da atribuição ao Estado de atos de pessoas privadas desempenhando, de fato, funções públicas, ou agindo, de fato, em nome do Estado (artigo 8); e a atribuição ao Estado de ato de órgão colocado à sua disposição por outro Estado ou organização internacional (artigo 9).

A CDI dedicou sua $23^{\text {a }}$ Sessão para tratar quase que exclusivamente do tema da relação entre Estados e organizações internacionais. O Relatório apresentado pelo Relator Especial Ago não chegou a ser discutido.

Em 1972 Ago apresentou seu Quarto Relatório sobre a responsabilidade do Estado. Neste Relatório, seguindo a linha dos anteriores, quatro artigos, precedidos de comentários, foram propostos. Dando continuação aos estudos sobre atos dos Estados, os artigos versavam sobre órgãos agindo fora da sua competência ou contrário às provisões relativas às suas atividades (artigo 10); a conduta de indivíduos privados (artigo 11); a conduta de órgãos de outros sujeitos de direito internacional (artigo 12); a

\footnotetext{
${ }^{168}$ Article 4. Irrelevance of municipal late to the characterization of an act as internationally wrongful The municipal law of a State cannot be invoked to prevent an act of that State from being characterized as wrongful in international law.

${ }^{169}$ Article 5. Attribution to the State, subject of international law, of the acts of its organs

For the purposes of these articles, the conduct of a person or group of persons who, according to the internal legal order of a State, possess the status of organs of that State and are acting in that capacity in the case in question, is considered as an act of the State from the standpoint of international law.
} 
conduta de órgãos de movimentos de insurreição cujas estruturas subsequentemente se tornaram, no total ou em parte, estruturas de um estado (artigo 13).

Mais uma vez a agenda da CDI não permitiu que o Relatório fosse examinado. A Comissão, no entanto, programou um extenso estudo sobre o tema na sua $25^{\text {a }}$ Sessão (ONU, p. 323, 1972).

Em 1973 a CDI dedicou as reuniões 1203 a 1213, 1215, 1225 e 1226 da sua $25^{\text {a }}$ Sessão para tratar da responsabilidade do Estado. Os 6 primeiros artigos apresentados por Ago em seus Relatórios foram discutidos detalhadamente. O Relatório da Comissão à Assembleia Geral (ONU, p. 161 et seq, 1973) contém um resumo das decisões tomadas durante os debates.

A Comissão mantém a metodologia e plano de trabalho definidos nas reuniões anteriores. O documento apresenta o texto preliminarmente aprovado dos artigos propostos, seguidos de comentários.

A redação do artigo 1 fica (ONU, p. 173, 1973): “Artigo 1. Responsabilidade de um Estado por seus atos internacionalmente ilícitos: Todo ato internacionalmente ilícito implica na responsabilidade internacional daquele Estado." ${ }^{170}$ (tradução nossa)

A Comissão aceita, assim, a posição do Relator em estabelecer uma regra básica geral, sem que seja necessário adotar nenhuma posição definitiva sobre problemas que devem ser estudados posteriormente, alterando apenas a terminologia empregada (ONU, p. 175, 1973).

$\mathrm{O}$ antigo artigo III com alterações na redação, passa a ser o artigo II, que estabelece (ONU, p. 176, 1973):

Artigo 2. Possibilidade de que todo Estado pode ser considerado como tendo cometido um ato internacionalmente ilícito

Todo estado está sujeito à possibilidade de ser considerado como tendo cometido um ato internacionalmente ilícito implicando em sua responsabilidade internacional. ${ }^{171}$ (tradução nossa)

Embora o artigo tenha sofrido algumas críticas devido a sua obviedade (ONU, p. 178, 1973), optou-se por manter o artigo.

\footnotetext{
${ }^{170}$ Article 1 . Responsibility of a State for its internationally wrongful acts Every internationally wrongful act of a State entails the international responsibility of that State. ${ }^{171}$ Article 2. Possibility that every State may be held to have committed an internationally wrongful act Every State is subject to the possibility of being held to have committed an internationally wrongful act entailing its international responsibility.
} 
O antigo artigo 2 se tornou o artigo 3 com a seguinte redação (ONU, p. 179, 1973):

Artigo 3. Elementos de um ato internacionalmente ilícito

Existe um ato internacionalmente ilícito de um Estado quando:

a) Conduta consistindo em uma ação ou omissão é atribuível ao Estado segundo o direito internacional e

b) Tal conduta constitui a violação de uma obrigação internacional do Estado. ${ }^{172}$ (tradução nossa)

Também este artigo, afora alterações na terminologia, foi mantido sem mudanças substanciais.

O artigo 4, ao invés de tratar da irrelevância do direito interno para a caracterização do ato internacionalmente ilícito, passa a tratar da caracterização deste ato, e prescreve (ONU, p. 184, 1973):

Artigo 4. Caracterização de um ato de um Estado como
internacionalmente ilícito
Um ato de um estado só pode ser caracterizado como
internacionalmente ilícito pelo direito internacional. Tal
caracterização não pode ser afetada pela caracterização do mesmo ato
como lícito pelo direito interno. ${ }^{173}$ (tradução nossa)

Já o artigo 5, que trata do ato do Estado, tem algumas alterações importantes na sua redação. Pelo novo texto (ONU, p. 191, 1973):

\begin{abstract}
Artigo 5. Atribuição ao Estado de conduta dos seus órgãos Para os propósitos dos presentes artigos, a conduta de qualquer órgão do Estado que tenha este status segundo o direito interno daquele Estado, deve ser considerada como um ato do Estado mencionado segundo o direito internacional, desde que tal órgão estivesse agindo naquela capacidade no caso em questão. ${ }^{174}$ (tradução nossa)
\end{abstract}

\footnotetext{
${ }^{172}$ Article 3. Elements of an internationally wrongful act of a State There is an internationally wrongful act of a State when:

(a) Conduct consisting of an action or omission is attributable to the State under international law; and

(b) That conduct constitutes a breach of an international obligation of the State.

${ }^{173}$ Article 4. Characterization of an act of a State as internationally wrongful

An act of a State may only be characterized as internationally wrongful by international law. Such characterization cannot be affected by the characterization of the same act as lawful by internal law.

${ }^{174}$ Article 5. Attribution to the State of the conduct of its organs

For the purposes of the present articles, conduct of any State organ having that status under the internal law of that State shall be considered as an act of the State concerned under international law, provided that organ was acting in that capacity in the case in question.
} 
Do artigo proposto pelo Relator foi tirada qualquer referência a indivíduo ou grupo de indivíduos, ficando somente a menção aos órgãos do Estado.

Também o artigo 6, sobre a irrelevância da posição do órgão na organização do Estado, foi mantido com alterações de redação que não alteraram em muito o seu conteúdo.

Em sua 26 $6^{\text {a }}$ Sessão, em 1974, nas reuniões 1251 a 1253e 1255 a 1263 a CDI continuou a discussão sobre os Relatórios apresentados. Na sessão 1278 a Comissão adotou o texto dos artigos 7 a 9 em uma primeira leitura.

O artigo 7 passou a tratar da "atribuição ao Estado da conduta de outras entidades com poderes para exercer elementos da autoridade governamental", sofrendo alterações na forma e na terminologia anteriormente proposta.

Também o artigo 8 teve a formatação alterada, e a redação do título passou a contar "atribuição ao Estado de conduta de pessoas agindo, de fato, em nome do Estado.

Já o artigo 9 manteve o título original mas teve seu corpo alterado.

As alterações sofridas pelos artigos 7 a 9, no entanto, embora alterando a terminologia e mesmo a forma do artigo, não alteraram substancialmente o conteúdo proposto pelo Relator Especial (ONU, p. 169 et seq, 1974).

Na sua 27 Sessão, em 1975, nas reuniões 1303 a 1317 e 1345 a CDI continuou o estudo da matéria. Além de ter examinado e adotado em primeira leitura os artigos 10 a $15^{175}$, propostos pelo Drafting Committee, aprovou-se o plano geral da estrutura do anteprojeto. Além da parte 1, tratando da origem da responsabilidade internacional, e da parte 2, tratando do conteúdo, forma e graus da responsabilidade internacional, foi prevista a possibilidade de uma parte 3 , sobre solução de disputas e implementação da responsabilidade internacional.

A parte 1 do anteprojeto ficaria dividida em 5 capítulos sendo o capítulo I sobre os Princípios Gerais, o capítulo II sobre o ato do Estado segundo o Direito Internacional, o capítulo III sobre a violação de uma obrigação internacional (e aqui, neste capítulo, haveria um artigo tratando do crime internacional), o capítulo IV sobre a

\footnotetext{
175 Os artigos adotados versavam sobre: artigo 10, atribuição ao Estado de conduta de órgãos agindo fora de sua competência ou contrariamente a instruções relativas a sua atividade; artigo 11, conduta de pessoas não agindo em nome do Estado; artigo 12, conduta de órgãos de outro estado; artigo 13, conduta de órgãos de uma organização internacional; artigo 14, conduta de órgãos de um movimento de insurreição; artigo 15, atribuição ao Estado de ato de movimento de insurreição de se torna o novo Governo de um Estado ou que resulta na formação de um novo Estado.
} 
participação de outros Estado no ato internacionalmente ilícito, e o capítulo V sobre circunstâncias precluindo a ilicitude e circunstâncias atenuantes ou agravantes.

Em 1976 Ago apresentou seu Sexto Relatório. Após ter tratado dos princípios gerais de responsabilidade internacional e do ato de Estado, capítulos I e II da primeira parte do plano de trabalho estabelecido da CDI, o Relator passa a estudar a violação da obrigação internacional, item do capítulo III da primeira parte. Em sua primeira abordagem do elemento objetivo da responsabilidade internacional Ago propões 3 artigos.

O primeiro trata da fonte a obrigação internacional violada. Após extensa análise da jurisprudência internacional e da prática dos Estados, Ago conclui que (ONU, p. 13, 1976):

[...] segundo o direito internacional existente, a fonte da obrigação internacional afetada pela conduta do Estado não tem nenhuma relação com a caracterização de tal conduta como um ato internacionalmente ilícito. Nem tem nenhuma relação com o regime de responsabilidade aplicável ao ato internacionalmente ilícito. ${ }^{176}$ (tradução nossa)

Por isso ele propõe o seguinte artigo 16 (ONU, p. 16, 1976):

Artigo 16. Fonte da obrigação internacional violada

1. A violação por um Estado de uma obrigação internacional a ele incumbida é um ato internacionalmente ilícito, independente da fonte da obrigação internacional violada.

2. O fato de que a obrigação internacional violada resulta de uma fonte, e não de outra, não justifica, em si mesmo, a aplicação de um regime de responsabilidade diferente à violação reclamada. ${ }^{177}$ (tradução nossa)

O segundo artigo contido no Relatório versa sobre a vigência da obrigação internacional. A questão se coloca tendo em vista que muitos atos internacionais são

\footnotetext{
176 under existing international law, the source of the international obligation affected by the conduct of a State has no bearing on the characterization of such conduct as an internationally wrongful act. Nor does it have any bearing on the regime of responsibility applicable to the internationally wrongful act.

${ }^{177}$ Article 16. Source of the international obligation breached

1. The breach by a State of an international obligation incumbent upon it is an internationally wrongful act, regardless of the source of the international obligation breached.

2. The fact that the international obligation breached results from one source rather than from another does not justify, in itself, the application of a different regime of responsibility to the breach complained of.
} 
contínuos, compostos ou complexos. Para determinar a vigência de um ato internacional

Ago elabora o seguinte artigo (ONU, p. 24, 1976):

Artigo 17. Vigência de uma obrigação internacional

1.Um ato do Estado contrário ao que é requerido por uma obrigação internacional específica constitui uma violação daquela violação se o ato foi realizado quando aquela obrigação estava vigente para o Estado implicado.

2. Entretanto, um ato de um Estado que, no momento em que foi realizado, era contrário ao que era requerido por uma obrigação internacional vigente para aquele Estado, não é considerado uma violação de uma obrigação internacional do Estado e assim, não resulta em responsabilidade internacional se, subsequentemente, um ato da mesma natureza se torna uma conduta apropriada em virtude de uma norma peremptória de direito internacional.

3. Se um ato de um Estado contrário ao que é requerido por uma obrigação internacional específica

a) é um ato de natureza contínua, ele constitui uma violação da obrigação em questão se tal obrigação ainda estava vigente por ao menos parte da duração do ato contínuo e enquanto a obrigação permaneça em vigor;

b) é um ato constituindo uma série de condutas separadas relacionadas a situações separadas, ele constitui uma violação da obrigação em questão se tal obrigação ainda estava vigente enquanto ao menos algumas das condutas compondo o ato tiveram lugar e estas condutas são suficientes, por elas mesmas, para constituir a violação;

c) é um ato complexo comportando um ato inicial ou omissão de um dado órgão e a subsequente confirmação de tal ato ou omissão por outros órgãos do Estado, el constitui uma violação da obrigação em questão se tal obrigação ainda estava vigente quando o processo de realização do ato do Estado não em conformidade com tal obrigação começou. ${ }^{178}$ (tradução nossa)

\footnotetext{
${ }^{178}$ Article 17. Force of an international obligation

1. An act of the State contrary to what is required by a specific international obligation constitutes a breach of that obligation if the act was performed when the obligation was in force for the State implicated.

2. However, an act of the State which, at the time it was performed, was contrary to what was required by an international obligation in force for that State, is not considered to be a breach of an international obligation of the State and hence does not engage its international responsibility, if subsequently, an act of the same nature has become proper conduct by virtue of a peremptory rule of international law.

3. If an act of the State contrary to what is required by a specific international obligation

(a) is an act of a continuing nature, it constitutes a breach of the obligation in question if the obligation was in force for at least part of the duration of the continuing act and so long as the obligation remains in force;

(b) is an act consisting of a series of separate conducts relating to separate situations, it constitutes a breach of the obligation in question if that obligation was in force while at least some of the conducts making up the act were taking place and those conducts were sufficient by themselves to constitute the breach;

(c) is a complex act comprising the initial act or omission of a given organ and the subsequent confirmation of such act or omission by other organs of the State, it constitutes a breach of the obligation in question if that obligation was in force when the process of carrying out the act of the State not in conformity with such obligation began.
} 
Neste artigo, o Relator estabelece que o surgimento de uma norma peremptória de direito internacional posterior poderia servir como excludente da ilicitude do ato internacional (artigo 17.2)

Embora não aceite, a existência, no Direito Internacional, do princípio de direito penal de aplicação da lei mais favorável ao réu (ONU, p. 15, 1976), Ago entende que ser necessária uma exceção à regra básica estabelecida no artigo 17.1. Em suas palavras (ONU, p. 18, 1976):

A exceção estabeleceria que a conduta de um Estado que, embora ilícita no momento de sua adoção, à luz do direito internacional contemporâneo, fosse julgada não só lícita, mas legalmente requerida segundo uma norma peremptória deste direito, não enseja a responsabilidade internacional daquele Estado. ${ }^{179}$ (tradução nossa)

O artigo mais relevante, para fins deste trabalho, apresentado no Relatório, no entanto, seria o artigo 18, que trata do conteúdo da obrigação internacional. Aqui, Ago defende a possibilidade de fazer uma distinção entre as violações de obrigações internacionais tanto para fins de caracterização da conduta violadora da obrigação internacional, quanto para estabelecer o tipo de responsabilidade resultante daquela conduta. Tal critério, porém, não seria meramente formal, como o critério da fonte da obrigação em questão, mas seria um critério substantivo, relativo ao conteúdo da obrigação violada (ONU, p. 24, 1976).

Embora admita que, anteriormente, a ampla maioria dos juristas internacionais reconhecia a existência de apenas um regime de responsabilidade aplicável a todos os atos internacionalmente ilícitos, o Relator menciona a formação de uma nova corrente que entende que o direito internacional geral estabelece dois regimes diferentes de responsabilidade. Segundo ele (ONU, p. 26, 1976):

Um se aplicaria no caso de uma violação cujo respeito é de fundamental importância para a comunidade internacional como um todo, por exemplo, a obrigação de se abster de qualquer ato de agressão e a obrigação de não praticar apartheid. O outro regime se aplicaria nos caos onde o Estado apenas falhou em respeitar uma obrigação de menor importância geral. ${ }^{180}$ (tradução nossa)

\footnotetext{
179 the exception would state that conduct of a State which, although wrongful at the time of its adoption would, in the light of contemporary international law, be judged not only lawful, but legally required under a peremptory rule of that law, does not entail the international responsibility of that State.

${ }^{180}$ One would apply in the case of a breach by the State of an obligation whose respect is of fundamental importance to the international community as a whole, for example the obligation to refrain from any act of aggression, the obligation not to commit genocide and the obligation not to practise apartheid. The
} 
No primeiro caso, a violação seria considerada um crime internacional, e no segundo uma simples violação.

Ao analisar a jurisprudência internacional sobre o tema, Ago conclui que embora não existam julgados admitindo a existência de dois regimes distintos, nenhum juiz ou árbitro internacional excluiu explicitamente esta possibilidade (ONU, p. 27, 1976). Por outro lado, ele menciona do caso Barcelona Traction, sentenciado pela Corte Internacional de Justiça em 1970. Para o Relator (ONU, p. 29, 1976):

No julgamento acima citado, a Corte Internacional de Justiça parece reconhecer implicitamente a necessidade de uma distinção entre duas categorias de atos internacionalmente ilícitos de um Estado, dependendo da obrigação violada, e assim, parece ter reconhecido as consequências lógicas de tal distinção em relação ao regime de responsabilidade internacional. ${ }^{181}$ (tradução nossa)

Sobre a prática dos Estados, Ago analisa as posições adotadas por estes nos trabalhos de codificação da responsabilidade internacional realizados sob os auspícios da Liga das Nações. Ao final, ele conclui que os Estados participantes não acreditavam que o conteúdo da obrigação violada tivesse influência no regime de responsabilidade a ser aplicado (ONU, p. 30, 1976).

No entanto, o Relator ressalta as mudanças ocorridas no período entre as Grandes Guerras e em especial as mudanças ocorridas após a Segunda Guerra Mundial. Para ele (ONU, p. 31, 1976): “A necessidade de distinguir, na categoria geral de ato internacionalmente ilícito, uma categoria separada incluindo atos ilícitos excepcionalmente sérios tem, em qualquer caso, se tornado mais e mais óbvia desde o fim da Segunda Guerra Mundial." 182 (tradução nossa)

As barbáries ocorridas neste período fizeram com que surgissem novas normas de Direito Internacional. "Essas regras impõem aos Estados obrigações cujo cumprimento apresenta um grande interesse coletivo por parte de toda a comunidade

other regime would apply in cases where the State had merely failed to respect an obligation of lesser and less general importance.

${ }^{181}$ In the judgment quoted above, the International Court of Justice seems to have implicitly recognized the need for a distinction between two categories of internationally wrongful acts of the State, depending on the obligation breached, and also seems to have recognized the logical consequences of that distinction as regards the regime of international responsibility.

182 The need to distinguish, in the general category of internationally wrongful acts of States, a separate category including exceptionally serious wrongful acts has, in any case, become more and more obvious since the end of the Second World War. 
internacional." 183 (tradução nossa) Surge também a convicção de que as violações a regras deste tipo deveriam ter um tratamento diferente, um regime de responsabilidade diferenciado. (ONU, p. 31, 1976)

Ainda, segundo Ago (ONU, p. 31, 1976):

Como evidência direta ou indireta desta convicção, três fatos parecem, na nossa visão, ser de considerável significância: a) a distinção, recentemente estabelecida nas regras de direito internacional, de uma categoria de normas conhecidas como normas 'imperativas', ou normas de jus cogens; b) o estabelecimento de que um indivíduoórgão que, por sua conduta, violou obrigações internacionais de um dado conteúdo, deve ele mesmo ser considerado, embora agindo como órgãos do Estado, como pessoalmente punível e, ainda mais, punível segundo algumas normas particularmente severas do direito penal internacional; e c) o fato de que a Carta das Nações Unidas atribui consequências especiais determinadas a violação de certas obrigações. ${ }^{184}$ (tradução nossa)

Sobre o jus cogens, o Relator admite que a simples existência de uma categoria de normas não derrogáveis, não implica necessariamente que tais normas estejam sujeitas a um regime de responsabilidade diferente. Porém, a seus ver (ONU, p. 32, 1976): "Mas seria difícil acreditar que tal evolução da consciência legal dos Estados em relação à ideia da inadmissibilidade da derrogação de certas normas não seja acompanhada, por uma evolução paralela no domínio da responsabilidade do Estado.”

Para Ago seria contraditório que as mesmas consequências continuassem a ser aplicadas a violação de normas imperativas. Também seria contraditório que no caso de violação de tais obrigações, importantes a toda comunidade internacional, a relação estabelecida pela responsabilidade seria apenas entre o Estado que cometeu a violações e o Estado diretamente lesado (ONU, p. 32, 1976).

$\mathrm{O}$ Relator esquece-se de mencionar dois pontos importantes. Em relação às normas cogentes, não só estas são inderrogáveis, como elas têm a capacidade de derrogar outras normas de direito internacional, contrárias a ela (art. 53 da Convenção

\footnotetext{
183 these rules impose on states obligations whose fulfilment represents an increased collective interest on the part of the entire international community.

184 As direct or indirect evidence of this conviction, three facts seem, in our view, to be of considerable significance: $(a)$ the distinction, recently established in the rules of international law, of a special category of rules known as "imperative" rules, or rules of jus cogens; $(b)$ the establishment of the principle that an individual-organ who has, by his conduct, breached international obligations of a given content must himself be regarded, even though he acted as an organ of the State, as being personally punishable, and, what is more, punishable under some particularly severe rules of internal penal law; and (c) the fact that the Charter of the United Nations attaches some specially determined consequences to the breach of certain international obligations.
} 
de Viena sobre o Direito dos Tratados). Essa capacidade fez diversos autores mencionarem uma hierarquização das normas de Direito Internacional, como vimos anteriormente. Ainda que não se aceite essa superioridade hierárquica, ao menos uma superioridade de valor a estas normas deve ser reconhecida (REUTER, p. 56, 1983, ALEXIDZE, p. 259, 1981).

Outra questão não mencionada pelo Relator neste Relatório é a existência de violações internacionais em relação às quais não existe um Estado diretamente lesado. Esses casos são extremamente comuns principalmente no que diz respeito às violações a normas de direitos humanos. Um Estado que comete genocídio contra uma parcela de seu próprio povo não estaria causando dano direto a nenhum outro Estado. Se, pela teoria clássica da responsabilidade internacional, esta só se caracterizasse pela formação de uma relação entre o Estado violador e um Estado diretamente lesado, teríamos de admitir que tal violação a uma regra imperativa de direito internacional não enseja responsabilidade internacional.

Sobre o segundo fato, mencionado por Ago, a criação de um Direito Internacional Penal em relação a indivíduos que tenham cometido crimes internacionais, o Relator entende que em tais hipóteses em que um "indivíduo-órgão" de um Estado é pessoalmente punido por outros Estados, consequentemente, o Estado ao qual este indivíduo pertence também deve estar sujeito a um regime especial de responsabilidade (ONU, p. 33, 1976).

Por outro lado o autor argumenta que a Carta das Nações Unidas estabelece o princípio da proibição do uso da força no Direito Internacional não só como o principal, mas também atribui consequências diferenciadas ao Estado que violar este princípio, consequências estas que estão descritas no artigo VII da Carta das Nações Unidas. O Relator, porém, vai mais além. Citando o artigo I da ONU que faz referência à igualdade de direitos e autodeterminação dos povos (artigo I.2) e ao respeito aos direito humanos e liberdades fundamentais sem distinção de raça, sexo, língua ou religião (artigo I.2), o autor menciona a posição da Assembleia Geral da ONU ao caracterizar como ameaças a paz e segurança mundiais atos como o apartheid e como a manutenção de colônias.

O Relator (ONU, p. 39-40, 1976), ainda sobre a posição dos Estados a respeito do tema, ressalta que nos debates ocorridos no seio do Sexto Comitê da Assembleia Geral, durante a apresentação dos Relatórios da CDI, sobre o tema da responsabilidade dos 
Estados, alguns países fizeram expressa menção à necessidade de atribuição de um regime especial de responsabilidade no caso de graves atos ilícitos internacionais ${ }^{185}$.

Após citar a evolução doutrinária em relação a matéria, Ago faz referência aos debates ocorridos durante as Sessões da CDI, mencionando a concordância de diversos membros com a ideia de atribuição de dois regimes diferentes de responsabilidade internacional.

Concluindo esta longa exposição, o Relator propõe o artigo 18, que estabeleceria (ONU, p. 54, 1976):

Artigo 18. Conteúdo da obrigação violada

1. A violação por um Estado de uma obrigação internacional existente a ele incumbida é um ato internacionalmente ilícito, independente do conteúdo da obrigação violada.

2. A violação por um Estado de uma violação estabelecida para o propósito da manutenção da paz e segurança mundial, e em particular, a violação por um Estado da proibição de recorrer ao uso da ameaça ou da força contra a integridade territorial ou independência política de outro Estado, é um 'crime internacional'.

3. A violação séria, por um Estado de uma obrigação internacional estabelecida por uma norma geral de direito internacional aceita como essencial para a comunidade internacional como um todo e tendo como propósito:

a) respeito ao princípio de direitos iguais para todos os povos e o seu direito a autodeterminação; ou

b) respeito por direitos humanos e liberdades fundamentais para todos, sem distinção baseada em raça, sexo, língua ou religião; ou

c) a conservação e o livre gozo de todos de um recurso comum a toda a humanidade;

também é um 'crime internacional'

4. A violação pelo Estado de qualquer outra obrigação internacional é um 'delito internacional'. ${ }^{186}$

${ }^{185}$ Iraque (1973), Alemanha (1974), URSS (1975), Cyprus (1975), dentre outros.

${ }^{186}$ Article 18. Content of the international obligation breached

1. The breach by a State of an existing international obligation incumbent upon it is an internationally wrongful act, regardless of the content of the obligation breached.

2. The breach by a State of an international obligation established for the purpose of maintaining international peace and security, and in particular the breach by a State of the prohibition of any resort to the threat or use of force against the territorial integrity or political independence of another State, is an "international crime".

3. The serious breach by a State of an international obligation established by a norm of general international law accepted and recognized as essential by the international community as a whole and having as its purpose:

(a) respect for the principle of the equal rights of all peoples and of their right of self-determination; or

(b) respect for human rights and fundamental freedoms for all, without distinction based on race, sex, language or religion; or

(c) the conservation and the free enjoyment for everyone of a resource common to all mankind is also an "international crime".

4. The breach by a State of any other international obligation is an "international delict". 
O quinto Relatório de Ago foi examinado pela CDI em sua $27^{a}$ Sessão, nas reuniões 1361 a 1377 e 1401 a 1403. O trabalho foi relativamente bem recebido. Os artigos propostos foram revisados pelo "Drafting Committee" e adotados, na forma de 4 artigos, os artigos 16 a 19, em primeira leitura. A nova redação dos 3 primeiros artigos estabelecia (ONU, p. 74, 1976a):

Artigo 16. Existência de uma violação a uma obrigação internacional Existe uma violação a uma obrigação internacional de um Estado quando um ato daquele Estado não está um conformidade com o que é requerido a ele por aquela obrigação.

Artigo 17. Irrelevância da origem da obrigação internacional violada 1. Um ato de um Estado que constitui uma violação a uma obrigação internacional é um ato internacionalmente ilícito independente da origem, seja consuetudinária, convencional ou outra, daquela obrigação.

2. A origem da obrigação internacional violada por um Estado não afeta a responsabilidade internacional decorrente do ato internacionalmente ilícito do Estado.

Artigo 18. Requerimento que a obrigação internacional esteja em vigor para o Estado

1. Um ato de um Estado que não está em conformidade com o que é requerido a ele por uma obrigação internacional, constitui uma violação de tal obrigação apenas se $\mathrm{o}$ ato foi realizado no momento em que a obrigação estava em vigor para aquele Estado.

2. Entretanto, um ato do Estado que, no momento em que foi realizado, não estava em conformidade com o que era requerido a ele por uma obrigação internacional em vigor para aquele Estado, deixa de ser considerado ato internacionalmente ilícito se, subsequentemente, tal ato se torna compulsório em virtude de uma norma peremptória de direito internacional geral.

3. Se um ato de um Estado que não está em conformidade com o que foi a ele requerido por uma obrigação internacional tem o caráter contínuo, existe uma violação àquela obrigação somente em relação ao período durante o qual o ato continua enquanto a obrigação internacional está em vigor para aquele Estado.

4. Se o ato de um Estado que não está em conformidade com o que é requerido a ele por uma obrigação internacional é composto de uma série de atos ou omissões em relação a casos separados, existe uma violação àquela obrigação se tal ato pode ser considerado como constituído pelas ações ou omissões ocorridas dentro do período durante o qual a obrigação está em força para aquele Estado.

5. Se um ato de um Estado que não está em conformidade com o que é requerido por ele por uma obrigação internacional é um ato complexo, constituído por ações e omissões do mesmo ou de diferentes órgãos do Estado em relação ao mesmo caso, existe uma violação àquela obrigação se o ato complexo não em conformidade com esta começa com uma ação ou omissão ocorrida dentro do período durante o qual a obrigação está em vigor para aquele Estado, mesmo se o ato for completado fora daquele período. ${ }^{187}$ (tradução nossa)

${ }^{187}$ Article 16. - Existence of a breach of an international obligation 
Percebe-se que apesar de algumas alterações na forma e na terminologia empregada, o conteúdo dos artigos propostos pelo Relator Especial não foi modificado.

Ainda, a redação aprovada pela CDI do artigo 19 rezava (ONU, p. 75, 1976a):

Artigo 19 Crimes internacionais e delitos internacionais

1. Um ato de um Estado que constitui uma violação de uma obrigação internacional é um ato internacionalmente ilícito independente do tema da obrigação violada.

2. Um ato internacionalmente ilícito que resulta da violação por um Estado de uma obrigação internacional, tão essencial para a proteção dos interesses da comunidade internacional que sua violação é reconhecida como um crime por aquela comunidade como um todo, constitui um crime internacional.

3. Sujeito ao disposto no parágrafo 2 , e com base nas regras do direito internacional em vigor, um crime internacional pode resultar, inter alia, de:

a) uma violação séria a uma obrigação internacional de essencial importância para a manutenção da paz e segurança internacionais.

b) uma violação séria a uma obrigação internacional de essencial importância para a salvaguarda do direito de autodeterminação dos povos, tais como aquela proibindo o estabelecimento ou a manutenção pela força de dominação colonial.

c) uma grave violação em larga escala de obrigação internacional de essencial importânci para a salvaguarda do ser humano, tais como aquelas proibindo a escravidão, o genocídio e o apartheid;

There is a breach of an international obligation by a State when an act of that State is not in conformity with what is required of it by that obligation.

Article 17. - Irrelevance of the origin of the international obligation breached

1. An act of a State which constitutes a breach of an international obligation is an internationally wrongful act regardless of the origin, whether customary, conventional or other, of that obligation.

2. The origin of the international obligation breached by a State does not affect the international responsibility arising from the internationally wrongful act of that State.

Article 18. - Requirement that the international obligation be in force for the State

1. An act of the State which is not in conformity with what is required of it by an international obligation constitutes a breach of that obligation only if the act was performed at the time when the obligation was in force for that State.

2. However, an act of the state which, at the time when it was performed, was not in conformity with what was required of it by an international obligation in force for that State, ceases to be considered an internationally wrongful act if, subsequently, such an act has become compulsory by virtue of a peremptory norm of general international law.

3. If an act of the State which is not in conformity with what is required of it by an international obligation has a continuing character, there is a breach of that obligation only in respect of the period during which the act continues while the obligation is in force for that State.

4. If an act of the State which is not in conformity with what is required of it by an international obligation is composed of a series of actions or omissions in respect of separate cases, there is a breach of that obligation if such an act may be considered to be constituted by the actions or omissions occurring within the period during which the obligation is in force for that State.

5. If an act of the State which is not in conformity with what is required of it by an international obligation is a complex act constituted by actions or omissions by the same or different organs of the State in respect of the same case, there is a breach of that obligation if the complex act not in conformity with it begins with an action or omission occurring within the period during which the obligation is in force for that State, even if that act is completed after that period. 
d) uma violação séria de direito internacional de essencial importância para a salvaguarda e preservação do ambiente humano, tais como a proibição à poluição massiva da atmosfera ou dos mares.

4. Qualquer ato internacional, que não é um crime internacional de acordo com o parágrafo 2 , constitui um delito internacional. ${ }^{188}$ (tradução nossa)

A CDI faz um longo comentário a este artigo. Começando pela jurisprudência internacional a CDI entende que (ONU, p.99-100, 1976a):

\begin{abstract}
A análise acima mencionada das opiniões dos tribunais internacionais mostra que em princípio tais órgãos não negam a existência de diferentes regimes de responsabilidade do Estado para atos internacionalmente ilícitos. Pelo contrário, eles parecem, em alguns casos, apoiar a ideia de que, ao menos em algumas circunstâncias, outro tipo de responsabilidade pode ser substituída pela obrigação de reparar, e sujeitos de direito internacional outros além daquele diretamente lesado podem ter capacidade de invocar a responsabilidade resultante do ato ilícito. [...] Entretanto, por mais isolada que a expressão de tal opinião possa ainda parecer, a passagem cotada do julgamento da Corte Internacional de Justiça no caso Barcelona Traction, e, em particular, as conclusões que podem ser deduzidas dele em relação ao sujeito de direito internacional capacitado a invocar tal responsabilidade parecem um importante argumento em apoio a teoria de que existem dois regimes distintos de responsabilidade dependendo do tema da obrigação internacional violada,e consequentemente, existem dois tipos de atos internacionalmente ilícitos do Estado. ${ }^{189}$ (tradução nossa)
\end{abstract}

\footnotetext{
${ }^{188}$ Article 19. - International crimes and international delicts

1. An act of a State which constitutes a breach of an international obligation is an internationally wrongful act, regardless of the subject-matter of the obligation breached.

2. An internationally wrongful act which results from the breach by a State of an international obligation so essential for the protection of fundamental interests of the international community that its breach is recognized as a crime by that community as a whole, constitutes an international crime.

3. Subject to paragraph 2, and on the basis of the rules of international law in force, an international crime may result, inter alia, from:

(a) a serious breach of an international obligation of essential importance for the maintenance of international peace and security, such as that prohibiting aggression;

(b) a serious breach of an international obligation of essential importance

for safeguarding the right of self-determination of peoples, such as that prohibiting the establishment or maintenance by force of colonial domination;

(c) a serious breach on a widespread scale of an international obligation of essential importance for safeguarding the human being, such as those prohibiting slavery, genocide and apartheid;

(d) a serious breach of an international obligation of essential importance for the safeguarding and preservation of the human environment, such as those prohibiting massive pollution of the atmosphere or of the seas.

4. Any internationally wrongful act which is not an international crime in accordance with paragraph 2 , constitutes an international delict.

189 The foregoing analysis of the opinions of international tribunals shows that in principle these bodies do not deny the existence of different regimes of State responsibility for internationally wrongful acts. On the contrary, they seem in some instances to support the idea that, at least in certain circumstances, another form of responsibility could be substituted for the obligation to make reparation, and subjects of international law other than the one directly injured could be entitled to invoke the responsibility flowing from the wrongful act. [...] Nevertheless, however isolated the expression of such an opinion in an
} 
Já em relação à pratica dos Estados a CDI incorpora em seu relatório, salvo um ponto ou outro de discordância ${ }^{190}$, boa parte do quinto Relatório de Ago (ONU, p. 100 et seq., 1976a).

A CDI ainda acrescenta (ONU, p. 109, 1976a):

Parece inegável que a atual condenação pronta e unânime de qualquer ataque direto a paz e segurança internacionais é paralela à desaprovação quase universal por parte dos Estados a certas atividades. O direito internacional contemporâneo chegou ao ponto de condenar totalmente a prática de certos Estados de manter a força outros povos sob dominação colonial ou impor a força regimes internos baseados na discriminação e na mais absoluta segregação racial, em colocar em perigo a vida e a dignidade humana de outras formas, ou agindo de forma tão grave que coloca em risco a preservação e a conservação do ambiente humano. A comunidade internacional como um todo e não apenas um ou outro de seus membros, agora considera que tais atos violam princípios formalmente incorporados na Carta, e mesmo fora do escopo da Carta, princípios que estão tão profundamente enraizados na consciência da humanidade que eles se tornaram parte essencial das regras de direito internacional. Existem suficientes manifestações dos Estados para assegurar a conclusão que, na opinião geral, alguns destes atos constituem genuinamente 'crimes internacionais', quer dizer, atos ilícitos que são mais sérios que outros e que, como tais, deveriam resultar em consequência s legais mais severas. ${ }^{191}$

Para a CDI, no entanto, a prática dos Estados confirma que somente violações sérias a estes princípios seriam crimes internacionais (ONU, p. 110, 1976a).

Por fim a CDI conclui (ONU, p. 117, 118, 1976a):

international judgment may still appear to be, the passage quoted from the judgment of the International Court of Justice in the Barcelona Traction case and, in particular, the conclusions that can be drawn from it as regards the subject of international law entitled to invoke responsibility, seem an important argument in support of the theory that there are two separate regimes of international responsibility depending on the subject-matter of the international obligation breached, and consequently that, on the basis of that distinction, there are two different types of internationally wrongful acts of the State.

${ }^{190}$ Por exemplo, a CDI não concorda que o fato de que a atribuição de um crime segundo o Direito Internacional a um indivíduo agindo em nome do Estado deva, consequentemente, acarretar a atribuição de um crime internacional ao Estado ao qual ele pertence.

191 It seems undeniable that today's unanimous and prompt condemnation of any drect attack on international peace and security is paralleled by almost universal disapproval on the part of States towards certain other activities. Contemporary international law has reached the point of condemning outright the practice of certain States in forcibly keeping other peoples under colonial domination or forcibly imposing internal regimes based on discrimination and the most absolute racial segregation, in imperiling human life and dignity in other ways, or in so acting as gravely to endanger the preservation and conservation of the human environment. The international community as a whole, and not merely one or other of its members, now considers that such acts violate principles formally embodied in the Charter and, even outside the scope of the Charter, principles which are now so deeply rooted in the conscience of mankind that they have become particularly essential rules of general international law. There are enough manifestations of the views of States to warrant the conclusion that, in the general opinion, some of these acts genuinely constitute "international crimes", that is to say, international wrongs which are more serious than others and which, as such, should entail more severe legal consequences. 
Tendo assim, como as páginas acima indicam, analisado a evolução da jurisprudência internacional, da prática dos Estados e das opiniões legais em relação ao assunto tratado no presente artigo, os membros da Comissão chegaram unanimemente a duas conclusões. Primeiro, eles constataram que o tema da obrigação internacional violada não tem nenhuma relação com a caracterização como internacionalmente ilícito de um ato de um Estado que comete tal violação: independente do tema e do conteúdo específico da obrigação, um ato de um Estado que não esta em conformidade com o que é requerido dele por aquela obrigação é sempre e indiscutivelmente um ato internacionalmente ilícito. Segundo, a Comissão reconhece que o tema da obrigação internacional violada tem, por outro lado, relação inegável na definição do regime de responsabilidade resultando do ato internacionalmente ilícito constituído pela violação em questão. As formas de responsabilidade aplicáveis à violação de certas obrigações de importância essencial para a salvaguarda de interesses fundamentais da comunidade internacional naturalmente diferem daquelas que se aplicam a violações de obrigações cujo tema é diferente; e os respectivos sujeitos de direito internacional aos que é permitido implementar essas várias formas de responsabilidade também podem ser diferentes. A Comissão conclui disso que era necessário distinguir entre duas diferentes categorias de atos internacionalmente ilícitos, de acordo com o tema da obrigação internacional violada e que estas categorias devem ser diferentes em sua categorização. ${ }^{192}$ (tradução e grifo nosso)

A CDI faz ainda algumas considerações. A expressão "crime internacional" é utilizada para descrever atos atribuíveis a um Estado. Não deve se confundir com os termos "crime segundo o direito internacional", "crimes de guerra", "crimes contra a humanidade" que são utilizadas em Convenções para tratar de condutas de indivíduos (ONU, p. 119, 1976a). Também não se deve concluir que qualquer violação a uma norma peremptória de Direito Internacional consistiria num "crime internacional".

\footnotetext{
192 Having thus, as the foregoing pages indicate, analysed in turn the evolution of international jurisprudence, of State practice and of legal opinion with regard to the subject dealt with in the present article, the members of the Commission arrived unanimously at two conclusions. First, they found that the subject- matter of the international obligation breached has no bearing on the characterization as internationally wrongful of an act of a State which commit such a breach: regardless of the subject-matter and specific content of the obligation, an act of a State which is not in conformity with what is required of it by that obligation is always and indisputably an internationally wrongful act. Secondly, the Commission recognized that the subject-matter of the international obligation breached has, on the other hand, an undeniable bearing on the definition of the regime of responsibility attaching to the internationally wrongful act constituted by the breach in question. The forms of responsibility applicable to the breach of certain obligations of essential importance for the safeguarding of fundamental interests of the international community naturally differ from those which apply to the breach of obligations of which the subject-matter is different; and the respective subjects of international law permitted to implement (mettre en oeuvre) those various forms of responsibility may also be different. The Commission concluded from this that it was necessary to distinguish between two different categories of internationally wrongful act according to the subject-matter of the international obligation breached, and that those categories were bound to differ in their characterization.
} 
Embora geralmente os crimes internacionais advenham de violações a normas de jus cogens, esta categoria de normas é bem mais ampla do que a categoria de obrigações cuja violação ensejaria o crime internacional (ONU, p. 119-120,1976a).

O reconhecimento unânime dos membros da CDI da existência do crime internacional foi um passo importante para o desenvolvimento deste conceito na Direito Internacional. Baseado nos trabalhos da CDI, alguns doutrinadores passaram a estudar o tema e diversas obras sobre o crime internacional foram lançadas. Também os Estados, em especial no âmbito do Sexto Comitê da Assembleia Geral, passaram a discutir o tema, uns demonstrando seu apoio e reconhecimento, outros questionando a abordagem adotada pela CDI.

Em 1977 Ago apresenta seu sexto Relatório. Dando continuidade ao trabalho iniciado no ano anterior, o Relator continua tratando da violação da obrigação internacional (ONU, p. 3-43, 1977). Sobre o tema ele propõe mais três artigos. O primeiro tratando da violação da obrigação internacional que exige que o Estado adote uma conduta específica (artigo 20), o segundo, sobre a violação da obrigação internacional que exige um determinado resultado (artigo 21) e o terceiro versando sobre a exaustão dos remédios locais (artigo 22).

O tema da responsabilidade internacional foi estudado pela CDI na 29a Sessão, nas reuniões 1454 a 1457, 1460 a 1463 e 1465 a 1469. O Relatório do Relator Especial foi debatido e os artigos apresentados, conforme revisados pelo Drafting Committee, foram aprovados em primeira leitura ${ }^{193}$. Como anteriormente, as alterações feitas no

\footnotetext{
193 Article 20. Breach of an international obligation requiring the adoption of a particular course of conduct

There is a breach by a State of an international obligation requiring it to adopt a particular course of conduct when the conduct of that State is not in conformity with that required of it by that obligation.

Article 21. Breach of an international obligation requiring the achievement of a specified result

1. There is a breach by a State of an international obligation requiring it to achieve, by means of its own choice, a specified result if, by the conduct adopted, the State does not achieve the result required of it by that obligation.

2. When the conduct of the State has created a situation not in conformity with the result required of it by an international obligation, but the obligation allows that this or an equivalent result may nevertheless be achieved by subsequent conduct of the State, there is a breach of the obligation only if the State also fails by its subsequent conduct to achieve the result required of it by that obligation.

Article 22. Exhaustion of local remedies

When the conduct of a State has created a situation not in conformity with the result required of it by an international obligation concerning the treatment to be accorded to aliens, whether natural or juridical persons, but the obligation allows that this or an equivalent result may nevertheless be achieved by subsequent conduct of the State, there is a breach of the obligation only if the aliens concerned have exhausted the effective local remedies available to them without obtaining the treatment called for by the obligation or, where that is not possible, an equivalent treatment. (CDI, p. 11, 1977a)
} 
texto original proposto pelo Relator foram relativas à redação e à forma dos artigos, mantendo o conteúdo proposto quase inalterado.

A Assembleia Geral da ONU, após haver aprovado em 1974, 1975 e 1976 Resoluções ${ }^{194}$ instando a CDI a continuar seu trabalho sobre a responsabilidade dos Estados, dando a este prioridade, em 1977 aprova a Resolução 32/151, que recomenda à Comissão que continue seu trabalho sobre o tema com o objetivo de completar ao menos a primeira leitura da primeira parte do anteprojeto de artigos durante o presente mandato de seus membros ${ }^{195}$.

No seu Sétimo Relatório, apresentado em 1978, Ago conclui o capítulo III da primeira parte do anteprojeto de artigos, sobre a violação da obrigação internacional. Mais dois artigos são propostos sobres este tema. O primeiro sobre a violação de uma obrigação de evitar um evento (artigo 23) e o segundo sobre o tempo da violação de uma obrigação internacional (artigo 24). O Relator também deu início ao quarto capítulo, tratando da implicação de um Estado no ato internacionalmente ilícito de outro Estado. O primeiro artigo deste novo capítulo tratava da cumplicidade de um Estado no ato internacionalmente ilícito de outro Estado (artigo 25).

Em sua análise sobre a participação de um Estado na conduta ilícita de outro Estado, Ago verifica que existem três possibilidades de participação: a incitação, a coerção, e a assistência (ONU, p. 54, 1978).

Em relação à incitação, o Relator conclui que não existe, nem na prática dos Estados nem na jurisprudência, casos que justifiquem a atribuição de responsabilidade a um Estado por simples incitamento a ato internacionalmente ilícito (ONU, p. 55, 1978).

Já a questão da pressão de um Estado em relação a outro para cometer um ilícito é mais complexa. O Relator, deixando de lado o debate se a própria coerção, seja pelo uso ou ameaça ao uso da força seja econômica ou outra, seria, em si, um ato ilícito internacional, entende que nos casos em que a coerção seja tal que limite ou impeça um Estado de soberanamente tomar uma decisão, não existe a participação e sim um caso de responsabilidade por ato de outro (ONU, p. 57, 1978).

\footnotetext{
${ }^{194}$ Resoluções 3315 (XXIX), 3495 (XXX) e 31/97.

195 b) Continue on a high priority basis its work on State responsibility, taking into account resolutions of the General Assembly adopted at previous sessions, with the aim of completing at least the first reading of the set of articles constituting part I of the draft on responsibility of States for internationally wrongful acts, within the present term of office of the members of the International Law Commission. (Resolution 32/151, disponível em: http://daccess-ddsny.un.org/doc/RESOLUTION/GEN/NR0/313/86/IMG/NR031386.pdf?OpenElement. Acesso em: 3 de set. 2010.
} 
Assim, para Ago, o único caso de participação de um Estado na comissão de um ilícito de outro seria a assistência. Nesses casos, considerados pelo Relator como casos de cumplicidade, o Estado, por ato próprio, facilita a ação do Estado infrator. A cumplicidade pode ser tanto em relação a um "crime internacional" como em relação a um "delito internacional", tal como definidos pelo artigo 19 adotado pela CDI. Ela também pode envolver um ato que por si é um ilícito internacional ou um ato que, em si mesmo, não é um ilícito. Quanto a caracterização desta participação, Ago entende que esta, como regra geral, deve ser considerada como um ato distinto do ato ilícito principal, tendo características e consequências legais diferentes (ONU, p. 59-60, 1978).

Finalmente, ele propõe o seguinte artigo (ONU, p. 60, 1978):

Artigo 25. Cumplicidade de um Estado no ato internacionalmente ilícito de outro Estado

O fato de um Estado dar assistência a outro Estado em sua conduta, de forma a permitir ou ajudar aquele Estado a cometer uma ofensa internacional contra um terceiro Estado constitui um ato internacionalmente ilícito do Estado, que, então, se torna um acessório à comissão da ofensa e incorre em responsabilidade internacional, mesmo se a conduta em questão não fosse, de outra forma, internacionalmente ilícita. ${ }^{196}$ (tradução nossa)

A CDI analisou o Relatório apresentado na sua $30^{\mathrm{a}}$ Sessão, nas reuniões 1476 a 1482, 1513, 1516 a 1519 e 1524 . O artigo 23 proposto pelo Relator foi aprovado com algumas alterações na redação ${ }^{197}$. O Artigo 24 , que versava sobre o tempo da violação da obrigação internacional foi dividido em três artigos: o artigo 24, que tratava do momento e duração da violação de uma obrigação internacional que não se estende no tempo ${ }^{198}$, o artigo 25 , que tratava do momento e duração de uma obrigação

\footnotetext{
${ }^{196}$ Article 25. Complicity of a State in the internationally wrongful act of another State

The fact that a State renders assistance to another State by its conduct in order to enable or help that State to commit an international offence against a third State constitutes an internationally wrongful act of the State, which thus becomes an accessory to the commission of the offence and incurs international responsibility thereby, even if the conduct in question would not otherwise be internationally wrongful.

${ }^{197}$ Article 23. Breach of an international obligation to prevent a given event

When the result required of a State by an international obligation is the prevention, by means of its own choice, of the occurrence of a given event, there is a breach of that obligation only if, by the conduct adopted, the State does not achieve that result. (CDI, p. 80, 1978)

198 Article 24. Moment and duration of the breach of an international obligation by an act of the State not extending in time

The breach of an international obligation by an act of the State not extending in time occurs at the moment when that act is performed. The time of commission of the breach does not extend beyond that moment, even if the effects of the act of the State continue subsequently. (ibid, p. 80, 1978)
} 
internacional que se estende no tempo ${ }^{199}$ e o artigo 26, que tratava da violação de uma obrigação internacional de evitar um dado evento ${ }^{200}$.

Já o artigo 25, sobre a cumplicidade de um Estado no ato internacionalmente ilícito de outro, passou a ser o artigo 27, que tratava da ajuda ou assistência de um Estado a outro Estado para a comissão de um ato internacionalmente ilícito. A comissão, embora concordando com a maioria das considerações feitas pelo Relator, decidiu unanimemente excluir o termo "cumplicidade" e adotar os termos "ajuda ou assistência". Em seus comentários, a CDI ainda esclarece que para que os seguintes elementos devem estar presentes na regra geral que regule a participação: a ajuda ou assistência deve ter o efeito de facilitar materialmente a comissão do ato pelo outro Estado; a ajuda ou assistência deve ser dada com o intuito de facilitar essa comissão; a conduta do Estado participante deve ser considerada internacionalmente ilícita precisamente em razão desta participação; e o ato internacionalmente ilícito de participação através da ajuda ou assistência para a comissão de um ato internacionalmente ilícito de outro não deve ser confundido com a ofensa principal, e a responsabilidade internacional emergente deste também deve permanecer separada (ONU, p. 104, 1978a). Isto posto, o texto final adotado pela Comissão estabelece:

Artigo 27. Ajuda ou assistência de um Estado a outro Estado para a comissão de um ato internacionalmente ilícito

Ajuda ou assistência de um Estado a outro Estado, se se estabeleceu que esta foi dada para a comissão de um ato internacionalmente ilícito, realizado pelo segundo, constitui um ato internacionalmente ilícito em

\footnotetext{
199 Article 25. Moment and duration of the breach of an international obligation by an act of the State extending in time

1. The breach of an international obligation by an act of the State having a continuing character occurs at the moment when that act begins. Nevertheless, the time of commission of the breach extends over the entire period during which the act continues and remains not in conformity with the international obligation.

2. The breach of an international obligation by an act of the State, composed of a series of actions or omissions in respect of separate cases, occurs at the moment when that action or omission of the series is accomplished which establishes the existence of the composite act. Nevertheless, the time of commission of the breach extends over the entire period from the first of the actions or omissions constituting the composite act not in conformity with the international obligation and so long as such actions or omissions are repeated.

3. The breach of an international obligation by a complex act of the State, consisting of a succession of actions or omissions by the same or different organs of the State in respect of the same case, occurs at the moment when the last constituent element of that complex act is accomplished. Nevertheless, the time of commission of the breach extends over the entire period between the action or omission which initiated the breach and that which completed it. (ibid, p. 80, 1978)

${ }^{200}$ Article 26. Moment and duration of the breach of an international obligation to prevent a given event The breach of an international obligation requiring a State to prevent a given event occurs when the event begins. Nevertheless, the time of commission of the breach extends over the entire period during which the event continues. (ibid, p. 80, 1978)
} 
si mesmo, mesmo se, tomada isoladamente, tal ajuda u assistência não constituísse uma violação de uma obrigação internacional. ${ }^{201}$ (tradução nossa)

Nesta mesma Sessão a Comissão decidiu, devido à complexidade do tema, submeter aos Estados os artigos sobre a responsabilidade internacional dos Estados, adotados em primeira leitura pela Comissão, compondo os capítulo I, II e III da primeira parte do anteprojeto de artigos.

No seu oitava Relatório, apresentado em 1979, o Relator termina o capítulo IV, com um artigo sobre a responsabilidade indireta de um Estado pelo ato internacionalmente ilícito de outro (artigo 28), e inicia o capítulo V, sobre circunstâncias precluindo a ilicitude. Neste novo capítulo, quatro artigos são propostos. O primeiro sobre o consentimento do Estado lesado (artigo 29), o segundo sobre a aplicação legítima de uma sanção (artigo 30) e o terceiro e quarto sobre a força maior e eventos fortuitos (artigos 31 e 32).

$\mathrm{O}$ artigo 28 trataria dos casos em que a vontade do Estado que cometeu o ato internacionalmente ilícito se encontra limitada pela vontade de outro Estado. São os casos de dependência e coerção.

No capítulo V, vale destacar o artigo 30, que estabelece como circunstância precluindo a ilicitude de um ato, a aplicação legítima de uma sanção. O Relator explica que o termo "sanção" estaria sendo utilizado como sinônimo de "uma ação cujo objeto é infligir punição ou assegurar uma atuação e que toma a forma de uma infração ao que, em outras circunstâncias, seria considerado um direito subjetivo internacional, exigindo respeito do sujeito contra o qual a ação foi tomada." ${ }^{202}$ (ONU, p. 39, 1979)

Tal sanção encontra algumas limitações no Direito Internacional Contemporâneo. Represálias armadas, já não são admitidas e para ser considerada legítima, ela deve guardar proporcionalidade com o dano sofrido devido à ofensa em questão (ONU, p. 40 et seq, 1979).

Sob a questão da legalidade de aplicação destas medidas por Estados não diretamente lesados pelo ato ilícito, Ago faz um extenso comentário. Embora reconheça

\footnotetext{
201 Article 27. Aid or assistance by a State to another State for the commission of an internationally wrongful act

Aid or assistance by a State to another State, if it is established that it is rendered for the commission of an internationally wrongful act, carried out by the latter, itself constitutes an internationally wrongful act, even if, taken alone, such aid or assistance would not constitute the breach of an international obligation. 202 an action the object of which is to inflict punishment or to secure performance and which takes the form of an infringement of what in other circumstances would be an international subjective right, requiring respect, of the subject against which the action is taken.
} 
que (ONU, p. 43, 1979) “[...] o antigo monopólio do Estado diretamente lesado pelo ato internacionalmente ilícito de outro Estado, em relação à possibilidade de aplicar sanções contra aquele outro Estado que de outro modo seriam ilícitas, não é mais absoluto no direito internacional moderno" ${ }^{203}$, o Relator esclarece que (ONU, p. 43, 1979):

Ele [o monopólio] provavelmente ainda subsiste no direito internacional geral, mesmo se, em abstrato, alguns podem achar lógico fazer certas inferências da afirmação progressiva do princípio segundo o qual algumas obrigações - definidas como obrigações erga omnes são de tão grande alcance que a violação de uma delas deve ser considerada como uma ofensa cometida contra todos os membros da comunidade internacional e não simplesmente contra o Estado ou os Estados diretamente afetados pela violação. ${ }^{204}$ (tradução nossa)

A seu ver (ONU, p. 43, 1979):

Em realidade, não se pode subestimar os riscos envolvidos no reconhecimento deste princípio - o principal mérito do qual, seria que este afirma a necessidade de uma solidariedade universal ao tratar das violações mais sérias à ordem internacional - ao ponto onde qua lquer Estado estaria automaticamente autorizado a reagir contra uma violação de certas obrigações cometidas contra outro Estado e individualmente tomar medidas punitivas contra o Estado responsável pela violação. ${ }^{205}$ (tradução nossa)

Ainda, para Ago (ONU, p. 43, 1979):

É compreensível, assim, que uma comunidade como a comunidade internacional, procurando uma organização mais estruturada, mesmo se apenas com uma 'institucionalização incipiente, deva ter tomado outra direção, em direção a um sistema encarregando as instituições internacionais, em vez de os Estados, da responsabilidade exclusiva, primeiro, de determinar a existência de uma violação a uma obrigação de importância básica para toda a comunidade internacional, e depois,

\footnotetext{
203 the former monopoly of the State directly injured by the internationally wrongful act of another State, as regards the possibility of resorting against that other State to sanctions which would otherwise be unlawful, is no longer absolute in modern international law.

${ }^{204}$ It probably still subsists in general international law, even if, in abstracto some might find it logical to draw certain inferences from the progressive affirmation of the principle that some obligations-defined in this sense as obligations erga omnes - are of such broad sweep that the violation of one of them is to be deemed an offence committed against all members of the international community, and not simply against the State or States directly affected by the breach.

${ }^{205}$ In reality, one cannot underestimate the risks that would be involved in pressing recognition of this principle - the chief merit of which, in our view, is that it affirms the need for universal solidarity in dealing with the most serious assaults on international order-to the point where any State would be held to be automatically authorized to react against the breach of certain obligations committed against another State and individually to take punitive measures against the State responsible for the breach.
} 
de decidir quais medidas devem ser tomadas em resposta e como elas devem ser implementadas. ${ }^{206}$ (tradução nossa)

Sobre o tema ele também acrescenta (ONU, p. 43, 1979):

Segundo a Carta das Nações Unidas, essas responsabilidades são atribuídas aos órgãos competentes da Organização. Esses órgãos - e neste ponto que nos interessa no contexto do tema desta seção - tem o poder não só de autorizar, mas mesmo de dirigir um Estado Membro que não aquele diretamente lesado por uma ofensa internacional em particular, ou um grupo de Estados, ou as vezes, todos os Estados Membros, a aplicar certas sanções não envolvendo o uso da força contra um Estado que cometeu uma ofensa de um conteúdo e gravidade específicos. ${ }^{207}$ (tradução nossa)

Assim, o Relator Especial, embora admita que o princípio que estabelece que somente os Estados diretamente lesados pelo ato internacionalmente ilícito podem tomar, legalmente, sanções ou represálias contra o Estado violador, não é mais absoluto, reluta em reconhecer que o Direito Internacional Geral tenha admitido a possibilidade de aplicação de sanções a todos os Estados da comunidade internacional em caso de violação de uma obrigação erga omnes. Para ele cabe as instituições internacionais determinar tanto a existência de uma violação a regras deste tipo, quando as medidas a serem tomadas em virtude desta.

Em outras palavras, o Relator Especial não admite a adoção de contramedidas por Estados não diretamente lesados pelo ato internacionalmente ilícito, mesmo em caso de obrigações erga omnes.

Ao final, Ago propõe o seguinte artigo (ONU, p. 47, 1979):

Artigo 30. Aplicação legítima de uma sanção

A ilicitude internacional de um ato não em conformidade com o que, de outra forma, seria requerido de um Estado em virtude de uma obrigação internacional em relação a outro Estado é precluída se o ato

\footnotetext{
${ }^{206}$ It is understandable, therefore, that a community such as the international community, in seeking a more structured organization, even if only an incipient "institutionalization", should have turned in another direction, namely towards a system vesting in international institutions other than States the exclusive responsibility, first, for determining the existence of a breach of an obligation of basic importance to the international community as a whole, and thereafter, for deciding what measures should be taken in response and how they should be implemented.

207 Under the United Nations Charter, those responsibilities are vested in the competent organs of the Organization. These organs-and this is the point which interests us in the context of the subject matter of this section-are empowered not only to authorize, but even to direct a Member State other than the one directly injured by a particular international offence, or a group of Member States, 193 or at times, all Member States, to apply certain sanctions not involving the use of force against a State which has committed an offence of a specified content and gravity.
} 
foi cometido como uma aplicação legítima de uma sanção contra aquele outro Estado, em consequência de um ato internacionalmente ilícito cometido por aquele outro Estado. ${ }^{208}$ (tradução nossa)

Este Relatório foi examinado pela CDI em sua 31 ${ }^{\text {a }}$ Sessão, nas reuniões 1532 a $1538,1540,1542$ a $1545,1567,1569$ a 1573 e 1579.

O artigo 28 teve alterações substanciais, tanto na forma quanto no conteúdo. Ao invés de isentar o Estado que cometeu o ato internacionalmente ilícito de responsabilidade internacional quando dominado ou coagido por outro Estado, estabelecendo a responsabilidade indireta do estado dominante ou coator, a nova redação do artigo determinava que a responsabilidade do Estado dominado ou coagido não ficava prejudicada (ONU, p. 94, 1979a).

O artigo 29 sobre o consentimento como circunstância precluindo a ilicitude, teve mais um parágrafo adicionado ao seu texto estabelecendo a invalidade do consentimento como excludente de ilicitude em caso de norma peremptória ${ }^{209}$.

Já o artigo 30 teve a terminologia empregada modificada. Ao invés do termo "sanção" proposto pelo Relator foi utilizado o termo "contramedidas" que foram definidas pela CDI (ONU, p. 116, 1979) como "medidas cujo objeto é, por definição, infligir punição ou assegurar uma atuação - medidas que, sob condições diferentes, infringiriam um direito subjetivo válido do sujeito contra o qual a medida foi aplicada." ${ }^{210}$ (tradução nossa)

O comentário sobre a possibilidade de adoção de contramedidas por Estados não diretamente lesados também foi modificado pela Comissão que, após reconhecer que o principio que estabelece que somente os Estados diretamente lesados pelo ato internacionalmente ilícito podem tomar, le galmente, contramedidas contra o Estado violador, não é mais absoluto afirma (ONU, p. 118-119, 1979):

\footnotetext{
${ }^{208}$ Article 30, Legitimate application of a sanction

The international wrongfulness of an act not in conformity with what would otherwise be required of a State by virtue of an international obligation towards another State is precluded if the act was committed as the legitimate application of a sanction against that other State, in consequence of an internationally wrongful act committed by that other State.

${ }^{209}$ Article 29. Consent

1. The consent validly given by a State to the commission by another State of a specified act not in conformity with an obligation of the latter State towards the former State precludes the wrongfulness of the act in relation to that State to the extent that the act remains within the limits of that consent.

2. Paragraph 1 does not apply if the obligation arises out of a peremptory norm of general international law. For the purposes of the present draft articles, a peremptory norm of general international law is a norm accepted and recognized by the international community of States as a whole as a norm from which no derogation is permitted and which can be modified only by a subsequent norm of general international law having the same character.

210 measures the object of which is, by definition, to inflict punishment or to secure performancemeasures which, under different conditions, would infringe a valid and subjective right of the subject against which the measures are applied.
} 
A progressiva afirmação no direito internacional moderno do princípio que algumas obrigações - denominadas obrigações erga omnes - são de tão grande alcance que a violação de qualquer uma delas é tida como uma ofensa a todos os membros da comunidade internacional e não simplesmente contra o Estado ou os Estados diretamente afetados pela violação, levou a comunidade internacional a se voltar a um sistema que encarrega as instituições internacionais em vez dos Estados da responsabilidade exclusiva, primeiro, de determinar a existência de uma obrigação de importância básica para toda a comunidade internacional, e depois, de decidir quais medidas devem ser tomadas em resposta e como elas devem ser implementadas. ${ }^{211}$ (tradução nossa)

O texto final aprovado pela CDI, embora não reconheça a possibilidade de Estados não diretamente lesados de adotarem contramedidas, estabelece sem sombra de dúvida que a violação de uma obrigação erga omnes atinge a todos os Estados da comunidade internacional.

A CDI também adotou mais dois artigos no capítulo referente a circunstâncias precluindo a ilicitude, um referente à força maior e ao evento fortuito (artigo $31^{212}$ ) e outro referente ao perigo (artigo $32^{213}$ ).

Ago foi eleito e assumiu as funções de Juiz da Corte Internacional de Justiça neste mesmo ano, tendo participado da $31^{\text {a }}$ Sessão da CDI apenas como convidado. CDI, então, designou Willem Riphagen como Relator Especial para o tema da responsabilidade do Estado (CDI, p. 90, 1979).

Ago ainda apresentaria um addendum ao Oitavo Relatório em 1980, para finalizar o trabalho até então realizado.

\footnotetext{
211 The progressive affirmation in modern international law of the principle that some obligationstermed obligations erga onmes - are of such broad sweep that a breach of any one of them is to be deemed an offence against all the members of the international community and not simply against the State or States directly affected by the breach, has led the international community to turn towards a system which vests in international institutions other than States exclusive responsibility, first, for determining the existence of a breach of an obligation of basic importance to the international community as a whole, and, thereafter, for deciding what measures are to be taken in response and how they are to be implemented.

${ }^{212}$ Article 31. Force majeure and fortuitous event

1. The wrongfulness of an act of a State not in conformity with an international obligation of that State is precluded if the act was due to an irresistible force or to an unforeseen external event beyond its control which made it materially impossible for the State to act in conformity with that obligation or to know that its conduct was not in conformity with that obligation.

2. Paragraph 1 shall not apply if the State in question has contributed to the occurrence of the situation of material impossibility.

${ }^{213}$ Article 32. Distress

1. The wrongfulness of an act of a State not in conformity with an international obligation of that State is precluded if the author of the conduct which constitutes the act of that State had no other means, in a situation of extreme distress, of saving his life or that of persons entrusted to his care.

2. Paragraph 1 shall not apply if the State in question has contributed to the occurrence of the situation of extreme distress or if the conduct in question was likely to create a comparable or greater peril.
} 
O addendum apresentado em 1980 continha dois artigos que encerravam o capítulo $\mathrm{V}$ do anteprojeto. Os artigos tratavam do Estado de Necessidade (artigo 33) e da Legítima Defesa (artigo 34) como circunstâncias precluindo a ilicitude.

O trabalho do Relator Especial Ago estabeleceu as bases do conceito de responsabilidade internacional que seria consagrado pela CDI em seu projeto de artigos. Segundo Crawford (ONU, p. 3, 2002):

Em particular, seu tratamento detalhado das regras de atribuição e de justificação ou desculpa para um ato internacionalmente ilícito (sob o título 'Circunstâncias precluindo ilicitude') foi influenciador. Ele foi frequentemente mencionado por doutrinadores e citado por cortes. Ele estabeleceu um padrão para o projeto. ${ }^{214}$ (tradução nossa)

A estrutura da primeira parte do anteprojeto de artigos, por ele proposta, foi mantida no projeto final, e embora o conceito de crime internacional tenha sido retirado do projeto, o conceito de violações sérias a normas imperativas de Direito Internacional o substituiu.

Em suma, o trabalho de Ago definiu a primeira parte do anteprojeto de artigos, estabelecendo padrões importantes que seriam seguidos pelos demais Relatores Especiais encarregados do tema.

\subsection{Trabalho realizado pelo Relator Willem Riphagen (1979-1986)}

Tendo sido indicado pela CDI como Relator Especial para o tema da responsabilidade do Estado em 1979, após a eleição do Relator anterior a Juiz da Corte Internacional de Justiça, Riphagen apresenta seu Relatório Preliminar em 1980. Estando a primeira parte do anteprojeto de artigos praticamente terminada, faltando apenas a consideração de dois artigos sobre circunstâncias precluindo a ilicitude, cabe ao novo Relator iniciar a segunda parte do trabalho, sobre o conteúdo, forma e grau da responsabilidade do Estado.

Neste Relatório Preliminar, Riphagen parte da definição dada por Ago e adotada pela CDI de responsabilidade internacional como (ONU, p. 112, 1980) "todas as novas relações jurídicas que poder ser estabelecidas pelo Direito Internacional devido ao ato

\footnotetext{
${ }^{214}$ In particular, its detailed treatment of the rules of attribution and the general justification or excuses for an internationally wrongful act (under the title 'Circumstances precluding wrongfulness') was influential. It was frequently referred to by scholars and cited by courts. It set a standard for the project.
} 
internacionalmente ilícito"215 (tradução nossa), para desenhar um catálogo sistemático destas novas relações.

De acordo com o Relator, três parâmetros aparecem. Primeiro, as novas obrigações do Estado culpado. Segundo, os novos direitos do Estado lesado. Terceiro, a posição dos Estados terceiros a respeito da situação criada pelo ato internacionalmente ilícito.

Em relação ao primeiro parâmetro, o objetivo primário seria o restabelecimento da situação anterior ao ato internacionalmente ilícito, ou seja, o restitutio in integrum. Este estaria dividido em três aspectos. $\mathrm{O}$ aspecto ex nunc, relativo ao presente, que geralmente trata do restabelecimento de um direito que foi tomado pelo ato ilícito. $\mathrm{O}$ aspecto ex tunc, relativo ao passado, que geralmente prevê o pagamento dos danos como uma reparação das consequências causadas pelo ato ilícito. E o aspecto ex ante, relativo ao futuro, que prevê a confirmação da obrigação violada, provavelmente na forma de uma garantia contra futuras violações da mesma obrigação (ONU,, p. 113, 1980).

Segundo o Relator (ONU,, p. 113, 1980): "quanto mais séria a violação, mais completa a nova obrigação de restitutio in integrum (lato sensu, i.e., nos seus três aspectos mencionados acima)." ${ }^{\text {,16 }}$ (tradução nossa)

Assim, para o Relator (ONU, p. 113, 1980):

Em geral, o provimento de 'garantias' contra violações futuras (o aspecto ex ante) é reservada para os casos de violação, através do uso de força externa ou meios similares, de direitos fundamentais de outro Estado, enquanto uma mera reparação ex tunc é requerida em casos onde, dentro do quadro do exercício interno de jurisdição de um Estado, uma obrigação 'relativa ao tratamento a ser dado aos estrangeiros' (art. 22) foi violada. ${ }^{217}$ (tradução nossa)

Já em relação ao terceiro parâmetro, o Relator analisa a posição de um Estado, parte de um tratado multilateral, cuja obrigação foi violada, mas que não foi diretamente lesado por esta violação.

\footnotetext{
215 all the forms of new legal relationships that may be established by international law by a State's wrongful act.

216 the more serious the breach, the more complete the new obligation of restitutio in integrum (lato sensu, i.e., in its three aspects mentioned above).

217 in general, the giving of "guarantees" against future breaches (the ex ante-aspect) is reserved for cases of violation, through the use of external force or similar means, of fundamental rights of another State, whereas a mere reparation ex tunc is required in cases where, within the framework of the exercise of internal jurisdiction of a State, an obligation "concerning the treatment to be accorded to aliens" (art. 22) has been breached.
} 
Para ele (ONU, p. 114-115, 1980):

Obviamente aquele Estado não pode reclamara danos ex tunc, uma vez que, por definição, não houve dano aos seus interesses materiais. Mas um restabelecimento ex nunc (para o benefício direto do Estado lesado!) e uma garantia ex ante contra futuras violações pode ser do interesse (não material) daquele Estado, em particular no caso mencionado no artigo 60 da Convenção de Viena, i.e. '... se o tratado é de tal natureza que uma violação substancial de suas disposições por uma das partes modifique radicalmente a situação de cada uma das partes quanto ao cumprimento posterior de suas obrigações decorrentes do tratado, ${ }^{218}$ (tradução nossa)

Riphagen ainda afirma (ONU, p. 115, 1980):

O Relator Especial se inclina a ir além e a aceitar que um tratado multilateral pode ser de tal natureza que mesmo uma violação por uma das partes que pode não ser considerada como uma 'violação substancial' para os propósitos do artigo 60 da Convenção de Viena, pode capacitar outro Estado parte, cujos interesses materiais não foram diretamente afetados, a reclamar do Estado culpado um restabelecimento ex nunc e talvez mesmo uma garantia ex ante, mesmo se a violação não 'modifique radicalmente a situação de cada uma das partes'. ${ }^{219}$ (tradução nossa)

O Relator ainda considera que tais garantias ex ante, seriam (ONU, p. 115, 1980) “comparáveis a 'contramedidas' contra o não cumprimento da obrigação primaria original. ${ }^{, 220}$ (tradução nossa)

Para Riphagen a regra geral seria a que estabelece que um ato ilícito não criaria uma nova relação jurídica entre o Estado culpado e outro Estado além do Estado lesado. Mas esta regra teria três exceções. A primeira seria quando houvesse mais de um Estado lesado; a segunda seria quando a regra primária, cuja obrigação foi violada, está contida em um tratado multilateral; e a terceira seria quando a obrigação violada protege um

\footnotetext{
${ }^{218}$ Obviously that State can not claim damages ex tunc, since by definition there is no injury to its material interest. But a re-establishment ex nunc (to the direct benefit of the injured State!) and a guarantee ex ante against further breaches may well be in the (non-material) interest of that State, in particular in the case mentioned in article 60 of the Vienna Convention, i.e. "...if the treaty is of such a character that a material breach of its provisions by one party radically changes the position of every party with respect to the further performance of its obligations under the treaty".

${ }^{219}$ The Special Rapporteur is even inclined to go further and to accept that a multilateral treaty may be of such a character that even a breach by one party, which can not be considered a "material breach" for the purpose of article 60 of the Vienna Convention, may entitle another State party, whose material interests are not directly affected, to claim from the guilty State a re-establishment ex nunc and perhaps even a guarantee ex ante, even if the breach does not "radically change the position of every party".

${ }^{220}$ Comparable to "counter measures" against the non-fulfilment of the original primary obligation.
} 
interesse que não diz respeito a somente um Estado, tal como estabelecido no artigo 19 do anteprojeto (ONU, p. 119, 1980)

A primeira exceção não traz grandes dificuldades. Um ato internacionalmente ilícito pode perfeitamente causar danos diretos a mais de um Estado.

Sobre a segunda exceção, Riphagen escreve (ONU, p. 120, 1980):

[...] a Convenção de Viena reconhece a existência de tratados multilaterais nos quais as relações jurídicas entre cada parte e as outras partes estão inextricavelmente interligadas e constituem um todo indivisível. Isto não é longe de dizer que tais tratados multilaterais particulares criam uma situação jurídica na qual cada obrigação de um Estado parte em relação ao tratado é uma obrigação erga omnes (claro, dentro do quadro da comunidade dos Estados parte do tratado multilateral). Vista deste modo, o segundo tipo de exceção é mais uma prefiguração em escala regional, do terceiro. ${ }^{221}$ (tradução nossa)

Em relação ao terceiro tipo de exceção, Riphagen entende que (ONU, p. 120, 1980) "uma 'posição não neutra' de um terceiro Estado em respeito ao ato ilícito parece implicar na qualificação de ato ilícito como um crime internacional" 222 (tradução nossa)

O Relator Especial ainda vai mais além ao afirmar que (ONU, p. 121, 1980): "uma 'posição não neutra' de um terceiro Estado, ou mesmo de todo terceiro Estado, é uma 'consequência legal' de um ato ilícito que não está necessariamente reservada para os atos ilícitos que constituem crime internacional. ${ }^{, 223}$ (tradução nossa) Para ele, esta posição adviria de violação de uma norma do jus cogens, ainda que tal violação não pudesse ser caracterizada como crime internacional (ONU, p. 120-121, 1980)

Apesar de reconhecer que os Estados não diretamente lesados pelo ato internacionalmente ilícito gozam de uma posição "não neutra", Riphagen estabelece uma condição para que estes possam aplicar contramedidas contra o Estado violador.

Ao analisar a jurisprudência internacional, em especial o Parecer Consultivo da Corte Internacional de Justiça sobre as Consequências Legais para os Estados da presença contínua da África do Sul na Namíbia, o Relator conclui que (ONU, p. 121,

\footnotetext{
${ }^{221}[\ldots]$ the Vienna Convention does recognize the existence of particular multilateral treaties in which the legal relations between each party and each other party are inextricably interwoven and constitute an indivisible whole. This is not far from saying that such particular multilateral treaties create a legal situation in which each obligation of a State party to the treaty is an obligation erga omnes (of course, within the framework of the community of States parties to the multilateral treaty). Seen in this light, the second type of exception is rather a prefiguration on a regional scale, of the third.

222 a "non-neutral position" of the third State in respect of the wrongful act seems to be implied in the qualification of the wrongful act as an "international crime".

${ }_{223}^{23}$ a "non-neutral position" of a third State, or even of every third State, is a "legal consequence" of a wrongful act that is not necessarily reserved for such wrongful acts as constitute international crimes.
} 
1980) "uma decisão coletiva é requerida antes que os Estados terceiros possam tomar qualquer ação em relação à 'nova relação jurídica' criada pelo ato ilícito, entre o Estado culpado e o terceiro Estado."224 (tradução nossa)

Ainda, para Riphagen, mais que um direito, a nova relação jurídica entre o Estado violador e o Estado não diretamente lesado pode constituir mesmo um dever. Em suas palavras (ONU, p. 122, 1980):

não se pode, parece, excluir a priori um dever dos Estados segundo regras de direito internacional geral de agir (ou de abster-se de atos que de outra forma seriam admissíveis) em resposta a uma violação de uma obrigação internacional, em particular quando esta violação constitui um 'crime internacional' no sentido do artigo 19 do anteprojeto de artigos sobre a responsabilidade do Estado, mesmo se tal violação não envolve, de fato, a paz e segurança internacionais. De novo, uma decisão coletiva pare esse efeito seria um pré-requisito para estabelecer tal dever, e a regra da proporcionalidade deve sempre ser observada. $^{225}$ (tradução nossa)

Sobre a proporcionalidade o Relator ainda comenta (ONU, p. 126, 1980): "dificilmente se pode imaginar um 'crime internacional' ser justificado como uma contramedida contra qualquer violação de uma obrigação internacional, mesmo se a violação, em si, constitui um crime internacional."226

O novo Relator Especial, em seu Relatório preliminar, reconhece a possibilidade do ato internacionalmente ilícito criar uma nova relação entre o Estado violador e um Estado que não tenha sido diretamente lesado pelo ato internacionalmente ilícito. Isto pode ocorrer tanto quando a obrigação violada está contida em um tratado multilateral do qual os dois Estados fazem parte, quanto quando esta violação for de uma obrigação internacional determinada por uma norma do jus cogens, ou seja, uma norma peremptória. Nestes dois casos o Estado não diretamente lesado tem o direito, e por vezes mesmo o dever, de adotar medidas contra o Estado violador visando os aspectos

\footnotetext{
224 This, then, rather seems to confirm the statement that a collective decision is required before third States can take any action under a "new legal relationship", created by a wrongful act, between the guilty State and third States.

${ }^{225}$ Be that as it may, one cannot, it would seem, exclude a priori a duty of States under rules of general international law to act (or to refrain from otherwise admissible acts) in response to a breach of an international obligation, in particular when such a breach constitutes an "international crime" in the sense of article 19 of the draft articles on State responsibility, even if such breach does not, in fact, involve international peace and security. Again, a collective decision to that effect would seem to be a prerequisite for establishing such duty, and the rule of proportionality should at all times be observed. 226 one could hardly imagine an "international crime" to be justified as a counter-measure against any breach of an international obligation, even a breach which constitutes itself an international crime.
} 
ex nunc e ex ante da restitutio in integrum, ou seja, medidas visando a restituição do direito violado e medidas de garantia de não repetição.

Riphagen, assim, admite a possibilidade de adoção de contramedidas por Estados não diretamente lesados desde que estas respeitem dois requisitos. A existência de uma decisão coletiva sobre a licitude do ato internacional, e a proporcionalidade entre a medida tomada e a violação cometida.

Em relação a esta decisão coletiva, não fica claro, porém, que "coletividade" teria competência para determinar a ilegalidade do ato ilícito e qual o alcance desta determinação. Bastaria declarar simplesmente a ilicitude, ou a decisão deveria conter autorização expressa e mesmo os parâmetros das medidas a serem tomadas diante do ato internacionalmente ilícito?

O Relatório Preliminar de Riphagen foi examinado pela CDI na sua $32^{\mathrm{a}}$ Sessão, nas reuniões 1597 a 1601 (ONU, p. 73 et seq., 1980a). Durante os debates alguns membros $^{227}$ expressaram a opinião de que demasiada ênfase foi dada a questão dos Estados não diretamente lesados e das contramedidas. Questionou-se também a terminologia utilizada, tanto em relação ao termo "Estados terceiros" quanto ao termo "Estado culpado". Outros membros, no entanto, apoiaram as posições adotadas pelo Relator Especial. Destaca-se o discurso de Schwebel segundo o qual (ONU, p. 92, 1980b):

Tendo em vista a atual ordem legal internacional descentralizada, as descaradas e repetidas violações ao direito internacional que caracterizam a presente era, e a ineficácia das instituições internacionais, contramedidas podem ser o único recurso aberto para Estados lesados cumpridores da lei. No mundo de hoje, contramedidas podem não só ser legais, mas necessárias. $^{228}$ (tradução nossa)

\footnotetext{
${ }^{227}$ Sahovic, Vallat e Barboza.

228 in view of the current decentralized international legal order, the brazen and repeated violations of international law that characterized the present era and the ineffectiveness of international institutions, countermeasures might be the only recourse open to law-abiding injured States. In the world of today, countermeasures might be not only lawful but necessary,
} 
Este membro da CDI também entende que (ONU, p. 92, 1980b) "uma ofensa particularmente séria poderia criar uma nova relação entre o Estado transgressor e um grupo de Estados, ou mesmo toda a comunidade internacional." ${ }^{229}$ (tradução nossa)

Schwebel vai ainda mais além do que o Relator em relação à possibilidade de aplicação de contramedidas por Estados não diretamente lesados ao afirmar que (ONU, P. 93, 1980b): "Uma decisão coletiva pode ser e provavelmente é necessária para requerer que os Estados terceiros tome m uma ação em resposta, mas se ela é necessária para autorizá- los a tomar tal ação é menos certo."230 (tradução nossa)

Nesta Sessão também foram analisados os artigos propostos pelo antigo Relator Especial Ago, referentes ao Estado de Necessidade e Legítima Defesa, sendo adotados em primeira leitura 3 artigos. Um relativo ao Estado de necessidade (artigo 33), outro relativo à Legítima Defesa (artigo 34), e um terceiro tratando de um reserva a compensação por dano (artigo 35) ${ }^{231}$. Tendo concluído os trabalhos na primeira parte do anteprojeto, a CDI decidiu submetê-la à apreciação dos Estados (ONU, p. 30, 1980a).

Tendo em vista a decisão da CDI na Sessão anterior de submeter aos Estados os três primeiros capítulos do anteprojeto de artigos, a CDI recebeu alguns comentários dos Estados sobre o trabalho realizado. O artigo 19, que tratava do crime internacional,

\footnotetext{
${ }^{229}$ a particularly serious offence could well give rise to a new relationship between the transgressor State and a group of States or, indeed, the entire international community.

${ }^{230}$ A collective decision might be and probably was needed in order to require third States to take responsive action, but whether it was needed in order to authorize them to take such action was less certain.

${ }^{231}$ Article 33. State of necessity

1. A state of necessity may not be invoked by a State as a

ground for precluding the wrongfulness of an act of that State not in conformity with an international obligation of the State unless:

(a) the act was the only means of safeguarding an essential interest of the State against a grave and imminent peril; and

(b) the act did not seriously impair an essential interest of the State towards which the obligation existed.

2. In any case, a state of necessity may not be invoked by a State as a ground for precluding wrongfulness:

(a) if the international obligation with which the act of the State is not in conformity arises out of a peremptory norm of general international law; or

(b) if the international obligation with which the act of the State is not in conformity is laid down by a treaty which, explicitly or implicitly, excludes the possibility of invoking the state of necessity with respect to that obligation; or

(c) if the State in question has contributed to the occurrence of the state of necessity.

Article 34. Self defence

The wrongfulness of an act of a State not in conformity with an international obligation of that State is precluded if the act constitutes a lawful measure of self-defence taken in conformity with the Charter of the United Nations.

Article 35. Reservation as to compensation for damage

Preclusion of the wrongfulness of an act of a State by virtue of the provisions of articles 29, 31, 32 or 33 does not prejudge any question that may arise in regard to compensation for damage caused by that act. (CDI, p. 33-34, 1980a)
} 
recebeu apoio $^{232}$, em especial dos países do bloco soviético. Já Áustria, Canadá e Holanda preferiram reservar suas posições até que as consequências do referido artigo estivessem estabelecidas (ONU, A/CN.4/328, 1980b).

No seu segundo Relatório, Riphagen propõe cinco novos artigos para compor a parte II do anteprojeto. Os três primeiros seriam princípios gerais que fariam parte do capítulo $\mathrm{I}^{233}$. Já os dois últimos seriam parte do Capítulo II, que trataria das obrigações do Estado que cometeu um ato internacionalmente ilícito. $\mathrm{O}$ artigo 4 estabeleceria (ONU, p. 101, 1981):

Artigo 4. Sem prejuízo das determinações do artigo 5,

1. Um Estado que cometeu um ato internacionalmente ilícito deve:

a) descontinuar o ato, libertar e retornar as pessoas e objetos apreendidos através de tal ato, e evitar os efeitos contínuos de tal ato, e

b) segundo o artigo 22 da parte 1 dos presentes artigos, aplicar tais remédios que estão previstos por, ou admitidos segundo seu direito interno; e

c) restabelecer a situação que existia antes da violação.

2. Na medida em que for materialmente impossível agir em conformidade com as determinações do parágrafo 1 do presente artigo, ele deve pagar uma soma em dinheiro ao Estado lesado, correspondente ao valor que o cumprimento de tais obrigações implicaria.

3. No caso mencionado no parágrafo 2 do presente artigo, o Estado deve, adicionalmente, prover satisfação ao Estado lesado na forma de um pedido de desculpas ou de garantias de não repetição da violação apropriadas. $^{234}$ (tradução nossa)

\footnotetext{
232 Bielorússia, Mali, Ucrânia, URSS e Iugoslávia.

233 Article 1
}

A breach of an international obligation by a State does not, as such and for that State, affect [the force of] that obligation.

Article 2

A rule of international law, whether of customary, conventional or other origin, imposing an obligation on a State, may explicitly or implicitly determine also the legal consequences of the breach of such obligation.

Article 3

A breach of an international obligation by a State does not, in itself, deprive that State of its rights under international law.

234 Article 4

Without prejudice to the provisions of article 5 ,

1. A State which has committed an internationally wrongful act shall:

(a) discontinue the act, release and return the persons and objects held through such act, and prevent continuing effects of such act; and

(b) subject to article 22 of part 1 of the present articles, apply such remedies as are provided for in, or admitted under, its internal law; and

(c) re-establish the situation as it existed before the breach.

2. To the extent that it is materially impossible for the State to act in conformity with the provisions of paragraph 1 of the present article, it shall pay a sum of money to the injured State, corresponding to the value which a fulfilment of those obligations would bear. 
Já o artigo 5 proposto teria a seguinte redação (ONU, p. 101, 1981):

\begin{abstract}
Artigo 5
1. Se o ato internacionalmente ilícito é uma violação de uma obrigação internacional relativa ao tratamento a ser dado por um Estado [dentro de sua jurisdição] aos estrangeiros, sejam pessoas naturais ou jrídicas, o Estado que cometeu a violação tem a opção tanto de cumprir a obrigação mencionada no artigo 4, parágrafo 1 , item c, ou se agir de acordo com o artigo 4, parágrafo 2.

2. Entretanto, se, no caso mencionado no parágrafo 1 do presente artigo,

a) o ato ilícito foi cometido com a intenção de causar dano direto ao Estado lesado, ou

b)os remédios, referidos no artigo 4 , parágrafo 1 , item b não estão em conformidade com uma obrigação internacional do Estado de prover remédio efetivo, e o Estado concernido exerce a opção de agir em conformidade com o artigo 4 parágrafo 2 , o parágrafo 3 daquele artigo deve ser aplicado. ${ }^{235}$ (tradução nossa)
\end{abstract}

Os artigos foram estudados pela CDI na sua 33ª Sessão, nas reuniões 1666 a 1670 e 1682 a 1684. Houve grande discussão entre os membros sobre a necessidade de inserir os três primeiros artigos em um capítulo introdutório. O artigo 5, tratando dos estrangeiro, também foi questionado. No artigo 4, a referência feita ao direito interno também foi criticada. No final dos debates, os artigos mencionados foram enviados para o Drafting Committee.

Tendo em vista a decisão da CDI de submeter a primeira parte do anteprojeto de artigos aos Estados, alguns governos apresentaram seus comentários por escrito (ONU, A/CN.4/342, p. 71, 1981a). A Bulgária, embora apoiando a ideia geral contida no artigo 19, em relação ao crime internacional, fez algumas ressalvas referentes à inclusão da poluição como crime internacional. A Checoslováquia, seguindo a mesma linha, reservou sua posição até que as implicações do artigo estivessem melhor estabelecidas.

3. In the case mentioned in paragraph 2 of the present article, the State shall, in addition, provide satisfaction to the injured State in the form of an apology and of appropriate guarantees against repetition of the breach.

235 Article 5

1. If the internationally wrongful act is a breach of an international obligation concerning the treatment to be accorded by a State [within its jurisdiction] to aliens, whether natural or juridical persons, the State which has committed the breach has the option either to fulfil the obligation mentioned in article 4, paragraph 1, under (c), or to act in accordance with article 4, paragraph 2.

2. However, if, in the case mentioned in paragraph 1 of the present article,

(a) the wrongful act was committed with the intent to cause direct damage to the injured State, or

(b) the remedies, referred to in article 4, paragraph 1, under (b $\backslash$ are not in conformity with an international obligation of the State to provide effective remedies, and the State concerned exercises the option to act in conformity with article 4, paragraph 2, paragraph 3 of that article shall apply. 
A Alemanha, apesar de não concordar com a utilização da terminologia crime internacional, afirmou: "se normas de direito internacional, cuja observância das quais a comunidade internacional como um todo tem interesse, são violadas, terceiros Estados, embora não diretamente envolvidos, podem estar habilitados a tomar contramedidas ou a participar de tais medidas."236 (tradução nossa). Já a Suécia expressou claramente suas reservas em relação ao artigo 18 e 19 propostos.

No seu terceiro Relatório, apresentado em 1982, Riphagen faz uma revisão dos artigos propostos no segundo Relatório e discorre sobre o problema geral da redação da parte 2 do anteprojeto de artigos, sobre o catálogo de consequências jurídicas e a relação entre a violação de uma obrigação internacional e as consequências desta.

Durante estas considerações o Relator discorre sobre as obrigações de um terceiro Estado a reagir contra uma violação de uma obrigação internacional. Em suas palavras (ONU, p. 38, 1982):

Aqui, novamente, existem vários graus desta obrigação. Pode-se distinguir entre a) uma obrigação de não reconhecer o resultado legal de tal violação pelo Estado autor; b) uma obrigação de aceitar para si alguma consequência lesiva de medidas legais tomadas pelo Estado lesado em resposta a uma violação, e c) uma obrigação de tomar medidas (positivas) de modo a restaurar a situação existente antes da violação, e mesmo, possivelmente, de modo a evitar uma repetição da violação. ${ }^{237}$ (tradução nossa)

Já em relação especificamente ao crime internacional Riphagem escreve (ONU, p.

44, 1982):

Pode ser dito que a noção de 'crime internacional' implica em ao menos um terceiro parâmetro de consequências jurídicas: alguma forma de implementação internacional. Não se pode aceitar esta noção sem ao mesmo tempo prover consequências jurídicas específicas ou os meios de implementação. ${ }^{238}$ (tradução nossa)

\footnotetext{
${ }^{236}$ If rules of international law are violated in the observation of which the community of States as a whole has a vested interest, third States, although not immediately involved, might well be entitled to take countermeasures or to participate in such measures.

237 Here again there are various degrees of such obligation. One may distinguish between $(a)$ an obligation not to recognize as legal the result of such violation by the author State; $(b)$ an obligation to accept for oneself some injurious consequences of measures lawfully taken by the injured State in response to the violation; and (c) an obligation to take (positive) measures in order to restore the situation as it existed before the breach, and possibly even in order to prevent a repetition of the breach.

${ }^{238}$ Nevertheless, it may be stated that the notion of "international crime" implies at least a third parameter of legal consequences: some form of international enforcement. One can hardly accept this notion without at the same time providing for its specific legal consequences and the means of "implementation" (mise en oeuvre).
} 
Ainda para o Relator (ONU, p. 44, 1982):

Uma tal consequência jurídica poderia ser a obrigação de todos os Estados de contribuir para a situação na qual o Estado autor de um crime internacional seja compelido a parar a violação. Como um mínimo, tal contribuição incluiria evitar dar apoio a posteriori à conduta constituindo um crime internacional. O segundo grau de contribuição seria dar apoio as contramedidas tomadas por outro Estado ou Estados, e um terceiro grau de seria tomar contramedidas contra o Estado autor. ${ }^{239}$

Tais medidas, como anteriormente defendido por Riphagen, deveriam ser precedidas de uma decisão coletiva. Ele, no entanto, prevê a hipótese de uma exceção a este requisito. Em suas palavras (ONU, p. 45, 1982):

A distinção entre graus de contramedidas pode, talvez, ser aplicada na questão do direito de um Estado ou Estados de responder ao crime internacional na ausência de uma decisão coletiva a este respeito do órgão competente das Nações Unidas. Pode-se tirar a conclusão de que medidas relativas a retirada de apoio a posteriori e o término ou a suspensão de relações de tratado com o Estado autor são permitidas, ao menos até uma decisão do órgão das Nações Unidas competente. 240 (tradução nossa)

O Relator Especial, no seu estudo sobre o tema das consequências jurídicas da responsabilidade internacional reconhece a criação de relações jurídicas entre o Estado autor do ilícito e outros Estados que não os diretamente lesados pelo ato. Tais relações poderiam tomar a forma de direitos e mesmo obrigações de agir de forma a impedir a continuação da violação, e mesmo garantir a sua não repetição. Tais direitos ou obrigações poderiam tomar a forma de contramedidas, que o Estado não diretamente lesado poderia ou deveria adotar contra o Estado violador. Tais contramedidas geralmente deveriam ser precedidas de uma decisão coletiva sobre a ilicitude do ato e

239 133. One such specific legal consequence could be an obligation of all States to contribute to a situation in which the author State of an international crime could be compelled to stop the breach. As a minimum, such contribution would include refraining from support a posteriori of the conduct constituting an international crime. A second degree of contribution would be a support of countermeasures taken by another State or States, and a third degree would be the taking of countermeasures against the author State.

240 the distinction between the degrees of countermeasures may perhaps be applied also to the question of the right of a State or States to respond to an international crime in the absence of a collective decision to that effect of the competent United Nations body. One could then draw the conclusion that measures amounting to the withdrawal of support a posteriori and termination or suspension of treaty relationships with the author State are allowed, at least pending a decision of the competent organ of the United Nations. 
mesmo da natureza das medidas a serem adotadas. No entanto, tal requisito pode ser dispensável quando a contramedida se tratar da retirada de apoio ou rompimento de relações estabelecidas em um tratado, em especial se estas medidas forem temporais ou ao menos reversíveis (ONU, p. 45, 1982).

Neste Relatório Riphagen também propõe 6 artigos. O primeiro tratando da relação entre a primeira parte do anteprojeto de artigos com a segunda parte (artigo I), o segundo tratando da proporcionalidade entre o ilícito e o direito dos outros Estados (artigo 2), o terceiro sobre outras consequências jurídicas advindas do ato ilícito previsto em outras normas de direito internacional (artigo 3), o quarto sobre a compatibilidade das consequências jurídicas com as normas de jus cogens, o quinto sobre a compatibilidade destas consequências com as disposições estabelecidas pela Carta Das Nações Unidas, e o sexto estabelecendo o seguinte (ONU, p. 48, 1982):

\begin{abstract}
Artigo 6
1. Um ato internacionalmente ilícito de um Estado, que constitui um crime internacional, acarreta uma obrigação para todos os outros Estados:

a) de não reconhecer como legal a situação criada por tal ato; e

b) de não dar ajuda ou assistência ao autor do ato para manter a situação criada por tal ato; e

c) de juntar-se aos outros Estados dando assistência mútua ao executar as obrigações segundo o item a e b.

2. A não ser que de outra forma estabelecido por uma norma aplicável de direito internacional, o cumprimento das obrigações mencionadas no parágrafo lestá sujeito mutatis mutandis aos procedimentos previstos na Carta das Nações Unidas a respeito da manutenção da paz e segurança internacionais.

3. Sujeito ao artigo 103 da Carta das Nações Unidas, no evento de um conflito entre as obrigações de um Estado segundo os parágrafos 1 e 2 acima, e seus direitos e obrigações segundo qualquer outra norma de direito internacional, as obrigações segundo o presente artigo devem prevalecer. ${ }^{241}$
\end{abstract}

${ }^{241}$ Article 6

1. An internationally wrongful act of a State, which constitutes an international crime, entails an obligation for every other State:

(a) not to recognize as legal the situation created by such act; and

(b) not to render aid or assistance to the author State in maintaining the situation created by such act; and

(c) to join other States in affording mutual assistance in carrying out the obligations under (a) and (b).

2. Unless otherwise provided for by an applicable rule of international law, the performance of the obligations mentioned in paragraph 1 is subject mutatis mutandis to the procedures embodied in the United Nations Charter with respect to the maintenance of international peace and security.

3. Subject to Article 103 of the United Nations Charter, in the event of a conflict between the obligations of a State under paragraphs 1 and 2 above, and its rights and obligations under any other rule of international law, the obligations under the present article shall prevail. 
O artigo 6, proposto pelo Relator Especial, autoriza, ainda que indiretamente, a adoção de contramedidas por Estados não diretamente lesados. Ao estabelecer no seu parágrafo 3 que as obrigações contidas no parágrafo primeiro se sobrepõem as demais obrigações internacionais dos Estados, o artigo permite que um Estado tome medidas que, de outra forma seriam consideradas ilícitas segundo o Direito Internacional, ainda que seja para: não reconhecer a situação criada pelo ato ilícito; não dar ajuda ou assistência na manutenção desta situação; ou auxiliar outros Estados a cumprir com estas obrigações.

Em tais situações não seria necessária nem mesmo uma decisão coletiva anterior, defendida pelo próprio Relator para a tomada de contramedidas por Estados não diretamente lesados.

Este terceiro Relatório foi examinado pelo CDI em sua $34^{\mathrm{a}}$ Sessão, nas reuniões 1731 a 1734 e 1736 a 1738. Os debates foram intensos em relação a todos os artigos propostos.

Sobre o artigo 6, ponderourse que as consequências jurídicas do crime internacional deveriam ser tratadas em um capítulo exclusivo, quando poderiam ser abordadas na sua totalidade. Enquanto alguns membros preferiram reservar suas posições em relação a este artigo, outros defenderam que mais obrigações positivas deveriam ser definidas no tocante aos Estados não diretamente lesados diante de um crime internacional. Alguns membros, ainda, questionaram a eficácia das disposições do referido artigo para evitar os crimes internacionais. Ao final, a Comissão decidiu encaminhar os artigos propostos para o Drafting Committee (ONU, p. 82, 1982a).

Alguns países apresentaram comentários à parte I do anteprojeto. Dentre estes, a Espanha, que embora apoiasse a ideia de crime internacional, contida no artigo 19, acreditava que esta requeria um suporte institucional difícil de ser proporcionado naquele momento histórico.

Em 1983 Riphagen apresenta seu quarto Relatório. Após resumir rapidamente o trabalho apresentado nos Relatórios anteriores, o Relator apresenta um plano do possível conteúdo das partes 2 e 3 do anteprojeto de artigos.

Segundo o Relator (ONU, p. 12, 1983):

é pequena as chances dos Estados em geral aceitaram uma norma jurídica segundo as linhas do artigo 19 da parte 1 do projeto de artigos sem uma garantia legal de que eles não serão acusados por um ou por todos os outros Estados de ter cometido um crime internacional, e 
enfrentar demandas e contramedidas de um ou todos os Estados sem um estabelecimento independente e mandatório dos fatos e do direito aplicável. ${ }^{242}$

Para este, também a comunidade internacional e os outros Estados iriam requerer uma (ONU, p. 13, 1983) "declaração independente e mandatória e uma discussão e decisão coletivas sobre a divisão do ônus de implementação."243 (tradução nossa)

Ainda para Riphagen (ONU, p. 15, 1983) “represálias são geralmente consideradas como permitidas só em formas limitadas e em casos limitados." 244 (tradução nossa)

Dentre as limitações às represálias destacam-se às limitações referentes ao uso da força (ONU, p. 15, 1983), e as limitações impostas por regimes objetivos que defendem o respeito aos direitos humanos (ONU, p. 17, 1983).

Assim Riphagen defendia a possibilidade da adoção de contramedidas por Estados terceiros, porém estas contramedidas deveriam ser precedidas de uma decisão coletiva sobre a ilicitude do ato internacional e mesmo sobre a natureza das medidas a serem tomadas. Estas contramedidas ou represálias deveriam ser vistas como excepcionais e estariam sujeitas a diversas limitações como o recurso ao uso da força ou a violação de direitos humanos.

O Relator também define, neste Relatório, o que ele entende por Estado lesado. Em suas palavras (ONU, p. 23, 1983):

O Estado lesado é: a) o Estado cujo direito segundo uma norma de direito consuetudinário foi afetado pela violação; ou b) se a violação é uma violação de uma obrigação imposta por um tratado, o Estado parte daquele tratado, se esta estabelecido que a obrigação foi estipulada em seu favor; ou c) se a violação é uma violação de uma obrigação segundo um julgamento ou outra decisão vinculante na solução de uma disputa por uma instituição internacional, o Estado parte da disputa. $^{245}$ (tradução nossa)

\footnotetext{
242 The Special Rapporteur is of the opinion that there is little chance that States generally will accept a legal rule along the lines of article 19 of part 1 of the draft articles without a legal guarantee that they will not be charged by any or all other States with having committed an international crime, and be faced with demands and countermeasures by any or all other States without an independent and authoritative establishment of the facts and the applicable law.

243 independent and authoritative statement and a collective discussion and decision on the sharing of the burden of implementation.

${ }^{244}$ reprisals are generally considered as allowed only in limited forms and in limited cases.

245 123. The injured State is: $(a)$ the State whose right under a customary rule of international law is infringed by the breach; or $(b)$ if the breach is a breach of an obligation imposed by a treaty, the State party to that treaty, if it is established that the obligation was stipulated in its favour; or (c) if the breach is a breach of an obligation under a judgment or other binding decision in settlement of a dispute by an international institution, the State party to the dispute.
} 
Ainda segundo Riphagen (ONU, p. 23, 1983):

O Estado lesado tem direito a: a) reclamar reparação; b) suspender o cumprimento de suas obrigações em relação ao Estado autor, que corresponde a ele ou que esta diretamente conectada com a obrigação violada; e c) após a exaustão dos remédios internacionais disponíveis, suspender, por meio de represália, o cumprimento de usas outras obrigações em relação ao Estado autor (sujeito a proibição de medidas manifestamente desproporcionais). ${ }^{246}$ (tradução nossa)

O Relator, no entanto, amplia a noção tradicional de Estado lesado. Segundo este (ONU, p. 23, 1983):

No caso mencionado no parágrafo anterior [obrigação cujo descumprimento por uma parte necessariamente afeta os direitos ou o cumprimento da obrigação de todas as outras partes; obrigação estipulada para a proteção dos interesses coletivos dos Estados partes do tratado ou para a proteção individual de pessoas independente de sua nacionalidade; ou tratado multilateral impondo obrigações previstas por um procedimento de decisões coletivas], todas as outras partes do tratado multilateral são consideradas Estados lesados em relação à violação de uma daquelas obrigações por um deles. ${ }^{247}$ (tradução nossa)

Para Riphagen, em caso de tratados multilaterais, como os tratados de direitos humanos, todos os Estados parte do tratado podem ser considerados Estados lesados quando violada uma obrigação contida neste tratado. Assim, todos os Estados, partes do tratado, podem tomar contramedidas contra o Es tado violador, desde que exauridos os remédios legais internacionais.

O tema da responsabilidade do Estado foi debatido pela CDI na sua $35^{\text {a }}$ Sessão, nas reuniões 1771 a 1773, 1775 a 1780 e 1806. Mais uma vez os debates foram intensos e não houve consenso entre os membros sobre a forma como os trabalhos deveriam prosseguir. Sobre a questão das represálias, vários membros aconselharam cuidado ao lidar com o tema por medo que este pudesse desencadear uma escalada de conflitos. Outros membros questionaram a necessidade de exaustão dos remédios internacionais

\footnotetext{
${ }^{246}$ The injured State is entitled: $(a)$ to claim reparation; $(b)$ to suspend the performance of its obligation towards the author State, which corresponds to or is directly connected with the obligation breached; and (c) after exhaustion of the international legal remedies available, to suspend, by way of reprisal, the performance of its other" obligations towards the author State (subject to the prohibition of manifestly disproportional measures).

${ }^{247} 125$. In the case mentioned in the preceding paragraph, all other States parties to the multilateral treaty are considered to be injured States in respect of the breach of those obligations by one of them.
} 
para a adoção de contramedidas. Outros membros, ainda expressaram a necessidade de maior elaboração da ideia de que um ato internacionalmente ilícito poderia ser considerado um (ONU, p. 42, 1983a) "ilícito erga omnes, em particular com respeito a questão das respostas dos Estados individuais a tais atos."248 (tradução nossa)

Por fim, a Comissão adotou provisoriamente os artigos 1, 2, 3 e 5, apresentados pelo Drafting Committee. O artigo I tratava da relação da parte 2 com a primeira parte do anteprojeto $^{249}$. O artigo 2 versava sobre as consequências jurídicas de responsabilidade do Estado previstas por outras normas de direito internacional ${ }^{250}$. O artigo 3 tratava da competência residual do direito consuetudinário para regular aspectos da responsabilidade não tratados no anteprojeto $^{251}$, e o artigo 5 vinculava as consequências jurídicas da responsabilidade as determinações da Carta das Nações Unidas $^{252}$.

No seu quinto Relatório, Riphagen propõe 16 artigos cujo conteúdo demonstra uma modificação no pensamento exposto até então. A começar pelo artigo 5 , que estabelece (ONU, p. 3, 1984):

\section{Artigo 5}

Para os propósitos do presente artigo, ‘Estado lesado' significa:

a) Se o ato internacionalmente ilícito constitui uma violação de um direito pertencendo a um Estado em virtude de uma norma consuetudinária de direito internacional ou a um direito advindo de uma determinação de um tratado para um Estado terceiro, o Estado cujos direitos foram violados;

b) Se o ato internacionalmente ilíc ito constitui uma violação de uma obrigação imposta por um julgamento ou outra decisão de solução de

\footnotetext{
248 wrongful erga omnes, in particular with respect to the question of responses of individual States to such acts.

249 Article 1

The international responsibility of a State which, pursuant to the provisions of part 1, arises from an internationally wrongful act committed by that State, entails legal consequences as set out in the present part. (CDI, p. 44, 1983)

250 Article 2

Without prejudice to the provisions of articles [4] and 5, the provisions of this part govern the legal consequences of any internationally wrongful act of a State, except where and to the extent that those legal consequences have been determined by other rules of international law relating specifically to the internationally wrongful act in question. (ibid, p. 44, 1983)

251 Article 3

Without prejudice to the provisions of articles [4] and 5, the rules of customary international law shall continue to govern the legal consequences of an internationally wrongful act of a State not set out in the provisions of the present part. (ibid, p. 45, 1983)

252 Article 5

The legal consequences of an internationally wrongful act of a State set out in the provisions of the present part are subject, as appropriate, to the provisions and procedures of the Charter of the United Nations relating to the maintenance of international peace and security. (ibid, p. 45, 1983)
} 
disputas vinculante de um tribunal ou uma corte internacional o outro Estado parte ou Estados partes da disputa;

c) se o ato internacionalmente ilícito constitui uma violação de uma obrigação imposta por um tratado bilateral, o outro Estado parte do tratado;

d) se o ato internacionalmente ilícito constitui uma violação de uma obrigação imposta por um tratado multilateral, um Estado parte daquele tratado, se estabelecido que:

i) a obrigação foi estipulada em seu favor;

ii) a violação da obrigação por um Estado parte necessariamente afeta o exercício de direitos ou o cumprimento de obrigações de todos os outros Estados partes; ou

iii) a obrigação foi estipulada para a proteção dos interesses coletivos dos Estados partes; ou

iv) a obrigação foi estipulada para a proteção de pessoas individuais, independente de sua nacionalidade;

e) se o ato internacionalmente ilícito constitui um crime internacional, todos os outros Estados. ${ }^{253}$ (tradução nossa)

Neste artigo o Relator Especial amplia a noção de Estado lesado, incluindo nesta categoria não só os Estados que sofreram diretamente o dano pela violação ocorrida, mas também os demais Estados partes de um tratado multilateral, dependendo da natureza do tratado e das obrigações nele estabelecidas, e no caso de crimes internacionais, todos os Estados membros da comunidade internacional.

A ampliação da noção de Estado lesado tem consequências importantes em relação aos direitos e obrigações de Estados, até então considerados "Estados terceiros", em relação ao Estado violador. Estas consequências estão descritas nos artigos seguintes. Estabelece o artigo 6 (ONU, p. 3, 1984):

\section{Artigo 6}

\section{Article 5}

For the purposes of the present articles, "injured State" means:

(a) if the internationally wrongful act constitutes an infringement of a right appertaining to a State by virtue of a customary rule of international law or of a right arising from a treaty provision for a third State, the State whose right has been infringed;

(b) if the internationally wrongful act constitutes a breach of an obligation imposed by a judgment or other binding dispute-settlement decision of an international court or tribunal, the other State party or States parties to the dispute;

(c) if the internationally wrongful act constitutes a breach of an obligation imposed by a bilateral treaty, the other State party to the treaty;

(d) if the internationally wrongful act constitutes a breach of an obligation imposed by a multilateral treaty, a State party to that treaty, if it is established that:

(i) the obligation was stipulated in its favour; or

(ii) the breach of the obligation by one State party necessarily affects the exercise of the rights or the performance of the obligations of all other States parties; or

(iii) the obligation was stipulated for the protection of collective interests of the States parties; or

(iv) the obligation was stipulated for the protection of individual persons, irrespective of their nationality;

(e) if the internationally wrongful act constitutes an international crime, all other States. 
1. O Estado lesado pode requerer ao Estado que cometeu o ato internacionalmente ilícito que:

a) descontinue o ato, libertando e retornando as pessoas e objetos apreendidos através de tal ato, e evitar os efeitos contínuos de tal ato; e

b) aplicar os remédios que estão previstos no seu direito interno; e

c) sujeito ao disposto no artigo 7 , restabelecer a situação tal como existia antes do ato; $\mathrm{e}$

d) providenciar garantias apropriadas contra a repetição do ato.

2. Na medida em que for materialmente impossível agir em conformidade com o parágrafo $1 \mathrm{c}$ ), o Estado lesado pode requerer do Estado que cometeu o ato internacionalmente ilícito a pagar a ele uma soma correspondente ao valor que o restabelecimento da situação como existia antes da violação iria implicar. ${ }^{254}$ (tradução nossa)

O artigo 9 vai ainda ma is além em relação aos direitos do Estado lesado (ONU, p.

3, 1984):

\begin{abstract}
Artigo 9
1. Sujeito às determinações dos artigos $10 \mathrm{a} 13$, o Estado lesado tem o direito de, por meio de represália, suspender o cumprimento de suas outras obrigações em relação ao Estado que cometeu o ato internacionalmente ilícito.

2. O exercício deste direito pelo Estado lesado não deve, em seus efeitos, ser manifestamente desproporcional a gravidade do ato internacionalmente ilícito cometido. ${ }^{255}$ (tradução nossa)
\end{abstract}

A discussão sobre os direitos dos Estados não diretamente lesados em relação ao Estado violador muda de enfoque quando os grupos mais relevantes dentre estes Estados são inseridos na categoria de Estados lesados. Ao serem equiparados a estes Estados, os Estados não diretamente lesados adquirem todos os seus direitos, inclusive o de adotar contramedidas em relação ao Estado violador, nos casos previstos.

\footnotetext{
${ }^{254}$ Article 6
}

1. The injured State may require the State which has committed an internationally wrongful act to:

(a) discontinue the act, release and return the persons and objects held through such act, and prevent continuing effects of such act; and

(b) apply such remedies as are provided for in its internal law; and

(c) subject to article 7, re -establish the situation as it existed before the act; and

(d) provide appropriate guarantees against repetition of the act.

2. To the extent that it is materially impossible to act in conformity with paragraph 1 (c), the injured State may require the State which has committed the internationally wrongful act to pay to it a sum of money corresponding to the value which a re-establishment of the situation as it existed before the breach would bear.

${ }^{255}$ Article 9

1. Subject to articles 10 to 13 , the injured State is entitled, by way of reprisal, to suspend the performance of its other obligations towards the State which has committed the internationally wrongful act.

2. The exercise of this right by the injured State shall not, in its effects, be manifestly disproportional to the seriousness of the internationally wrongful act committed. 
Os artigos 10 a 13 estabeleciam alguns limites e requisitos para a utilização de contramedidas. $\mathrm{O}$ artigo $10^{256}$ estabelecia a necessidade de exaustão dos procedimentos pacíficos de solução de disputas internacionais. Os artigos 11 e $12^{257}$ tratavam da proibição da suspensão do cumprimento de determinadas obrigações e o artigo $13^{258}$ da exceção a esta proibição.

Ainda sobre o crime internacional o Relator propôs o artigo $14^{259}$, uma versão ampliada do antigo artigo 6 proposto anteriormente e o artigo $15^{260}$, que trata das consequências legais do ato de agressão.

\section{${ }^{256}$ Article 10}

1. No measure in application of article 9 may be taken by the injured State until it has exhausted the international procedures for peaceful settlement of the dispute available to it in order to ensure the performance of the obligations mentioned in article 6 .

2. Paragraph 1 does not apply to:

(a) interim measures of protection taken by the injured State within its jurisdiction, until a competent international court or tribunal, under the applicable international procedure for peaceful settlement of the dispute, has decided on the admissibility of such interim measures of protection;

(b) measures taken by the injured State if the State alleged to have committed the internationally wrongful act fails to comply with an interim measure of protection ordered by such international court or tribunal. (RIPHAGEN, p. 3, 1984)

${ }^{257}$ Article 11

1. The injured State is not entitled to suspend the performance of its obligations towards the State which has committed the internationally wrongful act to the extent that such obligations are stipulated in a multilateral treaty to which both States are parties and it is established that:

(a) the failure to perform such obligations by one State party necessarily affects the exercise of the rights or the performance of obligations of all other States parties to the treaty; or

(b) such obligations are stipulated for the protection of collective interests of the States parties to the multilateral treaty; or

(c) such obligations are stipulated for the protection of individual persons irrespective of their nationality.

2. The injured State is not entitled to suspend the performance of its obligations towards the State which has committed the internationally wrongful act if the multilateral treaty imposing the obligations provides for a procedure of collective decisions for the purpose of enforcement of the obligations imposed by it, unless and until such collective decision, including the suspension of obligations towards the State which has committed the internationally wrongful act, has been taken; in such case, paragraph 1 (a) and (b) do not apply to the extent that such decision so determines.

Article 12

Articles 8 and 9 do not apply to the suspension of obligations:

(a) of the receiving State regarding the immunities to be accorded to diplomatic and consular missions and staff;

(b) of any State by virtue of a peremptory norm of general international law. . (ibid, p. 3-4, 1984)

${ }^{258}$ Article 13

If the internationally wrongful act committed constitutes a manifest violation of obligations arising from a multilateral treaty, which destroys the object and purpose of that treaty as a whole, article 10 and article 11, paragraph 1 (a) and (b) and paragraph 2, do not apply. (ibid, p. 4, 1984)

${ }^{259}$ Article 14

1. An international crime entails all the legal consequences of an internationally wrongful act and, in addition, such rights and obligations as are determined by the applicable rules accepted by the international community as a whole.

2. An international crime committed by a State entails an obligation for every other State:

(a) not to recognize as legal the situation created by such crime; and

(b) not to render aid or assistance to the State which has committed such crime in maintaining the situation created by such crime; and

(c) to join other States in affording mutual assistance in carrying out the obligations under subparagraphs

(a) and (b). 
O Relatório foi examinado pela CDI na sua $36^{\mathrm{a}}$ Sessão, nas reuniões 1858,1860 , 1861 e 1865 a 1867. Durante os debates, diversos membros expressaram dúvida na inclusão e na terminologia da alínea (e) do artigo 5. Para estes, tal alínea deveria ser apagada, ou uma distinção entre Estados diretamente lesados e não diretamente lesados deveria ser feita. Porém, segundo a CDI (ONU, p. 103, 1984a):

Foi destacado, entretanto, que um crime internacional pode ser, ao mesmo tempo, um ato internacionalmente ilícito como referido a ele em um ou mais dos outros subparágrafos do artigo 5 , de forma que 'todos os Estados' não são necessariamente igualmente afetados, que em tal caso as consequências jurídicas como descritas no projeto de artigos 6, 8 e 9 podem não ser excluídas,[... ${ }^{261}$ (tradução nossa)

Assim, embora alguns membros da CDI tenham relutância em aceitar todos os Estados da comunidade internacional como Estados lesados pelo crime internacional, estes reconhecem que, em alguns casos, estes Estados podem ter os direitos previstos nos artigos 6, 8 e 9, ou seja o direito, inclusive, de adotar contramedidas contra o Estado violador.

Ao fim dos debates, a CDI enviou os artigos 5 e 6 ao Drafting Committee para estudo.

O sexto Relatório foi apresentado por Riphagen em 1985. Neste documento o Relator apresenta comentários aos artigos propostos no Relatório anterior, além de considerações sobre a terceira parte do anteprojeto de artigos.

Nos comentários feitos ao artigo 5, Riphagen esclarece (ONU, p. 8, 1985):

Alguns tratados multilaterais reconhecem ou criam, entre os Estados, um interesse coletivo (em contradição a um meramente comum ou paralelo) daqueles Estados, para a promoção ou proteção do qual aqueles Estados assumem obrigações. Uma violação de tal obrigação,

3. Unless otherwise provided for by an applicable rule of general international law, the exercise of the rights arising under paragraph 1 of the present article and the performance of the obligations arising under paragraphs 1 and 2 of the present article are subject, mutatis mutandis, to the procedures embodied in the United Nations Charter with respect to the maintenance of international peace and security.

4. Subject to Article 103 of the United Nations Charter, in the event of conflict between the obligations of a State under paragraphs 1, 2 and 3 of the present article and its rights and obligations under any other rule of international law, the obligations under the present article shall prevail.

${ }^{260}$ Article 15

An act of aggression entails all the legal consequences of an international crime and, in addition, such rights and obligations as are provided for in or by virtue of the United Nations Charter.

261 it was pointed out, however, that an international crime might well be, at the same time, an internationally wrongful act as referred to in one or more of the other subparagraphs of article 5, so that "all other States" were not necessarily equally affected, that in such a case legal consequences as described in draft artic les 6,8 and 9 could not be excluded, [...] 
então, lesa a coletividade destes Estados partes mais que um ou mais Estados partes. ${ }^{262}$

O Relator complementa (ONU, p. 8, 1985):

Outro exemplo de reconhecimento ou criação de um interesse não alocado a um Estado parte particular do tratado multilateral é o tratado multilateral prevendo obrigações dos Estados partes de respeitar direitos humanos fundamentais como tais. Aqui, novamente, a ausência em tal tratado de regras específicas organizando a resposta a violação de tais obrigações não pode significar que tal violação é deixada sem nenhuma consequência jurídica que seja. ${ }^{263}$

Já sobre o crime internacional, ele escreve (ONU, p. 8, 1985):

Não se pode concluir, de novo, pela ausência de determinação de tal regra particular secundária e/ou terciária que, no caso de um crime internacional ter sido cometido, não há nenhum Estado lesado. A alternativa é considerar todo outro Estado, em princípio, um Estado lesado. Obviamente, isto não implica necessariamente que, para cada outro Estado individualmente, a comissão de um crime internacional implique os mesmos 'novos direitos'. ${ }^{264}$

O Relator justifica, assim, a ampliação da definição de Estado lesado no anteprojeto. Já a respeito do artigo 9, que trata das contramedidas, Riphagen comenta (p. 11, 1985): "No caso de uma contramedida por meio de represália, não existe conexão legal entre a obrigação violada pelo Estado autor e a obrigação cujo cumprimento é suspenso pelo Estado lesado."265 (tradução nossa)

Sobre o tema, ele ainda discorre (ONU, p. 11, 1985):

\footnotetext{
262 some multilateral treaties recognize or create, as between the States parties to them, a collective (in contradistinction to a merely common or parallel) interest of those States, for the protection or promotion of which those States enter into obligations. A breach of such an obligation then injures the collectivity of such States parties rather than one or more individual States parties.

${ }^{263}$ The other instance of recognition, or creation, of an interest not allocated to a particular State party to the multilateral treaty is the multilateral treaty providing for obligations of States parties to respect fundamental human rights as such. Here again, the absence from such a treaty of specific rules organizing the response to a breach of such obligations cannot mean that that breach is left with no legal consequence whatever.

264 It cannot be concluded, again, from the absence of determination of such particular secondary and/or tertiary rules that, in the case of an international crime having been committed, there is no injured State at all. The alternative is to consider every other State, in principle, an injured State. (26) Obviously, this does not necessarily imply that, for every other State individually, the commission of an international crime entails the same "new rights".

${ }^{265}$ In the case of a countermeasure by way of reprisal, there is no legal connection between the obligation breached by the author State and the obligation whose performance is suspended by the injured State
} 
Na verdade, a represália é um não cumprimento deliberado de uma obrigação internacional com efeitos pretendidos sobre o Estado autor. Desta forma, sua justificação deveria também ser medida pela intenção e/ou efeitos - resumindo, a seriedade - do ato internacionalmente ilícito em relação ao Estado lesado. ${ }^{266}$ (tradução nossa)

Riphagen, neste artigo, diferencia as contramedidas do simples descumprimento da obrigação recíproca à que foi violada, ao qual denomina reciprocidade, tratado no artigo $8^{267}$. A contramedida é uma medida tomada em relação a uma obrigação não vinculada diretamente ao ato internacionalmente ilícito, com a intenção de afetar o Estado violador. Ele também estabelece o princípio da proporcionalidade entre a contramedida e o ato ilícito.

Nos seus comentários ao artigo 14, Riphagen deixa ainda mais clara a sua posição em relação as contramedidas e os Estados lesados, segundo a definição dada pelo artigo 5 (ONU, p. 13-14, 1985):

Sobre as novas obrigações do Estado autor - reparação lato sensu - é difícil imaginar que elas não surgiriam no caso da comissão de um crime internacional, e o mesmo se aplica aos novos direitos de Estado lesado de adotar contramedidas. Em outras palavras, a questão é sobre as consequências jurídicas adicionais. ${ }^{268}$ (tradução nossa)

O Relator ainda complementa (ONU, p. 14, 1985):

Um crime internacional é sempre um ato internacionalmente ilícito; assim, pode haver um Estado lesado ou Estados lesados segundo o artigo 5, subparágrafos (a) a (d). Ainda, a resposta comparável a uma medida de legitima defesa coletiva pode ser permitida; e finalmente, a comunidade internacional como um todo pode reconhecer que, segundo certas circunstâncias, a matéria poderia ser tratada mais

\footnotetext{
${ }^{266}$ Indeed, the reprisal is a deliberate non-performance of an international obligation with intended effects on the author State. Accordingly, its justification should also be measured against the intention and/or effects - in short, the seriousness - of the internationally wrongful act with regard to the injured State. 267 Article 8

Subject to articles 11 to 13 , the injured State is entitled, by way of reciprocity, to suspend the performance of its obligations towards the State which has committed an nternationally wrongful act, if such obligations correspond to, or are directly connected with, the obligation breached. (RIPHAGEN, p. 10, 1985)

${ }^{268}$ As to the new obligations of the author State-reparation lato sensu-it is hard to imagine that they would not arise in the case of the commission of an international crime, and the same applies to the new rights of the injured States to take countermeasures. In other words, the question is rather one of additional legal consequences.
} 
apropriadamente por meio de ação regional, apenas. ${ }^{269}$ (tradução nossa)

Apesar da redação um tanto confusa e de artigos que podem dar margem a interpretações diferente da pretendida pelo autor, pode-se entender que, em linhas gerais, o Relator amplia a noção de Estado diretamente lesado, incluindo dentre estes tanto os Estados partes de um tratado multilateral cuja obrigação foi violada, quanto todos os Estados, no caso de crime internacional.

Embora não esteja claro na redação dos artigos, deduz-se de seus comentários, que Riphagen prevê consequências jurídicas diferenciadas no caso dos crimes internacionais. Apesar de todos os Estados serem considerados Estados lesados, neste caso somente após uma decisão coletiva estes teriam direito a adotar contramedidas, a não ser que estivessem numa das categorias previstas nos subparágrafos (a) a (d) do artigo 5. Nessa hipótese, eles poderiam adotar contramedidas, independente desta decisão. Os crimes internacionais também teriam consequências jurídicas além daquelas previstas para os demais delitos internacionais. Tais consequências estariam previstas nos artigos 14 e 15, propostos.

O Relatório apresentado foi estudado pela CDI na sua $37^{\text {a }}$ Sessão , em 1985, nas reuniões 1890 a 1902. Os artigos apresentados foram debatidos um a um.

Em relação aos artigos 8 e 9, diversos membros afirmaram que a distinção entre reciprocidade e contramedida não estava bem determinada. Sobre o artigo $9 \mathrm{em}$ específico, alguns membros consideraram o termo "manifestamente desproporcional" muito vago e outros mencionaram a necessidade de se incluir neste artigo uma proibição às represálias armadas. Em relação ao artigo 14, diversos membros consideraram que as consequências jurídicas dos crimes internacionais deveriam ser mais elaboradas. Ao final dos debates os artigos 7 a 16 foram encaminhados ao Drafting Committee. $\mathrm{Na}$ reunião 1930 o artigo 5 foi adotado pela Comissão com a seguinte redação (ONU, p. 25, 1985a) :

\section{Artigo 5}

1. Para o propósito dos presentes artigos, 'Estado lesado' significa qualquer Estado cujo direito foi afetado pelo ato de outro Estado, se

\footnotetext{
${ }^{269}$ An international crime is always an internationally wrongful act; accordingly, there may be an injured State or injured States under article 5, subparagraphs $(a)$ to $(d)$. Furthermore, a response comparable to a measure of collective self-defence may be allowed; and finally, the international community as a whole may recognize that, under certain circumstances, the matter could be more appropriately dealt with by regional action only.
} 
tal ato constitui, de acordo com a parte 1 dos presentes artigos um ato internacionalmente ilícito daquele Estado.

2. Em particular, 'Estado lesado' significa:

a) se o direito violado pelo ato de um Estado advém de um tratado bilateral, o outro Estado parte do tratado;

b) se o direito violado pelo ato de um Estado advém de um julgamento ou outra decisão vinculante de uma solução de disputas de uma corte ou tribunal internacional, o outro Estado ou Estados partes da disputa e habilitados a se beneficiar daquele direito;

c) se o direito violado pelo ato do Estado advém da decisão vinculante de um órgão internacional outro que não uma corte ou tribunal internacional, o Estado ou Estados que, de acordo com o instrumento constitutivo da organização internacional interessada, estão habilitados a se beneficiar daquele direito;

d) se o direito violado pelo ato do Estado advém de uma determinação de tratado para um Estado terceiro, aquele Estado terceiro;

e) se o direito violado pelo ato do Estado advém de um tratado multilateral ou de uma norma do direito consuetudinário internacional, qualquer outro Estado parte do tratado multilateral ou vinculado pela norma de direito consuetudinário internacional, se estabelecido que:

i) o direito foi criado ou é estabelecido em seu favor.

ii) a violação do direito pelo ato de um Estado necessariamente afeta o gozo dos direitos ou o cumprimento de obrigações de outros Estados partes do tratado multilateral ou vinculados pela norma de direito consuetudinário, ou

iii) o direito foi criado ou é estabelecido para a proteção de direitos humanos e liberdades fundamentais.

f) se o direito violado pelo ato do Estado advém de um tratado multilateral, qualquer outra parte do tratado multilateral, se ficar estabelecido que o direito foi expressamente estipulado naquele tratado para a proteção dos interesses coletivos dos Estados partes.

3. Também, 'Estado lesado' significa, se o ato internacionalmente ilícito constitui um crime internacional (e no contexto dos direitos e obrigações dos Estados segundo os artigos 14 e 15), todos os outros Estados. ${ }^{270}$ (tradução nossa)

\section{${ }^{270}$ Article 5}

1. For the purposes of the present articles, "injured State" means any State a right of which is infringed by the act of another State, if that act constitutes, in accordance with part 1 of the present articles, an internationally wrongful act of that State.

2. In particular, "injured State" means :

(a) if the right infringed by the act of a State arises from a bilateral treaty, the other State party to the treaty ;

(b) if the right infringed by the act of a State arises from a judgment or other binding dispute-settlement decision of an international court or tribunal, the other State or States parties to the dispute and entitled to the benefit of that right;

(c) if the right infringed by the act of a State arises from a binding decision of an international organ other than an international court or tribunal, the State or States which, in accordance with the constituent instrument of the international organization concerned, are entitled to the benefit of that right;

(d) if the right infringed by the act of a State arises from a treaty provision for a third State, that third State;

(e) if the right infringed by the act of a State arises from a multilateral treaty or from a rule of customary international law, any other State party to the multilateral treaty or bound by the relevant rule of customary international law, if it is established that:

(i) the right has been created or is established in its favour, 
A CDI adota o artigo proposto pelo Relator com algumas pequenas alterações. A ampliação da definição de Estado lesado permanece, o termo passando a branger também os Estados partes de tratados multilaterais em casos determinados. Dentre as hipóteses previstas está a violação de direitos determinados por tratado multilateral que estabeleçam a "proteção de direitos humanos e liberdades fundamentais". Assim, violado um direito humano previsto num tratado multilateral por um dos Estados partes, todos os outros Estados partes são considerados Estados lesados e podem como tal, aplicarem contramedidas.

O parágrafo 3 foi alterado, mas continua prevendo que em caso de crime internacional, todos os Estados são considerados Estados lesados. No entanto, apesar da nova definição, as consequências jurídicas advindas de crimes internacionais para os Estados lesados segundo o subparágrafo 3, se restringem àquelas previstas nos artigos 14 e 15 .

A CDI, ao adotar uma ampla definição do Estado lesado no artigo 5, permite a adoção de contramedidas por Estados não diretamente lesados, dentre estes todos os Estados que fazer parte de um tratado multilateral de proteção direitos humanos, no caso de violação de alguma de suas disposições. No caso dos crimes internacionais, a CDI estabelece que as consequências jurídicas serão estabelecidas pelos artigos 14 e 15, que segundo a redação proposta pelo Relator Especial, determina que todos os Estados tem obrigações diante da situação criada pelo ato ilícito, e que tais obrigações estariam acima de suas demais obrigações internacionais, deixando espaço para interpretações acerca da legalidade de contramedidas para o cumprimento das obrigações previstas neste $\operatorname{artigo~}^{271}$.

(ii) the infringement of the right by the act of a State necessarily affects the enjoyment of the rights or the performance of the obligations of the other States parties to the multilateral treaty or bound by the rule of customary international law, or

(iii) the right has been created or is established for the protection of human rights and fundamental freedoms ;

(f) if the right infringed by the act of a State arises from a multilateral treaty, any other State party to the multilateral treaty, if it is established that the right has been expressly stipulated in that treaty for the protection of the collective interests of the States parties thereto.

3. In addition, "injured State" means, if the internationally wrongful act constitutes an international crime [and in the context of the rights and obligations of States under articles 14 and 15], all other States.

271 Artigo 14. 4. Sujeito ao Artigo 103 da Carta das Nações Unidas, no caso de conflito entre as obrigações de um Estado segundo os parágrafos 1, 2 e 3 do presente artigo e seus direitos e obrigações segundo qualquer outra regra de direito internacional, as obrigações segundo o presente artigo devem prevalecer. (RIPHAGEN, p. 13, 1985) (tradução nossa) 
No seu sétimo Relatório, elaborado em 1986, Riphagen deu início à terceira parte do anteprojeto de artigos, tratando da implementação da responsabilidade internacional e resolução de disputas. O Relator propõe 5 novos artigos e um anexo que estabelecem os procedimentos a serem tomados no caso de uma violação a uma obrigação internacional. $\mathrm{O}$ artigo 1 determina a necessidade de notificação ao Estado violador caso o Estado lesado deseje tomar as medidas previstas no artigo 6 da parte $2^{272}$. O artigo 2 determina a necessidade de notificação e a regra geral estabelecendo um prazo de 3 meses antes da primeira notificação para a adoção de medidas de reciprocidade ou represália $^{273}$. O artigo 3 estabelece que em caso de discordância quanto as medidas de reciprocidade ou represália tomadas, os Estados devem procurar uma solução seguindo o disposto no artigo 33 da Carta das Nações Unidas ${ }^{274}$. O artigo 4 estabelece o procedimento a ser tomado caso não se consiga uma solução no período de doze meses ${ }^{275}$. E o artigo 5 estabelece a impossibilidade de reservas a esta parte do

\footnotetext{
272 Article 1
}

A State which wishes to invoke article 6 of part 2 of the present articles must notify the State alleged to have committed the internationally wrongful act of its claim. The notification shall indicate the measures required to be taken and the reasons therefore.

273 Article 2

1. If, after the expiry of a period which, except in cases of special urgency, shall not be less than three months after the receipt of the notification prescribed in article 1, the claimant State wishes to invoke article 8 or article 9 of part 2 of the present articles, it must notify the State alleged to have committed the internationally wrongful act of its intention to suspend the performance of its obligations towards that State. The notification shall indicate the measures intended to be taken.

2. If the obligations the performance of which is to be suspended are stipulated in a multilateral treaty, the notification prescribed in paragraph 1 shall be communicated to all States parties to that multilateral treaty.

3. The fact that a State has not previously made the notification prescribed in article 1 shall not prevent it from making the notification prescribed in the present article in answer to another State claiming performance of the obligations covered by that notification.

${ }^{274}$ Article 3

1. If objection has been raised against measures taken or intended to be taken under article 8 or article 9 of part 2 of the present articles, by the State alleged to have committed the internationally wrongful act or by another State claiming to be an injured State in respect of the suspension of the performance of the relevant obligations, the States concerned shall seek a solution through the means indicated in Article 33 of the Charter of the United Nations. 2. Nothing in the foregoing paragraph shall affect the rights and obligations of States under any provisions in force binding those States with regard to the settlement of disputes.

${ }^{275}$ Article 4

If, under paragraph 1 of article 3, no solution has been reached within a period of twelve months following the date on which the objection was raised, the following procedures shall be followed:

(a) Any one of the parties to a dispute concerning the application or the interpretation of article 12 (6) of part 2 of the present articles may, by a written application, submit it to the International Court of Justice for a decision;

(b) Any one of the parties to a dispute concerning the additional rights and obligations referred to in article 14 of part 2 of the present articles may, by a written application, submit it to the International Court of Justice for a decision;

(c) Any one of the parties to a dispute concerning the application or the interpretation of articles 9 to 13 of part 2 of the present articles may set in motion the procedure specified in the annex to part 3 of the present articles by submitting a request to that effect to the Secretary- General of the United Nations. 
anteprojeto com apenas uma ressalva ${ }^{276}$. Já o anexo propõe a criação de uma Comissão de Conciliação para solucionar eventuais disputas ${ }^{277}$.

O Relatório também continha, como preparação para a segunda leitura pela CDI, os artigos da parte 1 com os comentários feitos pelos Estados.

Este documento foi examinado pela CDI na sua $38^{\text {a }}$ Sessão, em 1986, nas reuniões

1952 a 1956. Após os debates os artigos foram encaminhados pelo Drafting Committee,

\footnotetext{
${ }^{276}$ Article 5
}

No reservations are allowed to the provisions of part 3 of the present articles, except a reservation excluding the application of article 4 (c) to disputes concerning measures taken or intended to be taken under article 9 of part 2 of the present articles by an alleged injured State, where the right allegedly infringed by such a measure arises solely from a treaty concluded before the entry into force of the present articles. Such reservation shall not affect the rights and obligations of States under such treaties or under any provisions in force, other than the present articles, binding those States with regard to the settlement of disputes.

277 ANNEX

1. A list of conciliators consisting of qualified jurists shall be drawn up and maintained by the SecretaryGeneral of the United Nations. To this end, every State which is a Member of the United Nations or a Party to the present articles shall be invited to nominate two conciliators, and the names of the persons so nominated shall constitute the list. The term of a conciliator, including that of any conciliator nominated to fill a casual vacancy, shall be five years and may be renewed. A conciliator whose term expires shall continue to fulfil any function for which he shall have been chosen under the following paragraph.

2. When a request has been made to the Secretary-General under article 4 (c) of part 3 of the present articles, the Secretary-General shall bring the dispute before a Conciliation Commission constituted as follows: The State or States constituting one of the parties to the dispute shall appoint:

(a) one conciliator of the nationality of that State or of one of those States, who may or may not be chosen from the list referred to in paragraph 1 ; and

(b) one conciliator not of the nationality of that State or of any of those States, who shall be chosen from the list. The State or States constituting the other party to the dispute shall appoint two conciliators in the same way. The four conciliators chosen by the parties to the dispute shall be appointed within sixty days following the date on which the Secretary- General receives the request. The four conciliators shall, within sixty days following the date of the last of their own appointments, appoint a fifth conciliator chosen from the list, who shall be chairman. If the appointment of the chairman or of any of the other conciliators has not been made within the period prescribed above for such appointment, it shall be made by the Secretary-General within sixty days following the expiry of that period. The appointment of the chairman may be made by the Secretary-General either from the list or from the membership of the International Law Commission. Any of the periods within which appointments must be made may be extended by agreement between the parties to the dispute. Any vacancy shall be filled in the manner prescribed for the initial appointment.

3. The failure of a party or parties to submit to conciliation shall not constitute a bar to the proceedings.

4. A disagreement as to whether a Conciliation Commission acting under this annex has competence shall be decided by the Commission.

5. The Conciliation Commission shall decide its own procedure. The Commission, with the consent of the parties to the dispute, may invite any State to submit to it its views orally or in writing. Decisions and recommendations of the Commission shall be made by a majority vote of the five members.

6. The Commission may draw the attention of the parties to the dispute to any measures which might facilitate an amicable settlement.

7. The Commission shall hear the parties, examine the claims and objections, and make proposals to the parties with a view to reaching an amicable settlement of the dispute.

8. The Commission shall report within twelve months of its constitution. Its report shall be deposited with the Secretary-General and transmitted to the parties to the dispute. The report of the Commission, including any conclusions stated therein regarding the facts or questions of law, shall not be binding upon the parties and shall have no other character than that of recommendations submitted for the consideration of the parties in order to facilitate an amicable settlement of the dispute.

9. The fees and expenses of the Commission shall be borne by the parties to the dispute. 
que em razão do encurtamento excepcional da Sessão da CDI, não conseguiu examinar o assunto. Os trabalhos referentes aos demais artigos enviados também não puderam ser concluídos.

Apesar do extenso trabalho apresentado por Riphagen, somente 5 artigos relativos a Parte II do anteprojeto foram provisoriamente adotados pela CDI. Destes artigos destacamos o artigo 5, que continha uma definição extensiva de Estado lesado, considerando, em caso de crime internacional, todos os Estados da comunidade internacional como tal. Tal definição foi adotada em primeira leitura, pela CDI, mas foi abandonada pelo Relator Especial Crawford, tendo a CDI adotada uma definição bem mais restrita de Estados lesados no seu anteprojeto final.

\subsection{Trabalho realizado pelo Relator Gaetano Arangio-Ruiz (1987-1996)}

Tendo em vista que o mandato de Riphagen como membro da CDI terminou em 1987 e este não foi reeleito, a CDI indicou Gaetano Arangio-Ruiz como Relator Especial para o tema da responsabilidade do Estado em sua 39ª Sessão, em 1987.

O novo Relator Especial apresentou seu primeiro Relatório, um Relatório preliminar em 1988. Neste documento Arangio-Ruiz propõe algumas modificações às partes 2 e 3 do anteprojeto de artigos. Em especial, o Relator propõe uma nova redação aos artigos 6 e 7 da parte 2 do anteprojeto. Segundo a nova proposta, o artigo 6 trataria da cessação do ato internacionalmente ilícito contínuo ${ }^{278}$ e o artigo 7 trataria da restituição em espécie ${ }^{279}$. O relator também propõe algumas mudanças na estrutura das

\footnotetext{
${ }^{278}$ Article 6. Cessation of an internationally wrongful act of a continuing character

A State whose action or omission constitutes an internationally wrongful act [having] [of] a continuing character remains, without prejudice to the responsibility it has already incurred, under the obligation to cease such action or omission. (ONU, p. 42, 1988)

${ }^{279}$ Article 7. Restitution in kind

1. The injured State has the right to claim from the State which has committed an internationally wrongful act restitution in kind for any injuries it suffered therefrom, provided and to the extent that such restitution:

(a) is not materially impossible;

(b) would not involve a breach of an obligation arising from a peremptory norm of general international law;

(c) would not be excessively onerous for the State which has committed the internationally wrongful act.

2. Restitution in kind shall not be deemed to be excessively onerous unless it would: (a) represent a burden out of proportion with the injury caused by the wrongful act;

(b) seriously jeopardize the political, economic or social system of the State which committed the internationally wrongful act.

3. Without prejudice to paragraph 1 (c) of the present article, no obstacle deriving from the internal law of the State which committed the internationally wrongful act may preclude by itself the injured State's right to restitution in kind. (ONU, p. 42, 1988)
} 
partes em estudo. Na parte 2, por exemplo, um capítulo seria destinado a tratar das consequências jurídicas do delito internacional, o capitulo II; e outro capítulo trataria exclusivamente das consequências jurídicas dos crimes internacionais, o capítulo III.

O Relatório foi considerado pela CDI na sua $40^{\text {a }}$ Sessão tendo sido exposto nas reuniões 2081 e 2082. Devido à falta de tempo, porém, o tema não foi considerado pela Comissão (ONU, p. 104, 1988a).

Em 1988 a Alemanha entregou seus comentários a primeira parte do anteprojeto. Destaca-se a mudança de posição em relação ao artigo 19 , que trata do crime internacional. Tendo inicialmente desaprovado a adoção do termo crime internacional (CDI, p. 75, 1981), neste novo documento o Estado alemão dá seu "apoio total" ao artigo mencionado e destaca a importância de um regime diferenciado de consequências jurídicas para estes atos na parte 2 (ONU, p. 4, 1988b).

Em 1989 Arangio-Ruiz apresenta seu segundo Relatório. Neste documento o Relator propõe 3 novos artigos relativos a parte 2 do anteprojeto. $\mathrm{O}$ primeiro artigo trataria da reparação por equivalência (artigo 8), o segundo artigo trataria dos juros (artigo 9) e o terceiro trataria da satisfação e das garantias de não repetição (artigo 10).

Sobre a satisfação, o Relator deixa claro que esta não tem nenhuma relação com (ONU, p. 41, 1989) "qualquer ação ou medida tomada diretamente pelo Estado lesado contra o ofensor"280 (tradução nossa). Em suas palavras (ONU, p. 42, 1989): "Embora a demanda por satisfação venha normalmente - a não ser que felizmente precedida pela iniciativa do próprio Estado ofensor - do Estado lesado, a satisfação a ser dada consiste em ações a serem tomadas pelo ofensor mesmo." 281 (tradução nossa)

A satisfação prevista no artigo 10, não tem, assim como as garantias de repetição, nenhuma relação com contramedidas.

Na sua 41ª Sessão, em 1989, a CDI examinou o Relatório Preliminar apresentado pelo Relator em 1988 nas reuniões 2102 a 2105, 2122 e 2127. Muitos membros da Comissão concordaram com a proposta feita de separar em capítulos diferentes as consequências jurídicas advinda de delitos internacionais e as advinda de crimes

\footnotetext{
4. The injured State may, in a timely manner, claim [reparation by equivalent] [pecuniary compensation] to substitute totally or in part for restitution in kind, provided that such a choice would not result in an unjust advantage to the detriment of the State which committed the internationally wrongful act, or involve a breach of an obligation arising from a peremptory norm of general international law. (ibid, p. 42-43, 1988)

280 any action or measure taken directly by the injured State itself against the offender

281 Although the demand for satisfaction will normally come-unless felicitously preceded by the offending State's own initiative-from the injured State, the satisfaction to be given consists of actions to be taken by the offender itself.
} 
internacionais. Após os debates, os artigos 6 e 7 da parte 2, propostos pelo Relator foram encaminhados ao Drafting Committee. O Segundo Relatório, apresentado por Arangio-Ruiz em 1989, no entanto, não foi examinado devido à falta de tempo.

Já na sua 42a Sessão, em 1990, a CDI analisou o segundo Relatório apresentado por Arangio-Ruiz no ano anterior, nas reuniões 2168 a 2175 e 2185. Após os debates, os novos artigos 8, 9 e 10 da parte 2 foram encaminhados ao Drafting Committee.

Em 1991, o Relator apresenta seu terceiro Relatório sobre o tema. Neste documento, ele faz um estudo sobre as "consequências instrumentais" da responsabilidade dos Estados por delito internacional, ou seja, das medidas a serem tomadas em função desta responsabilidade. Dentre estas medidas estão: a legítima defesa, a sanção, a retorsão, a represália, a contramedida, a medida recíproca e a suspensão e o término de tratados. O texto trata também de alguns aspectos gerais de tais medidas, como suas funções e propósitos, o problema da proporcionalidade e suas limitações substantivas.

Segundo Arangio-Ruiz, sanções seriam, na perspectiva da CDI, "medidas adotadas por um órgão internacional” (p. 10, 1991). Já as retorsões seriam (ONU, p. 10, 1991) "reações de um Estado a um ato ilícito hostil que embora possam ser hostis não são, per se, ilícitas ${ }^{282 ", ~(t r a d u c ̧ a ̃ o ~ n o s s a) . ~ A s ~ r e p r e s a ́ l i a s ~ s e r i a m ~ m e d i d a s ~ q u e ~ s e r i a m ~}$ ilícitas, per se, mas que se tornam lícitas por terem sido tomadas como reação a um ato internacionalmente ilícito (ONU, p. 11, 1991). O Relator também utiliza o termo contramedidas no sentido de (ONU, p. 12, 1991) “reações unilaterais ou 'horizontais' de um ou mais Estados a um ato internacionalmente ilícito, excluindo a legítima defesa e a retorsão",283 (tradução nossa). Em relação às medidas recíprocas, ele questiona a necessidade prática de estabelecer um tratamento próprio a tais medidas (ONU, p. 1314, 1991)

Sobre os aspectos gerais, Arangio-Ruiz menciona as diversas correntes doutrinárias sobre a função das represálias (restitutiva e compensatória ou punitiva) (p. 15, 1991); analisa a necessidade de notificação prévia a adoção de represálias; estuda o impacto das obrigações relativas á solução de disputas ao direito de adotar represálias; estuda a questão da proporcionalidade, dos regimes especiais e das limitações substantivas as medidas adotadas em resposta aos atos internacionalmente ilícitos, entre

\footnotetext{
282 reactions of a State to an unlawful, hostile act, which while they may be hostile per se are not unlawful.

283 Unilateral or "horizontal" reactions of one or more States to an internationally wrongful act, to the exclusion of self-defence and retorsion.
} 
outros temas. O Relator, entretanto, não toma nenhuma posição definida sobre os assuntos tratados e também não propõe nenhum novo artigo.

Na sua $43^{\text {a }}$ Sessão a CDI não teve tempo de considerar o tema da responsabilidade do Estado. O Relator apresentou seu terceiro Relatório na reunião 2238, mas este não foi posto em discussão (ONU, p. 127, 1991a).

Em 1992 Arangio-Ruiz apresenta seu quarto Relatório. Neste são analisadas as funções e condições das contramedidas, o impacto das obrigações de solução de disputas, a questão da proporcionalidade e a proibição de determinadas contramedidas. São propostos quatro novos artigos além de um artigo 5 bis. Tais artigos se refeririam às medidas a serem tomadas apenas em caso de delitos internacionais. As consequências jurídicas advindas dos crimes internacionais, como mencionado anteriormente, seriam tratadas em capítulo próprio.

Sobre as contramedidas Arangio-Ruiz menciona a necessidade de um ato ilícito internacional contra o Estado que adota a contramedida. Tal ato, entretanto, não precisa ser previamente reconhecido por uma decisão arbitral ou judicial, nem por um órgão internacional ou pelo Estado violador. Porém, a mera presunção de ilicitude também não é suficiente. O Estado que adota a contramedida, o faz com o risco de responder internacionalmente pelo seu ato ilícito, se a ilicitude do ato anterior não ficar comprovada (ONU, p. 6, 1992).

Sobre as funções das contramedidas, embora admita que as principais estejam ligadas à cessação do ato ilícito, à reparação, em sentido amplo, e à garantia de não repetição, o Relator afirma que (ONU, p. 6-7, 1992) "estabelecer uma norma com o propósito explícito de proibir qualquer função punitiva das contramedidas seria igualmente inapropriado."284 (tradução nossa)

Por fim Arangio-Ruiz propõe dois artigos. O artigo 11 que estabeleceria (ONU, p. 22, 1992):

Artigo 11. Contramedidas por um Estado lesado

Um Estado lesado cujas demandas segundo os artigos 6 a 10, não tenham encontrado resposta adequada do Estado que cometeu o ato internacionalmente ilícito esta habilitado, sujeito às restrições e condições colocadas pelos artigos a seguir, a não cumprir com uma ou mais obrigações em relação àquele Estado. ${ }^{285}$

\footnotetext{
284 lay down a rule with the explicit intent of prohibiting any punitive function of countermeasures would be equally inappropriate.

285 Article 11. Countermeasures by an injured State
} 
De acordo com este artigo, a adoção de contramedidas deverá ser precedida de demandas baseadas nos artigos 6 a 10, ou seja, de demandas visando a cessação e a reparação do ato internacionalmente ilícito.

Já o artigo 12 trataria das condições para recorrer às contramedidas. Segundo este (ONU, p. 22, 1992):

Artigo 12. Condições para recorrer a contramedidas

1. Sujeito as provisões estabelecidas nos parágrafos 2 e 3 , nenhuma medida do tipo indicado no artigo precedente deve ser tomada por um Estado lesado antes da:

a) exaustão de todos os procedimentos amigáveis de solução disponíveis segundo o direito internacional geral, a Carta das Nações Unidas ou qualquer instrumento de solução de disputas do qual é parte; e

b) comunicação apropriada e a tempo da sua intenção.

2. A condição estabelecido no parágrafo (a) do parágrafo anterior não se aplica:

a) quando o Estado que cometeu o ato internacionalmente ilícito não coopera de boa-fé com a escolha e implementação dos procedimentos de solução disponíveis;

b) a medidas interinas de proteção tomadas pelo Estado lesado, até que a admissibilidade de tais medidas seja decidida por um órgão internacional dentro do quadro de um procedimento de disputas com terceiros;

c) a qualquer medida tomada pelo Estado lesado, se o Estado que cometeu o ato ilícito deixa de cumprir com uma das medidas interinas de proteção indicadas por este órgão.

3. A exceção estabelecida no parágrafo anterior não se aplica quando a medida prevista não está em conformidade com a obrigação de solucionar disputas de uma maneira que a paz, a segurança internacional e a justiça não sejam prejudicadas. ${ }^{286}$

An injured State whose demands under articles 6 to 10 have not met with adequate response from the State which has committed the internationally wrongful act is entitled, subject to the conditions and restrictions set forth in the following articles, not to comply with one or more of its obligations towards the said State.

286 Article 12. Conditions of resort to countermeasures

1. Subject to the provisions set forth in paragraphs 2 and 3, no measure of the kind indicated in the preceding article shall be taken by an injured State prior to:

(a) the exhaustion of all the amicable settlement procedures available under general international law, the Charter of the United Nations or any other dispute settlement instrument to which it is a party; and

(b) appropriate and timely communication of its intention.

2. The condition set forth in subparagraph (a) of the preceding paragraph does not apply:

(a) where the State which has committed the internationally wrongful act does not cooperate in good faith in the choice and the implementation of available settlement procedures;

(b) to interim measures of protection taken by the injured State, until the admissibility of such measures has been decided upon by an international body within the framework of a third-party settlement procedure;

(c) to any measures taken by the injured State if the State which has committed the internationally wrongful act fails to comply with an interim measure of protection indicated by the said body. 
No artigo 12 se estabelece a necessidade de exaustão dos meios pacíficos de solução de litígios disponíveis no Direito Internacional para que se possa adota contramedidas. Tal artigo prevê três exceções. A primeira quando o Estado violador se recusa a participar destes procedimentos pacíficos de solução de controvérsias; a segunda exceção seria relativa a medidas interinas de proteção. E a terceira exceção seria no caso de descumprimento pelo Estado violador de alguma medida determinada pelo órgãos encarregado da solução da controvérsia.

Ainda sobre as contramedidas o Relator propõe mais dois artigos. O artigo 13 prescreveria (ONU, p. 35, 1992): “Artigo 13. Proporcionalidade: Qualquer medida tomada por um Estado lesado Segundo os artigos 11 e 12 não deve ser fora da proporção com a gravidade do ato internacionalmente ilícito e com os efeitos deste."287 (tradução nossa)

Este artigo coloca em outros termos o princípio da proporcionalidade das contramedidas, também proposto por Riphagen.

Já o artigo 14 trataria das contramedidas proibidas, estabelecendo (ONU, p. 35, 1992):

Artigo 14. Contramedidas proibidas

1. Um Estado lesado não deve recorrer, por meio de contramedidas a:

a) a ameaça ou uso da força [em contravenção ao Artigo 2, parágrafo

4, da Carta das Nações Unidas];

b) qualquer conduta que:

i) não está em conformidade com as regras de direito internacional sobre a proteção de direitos humanos fundamentais;

ii) é um sério prejuízo a operação normal da diplomacia bilateral ou multilateral;

iii) é contrária a uma norma peremptória de direito internacional geral; iv) consiste na violação de uma obrigação internacional contra qualquer Estado que não seja o Estado que cometeu $o$ ato internacionalmente ilícito.

2. A proibição estabelecida no parágrafo 1 (a) inclui não só a força armada, mas, também, medidas de coerção política ou econômica extremas, comprometendo a integridade territorial ou a independência política do Estado contra o qual ela é tomada. ${ }^{288}$ (tradução nossa)

3. The exceptions set forth in the preceding paragraph do not apply wherever the measure envisaged is not in conformity with the obligation to settle disputes in such a manner that international peace and security, and justice, are not endangered.

287 Article 13. Proportionality

Any measure taken by an injured State under articles 11 and 12 shall not be out of proportion to the gravity of the internationally wrongful act and of the effects thereof.

${ }^{288}$ Article 14. Prohibited countermeasures 
$\mathrm{O}$ artigo, ao tratar das contramedidas proibidas, indiretamente estabelece limites para a aplicação deste tipo de medidas. O primeiro destes limites é a proibição do uso da força. Seguindo a posição adotada pela própria CDI em comentário ao artigo 30 da parte 1, o Relator confirma a impossibilidade de adoção de contramedidas por meio do uso da força em tempos de paz (ONU, p. 28, 1992).

Outra limitação das contramedidas é a proteção de direitos humanos fundamentais. Tal limitação se restringiria, porém, aos direitos humanos mais essenciais, e não se estenderia, por exemplo, aos direitos de propriedade (ONU, p. 32, 1992).

A terceira limitação estaria ligada a imunidade diplomática. Contramedidas tomadas violando as imunidades diplomáticas de funcionários do Estado violador também estariam proibidas (ONU, p. 33, 1992).

A quarta limitação diz respeito a medidas que violem uma norma de jus cogens. Tais normas seriam de tal natureza que, para o Relator, seria até mesmo desnecessário explicar a existência de uma limitação geral (ONU, p. 33, 1992) "que deriva de necessidade de cumprir com qualquer norma peremptória de direito internacional geral."289 (tradução nossa)

A quinta limitação se referiria a proibição de adoção de contramedidas que atinjam outro Estado que não o Estado lesado.

E a sexta limitação diz respeito a medidas de coerção política ou econômica de tal intensidade que poderiam ameaçar a integridade territorial ou a independência política do Estado violador. Sobre estas Arangio-Ruiz comenta (ONU, p. 30, 1992):

é obvio que uma grande variedade de forma de reações políticas e econômicas são frequentemente adotadas e são consideradas perfeitamente admissíveis como contramedidas contra ato

1. An injured State shall not resort, by way of countermeasure, to: (a) the threat or use of force [in contravention of Article 2, paragraph 4, of the Charter of the United Nations];

(b) any conduct which:

(i) is not in conformity with the rules of international law on the protection of fundamental human rights;

(ii) is of serious prejudice to the normal operation of bilateral or multilateral diplomacy;

(iii) is contrary to a peremptory norm of general international law;

(iv) consists of a breach of an obligation towards any State other than the State which has committed the internationally wrongful act.

2. The prohibition set forth in paragraph 1 (a) includes not only armed force but also any extreme measures of political or economic coercion jeopardizing the territorial integrity or political independence of the State against which they are taken.

289 which derives from the legal necessity to comply with any peremptory rule of general international law. 
internacionalmente ilícitos. Sua admissibilidade, entretanto, não é totalmente ilimitada. ${ }^{290}$ (tradução nossa)

O Relator defende (ONU, p. 30, 1992) "a proibição de medidas econômicas e políticas que comprometam a integridade territorial ou a independência política do Estado contra a qual elas são tomadas. ${ }^{291}$ (tradução nossa)

Vale lembrar que todos os artigos apresentados se referem às consequências jurídicas advindas de delitos internacionais, ou seja, não se aplicam, necessariamente, as consequências jurídicas advindas dos chamados "crimes internacionais".

Neste Relatório Arangio-Ruiz também discorre sobre os problemas da pluralidade de Estados lesados. Para o Relator, a diferenciação entre Estados diretamente e indiretamente lesados não tem substância. Um exemplo dado por ele são as normas de proteção de direitos humanos. Em suas palavras (ONU, p. 44, 1992):

Como é geralmente sabido, regras deste tipo [de proteção dos direitos humanos] criam entre os Estados as quais elas se aplicam uma relação jurídica caracterizada pela obrigação de cada Estado de assegurar o gozo dos direitos humanos para todos sob sua jurisdição, independente da nacionalidade. Qualquer violação desta obrigação pelo Estado A constituirá uma violação simultânea do direito correspondente dos Estados B, C, D e E respectivamente. Os direitos de todos os últimos Estados sendo o mesmo - o direito de ter o Estado A respeitando os direitos humanos daqueles sob sua jurisdição - nenhum deles é mais ou menos afetado pela violação que o outro. ${ }^{292}$ (tradução nossa)

Ainda, segundo o Relator (ONU, p. 44-45, 1992):

Pode haver, é claro, uma diferença quando um ou mais Estados lesados se sentem particularmente afetados porque o Estado A violou os direitos humanos de indivíduos com os quais eles tenham uma ligação étnica ou de outro tipo. Isto, entretanto, não faz o dano sofrido por aqueles Estados legalmente mais direto que o sofrido pelos outros Estados. ${ }^{293}$ (tradução nossa)

\footnotetext{
${ }^{290}$ it is quite obvious that a great variety of forms of economic or political reaction are frequently resorted to and are considered perfectly admissible as countermeasures against internationally wrongful acts. Their admissibility, however, is not totally unlimited.

${ }^{291}$ the prohibition of economic or political measures which jeopardize the territorial integrity or the political independence of the State against which they are taken.

${ }^{292}$ As generally acknowledged, rules of this kind create among the States to which they apply a legal relationship characterized by each State's obligation to ensure the enjoyment of human rights for everyone under its jurisdiction, irrespective of nationality. Any violation of its obligation by State A will constitute a simultaneous infringement of the corresponding right of States B, C, D and E respectively. The rights of all the latter States being the same-namely the right to have State A respect the human rights of those under its jurisdiction - no one of them is more or less directly affected by the violation than any other.

${ }^{293}$ There may, of course, be a difference where one or more of the injured States feel particularly affected because State A has violated the human rights of individuals with whom they have ethnic or other ties. This, however, does not make the injury sustained by those States legally more direct than that suffered by the other States.
} 
Para Arangio-Ruiz, no caso de violação de uma norma de proteção dos direitos humanos, todos os Estados são lesados da mesma forma, não havendo diferenciação entre Estados diretamente e indiretamente lesados. Mesmo quando um Estado se sente particularmente atingido pela violação por esta se dar, por exemplo, em relação a indivíduos de mesma etnia ou religião que a sua, juridicamente o dano sofrido, ainda assim, é o mesmo que o sofrido pelos demais Estados.

A nosso ver, o mesmo não se pode dizer, porém, se o Estado lesado sofre diretamente as consequências de tal violação, como a perseguição de indivíduos da sua nacionalidade, ou a invasão do seu território por um grande número de refugiados.

Sobre a questão da adoção de contramedidas no caso de violações de obrigações erga omnes o Relator também escreve (ONU, p. 47-48, 1992):

\begin{abstract}
Qualquer restrição especial da faculdade individual de recorrer a contramedidas da parte do Estado lesado por uma violação a uma obrigação erga omnes não deriva do fato do dano ser indireto. Elas são meramente a consequência da aplicação, em cada situação hipotética ou fática, das regras gerais ou princípios governando as contramedidas, tais como a obrigação de demanda por cessação ou reparação anterior, ou exaustão dos procedimentos de solução de disputas anterior e, claro, do requerimento de proporcionalidade. ${ }^{294}$ (tradução nossa)
\end{abstract}

Arangio-Ruiz, assim, não só admite a possibilidade de adoção de contramedidas por todos os Estados da comunidade internacional no caso de violação a uma obrigação erga omnes, como entende que estas contramedidas estariam sujeitas as mesmas regras que regulam as contramedidas tomadas em caso de delito internacional. Nenhuma restrição ou limitação a mais seria necessária para regulamentar este tipo de medidas.

Sobre o tema, ele ainda defende (ONU, p. 49, 1992):

De fato, dois aspectos caracterizam as consequências instrumentais de uma violação a uma obrigação erga omnes. A primeira é que o resultado a ser perseguido pelas medidas unilaterais, por causa da identidade do interesse coletivo protegido pela norma, é o mesmo para todas as partes lesadas. O segundo é que este resultado pode ser

\footnotetext{
294 any special restrictions of the individual faculte of resort to countermeasure on the part of the States injured by the breach of an erga omnes obligation, do not derive from any alleged indirectness of the injury. They are merely the consequence of the application, in each hypothetical or actual situation, of the general rules or principles governing countermeasures, such as the obligation of prior demand for cessation or reparation or prior exhaustion of dispute settlement procedures, and, of course, the requirement of proportionality.
} 
perseguido solidariamente por uma pluralidade de partes lesadas. A primeira peculiaridade explica porque contramedidas unilaterais por qualquer Estado sozinho são justificadas somente na medida em que elas estão conforme ao interesse comum. Como a norma violada protege um interesse coletivo, quaisquer reações a violação, apesar de numerosas e unilaterais, podem ser legalmente adotadas somente na medida em que elas cumprem a função de garantir a situação legal (primária) representada pelo interesse jurídico comum. Quando quaisquer reações não estão em conformidade com tal função (por exemplo, porque elas visam objetivos individuais de um dado Estado ou fins não protegidos pela norma violada) elas cairiam fora da esfera de consequências (substantivas ou instrumentais) da dada violação erga omnes: na medida em que elas violam obrigações internacionais, elas seriam, por sua vez, ilegais. ${ }^{295}$ (tradução nossa)

Para o Relator, no caso de uma violação a uma obrigação erga omnes diversos Estados podem tomar contramedidas unilaterais legalmente, desde que estas tenham como objetivo proteger o interesse coletivo violado.

A CDI em sua $44^{\text {a }}$ Sessão examinou o terceiro e o quarto Relatórios apresentados pelo Relator Especial nas reuniões 2265 a 2267, 2273 a 2280 e 2283.

Apesar de algumas posições contrárias a necessidade de tratar das contramedidas no anteprojeto de artigos sobre responsabilidade internacional, concluiu-se que, pela importância do tema, este não poderia ser ignorado.

Sobre a definição de contramedidas, houve concordância geral com a posição adotada pelo Relator, estabelecendo que estas se identificam com a noção de represálias (ONU, p. 22, 1992a).

Ponderou-se também que as medidas de retorsão, pela sua legalidade, deveriam ficar fora do escopo do anteprojeto e que as medidas recíprocas deveriam ser consideradas como uma categoria de contramedidas em relação às quais não havia necessidade de tratamento especial (ONU, p. 23, 1992a).

Em relação às funções das contramedidas, foi sugerido que se não se reconhecesse qualquer função punitiva em relação a estas (ONU, p. 23, 1992a). Por outro lado,

\footnotetext{
295 Indeed, two features characterize the instrumental consequences of a violation of an erga omnes obligation. The first is that the result to be pursued by the unilateral measures, because of the identity of the collective interest protected by the rule, is the same for all the injured parties. The second is that that result may be pursued severally by a plurality of injured parties. The first peculiarity explains why unilateral countermeasures by any single State are justified only in so far as they conform to the common interest. As the infringed rule protects a collective interest, any reactions to the breach, however numerous and unilateral, may be lawfully resorted to only to the extent to which they perform the function of guaranteeing the (primary) legal situation represented by the common legal interest. Were any reactions not to be in conformity with such a function (for example, because they pursue individual aims of a given State or ends otherwise not protected by the infringed rule) they would fall outside the sphere of the consequences (substantive or instrumental) of the given erga omnes breach: to the extent that they were in violation of international obligations, they would in turn be unlawful.
} 
admitiu-se a possibilidade de uma função punitiva no caso de crimes internacionais (ONU, p. 26, 1992a)

Diante da sugestão de não se fazer referência tanto as contramedidas quanto aos procedimentos pacíficos de solução de disputas, pois estes não teriam relação direta com a responsabilidade internacional o Relator respondeu (ONU, p. 24, 1992a):

Contramedidas cuidadosamente definidas são essenciais porque, no momento, elas representam o modo mais importante de assegurar o respeito mínimo às obrigações internacionais; procedimentos para a solução de disputas também são essenciais porque eles representam o único meio de prevenir o abuso das contramedidas. ${ }^{296}$ (tradução nossa)

Diversas críticas foram feitas ao artigo 12 (ONU, p. 27-29, 1992a), em especial à necessidade de exaustão dos meios pacíficos de solução de controvérsias para a adoção de contramedidas. Foi mencionada a lentidão de tais procedimentos, que poderiam durar por vezes dois anos e meio.

Em relação aos limites das contramedidas, diversos membros mencionaram que a quebra das relações diplomáticas seria uma contramedidas eficaz, e que a limitação deveria se focar na inviolabilidade das pessoas e premissas protegidas pelo direito diplomático.

Sobre a proibição de medidas de coerção política e econômica, embora diversos membros concordassem com seu conteúdo, a sua formulação, equiparando-a ao uso da força, foi questionada. Sugeriu-se que esta questão poderia ser tratada no âmbito da proporcionalidade das contramedidas.

Sobre a posição do Relator em relação à definição de Estado lesado a CDI comenta (ONU, p. 40, 1992a):

Duas categorias de problemas foram mencionadas nesse contexto. A primeira, relacionada com o equilíbrio entre as reações pelos vários Estados lesados em uma situação onde há mais de um Estado lesado nos termos do artigo5. Presumindo que nenhuma ação coletiva coordenada ('horizontal') foi tomada por estes Estados, é provável que cada Estado lesado deve estar predominantemente preocupado com sua própria relação com o Estado que cometeu o ato ilícito. Tomada isoladamente, aquela conduta pode perecer razoável. Mas e se, coletivamente, a conduta de todos os Estados lesado resultar em uma resposta desproporcional? A provisão de que cada Estado deve

\footnotetext{
296 carefully defined countermeasures were essential because, for the time being, they represented the most important means of ensuring minimum respect for international obligations; procedures for settlement of disputes were also essential because they represented the only way of preventing abuses of countermeasures.
} 
responder tendo em conta as respostas dos outros Estados foi vista como muito vaga. A segunda e mais séria categoria de dificuldades está no fato de que, embora todos os Estados lesados sejam iguais no sentido do artigo 5, um ou vários Estados podem, em algumas situações, sofrer inquestionavelmente mais dano que outros. Por exemplo, o Estado A pode tomar conduta repressiva discriminatória contra os nacionais do Estado B contrária as provisões do Pacto de Direitos Civis e Políticos. [...] Uma abordagem em que nenhuma prioridade é dada ao Estado B pode gerar alguns problemas. ${ }^{297}$

Considerou-se porém que o artigo 5 bis, proposto pelo Relator também conteria pontos positivos.

Os artigos propostos foram enviados ao Drafting Committee que, na reunião 2288, apresentou um novo parágrafo 2 ao artigo 1, e os artigos 6, 6 bis, 7, 8, 10 e 10 bis. A consideração de tais artigos, entretanto, foi adiada até a próxima sessão.

Em 1993 o Relator apresentou o seu quinto Relatório sobre a responsabilidade dos Estados. O documento era composto por dois capítulos, um tratando dos procedimentos de solução de disputas, que fariam parte da parte 3 do anteprojeto, e outro tratando das consequências jurídicas advindas de crimes internacionais.

No primeiro capítulo, o Relator, ao sumarizar os debates ocorridos no Sexto Comitê da Assembleia Geral da ONU em 1992 sobre as contramedidas chega æ̀̀ seguintes conclusões (ONU, p. 15, 1993):

a) Ao menos a longo prazo, as contramedidas devem ser substituídas por meios mais consonantes com um Estado de Direito;

b) o recurso a contramedidas deve ser limitado; e

c) mais importante, as salvaguardas contra o abuso das reações unilaterais devem ser fortalecidas. ${ }^{298}$

\footnotetext{
297 Two separate categories of problems were mentioned in this context. The first related to the balance between reactions by various injured States in a situation where there was more than one such State under the terms of article 5. Assuming that no coordinated, collective ("'horizontal") action was undertaken by those States, it was likely that each injured State would be predominantly concerned with its own relationship with the State which had committed the wrongful act. Taken alone, that conduct might seem reasonable. But what if, collectively, the conduct of all the injured States amounted to a disproportionate response? A provision to the effect that each State should respond with due regard to the responses of other injured States was viewed as too vague. The second and more serious category of difficulties lay in the fact that, although all injured States were equal within the meaning of article 5, one or several States would, in some situations, suffer unquestionably more damage than others. For example, State A might engage in repressive discriminatory conduct against nationals of State B contrary to the provisions of the International Covenant on Civil and Political Rights. Under article 5, every State party to the International Covenant would be an injured State, but there could be no doubt that State B would be damaged to a significantly greater degree than others. An approach whereby no priority whatever was given to State B would give rise to some problems.

298 (a) At least in the long run, countermeasures should be replaced by means more consonant with an adequate rule of law;

(b) Resort to countermeasures should be limited; and

(c) Most important, the safeguards against abuse of unilateral reactions should be strengthened.
} 
Visando fortalecer o controle sobre as contramedidas, o Relator propõe um sistema de solução de controvérsia composto por três fases. A primeira, uma fase de conciliação, a segunda uma fase de arbitragem e a terceira uma fase de solução judicial. Esta terceira fase, porém, só seria tomada em alguns casos específicos onde houvesse falha de cumprimento das determinações do tribunal arbitral, ou falha do tribunal arbitral em se manifestar em um prazo razoável. Foram propostos 6 novos artigos formando a parte 3 do anteprojeto. $\mathrm{O}$ artigo 1 sobre a conciliação, o artigo 2 sobre as tarefas da Comissão de Conciliação, o artigo 3 sobre a arbitragem, o artigo 4 sobre os termos de referência do Tribunal Arbitral, o artigo 5 sobre a solução judicial e o artigo 6 sobre o excesso de poder ou a violação de princípios fundamentais do procedimento arbitral. Também foi proposto um anexo composto por três artigos sobre a composição da Comissão de Conciliação e do Tribunal Arbitral.

No segundo capítulo do Relatório, depois de resumir as consequências dos crimes internacionais segundo a visão da CDI, analisar as reações do $6^{\circ}$ Comitê da Assembleia Geral sobre o tema, e mencionar a posição da doutrina, Arangio-Ruiz discorre sobre os problemas de um possível regime especial de responsabilidade internacional para os crimes internacionais.

Em relação às consequências jurídicas dos crimes internacionais, o Re lator estuda as diferenças nas consequências substantivas decorrentes do delito e do crime internacional. Segundo Arangio-Ruiz, algumas das limitações das formas de reparação devidas em função de delitos internacionais poderiam ser derrogadas no caso de crimes internacionais. Dentre elas, estão a limitação de onerosidade excessiva da restituição, a proibição de danos punitivos, e as demandas de satisfação ou garantias de não repetição que possam ter um maior impacto nas áreas sob a jurisdição doméstica do Estado responsável.

Ao tratar de medidas que incluem o uso da força, o Relator analisa se os existentes órgãos da ONU teriam competência para atuar determinando a existência, a atribuição e a existência dos crimes internacionais. Em relação à Assembleia Geral, ele conclui (ONU, p. 48, 1993): “a Assembleia não pode ir além de declarações não vinculantes da ilegalidade e atribuição e recomendações não vinculantes de reação aos Estados e ao Conselho de Segurança." 299 (tradução nossa)

\footnotetext{
299 the Assembly cannot go beyond non-binding declarations of unlawfulness and attribution and nonbinding recommendations of reaction by States or by the Security Council.
} 
Já em relação a Corte Internacional de Justiça (CIJ), Arangio-Ruiz, embora admita que esta seria (ONU, p. 49, 1993) "o único órgão permanente existente que, em princípio, possui a competência e os meios técnicos para determinar a existência, atribuição e consequências de um ato internacionalmente ilícito"300 (tradução nossa), vê dois tipos de dificuldades para o estabelecimento de um sistema neste sentido, sendo o primeiro tipo derivado da natureza voluntária da submissão do Estado às funções da CIJ e o segundo tipo fruto da ausência, na CIJ, de órgãos juridicamente competentes para investigar os fatos, agir no papel de um "promotor público" e determinar e implementar sanções.

O Conselho de Segurança, apesar da doutrina dos poderes implícitos que poderia lhe atribuir competência para lidar com os crimes internacionais, é visto como um órgão político que opera em bases altamente discricionárias, sem a utilização de um critério uniforme para situações similares. Não há, por parte deste órgão, nenhum dever de substanciar suas decisões, sua ação ou sua inação. Assim, segundo o Relator (ONU, p. 50, 1992) "a natureza da ação do Conselho de Segurança - dado os aspectos relevantes e o modo de ação deste órgão - não parece preencher os requisitos elementares, mas fundamentais de justiça criminal [...]”301 (tradução nossa)

O Relator Especial também discorre sobre as medidas que não envolvem o uso da força. Em suas palavras (ONU, p. 51, 1993): “O recurso a medidas sem o uso da força em reação a um crime, ao contrário da adoção de medidas envolvendo o uso da força, não enseja questões de admissibilidade, tais questões sendo geralmente decididas afirmativamente em relação a qualquer violação erga omnes." $" 302$

Em comparação com as medidas possíveis de serem adotadas no caso de delitos internacionais, as contramedidas no caso de crimes internacionais poderiam ter suas limitações atenuadas nos seguintes casos (ONU, p. 51, 1993):

a) medidas extremas de natureza econômica ou política;

b) medidas afetando a independência, soberania ou jurisdição doméstica do infrator;

c) Medidas afetando Estados terceiros;

\footnotetext{
${ }^{300}$ The only existing permanent body which, in principle, possesses the competence and technical means to determine the existence, attribution and consequences of an internationally wrongful act

301 the nature of the Security Council's action-given the relevant features and mode of action of that organ-does not seem to be such as to meet the elementary, but fundamental, requirements of criminal justice referred to above.

${ }^{302}$ Resort to measures short of force in reaction to a crime, unlike the adoption of measures involving force, does not give rise to questions of admissibility, such questions being generally settled in the affirmative with respect to any erga omnes breach.
} 
d) medidas punitivas. ${ }^{303}$ (tradução nossa)

Arangio-Ruiz não só prevê a possibilidade de adoção de contramedidas por todos os Estados que fazem parte da comunidade internacional no caso de crimes internacionais, como entende que tais contramedidas têm menos limitações que as contramedidas adotadas em função de um delito internacional.

A CDI examinou o Relatório apresentado na sua $45^{\mathrm{a}}$ Sessão. Nas reuniões 2314 a 2316 foram adotados o parágrafo 2 do artigo 1, o artigo 6, sobre a cessação da conduta ilícita, o artigo 6 bis, sobre reparação, o artigo 7, sobre restituição em espécie, o artigo 8, sobre compensação, o artigo 10, sobre satisfação, e o artigo 10 bis, sobre garantias de não repetição, encaminhados pelo Drafting Committee.

Já nas reuniões de 2305 a 2310 e 2314 discutiu-se o capítulo I do Relatório, tratando da questão dos procedimentos de solução de disputas. O capítulo II, sobre as consequências jurídicas dos crimes internacionais não foi debatido devido à falta de tempo (ONU, p. 35, 1993a).

Em 1994 o Relator apresenta seu sexto Relatório. O documento, composto de dois capítulos, trata, no primeiro, das provisões sobre solução de disputas pré-contramedidas, analisando o artigo 12 aprovado pelo Drafting Committee, que ao invés de determinar a exaustão dos meios de solução de disputas pacíficos disponíveis no plano internacional, como o artigo 12 originalmente proposto pelo Relator fazia, determinava apenas a necessidade do Estado lesado recorrer a um procedimento de solução de disputas antes de adotar a contramedida e a suspensão do direito adotar contramedidas caso o Estado violador colaborasse de boa fé com este procedimento ${ }^{304}$. Ao final o Relator propõe uma nova redação para os artigos 11 e 12 .

303 (a) Extreme measures of an economic or political nature;

(b) Measures affecting the independence, sovereignty or domestic jurisdiction of the wrongdoer;

(c) Measures affecting "third" States;

(d) "Punitive" measures.

${ }^{304}$ Article 12. Conditions of recourse to countermeasures

1. An injured State may not take countermeasures unless:

(a) It has recourse to a [binding/third-party] dispute settlement procedure which both the injured State and the State which has committed the internationally wrongful act are bound to use under any relevant treaty to which they are parties; or

(b) In the absence of such a treaty, it offers a [binding/ third-party] dispute settlement procedure to the State which has committed the internationally wrongful act.

2. The right of the injured State to take countermeasures is suspended when and to the extent that an agreed [binding] dispute settlement procedure is being implemented in good faith by the State which has committed the internationally wrongful act, provided that the internationally wrongful act has ceased.

3. A failure by the State which has committed the internationally wrongful act to honour a request or order emanating from the dispute settlement procedure shall terminate the suspension of the right of the injured State to take countermeasures. 
O segundo capítulo que trata das consequências dos crimes internacionais, Arangio-Ruiz apenas menciona os principais problemas relacionados com o tema, como a definição de crimes e as suas possíveis consequências jurídicas, sem no entanto chegar a nenhuma conclusão definitiva.

A CDI em sua $46^{\text {a }}$ Sessão examinou os capítulos 2 do quinto e do sexto Relatório apresentado pelo Relator Especial nas reuniões 2338 a 2343, 2348 e 2353.

Nas discussões sobre o tema ficou clara a existência de duas correntes de opinião entre os membros da CDI. Uma que defendia que o conceito de crime já se encontrava enraizado no Direito Internacional, e outra que entendia que tal conceito ainda não se contraria bem estabelecido (ONU, p. 137-138, 1994a). Consequentemente, havia também duas correntes opostas sobre a existência de uma responsabilidade criminal por parte dos Estados (ONU, p. 138-139, 1994a).

Durante os debates algumas alternativas ao conceito de crime foram mencionadas, como a violação de normas do jus cogens ou das obrigações erga omnes, porém ponderourse que os dois institutos seriam mais abrangentes do que o conceito de crime previsto pelo artigo 19 do anteprojeto.

Este artigo, novamente debatido pelos membros da Comissão, foi criticado por alguns membros e elogiado por outros.

Sobre a possibilidade de adoção de contramedidas por Estados não diretamente lesados, os debates foram assim resumidos pela CDI, de um lado (ONU, p. 143, 1994a):

\begin{abstract}
Alguns membros advertiram que a posição de 'Estados indiretamente lesados' não deveria ser igualada com a de uma vítima direta. A opinião expressada em relação ao tema foi de que a comissão de um crime não confere aos Estados outros que não o Estado vítima o status de Estado lesado para o propósito de recorrer a contramedidas e este Estado individual, que não o Estado vítima não poderia intervir em resposta a um crime e não ser que não houvesse reação coletiva, para que o conceito de crime não leve a confirmação das relações de poder existentes. O poder de reação, foi dito, deve estar essencialmente co a comunidade internacional ${ }^{305}$ (tradução nossa)
\end{abstract}

De outro (ONU, p. 143, 1994a):

\footnotetext{
305 Some members warned that the position of "indirectly injured States" should not be equated lightly with that of the direct victim. The view was expressed in this connection that the commission of a crime did not confer on States other than the victim State the status of an injured State for the purpose of resort to countermeasures and that individual States other than the victim State could not intervene in riposte to a crime unless there was no collective reaction, lest the concept of crime led to the confirmation of existing power relationships. The power of reaction, it was said, should lie essentially with the international community.
} 
Outros membros mencionaram que a comunidade internacional estava mal equipada para lidar com os crimes internacionais dos Estados e que, no presente, não havia um órgão expressamente competente para reagir a todas as categorias de crimes internacionais, então a reação ao crime teria que permanecer um assunto para os Estados individuais decidirem. Embora concordasse que o presente estado de fato era distante do satisfatório, alguns membros observaram que a proibição do uso da força, o princípio da solução pacífica de disputas e o princípio da proporcionalidade forneciam garantias contra o abuso. ${ }^{306}$ (tradução nossa)

A CDI também debateu sobre qual órgão da ONU estaria apto a determinar a existência, atribuição e consequências do crime internacional, mas assim, como o Relator, não conseguiu chegar a nenhuma decisão definitiva (ONU, p. 145-147, 1994a).

Diante destas dificuldades, considerourse a possibilidade de não apresentar, na primeira leitura, artigos sobre as consequências jurídicas dos crimes internacionais.

Na reunião 2353 a CDI analisou a parte I do sexto Relatório de Arangio-Ruiz e na reunião 2366 adotou os artigos 11, sobre as contramedidas adotadas por um Estado lesado, o artigo 13, sobre a proporcionalidade e o artigo 14, sobre as contramedidas proibidas, de acordo com a redação proposta pelo Drafting Committee ${ }^{307}$.

\footnotetext{
306 Other members pointed out that the international community was ill-equipped to deal with international crimes of States and that at present there was no international body expressly empowered to react to all categories of international crimes, so that the reaction to a crime had to remain a matter for individual States to determine. While agreeing that the present state of affairs was far from satisfactory, some members observed that the prohibition of the use of force, the principle of peaceful settlement of disputes and the principle of proportionality provided guarantees against abuse.

307 'Article 11. Countermeasures by an injured State

" 1 . As long as the State which has committed an internationally wrongful act has not complied with its obligations under articles 6 to 10 bis, the injured State is entitled to take countermeasures, that is, subject to the conditions and restrictions set forth in articles 12,13 and 14, not to comply with one or more of its obligations towards the State which has committed the internationally wrongful act, as necessary in the light of the response to its demands by the State which has committed the internationally wrongful act in order to induce it to comply with its obligations under articles 6 to 10 bis.

"2. Where a countermeasure against a State which has committed an internationally wrongful act involves a breach of an obligation towards a third State, such a breach cannot be justified as against the third State by reason of paragraph 1 .

Article 13. Proportionality

"Any countermeasure taken by an injured State shall not be out of proportion to the degree of gravity of the internationally wrongful act and the effects thereof on the injured State.

"Article 14. Prohibited countermeasures

"An injured State shall not resort, by way of countermeasure, to:

"(a) The threat or use of force as prohibited by the Charter of the United Nations;

"(b) Extreme economic or political coercion designed to endanger the territorial integrity or political independence of the State which has committed an internationally wrongful act;

"(c) Any conduct which infringes the inviolability of diplomatic or consular agents, premises, archives and documents;

"(d) Any conduct which derogates from basic human rights; or
} 
O Drafting Committee não conseguiu chegar a uma conclusão em relação ao artigo 12 e a redação do artigo 11 ficou pendente, podendo ser revisada a luz deste futuro artigo (ONU, p. 151-152, 1994a).

Em 1995 o Relator Especial apresenta seu sétimo Relatório sobre a responsabilidade dos Estados. Este documento, dividido em dois capítulos, traz no seu capítulo 1 a proposta de 5 novos artigos relativos a parte 2 do anteprojeto. $\mathrm{O}$ artigo 15 , que prevê a existência de consequências especiais ou suplementares advindas do crime internacional $^{308}$; o artigo 16 , que trata de cessação, da reparação, da satisfação e das garantias de não repetição em caso de crime internacional ${ }^{309}$; o artigo 17 , que estabelece o direito de qualquer Estado adotar contramedidas em caso de crime internacional, desde que a Corte Internacional de Justiça tenha se pronunciado reconhecendo a ocorrência deste crime; o artigo 18, descrevendo as obrigações dos demais Estados diante de um crime internacional ${ }^{310}$; o artigo 19 , estabelecendo um procedimento para a

"(e) Any other conduct in contravention of a peremptory norm of general international law." (CDI, p. 151-152, 1994a)

${ }^{308}$ Article 15

Without prejudice [In addition] to the legal consequences entailed by an international delict under articles 6 to 14 of the present part, an international crime as defined in article 19 of part one entails the special or supplementary consequences set forth in articles 16 to 19 below.

309 Article 16

1. Where an internationally wrongful act of a State is an international crime, every State is entitled, subject to the condition set forth in paragraph 5 of article 19 below, to demand that the State which is committing or has committed the crime should cease its wrongful conduct and provide full reparation in conformity with articles 6 to 10 bis, as modified by paragraphs 2 and 3 below.

2. The right of every injured State to obtain restitution in kind as provided in article 7 shall not be subject to the limitations set forth in subparagraphs (c) and (d) of paragraph 1 of the said article, except where restitution in kind would jeopardize the existence of the wrongdoing State as an independent member of the international community, its territorial integrity or the vital needs of its people.

3. Subject to the preservation of its existence as an independent member of the international community and to the safeguarding of its territorial integrity and the vital needs of its people, a State which has committed an international crime is not entitled to benefit from any limitations of its obligation to provide satisfaction and guarantees of non-repetition as envisaged in articles 10 and 10 bis, relating to the respect of its dignity, or from any rules or principles of international law relating to the protection of its sovereignty and liberty.

${ }^{310}$ Article 18

1. Where an internationally wrongful act is an international crime, all States shall, subject to the condition set forth in paragraph 5 of article 19 below:

(a) Refrain from recognizing as legal or valid, under international or national law, the situation created by the international crime;

(b) Abstain from any act or omission which may assist the wrongdoing State in maintaining the said situation;

(c) Assist each other in carrying out their obligations under subparagraphs (a) and (b) and, insofar as possible, coordinate their respective reactions through available international bodies or ad hoc arrangements;

(d) Refrain from hindering in any way, by act or omission, the exercise of the rights or powers provided for in articles 16 and 17;

(e) Fully implement the aut dedere aut judicare principle, with respect to any individuals accused of crimes against the peace and security of mankind the commission of which has brought about the international crime of the State or contributed thereto; 
averiguação da ocorrência de um crime internacional baseado em duas etapas, uma feita pela Assembleia Geral ou o Conselho de Segurança, e a outra pela Corte Internacional de Justiça ${ }^{311}$; e o artigo 20, salvaguardando as medidas adotadas pelo Conselho de Segurança e no exercício de direito à legítima defesa ${ }^{312}$ (ONU, p. 29-30, 1995).

No artigo 17 proposto, o Relator admite a possibilidade de adoção de contramedidas por todos os Estados membros da comunidade internacional diante de um crime internacional. Em suas palavras (ONU, p. 11, 1995):

A opção de recorrer a contramedidas, reservada, no caso da maioria dos delitos, a um ou mais Estados, se estende, no caso dos crimes assim como o direito de reclamar a observância das consequências

(f) Take part, jointly or individually, in any lawful measures decided or recommended by any international organization of which they are members against the State which has committed or is committing the international crime;

(g) Facilitate, by all possible means, the adoption and implementation of any lawful measures intended to remedy any emergency situations caused by the international crime.

2. Subject to the conditions set forth in paragraph 5 of article 19 below, the State which has committed or is committing an international crime shall not oppose fact-finding operations or observer missions in its territory for the verification of compliance with its obligations of cessation or reparation.

${ }^{311}$ Article 19

1. Any State Member of the United Nations Party to the present Convention claiming that an international crime has been or is being committed by one or more States shall bring the matter to the attention of the General Assembly or the Security Council of the United Nations in accordance with Chapter VI of the Charter of the United Nations.

2. If the General Assembly or the Security Council resolves by a qualified majority of the Members present and voting that the allegation is sufficiently substantiated to justify the grave concern of the international community, any Member State of the United Nations Party to the present Convention, including the State against which the claim is made, may bring the matter to the International Court of Justice by unilateral application for the Court to decide by a judgment whether the alleged international crime has been or is being committed by the accused State.

3. The qualified majority referred to in the preceding paragraph shall be, in the General Assembly, a twothirds majority of the members present and voting, and in the Security Council, nine members present and voting including permanent members, provided that any members directly concerned shall abstain from voting.

4. In any case where the International Court of Justice is exercising its competence in a dispute between two or more Member States of the United Nations Parties to the present Convention, on the basis of a title of jurisdiction other than paragraph 2 of the present article, with regard to the existence of an international crime of State, any other Member State of the United Nations which is a Party to the present Convention shall be entitled to join, by unilateral application, the proceedings of the Court for the purpose of paragraph 5 of the present article.

5. A decision of the International Court of Justice that an international crime has been or is being committed shall fulfil the condition for the implementation, by any Member State of the United Nations Party to the present Convention, of the special or supplementary legal consequences of international crimes of States as contemplated in articles 16, 17 and 18 of the present part.

312 Article 20

The provisions of the articles of the present part are without prejudice to:

(a) Any measures decided upon by the Security Council of the United Nations in the exercise of its functions under the provisions of the Charter;

(b) The inherent right of self-defence as provided in Article 51 of the Charter. 
substantivas especiais ou suplementares - a todos os Estados. ${ }^{313}$ (tradução nossa)

Este artigo, no entanto, coloca algumas condições para o exercício deste direito. Estabelece o artigo (ONU, p. 29, 1995):

\section{Artigo 17.}

1. Quando o ato internacionalmente ilícito de um Estado é um crime internacional, todo Estado cujas demandas, segundo o artigo 16 não tiveram uma resposta adequada do Estado que cometeu ou esta cometendo o crime é habilitado, sujeito a condição estabelecida no parágrafo 5 do artigo 19 abaixo, a adotar contramedidas de acordo com as condições e restrições estabelecidas nos artigos 11, 13 e 14, como modificadas pelos parágrafos 2 e 3 do presente artigo.

2. A condição estabelecida no parágrafo 5 do artigo 19 , abaixo, não se aplica as medidas urgentes e interinas que são requeridas para proteger os direitos de um Estado lesado ou para limitar o dano causado pelo crime internacional.

3. $\mathrm{O}$ requerimento de proporcionalidade estabelecido no artigo 13 deve se aplicar a contramedidas tomadas por quaisquer Estados de modo que a medida não seja fora de proporção com a gravidade do crime internacional. ${ }^{314}$

O parágrafo 5 do artigo 19 se refere a uma decisão da Corte Internacional de Justiça (CIJ) reconhecendo a existência do crime internacional.

Assim, a adoção de contramedidas pelos Estados em caso de crime deve ser precedida de uma decisão de um órgão judiciário reconhecendo a existência deste crime, exceto no caso de medidas urgentes e provisórias visando proteger os direitos de um Estado lesado ou limitar o dano causado pelo crime.

O procedimento exigido por Arangio-Ruiz, é diferente da autorização coletiva prevista por Riphagen, sendo mais complexo, pois em alguns casos requer tanto a

\footnotetext{
313 the option to resort to countermeasures, reserved, in the case of most delicts, to one or more States, extends in the case of crimes - as does the right to claim compliance with the special or supplementary substantive consequences - to all States.

314 Article 17

1. Where the internationally wrongful act of a State is an international crime, every State whose demands under article 16 have not met with an adequate response from the State which has committed or is committing the crime is entitled, subject to the condition set forth in paragraph 5 of article 19 below, to resort to countermeasures under the conditions and restrictions set forth in articles 11,13 and 14 as modified by paragraphs 2 and 3 of the present article.

2. The condition set forth in paragraph 5 of article 19 below does not apply to such urgent, interim measures as are required to protect the rights of an injured State or to limit the damage caused by the international crime.

3. The requirement of proportionality set forth in article 13 shall apply to countermeasures taken by any State so that such measures shall not be out of proportion to the gravity of the international crime.
} 
manifestação da Assembleia Geral ou do Conselho de Segurança, num primeiro momento (artigo 19 parágrafos 1 a 3) quanto a manifestação da CIJ, posteriormente.

O Relator, na dúvida em relação a qual órgão da ONU seria competente para avaliar a existência e determinar as consequências de um crime internacional, elaborou um procedimento no qual os 3 principais órgãos da ONU poderiam ser envolvidos.

A CDI estudou o sétimo Relatório apresentado por Arangio-Ruiz na sua $47^{\mathrm{a}}$ Sessão, nas reuniões 2391 a 2398.

Apesar de reconhecer os esforços empreendidos pelo Relator no sentido de se adequar aos desejos da Comissão, as propostas foram tidas como (CDI, p. 47, 1995a) "muito amplas para serem realistas e revolucionárias e não sintonizadas com a

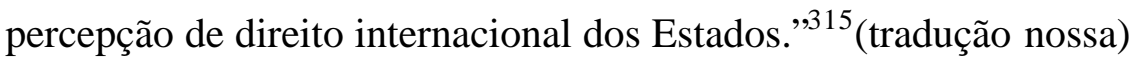

Durante os debates, novamente duas correntes se formaram, uma defendendo o conceito de crime internacional e a criminalização do Estado e outra em sentido oposto (ONU, p. 47-49, 1995a)

O conceito de Estado lesado, estendido a todos os Estados no caso dos crimes internacionais, também foi questionado pela aplicação das mesmas consequências jurídicas, em relação a Estados diferentemente afetados pelo crime.

Em relação ao artigo 17 proposto, embora poucos membros tenham decidido comentar o referido artigo, diversos membros mencionaram a reserva em tratar das contramedidas no anteprojeto (ONU, p. 53, 1995a). Criticas também foram feitas ao parágrafo 2, que trata da possibilidade de medidas interinas e urgentes.

A vinculação da aplicação das hipóteses previstas no artigo 18 à necessidade de decisão prévia da CIJ também foi questionada (ONU, p. 54, 1995a).

Já o artigo 19 foi objeto de amplos debates, por um lado sendo apoiado por alguns membros, por outros sofrendo severas críticas. Dentre estas podemos destacar a atribuição de competências aos órgãos da ONU não prevista em sua Carta e a demora e complexidade do procedimento, que resultaria em condições mais restritas para as respostas aos crimes internacionais em relação aos delitos, tidos como menos graves.

A oposição a este artigo foi tão forte que alguns membros se opuseram ao seu envio ao Drafting Committee. A questão foi decidida por votação na reunião 2406, quando a maioria decidiu pelo envio dos artigos contidos m sétimo Relatório a este órgão (ONU, p. 61, 1995a).

\footnotetext{
315 too broad to be realistic and as revolutionary and unattuned to States' sense of international law.
} 
Nesta mesma Sessão, a CDI adotou os artigos 13 e 14 da segunda parte, com seus respectivos comentários, e os artigos 1 a 7 da parte 3 do anteprojeto de artigos sobre a responsabilidade dos Estados.

Em 1996, Arangio-Ruiz apresenta seu oitavo e último Relatório como Relator Especial. Neste documento, ele faz uma defesa, no primeiro capítulo, dos artigos propostos no Relatório anterior, e no segundo capítulo, ele menciona alguns assuntos em relação aos quais chama a atenção da Comissão tendo em vista a finalização da primeira leitura dos artigos sobre a responsabilidade dos Estados.

Em relação ao artigo 17, ele entende que a condição colocada para a adoção de contramedidas pelos Estados em caso de crime internacional, de uma decisão anterior da CIJ reconhecendo a existência do crime internacional, seria mais justa e equitativa do que um esquema em que os Estados detêm este controle exclusivo. O Relator também não compreende a relutância em aceitar o parágrafo 2 , que trata das medidas interinas e urgentes (ONU, p. 4, 1996).

A CDI examinou o oitavo Relatório apresentado pelo Relator na sua $48^{a}$ Sessão, na reunião 2436. Na reunião 2438 Arangio-Ruiz apresentou a sua renuncia ao cargo de Relator Especial. O Drafitng Committee terminou a primeira leitura dos artigos referentes às partes 2 e 3 do anteprojeto sobre a responsabilidade dos Estados. O Relatório apresentado por este foi discutido nas reuniões 2452 e 2454 a 2459 . Na reunião 2471 a Comissão decidiu submeter os artigos compondo a parte 1, 2 e 3 do anteprojeto aos governos para comentários e observações.

A estrutura do anteprojeto estava organizada de seguinte forma: a parte 1 cuidava da origem da responsabilidade internacional e era composta por cinco capítulos. O primeiro tratando dos princípios gerais; o segundo tratando do ato do Estado, segundo o Direito Internacional; o terceiro tratando da violação da obrigação internacional; o quarto tratando da implicação de um Estado no ato internacionalmente ilícito de outro Estado; e o quinto tratando das circunstâncias precluindo a ilicitude. Neste quinto capítulo destaca-se o artigo 30, estabelecendo as contramedidas como uma excludente de ilicitude.

A parte 2 do anteprojeto era dedicada ao conteúdo, formas e graus de responsabilidade internacional. Ela era dividida em três capítulos.

O primeiro tratava dos princípios gerais. Neste capítulo destaca-se o artigo 40, antigo artigo 5 da parte 2, que define o significado de Estado lesado. 


\section{Artigo 40}

1. Para o propósito dos presentes artigos, 'Estado lesado' significa qualquer Estado cujo direito foi afetado pelo ato de outro Estado, se tal ato constitui, de acordo com a parte 1, um ato internacionalmente ilícito daquele Estado.

2. Em particular, 'Estado lesado' significa:

a) se o direito violado pelo ato de um Estado advém de um tratado bilateral, o outro Estado parte do tratado;

b) se o direito violado pelo ato de um Estado advém de um julgamento ou outra decisão vinculante de uma solução de disputas de uma corte ou tribunal internacional, o outro Estado ou Estados partes da disputa e habilitados a se beneficiar daquele direito;

c) se o direito violado pelo ato do Estado advém da decisão vinculante de um órgão internacional outro que não uma corte ou tribunal internacional, o Estado ou Estados que, de acordo com o instrumento constitutivo da organização internacional interessada, estão habilitados a se beneficiar daquele direito;

d) se o direito violado pelo ato do Estado advém de uma determinação de tratado para um Estado terceiro, aquele Estado terceiro;

e) se o direito violado pelo ato do Estado advém de um tratado multilateral ou de uma norma do direito consuetudinário internacional, qualquer outro Estado parte do tratado multilateral ou vinculado pela norma de direito consuetudinário internacional, se estabelecido que:

i) o direito foi criado ou é estabelecido em seu favor.

ii) a violação do direito pelo ato de um Estado necessariamente afeta o gozo dos direitos ou o cumprimento de obrigações de outros Estados partes do tratado multilateral ou vinculados pela norma de direito consuetudinário, ou

iii) o direito foi criado ou é estabelecido para a proteção de direitos humanos e liberdades fundamentais.

f) se o direito violado pelo ato do Estado advém de um tratado multilateral, qualquer outra parte do tratado multilateral, se ficar estabelecido que o direito foi expressamente estipula do naquele tratado para a proteção dos interesses coletivos dos Estados partes.

3. Também, 'Estado lesado' significa, se o ato internacionalmente ilícito constitui um crime internacional, todos os outros Estados. ${ }^{316}$ (tradução nossa)

\footnotetext{
${ }^{316}$ Article 40. Meaning of injured State
}

1. For the purposes of the present articles, "injured State" means any State a right of which is infringed by the act of another State, if that act constitutes, in accordance with part one, an internationally wrongful act of that State.

2. In particular, "injured State" means:

(a) If the right infringed by the act of a State arises from a bilateral treaty, the other State party to the treaty;

(6) If the right infringed by the act of a State arises from a judgement or other binding dispute settlement decision of an international court or tribunal, the other State or States parties to the dispute and entitled to the benefit of that right;

(c) If the right infringed by the act of a State arises from a binding decision of an international organ other than an international court or tribunal, the State or States which, in accordance with the constituent instrument of the international organization concerned, are entitled to the benefit of that right;

(d) If the right infringed by the act of a State arises from a treaty provision for a third State, that third State;

(e) If the right infringed by the act of a State arises from a multilateral treaty or from a rule of customary international law, any other State party to the multilateral treaty or bound by the relevant rule of customary international law, if it is established that: 
Pela definição adotada neste artigo, seriam Estados lesados todos os Estados partes de um tratado multilateral ou vinculados a uma norma consuetudinária no caso de uma violação a um direito nestas normas previsto para a proteção de direitos humanos ou liberdades fundamentais (artigo 40, parágrafo 2, alínea e, iii). Também seriam considerados Estados lesados todos os outros Estados se o ato internacionalmente ilícito constituísse um crime internacional (artigo 40, parágrafo 3).

A referência feita no parágrafo 3 do antigo artigo 5, limitando os direitos e obrigações do Estados lesados em função de um crime internacional aos estabelecidos nos artigos 24 e 15, foi apagada pelo Drafting Committee na revisão final da primeira leitura (ONU, p. 137 1996b).

O segundo capítulo versava sobre os direitos dos Estados lesados, e obrigações do Estado que cometeu o ato internacionalmente ilícito. Neste capítulo, o artigo 41 tratava da cessação do ato ilícito, o artigo 42 da reparação, o artigo 43 da restituição em espécie, o artigo 44 da compensação, o artigo 45 da satisfação e o artigo 46 das garantias de não repetição.

Já o capítulo III era totalmente dedicado às contramedidas. O artigo 47, antigo artigo 11 da parte 2, foi finalmente adotado com a seguinte redação (ONU, p. 63, 1996a):

Artigo 47. Contramedidas por um Estado lesado

1. Para os propósitos do presente artigo, a tomada de contramedidas significa que um Estado lesado não cumpre com uma ou mais obrigações em relação ao Estado que cometeu $o$ ato internacionalmente ilícito, de modo a induzi-lo a cumprir com suas obrigações segundo os artigos 41 a 46, desde que este não tenha cumprido com estas obrigações e se necessário tendo em vista a sua resposta as demandas feitas pelo Estado lesado.

2. A tomada de contramedidas é sujeita às condições e restrições estabelecidas nos artigos 48 a 50 .

(i) The right has been created or is established in its favour;

(ii) The infringement of the right by the act of a State necessarily affects the enjoyment of the rights or the performance of the obligations of the other States parties to the multilateral treaty or bound by the rule of customary international law; or

(iii) The right has been created or is established for the protection of human rights and fundamental freedoms;

(f) If the right infringed by the act of a State arises from a multilateral treaty, any other State party to the multilateral treaty, if it is established that the right has been expressly stipulated in that treaty for the protection of the collective interests of the States parties thereto.

3. In addition, "injured State" means, if the internationally wrongful act constitutes an international crime, all other State 
3. Quando uma contramedida contra um Estado que cometeu um ato internacionalmente ilícito envolve a violação de uma obrigação em relação a um terceiro Estado, tal violação não pode ser justificada segundo este capítulo, em relação ao terceiro Estado. ${ }^{317}$ (tradução nossa)

Assim as contramedidas eram medidas que poderiam ser adotadas por um Estado lesado, contra o Estado violador em descumprimento a uma ou mais obrigações do primeiro em relação ao segundo. Tais medidas deveriam ter um fim específico, ou seja, induzir o Estado violador a cumprir com suas obrigações segundo os artigos 41 a 46.

$\mathrm{O}$ artigo 48, antigo artigo 12, estabelecia as condições para a adoção destas contramedidas. Seu texto estabelecia (ONU, p. 63-64, 1996a):

Artigo 48. Condições relacionadas ao recurso a contramedidas 1. Antes de tomar contramedidas, um Estado lesado deve cumprir com sua obrigação de negociar, estabelecida no artigo 54. Esta obrigação é sem o prejuízo da tomada pelo Estado de medidas interinas de proteção que são necessárias para preservar seus direitos e que de outra forma cumpririam com os requerimentos deste capítulo.

2. Um Estado lesado tomando contramedidas deve cumprir as obrigações em relação à solução de disputas advindas da parte três ou de qualquer outro procedimento de solução de disputas em vigor entre o Estado lesado e o Estado que cometeu o ato internacionalmente ilícito

3. Desde que o ato internacionalmente ilícito tenha cessado, o Estado lesado deve suspender as contramedidas quando e na medida em que o procedimento de solução de disputas referido no parágrafo 2 estiver sendo implementado de boa fé pelo Estado que cometeu o ato internacionalmente ilícito e a disputa é submetida a um tribunal que tem a autoridade de emanar ordens obrigatórias para as partes.

4. A obrigação de suspender as contramedidas termina no caso de falha pelo Estado que cometeu o ato internacionalmente ilícito de honrar um requerimento ou ordem emanada do procedimento de solução de disputas. ${ }^{318}$ (tradução nossa)

\footnotetext{
${ }^{317}$ Article 47. Countermeasures by an injured State

1. For the purposes of the present articles, the taking of countermeasures means that an injured State does not comply with one or more of its obligations towards a State which has committed an internationally wrongful act in order to induce it to comply with its obligations under articles 41 to 46 , as long as it has not complied with those obligations and as necessary in the light of its response to the demands of the injured State that it do so.

2. The taking of countermeasures is subject to the conditions and restrictions set out in articles 48 to 50 .

3. Where a countermeasure against a State which has committed an internationally wrongful act involves a breach of an obligation towards a third State, such a breach cannot be justified under this chapter as against the third State.

${ }^{318}$ Article 48. Conditions relating to resort to countermeasures

1. Prior to taking countermeasures, an injured State shall fulfil its obligation to negotiate provided for in article 54. This obligation is without prejudice to the taking by that State of interim measures of protection which are necessary to preserve its rights and which otherwise comply with the requirements of this chapter.
} 
Diferente do proposto pelo Relator, a CDI estabelecia como requisito para a adoção de contramedidas apenas a tentativa de negociação. As demais obrigações referentes à solução de disputas deveriam ser cumpridas durante a adoção das medidas. E a suspensão do direito de adotar contramedidas se daria somente nos casos em que tribunal a que o litígio foi submetido tivesse autoridade para emanar ordens obrigatórias as partes.

$\mathrm{O}$ artigo $49^{319}$, antigo artigo 13 , estabelecia a necessidade de proporcionalidade da contramedida com a gravidade do ato internacionalmente ilícito, e o artigo $50^{320}$, antigo artigo 14, tratava das contramedidas proibidas.

O capitulo IV da parte 2 tratava dos crimes internacionais. Ao contrário do proposto pelo Relator, nenhum artigo neste capítulo faz referência às contramedidas, que recairiam, então, no disposto pelo artigo 51, segundo o qual (CDI, p. 64, 1996a) "um crime internacional acarreta todas as consequências jurídicas de outro ato internacionalmente ilícito [...]”321 (tradução nossa)

Sem nenhuma regra específica que regulasse restrições ou ampliações em relação ao regime aplicado no caso de delitos internacionais, as contramedidas a serem adotas em face de crimes internacionais deveriam seguir a regra geral estabelecida no capitulo 3 da parte 2 .

2. An injured State taking countermeasures shall fulfil the obligations in relation to dispute settlement arising under part three or any other binding dispute settlement procedure in force between the injured State and the State which has committed the internationally wrongful act.

3. Provided that the internationally wrongful act has ceased, the injured State shall suspend countermeasures when and to the extent that the dispute settlement procedure referred to in paragraph 2 is being implemented in good faith by the State which has committed the internationally wrongful act and the dispute is submitted to a tribunal which has the authority to issue orders binding on the parties.

4. The obligation to suspend countermeasures ends in case of failure by the State which has committed the internationally wrongful act to honour a request or order emanating from the dispute settlement procedure.

${ }^{319}$ Article 49.Proportionality

Countermeasures taken by an injured State shall not be out of proportion to the degree of gravity of the internationally wrongful act and the effects thereof on the injured State.

${ }^{320}$ Article 50. Prohibited countermeasures

An injured State shall not resort by way of countermeasures to:

(a) The threat or use of force as prohibited by the Charter of the United Nations;

(b) Extreme economic or political coercion designed to endanger the territorial integrity or political independence of the State which has committed the internationally wrongful act;

(c) Any conduct which infringes the inviolability of diplomatic or consular agents, premises, archives and documents;

(d) Any conduct which derogates from basic human rights; or

(e) Any other conduct in contravention of a peremptory norm of general international law.

${ }^{321}$ An international crime entails all the legal consequences of any other internationally wrongful act 
As consequências jurídicas específicas dos crimes internacionais se restringiriam a uma menor limitação das medidas tomadas visando à restituição em espécie e a satisfação (artigo 52) ${ }^{322}$, e às obrigações de todos os Estados diante de um crime internacional (artigo 53) ${ }^{323}$.

A parte 3 do anteprojeto foi dedicada à solução de disputas, contendo o procedimento trifásico proposto pelo Relator. O anteprojeto também dispunha de dois anexos, um tratando da Comissão de Conciliação e outro tratando do Tribunal Arbitral.

Em seus comentários ao capítulo de contramedidas a CDI esclarece o porquê da inserção destas medidas no anteprojeto. Dois ao os principais motivos (ONU, p. 66, 1996a):

Primeiro, existe evidência suficiente de que a prática de contramedidas é admitida, segundo o direito consuetudinário, como forma de responder a uma conduta ilícita. [...] Segundo, não se pode subestimar a importância de restringir a capacidade de um Estado lesado de recorrer a contramedidas, quer dizer, de definir as condições segundo as quais contramedidas são uma resposta legal a uma conduta ilícita. ${ }^{324}$

Ainda segundo os comentários da CDI ao artigo 47, (CDI, p. 67, 1996a) "A noção básica de contramedidas é o direito do Estado lesado de não cumprir com uma ou mais de suas obrigações em relação ao Estado infrator."325 (tradução nossa)

A CDI também rejeita a função punitiva das contramedidas. Em suas palavras (ONU, p. 67, 1996a):

Por outro lado, a função da contramedida não pode ir além da persecução, pelo Estado lesado, da cessação ou reparação. Qualquer medida adotada por um Estado lesado que exceda essas funções ou

\footnotetext{
${ }^{322}$ Article 51. Consequences of an international crime

An international crime entails all the legal consequences of any other internationally wrongful act and, in addition, such further consequences as are set out in articles 52 and 53. (CDI, p. 70, 1996a)

323 Article 52. Specific consequences

Where an internationally wrongful act of a State is an international crime:

(a) An injured State's entitlement to obtain restitution in kind is not subject to the limitations set out in subparagraphs (c) and (d) of article 43;

(b) An injured State's entitlement to obtain satisfaction is not subject to the restriction in paragraph 3 of article 45. (CDI, p. 71, 1996a)

${ }^{324}$ First, there is sufficient evidence that the practice of countermeasures is admitted under customary international law as a means of responding to unlawful conduct [...] Secondly, one should not underestimate the importance of circumscribing the ability of an injured State to resort to countermeasures, that is to say, of defining the conditions under which countermeasures are a lawful response to unlawful conduct.

${ }^{325}$ The basic notion of countermeasures is the entitlement of the injured State not to comply with one or more of its obligations towards the wrongdoing State.
} 
objetivos legais constituirá um ato ilícito. Em particular, um Estado lesado não pode adotar medidas para infligir punição ao alegado infrator. ${ }^{326}$ (tradução nossa)

Os artigos sobre a Responsabilidade do Estado, tal como adotados pela CDI em primeira leitura, tendo em vista a definição abrangente de "Estado lesado" adotada pelo artigo 40, admitiam a possibilidade de aplicação de contramedidas por Estados que não sofreram dano direto advindo do ato internacionalmente ilícito. Tanto os Estados partes de um tratado multilateral de proteção aos direitos humanos, quanto qualquer Estado vinculado por uma norma consuetudinária protetiva destes direitos, poderiam ser considerados Estados lesados nos termos do artigo 40, caso um direito previsto neste tratado ou norma fossem desrespeitados por um Estado. E como Estados lesados, tendo em vista que nenhuma diferenciação a estes é feita no anteprojeto adotado, poderiam adotar contramedidas, respeitando as condições e restrições estabelecidas no capítulo 3 da parte 2 do anteprojeto.

Também no caso de crime internacional, todos os Estados da comunidade internacional seriam considerados Estados lesados, e gozariam do mesmo direito em relação às contramedidas.

Assim, em primeira leitura, os artigos sobre a responsabilidade do Estado permitiriam a adoção de contramedidas em diversos casos de violação a normas protetivas de direitos humanos, por Estados não diretamente afetados por esta violação.

Em 1996, devido a desentendimentos com a CDI em diversas questões, em particular a relação entre a Responsabilidade do Estado e os poderes do Conselho de Segurança, Aragio-Ruiz se demitiu do cargo de Relator Especial. Não tendo sido indicado pela Itália, ele deixou de ser membro da CDI no mesmo ano (CRAWFORD, p. 4, 2002).

Destaca-se do seu trabalho, os artigos dedicados às contramedidas e as consequências jurídicas dos crimes internacionais. Devido, no entanto, aos desentendimentos com a CDI, acima mencionados, algumas de suas propostas não foram acolhidas, em especial as referentes aos requisitos para adoção de contramedidas, e as referentes às consequências jurídicas dos crimes internacionais. Seu trabalho,

\footnotetext{
${ }^{326}$ On the other hand, the function of countermeasures may not go beyond the pursuit by the injured State of cessation and reparation. Any measures resorted to by an injured State that exceeds those lawful functions or aims would constitute an unlawful act. In particular, an injured State may not take measures in order to inflict punishment on the alleged lawbreaker.
} 
assim, teve influência limitada no anteprojeto de artigos sobre a responsabilidade internacional dos Estados.

A CDI na sua $49^{\mathrm{a}}$ Sessão, na reunião 2477 , nomeou um Grupo de Trabalho em responsabilidade do Estado para cuidar dos assuntos ligados à segunda leitura dos artigos. Tendo em vista o fato dos governos ainda não terem respondido ao pedido de comentários sobre o anteprojeto e a natureza delicada do tema, o Grupo de Trabalho recomendou apenas questões procedimentais. A Comissão também indicou James Crawford como Relator Especial para o tema.

\subsection{Trabalho realizado pelo Relator James Crawford (1997 -2001)}

O primeiro Relatório de James Crawford foi apresentado em 1998, e era dividido em uma introdução e dois capítulos. A introdução tratava de alguns assuntos gerais; o primeiro capítulo tratava da distinção entre responsabilidade criminal e delitual; e o segundo capítulo continha uma revisão dos artigos formando a parte 1 , com exceção do artigo 19.

No primeiro capítulo, o Relator constatava a relutância dos diversos Estados em aceitar o conceito de crime internacional, demonstrada nos seus comentários ao anteprojeto de artigos. O Relator menciona a possibilidade de cinco diferentes enfoques sobre a questão da responsabilidade criminal dos Estados. A manutenção do enfoque até então adotado; a substituição do conceito de crime internacional pelo de "ato ilícito excepcionalmente sério"; o desenvolvimento de um regime completo de responsabilidade criminal elaborado nestes artigos; a rejeição do conceito de responsabilidade criminal do Estado; a exclusão desta noção do anteprojeto de artigos.

Após analisar todos os enfoques mencionados o Relator conclui (ONU, p. 23, 1998):

O reconhecimento do conceito de 'crime internacional' representaria uma grande etapa no desenvolvimento do direito internacional. O presente anteprojeto de artigos não faz justiça ao conceito e suas implicações para a ordem jurídica internacional, e não pode se esperar que faça. O tema requer tratamento separado, seja pela Comissão, se o Sexto Comitê a encarregar da tarefa, ou por outro órgão. ${ }^{327}$ (tradução nossa)

\footnotetext{
327 the recognition of the concept of "international crimes" would represent a major stage in the development of international law. The present draft articles do not do justice to the concept or its
} 
Por isto ele recomenda (ONU, p. 23, 1998):

Recomenda-se que os artigos 19 ( e consequentemente, os artigos 51 a 53) sejam deletados do anteprojeto de artigos. No contexto da segunda leitura dos da parte dois, o artigo 40, parágrafo 3, deve ser reconsiderados, inter alia, para lidar com o tema das violações de obrigações erga omnes. Deve se entender que a exclusão do anteprojeto de artigos da noção de 'crimes internacionais' é sem o prejuízo (a) do escopo do anteprojeto de artigos, que continuaria a cobrir todas as violações de obrigações internacionais, qualquer que seja a sua origem, e (b) a noção de 'crime internacional dos Estados' e seu possível desenvolvimento futuro, tanto como um tópico separado ara a Comissão, ou através da prática estatal e da prática das organizações internacionais competentes. ${ }^{328}$ (tradução nossa)

De fato, diversos Estados nos seus comentários sobre o anteprojeto de artigos, criticaram o conceito de crime internacional. Entretanto, um número ligeiramente superior de Estados também apoiou o conceito adotado pela CDI. Enquanto Áustria, França, Irlanda, México, Suíça, Reino Unido, Estados Unidos, e Alemanha (oito países no total) se manifestaram contra o uso da terminologia "crime internacional", Argentina, República Tcheca, Dinamarca (representando os países nórdicos Finlândia, Islândia, Noruega e Suécia), Itália e Mongólia (totalizando nove países), se mostraram a favor da utilização do conceito pela CDI, de acordo com o documento elaborado pela Comissão compilando os comentários e observações dos Estados, publicado em 1998 (ONU, p. 81 et seq, 1998b).

A posição adotada pelo novo Relator Especial poderia ser considerada prematura, tendo em vista o número limitado de manifestações recebido pela CDI da parte dos Estados e a divergência de opinião sobre o tema nas manifestações recebidas. Embora a retirada do conceito de crime internacional do anteprojeto de artigos pudesse facilitar a

implications for the international legal order, and cannot be expected to do so. The subject is one that requires separate treatment, whether by the Commission, if the Sixth Committee should entrust it with this task, or by some other body.

${ }^{328}$ It is recommended that articles 19 (and, consequently, articles 51 to 53) be deleted from the draft articles. In the context of the second reading of part two, article 40, paragraph 3, should be reconsidered, inter alia, so as to deal with the issue of breaches of obligations erga omnes. It should be understood that the exclusion from the draft articles of the notion of "international crimes" of States is without prejudice (a) to the scope of the draft articles, which would continue to cover all breaches of international obligation whatever their origin; and $(b)$ to the notion of "international crimes of States" and its possible future development, whether as a separate topic for the Commission, or through State practice and the practice of the competent international organizations. 
aceitação deste por diversos Estados, por outro lado deixar-se-ia passar uma grande oportunidade para o desenvolvimento de Direito Internacional.

Em relação aos demais artigos da primeira parte do anteprojeto, o Relator recomenda algumas alterações terminológicas, que não afetam a substância dos artigos revisados, e a deleção de alguns artigos, dentre eles o artigo 2, o artigo 6 e os artigos 11 a 14, por serem considerados supérfluos, podendo os seus elementos serem inseridos nos demais artigos.

Além do conceito de crime internacional, também as contramedidas foram alvo de comentários por parte dos Estados. Embora alguns destes tenham se mostrado contra a codificação de regras sobre este instituo no anteprojeto de $\operatorname{artigos}^{329}$, outros se manifestaram a favor da inclusão do tema ${ }^{330}$, ainda que dentre estes houvesse quem criticasse a redação do artigo 47 , que define contramedidas ${ }^{331}$.

Destaca-se a posição dos Estados Unidos e Reino Unido, repudiando a imposição de limites às contramedidas, não reconhecidos pelas regras de direito consuetudinário (artigos 48 e 50).

Diversas críticas também foram feitas ao artigo 40, que define "Estado lesado", tanto em relação ao parágrafo $2^{332}$, quanto em relação ao parágrafo $3^{333}$, considerados vagos, e ampliando demasiadamente o conceito.

A CDI examinou o primeiro Relatório de Crawford na sua $50^{\text {a }}$ Sessão nas reuniões 2532 a 2540,2546 e 2547 , e 2553 a 2558.

Um profundo debate sobre a questão do crime internacional teve lugar. Porém a CDI, concluiu (ONU, p. 77, 1998a): "notou-se que não há consenso na questão do tratamento de 'crimes' e 'delitos' no anteprojeto de artigos, e que mais trabalho é necessário sobre os possíveis meios de lidar com as questões substâncias levantadas."’334 (tradução nossa)

Tendo em vista este impasse, a Comissão decidiu (ONU, p. 77, 1998a):

a) Sem o prejuízo das opiniões de quaisquer membros da Comissão, o projeto de artigo 19 deve ser posto de lado no momento enquanto a

\footnotetext{
${ }^{329}$ França, Singapura e Reino Unido

${ }^{330}$ República Tcheca, Alemanha, Irlanda, Itália e Mongólia.

${ }_{331}$ República Tcheca e Dinamarca.

332 Áustria, França, Alemanha, Reino Unido, e Estados Unidos,

${ }^{333}$ República Tcheca, França, Alemanha, Suíça, Estados Unidos.

334 it was noted that no consensus existed on the issue of the treatment of "crimes" and "delicts" in the draft articles, and that more work needed to be done on possible ways of dealing with the substantial questions raised.
} 
Comissão procede a consideração de outros aspectos da parte um; b) deve ser feita a consideração sobre se o desenvolvimento sistemático no anteprojeto de artigos de noções chave como obrigações (erga omnes), normas peremptórias (jus cogens) e uma possível categoria de violações de obrigações internacionais mais sérias seria suficiente para resolver as questões levantadas pelo artigo 19; c) esta consideração deve ocorrer, em primeira instância, no Grupo de Trabalho estabelecido para o tema e também no segundo relatório do Relator Especial; d) no caso em que nenhum consenso seja atingido através deste processo de mais considerações e debates, a Comissão deve retornar às questões levantadas no primeiro relatório em relação ao artigo 19, com o objetivo de tomar uma decisão. ${ }^{335}$ (tradução nossa)

Em relação aos demais artigos da primeira parte, a CDI enviou para o Drafting Committee os artigos 1 a 15 bis. Na reunião 2562, a Comissão tomou nota de relatório deste Comitê sobre os artigos 1, 3, 4, 5, 7, 8, 8 bis, 9, 10, 15, 15 bise da deleção dos artigos 2, 6 e 11 a 14, feita à luz das sugestões do Relator Especial.

O segundo Relatório de Crawford foi apresentado em 1999. Este documento tratava da revisão dos artigos da primeira parte do anteprojeto, em especial do capítulo III, sobre a violação da obrigação internacional, o capítulo IV, sobre a implicação de um Estado no ato internacionalmente ilícito de outro, o capítulo $\mathrm{V}$, sobre as circunstâncias precluindo a ilicitude e a questão das contramedidas.

Sobre as contramedidas, o Relator discorre (ONU, p. 91, 1999):

É verdade que segundo a definição de 'Estado lesado' no artigo 40, todos os Estados são definidos como lesados pelo crime, e assim, todos os Estados têm o direito individual de procurar reparação e de tomas contramedidas em resposta a um crime. Os projetos de artigos, entretanto, não contêm nenhuma disposição lidando com as possíveis consequências de muitos Estados tomando contramedidas em resposta a um ato ilícito descrito como 'crime' exceto, talvez pelo artigo 53 (d) que prevê que todos Estados devem 'cooperar com outros Estados na aplicação das medidas designadas para eliminar as consequências do crime'. ${ }^{336}$ (tradução nossa)

\footnotetext{
335 (a) without prejudice to the views of any member of the Commission, draft article 19 would be put to one side for the time being while the Commission proceeded to consider other aspects of part one; $(b)$ consideration should be given to whether the systematic development in the draft articles of key notions such as obligations (erga omnes), peremptory norms (jus cogens) and a possible category of the most serious breaches of international obligation could be sufficient to resolve the issues raised by article 19; (c) this consideration would occur, in the first instance, in the Working Group established on this topic and also in the Special Rapporteur's second report; and $(d)$ in the event that no consensus was achieved through this process of further consideration and debate, the Commission would return to the questions raised in the first report as to draft article 19, with a view to taking a decision thereon.

${ }^{336}$ It is true that under the definition of. "injured State" in article 40 all States are defined as injured by a crime, and that therefore all States have the individual right to seek reparation for, and to take counter-. measures in response to, a crime. The draft articles, however, contain no provision dealing with the possible consequences of many States taking countermeasures in response to a wrongful act described as
} 
O Relator, assim, reconhece que pela redação dos artigos adotada em primeira leitura, todos os Estados teriam direito a adotar contramedidas em caso de crime internacional, e que nenhuma disposição específica para regular este direito teria sido aprovada.

Ele propõe quatro possibilidades para lidar com a questão das contramedidas, à luz dos comentários feitos pelos governos. A primeira seria manter o artigo 30 na atual redação e apagar o tratamento das contramedidas da parte II, a segunda seria não tratar das contramedidas na parte II, mas incorporar os elementos essenciais de seu regime no artigo 30, a terceira seria manter o tratamento do tema na parte II, inclusive com a manutenção da sua relação com o sistema de solução de controvérsias, e a quarta seria manter o tratamento das contramedidas na parte II, lidando com as críticas recebidas e retirando a relação com o sistema de solução de controvérsias. Esta quarta possibilidade é a recomendada pelo Relator, que propõe a manutenção do artigo 30. Ele também propõe um novo artigo 30 bis, tratando do não cumprimento de uma obrigação em virtude do não cumprimento anterior de outro Estado. Seria uma retomada do conceito de medidas recíprocas, adotada como excludente de ilicitude.

A CDI examinou o Relatório na sua 51 ${ }^{\text {a }}$ Sessão, nas reuniões 2566 a 2571, 2573, 2574, 2576 a 2578, 2587 a 2592, 2599 e 2600.

Nos debates sobre o tema das contramedidas, a discussão focourse na questão da desvinculação deste instituto com o sistema de solução de controvérsias. Segundo o Relator, apenas uma minoria se colocou contra esta posição (CDI, p. 88, 1999).

Nesta Sessão a Comissão decidiu submeter os artigos 16 a 35, tal como revisados pelo Relator, ao Drafting Committee. Ela recebeu o Relatório deste Comitê sobre os artigos 16, 18, 24, 25, 27, 27 bis, 28, 28 bis, 29, 29 bis, 29 ter, 31, 32, 33 e 35 e tomou nota da deleção dos artigos 17, 19, § 1, 20, 21, 22, 23, 26 e 34.

Crawford apresentou seu terceiro Relatório em 2000. Neste, ele analisou diversas questões referentes à Parte II do anteprojeto de artigos. Em relação ao artigo 40, que define o que seriam Estados lesados, o Relator mencionou as diversas críticas feitas pelos Estados à ampliação deste conceito e propôs fazer uma diferenciação entre Estados lesados pela violação e Estados com interesse jurídico no cumprimento desta. $\mathrm{O}$ novo artigo 40 bis teria a seguinte redação (ONU, p. 54, 2000):

a "crime", except perhaps for article $53(d)$ which provides that States should "cooperate with other States in the application of measures designed to eliminate the consequences of the crime". 
Direito de um Estado de invocar a responsabilidade de outro Estado

1. Para os propósitos deste projeto de artigos, um Estado é lesado pelo ato internacionalmente ilícito de outro Estado se:

a) a obrigação violada é devida individualmente a ele, ou

b) a obrigação em questão é devido à comunidade internacional como um todo (erga omnes), ou a um grupo de Estados dos quais é parte, e a violação da obrigação:

i) afeta especialmente aquele Estado; ou

ii) necessariamente afeta o gozo de seus direitos ou o cumprimento de suas obrigações.

2. Além disso, para os propósitos deste anteprojeto de artigos, um Estado tem um interesse legal no cumprimento de uma obrigação internacional da qual é parte se:

a) a obrigação é devida a comunidade internacional como um todo (erga omnes)

b) a obrigação é estabelecida para a proteção do interesse coletivo de um grupo Estados, incluindo aquele Estado.

3. Este artigo não prejudica nenhum direito, surgido da comissão de um ato internacionalmente ilícito por um Estado, que resulte diretamente a qualquer pessoa ou entidade que não um Estado. ${ }^{337}$ (tradução nossa)

Crawford reduz consideravelmente o conceito de Estado lesado, sendo este somente aquele em relação ao qual a obrigação é devida, ou um Estado que seja especialmente afetado, ou tenha seus direitos ou obrigações afetados pelo ato. Por outro lado, o Relator cria a figura do Estado com interesse jurídico no cumprimento da obrigação, nos casos de obrigações erga omnes, ou de obrigações visando a proteção de um interesse coletivo. As consequências jurídicas decorrentes destas duas classificações seriam definidas em outros artigos.

À luz deste novo conceito de Estado lesado, o Relator propõem também uma série de artigos em relação as contramedidas (ONU, p. 36-38, 2000a).

${ }^{337}$ Right of a State to invoke the responsibility of another State

1. For the purposes of these draft articles, a State is injured by the internationally wrongful act of another State if:

(a) the obligation breached is owed to it individually; or

(b) the obligation in question is owed to the international community as a whole (erga omnes), or to a group of States of which it is one, and the breach of the obligation:

(i) specially affects that State; or

(ii) necessarily affects the enjoyment of its rights or the performance of its obligations.

2. In addition, for the purposes of these draft articles, a State has a legal interest in the performance of an international obligation to which it is a party if:

(a) the obligation is owed to the international community as a whole (erga omnes);

(b) the obligation is established for the protection of the collective interests of a group of States, including that State.

3. This article is without prejudice to any rights, arising from the commission of an internationally wrongful act by a State, which accrue directly to any person or entity other than a State. 
O artigo 47 estabeleceria a possibilidade de adoção de contramedidas pelo Estado lesado, para induzir o Estado violador a cumprir com suas obrigações segundo a Parte II do anteprojeto.

O artigo 47 bis estabeleceria as obrigações que não podem ser objeto de contramedidas, sendo estas as obrigações sobre ameaça ou uso da força, as obrigações relativas a inviolabilidade diplomática ou consular, obrigações relativas à solução de disputas, obrigações de caráter humanitário, e quaisquer obrigações segundo as normas peremptórias de Direito Internacional.

O artigo 48 estabeleceria três condições para a adoção de contramedidas. A submissão de um pedido razoável ao Estado violador requerendo o cumprimento de suas obrigações, a notificação do Estado sobre as contramedidas a serem tomadas, a concordância em negociar de boa fé com o Estado violador. Este artigo também permite a adoção provisória de contramedidas (parágrafo 2).

$\mathrm{O}$ artigo 40 trataria da proporcionalidade das contramedidas.

$\mathrm{O}$ artigo 50 traria as contramedidas proibidas, sendo elas as que pusessem em perigo a integridade territorial do Estado ou acarretassem em intervenção na jurisdição doméstica deste.

$\mathrm{O}$ artigo 50 bis estabeleceria as condições para a suspensão e término das contramedidas.

Em relação à adoção de contramedidas por Estados não diretamente lesados pelo ato ilícito, à luz da nova redação do artigo 40 proposta, o Relator propõe dois artigos, o artigo 50A e o artigo 50B. Segundo estes (ONU, p. 25, 2000b):

Artigo 50A. Contramedidas em nome de um Estado lesado

Qualquer outro Estado habilitado a invocar a responsabilidade de um Estado segundo (o artigo 40 bis 2) pode adotar contramedidas por requerimento e em nome de um Estado lesado, sujeitas a quaisquer condições colocadas por aquele Estado e na medida em que aquele Estado é habilitado a adotar aquelas contramedidas.

Artigo 50B. Contramedidas em caso de violações sérias a obrigações devidas a comunidade internacional como um todo

1) Nos casos referidos no artigo 51 onde nenhum Estado individual é lesado pela violação, qualquer Estado pode adotar contramedidas, sujeito a e de acordo com este Capítulo, de modo a assegurar a cessação da violação da violação e a reparação no interesse das vítimas.

2) Quando mais de um Estado adota contramedidas segundo o parágrafo 1, estes Estados devem cooperar de modo a assegurar que as 
condições estabelecidas neste Capítulo para a adoção de contramedidas sejam preenchidas. ${ }^{338}$

Preveem-se, assim, duas possibilidades de aplicação de contramedidas por Estados não diretamente lesados. A primeira seria quando tal Estado atua a requerimento e em nome do Estado lesado. A segunda seria em caso de grave violação a obrigação erga omnes, qua ndo qualquer Estado poderia aplicar as contramedidas, desde que visando a cessação da conduta ilícita ou a reparação, no interesse das vítimas. Nesta hipótese, todos os Estados aplicando contramedidas teriam que se coordenar para que estas preencham os requisitos presentes no capítulo que trata deste instituto, sobretudo em relação à questão da proporcionalidade.

Assim, segundo a proposta do Relator, seria possível a adoção de contramedidas por Estado não diretamente lesado, em caso de violações graves a normas de direitos humanos que se configurassem obrigações erga omnnes.

Finalmente o Relator propõe o artigo 51, para tratar das graves violações de obrigações devidas pela comunidade internacional como um todo (ONU, p. 24, 2000b):

Artigo 51. Consequências de violações sérias a obrigações devidas a comunidade internacional como um todo

1) Este Capítulo se aplica a responsabilidade internacional que surge de violações sérias e manifestas pó um Estado de uma obrigação devida a comunidade internacional como um todo.

2) Tal violação acarreta, para o Estado responsável, todas as consequências jurídicas de qualquer outro ato internacionalmente ilícito e, ainda (danos punitivos) (danos refletindo a gravidade da violação).

3) Ela também acarreta, para todos os outros Estados, as seguintes obrigações adicionais:

a) não reconhecer como legal a situação criada pela violação;

b) não prestar ajuda ou assistência ao Estado que cometeu a violação para a manutenção da situação criada;

c) cooperar na aplicação das medidas designadas a trazer um fim a violação e na medida do possível, a eliminar suas consequências.

\footnotetext{
${ }^{338}$ Article 50A Countermeasures on behalf of an injured State

Any other State entitled to invoke the responsibility of a State under [article 40 bis (2)] may take countermeasures at the request and on behalf of an injured State, subject to any conditions laid down by that State and to the extent that that State is itself entitled to take those countermeasures.

Article 50B Countermeasures in cases of serious breaches of obligations to the international community as a whole

(1) In cases referred to in article 51 where no individual State is injured by the breach, any State may take countermeasures, subject to and in accordance with this Chapter, in order to ensure the cessation of the breach and reparation in the interests of the victims.

(2) Where more than one State takes countermeasures under paragraph 1, those States shall cooperate in order to ensure that the conditions laid down by this Chapter for the taking of countermeasures are fulfilled.
} 
4) Os parágrafos 2 e 3 são sem prejuízo de consequências adicionais, penais ou outras, que a violação possa acarretar segundo o direito internacional. ${ }^{339}$ (tradução nossa)

O artigo proposto substituiria o antigo artigo 19, retirando o conceito de crime internacional do anteprojeto, e inserindo o conceito de violações sérias a obrigações devidas a comunidade internacional como um todo. $\mathrm{O}$ crime internacional seria substituído pelas obrigações erga omnes. As consequências deste novo conceito seriam uma responsabilidade internacional agravada pelo dano, e obrigações de todos os outros Estados em face da nova situação criada.

A CDI analisou o Relatório apresentado na sua 52 ${ }^{\text {a }}$ Sessão, nas reuniões 2613 a 2616, 2621 a 2623, 2634 a 2640 e 2643 a 2653.

Nos debates sobre o novo artigo 40 bis, proposto pelo Relator, reconheceurse os problemas criados pela redação do artigo 40, tal como adotado em primeira leitura, e diversos membros congratularam a nova proposta por solucionar alguns problemas como a distinção entre os Estados lesados e Estados com interesse jurídico.

Ainda, segundo a CDI (ONU, p. 30, 2000c): "Foi expressa a opinião de que a categoria de obrigações erga omnes deveria ser reservada para direitos humanos fundamentais derivados do direito internacional geral e não somente de algum regime de tratado particular [...]"340 (tradução nossa)

As obrigações erga omnes, previstas no parágrafo 2 (a) do artigo 40 bis, ou seja, obrigações que implicariam num interesse jurídico de todos os Estados no seu cumprimento, se refeririam apenas aos direitos humanos fundamentais, embora também fosse mencionada a dificuldade de se definir quais seriam estes direitos humanos (ONU, p. 31,2000 c).

${ }^{339}$ Article 51 Consequences of serious breaches of obligations to the international community as a whole (1) This Chapter applies to the international responsibility that arises from the serious and manifest breach by a State of an obligation owed to the international community as a whole.

(2) Such a breach entails, for the State responsible for that breach, all the legal consequences of any other internationally wrongful act and, in addition, [punitive damages] [damages reflecting the gravity of the breach].

(3) It also entails, for all other States, the following further obligations:

(a) not to recognize as lawful the situation created by the breach;

(b) not to render aid or assistance to the State which has committed the breach in maintaining the situation so created;

(c) to cooperate in the application of measures designed to bring the breach to an end and as far as possible to eliminate its consequences.

(4) Paragraphs 2 and 3 are without prejudice to such further penal or other consequences that the breach may entail under international law.

${ }^{340}$ The view was expressed that the category of obligation erga omnes should be reserved for fundamental human rights deriving from general international law and not just from a particular treaty regime, 
Também foi discutida a possibilidade de incluir o conceito de crime internacional neste artigo (ONU, p. 31, 2000c).

Em relação às contramedidas em geral, os debates em torno dos artigos 47 a 50 bis, a substância, em geral, foi aprovada, havendo algumas críticas quanto a terminologia e a estruturação, como, por exemplo, a separação feita pelo artigo 47 bis e o artigo 50 dos limites das contramedidas.

Também os dois artigos que tratam das contramedidas coletivas foram apoiados (ONU, p. 60, 2000c), algumas críticas sendo feitas apenas a alguns pontos específicos, como a referência feita ao interesse das vítimas no parágrafo 1 do artigo 50B, pois em casos como o de genocídio, o interesse seria da comunidade internacional como um todo.

Já o artigo 51, que trataria das violações sérias a obrigações devidas a comunidade internacional como um todo, causou críticas tanto dos que anteriormente objetavam ao conceito de crime internacional, como dos que advogavam a favor do conceito. Os primeiros por acharem que se tratava de uma reinserção do crime com outra terminologia, os segundo por que entendiam que o artigo era pouco abrangente. Considerou-se entretanto, o artigo apresentado como um avanço em relação ao artigo 19.

A Comissão remeteu os artigos 30, 36 a 38, 40 bis, 43 a 51 ao Drafting Committee. Este adotou o texto completo do anteprojeto de artigos em segunda leitura e submeteu-os à Comissão, que tomou nota.

Dos novos artigos propostos pelo Drafting Committee, destacam-se os artigos $41^{341}$ e $42^{342}$, que tratam da violação séria a uma obrigação essencial à comunidade internacional como um todo (desmembramentos do artigo 51 proposto pelo Relator); os

\footnotetext{
${ }^{341}$ Article 41. Application of this chapter

1. This chapter applies to the international responsibility arising from an internationally wrongful act that constitutes a serious breach by a State of an obligation owed to the international community as a whole and essential for the protection of its fundamental interests.

2. A breach of such an obligation is serious if it involves a gross or systematic failure by the responsible State to fulfil the obligation, risking substantial harm to the fundamental interests protected thereby.

${ }^{342}$ Article $42[51,53]$. Consequences of serious breaches of obligations to the international community as a whole

1. A serious breach within the meaning of article 41 may involve, for the responsible State, damages reflecting the gravity of the breach.

2. It entails, for all other States, the following obligations:

(a) Not to recognize as lawful the situation created by the breach;

(b) Not to render aid or assistance to the responsible State in maintaining the situation so created;

(c) To cooperate as far as possible to bring the breach to an end.

3. This article is without prejudice to the consequences referred to in chapter II and to such further consequences

that a breach to which this chapter applies may entail under international law.
} 
$\operatorname{artigos~} 43^{343}$, que trata do Estado lesado, e 49 ${ }^{344}$, que trata da invocação da responsabilidade por Estado outro que não o Estado lesado (desmembramentos do artigo 40 bis); e o artigo $54^{345}$, que trata das contramedidas por Estados outros que não o Estado lesado (fundindo os artigos 50A e 50B, apresentados pelo Relator) (ONU, p. 68$71,2000 \mathrm{c})$.

Em 2001 Crawford apresenta seu quarto Relatório, no qual faz uma defesa de alguns pontos do anteprojeto, criticados pelos Estados nos debates do Sexto Comitê da Assembleia Geral da ONU.

Neste ele advoga a importância de retenção do capítulo II da Parte II, sobre as contramedidas, e do capítulo III da parte II sobre as violações sérias a obrigações essenciais devidas a comunidade internacional como um todo.

Sobre a possibilidade de deleção do artigo 54, o Relator escreve (ONU, p. 29, 2001):

Existe uma dificuldade adicional, que a mera deleção do artigo 54 implicará que contramedidas só possam ser adotadas por Estados lesados, estreitamente definidos. $\mathrm{O}$ atual estado do direito internacional sobre medidas tomadas pelo interesse geral ou comum é,

${ }^{343}$ Article 43 [40]. The injured State

A State is entitled as an injured State to invoke the responsibility of another State if the obligation breached is owed to:

(a) That State individually; or

(b) A group of States including that State, or the international community as a whole, and the breach of the obligation:

(i) Specially affects that State; or

(ii) Is of such a character as to affect the enjoyment of the rights or the performance of the obligations of all the States concerned.

344 Article 49. Invocation of responsibility by States other than the injured State

1. Subject to paragraph 2, any State other than an injured State is entitled to invoke the responsibility of another State if:

(a) The obligation breached is owed to a group of States including that State, and is established for the protection of a collective interest;

(b) The obligation breached is owed to the international community as a whole.

2. A State entitled to invoke responsibility under paragraph 1 may seek from the responsible State:

(a) Cessation of the internationally wrongful act, and assurances and guarantees of non-repetition in accordance with article $30[41,46]$;

(b) Compliance with the obligation of reparation under chapter II of Part Two, in the interest of the injured State or of the beneficiaries of the obligation breached.

3. The requirements for the invocation of responsibility by an injured State under articles 44, 45 [22] and 46 apply to an invocation of responsibility by a State entitled to do so under paragraph 1 .

${ }^{345}$ Article 54. Countermeasures by States other than the injured State

1. Any State entitled under article 49, paragraph 1, to invoke the responsibility of a State may take countermeasures at the request and on behalf of any State injured by the breach, to the extent that that State may itself take countermeasures under this chapter.

2. In the cases referred to in article 41 , any State may take countermeasures, in accordance with the present chapter in the interest of the beneficiaries of the obligation breached.

3. Where more than one State takes countermeasures, the States concerned shall cooperate in order to ensure that the conditions laid down by this chapter for the taking of countermeasures are fulfilled. 
sem dúvida, incerto. Mas não é o caso, na visão do Relator Especial, de que contramedidas em prol da observância do direito internacional sejam limitadas às violações afetando os interesses individuais de Estados poderosos ou seus aliados. Obrigações em relação à comunidade internacional como um todo, ou de outro modo, de interesse coletivo, não são obrigações de 'segunda classe' em comparação com as obrigações previstas em tratados bilaterais. Embora se possa esperar que as organizações internacionais sejam hábeis para resolver crises humanitárias e outras que frequentemente surgem das sérias violações de direito internacional, os Estados não abdicaram de seus poderes de ação individual. Assim, se o artigo 54 for apagado, haverá a necessidade de ao menos uma cláusula de salvaguarda. ${ }^{346}$

O Relatório apresentado por Crawford, junto com os artigos adotados pelo Drafting Committee e os comentários dos governos foram examinados pela CDI na sua $53^{\text {a }}$ Sessão. Nas reuniões 2665, 2667, 2668, 2670 a 2675 e 2677, o Relatório foi debatido. Nas reuniões 2672 e 2674, os artigos foram enviados para o Drafting Committee. Na reunião 2673 foram criados dois Grupos de Trabalho sobre o tema.

Como resultado dos debates, a CDI decidiu, como uma exceção à longa prática de adoção de artigos em segunda leitura, incluir um breve sumário dos debates sobre quatro importantes pontos do anteprojeto.

Sobre as sérias violações a obrigações devidas a comunidade internacional como um todo, decidiu-se, tendo em vista as diferentes correntes em relação ao tema e a questão do crime internacional, manter as disposições do capítulo III da parte II, com a deleção do parágrafo 1 do artigo 42, que fazia referência a danos refletindo a gravidade de violação e substituir as referências anteriores às violações a obrigações devidas a comunidade como um todo pela categoria de normas peremptórias.

No tocante às contramedidas, foi decidia a manutenção do capítulo II da parte II, com a deleção do artigo 54 e a inclusão de uma cláusula de salvaguarda em seu lugar.

\footnotetext{
346 There is a further difficulty, in that the mere deletion of article 54 will carry the implication that countermeasures can only be taken by injured States, narrowly defined. The current state of international law on measures taken in the general or common interest is no doubt uncertain. But it cannot be the case, in the Special Rapporteur's view, that countermeasures in aid of compliance with international law are limited to breaches affecting the individual interests of powerful States or their allies. Obligations towards the international community, or otherwise in the collective interest, are not "second-class" obligations by comparison with obligations under bilateral treaties. While it can be hoped that international organizations will be able to resolve the humanitarian or other crises that often arise from serious breaches of international law, States have not abdicated their powers of individual action. Thus if article 54 were to be deleted, there would at least be a need for some form of saving clause.
} 
Decidiu-se, também, pela exclusão das disposições sobre a solução de controvérsias, deixando à Assembleia Geral a decisão se e de que forma se deveriam incluir disposições a respeito do tema.

A Comissão decidiu, ainda, recomendar a Assembleia Geral a adoção do texto do anteprojeto de artigos em resolução e posteriormente, a consideração sobre a adoção de uma convenção sobre o assunto.

Por fim, nas reuniões 2683 e 2701 a 2709 de sua 53 ${ }^{\text {a }}$ Sessão, a CDI adotou os artigos e os seus comentários, submetendo-os à Assembleia Geral.

O trabalho de Crawford foi essencial para que o anteprojeto de artigos finalmente adquirisse sua forma final. Em um espaço de tempo relativamente curto (cinco anos de trabalho), este Relator Especial conseguiu realizar a segunda leitura do anteprojeto de artigos e adotá-lo definitivamente.

Isto foi possível com a alteração de dois pontos controversos no anteprojeto final. O conceito de crime internacional foi substituído pela expressão "violação séria de uma obrigação internacional segundo normas imperativas de direito internacional geral". O conceito de "Estados lesado" foi bastante reduzido em relação ao adotado em primeira leitura pela CDI.

Se por um lado, esta atitude permitiu a CDI finalmente concluir os seus trabalhos sobre a questão da responsabilidade internacional do Estado, por outro deixou passar uma importante oportunidade de desenvolver o Direito Internacional, como veremos mais a frente.

1.3.2.3 O Anteprojeto de artigos sobre a Responsabilidade Internacional do Estado da CDI.

A estrutura final do anteprojeto de artigos da CDI ficou da seguinte forma: a Parte I, tratando do ato internacionalmente ilícito é composta por 5 capítulos, sendo o capítulo I sobre os princípios gerais, o capítulo II sobre a atribuição da conduta a um Estado, o capítulo III sobre a violação de uma obrigação internacional, o capítulo IV sobre a responsabilidade de um Estado em conexão com um ato de outro Estado, e o capítulo V sobre as excludentes de ilicitude.

A Parte II versa sobre o conteúdo da Responsabilidade Internacional do Estado e é composta por três capítulo, o primeiro sobre os princípios gerais, o segundo sobre a 
reparação pelo prejuízo, e o terceiro sobre as violações sérias de obrigações decorrentes de normas imperativas de direito internacional geral.

A Parte III trata da implementação da Responsabilidade Internacional de um Estado e possui dois capítulos, sendo o primeiro sobre a invocação da responsabilidade de um Estado e o segundo sobre as contramedidas.

A quarta e última parte trata das provisões gerais.

Principais artigos do Anteprojeto sobre a Responsabilidade Internacional do Estado

Segundo o artigo $1^{\circ}$ do anteprojeto (ONU, p. 32, 2001a): "Todo o ato internacionalmente ilícito de um Estado acarreta sua responsabilidade internacional."347 (tradução nossa) E segundo a CDI em seus comentários ao artigo $1^{\circ}$ (ONU, p. 32, 2001a): "O termo "responsabilidade internacional cobre as novas relações jurídicas que surgem segundo o direito internacional em razão do ato internacionalmente ilícito de um Estado. O conteúdo destas novas relações jurídicas é especificado na Parte Dois.”ß34 (tradução nossa)

Assim, a responsabilidade internacional é o conjunto de novas relações jurídicas que surgem com a comissão de um ato internacionalmente ilícito. Dentre estas novas relações jurídicas estão o dever de cessação do ato internacionalmente ilícito (artigo 30), o dever de não repetição da conduta (artigo 30) e o dever de reparação (artigo 31).

Ainda, segundo a CDI (ONU, p. 33, 2001a):

Assim , o termo 'responsabilidade internacional' no artigo 1 cobre as relações que surgem segundo o direito internacional de um ato internacionalmente ilícito quer tais relações sejam limitadas ao Estado infrator e a um Estado lesado, quer elas se estendam também a outros Estados ou, na verdade, a outros sujeitos de direito internacional, e quer elas estejam centradas em obrigações de restituição ou compensação, ou também deem ao Estado lesado a possibilidade de responder por meio de contramedidas. ${ }^{349}$ (tradução nossa)

\footnotetext{
${ }^{347}$ Every internationally wrongful act of a State entails the international responsibility of that State.

348 The term "international responsibility" covers the new legal relations which arise under international law by reason of the internationally wrongful act of a State. The content of these new legal relations is specified in Part Two.

349 Thus the term "international responsibility" in article 1 covers the relations which arise under international law from the internationally wrongful act of a State, whether such relations are limited to the wrongdoing State and one injured State or whether they extend also to other States or indeed to other subjects of international law, and whether they are centred on obligations of restitution or compensation or also give the injured State the possibility of responding by way of countermeasures.
} 
A CDI não limita a responsabilidade internacional às relações bilaterais entre Estado lesado e Estado violador. O termo, tal como empregado do artigo $1^{\circ}$, inclui também as relações surgidas entre o Estado violador e Estados não diretamente lesados (por exemplo, as previstas no artigo 48), e as relações com outros sujeitos Direito Internacional. As consequências jurídicas advindas desta responsabilidade não se restringem a obrigações substantivas, como as de cessação ou de reparação, mas de desdobram em direitos instrumentais, como o de tomar contramedidas contra o Estado violador.

Os dois elementos do ato internacionalmente ilícito estão descritos no artigo II, sendo o primeiro a existência de uma conduta, seja uma ação ou omissão, atribuível a um Estado conforme o Direito Internacional, e o segundo a caracterização de tal conduta como uma violação a uma obrigação internacional ${ }^{350}$.

Sobre o primeiro elemento, a CDI comenta (ONU, p. 35, 2001a):

Neste e em outros aspectos, a atribuição de conduta ao Estado é necessariamente uma operação normativa. O que é crucial é que dado evento seja suficientemente conectado à conduta (seja ação ou omissão) que é atribuível ao Estado segundo uma ou outra das normas estabelecidas no capítulo II. ${ }^{351}$ (tradução nossa)

Já em relação ao segundo elemento a CDI escreve (ONU, p. 36, 2001a):

No subparágrafo (b), a referência é feita à violação de uma obrigação internacional ao invés de uma regra ou uma norma de direito internacional. $\mathrm{O}$ que importa para este propósito não é a simples existência de uma regra, mas sua aplicação no caso específico ao Estado responsável. ${ }^{352}$ (tradução nossa)

\footnotetext{
${ }^{350}$ Article 2. Elements of an internationally wrongful act of a State

There is an internationally wrongful act of a State when conduct consisting of an action or omission:

(a) is attributable to the State under international law; and

(b) constitutes a breach of an international obligation of the State.

${ }^{351}$ In this as in other respects the attribution of conduct to the State is necessarily a normative operation. What is crucial is that a given event is sufficiently connected to conduct (whether an act or omission) which is attributable to the State under one or other of the rules set out in chapter II.

${ }^{352}$ In subparagraph $(b)$, reference is made to the breach of an international obligation rather than a rule or a norm of international law. What matters for these purposes is not simply the existence of a rule but its application in the specific case to the responsible State.
} 
Parte da doutrina e alguns governos criticaram o artigo II pela ausência da culpa como elemento do ato internacionalmente ilícito. Sobre o tema a CDI esclarece (ONU, p. 36, 2001a):

Uma questão relacionada é se a culpa constitui um elemento necessário do ato internacionalmente ilícito de um Estado. Não é certamente o caso se por culpa entende-se, por exemplo, uma intenção de prejudicar. Na ausência de qualquer requerimento específico de um elemento mental em termos de obrigação primária, é só o ato do Estado que importa, independente da intenção. ${ }^{353}$ (tradução nossa)

Portanto, são elementos do ato internacionalmente ilícito a imputabilidade de uma conduta a um Estado, segundo as disposições estabelecidas no capitulo II do anteprojeto; e a caracterização de tal conduta como uma violação a uma obrigação internacional relativa ao Estado responsável. A culpa, se não for um elemento exigido pela obrigação internacional violada (regra primária), não é necessária para a caracterização de um ato como ilícito.

Outro artigo importante da Parte I, para fins deste trabalho, é o artigo 22 do capítulo $\mathrm{V}$, que estabelece a adoção de contramedidas contra um ato internacionalmente ilícito como uma excludente de ilicitude. Segundo este (ONU, p. 75, 2001a):

Artigo 22. A ilicitude de um ato de um Estado em desacordo com uma obrigação internacional em relação a outro Estado será excluída se e na medida em que o ato constitua uma contramedida tomada contra o último Estado em conformidade com o capítulo II da Parte Três. ${ }^{354}$ (tradução nossa)

Em seus comentários a este artigo, a CDI escreve (ONU, p. 76, 2001a):

Uma questão é se contramedidas podem ser tomadas por Estados terceiros que não foram eles mesmos, individualmente lesados pelo ato internacionalmente ilícito em questão, embora a obrigação que foi violada seja devida a eles. Por exemplo, no caso de uma obrigação devida à comunidade internacional como um todo a CIJ afirmou que todos os Estados têm interesse jurídico no seu cumprimento. $\mathrm{O}$ artigo 54 deixa em aberto a questão se qualquer Estado pode adotar medidas

\footnotetext{
${ }^{353}$ A related question is whether fault constitutes a necessary element of the internationally wrongful act of a State. This is certainly not the case if by "fault" one understands the existence, for example, of an intention to harm. In the absence of any specific requirement of a mental element in terms of the primary obligation, it is only the act of a State that matters, independently of any intention.

354 The wrongfulness of an act of a State not in conformity with an international obligation towards another State is precluded if and to the extent that the act constitutes a countermeasure taken against the latter State in accordance with chapter II of Part Three.
} 
para assegurar o cumprimento de certas obrigações internacionais no interesse geral, distinto do seu próprio interesse individual como Estado lesado. Embora o artigo 22 não cubra medidas tomadas neste caso, tendo em vista que estas não se qualificam como contramedidas, ele também não exclui essa possibilidade. ${ }^{355}$ (tradução nossa)

Na Parte II do anteprojeto, vale destacar os artigos 40 e 41, que compõem o capítulo III, tratando das violações sérias de obrigações decorrentes de normas imperativas de direito internacional. O artigo 40 estabelece (ONU, p, 112, 2001a):

Artigo 40. Aplicação deste capítulo

1. Este capítulo se aplica à responsabilidade que é acarretada por uma violação séria por um Estado de uma obrigação decorrentes de uma norma imperativa de direito internacional geral.

2. Uma violação de tal obrigação é séria se envolve uma falha flagrante ou sistemática do Estado responsável de cumprir a obrigação. ${ }^{356}$ (tradução nossa)

O termo "violação séria de uma obrigação internacional segundo normas imperativas de direito internacional geral" é utilizado em substituição ao termo "crime internacional" adotado no antigo artigo 19, aprovado em primeira leitura pela CDI. Tendo em vista estes terem sido postos de lado pela Comissão, o artigo 40 é adotado visando conciliar opiniões divergentes, tanto no âmbito da CDI, como no âmbito dos Estados.

Segundo a Comissão (ONU, p. 112, 2001a):

O artigo 40 serve para definir o escopo das violações cobertas pelo capítulo. Ele estabelece dois critérios para distinguir 'violações sérias de obrigações segundo normas imperativas de direito internacional geral' de outros tipos de violações. A primeira se relaciona com o caráter da obrigação violada, que deve derivar de uma norma imperativa de direito internacional geral. A segunda qualifica a intensidade da violação, que deve ter sido de natureza séria. $\mathrm{O}$

\footnotetext{
355 One issue is whether countermeasures may be taken by third States which are not themselves individually injured by the internationally wrongful act in question, although they are owed the obligation which has been breached. For example, in the case of an obligation owed to the international community as a whole ICJ has affirmed that all States have a legal interest in compliance.344 Article 54 leaves open the question whether any State may take measures to ensure compliance with certain international obligations in the general interest as distinct from its own individual interest as an injured State. While article 22 does not cover measures taken in such a case to the extent that these do not qualify as countermeasures, neither does it exclude that possibility.

${ }^{356}$ Article 40. Application of this chapter

1. This chapter applies to the international responsibility which is entailed by a serious breach by a State of an obligation arising under a peremptory norm of general international law.

2. A breach of such an obligation is serious if it involves a gross or systematic failure by the responsible State to fulfil the obligation.
} 
Capítulo III se aplica somente aquelas violações de direito internacional que preenche os dois critérios. ${ }^{357}$ (tradução nossa)

Em relação ao conteúdo das normas imperativas de direito internacional, a CDI entende que não seria apropriado colocar exemplos de normas imperativas. Entretanto esta reconhece que a proibição de agressão, proibição de escravidão e de tráfico de escravos, de genocídio, de discriminação racial e de apartheid, de tortura, regras básicas de direito humanitário aplicáveis em caso de conflitos armados, e o direito de autodeterminação são normas usualmente reconhecidas como imperativas ONU, p. 112-13, 2001a).

Já no que se refere à seriedade da violação a CDI comenta (ONU, p. 113, 2001a):

Para ser tida como sistemática, uma violação deve ter sido feita de maneira organizada e deliberada. Em contraste, o termo 'flagrante' se refere à intensidade da violação ou de seus efeitos; ele denota violações de natureza flagrantes, importando em um ataque direto e total aos valores protegidos pela norma. Os termos, obviamente não são mutuamente excludentes: violações sérias serão geralmente tanto sistemáticas como fla grantes. ${ }^{358}$ (tradução nossa)

Abandonado o conceito de crime internacional, o mesmo ocorre com as tentativas de se estabelecer um procedimento para determinar sua ocorrência. Neste sentido a CDI escreve (ONU, p. 113, 2001a):

$\mathrm{O}$ artigo 40 não estabelece nenhum procedimento para determinar se uma violação séria foi cometida, ou não. Não é função dos artigos estabeleceram novos procedimentos institucionais para lidar com casos individuais, tenham eles surgido segundo o capítulo III da Parte Dois, ou não. Ademais, as violações sérias tratadas neste capítulo serão provavelmente tratadas pelas organizações internacionais competentes, incluindo o Conselho de Segurança e a Assembleia Geral. Em caso de agressão é dado um papel específico ao Conselho de Segurança pela Carta das Nações Unidas. ${ }^{359}$ (tradução nossa)

\footnotetext{
357 Article 40 serves to define the scope of the breaches covered by the chapter. It establishes two criteria in order to distinguish "serious breaches of obligations under peremptory norms of general international law" from other types of breaches. The first relates to the character of the obligation breached, which must derive from a peremptory norm of general international law. The second qualifies the intensity of the breach, which must have been serious in nature. Chapter III only applies to those violations of international law that fulfil both criteria.

${ }^{358}$ To be regarded as systematic, a violation would have to be carried out in an organized and deliberate way. In contrast, the term "gross" refers to the intensity of the violation or its effects; it denotes violations of a flagrant nature, amounting to a direct and outright assault on the values protected by the rule. The terms are not of course mutually exclusive; serious breaches will usually be both systematic and gross.

359 Article 40 does not lay down any procedure for determining whether or not a serious breach has been committed. It is not the function of the articles to establish new institutional procedures for dealing with
} 
Já o artigo 41 estabelece (ONU, p.114, 2001a):

Art. 41. Consequências particulares da violação séria de uma obrigação de acordo com este Capítulo

1. Os Estados deverão cooperar para pôr fim, através de meios lega is, a toda violação séria no sentido atribuído no artigo 40.

2. Nenhum Estado reconhecerá como lícita uma situação criada por uma violação séria no sentido atribuído no artigo 40, nem prestará auxílio ou assistência para manutenção daquela situação.

3. Este artigo não prejudica as outras consequências referidas nesta Parte bem como as demais consequências que uma violação a qual se aplique este Capítulo possa acarretar, de acordo com o Direito Internacional. ${ }^{360}$ (tradução nossa)

Sobre o parágrafo 1 deste artigo a CDI comenta (ONU, p. 114, 2001a):

De acordo com o parágrafo 1 do artigo 41, os Estados têm um dever positivo de cooperar para pôr um fim às violações sérias no sentido do artigo 40. Por causa da diversidade de circunstâncias que poderiam possivelmente estar envolvidas, a disposição não prescreve em detalhes que forma esta cooperação deve ter. A cooperação pode ser organizada no quadro de uma organização internacional competente, em particular as Nações Unidas. Entretanto o parágrafo 1 também prevê a possibilidade de cooperação não institucional. [...] Tal cooperação deve se dar através de meios legais, a escolha dos quais dependerá das circunstâncias de cada situação. Fica, entretanto, claro que a obrigação de cooperar se aplica aos Estados sejam eles individualmente afetados pela violação séria ou não. $O$ que é requerido em face de sérias violações é um esforço conjunto e coordenado de todos os Estados para neutralizar os efeitos destas violações. ${ }^{361}$ (tradução nossa)

individual cases, whether they arise under chapter III of Part Two or otherwise. Moreover, the serious breaches dealt with in this chapter are likely to be addressed by the competent international organizations, including the Security Council and the General Assembly. In the case of aggression, the Security Council is given a specific role by the Charter of the United Nations.

${ }^{360}$ Article 41. Particular consequences of a serious breach of an obligation under this chapter

1. States shall cooperate to bring to an end through lawful means any serious breach within the meaning of article 40.

2. No State shall recognize as lawful a situation created by a serious breach within the meaning of article 40 , nor render aid or assistance in maintaining that situation.

3. This article is without prejudice to the other consequences referred to in this Part and to such further consequences that a breach to which this chapter applies may entail under international law.

${ }^{361}$ Pursuant to paragraph 1 of article 41, States are under a positive duty to cooperate in order to bring to an end serious breaches in the sense of article 40 . Because of the diversity of circumstances which could possibly be involved, the provision does not prescribe in detail what form this cooperation should take. Cooperation could be organized in the framework of a competent international organization, in particular the United Nations. However, paragraph 1 also envisages the possibility of non-institutionalized cooperation. [...] Such cooperation must be through lawful means, the choice of which will depend on the circumstances of the given situation. It is, however, made clear that the obligation to cooperate applies to States whether or not they are individually affected by the serious breach. What is called for in the face of serious breaches is a joint and coordinated effort by all States to counteract the effects of these breaches. 
A redação do parágrafo 1 do artigo 41 deixa margem a interpretações. O dever de cooperar para o fim da violação séria a uma norma imperativa de direito internacional poderia implicar na adoção de contramedidas coletivas? Segundo a Carta da ONU (artigo 41) somente o Conselho de Segurança tem competência para adotar medidas coercitivas, ainda que somente de caráter econômico, contra um Estado. Ainda assim, a Assembleia Geral, em algumas ocasiões, como veremos mais detalhadamente a frente, adotou resoluções recomendando aos Estados a adoção de medidas que poderiam se configurar contramedidas de um Estado em relação ao Estado responsabilizado. Nestes casos, seria possível estabelecer que o artigo 41 reconhece não só o direito, mas o dever de alguns Estados de adotar contramedidas em relação ao Estado violador? Voltaremos a esta questão mais adiante.

Já sobre o parágrafo 2 do artigo 41 a CDI explica (ONU, p. 115, 2001a):

Ele trata da conduta 'após o fato' que ajuda o Estado responsável a manter a situação 'oponível a todos os Estados no sentido de barrar erga omnes a legalidade da situação que é mantida em violação do direito internacional. Ele se estende além da comissão da violação séria, ela mesma, até a manutenção da situação criada pela violação, e ele se aplica quer a violação seja contínua ou não. ${ }^{362}$ (tradução nossa)

Também a redação do parágrafo 2 do artigo 41 poderia dar margem a interpretações. Ao estabelecer a proibição de prestar auxílio ou assistência ao Estado violador, o artigo não menciona a possibilidade de que tal auxílio ou assistência possa decorrer de uma obrigação internacional de um Estado em relação ao Estado violador. Neste caso, a negação de assistência ou auxílio poderia se configurar em uma contramedida contra este Estado?

A parte III do anteprojeto trata da implementação da Responsabilidade Internacional do Estado. O seu artigo 48 versa sobre a invocação de responsabilidade por um Estado que não o lesado. Ele estabelece (ONU, p. 126, 2001a):

Art. 48. Invocação de responsabilidade por um Estado que não seja o lesado:

\footnotetext{
362 It deals with conduct "after the fact" which assists the responsible State in maintaining a situation "opposable to all States in the sense of barring erga omnes the legality of a situation which is maintained in violation of international law". It extends beyond the commission of the serious breach itself to the maintenance of the situation created by that breach, and it applies whether or not the breach itself is a continuing one.
} 
1. Qualquer Estado, além do lesado, pode invocar a responsabilidade de outro Estado, de acordo com o parágrafo 2 se:

a) a obrigação violada existe em relação a um grupo de Estados incluindo aquele Estado, e está estabelecida para a proteção de um interesse cole tivo do grupo; ou

b) a obrigação violada existe em relação à comunidade internacional corno um todo.

2. Qualquer Estado apto a invocar a responsabilidade de acordo com o parágrafo $1^{\circ}$ pode reclamar ao Estado responsável:

a) a cessação do ato internacionalmente ilícito, e seguranças e garantias de não repetição de acordo com o artigo 30; e

b) o cumprimento da obrigação de reparação de acordo com os artigos precedentes, no interesse do Estado lesado ou dos beneficiários da obrigação violada.

3. Os requisitos para a invocação da responsabilidade por um Estado lesado de acordo com os artigos 43, 44 e 45 se aplicam a uma invocação da responsabilidade por um Estado habilitado segundo o parágrafo $1 .^{363}$ (tradução nossa)

O artigo 48 permite a invocação da responsabilidade internacional por Estados com interesse jurídico no cumprimento da obrigação, mas que não foram diretamente lesados por esta. Ele é uma contrapartida à redução do conceito de Estado lesado pelo artigo 42 da versão final do anteprojeto em relação ao antigo artigo 40, aprovado em primeira leitura. Segundo o novo artigo 42 (ONU, p. 117, 2001a):

Um Estado terá o direito, como Estado lesado, de invocar a responsabilidade de outro Estado se a obrigação violada existe:

a) Em relação a este Estado individualmente; ou

b) em relação a um grupo de Estados, do qual este Estado faça parte, ou a comunidade internacional como um todo, e a violação da obrigação:

i) especialmente afeta este Estado; ou

ii) for de tal natureza que modifique radicalmente a posição de todos os outros Estados em relação aos quais a obrigação é devida com respeito ao cumprimento posterior da obrigação. ${ }^{364}$ (tradução nossa)

${ }^{363}$ Article 48. Invocation of responsibility by a State other than an injured State

1. Any State other than an injured State is entitled to invoke the responsibility of another State in accordance with paragraph 2 if:

(a) the obligation breached is owed to a group of States including that State, and is established for the protection of a collective interest of the group; or

(b) the obligation breached is owed to the international community as a whole.

2. Any State entitled to invoke responsibility under paragraph 1 may claim from the responsible State:

(a) cessation of the internationally wrongful act, and assurances and guarantees of non-repetition in accordance with article 30; and

(b) performance of the obligation of reparation in accordance with the preceding articles, in the interest of the injured State or of the beneficiaries of the obligation breached.

3. The requirements for the invocation of responsibility by an injured State under articles 43,44 and 45 apply to an invocation of responsibility by a State entitled to do so under paragraph 1 .

364 Article 42 . Invocation of responsibility by an injured State

A State is entitled as an injured State to invoke the responsibility of another State if the obligation breached is owed to: 
Segundo a CDI (ONU, p. 127, 2001a) "a invocação da responsabilidade segundo o artigo 48 dá origem a uma gama mais limitada de direitos comparados aos dos Estados lesados segundo o artigo 42." ${ }^{365}$ Por outro lado, nas palavras da Comissão (ONU, p. 127, 2001a):

No caso de violações de obrigações segundo o artigo 48, pode ocorrer que não exista Estado que seja individualmente lesado pela violação, e ainda sim ser altamente desejável que algum Estado ou Estados estejam na posição de reclamar reparação, em particular, restituição. De acordo com o parágrafo 2 (b), tal reclamação deve ser feita no interesse do Estado lesado, se houver, ou dos beneficiários da obrigação violada. Esse aspecto do artigo 48, parágrafo 2 envolve uma medida de desenvolvimento progressivo, que é justificada uma vez que ela provê meios de proteger o interesse coletivo ou comunitário em questão. ${ }^{366}$ (tradução nossa)

O capítulo II da Parte III é totalmente consagrado às contramedidas. Segundo a CDI (ONU, p. 128, 2001a): "Contramedidas são uma característica de um sistema descentralizado pelo qual Estados lesados podem reivindicar seus direitos e restaurar a relação jurídica com o Estado responsável, que foi rompida pelo ato internacionalmente ilícito."367

Sobre a terminologia escolhida, a CDI explica (ONU, p. 128, 2001a):

Em relação à terminologia, tradicionalmente o termo 'represálias' era usado para abranger ações de outro modo ilícitas, incluindo ações com uso da força, tomadas por meio de autoajuda em reposta a violação. Mais recentemente, o termo 'represálias' tem se limitado a ações tomadas em período de conflito armado internacional; i.e. ele é tido

(a) that State individually; or

(b) a group of States including that State, or the international community as a whole, and the breach of the obligation:

(i) specially affects that State; or

(ii) is of such a character as radically to change the position of all the other States to which the obligation is owed with respect to the further performance of the obligation.

${ }^{365}$ invocation of responsibility under article 48 gives rise to a more limited range of rights as compared to those of injured States under article 42.

${ }^{366}$ In case of breaches of obligations under article 48, it may well be that there is no State which is individually injured by the breach, yet it is highly desirable that some State or States be in a position to claim reparation, in particular restitution. In accordance with paragraph $2(b)$, such a claim must be made in the interest of the injured State, if any, or of the beneficiaries of the obligation breached. This aspect of article 48 , paragraph 2 , involves a measure of progressive development, which is justified since it provides a means of protecting the community or collective interest at stake.

367 Countermeasures are a feature of a decentralized system by which injured States may seek to vindicate their rights and to restore the legal relationship with the responsible State which has been ruptured by the internationally wrongful act. 
como equivalente a represálias bélicas. O termo 'contramedidas' cobre aquela parte do tema das represálias não associada com conflito armado, e de acordo com a prática moderna e as decisões judiciais o termo é usado neste sentido neste capítulo. ${ }^{368}$ (tradução nossa)

Assim, para a CDI, as contramedidas seriam represálias sem o uso da força. $\mathrm{O}$ termo foi preferido em relação ao termo 'represália', que atualmente teria uma conotação mais voltada a conflitos armados, e em relação ao termo "sanção" que teria uma função punitiva não reconhecida nas contramedidas segundo o texto final aprovado pela CDI.

O Capítulo, ainda, se limita as contramedidas tomadas pelo Estado lesado contra o Estado responsável. Em relação às contramedidas tomadas por outros Estados a CDI comenta (ONU, p. 129, 2001a):

O foco deste capítulo são contramedidas tomadas por Estados lesados como definidos pelo artigo 42. Surgiram ocasiões, na prática, de contramedidas sendo tomadas por outros Estados, em particular aqueles identificados no artigo 48, quando nenhum Estado é lesado ou ainda, em nome e a pedido do Estado lesado. Tais casos são controversos e a prática é embrionária. Este capítulo não pretende regular a tomada de contramedidas por Estados outros que não o Estado lesado. Ele, entretanto, não prejudica o direito de nenhum Estado identificado no artigo 48, parágrafo1, de tomar medidas lícitas contra o Estado responsável para assegurar a cassação da violação e a reparação no interesse do Estado lesado ou dos beneficiários da obrigação violada (art. 54) ${ }^{369}$ (tradução nossa)

O artigo 49 estabelece o objeto e limites das contramedidas. Segundo este (ONU,

p. 129, 2001a):

Art. 49. Objeto e limites das contramedidas

\footnotetext{
368 As to terminology, traditionally the term "reprisals" was used to cover otherwise unlawful action, including forcible action, taken by way of self-help in response to a breach. More recently, the term "reprisals" has been limited to action taken in time of international armed conflict; i.e. it has been taken as equivalent to belligerent reprisals. The term "countermeasures" covers that part of the subject of reprisals not associated with armed conflict, and in accordance with modern practice and judicial decisions the term is used in that sense in this chapter.

369 The focus of the chapter is on countermeasures taken by injured States as defined in article 42. Occasions have arisen in practice of countermeasures being taken by other States, in particular those identified in article 48, where no State is injured or else on behalf of and at the request of an injured State. Such cases are controversial and the practice is embryonic. This chapter does not purport to regulate the taking of countermeasures by States other than the injured State. It is, however, without prejudice to the right of any State identified in article 48, paragraph 1, to take lawful measures against a responsible State to ensure cessation of the breach and reparation in the interest of the injured State or the beneficiaries of the obligation breached (art. 54).
} 
1. Um Estado lesado somente pode adotar contramedidas contra um Estado que seja responsável por um ato internacionalmente ilícito com o objetivo de induzi-lo a cumprir com suas respectivas obrigações dispos tas na Parte Dois.

2. As contramedidas são limitadas ao não cumprimento momentâneo de obrigações internacionais do Estado que adota as medidas em relação ao Estado responsável.

3. As contramedidas deverão, na medida do possível, ser tomadas de tal modo a permitir a retomada da realização das obrigações em questão. ${ }^{370}$ (tradução nossa)

O artigo 49 deixa clara a função instrumental da contramedida. Segundo a CDI (ONU, p. 130, 2001a):

Contramedidas só podem ser tomadas por um Estado lesado de modo a induzir o Estado responsável a cumprir com suas obrigações segundo a Parte Dois, ou seja, a cessar com a conduta internacionalmente ilícita, se ela for contínua, e prover reparação ao Estado lesado. Contramedidas não são projetadas como uma forma de punição pela conduta ilícita, mas como um instrumento para conseguir o cumprimento das obrigações pelo Estado responsável segundo a Parte Dois. ${ }^{371}$ (tradução nossa)

Ainda, nas palavras da Comissão (ONU, p. 130, 2001a): "Um pré-requisito fundamental para qualquer contramedida lícita é a existência de um ato internacionalmente ilícito que lesou o Estado que adota as contramedidas."372 (tradução nossa)

A CDI também escreve (ONU, p. 130, 2001a): "Um segundo elemento essencial das contramedidas é que elas 'devem ser direcionadas contra' um Estado que cometeu

\footnotetext{
${ }^{370}$ Article 49. Object and limits of countermeasures

1. An injured State may only take countermeasures against a State which is responsible for an internationally wrongful act in order to induce that State to comply with its obligations under Part Two.

2. Countermeasures are limited to the non-performance for the time being of international obligations of the State taking the measures towards the responsible State.

3. Countermeasures shall, as far as possible, be taken in such a way as to permit the resumption of performance of the obligations in question.

${ }^{371}$ Countermeasures may only be taken by an injured State in order to induce the responsible State to comply with its obligations under Part Two, namely, to cease the internationally wrongful conduct, if it is continuing, and to provide reparation to the injured State. Countermeasures are not intended as a form of punishment for wrongful conduct, but as an instrument for achieving compliance with the obligations of the responsible State under Part Two.

372 A fundamental prerequisite for any lawful countermeasure is the existence of an internationally wrongful act which injured the State taking the countermeasure.
} 
um ato internacionalmente ilícito, e que não cumpriu com suas obrigações de cessação e reparação segundo a Parte Dois dos presentes artigos."373 (tradução nossa)

Outra característica importante é a reversibilidade das medidas adotadas. Segundo a CDI (ONU, p. 130-131, 2001a):

A frase 'momentâneo' no parágrafo 2 indica o caráter temporário ou provisório das contramedidas. Seu objetivo é a restauração de uma condição de legalidade entre o Estado lesado e o Estado responsável e não a criação de novas situações que não podem ser retificadas qualquer que seja a resposta do último Estado às reclamações feitas contra ele. ${ }^{374}$ (tradução nossa)

Assim, as contramedidas são medidas temporárias tomadas por um Estado lesado contra o Estado responsável pelo ato internacionalmente ilícito que o lesou.

O artigo 50 estabelece obrigações que não devem ser afetadas pelas contramedidas. Seu texto estabelece (ONU, p. 131, 2001a):

Art. 50. Obrigações não afetadas pelas contramedidas

1. As contramedidas não deverão afetar:

a) a obrigação de abster-se da ameaça ou uso de força como disposto na Carta da ONU;

b) obrigações estabelecidas para a proteção de direitos humanos fundamentais;

c) obrigações de caráter humanitário proibindo represálias;

d) outras obrigações segundo as normas imperativas de Direito Internacional geral.

2. Um Estado que realize as contramedidas não está isento de cumprir com suas obrigações:

a) de acordo com qualquer procedimento de solução de controvérsias aplicável a ele e ao Estado responsável;

b) de respeitar a inviolabilidade de agentes diplomáticos e consulares, locais, arquivos e documentos. ${ }^{375}$ (tradução nossa)

\footnotetext{
373 A second essential element of countermeasures is that they "must be directed against" a State which has committed an internationally wrongful act, and which has not complied with its obligations of cessation and reparation under Part Two of the present articles.

374 The phrase "for the time being" in paragraph 2 indicates the temporary or provisional character of countermeasures. Their aim is the restoration of a condition of legality as between the injured State and the responsible. State, and not the creation of new situations which cannot be rectified whatever the response of the latter State to the claims against it.

${ }^{375}$ Article 50. Obligations not affected by countermeasures

1. Countermeasures shall not affect:

(a) the obligation to refrain from the threat or use of force as embodied in the Charter of the United Nations;

(b) obligations for the protection of fundamental human rights;

(c) obligations of a humanitarian character prohibiting reprisals;

(d) other obligations under peremptory norms of general international law.

2. A State taking countermeasures is not relieved from fulfilling its obligations:

(a) under any dispute settlement procedure applicable between it and the responsible State;
} 
Dentre as obrigações que não podem ser afetadas por contramedidas, estão as estabelecidas para a proteção de direitos humanos fundamentais, e as de caráter humanitário. A CDI não menciona, entretanto, quais direitos humanos deveriam ser considerados fundamentais.

$\mathrm{O}$ artigo 51 estabelece o princípio da proporcionalidade. Segundo ele (ONU, p. 134, 2001a): “Art. 51. Proporcionalidade: As contramedidas devem ser estabelecidas de acordo com o prejuízo sofrido, levando em consideração a gravidade do ato internacionalmente ilícito e os direitos em questão.”376 (tradução nossa)

Sobre este princípio a CDI escreve (ONU, p. 135, 2001a):

Considerando a necessidade de assegurar que a adoção de contramedidas não leve a resultados não equânimes, a proporcionalidade deve ser avaliada levando em conta não somente o elemento puramente 'quantitativo' do dano sofrido, mas também fatores 'qualitativos', tais como a importância do interesse protegido pela norma infringida e a seriedade da violação. $\mathrm{O}$ artigo 51 relaciona a proporcionalidade primariamente ao dano sofrido, mas 'levando em conta' dois outros critérios: a gravidade do ato internacionalmente ilícito, e os direitos em questão. A referência aos 'direitos em questão' tem um significado amplo, e inclui não só o efeito do ato ilíc ito no Estado lesado, mas também os direitos do Estado responsável. Também, a posição de outros Estados que possam ser afetados pode ser levada em consideração. ${ }^{377}$ (tradução nossa)

$\mathrm{O}$ artigo 52 estabelece as condições para a adoção de contramedidas. Pelo seu texto (ONU, p. 135, 2001a):

Art. 52. Condições relativas a recorrer a contramedidas

1. Antes de tomar as contramedidas, um Estado lesado deverá:

a) requerer ao Estado responsável, de acordo com o artigo 43, que cumpra com suas obrigações em conformidade com a Parte Dois;

(b) to respect the inviolability of diplomatic or consular agents, premises, archives and documents.

${ }^{376}$ Article 51. Proportionality

Countermeasures must be commensurate with the injury suffered, taking into account the gravity of the internationally wrongful act and the rights in question.

377 Considering the need to ensure that the adoption of countermeasures does not lead to inequitable results, proportionality must be assessed taking into account not only the purely "quantitative" element of the injury suffered, but also "qualitative" factors such as the importance of the interest protected by the rule infringed and the seriousness of the breach. Article 51 relates proportionality primarily to the injury suffered but "taking into account" two further criteria: the gravity of the internationally wrongful act, and the rights in question. The reference to "the rights in question" has a broad meaning, and includes not only the effect of a wrongful act on the injured State but also on the rights of the responsible State. Furthermore, the position of other States which may be affected may also be taken into consideration. 
b) notificar o Estado responsável de qualquer decisão para tomar as contramedidas e oferecer para negociar com aquele Estado.

2. Sem desconsiderar o 1 (b), o Estado lesado pode tomar contramedidas urgentes que sejam necessárias para preservar seus direitos.

3. As contramedidas não podem ser tomadas, e se já tomadas devem ser suspensas sem atraso injustificado se:

a) o ato internacionalmente ilícito cessou, e

b) a disputa está pendente perante uma Corte ou tribunal que tenha a autoridade para proferir decisões vinculantes para as partes.

4. O parágrafo $3^{\circ}$ não se aplicará se o Estado responsável falhar ao implementar os procedimentos de solução da controvérsia de boafé. ${ }^{378}$ (tradução nossa)

Sobre este artigo a CDI comenta (ONU, p. 135, 2001a):

$\mathrm{O}$ artigo 52 estabelece acertas condições procedimentais relacionadas ao recurso a contramedidas pelo Estado lesado. Antes de adotar contramedidas, requer-se de um Estado lesado que peça ao Estado responsável, de acordo com o artigo 43 que cumpra com suas obrigações segundo a Parte Dois. Requer-se ao Estado lesado, também, que notifique o Estado responsável da sua intenção de tomar contramedidas e que se ofereça para negociar com aquele Estado. Não obstante este segundo requerimento, o Estado lesado pode adotar certas contramedidas urgentes para preservar seus direitos. Se o Estado responsável cessou o ato internacionalmente ilícito e a disputa esta diante de um tribunal ou corte competente, contramedidas não podem ser tomadas. Entretanto, este requerimento não se aplica se o Estado responsável falha em implementar procedimentos de solução de disputas em boa fé. Em tal caso, a contramedida não tem que ser suspensa em pode ser retomada. ${ }^{379}$ (tradução nossa)

\footnotetext{
${ }^{378}$ Article 52. Conditions relating to resort to countermeasures
}

1. Before taking countermeasures, an injured State shall:

(a) call upon the responsible State, in accordance with article 43, to fulfil its obligations under Part Two;

(b) notify the responsible State of any decision to take countermeasures and offer to negotiate with that State.

2. Notwithstanding paragraph 1 (b), the injured State may take such urgent countermeasures as are necessary to preserve its rights.

3. Countermeasures may not be taken, and if already taken must be suspended without undue delay if:

(a) the internationally wrongful act has ceased; and

(b) the dispute is pending before a court or tribunal which has the authority to make decisions binding on the parties.

4. Paragraph 3 does not apply if the responsible State fails to implement the dispute settlement procedures in good faith.

379 Article 52 lays down certain procedural conditions relating to the resort to countermeasures by the injured State. Before taking countermeasures an injured State is required to call on the responsible State in accordance with article 43 to comply with its obligations under Part Two. The injured State is also required to notify the responsible State that it intends to take countermeasures and to offer to negotiate with that State. Notwithstanding this second requirement, the injured State may take certain urgent countermeasures to preserve its rights. If the responsible State has ceased the internationally wrongful act and the dispute is before a competent court or tribunal, countermeasures may not be taken; if already taken, they must be suspended. However, this requirement does not apply if the responsible State fails to implement dispute settlement procedures in good faith. In such a case countermeasures do not have to be suspended and may be resumed. 
Já o artigo 53 trata do término das contramedidas. Ele estabelece (p. 137, 2001a): “Art. 53. Término das contramedidas: As contramedidas deverão cessar tão logo o Estado responsável cumpra com suas obrigações em relação ao ato internacionalmente ilícito consoante a Parte Dois. ${ }^{380}$

Sobre este a CDI escreve (ONU, p. 137, 2001a):

O artigo 53 trata da situação em que o Estado responsável cumpriu com suas obrigações de cessação e reparação segundo a Parte Dois em resposta as contramedidas tomadas pelo Estado lesado. Uma vez que o Estado responsável cumpriu com suas obrigações segundo a Parte Dois, nenhuma razão sobra para a manutenção das contramedidas, e elas devem ser terminadas imediatamente. ${ }^{381}$ (tradução nossa)

Assim alcançado o resultado pretendido pela contramedida ela perde sua razão de ser e deve ser terminada imediatamente.

O artigo 54 substitui o artigo proposto pela CDI sobre contramedidas tomadas por Estados que não o Estado lesado. Este artigo é tido como uma salvaguarda, deixando para o futuro desenvolvimento do Direito Internacional qualquer decisão definitiva sobre a matéria. De acordo com este (ONU, p. 137, 2001a):

Art. 54. Medidas tomadas por Estados que não sejam o Estado lesado Este Capítulo não prejudica o direito de qualquer Estado, apto, de acordo com o art. 48, parágrafo 1, de invocar a responsabilidade de outro Estado para tomar medidas lícitas contra o Estado para assegurar a cessação da viola ção e a reparação no interesse do Estado lesado ou dos beneficiários da obrigação violada. ${ }^{382}$ (tradução nossa)

A CDI, após citar 8 casos de aplicação de contramedidas por Estados não diretamente lesados, ainda assim conclui (ONU, p. 139, 2001a):

\footnotetext{
${ }^{380}$ Article 53. Termination of countermeasures

Countermeasures shall be terminated as soon as the responsible State has complied with its obligations under Part Two in relation to the internationally wrongful act.

381 Article 53 deals with the situation where the responsible State has complied with its obligations of cessation and reparation under Part Two in response to countermeasures taken by the injured State. Once the responsible State has complied with its obligations under Part Two, no ground is left for maintaining countermeasures, and they must be terminated forthwith.

382 Article 54. Measures taken by States other than an injured State

This chapter does not prejudice the right of any State, entitled under article 48, paragraph 1, to invoke the responsibility of another State, to take lawful measures against that State to ensure cessation of the breach and reparation in the interest of the injured State or of the beneficiaries of the obligation breached.
} 
Com esta revisão mostra, o presente estado do direito internacional sobre contramedidas tomadas no interesse geral ou coletivo é incerto. A prática estatal é esparsa e envolve um número limitado de Estados. No presente, não parece haver um direito claramente reconhecido dos Estados referidos no artigo 48 de tomarem contramedidas no interesse coletivo. Consequentemente, não é apropriado incluir nos presentes artigos uma provisão relativa a questão se outros Estados, identificados no artigo 48, têm permissão de tomar contramedidas de modo a induzir o Estado responsável a cumprir com suas obrigações. Ao invés disso, o capítulo II inclui uma cláusula de salvaguarda que reserva a posição e deixa a resolução da matéria para o futuro desenvolvimento do direito internacional. ${ }^{383}$ (tradução nossa)

Por fim a CDI comenta sobre o artigo 54 (ONU, p.139, 2001a):

$\mathrm{O}$ artigo 54, portanto, prevê que o capítulo sobre contramedidas não prejudica o direito de nenhum Estado, habilitado, segundo o artigo 48, parágrafo 1, a invocar a responsabilidade de outro Estado, de tomar medidas lícitas contra o Estado responsável para assegurar a cessação da violação e a reparação no interesse do Estado lesado ou dos beneficiários da obrigação violada. $\mathrm{O}$ artigo fala de 'medidas lícitas' ao invés de 'contramedidas' de modo a não prejudicar qualquer posição relativa a medidas tomadas por Estados outros que não o Estado lesado, em resposta à violação de obrigações para a proteção de um interesse coletivo ou aquelas devidas à comunidade internacional como um todo. ${ }^{384}$ (tradução nossa)

A Comissão não chega a nenhuma conclusão definitiva a respeito da adoção de contramedidas por Estados que não os diretamente lesados pelo ato internacionalmente ilícito. Retrocedendo da sua posição anterior que reconhecia claramente esta possibilidade, a CDI na versão final dos artigos apenas insere uma cláusula de salvaguarda, que pretende reservar a posição para o futuro desenvolvimento do direito internacional. Esta posição é adotada por se considerar que a prática deste tipo de contramedidas seria esparsa e embrionária. Pretende-se neste trabalho, demonstrar que,

\footnotetext{
${ }^{383}$ As this review demonstrates, the current state of international law on countermeasures taken in the general or collective interest is uncertain. State practice is sparse and involves a limited number of States. At present, there appears to be no clearly recognized entitlement of States referred to in article 48 to take countermeasures in the collective interest. Consequently, it is not appropriate to include in the present articles a provision concerning the question whether other States, identified in article 48, are permitted to take countermeasures in order to induce a responsible State to comply with its obligations. Instead, chapter II includes a saving clause which reserves the position and leaves the resolution of the matter to the further development of international law.

${ }^{384}$ Article 54 accordingly provides that the chapter on countermeasures does not prejudice the right of any State, entitled under article 48, paragraph 1, to invoke the responsibility of another State, to take lawful measures against the responsible State to ensure cessation of the breach and reparation in the interest of the injured State or the beneficiaries of the obligation breached. The article speaks of "lawful measures" rather than "countermeasures" so as not to prejudice any position concerning measures taken by States other than the injured State in response to breaches of obligations for the protection of the collective interest or those owed to the international community as a whole.
} 
ao contrário do alegado pela CDI, a prática da adoção de contramedidas por Estados "terceiros" não só é antiga, como abrange Estados de diversos grupos regionais, não podendo ser considerada nem limitada nem embrionária. Em relação a ser esparsa, a utilização crescente destas medidas nas últimas décadas põe em xeque, também, esta afirmação.

É de se lamentar, também, que a CDI tenha perdido a oportunidade de consolidar o conceito de "crime internacional". Apesar da exclusão deste conceito ter ocorrido sem prejuízo deste ou do futuro desenvolvimento deste pela CDI ou outro órgão internacional (ONU, p. 23, 1998), o fato é que esta exclusão fez com que os debates sobre este conceito se reduzissem na doutrina e entre os Estados. Nenhum esforço significativo para a consolidação do crime internacional foi feito desde então, e a não ser que algum evento importante ocorra no plano internacional, corre-se o risco de que as discussões sobre a matéria não ocorram num futuro próximo.

A substituição deste pelo termo "violação séria de uma obrigação internacional segundo normas imperativas de direito internacional geral" não satisfaz tanto pelo fato de que estes não se sobrepõem conceitualmente, quanto pelas consequências jurídicas, reduzidas em relação à "séria violação de uma obrigação internacional [...]".

A consagração do crime internacional poderia ter sido um grande avanço em relação à proteção dos direitos humanos. Ela poderia ter dado um novo status em relação à violação de, ao menos, algumas normas protetivas destes direitos. Novas normas e mecanismos de proteção aos direito humanos poderiam ter sido criados no âmbito de Direito Internacional Geral.

Outro ponto a ser ressaltado foi a substituição do conceito de "obrigações devidas a comunidade internacional como um todo" ou obrigações erga omnes, pelo conceito de "normas imperativas do Direito Internacional geral" nos artigos 40 e 41. Embora as normas imperativas ou o jus cogens, sejam um conceito mais bem estabelecido no Direito Internacional, tendo sido consagrado no artigo 53 da Convenção de Viena sobre o Direito dos Tratados, foi baseado na ideia de obrigações erga omnes que o trabalho da CDI se desenvolveu. Isto pode se perceber tanto nos comentários a diversos artigos, quanto no texto do artigo 48, que faz referência, no seu parágrafo 2 , a obrigação "em relação à comunidade internacional como um todo". Os dois conceitos, embora possam 
ter algum conteúdo em comum, não se confundem ${ }^{385}$. Para Alland (p. 1237, 2002) o jus cogens "não é estritamente falando, um direito substantivo, nem uma categoria de normas, mas um atributo pertencente a certas normas (às quais não se pode derrogar) ${ }^{\text {,386 }}$ (tradução nossa).

Ainda que não se aceite esta posição, é certo que a inclusão do jus cogens no texto do anteprojeto fez com que dois conceitos diferentes fossem empregados nos artigos, de forma a tornar mais confusa a sua interpretação.

Ainda assim, o anteprojeto final de artigos da CDI estabelece uma importante base para o estudo do instituto no Direito Internacional. Embora não tenha, ainda ${ }^{387}$, sido incorporado por uma Convenção Internacional e a maioria de seus artigos não tenham, portanto, caráter vinculante ${ }^{388}$, este anteprojeto serve de referência tanto para a doutrina quanto para a jurisprudência internacional ${ }^{389}$.

Ao definir definitivamente o que é a responsabilidade internacional do Estado e quais as suas consequências e meios de implementação a CDI contribuiu não só para uma maior segurança jurídica no plano internacional, mas também para uma maior estabilidade nas relações entre os Estados.

Após a submissão do anteprojeto à Assembleia Geral, esta tomou nota do mesmo, publicando-o em anexo à Resolução A/RES/56/83 de 2002, em sua 56 sessão (ONU, 2002). O tema da responsabilidade internacional do Estado se encontra na pauta da $65^{\mathrm{a}}$ Sessão da Assembleia Geral, em 2010, quando ela deve decidir sobre a possibilidade de convocar uma convenção internacional para tratar do assunto.

\footnotetext{
${ }^{385}$ Whether or not peremptory norms of general international law and obligations to the international community as a whole are aspects of a single basic idea, there is at the very least substantial overlap between them. (CDI, p. 111, 2001a)

${ }^{386}$ It is not strictly speaking, substantive law, nor a category of norms, but an attribute pertaining to certain norms (from which one may not derogate)

${ }^{387}$ A Assembleia Geral, de acordo com a Resolução A/RES/65/19, de 2010, incluirá na agenda provisória da sua $68^{\mathrm{a}}$ Sessão, em 2013, o tema "responsabilidade dos Estados por atos internacionalmente ilícitos" e pode decidir sobre a possibilidade da convocação de uma convenção internacional para tratar sobre o tema.

${ }^{388}$ Segundo a CIJ (Parágrafo 385 do julgamento de 26 de fevereiro de 2007 do caso entre Bósnia Herzegovina e Sérvia e Montenegro sobre a aplicação da Convenção sobre Genocídio de 9 de dezembro de 1948) ao menos o seu artigo 4 seria a consolidação de uma norma consuetudinária e portanto teria caráter vinculante.

$389 \mathrm{O}$ anteprojeto já foi citado como referência pela CIJ no em julgamento de 26 de fevereiro de 2007 do caso entre Bósnia Herzegovina e Sérvia e Montenegro sobre a aplicação da Convenção sobre Genocídio de 9 de dezembro de 1948 e pro tribunais arbitrais como o Laudo Arbitral ad hoc do Mercosul de 9 de janeiro de 2002 para dirimir controvérsia entre Brasil e Uruguai sobre a "Proibição de importação de pneus remodelados procedentes do Uruguai" (Laudo ${ }^{\circ} 6$ )
} 


\section{CAPITULO II: NORMAS INTERNACIONAIS DE DIREITOS HUMANOS}

Como visto anteriormente, todo o trabalho de codificação da responsabilidade internacional do Estado foi permeado pela ideia de que existem determinadas normas ou determinadas obrigações internacionais, que pela sua relevância, devem ter um tratamento diferenciado das demais normas de Direito Internacional. O surgimento desta nova mentalidade está intimamente interligado com a internacionalização dos direitos humanos e com o reconhecimento de novos valores norteando Direito das Gentes.

2.1. Fatores que levaram à internacionalização das normas de Direitos Humanos

Comparato (p.55-58, 2007) divide a internacionalização dos Direitos Humanos em duas fases. A primeira teve início na segunda metade do século XIX e acabou com o advento da Segunda Guerra Mundial. Neste momento 3 principais setores se destacaram: o direito humanitário, especialmente as questões ligadas ao Jure Belli, a luta contra a escravidão e a regulação dos direitos do trabalhador assalariado.

A segunda fase tem como marcos iniciais a Declaração Universal de 1948 e a Convenção Internacional sobre a prevenção e punição do crime de genocídio. Escreve este autor (p. 57, 2007): "Ela é assinalada pelo aprofundamento e a definitiva internacionalização dos direitos humanos."

Com efeito, é no pós-Segunda Guerra que muitos autores situam o nascimento do direito internacional dos direitos humanos. Nesse sentido Burgenthal (p. 17, 1988): "O direito internacional dos direitos humanos moderno é um fenômeno pós-segunda guerra mundial." 390

Para Vasak (p. 343, 1974):

Ninguém contesta hoje em dia que o ponto de partida do direito
internacional dos direitos do homem é a Declaração universal dos
direitos do homem de 10 de dezembro 1948. Certamente, existem
precedentes que remontam a um passado longínquo: sem mencionar
os acordos entre as cidades gregas, pode-se ao menos citar a parte
relativa aos problemas de religião nos tratados de Westphalie, e mais
recentemente ainda, o sistema de proteção internacional dos direitos

${ }^{390}$ Modern international human rights law is a post-world war II phenomenon. 
das minorias instituído pela Sociedade das Nações após a primeira guerra mundial. (...)

[Mas] Para o direito internacional moderno dos direitos do homem, é a Declaração universal que constitui a fonte de inspiração e a fonte de direito. ${ }^{391}$

Já segundo Ramos (p. 50, 2005):

É claro que, antes de 1945, houve importantes tratados internacionais de proteção a direitos específicos. (...)

Mas, o passo decisivo para a internacionalização da temática dos direitos humanos foi a edição da carta de São Francisco, que além de mencionar expressamente o dever de promoção de direitos humanos por parte dos Estados signatários, estabeleceu tal promoção como sendo um dos pilares da Organização Internacional das Nações Unidas (ONU), então criada.

No entanto, mais que o momento em que se iniciou essa internacionalização, interessa saber os motivos que levaram a esse fenômeno. Lafer (p. XXV, 1994) esclarece:

(...) os direitos humanos, como tema global, não resultam, por analogia com o meio ambiente, apenas das inadequações de sua tutela que tem repercussão transfronteiras, com impacto no campo político ou econômico da vida mundial, como a emigração em massa ou as levas de refugiados.

Assim, se os direitos humanos não são um tema internacional por sua própria natureza, que fatores levaram à intensa internacionalização dos mesmos desde o fim da Segunda Guerra?

Segundo Ramos (p. 60, 2005): “Na análise doutrinária sobre o tema [internacionalização dos direitos humanos], sobressaem-se seis grandes motivos, a seguir analisados." Seriam eles (RAMOS, p. 61, 2005): “A começar pelo próprio nascimento do Direito Internacional dos Direitos Humanos, é certo que vários Estados foram motivados pelo repúdio às barbáries da $2^{\circ}$ Grande Guerra, o que gerou a

\footnotetext{
${ }^{391}$ Personne ne conteste aujourd'hui que le point de départ du droit international des droits de l'homme est la Déclaration universelle des droits de l'homme du 10 décembre 1948. certes, des précédents existent qui remontent dans un passé lointain: sans mentionner les accords entre les cités grecques, on peut au moins noter la partie relative aux problèmes de religoin dans les traités de Wsetphalie, et plus récemment encore le système de protection internationale des droits des minorités institué par la Société des Nations au lendemain de la primière guerre mondiale. (...)

Pour le droit international moderne des droits de l'homme, c'est la Déclaration universelle qui constitue la source d'inspiration et la source de droit.
} 
necessidade de se evitar repetições do ocorrido." Nesse mesmo sentido afirma Buergenthal (p. 17, 1988):

Seu desenvolvimento [do direito internacional dos direitos humanos] pode ser atribuído às violações monstruosas de direitos humanos na era de Hitler e a crença de que algumas violações poderiam ser previstas tivesse um sistema internacional de proteção aos direitos humanos efetivo existisse nos dias da Liga das Nações. ${ }^{392}$

Ramos continua (p. 62, 2005): "Um segundo motivo muito lembrado pela doutrina é o anseio de vários governos em adquirir legitimidade política na arena internacional e distanciar-se de passados ditatoriais e de constante violação de direitos humanos."

Na mesma linha escreve Lafer (p. XXV, 1994):

De fato os diretos humanos, como tema global, significam, ao internacionalmente deles se tratar, no âmbito da jurisdição de cada estado, em tempos de paz, que somente a garantia efetiva dos direitos humanos da população confere legitimidade plena aos governantes no plano mundial.

Também para Ramos (p. 63, 2005):

Em sintonia com esta busca de legitimidade, surge outra motivação, relativa à política internacional. A internacionalização intensiva da proteção dos direitos humanos explica-se também por servir para o estabelecimento de diálogo entre os povos, diálogo revestido de legitimidade pelo seu conteúdo ético.

Em outra obra o mesmo autor esclarece (RAMOS, p. 37-38, 2001):

(...) a proteção internacional dos diretos humanos é ingrediente essencial de governabilidade mundial, servido de parâmetro comum para todos os governos da comunidade internacional. A proteção de direitos humanos torna-se fator-chave para a convivência dos povos na comunidade internacional.

Mais um motivo de acordo com Ramos (p. 64, 2005):

Neste ponto, ingressamos em uma quarta e recente motivação da internacionalização dos direitos humanos: a motivação econômica.

\footnotetext{
${ }^{392}$ Its development can be attributed to the monstrous violations of human rights of the Hitler era and to the belief that some of this violations might have been prevented had an effective international system for the protection of the human rights existed in the days of the League of Nations.
} 
Para vários doutrinadores, os países desenvolvidos, exportadores de capital, defendem a internacionalização dos direitos humanos para exigir o respeito a um Standard mínimo de direitos dos investidores (direitos de propriedade, direito ao devido processo legal, vedação do confisco, entre outros direitos).

Já os países subdesenvolvidos estão, cada vez mais, utilizando a proteção internacional dos direitos humanos como forma de exigir mudanças drásticas em outros setores do Direito Internacional, como o Direito do Comércio Internacional ou o Direito Internacional Econômico.

Sobre o motivo econômico Alves (p. 3, 1994) também comenta:

Do ponto de vista econômico, confluem, por sua vez, interesses opostos: os países mais ricos utilizam os diretos humanos como argumento adicional de condicionalidade à assistência e à cooperação econômica ao Terceiro Mundo; os países em desenvolvimento, do Terceiro e do 'ex-Segundo' Mundos, buscam obter assistência e maior cooperação econômica para que possam ter meios de assegurar os direitos humanos de suas populações.

Ainda segundo Ramos (p.65-66, 2005): "Outro importante fator que impulsiona a internacionalização dos direitos humanos é a atuação da sociedade civil organizada." A multiplicação das chamadas organizações não governamentais (ONGs) é resultado da organização da sociedade civil, que busca por meio de entidades coletivas a defesa de seus interesses e ideais. Essas ONGs se tornaram atores internacionais de peso no plano internacional com grande capacidade de mobilização da opinião pública, influenciando por meio desta a atuação dos Estados.

E finalmente: "Por fim, como importante motivo no mundo globalizado, há a já conhecida indignação das comunidades nacionais com o desrespeito a direitos básicos do ser humano, mesmo que venham a ocorrer em lugares distantes do mundo." (RAMOS, p. 67, 2005) Essa indignação, fruto do sentimento de solidariedade humana, ganha ainda mais impulso com os avanços tecnológicos que permitem a divulgação de imagens quase em tempo real de acontecimentos ocorridos em lugares remotos e distantes.

A estes 6 motivos se acrescente ainda mais um lembrado por Lafer (p. XXV, 1994):“(...) uma elaboração no campo dos valores, derivada da percepção de um comum universal nas formas de conceber a vida em sociedade, que ultrapassa as concepções tradicionais de 'interesses' da soberania, pois diz respeito à questão da legitimidade." Esse "comum universal" seria segundo uma parte da doutrina a base para a universalização dos direitos humanos. Seria um denominador mínimo comum de 
valores que todas as culturas e sociedades reconhecem como dignos de proteção, e que outra parte da doutrina reluta em admitir.

Assim a internacionalização dos direitos humanos se dá pela conjugação de diversos fatores, sendo os principais, a reação da comunidade internacional às atrocidades ocorridas na Segunda Guerra; a necessidade de legitimação internacional de diversos países, principalmente aqueles saídos de regimes totalitários ou ditatoriais nos quais as violações de direitos humanos eram sistemáticas; a construção de um "diálogo entre povos" que possibilite uma melhor convivência entre os mesmos; interesses econômicos, tanto por parte dos países desenvolvidos como por parte dos países em desenvolvimento; a atuação da sociedade civil organizada, especialmente através da atuação das ONGs; e a indignação das comunidades nacionais ante violações graves a diretos humanos ainda que ocorridas em lugares distantes, tendo em vista os grandes avanços tecnológicos ocorridos no campo das telecomunicações e do acesso às informações e a possibilidade da existência de um entendimento "comum universal" sobre valores mínimos a serem preservados.

Essa internacionalização resultou em profundas mudanças no Direito Internacional Contemporâneo. O paradigma do Direito Internacional como "sistema jurídico autônomo, onde se ordenam as relações entre Estados soberanos" (REZEK, p. 3, 1995), que perdurou durante séculos, passou a ser questionado com o advento de novos atores no jogo das relações internacionais.

Também a consolidação da ideia de uma comunidade internacional trouxe consequências que serão devidamente estudadas adiante.

\subsection{A Natureza das Normas de Direito Humanos}

\subsubsection{A diversidade das normas de Direitos Humanos}

A intensa internacionalização dos direitos humanos desde o fim da Segunda Guerra deu origem nas palavras de Vasak (p. 348, 1974) a "um corpo de regras relativamente complexo e disperso para não dizer disparatado. ${ }^{1393}$ Para este autor (VASAK, p.348-349, 1974) essas regras são de origens diversas (elaboradas pelas Nações Unidas, organizações especializadas, organizações regionais ou conferências

\footnotetext{
${ }^{393}$ Un corps de règles relativament complexe et épars, pour ne pas dire disparate.
} 
diplomáticas), de força jurídica diferente (declarações, tratados, regras consuetudinárias, princípios gerais de direito, jurisprudência, prática e doutrina), diferentes quanto ao seu domínio de aplicação e quanto ao seu alcance (regras de vocação universal ou regional, de alcance geral ou específico), e diferentes quanto aos seus beneficiários e quanto aos seus destinatários (convenções redigidas em termos absolutas, vinculando todos os atores do jogo social ou convenções que vinculam somente os Estados). Á essas diferenciações Trindade acrescenta ainda duas (p. 3, 1991): "órgãos exercendo funções distintas (e. g., informações, instrução, tomada de decisão). São igualmente distintas as técnicas de controle e supervisão (e. g., reclamações ou petições de diversas modalidades, relatórios periódicos, investigações)."

Assim, segundo Trindade (p.1, 1991):

(...) o processo histórico de generalização e expansão da proteção internacional dos direitos humanos tem-se marcado pelo fenômeno de multiplicidade e diversidade dos mecanismos de proteção, acompanhadas pela identidade predominante de propósitos destes últimos e pela unidade conceitual dos direitos humanos.

Essa unidade conceitual, que pode ser traduzida pelo princípio da Universalidade dos Direitos Humanos, como veremos adiante, traz importantes consequências para as normas de proteção aos Direitos Humanos, apesar de sua diversidade.

\subsubsection{A Universalidade dos Direitos Humanos}

A universalidade dos direitos humanos pode ser inferida já do título da Declaração Universal dos Direitos do Homem de 1945, considerada o "ponto de partida" do Direito Internacional dos Direitos Humanos. ${ }^{394}$

Mais recentemente, ela foi reforçada pela Declaração e Programa de ação de Viena, adotada em 25 de junho de 1993 pela Conferência Mund ial de Direitos Humanos de Viena que estabelece:

Todos os direitos humanos são universais, indivisíveis, interdependentes, e inter-relacionados. A comunidade internacional deve tratar os direitos humanos globalmente, de modo justo e equitativo, com o mesmo fundamento e a mesma ênfase. Levando em

\footnotetext{
${ }^{394}$ Ninguém contesta hoje em dia que o ponto de partida do direito internacional dos direitos do homem é a Declaração universal dos direitos do homem de 10 de dezembro 1948. (tradução nossa) (VASAK, p. $343,1974)$
} 
conta a importância das particularidades nacionais e regionais, bem como os diferentes elementos de base históricos, culturais e religiosos, é dever dos Estados, independentemente de seus sistemas políticos, econômicos e culturais, promover e proteger todos os direitos humanos e as liberdades fundamentais. (apud, COMPARATO, p. 68, 2007) ${ }^{395}$

Deve-se ressaltar que o texto final da Conferência de Viena foi adotado, por consenso, por 171 Estados. ${ }^{396}$

O conceito de universalidade dos direitos humanos, portanto, é atualmente amplamente reconhecido. Ele enseja, no entanto, consequências importantes no presente estágio de desenvolvimento do Direito Internacional. A principal delas, a nosso ver, é o caráter erga omnes das normas de proteção internacional destes direitos. Segundo Ramos (p. 213, 2005):

O caráter erga omnes dos direitos humanos no plano internacional tem duas facetas. A primeira, estudada em capítulo próprio, consiste no reconhecimento do interesse de todos os Estados da comunidade internacional em ver respeitados os direitos protegidos pelo Direito Internacional.

A segunda faceta diz respeito à aplicação geral das normas protetivas a todos os seres humanos sob a jurisdição de um Estado. Assim, as normas internacionais de direitos humanos aplicam-se a todos os indivíduos, pela simples condição humana, sem qualquer consideração referente à nacionalidade, orientação política, etnia, credo e outras.

A universalidade dos direitos humanos atribui, assim, um caráter erga omnes a estes direitos e consequentemente, uma natureza diferenciada às normas protetoras de direitos humanos. Tal natureza adviria do fato de que a preservação dos Direitos Humanos, uma vez que são universalmente aceitos, são uma das principais preocupações e objetivos da comunidade internacional.

De fato, o artigo $1^{\circ}$, parágrafo 3 da Carta das Nações Unidas estabelece com um dos propósitos das Nações Unidas:

\footnotetext{
395 5. All human rights are universal, indivisible and interdependent and interrelated. The international community must treat human rights globally in a fair and equal manner, on the same footing, and with the same emphasis. While the significance of national and regional particularities and various historical, cultural and religious backgrounds must be borne in mind, it is the duty of States, regardless of their political, economic and cultural systems, to promote and protect all human rights and fundamental freedoms. Vienna Declaration and Programme of Action. Disponível em: http://www.unhchr.ch/huridocda/huridoca.nsf/(Symbol)/A.CONF.157.23.En?OpenDocument. Acesso em: 23.nov.2008.

${ }^{396}$ Ver mais em http://www.unhchr.ch/html/menu5/wchr.htm Acesso em: 23 nov. 2008.
} 
3. Conseguir uma cooperação internacional para resolver os problemas internacionais de caráter econômico, social, cultural ou humanitário, e para promover e estimular o respeito aos direitos humanos e às liberdades fundamentais para todos, sem distinção de raça, sexo, língua ou religião. (apud SALIBA, p. 672, 2006)

Assim, ainda, que não se leve em conta a posição de alguns doutrinadores de que a Carta da ONU poderia ser considerada uma verdadeira Constituição da comunidade internacional (SIMMA, p.258 et seq., 1994), a consagração da promoção e da proteção dos direitos humanos como um dos propósitos da Organização das Nações Unidas (ONU), organização internacional que atualmente conta com 192 membros, é um forte argumento de que tais direitos são um valor relevante para a comunidade internacional como um todo.

Assim, tendo em vista a Universalidade desses direitos, doutrina e jurisprudência são uniformes ao considerar que ao menos algumas normas de Direitos Humanos teriam um status diferenciado das demais normas de Direito Internacional. A emergência de conceitos como jus cogens e obrigações erga omnes trouxe a baila discussões sobre a hierarquização do Direito das Gentes. No entanto, o desenvolvimento relativamente recente destes institutos ainda gera certa confusão sobre sua natureza e conteúdo. Segundo Simma (p. 299, 1994), mesmo uma das principais responsáveis pelo reconhecimento destas categorias de normas, "a Corte [Internacional de Justiça] não distingue claramente entre os conceitos de jus cogens e obrigações erga omnes." (tradução nossa) $^{397}$

É necessário, então, para um estudo mais aprofundado da natureza jurídica das normas de Direitos Humanos, conhecer um pouco mais a origem e o desenvolvimento destes novos institutos do Direito Internacional.

\subsubsection{Obrigações erga omnes}

2.2.3.1 A origem do conceito de obrigações erga omnes

\footnotetext{
397 (...) the Court does not distinguish clearly between the concepts of jus cogens and of obligations erga omnes.
} 
Já no seu primeiro caso contencioso, o Caso do Estreito de Corfu, em sentença de 1949, a CIJ faz menção a princípios gerais e amplamente reconhecidos. Ao considerar as obrigações da Albânia em relação ao caso a Corte estabelece (CIJ, p. 22, 1949):

Tais obrigações são baseadas, não na Convenção de Haia de 1907, N. VIII, que é aplicável em tempos de guerra, mas em certos princípios gerais e amplamente reconhecidos, notadamente: considerações elementares de humanidade, ainda mais necessárias na paz do que na guerra; o princípio de liberdade de comunicação marítima; e a obrigação de todo o Estado de não permitir conscientemente que seu território seja usado para atos contrários aos direitos de outro Estado. (tradução nossa) $^{398}$

Dentre os princípios gerais arrolados, a Corte menciona uma obrigação relativa a todos os Estados, a de não permitir que seu território seja usado para atos que contrariem o direito de outros Estados. Tal obrigação é assumida pelos Estados mesmo na ausência de uma norma convencional neste sentido.

Em sede de sua jurisdição consultiva, no Parecer a respeito da possibilidade de reservas à Convenção de Genocídio de 1949, a Corte novamente faz menção a tais princípios (CIJ, p.23, 1951): “A primeira consequência que surge desta definição é que os princípios subjacentes à Convenção são princípios que são reconhecidos pelas nações civilizadas como vinculantes aos Estados, mesmo sem nenhuma obrigação convencional." (tradução nossa) 399

Mais adiante a Corte ainda afirma (CIJ, p. 23, 1951): "Em tal convenção, os Estados contratantes não têm nenhum interesse próprio; eles têm apenas, cada um e todos, um interesse comum, notadamente, a consecução daqueles grandes propósitos que são a razão de ser da convenção." (tradução nossa) ${ }^{400}$

Esses princípios se viram consubstanciados na ideia da existência de obrigações erga omnes, termo que ganhou reconhecimento internacional no caso Barcelona

\footnotetext{
398 Such obligations are based, not on the Hague Convention of 1907, No. VIII, which is applicable in time of war, but on certain general and well-recognized principles, namely: elementary considerations of humanity, even more exacting in peace than in war; the principle of the freedom of maritime communication; and every State's obligation not to allow knowingly its territory to be used for acts contrary to the rights of other States

${ }^{399}$ The first consequence arising from this conception is that the principles underlying the Convention are principles which are recognized by civilized nations as binding on States, even without any conventional obligation.

${ }^{400}$ In such a convention the contracting States do not have any interests of their own ; they merely have, one and all, a common interest, namely, the accomplishment of those high purposes which are the raison d'être of the convention.
} 
Traction, julgado pela Corte de Justiça (RAMOS, p. 73, 2005). Nos dizeres da Corte (CIJ, p. 32, 1970):

Em particular, uma distinção essencial deve ser feita entre as obrigações de um Estado em relação à comunidade internacional como um todo, e aquelas surgidas somente frente a outro Estado no campo da proteção diplomática. Por sua própria natureza, as primeiras dizem respeito a todos os Estados. Tendo em vista a importância dos direitos envolvidos, todos os Estados têm um interesse jurídico na sua proteção; estas são obrigações erga omnes.

34. Tais obrigações derivam, por exemplo, no direito internacional contemporâneo, de atos ilegais de agressão e de gnocídio, como também de princípios e regras relativos aos direitos básicos da pessoa humana, incluindo proteção contra a escravidão e discriminação racial. Alguns dos direitos de proteção correspondentes entraram no conjunto do direito internacional geral (Reservas à Convenção de Genocídio, Opinião Consultiva, Relatórios da C.I.J.1951, p. 23); outros são conferidos por instrumentos de um caráter universal ou quase universal (tradução nossa) ${ }^{401}$

A Corte, assim, reconhece a existência de obrigações de um Estado frente a toda comunidade internacional. Entre tais obrigações, as chamadas obrigações erga omnes estariam inseridos os "direitos básicos da pessoa humana".

Uma das principais consequências do reconhecimento das obrigações erga omnes é a consolidação da ideia de comunidade internacional. Embora esta comunidade ainda não seja considerada uma entidade concreta, ela congrega em si a concepção de um Direito Internacional não mais voltado exclusivamente ao interesse individual dos Estados, mas evoluindo no sentido de um sistema visando a proteção de interesses coletivos.

\subsubsection{O conceito de obrigações erga omnes}

\footnotetext{
401 In particular, an essential distinction should be drawn between the obligations of a State towards the international community as a whole, and those arising vis -à-vis another State in the field of diplomatic protection. By their very nature the former are the concern of all States. In view of the importance of the rights involved, all States can be held to have a legal interest in their protection; they are obligations erga omnes.

34. Such obligations derive, for example, in contemporary international law, from the outlawing of acts of aggression, and of genocide, as also from the principles and rules concerning the basic rights of the human person, including protection from slavery and racial discrimination. Some of the corresponding rights of protection have entered into the body of general international law (Reservations to the Convention on the Prevention and Punishment of the Crime of Genocide, Advisory Opinion, I.C.J. Reports 1951, p. 23); others are conferred by international instruments of a universal or quasiuniversal character.
} 
Tams descreve o que seriam os efeitos erga omnes. Em suas palavras (p. 115, 2005): “"Erga Omnes' tem notadamente sido usado (i) para justificar efe itos para partes terceiras em tratados ou Resoluções da ONU, (ii) para impedir restrições territoriais de obrigações, e (iii) de um modo descritivo, como substituto de 'todos os Estados",402

Estes diversos efeitos são atribuídos as obrigações erga omnes. Segundo Ramos (p. 71, 2005):

\begin{abstract}
A obrigação erga omnes é a obrigação que protege valores de toda comunidade internacional, fazendo nascer o direito dos Estados de exigir seu cumprimento. Assim, o conceito de obrigação internacional erga omnes nasce da valoração da obrigação (contém "valores essenciais"), gerando como consequência o direito por parte de todos os Estados da comunidade internacional de exigir seu respeito.
\end{abstract}

Portanto, se os direitos humanos são, como já exposto, valores de toda comunidade internacional, a sua proteção é, consequentemente, uma obrigação de todo Estado que dela faz parte.

Simma também escreve sobre tais obrigações (p. 298-299, 1994):

Assim, a noção de obrigações erga omnes não é idêntica àquela de obrigações advindas do direito internacional geral. Somente obrigações devidas à coletividade dos Estados pode ser considerada como obrigações erga omnes; por outro lado, nem todas as obrigações devidas à vários ou mesmo muitos Estados representam obrigações erga omnes. Somente se a comunidade dos Estados tem titularidade para demandar o cumprimento de uma obrigação estamos em presença de uma verdadeira regra com efeito erga omnes. (tradução nossa) ${ }^{403}$

A título de esclarecimento, tendo em vista as diferenças terminológicas que podem surgir uma vez que um mesmo texto é traduzido em várias línguas, o termo direito internacional geral (general international law em inglês) é normalmente utilizado como referente ao direito internacional consuetudinário. O direito internacional geral ou costumeiro, comum a todos os Estados, estaria em oposição ao direito convencional, que tem origem nos tratados internacionais e vinculam apenas aqueles que fazem parte

\footnotetext{
402 'Erga omnes' has notably been used (i) to justify third party effects of treaties or UN resolutions, (ii) to preclude the territorial restriction of obligations, and (iii) in a descriptive way as a substitute for 'all States'.

403 Thus, the notion of obligations erga omnes is not identical to that of obligations arising from general international law. Only obligations owed to the collectivity of States can be regarded as obligations erga omnes; on the other hand, not all obligations owed to several or even many States represent obligations erga omnes. Only if the community of States is entitled to demand fulfillment of an obligation we are in presence of a true rule with effect erga omnes.
} 
destes tratados. No entanto, quando usado no artigo 53 da Convenção de Viena de 1969 o termo "general international law", que aparece no texto original em inglês, foi usado no sentido de direito internacional universal (SZTUCKI, p. 106, 1974).

Assim, segundo Simma, as obrigações erga omnes diferem das demais normas de direito consuetudinário.

Tal distinção adviria do fato de que tais normas permeiam valores relevantes à comunidade internacional como um todo e por isso podem ser demandados tanto pela comunidade internacional no seu conjunto, como individualmente por cada Estado parte da comunidade internacional.

Neste sentido Tams (p. 156, 2005) para quem: “obrigações erga omnes se distinguem de outras obrigações do direito internacional geral com base na sua importância." ${ }^{404}$ (tradução nossa)

Assim, a primeira distinção entre as normas consuetudinárias e as obrigações erga omnes estaria no conteúdo destas. No entanto, se as normas do direito consuetudinário também obrigam todos os Estados, qual seria, na prática, o sentido de uma obrigação erga omnes? A segunda diferença essencial entre estas duas categorias de normas seria que, enquanto admite-se que uma norma consuetudinária pode não ser aplicada em relação a um Estado (como nos casos de objeção persistente e objeção subsequente, v.g. BROWNLIE, p. 22-23, 1995), as obrigações erga omnes são aplicáveis a todos os Estados (RAMOS, p. 81 et seq., 2002).

Outra questão que surge tendo em vista as obrigações erga omnes seria sua diferenciação das normas do jus cogens uma vez que ambos permeiam valores essenciais para a comunidade internacional.

\subsubsection{O conteúdo das obrigações erga omnes}

No caso Barcelona Traction, além do reconhecimento das obrigações erga omnes, a CIJ se manifestou também a respeito dos direitos humanos. Em suas palavras (p. 47, 1970):

Em relação mais particularmente aos direitos humanos, em relação aos quais já foi feita referência no parágrafo 34 deste julgamento, deve ser notado que estes também incluem a proteção contra a denegação de justiça. Entretanto, no nível

\footnotetext{
${ }^{404}$ Obligations erga omnes are distinguished from others obligations of general law on the basis of their importance.
} 
universal, os instrumentos que incorporam os direitos humanos não conferem aos Estados a capacidade de proteger vítimas das infrações de tais direitos independente da sua nacionalidade. ${ }^{405}$ (tradução nossa)

Esta afirmação levou a uma discussão doutrinária a respeito do conteúdo das obrigações erga omnes. Estariam os direitos humanos excluídos desta categoria?

Segundo Tams (p. 178, 2005):

O parágrafo 91 não contradiz os parágrafos 33 e 34, pois as duas passagens se referem a dois assuntos diferentes. A referência da Corte à 'instrumentos que contém direitos humanos' torna claro que o parágrafo 91 se refere somente aos mecanismos convencionais para a implementação dos direitos humanos; ele apresenta uma certa (incorreta) visão de como disposições convencionais de direitos humanos poderiam ser implementadas em 1970. Em contraste, a implementação de obrigações erga omnes (que deriva, como foi demonstrado, do direito internacional consuetudinário) não é uma questão de direito convencional. A questão crucial tratado pelos parágrafos 33 e 34 é se ao reconhecer a categoria de obrigações erga omnes, a Corte pretendeu conferir aos Estados o direito de reivindicar estas obrigações na ausência de disposições expressas de tratados. Uma vez que o parágrafo 91 não trata da questão, é difícil ver como ele poderia contradizer uma interpretação específica do conceito erga omnes. ${ }^{406}$

Assim, para Tams, o artigo 91 se refere apenas aos direitos humanos contidos em instrumentos convencionais de proteção aos direitos humanos. Tal parágrafo não teriam relação com o conceito de obrigações erga omnes, que diz respeito ao Direito Internacional Geral.

Neste mesmo sentido escreve Frowein (p. 406, 1994):

\footnotetext{
${ }^{405}$ With regard more particularly to human rights, to which reference has already been made in paragraph 34 of this Judgment, it should be noted that these also include protection against denial of justice. However, on the universal level, the instruments which embody human rights do not confer upon States the capacity to protect victims of infringements of such rights irrespective irrespective of their nationality. 406 Para. 91 does not contradict paras.33 and 34, as the two passages concern different subject matters. The Court's reference to 'instruments which embody human rights' makes clear that para. 91 is solely concerned with the treaty based mechanism for the enforcement of human rights; it presents a certain (incorrect) view of how conventional human rights provisions could be enforced in 1970 . In contrast, the enforcement of obligations erga omnes (which derive, as has been shown, form customary international law) is not a matter of treaty law. The crucial question prompted by paras. 33 and 34 is whether by recognizing the category of obligations erga omnes, the Court meant to confer upon States a right to vindicate these obligations in the absence of express treaty provisions. Since para. 91 does not bear on this matter, it is difficult to see how it could contradict a specific interpretation of the erga omnes concept.
} 
Embora a relação entre este parágrafo e aquele sobre obrigações erga omnes não seja absolutamente clara, pareceria incorreto interpretar a última como proibindo a possibilidade dos Estados de agir com base em obrigações erga omnes. Isto parece ser confirmado pela diferença de formulação que a Corte utiliza em relação aos direitos humanos. Enquanto a Corte explica na primeira parte que 'os direitos básicos da pessoa humana' formam parte daquelas normas que criam obrigações erga omnes, ela se refere ao espectro mais amplo de 'direitos humanos' na parte posterior. ${ }^{407}$ (tradução nossa)

De fato, esta é a interpretação que parece mais acertada. $\mathrm{O}$ desenvolvimento do conceito de obrigação erga omnes esteve intimamente ligado com a proteção dos direitos humanos, como a jurisprudência da CIJ anterior ao Caso Barcelona Traction, acima citada, demonstra. Menções a "considerações elementares de humanidade" dentre os princípios gerais de Direito Internacional e ao "interesse comum" de alguns tratados de direitos humanos são exemplos desta ligação. Assim, interpretar a sentença do Caso Barcelona Traction como limitando o alcance das obrigações erga omnes no campo dos direitos humanos, ou mesmo como excluindo estes direitos do âmbito destas obrigações seria contrária a uma análise histórica deste instituto e uma interpretação sistemática desta sentença. Assim, ao menos os direitos humanos fundamentais geram obrigações erga omnes em relação aos Estados, obrigações estas que não sofrem nenhuma restrição em relação as demais obrigações da mesma natureza.

\subsubsection{Jus Cogens}

\subsubsection{A origem do conceito de jus cogens}

A ideia de um jus cogens ou seja, de um direito cogente, acima do direito posto, não é nova. Pelo contrário. Para Nicoloudis (p. 36, 1974): "Por outro lado, a ideia de um jus cogens é muito mais antiga que seu significado. Parece legítimo crer que ela estava presente mesmo entre as sociedades ditas primitivas que possuíam algum sistema

\footnotetext{
407 Although the relationship between this paragraph and the one on obligations erga omnes is not absolutely clear, it would not seem to be correct to interpret the latter as foreclosing the possibility for States to act on the basis of obligations erga omnes. This seems to be confirmed by the difference of the formulation the Court uses as far as human rights are concerned. While the Court explains in the first part that the 'basic rights of the human person' form a part of those norms which create obligations erga omnes, it refers to the wider spectrum of 'human rights' in the latter part.
} 
jurídico." ${ }^{408}$ Ainda que não se vá tão longe, é certo que a ideia de um jus cogens remonta às teorias jusnaturalistas, que podiam ser encontradas já na Grécia antiga, como demonstra a famosa peça Antígona, de Sófocles.

Segundo Fassò (p. 655-656, 1994):

O Jusnaturalismo é uma doutrina segundo a qual existe e pode ser conhecido um 'direito natural' (ius naturale), ou seja, um sistema de normas de conduta intersubjetiva diverso do sistema constituído pelas normas fixadas pelo Estado (direito positivo). Este direto natural tem validade em si, é anterior e superior ao direito positivo e, em caso de conflito, é ele que deve prevalecer.

Grotius, um dos fundadores do Direito Internacional escrevia (p. 79, 2004):

1. O direito natural nos é ditado pela reta razão que nos leva a conhecer que uma ação, dependendo se é ou não conforme à natureza racional, é afetada por deformidade moral ou por necessidade moral e que, em decorrência, Deus, o autor da natureza, a proíbe ou a ordena.

E ainda para Grotius (p. 81, 2004): “O direito natural é tão imutável que não pode ser mudado nem pelo próprio Deus."

Segundo Robledo (p. 28, 1981): “O Jusnaturalismo de Grotius, e de maneira mais concreta o jusnaturalismo racionalista, se prolonga até o século XIX, a dizer, até o aparecimento do positivismo, quando desapareceria toda a relação de verticalidade, de hierarquia entre as normas do direito das gentes." (tradução nossa) 409

Alguns afirmam que o ressurgimento da ideia de jus cogens é uma retomada das ideias naturalistas em face da crise do positivismo jurídico. No entanto, apesar de uma certa influência jusnaturalista (ROBLEDO, p. 30 et seq., 1981), o jus cogens, como atualmente é concebido, não encontra seu fundamento em um direito natural imutável, fruto seja da vontade divina, seja da razão humana.

O jus cogens contemporâneo se fundamenta na existência de uma comunidade internacional que possui interesses e valores próprios, diferentes dos interesses individuais dos Estados que dela fazem parte e algumas vezes até antagônicos a estes.

\footnotetext{
${ }^{408}$ En revanche, l'idée d'un jus cogens est beaucoup plus ancienne que son signifiant. Il paraît légitime de croire qu'elle était présente même chez les sociétés dites primitives en possission d'un certain système jurudique.

${ }^{409}$ Le iusnaturalisme de Grotius, et de manière plus concrète le iusnaturalisme rationaliste, se prolonge jusqu'au XIX siècle,c'est-à-dire jusqu'à l'aaparition du positivisme, lorsque dispararât tuote relationde verticalité, de hiérarchie entre les normes du droit des gens.
} 
Segundo Simma (p. 285, 1994): “o conceito de jus cogens envolve normas criadas no interesse comunitário com a 'capacidade destrutiva, por assim dizer, de invalidar tratados que o contrariem ou outros atos legais (...)”. (tradução nossa) ${ }^{410}$

Um dos fatores que impulsionaram o desenvolvimento deste conceito foi a jurisprudência da Corte Internacional de Justiça sobre princípios gerais e obrigações erga omnes, acima mencionada.

Há certa discussão na doutrina sobre a influência de tais julgados no desenvolvimento do conceito de jus cogens. Para Sztucki (1974, p. 20):

É assim, duvidoso se a categoria de 'princípios gerais e amplamente reconhecidos', como formulada pela CIJ no caso do Canal de Corfu, seria semelhante à categoria do jus cogens ( à qual nenhuma derrogação entre as partes seria permitida sob pena de nulidade do tratado derrogatório). Nos casos sub g) [Major War Criminals] e j) [Reservas a Convenção de genocídio] as Cortes respectivas estabeleceram a força vinculante extra convencional de alguns princípios incorporados em convenções internacionais, como princípios universais de direito consuetudinário. Mas as Cortes não foram além disso, uma vez que a classificação de um princípio ou regra como pertencente ao direito internacional consuetudinário universal não previne, por si, a derrogação legal de deste por tratados aplicáveis apenas inter partes. [...] A categoria de 'princípios e regras universais de direito consuetudinário' não deve ser, assim, confundida com a categoria de normas peremptórias. (tradução nossa) ${ }^{411}$

No entanto, embora nos pareça claro que as regras e princípios universais de direito consuetudinário não possam ser confundidas com o jus cogens, a origem deste se encontra estreitamente ligada a tais princípios universais. Ainda, não nos parece que, embora a CIJ não tenha expressamente declarado o caráter de jus cogens de normas como a proibição do genocídio, esta reconhecesse a legalidade de um tratado bilateral legalizando esta conduta. O conceito de jus cogens atual, como já anteriormente mencionado, é de desenvolvimento recente, e vai se formando lentamente, através da prática dos Estados e da jurisprudência dos tribunais internacionais.

\footnotetext{
${ }^{410}$ The concept of jus cogens invests norms created in the community interest with the 'destructive capacity', so to speak, to invalidate contravening treaties or other legal acts, (...)

411 It is, therefore, doubtful whether the category of 'general and well recognized principles' as formulated by the ICJ in the Corfu channel case, was meant as akin to the category of jus cogens (from which no derogation as between the parties is permitted under the pain of voidness of the derogatory treaty). In the cases sub g) and $\mathrm{j}$ ) the respective Courts established an extra-convencional binding force of certain principles embodied in international conventions as principles of universal customary law does not prevent, per se, lawful derogation therefrom by treaties applicable inter partes only. [...] The category of 'principles and rules of universal customary law' should not be, therefore, confused with the category of 'peremptory norms'.
} 


\subsubsection{O conceito de jus cogens}

Tal conceito se viu finalmente consagrado na Convenção de Viena sobre o Direito dos Tratados de 1969. Esta estabelece em seu artigo 53:

Artigo 53: Tratados incompatíveis com uma norma imperativa de direito internacional geral (jus cogens)

É nulo todo o tratado que, no momento da sua conclusão, é incompatível com uma norma imperativa de direito internacional geral. Para os efeitos da presente Convenção, uma norma imperativa de direito internacional geral é a que for aceita e reconhecida pela comunidade internacional dos Estados no seu conjunto como norma à qual nenhuma derrogação é permitida e que só pode ser modificada por uma nova norma de direito internacional geral com a mesma natureza. (apud SALIBA, p. 845, 2006)

Também no artigo 64 a convenção prevê:

Artigo 64: Superveniência de uma norma imperativa de direito internacional geral (jus cogens)

Se sobrevier uma nova norma imperativa de direito internacional geral todo o tratado existente que seja incompatível com esta norma tornase nulo e cessa a sua vigência. (apud SALIBA, p. 848, 2006)

De acordo com Nicoloudis (p. 37, 1974): "No que concerne a expressão, é certo que esta foi mencionada pela primeira vez na Convenção de Viena sobre o direito dos tratados de 1969." (tradução nossa) ${ }^{412}$

De fato, nos julgados da CIJ, a expressão até então só havia aparecido em votos separados e opiniões dissidentes. No entanto o conceito de normas imperativas já jazia, a nosso entender, subjacente à jurisprudência da Corte. A própria Comissão de Direito Internacional da ONU (CDI, p. 198, 1963) em seus comentários ao projeto da convenção de Viena esclarece:

O direito na Carta [das Nações Unidas] no tocante a proibição do uso da força, na realidade, pressupõe a existência no direito internacional de regras tendo o caráter de jus cogens. Assim sendo, a comissão concluiu que ao codificar o direito dos tratados, deve adotar a posição de que hoje exitem certas regras

\footnotetext{
412 (...) en ce qui concerne l'expression, il est certain qu'elle est mentionnée pour la première fois dans la Convention de Vienne sur le droit des traités de 1969.
} 
e princípios aos quais os Estados não são competentes para derrogar por meio de disposição em tratados. (tradução nossa) ${ }^{413}$

Ainda mais contundente é a observação do Relator Especial da CDI sobre o tema (CDI, p. 27,1966):

Nós não pensamos que a Comissão pretendeu, no artigo 37, propor uma regra inteiramente nova do direito dos tratados. (...) Em outros termos, ela reconheceu que existem, em direito internacional, algumas regras de jus cogens, e o artigo 37 apenas tira as consequências lógicas deste estado de coisas. (tradução nossa) ${ }^{414}$

Ora, se a Comissão não criou o conceito de jus cogens, tendo apenas reconhecido a sua existência, só pode ter auferido esta da prática dos Estados e organizações internacionais e da jurisprudência internacional, que embora tenha apenas um papel auxiliar na determinação das regras de direito (art. 38 do Estatuto da Corte Internacional de Justiça), ainda tem desenvolvido um trabalho relevante ao extrair da prática dos Estados e das normas de Direito Internacional os princípios subjacentes que regem a comunidade internacional.

A definição de jus cogens consagrada pela Convenção de Viena de 1969 é extremamente formalista. Nas palavras de Simma (p. 290, 1994): "Para a identificação de normas peremptórias de direito internacional, a definição formalista de jus cogens fornecida no Artigo 53 da Convenção de Viena cria mais problemas do que resolve."

A Comissão, no entanto, se defende das críticas comentando (p. 198, 1963): “A formulação da regra, entretanto, não é livre de dificuldades, uma vez que não há ainda um critério com o qual identificar uma regra geral de direito internacional como tendo o caráter de jus cogens." (tradução nossa) ${ }^{415}$

E ainda (p. 198, 1963):

\footnotetext{
413 The law of the Charter concerning the prohibition of the use of force in reality presupposes the existence in international law of rules having the character of jus cogens. This being so, the Commission concluded that in codifying the law of the treaties it must take the position that today there are certain rules and principles from which states are not competent to derogated by a treaty arrangement.

414 Mais nous ne pensons pas que la Commission ait voulu, dans l'articcle 37, proposer une règle entièrement nouvelle du droit des traités. (...) En d'autres termes, elle a reconnu qu'il existe, en droit international, certaines règles du jus cogens, et l'article 37 ne fait que tirer les conséquences logiques de cet état de choses.

${ }^{415}$ The formulation of the rule, however, is not free from difficulty, since there is not as yet any generally recognized criterion by with to identify a general rule of international law as having the character of jus cogens.
} 
A emergência de regras com o caráter de jus cogens é recente, uma vez que o direito internacional está num processo de rápido desenvolvimento. A Comissão considerou que o curso certo seria estabelecer em termos gerais que um tratado é nulo se conflita com uma regra de jus cogens e deixar o pleno conteúdo desta regra para ser formulado na prática dos Estados e na jurisprudência de tribunais internacionais. (tradução nossa) ${ }^{416}$

No entanto, embora formalista, a definição do Artigo 53 traz alguns elementos para identificar o conteúdo das normas de jus cogens. Para Sztucki (p. 97, 1974):

De acordo com o Art. 53 da Convenção, a noção de normas peremptórias de direito internacional geral consiste de dois elementos: a) Essas são normas pelas quais não é permitida nenhuma derrogação sob a pena de nulidade dos tratados que conflitem com elas.

b) essas são normas que são aceitas e reconhecidas pela comunidade internacional dos Estados como um conjunto, na sua qualidade de normas peremptórias. (tradução nossa) ${ }^{417}$

O primeiro elemento repercute na organização do ordenamento internacional. Uma vez que o jus cogens é composto por regras que não podem ser derrogadas por outra categoria de norma, mas que derrogam as outras categorias, pode-se concluir que este tem uma hierarquia superior às outras normas de Direito Internacional.

Alexidze critica a ideia de hierarquia. Para ele (p. 259, 1981):

Há uma tentativa entre os doutrinadores de ligar o jus cogens internacional a uma hierarquia de normas. É difícil concordar com isso.

Primeiramente, toda a hierarquia presume a existência de vários níveis de norma legais, estando umas sobre as outras. Uma vez que todo tratado derrogado por uma norma de jus cogens é nulo e inválido $a b$ initio, não há nenhum lugar para eles no direito internacional.

Segundo, no direito internacional geral não há hierarquia de normas análoga a hierarquia existente no direito interno. Esta depende do nível de competência do órgão que criou ou sancionou uma dada regra

\footnotetext{
${ }^{416}$ The emergence of rules having the character of jus cogens is comparatively recent, while international law is in process of rapid development. The Commission considered the right course to be provide in general terms that a treaty is void if it conflicts with a rule of jus cogens and to leave the full content of this rule to be worked out in State practice and in the jurisprudence of international tribunals.

${ }^{417}$ According to Art. 53 of the Convention, the notion of peremptory norms of general international law consists of two elements:

a) these are norms from which no derogation by treaties is permitted under the pain of voidness of treaties conflicting with them;

b) these are norms which are accepted and recognized by the international community of States as a whole in their quality of peremptory norms.
} 
de direito - o parlamento, os órgãos executivos, o tribunal, etc. (tradução nossa) $^{418}$

Ainda segundo este autor (p. 260-261, 1981):

Jus cogens não deve ser reduzido a noção de hierarquia de normas. Pelo contrário, ele deve ser posto fora desta hierarquia tendo em vista sua natureza específica conectada com o grau do caráter obrigatório das prescrições. Tal regra pode ser encontrada em qualquer nível da hierarquia existente de normas de direito internacional geral. A essência do seu caráter é seu valor moral relevantíssimo para a humanidade contemporânea, sua natureza progressiva e democrática como determinada pelo presente estágio de civilização resultante de fatores econômicos e sociais objetivos, mencionados acima. (tradução nossa $)^{419}$

Reuter (p. 56, 1983) fala não em superioridade hierárquica, mas numa superioridade de valor. Em suas palavras:

Não existe em direito internacional forma que confere a uma norma um valor hierárquico particular: a Comunidade internacional não tem, no sentido formal do termo, uma constituição. Mas nenhum obstáculo técnico probe que a alguns princípios, a algumas regras, seja conferido um valor superior a outras regras. (tradução nossa) ${ }^{420}$

De fato, a falta de consenso a respeito do conteúdo das normas de jus cogens e seu recente desenvolvimento, não permitem que se possa falar, no estágio atual, em uma hierarquia em Direito Internacional. Com o desenvolvimento progressivo deste instituto e do Direito das Gentes, porém, a característica própria destas normas deve levar logicamente a uma hierarquização das normas internacionais.

\footnotetext{
${ }^{418}$ There is an attempt among scholars to link international jus cogens to the hierarchy of norms. It is difficult to agree with this.

First of all a hierarchy presumes the existence of several levels of legal rules standing one above the other. Since every treaty derogating from a jus cogens rule is null and void ab initio, there is no place for it in international law at all.

Secondly, in general international law there is no hierarchy of norms analogous to the hierarchy existing in domestic law. The latter depends on the level of the competence of the body which has enacted or sanctioned a given rule of law - the parliament, the executive bodies, the court, etc.

${ }^{419}$ Jus cogens should not be reduced to the notion of hierarchy of norms. On the contrary, it should be rather placed outside this hierarchy due to its specific nature connected with the degree of the obligatory character of prescriptions. Such a rule can be found at any level of the existing hierarchy of norms of general international law. The essence of this character is its outstanding moral value for contemporary mankind, its progressive, democratic nature as determined by the present stage of civilization resulting from the objective economic and social factors mentioned above.

${ }^{420}$ Il n'existe pas en droit international de forme qui confère à une norme une valeur hiérarchique particulière : la Communauté internationale n'a pas, au sens formel du terme, de contitution. Mais aucun obstacle technique ne vient interdire que certains principes, certaines règles se voient conférer une valeur supérieure à d'autres règles.
} 
O segundo elemento diz respeito à aceitação e reconhecimento da "comunidade internacional como um conjunto" do caráter obrigatório de tais regras. Para Reuter (p.57, 1983) este elemento fortifica o caráter costumeiro do jus cogens. De fato, a exigência de reconhecimento pela comunidade internacional de sua obrigatoriedade remete à opinio iuris sive necessitatis, elemento típico da norma consuetudinária, o que reforça a origem consuetudinária desta categoria de normas. No entanto, a opinio iuris exigida para este tipo de normas vai além da mera convicção de obrigatoriedade. Para que se caracterize uma norma de jus cogens a comunidade internacional deve reconhecer não só o caráter jurídico desta, mas também que a mesma reflete valores essenciais para esta sociedade, de forma que a relevância de seu conteúdo autoriza que as demais normas de direito internacional sejam derrogadas por esta e que nenhum outro tipo de normas possa derrogá-la. Seria, então, uma opinio iuris qualificada, reconhecendo tal norma não só como jurídica, mas como imperativa, que diferenciaria o jus cogens da norma universal consuetudinária de Direito Internacional.

Nesse sentido Nicoloudis (p. 39-40): "Pelo caráter de norma essencial de direito internacional geral, o jus cogens se distingue do conjunto de normas que não pertencem ao direito internacional geral e daquelas que mesmo fazendo parte, não podem ser qualificadas de normas essenciais." (tradução nossa) ${ }^{421}$

Outro ponto levantado por este elemento é o significado do termo "comunidade internacional como um conjunto". A importância da expressão é tal, que o termo "as a whole" ou "como um conjunto" foi votado separadamente na Convenção, tendo sido aprovado por 57 votos a favor, 3 contras e 27 abstenções (SZTUCKI, p. 99, n. 403, 1974).

Segundo Yasseen (p. 472, apud SZTUCKI, p. 99, 1974), presidente do Comitê do Projeto da Convenção de Viena:

O Comitê do Projeto desejou expressar que não é questão de requerer que uma regra seja aceita e reconhecida como peremptória por todos os Estados. Seria suficiente que uma grande maioria o fizesse; o que significaria que, se um Estado em isolado se recusasse a aceitar o caráter peremptório de uma regra, ou se esse Estado fosse apoiado por um grupo muito pequeno de Estados, a aceitação e o reconhecimento

\footnotetext{
421 Par le caractère de norme essentielle du droit international général, le jus cogens se distingue de l'ensemble des normes qui n'appartiennent pas au droit international général et de celles qui tout en faisant partie, ne puevvent pas être qualifiées des normes essentielles.
} 
do caráter peremptório da regra pela comunidade internacional não seria afetado. (tradução nossa) ${ }^{422}$

Neste mesmo sentido Gaja (p. 283, 1981): "Existe um acordo geral entre os intérpretes que a falta de aceitação ou mesmo oposição da parte de um ou poucos Estados não é obstáculo para uma norma se tornar peremptória." (tradução nossa)423

Uma vez determinado que não é necessário que todos os Estado individualmente reconheçam uma norma de jus cogens como tal para caracterizá-la, resta saber no que consistiria essa "grande maioria" capaz de criar tal norma. Segundo Ago (p. 323, apud SZTUCKI, p. 100, 1974):

A convicção do caráter imperativo da norma deve ser compartilhada por todos os elementos essenciais da comunidade internacional, e não só, por exemplo, pelos países do Ocidente ou os do Oriente, pelos países desenvolvidos ou em desenvolvimento, ou por aqueles de um continente ou outro. (tradução nossa) ${ }^{424}$

Na mesma linha segue Ramos (p. 84, 2002):

O novo consenso exige que,dentro da maioria dos Estados, encontrese representantes significativos dos diversos sistemas políticos e sociais existentes na comunidade internacional, a fim de que haja efetivamente uma maioria quantitativa e também qualitativa. Os Estados considerados representantes essenciais da comunidade internacional são aqueles que abarcam os países representativos das grandes correntes econômicas, políticas e geográficas do planeta, de modo a não excluir nenhum tipo de cultura ou de sistema políticoeconômico vigente.

Já para Sztucki, (p. 100, 1974):

Certamente uma norma não pode ser considerada como peremptória do direito internacional geral se a convicção de seu caráter imperativo é limitada a certas regiões geográficas ou a certos grupos políticos somente. Por outro lado, o requerimento de incluir todos os

\footnotetext{
422 The Drafting Committee had wished to stress that there was no question of requiring a rule to be accepted and recognized as peremptory by all States. It would be enough, if a very large majority did so; that would mean that, if one State in isolation refused to accept the peremptory character of a rule, or if that State was supported by a very small number of States, the acceptance and recognition of the peremptory character of the rule by the international community as a whole would not be affected.

423 There is general agreement among interpreters that lack of acceptance or even the opposition on the part of one or a few States is no obstacle to a norm becoming peremptory.

424 The conviction of the imperative character of the norm should be shared by all the essential components of the international community, and not only, for example, by the Western or the Eastern States, by the developed or by the developing countries, or by those from one continent or another.
} 
componentes essenciais da comunidade internacional pode - em certas circunstâncias - ser preenchido por uma minoria de Estados e mesmo sem a participação das Grandes Potências. (tradução nossa) ${ }^{425}$

A ideia de que uma minoria de Estados pudesse criar uma norma cogente só seria possível, a nosso ver, em duas possibilidades. A primeira seria o caso de tal minoria agir ativamente no sentido da criação desta norma e da maioria dos outros Estados não colocarem nenhuma objeção a esta, havendo, desta forma, um consentimento tácito da grande maioria de Estados. Ainda assim, quer por reconhecimento efetivo, quer por reconhecimento tácito, a maioria da comunidade internacional teria que aceitá-la. A segunda possibilidade seria a admissão da possibilidade da formação de um jus cogens regional.

Nesse sentido Gaja defende (p. 284, 1981):

Nenhuma razão convincente jamais foi dada para excluir a possibilidade de existência de normas peremptórias não universais ou 'regionais'. Valores prevalecentes em grupos regionais não necessariamente conflitam com valores operando num âmbito maior. Pode haver normas que adquirem um caráter regional só num contexto regional. A maior similaridade de valores de Estados pertencentes a um grupo particular pode tornar mais fácil para uma norma invalidar tratados concluídos por membros deste grupo. (tradução nossa) ${ }^{426}$

Também Reuter (p. 57, 1983): "Viu-se aparecer igualmente a ideia de jus cogens regional exprimindo as regras fundamentais de uma comunidade ideológica." (tradução nossa) 427

Uma vez que, como já ressaltado, o sistema internacional está em constante desenvolvimento, não se pode de plano, rechaçar a ideia de um jus cogens regional. Já se ressaltou sua ligação com as normas consuetudinárias e a própria CIJ se pronunciou no sentido da possibilidade da existência de costumes regionais (CIJ, Asylum Case, 1950). No entanto, atualmente no Direito Internacional, tendo em vista a definição dada

\footnotetext{
425 Certainly, a norm cannot be considered as peremptory one of general international law if the conviction of its imperative character is limited to certain geographic regions or to certain political groupings only. On the other hand, the requirement of including all the essential components of the international community may - under certain circumstances - be fulfilled even by a minority of States and even without participation of all the Great Powers.

${ }^{426}$ No convincing reason has ever been given for ruling out the possibility of the existence of nonuniversal, or 'regional' peremptory norms. Values prevailing in regional groups do not necessarily conflict with values operating in a larger framework. There may be norms which acquire a peremptory character only in a regional context. The greater similarity of values in states belonging to a particular group could make it easier for a norm to invalidate treaties concluded by members of the group.

427 On a vu apparaître également l'idée d'un jus cogens régional exprimant les règles fondamentales d'une communauté idéologique.
} 
pela Convenção de Viena, que claramente exige a aceitação e o reconhecimento da comunidade internacional no seu conjunto, fica difícil sustentar a possibilidade da existência de um jus cogens regional. A característica essencial destas regras é permear os valores universais da comunidade internacional. A consagração de valores regionais no mesmo nível, embora não impossível na prática, seria contra a definição formalística adotada pela Convenção.

Resumindo, o jus cogens seria o conjunto de regras que, por refletir os valores essenciais da comunidade internacional, são reconhecidas pela comunidade internacional no seu conjunto como normas peremptórias, ou seja, com a capacidade de derrogar outras categorias de normas do Direito Internacional, sem, no entanto, ser derrogado por estas.

\subsubsection{O conteúdo do jus cogens}

Um dos pontos mais controversos em relação ao jus cogens é a determinação de seu conteúdo. A própria CDI, como mencionado acima, optou por estabelecer uma definição formal deste instituto, deixando para a prática dos Estados e para a jurisprudência internacional a delimitação de seu conteúdo. Segundo Brownlie (p. 538, 1995): "É mais abundante a doutrina que existe em apoio da categoria do jus cogens do que a que existe em apoio do seu conteúdo concreto, não se desenvolvendo no Direito consuetudinário regras que correspondam prontamente às novas categorias."

No entanto alguns doutrinadores arriscam classificações.

Ripoll (p. 70, 1974, apud ROBLEDO, p. 172, 1981) classifica as normas imperativas mais gerais e notórias em:

1) As normas protetoras de interesses e valores da comunidade internacional considerada em si mesma.

2) As normas que protegem os direitos dos Estados considerados em si mesmos e nas suas relações recíprocas enquanto membros da sociedade internacional.

3) As normas que protegem os direitos fundamentais da pessoa humana, na sua proteção humanitária e universal.

Perdomo (p. 261-274, 1975, apud ROBLEDO, p. 173-174, 1981) faz outra classificação:

1) As normas imperativas relativas aos direitos soberanos dos Estados e dos povos (igualdade, integridade territorial, livre determinação dos povos, etc.) 
2) As normas imperativas sobre a manutenção da paz e segurança internacionais (proibição do uso da força, procedimentos de solução pacífica de controvérsias, definição de agressão, etc.)

3) As normas imperativas relativas a liberdade da vontade contratual e a inviolabilidade dos tratados (pacta sunt servanda, boa fé, etc.)

4) As normas imperativas relativas aos direitos do homem ( proibição do tráfico de escravos, habeas corpus, proibição da tortura, respeito ao asilo, respeito à liberdade de ensino, respeito à liberdade de reunião, respeito à liberdade religiosa, igualdade de direitos, etc.)

5) As normas imperativas relativas ao uso de espaço terrestre e ultraterrestre pertencente a comunidade de Estados em seu conjunto (alto mar, patrimônio comum da humanidade, espaço extra-atmosférico, etc.)

Alexidze (p. 262-263, 1981) por sua vez estabelece um rol de princípios que seriam de jus cogens:

a) Princípios que estabelecem os principais direitos soberanos dos Estados e dos povos: igualdade e autodeterminação dos povos, não intervenção;

b) Princípios que defendem a paz e a segurança das Nações: proibição do uso da força, solução pacífica de controvérsias, ação coletiva contra agressão de acordo com a Carta das Nações Unidas; c) Princípios que estabelecem as maiores demandas da humanidade: defendendo a liberdade,honra a dignidade dos seres humanos sem consideração de raça, sexo, língua e credo; banimento do genocídio, apartheid e todas as outras formas de discriminação racial, proibição da escravidão, tráfico de escravos, comércio de mulheres e crianças, etc., proibição de pirataria, inviolabilidade dos mais importantes direitos individuais econômicos, sociais, culturais, políticos, e civis;

d) Princípios proibindo crimes contra a humanidade, como estabelecido nos Estatutos dos Tribunais de Nuremberg e de Tóquio, e nas Convenções de Genebra de 1949 sobre as vítimas de Guerra;

e) Princípios proibindo a apropriação de partes do espaço vitalmente importantes para todos os Estados do mundo: liberdade do alto mar e espaço acima, princípio de uso pacífico do espaço sideral, da Lua e outros corpos celestiais, princípios de uso pacífico da Antártica. (tradução nossa) $^{428}$

\footnotetext{
428 a) Principles which establish the main sovereign rights of States and peoples: equality and selfdeterminations of peoples, non-interference;

b) Principles defending the peace and security of nations: prohibition of use of force, peaceful solution of disputes; collective struggle against aggression in accordance with the United Nations Charter;

c) Principles establishing major demands of humanity: defending the freedom, honour and dignity of human beings regardless of their race, sex, language and creed; ban of genocide, apartheid and all other kinds of racial discrimination, prohibition of slavery, slave trade, trade in women and children, etc., prohibition of piracy, inviolability of the major economic, social, cultural, political and civil rights of individuals;
} 
Porém o mesmo autor comenta (ALEXIDZE, p. 262, 1981): "Esta lista, é claro, não pode ser considerada exaustiva e os princípios enumerados nesta são apenas uma parte do conjunto agregado de normas de jus cogens permeando todos os ramos do direito internacional contemporâneo. (tradução nossa) 429

Ressalte-se a inclusão, em todas as classificações apresentadas, da temática dos direitos humanos, foco principal deste trabalho. Todos os autores citados entendem que os direitos humanos fariam parte do rol do chamado jus cogens, a diferença sendo apenas em relação a quais destes direitos estariam inseridos nesta categoria.

Segundo Sztucki (p. 121, 1974):

Parece haver uma discrepância tangível entre os exemplos [de normas de jus cogens] dados na literatura e os exemplos dados no nível diplomático. Em particular nota-se uma mudança de ênfase nos direitos humanos e nas normas humanitárias, como possíveis exemplos. A lista 'oficial' de exemplos parece ser muito mais 'orientada para os Estados'. A ênfase nos direitos humanos e nas normas humanitárias na literatura parece ser consideravelmente maior. (tradução nossa) $^{430}$

Entretanto em uma compilação das propostas apresentadas pelas representações dos Estados durante a Convenção de Viena, feita por este mesmo autor (SZTUCKI, p. 119-120, 1974) aparecem como os itens mais propostos: a proibição do uso da força: 13 delegações; a proibição do genocídio: 13 delegações; a proibição da escravidão e do tráfico de escravos: 12 delegações, os direitos humanos (direitos humanos fundamentais, conjunto de direito tratando da proteção dos direitos humanos, várias regras relacionadas com direitos humanos, etc.): 7 delegações; a soberania dos Estados: 7 delegações.

d) Principles prohibiting crimes against humanity, as established in the Statutes of Nuremberg and Tokio Tribunals, and in the Geneva Conventions of 1949 on Victims of War;

e) Principles prohibiting the appropriation of parts of space vitally important to all States of the world: freedom of the High Seas and space above, principle of peaceful uses of Outer Space, the Moon and other celestial bodies, principles of peaceful use of Antarctica.

${ }^{429}$ This list cannot, of course, be considered exhaustive and the principles enumerated in it are only a part of the whole aggregate of the norms of jus cogens permeating all branches of contemporary international law.

${ }^{430}$ There appears to exist a tangible discrepancy between the examples advanced in the literature and the examples advanced on the diplomatic level. In particular, one notes a switch of emphasis on human rights and humanitarian rules, as possible examples. The 'official' list of examples seems to be much more 'state-oriented'. Emphasis on human rights and humanitarian rules in literature seems to be considerably greater. 
A proibição de genocídio tem o mesmo número de propostas que a proibição do uso da força. Os direitos humanos têm o mesmo número de propostas que a soberania dos Estados. Desta forma parece que, mesmo no campo diplomático, o ênfase nos direitos humanos foi ao menos igual ao dado aos direitos dos Estados.

Nesse sentido Yansseen (1974, apud ROBLEDO, p. 171, 1981) ao agrupar as normas que naquele momento tinham o maior número de votos como normas imperativas, arrola: 1) as normas que concernem aos interesses vitais da comunidade internacional considerada em si mesmo, as normas que proíbem o recurso a força ou que só admitem o regulamento pacífico das controvérsias (artigos 2, parágrafo 4 e 33 da Carta das Nações Unidas); 2) as normas que reconhecem os direitos fundamentais do homem, e que protegem alguns valores morais e alguns princípios de direito humanitário.

Assim, tanto a doutrina quanto a prática dos Estados entende que ao menos algumas normas de direitos humanos são parte do jus cogens, ou seja são valores relevantes para a comunidade internacional de tal forma que derrogam e não são derrogadas por outras normas de direito Internacional.

\subsubsection{Diferença entre jus cogens e obrigações erga omnes}

Para Ramos (p. 50-51, 2002):

Portanto, a fundamentação do conceito de obrigação erga omnes não se baseia no interesse genérico de todos os Estados na preservação do Direito Internacional, nem na existência de um costume internacional que vincule todos os Estados. O termo erga omnes deve ser reservado ao uso dado pela Corte Internacional de Justiça no caso Barcelona Traction. Assim, somente algumas normas internacionais, diante de seu conteúdo, seriam erga omnes.

No entanto, para Simma (p. 299, 1994): “(...) o uso da noção de obrigações erga omnes pela própria Corte Internacional não pode ser considerado como uniforme." (tradução nossa) 431 Após analisar a jurisprudência da CIJ o autor conclui (p. 299,

\footnotetext{
431 (...) the use of the notion of obligations erga omnes by the International Court itself cannot be regarded as uniform,
} 
1994): “(...) a Corte não distingue claramente entre os conceitos de jus cogens e de obrigações erga omnes." (tradução nossa)432

Essa confusão, porém, advém do fato de que toda regra de jus cogens gera uma obrigação erga omnes, como o próprio Simma sustenta (p. 200-300, 1994). O contrário, porém, não é verdadeiro.

Ainda de acordo com Simma (p. 300, 1994):

\begin{abstract}
A noção de obrigações erga omnes somente expressa o interesse legal de toda a comunidade no cumprimento destas obrigações. Mas isto não implica que inter se acordos incompatíveis com tais obrigações devem ser considerados nulos em todas as circunstâncias. Normas peremptórias, por outro lado, são definidas precisamente como normas que tem o poder legal de invalidar tratados conflitantes. Assim é concebível, em teoria que algumas obrigações erga omnes não tenham esse efeito. (...) obrigações erga omnes advém de uma certa classe de normas cuja performance é devida à comunidade internacional como um todo, enquanto o conceito de jus cogens investe algumas ou todas essas normas com efeitos jurídicos particularmente mais extensos. Assim, jus cogens e obrigações erga omnes são dois lados da mesma moeda, notadamente, a existência de certas regras de direito internacional que são, nas palavras da Corte, 'concernentes a todos os Estados'. (tradução nossa) ${ }^{433}$
\end{abstract}

Para Ramos (p. 75, 2005) o conceito de obrigações erga omnes compõe, junto com o conceito jus cogens e o de crime internacional, o conjunto de normas imperativas internacionais. Segundo ele (RAMOS, p. 81-82, 2002):

Com feito, apesar das diferenças de conceitos (o jus cogens indica a existência de normas só derrogáveis por outra da mesma espécie; a 'obrigação erga omnes' refere-se a obrigações internacionais e $\mathrm{o}$ 'fato ilícito qualificado ou crime internacional' refere-se a violações de normas de Direito Internacional), tais termos provam a existência de normas imperativas de Direito Internacional.

\footnotetext{
432 (...) the Court does not distinguish clearly between the concepts of jus cogens and of obligations erga omnes.

433 The notion of obligations erga omnes only expresses the legal interest of the entire community in the fulfillment of these obligations. But this does not imply that inter se arrangements incompatible with such obligations must be considered void under all circumstances. Peremptory norms, on the other hand, are defined precisely as norms which have the legal power to invalidate conflicting treaties. Therefore, it is quite conceivable in theory that some obligations erga omnes do not have this effect. (...)

Obligations erga omnes flow from a certain class of norms the performance of which is owed to the international community as a whole, whereas the concept of jus cogens invests some or all of these norms with particularly far-reaching legal effects. Therefore, jus cogens and obligations erga omnes are but two sides of the same coin, namely, that of the existence of certain rules of international law which are in the words of the Court, 'the concern of all States'.
} 
A denominação genérica de norma imperativa relaciona-se justamente com a essencialidade dos valores nelas contidos e que, por conseguinte, se impõe a cada Estado isoladamente considerado. Logo, não é facultado ao Estado, enquanto autoridade internacional, o direito de violar normas imperativas. Nem possui o direito de renunciar a tais condutas tidas como essenciais a todos os Estados.

Ainda para Ramos (p. 82, 2002) estes conceitos não são estanques, devendo ser usada a "metáfora dos círculos com áreas que se interpenetram, mantendo-se a individualidade de cada conjunto."

Assim, a diferença entre o jus cogens e obrigações erga omnes é que, embora os dois institutos retratem valores essenciais à comunidade internacional, as normas de jus cogens gozam de um caráter peremptório que nem toda obrigação erga omnes possui. Assim, toda norma de jus cogens gera obrigações erga omnes, mas nem toda obrigação erga omnes tem o caráter peremptório, ou seja, gera a derrogação das outras normas de Direito Internacional incompatíveis com ela.

Reconhece-se, assim, que os dois conceitos se sobrepõem em algumas matérias. Um exemplo são as normas de proteção dos direitos humanos fundamentais. Tais normas, além de serem devidas à comunidade internacional como um todo, também não são passíveis de derrogação.

\subsubsection{O crime internacional}

O conceito de crime internacional surgiu a partir dos trabalhos preparatórios da Comissão de Direito Internacional da ONU (CDI) do projeto de artigos sobre a responsabilidade internacional do Estado. Tal termo foi mantido apesar das controvérsias, no projeto aprovado em 1996. (RAMOS, p. 57 et seq., 2002)

Segundo este projeto (artigo 19, parágrafo 2) o crime internacional seria (CDI, p. 60, 1996):

2. Um ato internacionalmente ilícito que resulta de uma violação por um Estado de uma obrigação internacional tão essencial para a proteção dos interesses da comunidade internacional que sua violação 
é reconhecida como crime por esta comunidade como um todo, constitui um crime internacional. (tradução nossa) ${ }^{434}$

Porém a própria CDI em seu Relatório de 1998 reconhece as dificuldades suscitadas por este conceito. Em suas palavras (CDI, 1998, p. 77):

Seguindo o debate, e levando em conta os comentários do Relator Especial, notou-se que nenhum consenso existe na matéria do tratamento dos 'crimes' e 'delitos' no projeto de artigos, e que seria necessário trabalhar mais nos possíveis modos de lidar com as questões levantadas. Foi, portanto, acordado que: a) sem prejuízo das opiniões de qualquer membro da Comissão, o projeto do artigo 19 seria posto de lado no presente enquanto a Comissão passaria a considerar outros aspectos da parte um; b) deve ser levado em consideração se o desenvolvimento sistemático nos projetos de artigos de noções chaves como obrigações (erga omnes), normas peremptórias (jus cogens) e uma possível categoria de violações mais sérias de obrigações internacionais poderia ser suficiente para resolver as questões levantadas pelo artigo 19; (tradução nossa) ${ }^{435}$

O artigo 19, que continha a definição de crime internacional, foi, então, posto de lado tendo em vista a falta de consenso a seu respeito. Tal posição, inicialmente temporária, acabou por tornar-se definitiva, sendo tal artigo eliminado do Projeto final de artigos adotado pela CDI em 2001 e anexado a Resolução 56/83 da Assembleia Geral de 2001 .

Com isso, tornou-se patente que o conceito de crime internacional ainda não está plenamente definido em Direito Internacional, sendo ainda um instituto que não goza de ampla aceitação.

O termo "crime internacional" foi substituído pelas "violações sérias de obrigação decorrente de normas imperativas do direito internacional geral". Assim, o crime internacional deu lugar, no regime da responsabilidade internacional, ao conceito mais consolidado de jus cogens.

\footnotetext{
434 2. An internationally wrongful act which results from the breach by a State of an international obligation so essential for the protection of fundamental interests of the international community that its breach is recognized as a crime by that community as a whole constitutes an international crime.

435 Following the debate, and taking into account the comments of the Special Rapporteur, it was noted that no consensus existed on the issue of the treatment of "crimes" and "delicts" in the draft articles, and that more work needed to be done on possible ways of dealing with the substantial questions raised. It was accordingly agreed that: $(a)$ without prejudice to the views of any member of the Commission, draft article 19 would be put to one side for the time being while the Commission proceeded to consider other aspects of part one; $(b)$ consideration should be given to whether the systematic development in the draft articles of key notions such as obligations (erga omnes), peremptory norms (jus cogens) and a possible category of the most serious breaches of international obligation could be sufficient to resolve the issues raised by article 19;
} 


\title{
PARTE II: A APLICAÇÃO DE CONTRAMEDIDAS POR ESTADOS NÃO DIRETAMENTE LESADOS DIANTE DE VIOLAÇÃO ÀS NORMAS DE DIREITOS HUMANOS
}

\section{CAPÍTULO I: CONTRAMEDIDAS}

Um dos aspectos mais controversos na codificação da responsabilidade internacional do Estado foi a inserção do instituto de contramedidas no anteprojeto elaborado pela CDI. Embora muitos alegassem que a falta de relação entre os temas, prevaleceu a corrente que entendia que, diante de um sistema jurídico descentralizado, as contramedidas seriam um mal necessário. $\mathrm{Na}$ falta de um quadro institucional capaz de lidar com todos os tipos de violações do Direito Internacional, a autotutela ainda seria o único recurso efetivo disponível aos Estados em algumas ocasiões.

Uma vez reconhecida sua necessidade, seria importante a sua regulamentação para evitar que este recurso não fosse utilizado abusivamente.

As contramedidas, assim, passaram a fazer parte integrante do anteprojeto de artigos sobre a responsabilidade internacional do Estado. Para melhor conhecer o instituto, necessário se faz uma breve análise da sua origem histórica.

\subsection{Breve retrospecto histórico}

Contramedida é a nova terminologia usada, sobretudo, pela CDI, para denominar um antigo instituto do Direito Internacional, as represálias não militares.

Segundo Zoller (p.35, 1984):

\begin{abstract}
A instituição que o direito internacional clássico tem designado pelo termo 'represálias' remonta às vendetas primitivas, nas quais uma organização considera todos os membros de outra coletividade responsável pelos atos de qualquer um de seus membros. Assim, represálias, no sentido da detenção da pessoa ou dos bens pertencendo a um membro de um grupo pela obrigação de um ou todos os seus companheiros, eram um fenômeno universal. ${ }^{436}$ (tradução nossa)
\end{abstract}

\footnotetext{
436 The institution which classical international law has designed by the term reprisal goes back to the primitive blood feud, in which one organization held all the members of another collectivity responsible for the acts of any single member. Thus, reprisal, in the sense of detention of the person or of goods belonging to a member of a group for the obligations of one or all their fellows, were a universal phenomenon.
} 
Para Reuter (p. 463, 1983) elas seriam "o sistema de justiça privada e da lei do talião, praticados pelas civilizações primitivas, transposto para as relações internacionais ${ }^{\wedge 437}$ (tradução nossa)

Um instituto medieval relacionado com a represália seria o das lettres de marque, que Arangio-Ruiz descreve como documentos que (ONU, p.13, 1991) "continham uma autorização oficial da parte do soberano para que a parte lesada adotasse represálias contra a propriedade dos nacionais de um Estado estrangeiro presentes no seu próprio país ou no mar. ${ }^{\star 38}$ (tradução nossa) Ainda, segundo o Relator Especial da CDI para o tema da responsabilidade do Estado, “as 'represálias privadas' foram posteriormente substituídas por 'represálias gerais' ou 'públicas', tendo apenas as 'nações' direito a recorrer as elas." 439 (tradução nossa)

Nys (p. 64 et seq., 1894) descreve diversos exemplos de represálias tomadas pelos Estados na Idade Média. Segundo este autor (p. 68, 1894) “As represálias são, talvez uma das instituições de direito das gentes que mais ocuparam a atenção dos grandes comentadores italianos do século XIV. A maior parte as examinou nas suas obras gerais. Bartole ${ }^{440}$ lhes consagra uma monografia ${ }^{441}$."(tradução nossa)

Ao descrever a obra de Bartole, Nys afirma (p. 69, 1894): “desde que elas reunissem a tripla condição, a autorização do príncipe, a justa causa e a honesta intenção do impetrante, as represálias são lícitas”442 (tradução nossa)

Assim para Bartole, as represálias, ainda uma espécie de justiça privada, mas autorizada pelo Estado na figura do Príncipe, teriam três condições. A primeira, a autorização do soberano, a segunda, a justa causa, e a terceira, a boa fé daquele que a aplica. Cumprindo estas três condições, as represálias seriam lícitas.

Também os "fundadores" do Direito Internacional moderno reconheciam o direito de represália. Grotius não só descrevia o instituto das represálias, como atestava que esta prática advinha da antiguidade. Em suas palavras (p. 1061, 2004):

\footnotetext{
${ }^{437}$ la système de la justice privée et de la loi du talion, pratiquées dans les civilisations primitives, transposé dans les relations internationales.

438 contained an official authorization on the part of the sovereign for the injured party to resort to reprisals against the property of the nationals of the foreign State present in his own country, or at sea.

439 "Private reprisals" were later replaced by "public" or "general reprisals", with only "nations" being entitled to resort to them

${ }^{440}$ Tractatus repraesaliarum (1357).

${ }^{441}$ Les représailles sont peut-être bien une des institutions du droit des gens qui occu`perent le plus l'attntion des grands commentateurs italiens du XVI siêcle. La plupart l'examinet dans leus ouvrages généraux. Bartole lui consagre une monographie.

${ }^{442}$ Pouvu qu'elles réunissent la triple condition de l'autorisation du prince, de la juste cause et de la droiture d'interntion chez l'impétrant, les représailles sont licites, [...]
} 
Outra espécie de execução violenta desse direito é a apreensão dos bens ou tomada de penhor entre diversos povos, que os juristas modernos chamam de direito de represália, os saxões e os ingleses, withernam e os franceses, entre os quais é ordinariamente obtido do rei, lettres de marque. Essa via ocorre, como dizem os juristas, quando o direito é negado.

E ainda (p. 1062, 2004):

Trata-se, pois, de uma coisa introduzida, senão pelo direito de natureza, ao menos pelo uso acatado em toda a parte, que se possa, por semelhante razão, apreender pessoas ou bens mobiliários dos súditos daquele que não faz justiça.

A tradução em inglês da obra de Grotius é ainda mais explícita ao dizer (p. 153, 1814):

Represálias são feitas sobre pessoas e propriedades de súditos, pertencendo a um poder, que se recusa a dar compensação e reparação por danos e agressões. É uma prática não estabelecida literalmente pelo direito da natureza, mas geralmente recebida pelo costume. É uma prática, também, muito antiga. ${ }^{43}$ (tradução nossa)

Assim, para este autor, represália é o direito de um Estado de apreender coisas e pessoas de outro Estado, tendo em vista a recusa do segundo a reparar danos ou agressões, de sua responsabilidade, sofridos pelo primeiro. Esse seria um direito consuetudinário reconhecido desde a antiguidade (p. 1062-1063, 2004).

Também Pufendorf, ao escrever sobre os Pactos, defendia (p.301, 1729): 'Mas em Pactos, quando a razão pela qual eu realizei qualquer Ação, é a perspectiva de algo ser feito para mim pela outra Pessoa, se ela falha na parte dela, eu não somente estou liberado da minha, mas posso obrigar a ela, por força, a cumprir o Acordo." ${ }^{444}$ (tradução nossa)

Este autor, assim, reconhece o direito de um Estado de "obrigar" a outro Estado que violou um Pacto, a cumprir com mesmo.

\footnotetext{
${ }^{443}$ Reprisals are made upon the persons and property of the subjects, belonging to a power, who refuses to grant redress and reparation for injuries and aggressions. It is a practice not literally enacted by the law of nature, but generally received through custom. It is a practice too of great antiquity: [...]

${ }^{444}$ But in Pacts, as the Reason why I have undertaken any Performance, is the Prospect of somewhat to be done for me by the other Person, so if he fail in his part, I am not only releas'd at present from mine, but I may oblige him by force to stand to the Agreement.
} 
Já para Vattel (p. 396, 2004):

§ 342. Das represálias: As represálias são utilizadas pelas Nações com o intuito de obter justiça, quando ela não pode ser obtida de outra forma. Se uma Nação se apossou do que pertence a outra, se ela recusa pagar um débito, reparar uma injúria, ou dar justa satisfação à Nação, vítima de injustiça, esta pode apossar-se de alguma cousa pertencente àquela e aplicar para seu proveito, junto com danos e lucros, até a restituição do que lhe é devido, ou ainda tê-la como garantia, até que possa ser devidamente ressarcida. Neste último caso, trata-se mais de arresto ou sequestro do que de represálias; eles se confundem frequentemente em linguagem ordinária. As cousas apreendidas são mantidas com a esperança de obter satisfação ou justiça. Quando essa esperança não mais existe, os bens são confiscados e, então, as represálias são tomadas.

As represálias seriam, então, o direito de um Estado de confiscar a propriedade de outro Estado que se recusa a pagar um débito, reparar uma injúria ou dar uma satisfação justa.

Este autor ainda estabelece os requisitos de legitimidade para as represálias. Segundo Vattel (p. 396-397, 2004): “O direito das gentes permite represálias somente quando a causa é manifestamente justa, para uma dívida definida e líquida. Onde a pretensão é duvidosa, não se pode pedir primeiramente senão a investigação equitativa do seu direito." Assim, a primeira condição de legitimidade de represália é a certeza da pretensão, ou seja, a certeza em relação ao ato da Nação contra a qual a medida seria tomada, seja este uma recusa de pagamento, de reparação ou de satisfação.

Também para Vattel (p. 397, 2004): “Além disso, antes de chegarem a este ponto, a justiça deve ter sido requerida em vão, ou ao menos, que haja razão para acreditar que ela seria requerida inutilmente."

Neste segundo requisito não fica claro se a demanda de justiça deve ser por meio de um procedimento de solução pacífica de controvérsias, ou se basta um requerimento à Nação contra a qual se pretende tomar essas medidas, para que pague, indenize ou satisfaça a Nação prejudicada.

Porém, Vattel esclarece (p. 397, 2004):

se nosso adversário em uma disputa se recusa a dar os passos necessários para mostrar a justeza de sua pretensão, ou se os elude artificialmente, se não se dispõe de boa fé a submeter-se a métodos pacíficos de solução de controvérsia e, acima de tudo, se for o primeiro a ter recorrido a vias de fato, ele assim converte a nossa pretensão de problemátic a em pretensão justa ao ponto de podermos, 
agora, pôr em andamento as represálias, ou a tomada de seus bens, com o intuito de forçá-lo a adotar os métodos de conciliação que a lei natural prescreve.

Portanto, no caso de recusa de um Estado a participar dos métodos pacíficos de solução de controvérsias, pode o outro Estado, legitimamente, adotar represálias contra este para forçá-lo à conciliação.

Wolff também escreve sobre as represálias, que ele chama "androlepsia". Estas seriam derivadas do direito de punir, que pertence tanto as nações como aos indivíduos no estado de natureza, e seriam uma consequência do direito de defesa (PILLET, p. 470, 1904).

As represálias são, assim, um instituto estudado pelos doutrinadores do Direito Internacional desde o século XIV. Elas eram consideradas, já no século XVII, como norma consuetudinária. Grotius cita exemplos de represálias contidos na Ilíada, de Homero, em textos de Aristóteles e na história romana (p. 1062-1063, 2004).

Na Idade Média ela era um tipo de justiça privada, realizado com a autorização do soberano, ou seja, com o consentimento de um Estado.

Por outro lado, na Idade Moderna, ela se caracterizava como um direito de um Estado que sofreu um dano ou uma injúria, de apreender bens e mesmo pessoas do Estado responsável pelo prejuízo sofrido. Esta apreensão seria uma forma de autotutela, típica de uma ordem jurídica descentralizada.

Para Vattel, as represálias poderiam ter três finalidades. Obter a reparação de um dano sofrido (função compensatória), obter a satisfação por uma injúria (função satisfatória) ou forçar um Estado a participar de procedimentos pacíficos de solução de controvérsias (função coercitiva).

O instituto das represálias evoluiu ao longo dos séculos, porém não perdeu algumas de suas características essenciais. Atualmente, ela continua sendo uma forma de autotutela, diante de um ordenamento jurídico descentralizado. E mantém a característica de reação a um ato anterior, ato este contrário às obrigações internacionais do Estado que o realizou.

\subsection{Jurisprudência}


Apesar de se referir a um instituto antigo, a jurisprudência sobre contramedidas é limitada. Alland (p. 43, 1994) vê duas explicações principais para este fato. A primeira seria por que "a prática das represálias armadas, que há muito tempo está em curso nas relações interestatais não se acomodam com a resolução jurídica de disputas» ${ }^{45}$ (tradução nossa). A segunda, porque "as contramedidas são frequentemente tomadas quando e porque as soluções disponibilizadas pela resolução de disputas não são

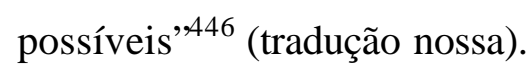

Ainda assim, podemos encontrar alguma jurisprudência específica, tanto no âmbito da Corte Internacional de Justiça (CIJ) e sua antecessora a Corte Permanente de Justiça Internacional (CPJI), quanto nos Tribunais Arbitrais.

\title{
1.2.1 Jurisprudência da Corte Permanente de Justiça Internacional (CPJI)
}

No caso da Usina Chorzow, de 1927 tratando da nacionalização de uma empresa de origem alemã pelo governo polonês, a CPJI escreve contra a possibilidade de adoção de contramedidas no caso de o Estado lesado ter concorrido para que a violação ocorresse, através de uma conduta ilícita anterior. Em suas palavras (CPJI, p. 31, 1927):

\begin{abstract}
É, assim, um princípio geralmente aceito na jurisprudência da arbitragem internacional, assim como pelas cortes internas, que uma Parte não pode se aproveitar do fato de que a outra não cumpriu alguma obrigação ou não recorreu a um meio de reparação, se a se a primeira Parte, por meio de um ato ilegal, impediu que a última cumprisse a obrigação em questão, ou recorresse a um tribunal que estaria aberto a ela. ${ }^{47}$ (tradução nossa)
\end{abstract}

A Corte, no entanto, não chega a se pronunciar sobre a possibilidade de adoção de contramedida caso o Estado beneficiário da obrigação violada tenha agido de boa fé.

No caso sobre o Tráfico Ferroviário entre Lituânia e Polônia, em 1931, a CPJI, em Parecer Consultivo, teve que se manifestar sobre a existência da uma obrigação da

\footnotetext{
${ }^{445}$ La practique des représailles armées, qui a longtemps eu cours dans les relations interétatiques, ne s'accommodait guère du règlement juridictionnel des différends.

${ }^{446}$ les contre-mesures sont souvent déclenchées quand et parce que des solutions concertées pour le règlement des différends ne sont pas envisageables.

${ }^{447}$ It is, moreover, a principle generally accepted in the jurisprudence of international arbitration, as well as by municipal courts, that one Party cannot avail himself of the fact that the other has not fulfilled some obligation or has not had recourse to some means of redress, if the former Party has, by some illegal act, prevented the latter from fulfilling the obligation in question, or from having recourse to the tribunal which would have been open, to him.
} 
Lituânia de abrir seu tráfico ferroviário. Este Estado se recusava a restaurar o uso de determinado setor ferroviário. Segundo os representantes deste governo (CPJI, p. 114, 1931):

ele adota esta atitude como uma forma de represália pacífica e ele acredita ter o direito de persistir 'até que a questão da alocação de Vilna e do território adjunto seja decidida por arbitragem ou por uma decisão dada pela Corte a requerimento dos dois Governos envolvidos. ${ }^{448}$ (tradução nossa)

A Lituânia, então, alegava o uso de contramedida como forma de pressão para que a Polônia concordasse em submeter uma disputa a um mecanismo de solução de controvérsias.

Para a CPJI, no entanto (p. 114, 1931):

Deve ser observado, entretanto, que a questão se a Lituânia tem ou não o direito de exercer represálias, inter alia, por manter o setor ferroviário Landwarów-Kaisiadorys sem uso, só surge se for demonstrado que as obrigações internacionais em vigor obrigam a Lituânia a abrir este setor para o tráfico. Se a Corte chegar à conclusão de que não existe nenhuma obrigação internacional desta natureza, o argumento baseado no direito alegado de um país de tomar represálias pacíficas deixa de ter importância. ${ }^{449}$ (tradução nossa)

Tendo em vista que a Corte decide que não existe nenhuma obrigação internacional neste sentido (CPJI, p. 122, 1931), ela deixa, mais de uma vez, de decidir sobre a questão das represálias ou contramedidas.

\subsubsection{Corte Internacional de Justiça}

\footnotetext{
${ }^{448}$ She adopts this attitude as a form of pacific reprisals and believes to be entitled to persist in it "until the question of the allocation of Vilna and the adjoining territory has been settled by arbitration or by a decision given by the Court at the request of the two Governments concerned.

449 It is however to be observed that the question whether Lithuania is or is not entitled to exercise reprisals, inter alia, by keeping the Landwarów-Kaisiadorys railway sector out of use, only arises if it is shown that the international engagements in force oblige Lithuania to open this sector for traffic. Should the Court arrive at the conclusion that no international engagements of this nature exist for Lithuania, the argument based on the alleged right of that country to engage in pacific reprisals ceases to be of any importance.
} 
No caso sobre os funcionários diplomáticos e consulares dos Estados Unidos no Teerã, a CIJ indiretamente reconhece a possibilidade de contramedidas ao analisar a conduta estadunidense. Segundo a Corte (p. 27-28, 1980):

Outro ponto também levantado é se, tendo em vista certas contramedidas tomadas pelos Estados Unidos frente ao Irã, é possível aos Estados Unidos invocar o Tratado de Amizade, Relações Econômicas e Direitos Consulares, nos presentes procedimentos. Entretanto, todas as medidas em questão foram tomadas pelos Estados Unidos após a invasão de sua Embaixada pro um grupo armado e subsequente detenção dos seus funcionários diplomáticos e consulares. Elas foram medidas tomadas em resposta ao que os Estados Unidos acreditavam ser graves e manifestas violações do direito internacional pelo Irã, incluindo violações ao próprio Tratado de $1955 .{ }^{450}$ (tradução nossa)

A Corte, sem entrar no mérito da legalidade das condutas adotadas ${ }^{451}$ pelos Estados Unidos, descreve estas como medidas tomadas em resposta a violações graves e manifestas de Direito Internacional.

Já na decisão sobre as Atividades Militares e Paramilitares na e contra a Nicarágua, em 1986, a Corte examina a possibilidade de adoção de contramedidas de caráter militar por um Estado terceiro, os Estados Unidos. Nessa decisão a CIJ determina (p. 127, 1986):

Enquanto um ataque armado poderia dar origem ao direito a uma legítima defesa coletiva, o uso da força em um grau menor não pode, como a Corte já observou (parágrafo 211 acima), produzir nenhum direito a tomar contramedidas coletivas envolvendo o uso da força. Os atos dos quais da Nicarágua é acusada, mesmo assumindo que tenham estabelecidos e imputáveis àquele Estado, poderiam apenas justificar contramedidas proporcionais da parte do Estado que foi vítima destes atos, notadamente, El Salvador, Honduras ou Costa Rica. Eles não poderiam justificar contramedidas tomadas por outro Estado, os Estados Unidos, e particularmente não poderiam justificar uma intervenção envolvendo o uso da força. ${ }^{452}$ (tradução nossa)

\footnotetext{
450 53. The point has also been raised whether, having regard to certain counter-measures taken by the United States vis -à-vis Iran, it is open to the United States to rely on the Treaty of Arnity, Economic Relations, and Consular Rights in the present proceedings. However, al1 the measures in question were taken by the United States after the seizure of its Embassy by an armed group and subsequent detention of its diplomatic and consular staff as hostages. They were measures taken in response to what the United States believed to be grave and manifest violations of international law by Iran, including violations of the 1955 Treaty itself.

${ }^{451}$ Somente o Juiz Morozov, em voto dissidente, descreve a conduta dos Estados Unidos como ilícita (CIJ, p. 55, 1980)

452 While an armed attack would give rise to an entitlement to collective self-defence, a use of force of a lesser degree of gravity cannot. as the Court has already observed (paragraph 211 above), produce any entitlement to take collective countermeasures involving the use of force. The acts of which Nicarágua is
} 
A Corte, não só estabelece o direito dos Estados diretamente lesados de tomarem contramedidas, como determina que tal direito deve ser exercido seguindo o princípio da proporcionalidade. Por outro lado, a CIJ rejeita, neste caso, a aplicação de contramedidas pelos Estados Unidos, tendo em vista este não ter sido diretamente lesado pela conduta da Nicarágua.

Em 1997, a CIJ ao tratar do caso do Projeto Gabcíkovo-Nagymaros, teve que decidir sobre o argumento subsidiário da Eslováquia, de que a conduta por ela adotada (a colocação de operação da Variante C) seria uma contramedida em reação a atos ilícitos da Hungria (CIJ, p. 55, 1997).

Na sua análise sobre a questão a CIJ estabelece (p. 55, 1997): "Para ser justificável, a contramedida deve cumprir certas condições. ${ }^{„ 453}$ (tradução nossa)

Sobre estas condições a CIJ escreve (p. 55, 1997): "Em primeiro lugar, ela deve ser tomada em resposta a um ato ilícito internacional prévio de outro Estado e deve ser direcionada contra aquele Estado. ${ }^{, 454}$ (tradução nossa)

Ainda, para a CIJ (p. 56, 1997): 'Segundo, o Estado lesado deve ter requerido ao Estado cometendo o ato internacionalmente ilícito que descontinue a sua conduta ilícita ou que faça a reparação por ela." ${ }^{455}$ (tradução nossa)

A CIJ também afirma (p. 56, 1997): “Na visão da Corte, uma consideração importante é que o efeito de uma contramedida deve ser proporcional com o dano sofrido, levando em conta os direitos em questão." ${ }^{, 456}$ (tradução nossa)

Por fim a Corte conclui (p. 56-57, 1997):

A Corte, assim, considera que o desvio do Danúbio efetuado pela Checoslováquia não é uma contramedida lícita porque não era proporcional. Ela não é requerida a passar por outra condição de licitude de uma contramedida, notadamente, seu propósito deve ser de induzir o Estado infrator a cumprir com suas obrigações

\footnotetext{
accused, even assuming them to have been established and imputable to that State, could only have justified proportionate counter-measures on the part of the State which had been the victim of these acts, namely El Salvador, Honduras or Costa Rica. They could not justify counter-measures taken by a third State, the United States, and particularly could not justify intervention involving the use of force.

${ }^{453}$ In order to be justifiable, a countermeasure must meet certain conditions.

${ }^{454}$ In the first place it must be taken in response to a previous international wrongful act of another State and must be directed against that State.

${ }^{455}$ Secondly, the injured State must have called upon the State committing the wrongful act to discontinue its wrongful conduct or to make reparation for it.

456 In the view of the Court, an important consideration is that the effects of a countermeasure must be commensurate with the injury suffered, taking account of the rights in question.
} 
internacionais, e esta medida, dever ser, assim, reversível. ${ }^{457}$ (tradução nossa)

Neste julgado a CIJ estabelece diversas condições para a licitude das contramedidas. Em primeiro lugar ela deve ser uma resposta a um ato internacionalmente ilícito anterior. Para tanto, ela deve ser precedida por este e adotada contra o Estado autor da conduta ilícita. A segunda condição seria uma conduta anterior do Estado que toma a contramedida, requerendo que o Estado violador cesse a conduta ilícita ou repare o prejuízo causado, uma espécie de notificação. A terceira condição estabelecida pela CIJ é a proporcionalidade da medida adotada com o dano sofrido, mas levando em consideração os direitos em questão. A quarta condição seria a reversibilidade da conduta, tendo em vista que esta deve ter como finalidade induzir ao infrator ao cumprimento de suas obrigações e não uma punição.

\subsubsection{Decisões de Tribunais Arbitrais}

Também os Tribunais Arbitrais lidaram com a questão das contramedidas em algumas decisões.

No caso da Pesca no Atlântico Norte (1910), entre Estados Unidos e Reino Unido, sobre a regulação das atividades de pesca dos pescadores americanos, o Tribunal Arbitral reconheceu o direito a adotar represálias no caso de descumprimento de um tratado. Em suas palavras (UNRIAA, Vol. IX, p. 186, 1910):

Porque todo Estado tem que executar as obrigações determinadas por um Tratado de boa fé, e é instado, assim, pelas sanções ordinárias do Direito Internacional em relação à observância das obrigações do Tratado. Tais sanções são, por exemplo, o apelo à opinião pública, a publicação da correspondência, a censura por voto do Parlamento, a demanda por arbitragem com o 'odium atttendant' na recusa à arbitrar, a ruptura das relações, a represálias, etc. ${ }^{458}$ (tradução nossa)

\footnotetext{
${ }^{457}$ The Court thus considers that the diversion of the Danube carried out by Czechoslovakia was not a lawful countermeasure because it was not proportionate. It is therefore not required to pass upon one other condition for the lawfulness of a countermeasure, namely that its purpose must be to induce the wrongdoing State to comply with its obligations under international law, and that the measure must therefore be reversible.

${ }^{458}$ Because every State has to execute the obligations incurred by Treaty bona fide, and is urged thereto by the ordinary sanctions of International Law in regard to observance of Treaty obligations. Such sanctions are, for instance, appeal to public opinion, publication of correspondence, censure by
} 
O Tribunal Arbitral, embora não defina represália, a reconhece como uma das sanções do Direito Internacional.

No caso Naulilaa (1928), o Tribunal Arbitral tem que decidir sobre a legalidade da conduta alemã como represálias lícitas ao incidente ocorrido em Naulilaa. Neste julgado o Tribunal escreve (UNRIAA, Vol. IV, p. 1026, 1928):

\begin{abstract}
A represália é um ato de justiça própria (Selbsthilfehandlung), do Estado lesado, ato respondendo - depois de um requerimento [sommation] sem êxito - a um ato contrário ao direito das gentes do Estado ofensor. Ela tem como efeito suspender momentaneamente nas relações entre os dois Estados, a observação de uma ou outra regra de direito das gentes. Ela é limitada pelas experiências da humanidade e regras de boa fé, aplicadas nas relações Estado a Estado. Ela seria ilegal se um ato anterior, contrário ao direito das gentes, não tivesse fornecido o motivo. Ela tende a impor, ao Estado ofensor, a reparação da ofensa ou o retorno à legalidade, evitando novas ofensas. ${ }^{459}$ (tradução nossa)
\end{abstract}

Ainda para o Tribunal (UNRIAA, Vol. IV, p. 1027, 1928): "A represália não é lícita se não foi precedida de uma notificação sem êxito. $\mathrm{O}$ emprego da força só se justifica, em efeito, por seu caráter de necessidade."460 (tradução nossa)

Por fim o Tribunal esclarece (UNRIAA, Vol. IV, p. 1028, 1928):

\begin{abstract}
A necessidade de uma proporção entre a represália e a ofensa parece ser reconhecida na resposta alemã. Mesmo que se admita que o direito das gentes não exija que a represália tenha aproximadamente, a mesma medida que a ofensa, deve-se certamente considerar como excessiva e, portanto, ilícitas as represálias fora de toda a proporção com o ato que as motivou. ${ }^{461}$ (tradução nossa)
\end{abstract}

\footnotetext{
Parliamentary vote, demand for arbitration with the odium attendant on a refusal to arbitrate, rupture of relations, reprisal, etc.

${ }^{459}$ La représaille est un acte de propre justice (Selbsthilfehandlung) de l'État lésé, acte répondant après sommation restée infructueuse - à un acte contraire au droit des gens de l'État offenseur. Elle a pour effet de suspendre momentanément, dans les rapports des deux États, l'observation de telle ou telle règle du droit des gens. Elle est limitée par les expériences de l'humanité et les règles de la bonne foi, applicables dans les rapports d'État à État. Elle serait illégale si un acte préalable, contraire au droit des gens, n'en avait fourni le motif. Elle tend à imposer, à l'État offenseur, la réparation de l'offense ou le retour à la légalité, en évitation de nouvelles offenses.

${ }^{460}$ La représaille n'est licite que lorsqu'elle a été précédée d'une sommation restée infructueuse. L'emploi de la force ne se justifie, en effet, que par son caractère de nécessité

461 La nécessité d'une proportion entre la représaille et l'offense, paraît être reconnue dans la réponse allemande *. Même si l'on admettait que le droit des gens n'exige pas que la représaille se mesure approximativement à l'offense, on devrait certainement considérer, comme excessives et partant illicites, des représailles hors de toute proportion avec l'acte qui les a motivées.
} 
O Tribunal Arbitral reconhece a existência do direito dos Estados de adotar represálias no Direito Internacional. Tal direito, no entanto, deve preencher duas condições. Uma notificação do Estado lesado ao Estado infrator anterior e que não é bem sucedida, e um mínimo de proporcionalidade entre a represália e a violação que a causou.

No caso Cysne (1930), o Tribunal Arbitral deve tratar da possibilidade de aplicação de represálias contra Estados terceiro, ou seja, que não tiveram relação com o ato internacionalmente ilícito anterior. A esse respeito o Tribunal esclarece (UNRIAA, Vol. IV, p. 1057, 1930):

A negativa deve ser admitida conforme a própria doutrina alemã. Esta solução é a consequência lógica da regra segundo a qual as represálias constituindo um ato em princípio contrário ao direito das gentes, só podem se justificar enquanto elas forem provocadas por algum outro ato igualmente contrário a este direito. As represálias só são admissíveis contra um Estado provocador. E possível, é verdade, que represálias legítimas, exercidas contra um Estado ofensor atinjam os nacionais de um Estado inocente. Mas se tratará de uma consequência indireta, involuntária, que o Estado ofendido se esforçará, na prática, sempre para evitar ou limitar o quanto for possível ${ }^{462}$ (tradução nossa)

O Tribunal Arbitral, embora reconheça o direito a represálias, entende que este direito só pode ser exercido contra o Estado autor da conduta ilícita anterior. Eventuais efeitos da contramedida contra Estados terceiros deve ser indireto, involuntário e evitado sempre que possível.

Já no caso do Acordo sobre Serviço Aéreo de 27 de março de 1946, de 1978, o Tribunal Arbitral tem que decidir sobre as contramedidas adotadas pelos Estados Unidos em virtude de uma suposta violação da França a este acordo internacional. Sobre a possibilidade de adoção das contramedidas o Tribunal escreve (UNRIAA, Vol. XVIII p. 483, 1978):

No estado atual do direito internacional geral, exceção das obrigações específicas decorrentes de tratados particulares e, notadamente, dos mecanismos instituídos no quadro das organizações internacionais,

\footnotetext{
${ }^{462}$ La négative doit être admise, conformément à la doctrine allemande elle-même. Cette solution est la conséquence logique de la règle suivant laquelle les représailles, consistant en un acte en principe contraire au droit des gens, ne peuvent se justifier qu'autant qu'elles ont été provoquées par un autre acte également contraire à ce droit. Les représailles ne sont admissibles que contre l'État provocateur. Il se peui, il est vrai, que des représailles légitimes, exercées contre un État offenseur, atteignent des ressortissants d'un État innocent. Mais il s'agira là d'une conséquence indirecte, involontaire, que l'État offensé s'efforcera, en pratique, toujours d'éviter ou de limiter autant que possible.
} 
cada Estado aprecia por si mesmo sua situação jurídica em relação aos outros Estados. Em face de uma situação que comporta, a seu ver, a violação de uma obrigação internacio nal por outro Estado, ele tem o direito, sob a reserva das regras gerais do direito internacional relativas às restrições armadas, de fazer respeitar seu direito por 'contramedidas'. ${ }^{463}$ (tradução nossa)

O Tribunal Arbitral também discorre sobre a necessidade de proporcionalidade das contramedidas. Em suas palavras (UNRIAA, Vol. XVIII, p. 483, 1978):

Mas é geralmente admitido que as contramedidas devem corresponder a uma certa equivalência com a violação alegada; se trata de uma regra bem conhecida. De uma maneira geral, deve se observar que a apreciação da 'proporcionalidade' concreta das contramedidas não é simples e só pode ser realizada de uma maneira aproximativa. Segundo o Tribunal, um dos problemas essenciais é levar em conta em um litígio entre Estados - não somente os danos sofridos pelas partes acompanhados de juros, mas a importância das questões de princípio incluídas na violação alegada. ${ }^{464}$ (tradução nossa)

Ainda para o Tribunal (UNRIAA, Vol. XVIII, p. 484, 1978): "De fato, deve-se mensurar o que representa, no quadro da proporcionalidade, as contramedidas. Elas têm por objeto reconstituir a igualdade entre as Partes e as incitar a perseguir a negociação com um desejo mútuo de chegar a um resultado aceitável.” ${ }^{, 465}$ (tradução nossa)

O Tribunal ainda se manifesta sobre duas questões importantes. Primeiro sobre a possibilidade de adotar contramedidas uma vez que forma iniciadas negociações entre as partes. Sobre este ponto, o Tribunal afirma (UNRIAA, Vol. XVIII, p. 484-485, 1978):

\footnotetext{
463 Dans l'état actuel du droit international général, abstraction faite des engagements spécifiques découlant de traités particuliers et notamment des mécanismes institués dans le cadre des organisations internationales, chaque Etat apprécie pour lui-même sa situation juridique au regard des autres Etats. En présence d'une situation qui comporte à son avis la violation d'une obligation internationale par un autre Etat, il a le droit, sous la réserve des règles générales du droit international relatives aux contraintes armées, de faire respecter son droit par des "contre-mesures".

${ }_{464}$ Mais il est généralement admis que les contre-mesures doivent tout d'abord correspondre à une certaine équivalence à la violation alléguée; il s'agit là d'une règle bien connue. Au cours des débats relatifs à cette affaire, les deux Parties ont reconnu qu'elle était applicable à l'espèce et en ont invoqué chacune le bénéfice. D'une manière générale, on a fait observer que l'appréciation de la "proportionnalité" concrète des contre-mesures n'était pas simple et ne pouvait être réalisée que d'une manière approximative. Selon le Tribunal, l'un des problèmes essentiels est de tenir compte- dans un litige entre Etats-non seulement des dommages subis par les compagnies intéressées, mais de l'importance des questions de principe incluses dans la violation alléguée.

${ }_{465}$ En effet, il faut bien mesurer ce que représentent, dans le cadre de la proportionnalité, des contremesures. Elles ont pour objet de reconstituer l'égalité entre les Parties et de les inciter à poursuivre la négociation avec un désir mutuel d'aboutir à un résultat acceptable.
} 
Desnecessário dizer que no recurso às contramedidas há um grande risco de que elas, por seu lado, só resultem numa réplica, provocando, assim, nula escala geral, um agravamento do conflito. As contramedidas deveriam ser, então, uma aposta na sabedoria e não na fraqueza da outra Parte. Elas deveriam ser manejadas com um espírito de grande moderação e acompanhadas de um real esforço para resolver o conflito. Mas o Tribunal arbitral não crê que no estado atual das relações internacionais se possa enunciar uma regra que proíbe as contramedidas no curso de uma negociação, sobretudo se as contramedidas são acompanhadas da oferta de um procedimento permitindo acelerar a solução da disputa. ${ }^{466}$ (tradução nossa)

O Tribunal também discorre sobre a licitude da adoção de contramedidas se a questão foi submetida à arbitragem ou a um Tribunal. Em suas palavras (UNRIAA, Vol. XVIII, p. 485, 1978) :

Muitos juristas entendem que o desenrolar de um procedimento jurisdicional proíbe o recurso a contramedidas, mesmo limitadas pela regra da proporcionalidade. Tal afirmação merece simpatia, mas carece de precisão. Se o procedimento em causa ocorre em um conjunto de instituições assegurando uma certa garantia de execução das obrigações, a licitude das contramedidas desaparece sem dúvida, porém mais pela existência desta garantia do que pelo simples fato da existência de um procedimento jurisdicional. ${ }^{467}$ (tradução nossa)

Ainda para o Tribunal (UNRIAA, Vol. XVIII, p. 485-486, 1978):

Portanto, se um Estado é capaz de intervir, a situação é diferente. Desde que o tribunal disponha de meios para assegurar os fins que justificam as contramedidas, deve-se admitir que os direitos das partes de tomas aquelas medidas, desaparece. Dito de outra forma, a faculdade de um tribunal de decidir sobre medidas conservatórias, quer sua capacidade seja exprimida em seu estatuto, ou seja inerente a este, (ao menos sobre a forma de recomendações sobre essa questão), faz desaparecer a capacidade de tomas contramedidas e pode tornar caducas as contramedidas já tomadas, desde que o tribunal assim

\footnotetext{
466 Il va sans dire qu'il y a dans le recours à des contre-mesures le grand danger qu'à leur tour elles n'engendrent une réplique, provoquant ainsi une escalade génératrice d'une aggravation du conflit. Les contremesures devraient donc être un pari sur la sagesse et non sur la faiblesse de l'autre Partie. Elles devraient être maniées dans un esprit de grande modération et accompagnées d'un réel effort pour résoudre le conflit. Mais le Tribunal arbitral ne pense pas que dans l'état actuel des relations internationales on puisse énoncer une règle qui prohibe les contre-mesures au cours d'une négociation, surtout lorsque ces contre-mesures sont accompagnées de l'offre d'une procédure permettant d'envisager d'accélérer la solution du différend.

467 Beaucoup de juristes ont pensé que le déroulement d'une procédure juridictionnelle interdisait le recours à des contre-mesures, même limitées par la règle de la proportionnalité. Une telle affirmation mérite la sympathie, mais elle appelle des précisions. Si la procédure en cause prend place dans un ensemble d'institutions assurant une certaine garantie d'exécution des obligations, la licéité des contremesures disparaîtra sans doute, mais plus par suite de l'existence de cette garantie que du seul fait de l'existence d'une procédure juridictionnelle.
} 
decida a título de medidas conservatórias. Entretanto, como o objeto e o que foi acordado sobre a capacidade do tribunal de decidir sobre as contramedidas podem se situar em um quadro muito restrito, a faculdade das Partes de tomar ou manter as contramedidas pode, igualmente, não desaparecer na sua totalidade. ${ }^{468}$ (tradução nossa)

\subsection{A CDI e as contramedidas}

Como já mencionado, o termo "contramedidas" tem origem relativamente recente. Ele adquiriu novos contornos e importância a partir dos trabalhos da CDI sobre a responsabilidade internacional do Estado. O termo foi introduzido no anteprojeto de artigos somente em 1979, em substituição ao termo "sanção", inicialmente proposto pelo Relator Especial Ago, para descrever uma das excludentes de ilicitude, previstas no artigo 30 (posteriormente aprovado na versão final do anteprojeto como artigo 22) . A substituição se deu por “divergências de opinião na Comissão em relação ao significado preciso daquele termo no contexto do capítulo $\mathrm{V}$ do anteprojeto, em particular, para deixar claro que a regra não se limitava a sanções que seriam obrigatórias segundo a Carta das Nações Unidas." ${ }^{469}$ (CDI, p. 171, 1979b)

Durante os trabalhos da CDI, este mesmo termo foi utilizado com diferentes significados. Segundo o Drafting Committee, em 1979 (CDI. P. 171, 1979b):

A palavra contramedida, utilizada tanto no título quanto no texto do artigo 30, assim, se estende a outras medidas legítimas (tais como a aplicação da exceptio non adimpleti contractus segundo o artigo $60 \mathrm{da}$ Convenção de Viena) que, no contexto das relações multilaterais ou bilaterais, podem, num sentido mais amplo constituir uma sanção segundo o direito internacional geral. ${ }^{470}$ (tradução nossa)

\footnotetext{
${ }^{468}$ Dès lors que le tribunal est en état d'intervenir, la situation est différente. Pour autant que le tribunal dispose des moyens d'assurer les fins qui justifient des contre-mesures, on doit admettre que le droit des Parties de prendre de telles mesures disparaît. Autrement dit, la faculté d'un tribunal de décider des mesures conservatoires, que cette faculté soit exprimée dans son statut ou impliquée par celui-ci (au moins sous la forme de recommandations portant sur cet objet), fait disparaître la faculté de prendre des contre- mesures et peut rendre caduques des contre-mesures déjà prises, pour autant que le tribunal en décide ainsi à titre de mesure conservatoire. Toutefois, comme l'objet et l'étendue de la faculté du tribunal de décider des contre-mesures peuvent se situer dans un cadre assez étroit, la faculté des Parties de prendre ou de maintenir des contre-mesures peut également ne pas disparaître dans sa totalité.

469 In article 30, the reference to a "sanction", appearing in the original text (A/CN.4/318 and Add. I-3, para. 99), had been deleted, in view of the divergence of opinion in the Commission as to the precise meaning of that term in the context of chapter $\mathrm{V}$ of the draft and, in particular, to make it clear that the rule was not limited to sanctions that were mandatory under the Charter of the United Nations.

470 The word "countermeasures", employed in both the title and the text of article 30, thus extended to other legitimate measures (such as the application of the exceptio non adimpleti contractus under article
} 
A CDI, em seu comentário ao artigo 30, em 1979, as descreveu assim (p. 116, 1979a):

As contramedidas sobre as quais este artigo se trata são medidas cujo objetivo é, por definição, infligir punição ou assegurar o cumprimento - medidas que, sob diferentes condições, infringiriam um direito subjetivo válido do sujeito contra o qual as medidas são tomadas. Essa característica geral serve para distinguir a aplicação destas contramedidas, algumas vezes chamadas de 'sanções', do mero exercício do direito de obter reparação pelo dano. ${ }^{471}$ (tradução nossa)

Riphagen, em seu sexto Relatório (ONU, 1985), propõe um artigo 9, que trataria das represálias, e um artigo 8, que trataria das medidas de reciprocidade (ONU, p. 10 e 11, 1985). Para este Relator Especial (ONU, p. 10, 1985):

Uma primeira distinção deve ser feita entre contramedidas tendo o propósito de restaurar o balanço nas posições do Estado autor e o Estado lesado (reciprocidade), e contramedidas tendo o propósito de influenciar a decisão do Estado autor de cumprir com suas (novas) obrigações (represálias). ${ }^{472}$ (tradução nossa)

Assim, para Riphagen, as contramedidas seriam um conceito que abrangeria tanto as represálias quanto as medidas de reciprocidade, incluindo-se dentre as segundas, as medidas de suspensão ou término de tratados.

Já o Relator Especial Arangio-Ruiz, que era contrário ao uso do termo (ONU, p. 9, n.12, 1988), o utilizava para "indicar essencialmente as assim chamadas reações unilaterais ou 'horizontais' de um ou mais Estados a um ato ilícito internacional, com a exclusão da legítima defesa e da retorsão. ${ }^{473}$ (ONU, p. 12, 1991)

A CDI, em 1992, resume seus debates sobre a questão (ONU, p. 21-22, 1992a):

\footnotetext{
60 of the Vienna Convention) which, in the context of multilateral or bilateral relations, might in a broad sense amount to a sanction under general international law

${ }^{471}$ The countermeasures with which this article is concerned are measures the object of which is, by definition, to inflict punishment or to secure performance- measures which, under different conditions, would infringe a valid and subjective right of the subject against which the measures are applied. This general feature serves to distinguish the application of these countermeasures, sometimes referred to as "sanctions" from the mere exercise of the right to obtain reparation for damage.

472 a first distinction must be made between countermeasures having the purpose of restoring the balance in the positions of the author State and the injured State (reciprocity), and countermeasures having the purpose of influencing a decision of the author State to perform its (new) obligations (reprisal).

473 to indicate essentially the so-called unilateral or "horizontal" reactions of one or more States to an internationally wrongful act, to the exclusion of selfdefence and retortion.
} 
Em relação à terminologia, houve uma concordância geral com a posição do Relator Especial de que, para os propósitos do anteprojeto de artigos, a noção de contramedidas era idêntica a de represálias. A maioria dos membros sentia que o termo 'contramedidas', que era neutro e foi utilizado pela Comissão no artigo 30 da Parte 1 do anteprojeto, assim como pela CIJ e por tribunais arbitrais, devia ser preferido em relação ao termo 'represálias', que transmitia uma ideia de retribuição e, na medida em que ele foi frequentemente associado com o uso da força, adquiriu uma conotação pejorativa com a emergência, no direito internacional, de proibição do uso da força. ${ }^{474}$ (tradução nossa)

A partir de 1992, então, o termo contramedidas é utilizado pela CDI num sentido mais restrito ao que originalmente foi empregado, sendo assim um sinônimo de represálias.

Em seus comentários ao anteprojeto final de artigos, a CDI mantém essa posição. Em suas palavras (ONU, p. 128, 2001ª): ‘O termo 'contramedidas' cobre aquela parte do tema das represálias não associada com conflito armado, e de acordo com a prática moderna e as decisões judiciais o termo é usado neste sentido neste capítulo., ${ }^{, 75}$ (tradução nossa)

Assim para a CDI as contramedidas seriam (ONU, p. 128, 2001a):

Medidas que seriam, de outra forma, contrárias às obrigações internacionais de um Estado lesado frente ao Estado responsável, se elas não fossem tomadas em resposta a um ato internacionalmente ilícito do segundo de modo a procurar a cessação e a reparação. ${ }^{476}$ (tradução nossa)

A CDI ainda diferencia as contramedidas de outras medidas possíveis segundo o Direito Internacional. De acordo com esta (ONU, p. 128, 2001a): "Contramedidas devem ser contrastadas com retorsão, i.e. conduta 'inamistosa' que não é inconsistente com

\footnotetext{
${ }^{474}$ As far as terminology is concerned, there was general agreement with the Special Rapporteur's view that, for the purposes of the draft articles, the notion of countermeasures was identical to that of reprisals. Most members felt that the term "countermeasures", which was neutral and had been used by the Commission in article 30 of part 1 of the draft as well as by ICJ and by arbitral tribunals, should be given preference over the term "reprisals", which conveyed an idea of retribution and, inasmuch as it had often been associated with the use of force, had acquired a pejorative connotation with the emergence in international law of the prohibition of the use of force.

${ }^{475}$ The term "countermeasures" covers that part of the subject of reprisals not associated with armed conflict, and in accordance with modern practice and judicial decisions the term is used in that sense in this chapter.

${ }^{476}$ measures that would otherwise be contrary to the international obligations of an injured State vis-à-vis the responsible State, if they were not taken by the former in response to an internationally wrongful act by the latter in order to procure cessation and reparation.
} 
nenhuma obrigação internacional do Estado nela engajado mesmo que ela possa ser uma resposta a um ato internacionalmente ilícito.,477

Ainda para a CDI (ONU, p. 128, 2001a):

O termo sanção é frequentemente usado como equivalente a ação tomada contra um Estado por um grupo de Estados ou ordenada por uma organização internacional. Mas o termo é impreciso: O Capítulo VII da Carta das Nações Unidas se refere apenas a medidas, mesmo que estas possam compreender um grande espectro de atos, incluindo o suo da força armada (Artigos 39, 41 e 42). ${ }^{478}$ (tradução nossa)

Finalmente, segundo a Comissão (ONU, p. 128, 2001a):

Contramedidas devem ser claramente distinguidas do término ou suspensão das relações de um tratado tendo em vista a violação material do tratado por outro Estado, como previsto pelo artigo 60 da Convenção de Viena de 1969. Quando um tratado é terminado ou suspenso de acordo com o artigo 60, as obrigações legais substantivas dos Estados partes serão afetadas, mas isto é bem diferente da questão da responsabilidade que pode já ter surgido desta violação. ${ }^{479}$ (tradução nossa)

A CDI, em seus comentários ao anteprojeto final de artigos sobre a Responsabilidade Internacional do Estado claramente contradiz a posição do Drafting Committee, de 1979, e mesmo o seu comentário sobre o artigo 30, no mesmo ano. Primeiro, ela faz uma distinção entre contramedidas e a exceptio non adimpleti contractus, quando, em 1979, a segunda estaria contida na primeira. E segundo, ela estabelece que o objetivo das contramedidas é a cessação do ato ilícito ou a reparação, deixando de lado a função punitiva prevista nos comentários de 1979.

A novidade do termo, aliada a alteração de seu significado ao longo dos trabalhos da CDI fez com que inúmeros doutrinadores preferissem continuar a usar a expressão represálias nas suas obras. E tendo em vista que, para CDI, as expressões contramedidas

\footnotetext{
477 Countermeasures are to be contrasted with retorsion, i.e. "unfriendly" conduct which is not inconsistent with any international obligation of the State engaging in it even though it may be a response to an internationally wrongful act.

${ }^{478}$ The term "sanction" is also often used as equivalent to action taken against a State by a group of States or mandated by an international organization. But the term is imprecise: Chapter VII of the Charter of the United Nations refers only to "measures", even though these can encompass a very wide range of acts, including the use of armed force (Articles 39, 41 and 42).

${ }^{479}$ Countermeasures are to be clearly distinguished from the termination or suspension of treaty relations on account of the material breach of a treaty by another State, as provided for in article 60 of the 1969 Vienna Convention. Where a treaty is terminated or suspended in accordance with article 60 , the substantive legal obligations of the States parties will be affected, but this is quite different from the question of responsibility that may already have arisen from the breach.
} 
e represálias são sinônimas, uma análise do tratamento que a doutrina faz das represálias se faz necessária.

\subsection{Contramedidas e represálias}

De acordo com Nys, (1894, p.64):

A doutrina moderna compreende sob o termo represália, derivado do italiano ripresaglie, de ripreso, tomada, de riprendere, retomar, as medidas de fato às quais um governo utiliza vis-à-vis outro Estado, os súditos deste último ou seus bens, com o fim de constranger a potência estrangeira a resolver as questões em litígio, ou obter uma justa satisfação, ou de fazer a justiça necessária." ${ }^{480}$ (tradução nossa)

Nys adota definição semelhante a dos primeiro internacionalistas modernos, voltada mais a apreensão de bens e pessoas. A função destas medidas seria coercitiva, reparatória ou de punitiva ${ }^{481}$.

Segundo Anzilotti (p. 450, 1935) represálias são "atos objetivamente ilícitos pelos quais um Estado reage contra o dano que lhe foi causado por outro Estado." ${ }^{\star 82}$ (tradução nossa)

$\mathrm{Na}$ definição dada por este autor, destacam-se dois elementos, um ato a priori ilícito, e um dano causado por outro Estado. Este dois elementos estariam ligados por um nexo causal.

La Brière, por sua vez, escreve (p.241, 1928):

As represálias, nós diremos, são atos de atos de constrangimento e de violência, derrogando as regras ordinárias do direito das gentes, e feitas com o objetivo incitar o adversário a reparar ou, ao menos a fazer cessar a partir de então, as violências injustificadas pelas quais ele é responsável. ${ }^{483}$ (tradução nossa)

\footnotetext{
${ }^{480}$ La doctrine moderne comprend sous le terme de représailles, derivé de l'italien ripresaglie, de ripreso, repris, de riprendere, rependre, toutes les mesures de fait dont un gouvernement se sert vis -à-vis d'un outre État, des sujets de ce dernier ou de leurs biens, dans le but de contraindre la puissance étrangère à faire droit sur les questions en litige, ou d'en obternir une juste satisfaction, ou de se faire au besoin justice.

${ }^{481}$ Uma análise mais pormenorizada das funções das contramedidas, e por conseguinte, das funções das represálias será feita mais adiante.

${ }^{482}$ actos objetivamente ilícitos por los cuales un Estado reacciona contra el daño que la ha sido causado por otro Estado.

483 Les représailles, dirons-nous, sont des actes de contrainte et de violence, dérogeant aux règles ordinaires du droit des gens, et accomplis en vue de déterminer l'adversaire à réparer ou, au moins à faire cesser désormais les violences injustifiées dont il est responsable.
} 
As represálias seriam assim, medidas utilizando ou não a força, contra as normas de direito internacional, com a função de reparar (função reparatória), ou de fazer cessar o ato ilícito anterior (função coercitiva).

Já o Institut de Droit International, em resolução de 1934, afirma:

As represálias são medidas de constrangimento, derrogatórias das regras ordinárias do Direito das Gentes, tomadas por um Estado, em seguida a atos ilícitos cometidos, com prejuízo seu, por um outro Estado e tendo por fim impor a este, por meio de um dano, o respeito ao direito. ${ }^{484}$ (tradução nossa)

No entendimento do Institut, as represálias seriam atos contra o Direito Internacional, tomadas por um Estado, em resposta ao ilícito de outro Estado. Elas teriam uma função punitiva pois, pretenderiam, através de um dano, impor o cumprimento do direito.

Para Oppenheim (p. 141, 1966):

As represálias são aqueles atos nocivos e, por outra parte, internacionalmente ilegais de um Estado contra outro, permitidos excepcionalmente, com o objetivo de forçar o último a admitir uma solução satisfatória de uma controvérsia criada por seu próprio delito internacional. [...] as represálias são atos, por vezes, ilegais, executados por um Estado com o objetivo de obter justiça por um delito internacional mediante a execução do direito por si mesmo. ${ }^{485}$ (tradução nossa)

As represálias, para este professor, seriam atos nocivos e ilegais cujo objetivo seria forçar um Estado autor de um delito internacional a uma conciliação ou seja , elas teriam uma função coercitiva.

Nas palavras de Ago, (p. 536, 1939):

\footnotetext{
${ }^{484}$ Les représailles sont des mesures de contrainte, dérogatoires aux règles ordinaires du Droit des Gens, prises par un Etat à la suite d'actes illicites commis à son préjudice par un autre Etat et ayant pour but d'imposer à celuicci, au moyen d'un dommage, le respect du droit. (Institut de Droit International, 1934, disponível em : http://www.idi-iil.org/idiF/resolutionsF/1934 paris 03 fr.pdf. Acesso em: 23 out. 2010.

${ }^{485}$ Las represalias son aquellos actos nocivos y por otra parte internacionalmente ilegales de un Estado contra otro permitidos excepcionalmente al objeto de forzar al último a admitir un arreglo satisfactorio de una controversia creada por su proprio delito internacional. [...] las represalias son actos, en ocasiones ilegales, ejecutados por un Estado con objeto de obtener justicia por un delito internacional mediante la ejecución del derecho por sí mismo.
} 
Estas represálias consistem precisamente em uma lesão de um direito subjetivo do Estado culpável, lesão, cuja extensão deve, segundo a opinião que parece mais correta, se medir pela lesão sofrida. A conduta do Estado que exerce as represálias seria, em outra circunstância, um ato ilícito internacional, mas ela não é, pela circunstância particular de seu caráter de sanção legítima de um dano, impede que um delito possa ser imputado ao sujeito que a tomou. $\mathrm{O}$ caráter de ilicitude é excluído por esta conduta, assim como a ação do carrasco que executa o condenado a morte. ${ }^{486}$ (tradução nossa)

O Relator Especial da CDI sobre responsabilidade internacional, em obra anterior aos seus trabalhos na Comissão insere a noção de proporcionalidade no próprio conceito de represália. Assim, uma represália, só pode ser considerada como tal, se for uma lesão a um direito subjetivo de um Estado culpável por um delito internacional, lesão esta que deve ser proporcional a lesão anterior sofrida. Em caso de desproporcionalidade, a lesão perderia seu caráter de represália. Outro ponto relevante, seria a caracterização das represálias como sanções internacionais, reconhecendo então, ainda que indiretamente um caráter punitivo ao instituto.

Verdross, por outro lado, escreve (p. 34, 1967):

Entende-se por represália uma ingerência jurídica de um Estado, lesionado em seus direitos, contra bens jurídicos particulares do Estado culpável para induzi-lo a que repare o ato ilícito ou a que desista no futuro de tais ações. Perseguem, em geral, a primeira finalidade as represálias pacíficas, e a segunda, as represálias bélicas. ${ }^{487}$ (tradução nossa)

Para este autor, a represália seria uma ingerência jurídica contra bens jurídicos particulares do Estado culpável. Este conceito recorda, de uma certa forma, aquele dos primeiros internacionalistas, que focavam este instituto na apreensão de bens, mais do que na ideia de violação de uma obrigação internacional. Ainda, para Verdross, as represálias teriam duas funções, a primeira reparatória, a segundo preventiva (garantia de não repetição)

\footnotetext{
${ }^{486}$ Ces représailles consistent précisément dans une lésion d'un droit subjectif de l'Etat coupable, lésion dont l'étendue doit d'après l'opinion qui paraît plus correcte, se mesurer sur la lésion subie. La conduite de l'Etat qui exerce les représailles serait, entoute autre circonstance, un fait illicite international, mais elle ne l'est pas, car la circonstance particulière de son caractère de sanction légitime d'un tort empêche qu'un délit puisse être imputé au sujet qui l'a tenue. Le caractère d'illicéité est exclu pour cette conduite, tout de même que pour l'action du bourreau qui exécute le condamné à mort.

${ }^{487}$ Se entiende por represalia una injerencia jurídica de un Estado, lesionado en sus derechos, contra bienes jurídicos particulares del Estado culpable para inducirle a que repare el acto ilícito o a que desista en el futuro de tales acciones. Persiguen, en general, la primera finalidad las represalias pacificas, y la segunda, las represalias bélicas (XIX, A, VIII, b)
} 
Segundo Reuter (p. 463, 1983): “As represálias são constituídas por atos que, considerados isoladamente, seriam ilícitos, mas que encontram sua justificação no fato de que eles são uma resposta a um ato ilícito do qual o ator das represálias foi vítima." ${ }^{488}$ (tradução nossa)

A definição de Reuter contém os dois elementos essenciais das contramedidas, um ato internacional a priori ilícito, e o nexo causal entre este ato e uma conduta ilícita anterior, do Estado contra o qual o segundo ato é dirigido.

Nessa mesma linha segue Shaw (p. 1023, 2005): "Represálias são atos que são em si mesmos ilegais e que foram adotados por um Estado em retaliação pela comissão de um ato ilegal anterior pelo outro Estado." 489 (tradução nossa)

E também Ramos (p. 334, 2004): "Define-se represália como sendo uma conduta, que deveria ser considerada ilícita, mas que é tida como lícita somente por ter sido praticada como reação ao descumprimento anterior de uma obrigação internacional."

Nquyên e Dinh têm entendimento parecido. Segundo eles (p. 896, 1999): “As represálias podem ser armadas e não armadas e, sobretudo, elas se exercem por meios que, em outras circunstâncias, seriam ilícitos." ${ }^{490}$ (tradução nossa) A diferença é que este autores reconhecem validade das represálias armadas

Mello segue uma linha parecida ao escrever (p. 1105, 1992):

As represálias são medidas empregadas por um Estado em relação a outro que tenha violado seus direitos. Elas, ao contrário da retorsão, violam norma internacional. Existem em tempos de paz e da guerra e visam a fazer com que o Estado autor da ofensa respeite o DI. Ela é uma forma de autotutela.

Brownlie, por outro lado, não adota uma posição definida sobre as represálias. Sobre o tema ele escreve (p. 466, 1995): "Represálias armadas são claramente excluídas pelo direito da Carta das Nações Unidas, mas a propriedade de represálias econômicas, e a alegação de necessidade econômica ainda são questões controversas."491 (tradução nossa)

\footnotetext{
${ }^{488}$ Les représailles sont constituées par des actes qui, considérés isolément, seraient illicites, mais qui trouvent leus justification dans le fait qu'ils sont une réponse à un acte illicite dont l'auteur des représailles a été victime.

${ }^{489}$ Reprisals are acts which are in themselves illegal and have been adopted by one state in retaliation for the commission of an earlier illegal act by another state.

${ }^{490}$ Les représailles peuvent être armées ou non armées et, surtout, elles s'exercent par des moyens qui, dans d'autres circonstances, seraient illícites.

${ }^{491}$ Armed reprisals are clearly excluded by the law of the United Nation Charter, but the property of economic reprisals and the plea of economic necessity is still a matter of controversy.
} 
Rezek, por sua vez, entende que as represálias estão "sempre carregadas de ilicitude" (p. 378, 1995) Elas ainda (REZEK, p. 378, 1995):

constituem à evidência uma afronta ao direito (se assim não fosse, não haveria represália, mas mera retorsão). Contudo o Estado que as pratica propende a alegar sua prerrogativa de autodefesa, intentando excusar a ilicitude do seu gesto com a invocação da ilicitude daquele outro procedimento, alheio, que lhe deu causa

Este autor assim as define (REZEK, p. 377-378, 1995):

Represália, por seu turno, é o ato ilícito com que certo Estado pretende penitenciar outro ilícito praticado por seu homólogo: assim certas injunções armadas, mas também outras atitudes não exatamente agressivas - porém não menos ilegais - , como a penhora forçada dos bens invioláveis de um escritório consular.

Assim, Rezek não só considera as represálias medidas ilícitas, como atribui a estas uma função punitiva.

Das definições adotadas por estes doutrinadores, verificamos dois pontos principais em comum. O primeiro, a adoção, por parte de um Estado, de uma conduta que vai contra suas obrigações segundo o Direito Internacional. O segundo ponto, seria o nexo causal entre esta conduta e uma outra conduta do Estado contra o qual a primeira foi adotada, conduta esta que seria internacionalmente ilícita.

Os doutrinadores atribuem às represálias a mais diversas funções. Dentre as principais podemos destacar as funções coercitiva, compensatória, e punitiva, que serão examinadas mais a frente.

\subsection{Definição de contramedidas}

Apesar da novidade do termo e da mudança de significado deste ao longo dos trabalhos da CDI, alguns autores de dedicaram a tratar do instituto das contramedidas. A doutrina, em geral, em especial nas obras produzidas antes de 1991 e 1992, dava uma definição mais abrangente ao termo.

Assim , para Leben (p. 17, 1982):

Assim, então, com a expressão 'contramedidas' pode-se cobrir um grande campo semântico que engloba, simultaneamente, as 
represálias, e retorsões, os boicotes e os embargos, assim como outras sanções econômicas ou financeiras, ou ao menos isso que se designa por tal na linguagem corrente. ${ }^{492}$ (tradução nossa)

Esse autor entende as contramedidas como um sinônimo de sanção, tendo em vista que a CDI primeiramente utilizouras em substituição a sanção no artigo 22, antigo artigo 30, proposto pelo Relator Especial Ago, em 1979.

Assim, nas palavras de Leben (p. 17, 1982):

O mecanismo do artigo 30 é um mecanismo de sanção da violação do direito internacional, mesmo se a Comissão prefere reservar este termo às decisões das organizações internacionais e, em particular, àquelas da Organização das Nações Unidas. ${ }^{493}$ (tradução nossa)

A ideia das contramedidas como sanção no Direito Internacional segue a linha do anteprojeto de artigos tal como aprovado em primeira leitura, que previa uma diferenciação entre delitos e crimes internacionais, os crimes se referindo à violações graves ao Direito Internacional que afetassem a comunidade internacional como um todo.

Nessa mesma linha segue Chazournes (p. 21, 1992), para quem:

O vocábulo contramedidas recobre diferentes tipos de medidas unilaterais de reação: que se trate de medidas de represália, de medidas de retorsão, de medidas de reciprocidade, de sanções institucionais ou de medidas de suspensão ou extinção de um tratado. $^{494}$ (tradução nossa)

Também Nquyên e Dinh escrevem (p. 895, 1999):

Conforme a terminologia adotada pela CDI, utilizar a expressão 'contramedidas' para designar o conjunto de atos pelos quais um Estado responde a uma medida tomada por um outro Estado e a qual

\footnotetext{
${ }^{492}$ Aisi donc, avec l'expression 'contre-mesure', on peut couvrir un large champ sémantique qui englobe tout à la fois les représailles et les rétorsions, les boycotts et les embargos ansi que les autres 'sanctions' économiques ou financières, du moins ce que l'on désigne par là dans le language courant.

${ }^{493}$ C'est que le mécanisme de l'art. 30 est bien un mécanisme de sanction de la violation du droit international même si la Comission a préféré réserver ce terme aux décisions des organisations internationales et en particulier à celles de l'Organisation des Nations Unies.

${ }^{494}$ Le vocable de contre-mesures recouvre différents types de mesures unilatérales de réaction: qu'ils s'agisse des mesures de représailles, des mesures de rétorsion, des mesures de réciprocité, des sanctions intitutionnelles ou des mesures de suspension ou d'extinction d'un traité.
} 
ele contesta o mérito. ${ }^{495}$ [...] Segundo as circunstâncias de sua adoção e seus caracteres, estas contramedidas constituem atos de retorsão ou represália, ou sanções. ${ }^{496}$ (tradução nossa)

Já para Zoller (p. 75, 1984):

Contramedidas podem ser definidas como medidas de implementação do direito, que consistem em uma dispensa temporária de cumprir com o direito. Em relação aos remédios unilaterais clássicos dos períodos de paz, este termo deveria teoricamente compreender a suspensão dos tratados e as represálias; quer dizer, duas medidas temporárias que vão além da equivalê ncia e que seriam, em princípio, ilícitas, se não fossem tomadas como reação a uma ofensa internacional. ${ }^{497}$ (tradução nossa)

Zoller, seguindo a posição do Drafting Committee, em 1979, e do Relator Especial Riphagen, em 1985, inclui entre as contramedidas, a suspensão dos tratados.

Alland, em sua obra de 1994, segue uma linha parecida. Este autor, seguindo também a posição de Riphagen, insere dentre as medidas de reciprocidade, o término e a suspensão dos tratados. Ao discorrer sobre a tese de fragmentação das contramedidas, ele menciona a corrente que defende (ALLAND, p. 53, 1994) "uma distinção entre as 'contramedidas convencionais' e as 'contramedidas não convencionais'."498 (tradução nossa) Ainda, para ele (ALLAND, p. 53, 1994): “as primeiras se caracterizariam pelo fato de que o ilícito inicial e a reação intrinsecamente ilícita que dele deriva se situam todos os dois no interior de um circulo convencional ao qual pertencem o autor ('culpável') e o Estado que reage." ${ }^{499}$ (tradução nossa)

Alland, no entanto, defende a unicidade de fenômeno das contramedidas (p. 5659, 1994). Para ele (p. 56, 1994): “Opor a reciprocidade e as contramedidas não tem

\footnotetext{
495 Em nota a este comentário ressalta-se a posição da CDI definindo contra-medidas como medidas ilícitas em circunstâncias normais, e a posição da doutrina recente, que adotaria a definição mais abrangente de contramedida.

496 Conformément à la terminologie adoptee par la CDI, on peut retenir l'expression 'contre-mesures' pour désigner l'ensemble des actes par lesquels un État riposte à une mesure prise par un autre État et dont il conteste le bien-fondé. [...] Selon les circonstances de leur adoption et leurs caractères, ces contremesures constituent des actes de rétorsion ou de représaille, ou des sanctions.

497 Countermeasures can be defined as law enforcement measures which consist in a temporary dispensation from complying with the law. In relation to the classic unilateral peacetime remedies, this term should theoretically encompass the suspension of the treaty and the reprisals; that is to say the two temporary measures which go beyond equivalence and which would in principle be unlawful if they were not resorted to as reactions to an international offence.

498 Une distiction entre les 'contre-mesures conventionnelles' et les 'contre-mesures non conventionnelles'.

${ }^{499}$ Les pemières se caractérisent par le fait que l'illicite initial et la réaction intrinsèquement illicite qui en dérive se situent tous les deux à l'interieur d'un cercle conventionnel auquel appartinnent l'Etat auteur ('coupable') et l'Etat réagissant.
} 
sentido uma vez que uma pode ser o motor das outras, e vê mal aquele que ensina, de modo geral, a oposição de uma 'qualidade essencial' e de uma instituição."500 (tradução nossa)

Nos trabalhos mais recentes, as contramedidas já aparecem como um sinônimo de represálias. Assim, segundo Sicilianos (p. 252, 1990): 'Por contramedidas entende-se medidas ilícitas per se cuja ilicitude é susceptível de ser excluída devido a uma infração anterior à qual ela responde." ${ }^{501}$ (tradução nossa)

Também para Alland, em artigo mais recente (p. 1221, 2002): 'Contramedidas são respostas a um ato internacionalmente ilícito. Elas são intrinsecamente ilícitas, mas são justificadas pela alegada falha inicial em relação a qual é uma resposta."502 (tradução nossa)

Por fim, nas palavras de Proukaki (p. 68, 2010):

Contramedidas podem ser definidas como medidas pacíficas tomadas por Estados em violação de suas obrigações internacionais segundo o direito internacional, em resposta a um ilícito internacional cometido por outro Estado. Nessas circunstâncias excepcionais, a ilicitude do ato, e consequentemente a responsabilidade do Estado recorrendo a contramedidas, é precluída. ${ }^{503}$ (tradução nossa)

Assim, existem três correntes doutrinárias definindo o instituto das contramedidas. A primeira, entende as contramedidas como um sinônimo de sanção, dando uma abrangência maior ao termo, que incluiria as medidas de retorsão, de represália e as sanções estabelecidas por organizações internacionais. Tal corrente se basearia no emprego do termo pela CDI em 1979, substituindo o termo sanção no artigo 22, antigo artigo 30, no anteprojeto de artigos sobre a responsabilidade internacional do Estado.

A segunda corrente, entende as represálias como abrangendo as medidas de represálias e as medidas de reciprocidade, incluindo as medidas de suspensão ou de

\footnotetext{
500 Opposer la réciprocité et les contre-mesures n'a guère de sens puisque l'une peut être le moteur des autres, et voit mal ce que peut apprendre, de façon générale, l'opposicion d'une 'qualité essentielle' et d'une institution.

501 "par contre-mesures on entend des measures illicites per se dont l'illicéité est susceptible d'être exclue à cause de l'infraction préalable à laquelle elles répondent.

502 Countermeasures are responses to an internationally wrongful act. They are intrinsically unlawful, but are justified by the alleged initial failing to which they were a response.

503 Countermeasures can be defined as peaceful measures taken by states in violation of their obligations under international law in response to an international wrongdoing committed by another state. In these exceptional circums tances, the wrongfulness of the act, and consequently the responsibility of the state resorting to countermeasures, is precluded.
} 
término dos tratados violados. Essa corrente se baseia no emprego do termo pelo Drafting Committee, em 1979 e pelo Relator Especial Riphagen, em 1985, no âmbito dos trabalhos da CDI sobre a responsabilidade internacional dos Estados e também na sentença arbitral do caso Rainbow Warrior, entre França e Nova Zelândia de 1990 (UNRIAA, Vol XX, p. 251), que estabelecia:

\begin{abstract}
A razão é de que os princípios gerais do Direito Internacional relativos à responsabilidade do Estado são igualmente aplicáveis no caso de violação de uma obrigação de um tratado, desde que no campo de direito internacional não há distinção entre responsabilidade contratual e responsabilidade delitual, de forma que qualquer violação por um Estado de uma obrigação, qualquer que seja sua origem, da origem à responsabilidade internacional e consequentemente, ao dever de reparação. ${ }^{504}$ (tradução nossa)
\end{abstract}

Ao estabelecer que não existe diferença entre a responsabilidade contratual e delitual, o Tribunal Arbitral indiretamente qualifica como artificial a divisão entre medidas de reciprocidade e medidas de represália.

Para a terceira corrente, as contramedidas seriam um sinônimo de represálias não militares, sendo seu significado, então, mais restrito. Esta corrente se apoia na posição final da CDI sobre o tema, expressada em seus comentários ao anteprojeto aprovado em segunda leitura.

Para fins deste trabalho, adotaremos o conceito mais restrito de contramedidas, entendendo-o como sinônimo de represálias não militares ou pacíficas. Isto porque, em que pese o parecer contrário de alguns membros da própria CDI, e mesmo a sentença arbitral do caso Rainbow Warrior, é esta definição mais restrita a que se depreende do artigo 22 do Anteprojeto de artigos sobre a responsabilidade internacional do Estado, adotado na sua versão final pela CDI em 2001, e anexado na Resolução A/RES/56/83 de 2002 da Assembleia Geral em sua 56 sessão (NAÇÕES UNIDAS, 2002). Também é esta definição que se infere mais claramente dos comentários da CDI a este anteprojeto, publicados em seu Relatório à Assembleia Geral em 2001.

Em relação às medidas de reciprocidade, embora a CDI não inclua medidas de término e suspensão dos tratados dentre as contramedidas (p. 128-129, 2001a), ela

\footnotetext{
504 The reason is that the general principles of International Law concerning State responsibility are equally applicable in the case of breach of treaty obligation, since in the international law field there is no distinction between contractual and tortious responsibility, so that any violation by a State of any obligation, of whatever origin, gives rise to State responsibility and consequently, to the duty of reparation.
} 
insere neste conceito as chamadas "contramedidas recíprocas", que seriam, em suas palavras (p. 129, 2001a): “contramedidas que envolvem a suspensão do cumprimento de obrigações em relação ao Estado responsável, 'se tais obrigações correspondem a, ou estão diretamente ligadas à obrigação violada'."505 (tradução nossa)

$\mathrm{Na}$ visão da CDI, estas medidas, que iriam contra uma ou mais obrigações estabelecidas no tratado, seriam represálias, justamente porque tomadas durante a vigência das obrigações estabelecidas no tratado ou na norma violada.

No caso de suspensão ou de término do tratado, além da justificativa legal ser baseada em outra norma do Direito Internacional (artigo 60 da Convenção de Viena sobre o Direito dos Tratados de 1969), a suspensão ou término do tratado, seguindo as normas de Direito Internacional, não poderia ser considerada como ilícita, nem mesmo a priori, sendo um direito do Estado de acordo com normas convencionais e consuetudinárias e estando, portanto, excluída do conceito de contramedidas.

Em suma, medidas tomadas contrariando uma ou mais obrigações do tratado originariamente violado pelo Estado responsável, ainda em vigor, seriam contramedidas recíprocas. Já medidas de suspensão ou término do tratado como um todo, baseadas no artigo 60 da Convenção de Viena de 1969, seriam medidas lícitas, ou seja, não contrariariam obrigações internacionais do Estado segundo o Direito Internacional e, portanto, não poderiam ser consideradas como contramedidas.

Assim, para fins deste trabalho, considera-se contramedidas aquelas medidas adotadas em violação a uma obrigação internacional, mas cuja ilicitude é excluída por serem respostas a um ato ilícito internacional anterior do Estado contra o qual elas são adotadas.

\subsection{Elementos das contramedidas}

Segundo Alland (p. 59, 1994): “As contramedidas são um mecanismo. Pode-se descrever este mecanismo como formado por três peças relevantes, uma de ordem

\footnotetext{
505 to countermeasures which involve suspension of performance of obligations towards the responsible State "if such obligations correspond to, or are directly connected with, the obligation breached".
} 
intelectual, enquanto que as outras duas se situando na ordem das coisas tangíveis." (tradução nossa)

Para ele (p. 59, 1994): “Os dois últimos polos são constituídos por dois atos ou comportamentos ilícitos sucessivos (o inicial e o derivado), no sentido em que eles são objetivamente contrários às obrigações dos diferentes sujeitos aos quais eles são imputáveis." ${ }^{507}$ (tradução nossa)

E ainda (p. 59, 1994): “O polo intelectual é formado pela articulação destes dois fatos ilícitos, resultando da operação de qualificação pela qual o primeiro destes fatos se torna o motivo do segundo, que se apresenta, portanto, como uma reação., 508 (tradução nossa)

Alland considera, então, que as contramedidas são formadas por três elementos, dois elementos fáticos, sendo, estes duas condutas ilícitas sucessivas, e um elemento intelectual, que seria a articulação destes dois elementos de forma que o segundo seria uma reação em relação ao primeiro.

De fato, se considerarmos que as contramedidas são "medidas adotadas em violação a uma obrigação internacional, mas cuja ilicitude é excluída por serem respostas a um ato ilícito internacional anterior do Estado contra o qual elas são adotadas", temos que seus elementos são duas condutas violando as obrigações internacionais dos Estados que as adotam (elemento objetivo), e um elemento subjetivo, que seria o nexo causal entre a primeira conduta e a segunda conduta.

Uma questão que se pode colocar seria se a primeira conduta, ou seja, o ato ilícito inicial que levou o Estado que adotar a contramedida seria um elemento das contramedidas ou uma condição de validade.

Tendo em vista que a contramedida se caracteriza justamente por seu caráter reativo, o ato ilícito inicial seria um elemento desta, pois está vinculado a segunda conduta por um nexo causal, sendo assim, uma condição de existência.

\footnotetext{
${ }^{506}$ Les contre-mesures sont um mécanisme. On peut décrire ce mécanisme comme formé de trois pièces relevant, pour l'une de l'ordre intellectuel, tandis que les deux autres s'enracinent dans l'ordre des choses tangibles.

${ }^{507}$ Ces deux derniers pôles sont constitués par deux actes ou comportement illicites successifs (l'initial et le dérivé), en ce sens qu'ils sont objectivement contraires aux obligations des différents sujets à qui ils sont imputables.

${ }^{508}$ Le pôle 'intellectuel' est forme del'articulation de ces deux faits illicites, résultant de l'opération de qualification par laquelle le premier de ces faits devient le motif du second, qui se présente dès lors comme une réaction.
} 
Por outro lado, a verificação da real existência do ato ilícito anterior terá, certamente, consequências em relação à legalidade da contramedida e, nesta perspectiva, o ato ilícito inicial também é uma condição para a validade do ato.

Outro ponto relevante é a necessidade da existência de um dano, para que se possa adotar as contramedidas. A CDI, a exemplo do que foi estabelecido nos artigos em relação à responsabilidade internacional, não faz ne nhuma referência à necessidade de dano para a adoção de contramedidas. Se por um lado, ela só estabelece claramente o direito de adotá-las em relação ao Estado diretamente lesado, por outro a definição de Estado lesado, contida no artigo 42 do anteprojeto, não faz menção nenhuma à necessidade de dano. A CDI também não estabelece claramente uma posição em relação às contramedidas tomadas por Estados não diretamente lesados, o que fortalece ainda mais o argumento de que o dano não é um dos elementos necessários às contramedidas

Assim, consideramos elementos das contramedidas:

a) os elementos objetivos: o ato internacionalmente ilícito inicial e o ato, subsequente, violando as obrigações internacionais do Estado em relação ao Estado autor do ato inicial.

b) o elemento subjetivo: o nexo causal entre o ato internacionalmente ilícito inicial e o ato violando as obrigações internacionais do Estado em relação ao Estado autor do primeiro ato.

\subsection{Funções das contramedidas}

A doutrina considera que as contramedidas exercem diversas funções.

Para Nys as contramedidas têm (p. 64, 1894): “o fim de constranger a potência estrangeira a resolver as questões em litígio, ou obter uma justa satisfação, ou de fazer a justiça necessária”. (tradução nossa) Elas teriam assim uma função coercitiva, reparatória ou punitiva.

Já segundo La Brière elas teriam como (p. 241, 1928) "objetivo incitar o adversário a reparar ou, ao menos a fazer cessar a partir de então, as violências injustificadas pelas quais ele é responsável" (tradução nossa) (função reparatória e coercitiva) 
De acordo com o Institut de Droit International entende que estas têm uma função punitiva (1934), "tendo por fim impor a este, por meio de um dano, o respeito ao direito". (tradução nossa)

Na visão de Openheim as contramedidas têm o (p. 141, 1966) "objetivo de forçar o último a admitir uma solução satisfatória de uma controvérsia criada por seu próprio delito internacional." (tradução nossa) (função coercitiva)

Já para Ago tendo em vista (p. 536, 1939) “seu caráter de sanção legítima de um dano" (tradução nossa), elas teriam função punitiva.

Verdross, por sua vez, entende que estas devem (p. 34, 1967): 'induzi-lo [ao Estado responsável] a que repare o ato ilícito ou a que desista no futuro de tais ações" (tradução nossa), reconhecendo, assim, uma função reparatória e preventiva ou repressiva.

Zoller (p. 47 et seq., 1984) ao tratar dos remédios unilaterais pacíficos, descreve três funções destes: a reparação, a coerção e a punição. Segundo esta autora (p. 62, 1984): “contramedidas não podem ser medidas de reparação como tais - especialmente medidas de reciprocidade, que são sempre legais - ou medidas de punição, que nunca são legais. Elas só podem ser medidas de coerção." ${ }^{\text {509 }}$ (tradução nossa)

Já para Chazournes (p. 52, 1992) "um Estado pode recorrer às contramedidas para fins de compensação, mas também, para fins de coerção ou ainda para impor uma sanção aflitiva" ${ }^{, 510}$. (tradução nossa)

Hoogh (p. 215-220, 1996) embora admita a função reparatória e mesmo coercitiva das contramedidas, não admite que estas possam ter uma função punitiva.

Elagab (p. 45-47, 1988), por outro lado, prevê as seguintes funções: autotutela, reciprocidade, pressão para induzir uma rápida solução da disputa ou vingança.

Todas essas funções, entretanto, podem ser enquadradas nas três principais funções das contramedidas. Medidas visando a autotutela podem ser consideradas medidas reparatórias, coercitivas ou punitivas, dependendo das circunstâncias. As medidas de reciprocidade geralmente são medidas reparatórias, as medidas de pressão por uma solução da disputa são medidas coercitivas e medidas visando a vingança, nada mais são do que medidas punitivas.

\footnotetext{
${ }^{509}$ Countermeasures cannot be either measures of reparation as such - especially measures of reciprocity, which are always lawful - or measures of punishment, which are never lawful. They can only be measures of coercion.

${ }^{510}$ Un Etat peut recourir à des contre-mesures à fin de compensation, mais aussi à fin de coercition ou encore pour imposeer une sanction afflictive.
} 
Em resumo, as funções das contramedidas, segundo a doutrina seriam:

a) Função reparatória: é a função que tem como objetivo reparar os efeitos do ato internacionalmente ilícito seja por meio da restituição, da compensação ou da satisfação.

b) Função coercitiva: é a função que tem como objetivo pressionar o Estado contra o qual elas foram tomadas a adotar uma conduta determinada, seja ela aderir a um procedimento de solução de controvérsias, ou cessar a conduta internacionalmente ilícita.

c) Função repressiva: é a função que tem como objetivo coibir o comportamento ilícito, e assim, assegurar o cumprimento das normas de Direito Internacional (law enforcement measures), seja por meio da punição do ato ilícito (função punitiva), como por meio da prevenção, garantindo que o ilícito não volte a acontecer (garantias de não repetição).

A função reparatória seria a principal função das contramedidas. Ela teria como objetivo restabelecer o equilíbrio nas relações entre o Estado que agiu ilicitamente e o que tomou as contramedidas. A CDI considera as contramedidas uma consequência instrumental da responsabilidade internacional, no sentido em que ela só existe para assegurar que as consequências "substanciais" desta responsabilidade sejam implementadas. Por isso o artigo 49 do anteprojeto, que trata das contramedidas estabelece que estas têm o objetivo de induzir o Estado responsável "a cumprir com suas respectivas obrigações dispostas na Parte Dois", ou seja obrigações de cessação do ato ilícito e de reparação.

A reparação, ainda, pode se dar de três formas: por meio da restituição, ou seja, o restabelecimento da situação que existia antes que o ato internacionalmente ilícito fosse cometido (artigo 35 do anteprojeto); por meio da compensação, nos casos em que a restituição é impossível, ou acarretaria prejuízos desproporcionais ao dano. Pela compensação o Estado lesado seria indenizado pelo dano sofrido, inclusive pelos lucros cessantes; e por meio da satisfação, que seria uma reparação envolvendo um aspecto mais moral do que financeiro e que pode tomar a forma de admissão da violação, expressão de arrependimento ou de desculpas formais.

A segunda função das contramedidas seria a função coercitiva. Para Zoller (p. 54, 1984): “o que todas essas medidas coercitivas têm em comum é que elas foram tomadas 
na esperança de conseguir um resultado específico, a dizer, uma mudança no comportamento daquele Estado. ${ }^{\circ 11}$ (tradução nossa)

Assim, a função coercitiva tem como objetivo mudar o comportamento do Estado contra o qual ela foi tomada. O principal objetivo da função coercitiva, segundo a CDI, é cessar o ato internacionalmente ilícito, se ele tiver caráter contínuo (CDI, p. 130, 2001a). Outro objetivo da função coercitiva que, embora não apareça claramente nos comentários finais de CDI ao anteprojeto de artigos, pode ser inferido como instrumental para viabilizar a reparação é a pressão para o Estado se submeter a um meio de solução pacífico de controvérsias. Esta função foi mencionada diversas vezes durante os trabalhos da CDI, em especial nos debates sobre as condições para a adoção das contramedidas.

Já a função repressiva é a função que visa reprimir atos ilícitos internacionais e assegurar o cumprimento das normas do Direito Internacional (law enforcement). Para Zoller (p. 72, 1984): "O direito internacional, assim, autoriza Estados a aplicar o direito [enforce the law] por meio das contramedidas." ${ }^{.512}$ (tradução nossa) Essa função pode se subdividir em duas. Na função punitiva, que tem como objetivo castigar o Estado responsável. E a função preventiva, que visa evitar que o Estado volte a violar a norma de direito internacional, em geral por fornecer garantias de não repetição.

A função punitiva, embora tenha sido reconhecida nos trabalhos da CDI até a adoção dos artigos em primeira leitura, foi claramente excluída por esta nos seus comentários finais. Em linha com a exclusão do conceito de crime internacional do anteprojeto, a CDI estabelece o caráter instrumental e não punitivo das contramedidas. Em suas palavras (p. 130, 2001a): “Contramedidas não são projetadas como uma forma de punição pela conduta ilícita, mas como um instrumento para conseguir o cumprimento das obrigações do Estado responsável segundo a Parte Dois." ${ }^{513}$ (tradução nossa)

Por outro lado, a CDI reconhece a possibilidade da função preventiva das contramedidas. O artigo 30 da Parte Dois do anteprojeto estabelece dentre as consequências jurídicas do ato ilícito não só a obrigação de cessar o ato internacionalmente ilícito, como a obrigação de oferecer garantias de não repetição. As

\footnotetext{
${ }^{511}$ What all these coercive measures have in common is that they are taken in the hope of achieving a specific result, namely a change in the behavior of that state.

512 International law does therefore authorize states to enforce the law by the way of countermeasures.

${ }^{513}$ Countermeasures are not intended as a form of punishment for wrongful conduct, but as an instrument for achieving compliance with the obligations of the responsible State under Part Two.
} 
contramedidas, assim, podem ser adotadas visando garantir a não repetição do ato internacionalmente ilícito.

As contramedidas, então, tal como delineada no anteprojeto de artigos da CDI teriam as seguintes funções: função reparatória, com medidas visando a restituição, a compensação ou a satisfação; a função coercitiva, com medidas visando a cessação do ato internacionalmente ilícito ou a submissão a um dos meios de solução pacífica de controvérsias; e a função preventiva, com medidas visando garantias de não repetição da conduta. A função punitiva, reconhecida por parte da doutrina, fica excluída.

1.8 Condições procedimentais para a adoção de contramedidas

Para Zoller (p. 119, 1984): “O principio é que não existem condições procedimentais preliminares para o uso de contramedidas por um Estado." ${ }^{\text {,14 }}$ (tradução nossa) Esse entendimento, porém não encontra respaldo na doutrina ou na jurisprudência.

Já Vattel escrevia sobre as represálias (p. 397, 2004): “antes de chegarem a esse ponto, a justiça deve ter sido requerida em vão, ou ao menos, que haja razão para acreditar que ela seria requerida inutilmente. Somente então pode-se fazer justiça por si mesmo." (tradução nossa)

Verdross, ao tratar dos princípios que regem as contramedidas pacíficas afirmava (p. 34-35, 1967):

Uma represália só se justifica quando consta que o adversário se nega a uma reparação do ato ilícito. Por isso, as represálias devem ser precedidas de uma injunção a reparar o dano causado e deverão ser interrompidas imediatamente se enquanto são praticadas a outra parte acede à reparação, porque então já não existe ato ilícito contra o qual se possa reagir. ${ }^{515}$ (tradução nossa)

Assim, para Verdross um requisito ou condição para a adoção das contramedidas seria o requerimento anterior ao Estado responsável de reparação pelo ato internacionalmente ilícito.

\footnotetext{
514 The principle is that there is no procedural condition for the use of countermeasures by a state.

${ }^{515}$ Una represalia solo se justifica cuando consta que el adversario se niega a una reparación del acto ilícito. Por eso, las represalias deben ir precedidas de una conminación a reparar el daño causado, y habrán de interrumpirse inmediatamente si mientras se practican la otra parte accede a la reparación, porque entonces no existe ya acto ilícito contra el que se pueda reaccionar.
} 
Neste mesmo sentido segue Hoogh (p. 236, 1996), para quem:

não há necessidade de nenhum recurso a procedimentos de solução de disputas antes que um Estado lesado recorra a contramedidas. Porém, é essencial reconhecer que deve haver alguma tentativa, como um mínimo, do Estado lesado de obter reparação por meios de cumprimento voluntário pelo Estado autor de suas obrigações a este respeito. ${ }^{516}$ (tradução nossa)

Também para Nquyên e Dinh (p. 899, 1999) as represálias só são lícitas “depois de um requerimento [sommation] sem êxito.".517 (tradução nossa)

Estes autores reproduzem literalmente a decisão do Tribunal Arbitral no caso Naulilaa (UNRIAA, Vol. IV, p. 1026, 1928), anteriormente citado, que descreve as represálias como "um ato de justiça própria (Selbsthilfehandlung), do Estado lesado, ato respondendo - depois de um requerimento [sommation] sem êxito". (tradução nossa)

Na mesma linha segue a CIJ, que no caso do Projeto Gabcíkovo-Nagymaros, já citado, escreve sobre as contramedidas (p. 56, 1997): “o Estado lesado deve ter requerido ao Estado cometendo o ato internacionalmente ilícito que descontinue a sua conduta ilícita ou que faça a reparação por ela." ${ }^{518}$ (tradução nossa)

$\mathrm{O}$ artigo 52 do anteprojeto estabelece duas condições ou pré-requisitos para que um Estado possa adotar contramedidas. São elas (CDI, p. 135, 2001a):

a) requerer ao Estado responsável, de acordo com o artigo 43, que cumpra com suas obrigações em conformidade com a Parte Dois; b) notificar o Estado responsável de qualquer decisão para tomar as contramedidas e oferecer para negociar com aquele Estado. (tradução nossa)

Assim, são condições procedimentais das contramedidas além do requerimento de reparação (sommation), uma notificação ao Estado responsável da decisão de tomar contramedidas, e o oferecimento para negociar com aquele Estado.

\footnotetext{
516 There need not be any recourse to dispute settlement to recognize that there must be some attempt, as a minimum, by the injured State to obtain reparation by means of the voluntary compliance by the author State of its obligations in that respect.

517 - après sommation restée infructueuse.

518 Secondly, the injured State mu st have called upon the State committing the wrongful act to discontinue its wrongful conduct or to make reparation for it.
} 
Segundo a CDI (p. 136, 2001a): “A relação temporal entre a operação dos subparágrafos (a) e (b) do parágrafo 1 não é estrita. As notificações podem ser feitas próximas uma da outra ou mesmo, ao mesmo tempo." ${ }^{, 519}$ (tradução nossa)

Também, a oferta de negociação prevista no subparágrafo 1.b do artigo 52, não implica, caso seja aceita, que o Estado não possa adotar contramedidas. De fato, não há nenhum impedimento para a adoção de contramedidas durante a fase de negociação. $\mathrm{O}$ mesmo não pode ser, dito, como veremos posteriormente, quando já está instaurado um procedimento de solução de controvérsias que tem capacidade de tomar decisões vinculantes.

Ainda segundo o artigo 52, a primeira condição procedimental pode ser desconsiderada no caso de contramedidas urgentes, necessárias para a preservação dos direitos do Estado que as adota (CDI, p. 135, 2001a).

1.9 Condições de validade das contramedidas

Para Nquyên e Dinh (p. 899, 1999) as represálias só são lícitas:

- se elas são dirigidas contra o próprio Estado autor do ato ilícito;

- se elas não são fora de proporção com o ato ilícito ao qual elas têm por fim responder [...];

- no caso de necessidade, quer dizer, de impossibilidade do autor das represálias de obter satisfação por outros meios e;

- após uma notificação [sommation] sem êxito. ${ }^{520}$ (tradução nossa)

Para estes autores, são condições de licitude das contramedidas a existência de um ato internacionalmente ilícito anterior realizado pelo Estado contra o qual se toma as contramedidas; a proporcionalidade entre estas medidas e o ato internacionalmente ilícito inicial; a necessidade das contramedidas; e uma notificação sem êxito.

A CDI coloca diversas condições de validade das contramedidas ao longo dos artigos que tratam sobre o tema no anteprojeto que trata da responsabilidade internacional do Estado. Dentre estas condições estão: a existência de um ato

\footnotetext{
519 The temporal relationship between the operation of subparagraphs $(a)$ and $(b)$ of paragraph 1 is not strict. Notifications could be made close to each other or even at the same time.

520 - si elles sont dirigées contre l'État auteur de l'acte illicite lui-même,

- si elles ne sont pas hors de proportion avec l'acte illicite auquel elles ont pour but de répondre [...] ;

- dans le cas de nécessité, c'est-à-dire d'impossibilité pour l'auteur des représailles d'obtenir satisfaction par d'autres moyens, et

- après sommation restée infructueuse.
} 
internacionalmente ilícito anterior (artigo 49.1); a temporalidade das contramedidas (artigo 49.2); e a proporcionalidade das contramedidas com o ato int ernacionalmente ilícito inicial (artigo 51).

Não há nenhuma referência direta à necessidade das contramedidas como condição de validade. O parágrafo 3 do artigo 52, no entanto, determina que as contramedidas não devem ser tomadas e, se já o foram, devem ser suspensas caso o ato internacionalmente ilícito tenha cessado e a disputa esteja pendente perante uma Corte ou tribunal que tenham autoridade para proferir decisões vinculantes para as partes.

A CDI considera que (p. 136, 2001a) "a ação unilateral por meio de contramedidas não está justificada" ${ }^{, 521}$ neste caso, porque a Corte poderá a requerimento de uma das partes "realizar uma função essencialmente equivalente a das contramedidas" ${ }^{\$ 22}$. (tradução nossa)

Assim, embora não seja necessário comprovar a necessidade das contramedidas para que estas possam ser aplicadas, estando em andamento um mecanismo de solução de controvérsias que possa substituí-las, estas, por seu caráter excepcional e instrumental, deixam de ser lícitas.

\subsubsection{Existência de um ato ilícito anterior}

Segundo a CDI (p. 130, 2001a): "Um pré-requisito fundamental para qualquer contramedida lícita é a existência de um ato internacionalmente ilícito que lesou o Estado adotando as contramedidas. ${ }^{, 523}$ (tradução nossa)

O Tribunal Arbitral no caso Naulilaa estabelece (UNRIAA, Vol. IV, p. 1057, 1930): "ás represálias constituindo um ato em princípio contrário ao direito das gentes, só podem se justificar enquanto elas forem provocadas por algum outro ato igualmente contrário a este direito." 524 (tradução nossa)

Também a CIJ, no caso do Projeto Gabcíkovo-Nagymaros, já citado, estabeleceu, os tratar das condições das contramedidas (p. 55, 1997): "Em primeiro lugar, ela deve

\footnotetext{
521 unilateral action by way of countermeasures is not justified

522 perform a function essentially equivalent to that of countermeasures.

523 A fundamental prerequisite for any lawful countermeasure is the existence of an internationally wrongful act which injured the State taking the countermeasure.

524 les représailles, consistant en un acte en principe contraire au droit des gens, ne peuvent se justifier qu'autant qu'elles ont été provoquées par un autre acte également contraire à ce droit.
} 
ser tomada em resposta a um ato ilícito internacional prévio de outro Estado e deve ser direcionada contra aquele Estado." 525 (tradução nossa)

Ainda, apara Hoogh (p. 226, 1996): "Existe uma condição essencial que deve, por necessidade, ser cumprida para justificar a adoção de contramedidas por um Estado lesado contra o Estado autor: a comissão anterior de um ato internacionalmente ilícito." ${ }^{26}$ (tradução nossa)

Neste mesmo sentido escreve Elagab (p. 47, 1988) segundo o qual: "O direito internacional estabelece que contramedidas só podem ser aplicadas por um Estado ofendido em resposta a uma violação que tenha se consumado de fato."527 (tradução nossa)

Uma condição que parece ser simples, no entanto, gera algumas dificuldades.

Em primeiro lugar, tendo em vista a descentralização do Direito Internacional, cabe a cada Estado determinar se e quando houve uma violação das obrigações internacionais de um Estado perante a si mesmo. Neste caso, segundo a CDI (p. 130, 2001a):

Um Estado adotando contramedidas age por sua própria conta, se a sua opinião sobre a ilicitude resulta não ser bem fundada. Um Estado que recorre a contramedidas baseado na sua própria avaliação da situação o faz correndo riscos, e pode incorrer em responsabilidade internacional pela sua própria conduta ilícita no caso de uma avaliação incorreta. ${ }^{528}$ (tradução nossa)

Uma vez que na ordem jurídica internacional nenhum Estado é obrigado a submeter uma disputa a um meio de solução pacífica de controvérsias, vincular a adoção de contramedidas à prévia determinação da ocorrência do ato ilícito a um órgão político ou jurisdicional seria inviabilizar o instituto.

Assim, a única alternativa é deixar, num primeiro momento, à discricionariedade dos Estados esta determinação, mas de forma a que esta possa ser revista a qualquer

\footnotetext{
${ }^{525}$ In the first place it must be taken in response to a previous international wrongful act of another State and must be directed against that State.

526 There is one essential condition that must, of necessity, be fulfilled in order to justify an injury State's resort to countermeasures against the author State: the latter's commission of an internationally wrongful act.

${ }^{527}$ International law holds that counter-measures may only be applied by an aggrieved State in response to breach which has in fact been consummated.

${ }^{528}$ A State taking countermeasures acts at its peril, if its view of the question of wrongfulness turns out not to be well founded. A State which resorts to countermeasures based on its unilateral assessment of the situation does so at its own risk and may incur responsibility for its own wrongful conduct in the event of an incorrect assessment.
} 
momento por um procedimento de solução de controvérsias, correndo o Estado que adotou as contramedidas, o risco de ter que arcar com sua responsabilidade internacional, caso comprove-se que o ato ilícito inicial não ocorreu.

Damrosch (p. 795, 1980) defende que bastaria o Estado estar agindo de boa fé ao adotar as contramedidas, para que a ilicitude destas fosse excluída. Em suas palavras:

é preferível adotar uma regra permitindo ao Estado implementar contramedidas sem o risco de responsabilização posterior quando ele age com acreditando, de boa fé, que é vítima de uma violação, embora esta crença posteriormente demonstre ser errônea à luz do resultado da arbitragem. ${ }^{529}$ (tradução nossa)

Esse entendimento, porém, não encontra respaldo na doutrina nem na jurisprudência.

Para Crawford (p. 66, 1994): "Não é suficiente para um Estado justificar sua conduta ilícita (distinta da conduta lícita, mas inamistosa, i. e. retorsão) com a afirmação de uma crença de que esta é em resposta a uma conduta ilícita. A conduta deve ser realmente ilícita." ${ }^{, 530}$ (tradução nossa)

Assim, a efetiva ocorrência do ato internacionalmente ilícito é uma condição essencial para a legalidade das contramedidas.

Outro desdobramento da exigência de um ato internacionalmente ilícito anterior é que as contramedidas só podem ser adotadas contra o Estado que cometeu este ato.

Tribunal Arbitral no caso Naulilaa, anteriormente citado, estabeleceu (UNRIAA, Vol. IV, p. 1057, 1930):

As represálias só são admissíveis contra um Estado provocador. É possível, é verdade, que represálias legítimas, exercidas contra um Estado ofensor atinjam os nacionais de um Estado inocente. Mas se tratará de uma consequência indireta, involuntária, que o Estado ofendido se esforçará, na prática, sempre para evitar ou limitar o quanto for possível. ${ }^{531}$ (tradução nossa)

\footnotetext{
${ }^{529}$ It seems preferable to adopt a rule allowing a state to implement countermeasures without risk of later liability when it acts upon a good faith belief that it is the victim of a breach, even though that belief later turns out to be erroneous in light of the results of an arbitration.

${ }^{530}$ It is not sufficient for a State to justify unlawful conduct (as distinct from lawful but unfriendly conduct, i.e. retorsion) by asserting a belief that this is in response to conduct which is unlawful. The conduct must actually be unlawful.

531 Les représailles ne sont admissibles que contre l'État provocateur. Il se peui, il est vrai, que des représailles légitimes, exercées contre un État offenseur, atteignent des ressortissants d'un État innocent. Mais il s'agira là d'une conséquence indirecte, involontaire, que l'État offensé s'efforcera, en pratique, toujours d'éviter ou de limiter autant que possible.
} 
Segundo a CDI (p. 130, 2001a):

Um segundo elemento essencial das contramedidas é que elas 'devem ser dirigidas contra' um Estado que cometeu um ato internacionalmente ilícito, e que não cumpriu com suas obrigações de cessação e reparação segundo a Parte Dois dos presentes artigos. ${ }^{532}$ (tradução nossa)

As contramedidas devem ser, então, direcionadas exclusivamente contra o Estado responsável pelo ato internacionalmente ilícito.

Ainda segundo a CDI (p. 130, 2001a): "Isto não significa que as contramedidas não podem incidentalmente afetar a posição de terceiros Estados ou outras terceiras partes. $" 533$ (tradução nossa)

Os efeitos em relação a terceiros, no entanto, devem ser incidentais, sendo a medida tomada visando uma obrigação devida ao Estado responsável. Para a CDI (p. 130, 2001a): "Na situação onde a obrigação internacional é devida a um terceiro Estado, e aquela obrigação é violada pelas contramedidas, a ilicitude da contramedida não é precluída em relação ao terceiro Estado." ${ }^{, 534}$ (tradução nossa)

Então, no caso de violação de obrigações contidas em tratados multilaterais, por exemplo, todo cuidado deve ser tomado em relação ao direito de terceiros, sob pena de incorrer em responsabilidade internacional.

\subsubsection{Proporcionalidade das contramedidas}

A proporcionalidade entre a contramedida e o ato internacionalmente ilícito que a originou é um princípio amplamente reconhecido pela doutrina e jurisprudência.

\footnotetext{
532 A second essential element of countermeasures is that they "must be directed against"748 a State which has committed an internationally wrongful act, and which has not complied with its obligations of cessation and reparation under Part Two of the present articles.

533 This does not mean that countermeasures may not incidentally affect the position of third States or indeed other third parties.

534 In a situation where a third State is owed an international obligation by the State taking countermeasures and that obligation is breached by the countermeasure, the wrongfulness of the measure is not precluded as against the third State.
} 
Para Verdross (p. 33, 1967): "Não deve haver uma desproporção manifesta entre a represália e o ato que a motiva (principio da proporcionalidade das represálias)., ${ }^{535}$ (tradução nossa)

Segundo Bennouna (p. 62,1994): “A contramedida deve ser em proporção com o grau de gravidade do fato ilícito e seus efeitos sobre o Estado lesado [...]. Na aplicação desta regra clássica, este último conserva um grande campo de apreciação e sua reação dependerá, obviamente, dos meios dos quais ele dispõe."536 (tradução nossa)

Também o Tribunal Arbitral no caso Naulilaa estabeleceu (UNRIAA, Vol. IV, p. 1028, 1928):

Mesmo que se admita que o direito das gentes não exija que a represália tenha aproximadamente, a mesma medida que a ofensa, deve-se certamente considerar como excessiva e, portanto, ilícitas as represálias fora de toda a proporção com o ato que as motivou. ${ }^{537}$ (tradução nossa)

O princípio da proporcionalidade está consagrado o artigo 51 do anteprojeto sobre a responsabilidade internacional do Estado que determina: “Art. 51. Proporcionalidade: As contramedidas devem ser estabelecidas de acordo com o prejuízo sofrido, levando em consideração a gravidade do ato internacionalmente ilícito e os direitos em questão." 538 (tradução nossa)

Porém, embora consolidado o entendimento de que a proporcionalidade é uma condição essencial de validade para as contramedidas, o mesmo não se pode dizer dos critérios utilizados para sua determinação.

Zoller compara equivalência e proporcionalidade (p. 131, 1984):

Ao contrário da equivalência, a proporcionalidade não exige uma relação de igualdade entre as coisas que são similares, seja porque elas são do mesmo tipo, seja porque elas podem ser avalizadas por um padrão monetário. Ao invés disso, proporcionalidade implica

\footnotetext{
535 No debe haber una desproporción manifiesta entre la represalia y el hecho que la motiva (principio de la proporcionalidad de las represalias).

${ }^{536}$ La contre-mesure doit être een proportion avec le degré de gravité du fait illicite et les effets de celui ci sur l'Etat lésé [...]. Dans la mise en oeuvre de cette règle classique, ce dernier conserve une grande latitude d'appréciation et sa réaction sera, bien entendu, fonction des moyens dont il dispose.

537 Même si l'on admettait que le droit des gens n'exige pas que la représaille se mesure approximativement à l'offense, on devrait certainement considérer, comme excessives et partant illicites, des représailles hors de toute proportion avec l'acte qui les a motivées.

538 Article 51. Proportionality

Countermeasures must be commensurate with the injury suffered, taking into account the gravity of the internationally wrongful act and the rights in question.
} 
meramente uma relação de harmonia entre coisas que são diferentes, seja por causa da sua natureza [...], ou por causa da sua respectiva importância [...]. Como resultado, proporcionalidade não exige matemática, mas igualdade relativa,e, enquanto a equivalência encontra seus limites no campo das coisas quantificáveis, a proporcionalidade não se sujeita a tais limites. A proporcionalidade pode se aplicar a quantidade, também, mas ela também se aplica a qualidade. É por isso que, contrário a equivalência, a proporcionalidade pose se referir a comportamento, i.e. valores morais. $^{539}$ (tradução nossa)

A aferição da proporcionalidade, então, é mais do que uma mera conta matemática ou uma operação quantitativa. Ela deve levar em conta fatores que não são quantificáveis, mas qualificáveis.

O Tribunal Arbitral, no caso Acordo sobre Serviços Aéreos, estabeleceu (UNRIAA, Vol. XVIII, p. 483, 1978):

é geralmente admitido que as contramedidas devem corresponder a uma certa equivalência com a violação alegada; se trata de uma regra bem conhecida. De uma maneira geral, deve se observar que a apreciação da 'proporcionalidade' concreta das contramedidas não é simples e só pode ser realizada de uma maneira aproximativa. Segundo o Tribunal, um dos problemas essenciais é levar em conta em um litígio entre Estados - não somente os danos sofridos pelas partes acompanhados de juros, mas a importância das questões de princípio incluídas na violação alegada. ${ }^{540}$ (tradução nossa)

O Tribunal Arbitral deixa claro que a apreciação da proporcionalidade não deve levar em conta apenas o dano sofrido, mas também “questões de princípio".

\footnotetext{
${ }^{539}$ Unlike equivalence, proportionality does not call for a relationship of equality between things which are similar, either because they are of the same kind, or because they can be evaluated by a monetary standard. Instead, proportionality implies merely a relationship of harmony between things which are different, either because of their own nature [...], or because of their respective importance [...]. As a result, proportionality calls not for mathematical but for relative equality, and, whereas equivalence finds its limits in the field of quantifiable things, proportionality is not constrained by such limits. Proportionality may apply to quantities too, but it may also apply to qualities. That is why, unlike equivalence, proportionality may refer to behaviors, i.e. to moral values.

${ }_{540}$ Mais il est généralement admis que les contre-mesures doivent tout d'abord correspondre à une certaine équivalence à la violation alléguée; il s'agit là d'une règle bien connue. Au cours des débats relatifs à cette affaire, les deux Parties ont reconnu qu'elle était applicable à l'espèce et en ont invoqué chacune le bénéfice. D'une manière générale, on a fait observer que l'appréciation de la "proportionnalité" concrète des contre-mesures n'était pas simple et ne pouvait être réalisée que d'une manière approximative. Selon le Tribunal, l'un des problèmes essentiels est de tenir compte- dans un litige entre Etats—non seulement des dommages subis par les compagnies intéressées, mais de l'importance des questions de principe incluses dans la violation alléguée.
} 
Sicilianos (p. 276-277, 1990) critica o critério adotado pelo Tribunal. Em sua opinião (p. 277, 1990): “O critério em causa pode também dar lugar a interpretações muito diversas e assim, pouco previsíveis." ${ }^{\text {,51 }}$ (tradução nossa)

Ainda segundo este autor (SICILIANOS, p. 277, 1990):

$\mathrm{O}$ critério dos efeitos que poderia engendrar concretamente o ato ilícito, assim como as contramedidas que a ele se relacionam parece, no entanto, mais fiável porque tangível e assim facilmente quantificável. Através deste parâmetro se levará em conta não somente o dano já sofrido pela violação, mas também a gravidade da situação criada pelo ato ilícito, não mais em abstrato, mas vis-à-vis os diferentes Estados lesados. Esta abordagem modulada permitirá apreciar a proporcionalidade das contramedidas em função da importância dos interesses jurídicos atingidos pela violação. ${ }^{542}$ (tradução nossa)

Em uma linha parecida segue a CDI, para quem CDI, (p. 135, 2001a):

a proporcionalidade deve ser avaliada levando em conta não apenas o elemento puramente 'quantitativo' do dano sofrido, mas também fatores 'qualitativos' como a importância do interesse protegido pela norma infringida e a seriedade da violação. $\mathrm{O}$ artigo 51 relaciona a proporcionalidade primariamente ao dano sofrido, mas 'levando em conta' dois outros critérios: a gravidade do ato internacionalmente ilícito, e os direitos em questão. ${ }^{543}$ (tradução nossa)

No entanto, uma análise baseada apenas nos efeitos possíveis, a nosso ver, seria limitada tendo em vista que não levaria em conta todos os elementos a serem considerados.

Para Hoogh (p. 266, 1996), os elementos a serem levados em conta para averiguar a proporcionalidade seriam o ato ilícito cometido, seus efeitos, a lesão sofrida, a importância das normas infringidas e o objetivo das medidas adotadas.

Também segundo Zoller (p. 135, 1984):

\footnotetext{
${ }^{541}$ Le critère en cause peut aussi donner lieu à des interprétations fort diverses et donc peu prévisibles.

${ }^{542}$ Le critère des effets que pourraient engendrer concrètemennt le fait illicite ainsi que les contre-mesures qui s'y rapportent semble en revanche plus fiable puisque tangible et donc plus facilement quatifiable. Pa le biais de ce paramètre entreront en ligne de compte non seulement le dommage déjà subi par la violation, mais aussi la gravité de la situation créée par le fait illicite, non pas in abstracto mais vis -à-vis des différents Etats lésés. Cette approche modulée permettra d'apprécier h proportionnalité des contremesures en fonction de l'importance des intérêts juridiques atteints par la violation.

543 CDI p. 135 , 2001a proportionality must be assessed taking into account not only the purely "quantitative" element of the injury suffered, but also "qualitative" factors such as the importance of the interest protected by the rule infringed and the seriousness of the breach. Article 51 relates proportionality primarily to the injury suffered but "taking into account" two further criteria: he gravity of the internationally wrongful act, and the rights in question.
} 
O papel genuíno da proporcionalidade nas contramedidas poderia ser por em uma relação o propósito perseguido, o retorno ao status quo ante, e os instrumentos adotados com o fim de trazer este retorno. As contramedidas poderiam ser consideradas como respeitando a proporcionalidade quando os seus efeitos não são desproporcionais ao propósito perseguido. ${ }^{544}$ (tradução nossa)

Canizzaro, por sua vez, entende que os critérios para a verificação da proporcionalidade das contramedidas variam de acordo com as funções em que esta é empregada (p.894, et seq, 2001).

A proporcionalidade teria duas formas, a proporcionalidade interna, que (CANIZZARO, p. 899, 2001) "consiste em avaliar a adequação do conteúdo das medidas adotadas em relação ao resultado que elas procuram conseguir." ${ }^{255}$ E a proporcionalidade externa que visaria a "avaliação da adequação do objetivo perseguido",546

Portanto, segundo Canizzaro, enquanto a proporcionalidade interna se preocuparia com a verificação da adequação da medida tomada com o objetivo perseguido, a proporcionalidade externa se preocuparia com a adequação do próprio objetivo em si, verificando sua licitude e relevância.

Assim, uma análise focada somente nos efeitos do ato ilícito, deixaria de considerar, inter alia, a "proporcionalidade externa" ou o objetivo da medida adotada, que pode ser relevante para a avaliação da proporcionalidade, em especial nos casos de violação séria de obrigações decorrentes de norma imperativa do Direito Internacional.

Nestes casos, tão relevante quanto o dano sofrido ou seus efeitos, pode ser assegurar cumprimento das normas de Direito Internacional (law enforcement), evitando futuras violações a normas relevantes para a comunidade internacional como um todo. Então, a avaliação da finalidade da medida pode ser um componente importante para verificar a sua adequação em relação à situação fática.

\subsubsection{Temporalidade das contramedidas}

\footnotetext{
544 The genuine role of proportionality in countermeasures could be to put into relationship the purpose aimed at, return to the status quo ante, and the devices resorted to in order to bring about that return. The countermeasures could be said to respect proportionality when its effects are not disproportionate to the purpose aimed at.

${ }^{545}$ Consists in appraising the appropriateness of the content of the measures adopted in relation to the result that they seek to achieve

${ }^{546}$ Assessing the appropriateness of the pursued objective.
} 
Tendo em vista que as contramedidas, como mencionado, têm caráter apenas instrumental e não uma função punitiva, uma das condições de validade desta é a sua temporalidade e, quando possível, sua reversibilidade.

Para Zoller (p. 72, 1984):

se a medida preclui qualquer possibilidade de um retorno ao status quo ante, ou tira da outra parte de qualquer interesse do o fazer seus efeitos estariam distorcidos. É por isso que uma medida cujos efeitos são finais não pode ser considerada como contramedida. Na medida em que a medida não pode ser revertida, levantada ou parada, ela não é uma verdadeira contramedida. Seu propósito não é mais a coerção, mas a imposição de um mal que não pode ser revertido i.e. uma punição. ${ }^{547}$ (tradução nossa)

Neste mesmo sentido Crawford (p. 68, 1994):

Uma forma primária de reparação pela conduta ilícita é a restituição (restituo in integrum). Similarmente o regime de contramedidas deve encorajar contramedidas que podem ser, elas próprias, revertidas em seus efeitos, e deve desencorajar medidas que fazem um mal irreversível. ${ }^{548}$ (tradução nossa)

O Tribunal Arbitral no caso Naulilaa estabeleceu (UNRIAA, Vol. IV, p. 1026, 1928): "Ela [a represália] tem como efeito suspender momentaneamente nas relações entre os dois Estados, a observação de uma ou outra regra de direito das gentes." 549 (tradução nossa)

Também a CIJ, no caso do Projeto Gabcíkovo-Nagymaros estabelece uma (p. 5657, 1997): "outra condição de licitude de uma contramedida, notadamente, seu

\footnotetext{
${ }^{547}$ If the measure precludes any possibility of a return to the status quo ante, or deprives the other party of any interest in doing so, its effects would be distorted. That is why a measure whose effects are final cannot be regarded as a countermeasure. As long as the measure cannot be reversed, lifted or stopped, it is not a true countermeasure. Its purpose is no longer coercion, but the imposition of a harm which will not $\mathrm{e}$ taken back, i.e a punishment.

548 A primary form of redress for unlawful conduct is restitution (restituo in integrum). Similarly, the regime of counter-measures should encourage counter-measures which can themselves be reversed in their effects, and should discourage counter-measures which do irreversible harm.

${ }^{549}$ Elle a pour effet de suspendre momentanément, dans les rapports des deux États, l'observation de telle ou telle règle du droit des gens.
} 
propósito deve ser de induzir o Estado infrator a cumprir com suas obrigações internacionais, e esta medida, dever ser, assim, reversível." ${ }^{, 50}$ (tradução nossa)

Estas condições estão incorporadas no artigo 49, parágrafos 2 e 3 que estabelecem (CDI, p. 129, 2001a):

2. As contramedidas são limitadas ao não cumprimento momentâneo de obrigações internacionais do Estado que adota as medidas em relação ao Estado responsável.

3. As contramedidas deverão, na medida do possível, ser tomadas de tal modo a permitir a retomada da realização das obrigações em questão. $^{551}$ (tradução nossa)

Segundo a CDI, já citada (p. 130-131,2001a):

A frase 'momentâneo' no parágrafo 2 indica o caráter temporário ou provisório das contramedidas. Seu objetivo é a restauração de uma condição de legalidade entre o Estado lesado e o Estado responsável e não a criação de novas situações que não podem ser retificadas qualquer que seja a resposta do último Estado às reclamações feitas contra ele. $^{552}$ (tradução nos sa)

A temporalidade das contramedidas não significa, porém, que todos os seus efeitos devem ser reversíveis. Uma medida pode ser temporária, mas alguns de seus efeitos podem ser permanentes.

Para a CDI (p.131, 2001a): "Entretanto, o dever de escolher medidas que s̃o reversíveis não é absoluto. Pode não ser possível em todos os casos reverter todos os efeitos das contramedidas depois que o motivo para tomá-las cessou."553 (tradução nossa)

\footnotetext{
550 other condition for the lawfulness of a countermeasure, namely that its purpose must be to induce the wrongdoing State to comply with its obligations under international law, and that the measure must therefore be reversible.

${ }^{551} 2$. Countermeasures are limited to the non-performance for the time being of international obligations of the State taking the measures towards the responsible State.

3. Countermeasures shall, as far as possible, be taken in such a way as to permit the resumption of performance of the obligations in question.

552 The phrase "for the time being" in paragraph 2 indicates the temporary or provisional character of countermeasures. Their aim is the restoration of a condition of legality as between the injured State and the responsible. State, and not the creation of new situations which cannot be rectified whatever the response of the latter State to the claims against it.

${ }^{553}$ However, the duty to choose measures that are reversible is not absolute. It may not be possible in all cases to reverse all of the effects of countermeasures after the occasion for taking them has ceased.
} 
É o caso, por exemplo, de um embargo econômico, que embora possa ser revertido, pode acarretar prejuízos para empresas e pessoas que não podem ser revertidos, mesmo com o restabelecimento do fluxo normal de comércio.

Segundo Crawford (p. 68, 1994): 'O dano de caráter financeiro (e.g. perda de lucros ou juros) é raramente ireversível, embora os efeitos consequentes de tal dano (e.g. a insolvência de uma companhia em questão) podem muito bem ser irreversíveis." 554 (tradução nossa)

Assim a Comissão conclui (p. 131, 2001a):

\begin{abstract}
A frase 'na medida do possível' no parágrafo 3 indica que se o Estado lesado tem a escolha entre um número de contramedidas lícitas e efetivas, ele deve selecionar uma que permita a continuidade do cumprimento das obrigações suspensas como resultado das contramedidas. $^{555}$ (tradução nossa)
\end{abstract}

Assim, enquanto a temporalidade é uma condição absoluta de validade das contramedidas, a reversibilidade é uma condição relativa. Se ficar comprovado que um Estado adotou uma medida irreversível havendo a possibilidade de que outra medida, de caráter reversível, pudesse ter sido efetivamente tomada, a legalidade da contramedida adotada pode ser questionada. No entanto, as contramedidas podem ter efeitos indiretos irreversíveis, sem que isto implique na ilegalidade da mesma.

\title{
1.10 Limites das contramedidas
}

Já Grotius reconhecia que as represálias possuem algumas limitações. No Capítulo II do Livro III, que trata das represálias, o item VI estabelece que a vida não pode ser empenhada. Para este autor (p. 1063, 2004):

Talvez entre alguns povos se acreditasse que a vida dos súditos inocentes está empenhada em semelhantes situações porque acreditavam provavelmente que um direito absoluto sobre a sua própria vida pertence a cada homem e que este direito podia ser

\footnotetext{
554 Damage of a financial character (e.g. loss of profits or interest) is rarely irreversible, although the consequential effects of such damage (e.g. the insolvency of the company in question) might well be irreversible.

555 The phrase "as far as possible" in paragraph 3 indicates that if the injured State has a choice between a number of lawful and effective countermeasures, it should select one which permits the resumption of performance of the obligations suspended as a result of countermeasures.
} 
transferido ao Estado: o que dissemos em outro local [...] não ser de todo sustentável, nem conforme à mais sã teologia.

Além de limitada pelo direito à vida, as represálias tinham outro limite para Grotius (p. 1064, 2004):

Segundo o jus gentium (direito das gentes), todos os súditos daquele que comete a injustiça, que são tais a título permanente, autóctones ou vindos de outros lugares, são submissos ao direito de represália. [...] São excetuados todavia, pelo direito da gentes, do número dos súditos, os embaixadores (não aqueles que são enviados a nossos inimigos) e as coisas que lhes pertencem.

Assim, um dos fundadores do Direito Internacional moderno reconhecia tanto o direito à vida, como a imunidade diplomática como limitações ao direito de adotar represálias, i.e. contramedidas.

Para Reuter (p. 463, 1983): "Dois limites são geralmente postos ao recurso às represálias: elas dever ser proporcionais ao dano sofrido e não podem incidir sobre obrigações de caráter humanitário ou decorrentes de normas imperativas absolutas." (tradução nossa)

Também Bennouna (p. 62, 1994) escrevia sobre o tema:

Enfim, certas medidas são puramente e simplesmente proibidas (artigo 14). É assim com aquelas que comportam a ameaça e o emprego da força em violação à carta das Nações unidas, aquelas que constituem uma coerção econômica e política extrema ou visando a integridade territorial e a independência do Estado, ou ainda aquelas dirigidas contra agentes locais, arquivos e documentos diplomáticos e/ou consulares, e enfim aquelas que derrogam os direitos fundamentais da pessoas humana. ${ }^{557}$ (tradução nossa)

O artigo 50 estabelece obrigações que não devem ser afetadas pelas contramedidas. Seu texto estabelece (CDI, p. 131, 2001a):

\footnotetext{
${ }^{556}$ Deux limites sont généralement posées au recours aux représailles : elles doivent être proportionelles au dommage subi et ne peuvent porter sur des obligations de caractère humanitaire ou découlant de règles impératives absolues.

557 Enfin, certaines contre-mesures sont purement et simplement interdites (article 14). Il est ainsi de celles qui comportent la menace et l'emploi de la force en violation de la charte des Nations unies, celles constituant une contrainte économique et politique extrême ou visant l'intégrité territoriale et l'indépendance de l'État, ou encore, celles dirigées contre les agents locaux, archives et documents diplomatiques et/ou consulaires, et enfin celles qui dérogent aux droits fondamentaux de la personne humaine.
} 
Art. 50. Obrigações não afetadas pelas contramedidas

1. As contramedidas não deverão afetar:

a) a obrigação de abster-se da ameaça ou uso de força como disposto na Carta da ONU;

b) obrigações estabelecidas para a proteção de direitos humanos fundamentais;

c) obrigações de caráter humanitário proibindo represálias;

d) outras obrigações segundo as normas imperativas de Direito Internacional geral.

2. Um Estado que realize as contramedidas não está isento de cumprir com suas obrigações:

a) de acordo com qualquer procedimento de solução de controvérsias aplicável a ele e ao Estado responsável;

b) de respeitar a inviola bilidade de agentes diplomáticos e consulares, locais, arquivos e documentos. ${ }^{558}$ (tradução nossa)

O parágrafo 1 do artigo 50 estabelece quatro limitações materiais às quais acrescentaríamos mais duas, contidas no parágrafo 2.b do mesmo artigo. Seriam elas: a obrigação de abster-se do uso ou da ameaça ao uso da força; obrigações estabelecidas para a proteção dos direitos humanos fundamentais; obrigações de caráter humanitário; obrigações derivadas de normas imperativas do Direito Internacional (jus cogens); obrigações estabelecidas por um procedimento de solução de controvérsias aplicados ao Estado que adota as contramedidas e ao Estado responsável; e obrigações estabelecidas pelo direito diplomático.

1.10.1 Obrigação de abster-se do uso ou da ameaça ao uso da força

A obrigação de abster-se do uso ou da ameaça ao uso da força está consagrada no artigo 2.4 da Carta das Nações Unidas. Assim, contramedidas que impliquem no uso ou ameaça ao uso da força (i.e. contramedidas armadas ou militares) estariam proibidas por este artigo, assim, como por normas consuetudinárias de Direito Internacional.

\footnotetext{
${ }^{558}$ Article 50. Obligations not affected by countermeasures

1. Countermeasures shall not affect:

(a) the obligation to refrain from the threat or use of force as embodied in the Charter of the United Nations;

(b) obligations for the protection of fundamental human rights;

(c) obligations of a humanitarian character prohibiting reprisals;

(d) other obligations under peremptory norms of general international law.

2. A State taking countermeasures is not relieved from fulfilling its obligations:

(a) under any dispute settlement procedure applicable between it and the responsible State;

(b) to respect the inviolability of diplomatic or consular agents, premises, archives and documents.
} 
Nesse sentido o Institut de Droit International, em resolução de 1934, estabeleceu no seu artigo 4 (1934): “As represálias armadas são proibidas nas mesmas condições que o recurso à guerra." 559 (tradução nossa)

Também a Assembleia Geral da ONU aprovou, por meio da Resolução 2625 (XXV), a Declaração dos Princípios do Direito Internacional em relação às relações amigáveis e cooperação entre os Estados de acordo com a Carta das Nações Unidas, na qual se proclama (ONU, 1970): “Os Estados tem o dever de evitar atos de represália envolvendo o uso da força." 560 (tradução nossa)

1.10.2 Obrigações estabelecidas para a proteção dos direitos humanos fundamentais

A segunda limitação material prevista no artigo $50 \mathrm{diz}$ respeito a obrigações estabelecidas para a proteção de direitos humanos fundamentais. Como mencionado, já Grotius reconhecia o direito à vida como um limite às contramedidas.

Também o Institut de Droit International em resolução de 1934, estabeleceu no seu artigo 6.4 (1934) que no exercício das represálias, um Estado deve "se abster de qualquer medida coercitiva que for contrária às leis de humanidade e às exigências da consciência pública." ${ }^{561}$ (tradução nossa)

O Tribunal Arbitral no caso Naulilaa estabeleceu (UNRIAA, Vol. IV, p. 1026, 1928): "Ela [ a represália] é limitada pelas experiências da humanidade e regras de boa fé, aplicadas nas relações Estado a Estado." 562 (tradução nossa)

A internacionalização das normas de proteção aos direito humanos, intensificada após a Segunda Guerra Mundial, criou uma rede complexa de normas convencionais e consuetudinárias para a proteção dos direitos do ser humano. Nem todas essas normas, no entanto, são limitações materiais às contramedidas. Pelo contrário, somente os direitos humanos fundamentais não podem ser atingidos por estas medidas.

Segundo a CDI (p. 132, 2001a): "Os tratados de diretos humanos relevantes identificam certos diretos humanos que não podem ser derrogados mesmo em tempo de guerra ou outra emergência pública." ${ }^{, 563}$ (tradução nossa)

\footnotetext{
${ }^{559}$ Les représailles armées sont interdites dans les mêmes conditions que le recours à la guerre.

${ }^{560}$ States have a duty to refrain from acts of reprisal involving the use of force.

${ }^{561}$ S'abstenir de toute mesure de rigueur qui serait contraire aux lois de l'humanité et aux exigences de la conscience publique ;

${ }_{562}$ Elle est limitée par les expériences de l'humanité et les règles de la bonne foi, applicables dans les rapports d'État à État.
} 
De fato, o Pacto Internacional sobre Direitos Civis e Políticos estabelece no seu artigo 4.1 que em situações excepcionais, os Estados podem adotar medidas que suspendam as obrigações decorrentes daquele tratado. Por outro lado, o parágrafo 2 deste mesmo artigo estabelece (apud SALIBA, p. 283, 2006): “A disposição precedente não autoriza qualquer suspensão dos artigos 6,7,8 (parágrafos 1 e 2), 11, 15, 16 e 18."

Estes artigos se referem ao direito à vida; à proibição contra tortura e tratamentos cruéis, desumanos ou degradantes; à proibição da escravidão ou servidão; à proibição de prisão por descumprimento de obrigação contratual; à irretroatividade de lei penal, ao direito à personalidade jurídica; e o direito à liberdade de pensamento, de consciência e de religião.

O Pacto de San José da Costa Rica ${ }^{564}$ amplia ainda mais o rol dos direitos não derrogáveis no seu artigo 27, incluindo o direito à Proteção da Família (artigo 17), o direito ao nome (artigo 18), os direitos da criança (artigo 19) o direito à nacionalidade (artigo 20) e os direitos políticos (artigo 23).

Considerados por alguns doutrinadores como direitos fundamentais, estes direitos não poderiam ser atingidos por contramedidas. Consequentemente, outros direitos, como o direito à propriedade e mesmo o direito à liberdade ou a proibição de prisão arbitrária, por não serem considerados direitos fundamentais, não estariam incluídos dentre os limites materiais às contramedidas.

Embora a CDI não quisesse entrar no mérito da discussão sobre os direitos humanos fundamentais, ela cita, ainda, em seus comentários, o parágrafo 2 do artigo primeiro, que em sua frase final estabelece (apud SALIBA, p.297, 2006): "Em nenhum caso, se poderá privar um povo dos seus próprios meios de subsistência."

Ao inserir, assim, indiretamente, direitos econômicos sociais e culturais dentre os direitos fundamentais a que se refere o artigo 50 do anteprojeto de artigos sobre a responsabilidade do Estado, a CDI dá uma indicação de que este conceito pode não se enquadrar exatamente nas exceções previstas pelo artigo 4.2 do Pacto sobre os Direitos Civis e Políticos.

Enquanto estas exceções são previstas para situações de grave instabilidade política interna, o conceito de direitos fundamentais, para fins do artigo 50, diz respeito à direitos humanos cujo respeito seria de fundamental importância para a comunidade

\footnotetext{
563 In particular, the relevant human rights treaties identify certain human rights which may not be derogated from even in time of war or other public emergency

${ }^{564}$ A Convenção Europeia sobre Direito Humanos também possui um rol de direitos irrevogáveis no seu artigo 15 , porém ele é mais limitado que os outros dois tratados citados.
} 
internacional. As exceções do artigo 4.2 podem ser consideradas exemplos destes direitos, o que não significa que estes se limitariam a elas.

Se por um lado podem ocorrer situações em que os direitos de propriedade de determinados indivíduos podem vir a ser afetados por contramedidas (como por exemplo, no caso de congelamento de bens de dirigentes ou de empresas de determinado Estado), por outro, parece difícil considerar como legítimas quaisquer contramedidas tomadas violando o direito à proibição de prisão arbitrária.

Consideramos, assim, que o conceito de direitos fundamentais para fins do artigo 50, embora inclua as exceções previstas no artigo 4.2 do Pacto dos Direitos Civis e Políticos e no artigo 27 do Pacto de San José da Costa Rica, não se limitam a estas.

\subsubsection{Obrigações de caráter humanitário}

O direito humanitário é composto por regras que visam regular a conduta dos Estados em período de guerra ou conflito armado. Ele nasce, assim, indiretamente ligado ao instituto das represálias, que até a Carta das Nações Unidas, em 1945, incluía represálias militares.

As limitações materiais às contramedidas advindas do direito humanitário são uma consequência lógica deste direito. Uma vez que o direito humanitário trata de regras que devem ser respeitadas mesmo em caso de conflitos armados, é evidente que tais regras devem ser respeitadas por contramedidas tomadas em períodos de paz.

Neste sentido, Verdross escreve (p. 33, 1967): "As represálias pacíficas não podem, por último, ultrapassar os limites do direito da guerra, ou seja, alcançar bens jurídicos protegidos por aquele.”(tradução nossa)

A CDI em seu comentário ao artigo 50.1 (a) escreve (p. 132, 2001a): “O parágrafo reflete a proibição básica de represálias contra indivíduos, que existe no direito internacional humanitário." ${ }^{565}$ (tradução nossa)

Ainda segundo a Comissão (p. 132, 2001a): "represálias são proibidas contra classes definidas de pessoas protegidas, e essas proibições são amplamente aceitas." 566 (tradução nossa)

\footnotetext{
565 The paragraph reflects the basic prohibition of reprisals against individuals, which exists in international humanitarian law.

566 reprisals are prohibited against defined classes of protected persons, and these prohibitions are very widely accepted.
} 
De fato, o artigo 2 da Convenção relativa ao Tratamento dos Prisioneiros de Guerra (Genebra, 1929) estabelece a proibição de represálias contra estes prisioneiros $^{567}$.

Todas as convenções de Genebra de 1949 têm artigos proibindo represálias contra pessoas feridas, doentes, náufragos, e demais pessoas protegidas pelas convenções (Genebra, 12 ago. 1949).

Também o Protocolo Adicional à Convenção de Genebra de 1949 (Protocolo I de 1977) estabelece no seu artigo $20^{568}$ a proibição de represálias contra feridos, doentes, náufragos e o pessoal médico encarregado do cuidado destes.

Em suma, o direito humanitário possui diversas disposições convencionais protegendo determinadas categorias de pessoas (prisioneiros, doentes, feridos náufragos, pessoas protegidas) contra represálias. Embora tais disposições pareçam ter sido elaboradas visando represálias militares em tempo de guerra, nada impede que tais disposições sejam válidas também em relação às contramedidas pacíficas em tempos de paz. cogens)

1.10.4 Obrigações derivadas de normas imperativas de Direito Internacional (jus

Uma norma imperativa de Direito Internacional ou jus cogens, segundo o artigo 53 da Convenção de Viena sobre o Direito dos Tratados, já mencionado, é "uma norma aceita e reconhecida pela comunidade internacional dos Estados no seu conjunto, como uma norma da qual nenhuma derrogação é permitida e que só pode ser modificada por nova norma de direito internacional geral da mesma natureza." (apud SALIBA, p. 820, 2006)

Segundo a CDI (p. 132, 2001a): 'Evidentemente, uma norma peremptória, não sujeita à derrogação entre dois Estados mesmo por um tratado, não pode ser derrogada pela ação unilateral na forma de contramedidas." ${ }^{569}$ (tradução nossa)

\footnotetext{
567 Art. 2. Prisoners of war are in the power of the hostile Government, but not of the individuals or formation which captured them.

They shall at all times be humanely treated and protected, particularly against acts of violence, from insults and from public curiosity.

Measures of reprisal against them are forbidden. (Genebra, 1929. Disponível em: http://www.icrc.org/ihl.nsf/FULL/305?OpenDocument. Acesso em: 22 out 2010)

${ }^{568}$ Art 20. - Prohibition of reprisals

Reprisals against the persons and objects protected by this Part are prohibited. (Genebra, 1977. Disponível

em: http://www.icrc.org/ihl.nsf/7c4d08d9b287a42141256739003e636b/f6c8b9fee14a77fdc125641e0052b079. Acesso em: 22 out 2010.
} 
Uma decorrência do próprio conceito de norma imperativa, a não derrogabilidade destas normas acarreta a ilegalidade de quaisquer contramedidas adotadas contra obrigações por elas estabelecidas.

Zoller, no entanto, defende outro ponto de vista. Ao diferenciar derrogação e dispensa, ela afirma (ZOLLER, p.82, 1984): "Normas de jus cogens certamente não podem ser derrogadas. Mas é menos certo que elas não possam ser objeto de uma dispensa em casos muito específicos." ${ }^{, 570}$ (tradução nossa)

Após citar inúmeros exemplos do que seriam dispensas a normas imperativas, como a legítima defesa no caso da proibição do uso da força, ela afirma (p. 83-84, 1984): “deve ser destacado que estados não aceitam violações a tais regras sem recorrer a contramedidas do mesmo tipo (guerra nuclear)." ${ }^{, 571}$ (tradução nossa)

Admitir que as normas imperativas de Direito Internacional nem sempre são absolutas é muito diferente de considerar que as contramedidas podem ser tomadas em descumprimento a obrigações por elas estabelecidas.

As eventuais "dispensas" às normas imperativas são estabelecidas por outras normas imperativas, princípios ou regras de Direito Internacional geral, aceitos e reconhecidos pela comunidade internacional como um todo.

As contramedidas, por outro lado, são atos unilaterais dos Estados. Se, por um lado, não se admite que a vontade de dois ou mais Estados derrogue normas imperativas, menos ainda se pode reconhecer que a vontade unilateral de um Estado tenha o condão de lhe conceder uma dispensa das obrigações decorrentes das normas imperativas.

Assim, as obrigações decorrentes de normas imperativas de Direito Internacional são limites materiais à adoção de contramedidas.

1.10.5 Obrigações estabelecidas por procedimento de solução de controvérsias Em seus comentários ao artigo 50, a CDI (p. 133, 2001a) reconhece:

o princípio de que disposições de solução de disputas entre o Estado lesado e o Estado responsável, e aplicáveis à sua disputa não podem

\footnotetext{
${ }^{569}$ Evidently, a peremptory norm, not subject to derogation as between two States even by treaty, cannot be derogated from by unilateral action in the form of countermeasures.

${ }^{570}$ Norms of jus cogens can certainly not be derogated from. But it is less certain that they can never be subject to a dispensation in very specific cases.

571 It should be stressed that states do not accept violations of such rules without resorting to countermeasures of the same kind (nuclear war).
} 
ser suspensas por meio de contramedidas. Do contrário, a ação unilateral substituiria uma disposição acordada, capaz de resolver a disputa que deu origem às contramedidas. ${ }^{572}$ (tradução nossa)

Ainda para a CDI (p. 133, 2001a): "Esta frase se refere apenas a procedimentos de solução de disputas que estejam relacionados com a disputa em questão e não com

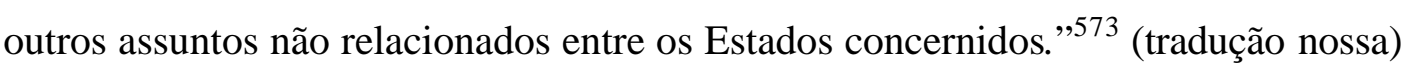

Esta limitação foi adotada com o objetivo de manter abertos os canais de negociação entre as partes envolvidas na disputa, para que seja possível encontrar uma solução amistosa.

Assim, a existência de disposições estabelecendo um procedimento de solução de controvérsias não impede, num primeiro momento, a adoção de contramedidas ${ }^{574}$. Tais contramedidas, no entanto, não podem afetar estas disposições. Tal limitação, a exemplo da limitação em relação à imunidade diplomática (CDI, p. 134, 2001a), seria baseada em motivos funcionais.

\subsubsection{Obrigações estabelecidas pelo direito diplomático}

A inviolabilidade de embaixadores ou diplomatas é um princípio reconhecido desde a Antiguidade. Grotius, anteriormente citado, já reconhecia a limitação das contramedidas em relação aos embaixadores e enviados diplomáticos.

Também para Oppenheim (p. 145, 1966):

A regra de que tudo o que pertença ao Estado delinquente pode ser objeto das represálias tem, no entanto, exceções; por exemplo, os indivíduos que gozam do privilégio de extraterritorialidade enquanto estão no estrangeiro, tais como chefes de Estado e enviados diplomáticos, não podem ser objeto de represálias, ainda que isto haja ocorrido ocasionalmente na prática. ${ }^{575}$ (tradução nossa)

\footnotetext{
572 Similar reasoning underlies the principle that dispute settlement provisions between the injured and the responsible State and applicable to their dispute may not be suspended by way of countermeasures. Otherwise, unilateral action would replace an agreed provision capable of resolving the dispute giving rise to the countermeasures.

573 This phrase refers only to dispute settlement procedures that are related to the dispute in question and not to other unrelated issues between the States concerned.

574 Tal só deve ocorrer se preenchido as condições estabelecidas no parágrafo 3 do artigo 52.

${ }^{575}$ Le regla de que todo lo que pertenezca al Estado delincuente puede ser el objeto de las represalias tiene, sin embargo, excepciones; por ejemplo, los individuos que gozan del privilegio de extraterritorialidad mientras están en el extranjero, tales como jefes de Estado y enviados diplomáticos, no pueden ser el objeto de represalias, aunque esto se ha hecho ocasionalmente en la práctica.
} 
A CIJ no caso do pessoal diplomático e consular dos Estados Unidos no Teerã estabeleceu (CIJ, p. 40, 1980):

As regras do direito diplomático, em resumo, constituem um regime de autocontenção que, por um lado, estabelece as obrigações do Estado receptor em relação às instalações, privilégios e imunidades a serem concedidas às missões diplomáticas e, por outro lado, prevê seu possível abuso pelos membros da missão e especifica os meios à disposição do Estado receptor para enfrentar qualquer abuso. ${ }^{576}$ (tradução nossa)

Para a CIJ, assim, as sanções contidas no próprio direito diplomático são as que devem ser utilizadas no caso de descumprimento deste. Contramedidas afetando a inviolabilidade destes agentes, portanto, não seriam aceitáveis (CDI, p. 134, 2001a).

Para a CDI (p. 134, 2001a):

Se o pessoal diplomático ou consular pudesse ser alvo de contramedidas, eles, em efeito, se constituiriam em reféns residentes contra erros percebidos do Estado que os envia, minando a instituição das relações diplomáticas e consulares. A exclusão de quaisquer contramedidas infringindo a inviolabilidade diplomática e consular é assim, justificada por motivos funcionais. ${ }^{577}$ (tradução nossa)

Segundo a CDI, essa limitação às contramedidas não é, porém, absoluta (p. 133134, 2001a):

O escopo das contramedidas proibidas segundo o artigo 50, parágrafo 2 (b), é limitado àquelas obrigações que são elaboradas para garantir a segurança física e inviolabilidade (incluindo imunidade de jurisdição) dos agentes, das instalações, dos arquivos e documentos diplomáticos em todas as circunstâncias, incluindo conflitos armados. O mesmo se aplica mutatis mutandis, aos oficiais consulares. ${ }^{578}$ (tradução nossa)

Assim, ainda segundo a CDI (p. 133, 2001a):

\footnotetext{
576 The rules of diplomatic law, in short, constitute a self-contained régime which, on the one hand, lays down the receiving State's obligations regarding the facilities, privileges and immunities to be accorded to diplomatic missions and, on the other, foresees their possible abuse by members of the mission and specifies the means at the disposal of the receiving State to counter any such abuse.

577 If diplomatic or consular personnel could be targeted by way of countermeasures, they would in effect constitute resident hostages against perceived wrongs of the sending State, undermining the institution of diplomatic and consular relations. The exclusion of any countermeasures infringing diplomatic and consular inviolability is thus justified on functional grounds.

578 p. 133-134the scope of prohibited countermeasures under article 50, paragraph $2(b)$, is limited to those obligations which are designed to guarantee the physical safety and inviolability (including the jurisdictional immunity) of diplomatic agents, premises, archives and documents in all circumstances, including armed conflict. The same applies, mutatis mutandis, to consular officials.
} 
Medidas por ser tomadas afetando privilégios diplomáticos ou consulares, não prejudicando a inviolabilidade das pessoas, instalações, arquivos e documentos diplomáticos ou consulares. Tais medidas podem ser lícitas como contramedidas se os requisitos deste capítulo forem cumpridos. ${ }^{579}$ (tradução nossa)

Portanto, as limitações à aplicação de contramedidas contra obrigações estabelecidas pelo direito diplomático se referem somente à inviolabilidade dos bens e pessoal pertencentes ao corpo diplomático e consular.

Também, a CDI, em seus comentários, não aponta este direito como um regime de autocontenção, preferindo atribuir essa limitação a uma necessidade funcional da instituição diplomático consular.

\subsubsection{Regimes de autocontenção dos tratados}

Além das limitações materiais contidas no artigo 50 do anteprojeto sobre a responsabilidade internacional do Estado, a CDI reconhece outra possibilidade. Em suas palavras (ONU, p. 133, 2001a):

Os Estados podem concordar entre si mesmos em outras regras do direito internacional que podem não ser objeto de contramedidas sejam ou não tais regras consideradas como normas imperativas segundo o direito internacional geral. Esta possibilidade é coberta pela provisão sobre lex specialis contida no artigo 55 mais do que pela exclusão de contramedidas segundo o artigo 50, parágrafo 1 (d). Em particular, um tratado bilateral ou multilateral pode renunciar à possibilidade de contramedidas serem tomadas por esta violação, ou em relação a esta matéria. Esse é o caso, por exemplo, dos tratados da União Europeia, que tem seu próprio sistema de assegurar $\mathrm{o}$ cumprimento. ${ }^{580}$ (tradução nossa)

Para Riphagen (ONU, p. 25, 1991) os regimes de auto contenção seriam:

\footnotetext{
579 measures may be taken affecting diplomatic or consular privileges, not prejudicing the inviolability of diplomatic or consular personnel or of premises, archives and documents. Such measures may be lawful as countermeasures if the requirements of this chapter are met.

${ }^{580}$ States may agree between themselves on other rules of international law which may not be the subject of countermeasures, whether or not they are regarded as peremptory norms under general international law. This possibility is covered by the lex specialis provision in article 55 rather than by the exclusion of countermeasures under article 50, paragraph $1(d)$. In particular, a bilateral or multilateral treaty might renounce the possibility of countermeasures being taken for its breach, or in relation to its subject matter. This is the case, for example, with the European Union treaties, which have their own system of enforcement.
} 
sistemas com base em tratados ou combinação de sistemas que tendem a dirigir, em seu próprio quadro contratual ou especial, o regime legal governando um número considerável de relações entre os Estado partes, incluindo em particular as consequências de quaisquer violações das obrigações do Estados partes segundo o sistema. ${ }^{581}$ (tradução nossa)

Também sobre os regimes de autocontenção, Zoller escreve (p. 92, 1984):

Sempre que a equivalência pode ser restabelecida em um 'regime de autocontenção', não há necessidade de se tomar outras medidas externas e adicionais. $\mathrm{O}$ sistema é, de fato, um círculo fechado, não porque ele está contido em um tratado, mas porque este sistema contém em si mesmo os 'meios' para 'enfrentar' a conduta ilícita, i.e. para restabelecer condições equivalentes entre as partes. Mas o caráter de 'autocontenção' de um sistema depende da eficiência dos meios que ele contém para restabelecer a equivalência das condições entre as partes. ${ }^{582}$ (tradução nossa)

Esta autora, porém, defende que mesmo tais regimes não implicam numa vedação absoluta de uma dispensa temporária das obrigações i.e, no direito de adotar contramedidas. Para ela (p. 92-93):

Se um tratado for violado, princípios de direito internacional externos ao tratado podem ser invocados para justificar medidas de retaliação que, na maioria das vezes, envolverá uma dispensa temporária de qualquer outra obrigação, seja consuetudinária ou convencional.

Em resumo, o direito internacional não contém normas consuetudinárias ou convencionais que nunca podem ser objeto de dispensa. ${ }^{583}$ (tradução nossa)

\footnotetext{
581 treaty-based systems or combinations of systems which tend to address, within their own contractual or special framework, the legal regime governing a considerable number of relationships among the States parties, including in particular the consequences of any breaches of the obligations of States parties under the system.

${ }^{582}$ Whenever equivalence can be re-established within a 'self-contained regime', there is no need to take additional external steps. The system is indeed a closed circle, not because it is clothed in a treaty, but because this system contains in itself the 'means' to 'counter' the unlawful conduct, i.e. to re-establish equivalent conditions between the parties. But the 'self-contained' character of a system hinges on the efficiency of the means it contains in order to re-establish the equivalence of conditions between the parties.

583 Should a treaty be violated, principles of international law outside the treaty can be invoked to justify retaliatory steps which, most of the time, will involve a temporary dispensation from any other obligation, whether a customary or a treaty obligation.

To sum up, international law does not contain customary or treaty rules which can never be subject to dispensation.
} 
Já para Hoogh (p. 271, 1996): “O recurso a contramedidas pode ser excluído

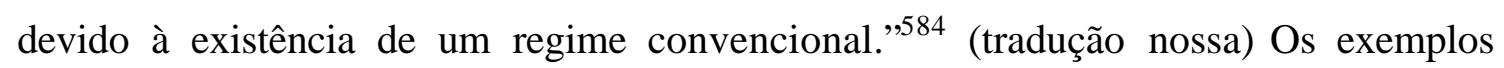
dados por este autor (imunidade diplomática e direitos humanos fundamentais), entretanto, se referem mais à limitações estabelecidas no artigo 50, do que a regimes de tratados efetivamente.

Os regimes de autocontenção seriam, então sistemas, baseados em um ou mais tratados, que regulariam diversas relações entre os Estados membros, inclusive as medidas que devem ser tomadas no caso de violação de uma das obrigações estabelecidas pelo próprio sistema. Este somente poderia ser considerado um círculo fechado na medida em que as medidas previstas forem eficazes para o restabelecimento do equilíbrio entre as partes afetadas por tal violação.

Deve-se ressaltar, entretanto, que se um tratado ou regime não permite que a violação de uma de suas obrigações seja justificativa para a adoção de medidas além das previstas neste mesmo tratado ou sistema, o mesmo não pode ser dito em relação a uma limitação para que contramedidas cujo fundamento seja a violação de uma obrigação externa ao tratado, não possam ser aplicadas em relação a obrigações contidas neste tratado ou regime.

Os regimes de autocontenção têm capacidade para regular suas próprias violações, mantendo-as dentro de um sistema fechado, mas não para impedir que princípios e normas de Direito Internacional geral afetem as obrigações nele contidas.

Essa limitação seria, assim, intrínseca e não extrínseca.

\subsection{Término das contramedidas}

$\mathrm{O}$ artigo 53 do anteprojeto sobre a responsabilidade internacional do Estado estabelece (p. 137, 2001a): “Art. 53. Término das contramedidas: As contramedidas deverão cessar tão logo o Estado responsável cumpra com suas obrigações em relação ao ato internacionalmente ilícito consoante a Parte Dois." ${ }^{255}$ (tradução nossa)

Assim as contramedidas só devem cessar se e quando o Estado responsável cumpra com as suas obrigações.

\footnotetext{
${ }_{584}^{58}$ Resort to countermeasures may be excluded due to the existence of a tre aty régime.

585 Article 53. Termination of countermeasures

Countermeasures shall be terminated as soon as the responsible State has complied with its obligations under Part Two in relation to the internationally wrongful act.
} 
Devemos considerar, no entanto, que tendo em vista o seu caráter instrumental e a ausência de função punitiva, as contramedidas devem ser temporárias e, sempre que possível, reversíveis.

Na prática, porém, em especial em situações de conflito complexas em que não existe uma solução em curto prazo, as contramedidas tendem a se prolongar ao longo do tempo.

Na medida em que sua duração se estende, elas vão perdendo a função coercitiva e reparatória, uma vez que a possibilidade de que influenciem na mudança de conduta do Estado ou gerem a reparação pelo ato internacionalmente ilícito, diminui.

Ao final de longos períodos de aplicação, quando fica claro que tais medidas não atingirão o efeito pretendido, a manutenção destas medidas teria, somente, a nosso ver, uma função punitiva. Uma vez, que esta não é uma das funções das contramedidas, elas deveriam ser terminadas.

Assim, ainda que o Estado responsável não tenha cumprido com as suas obrigações segundo a Parte Dois do anteprojeto de artigos sobre a responsabilidade do Estado, a contramedida deve ser terminada quando se tornar evidente que a sua finalidade não será cumprida. 


\section{CAPITULO II: A LEGALIDADE DAS CONTRAMEDIDAS ADOTADAS POR ESTADOS NÃO DIRETAMENTE LESADOS DIANTE DE VIOLAÇÃO ÀS NORMAS PROTETORAS DE DIREITOS HUMANOS}

Uma vez reconhecida a legalidade das contramedidas adotados por Estados lesados na defesa dos seus próprios interesses, resta discutir a legalidade destas mesmas medidas adotadas por Estados não diretamente lesados em nome dos interesses da comunidade internacional como todo.

Como mencionado anteriormente, a proteção dos direitos humanos fundamentais é um dos temas que interessam a sociedade internacional em conjunto. Quer seja incorporada em normas de jus cogens, ou imperativas de direito internacional geral, quer seja consubstanciada em obrigações devidas a toda a comunidade internacional ou obrigações erga omnes, a proteção dos direitos fundamentais é um dos princípios do Direito Internacional.

A seguir analisaremos se o Direito Internacional reconhece o direito de todos os Estados defenderem unilateralmente esta proteção.

\subsection{Breve retrospecto histórico}

A discussão sobre a legalidade de contramedidas adotadas por Estados não diretamente lesados pelo ato ilícito internacional, ao contrário do que se pode pensar, não é nova.

Já no século XVII doutrinadores discutiram o tema. Para Grotius (p. 851, 2004):

Deve-se saber também que reis e aqueles que têm um poder igual ao dos reis têm o direito de infligir penas não somente por injúrias cometidas contra eles ou seus súditos, mas também por aquelas que não os tocam particularmente e que violam em excesso o direito de natureza ou das gentes a respeito de quem quer que seja.

Grotius justifica esta capacidade dos soberanos. Em suas palavras (p. 851, 2004):

A liberdade de prover por castigos aos interesses da sociedade humana que, no começo, como dissemos, pertencia aos privados, ficou, após o estabelecimento dos Estados e das jurisdições, para os poderes soberanos, não propriamente porque eles mandam nos outros, mas porque não obedecem a ninguém. 
Ainda, ao tratar da guerra justa, Grotius afirma que defender alguém de uma injustiça é lícito, independente de qualquer laço. Para ele (p. 274, 2004) "a comunhão da natureza humana bastaria. Com efeito, não há nada de humano que seja estranho ao homem."

Assim, segundo este autor, os soberanos, em nome dos Estados, têm o direito de punir atos que violam em excesso o direito de natureza ou das gentes. Esse direito se baseia na sua capacidade de defender os interesses da sociedade humana, e assim, indiretamente, seu próprio interesse e a simples comunhão de natureza humana é suficiente para justificar a defesa de outrem de uma injustiça.

A ideia de "interesses da sociedade humana", presente no pensamento de Grotius, reflete sua visão do Direito Internacional, focado não na figura do Estado, mas na figura dos seres humanos. Estes, em conjunto, formam a sociedade humana, que possui interesses em comum. Cabe aos poderes soberanos dos Estados, a defesa destes interesses, e agindo em nome destes, eles podem atuar contra uma violação excessiva do direito natural ou direito das gentes.

Essa ideia de "interesses da sociedade humana" é próxima do atual conceito de "interesses da comunidade internacional como um todo" que serve de base para a classificação das normas do Direito Internacional contemporâneo.

Em 1662, a Inglaterra adota contramedidas contra a Holanda em defesa dos interesses da Ordem soberana de Malta. Este fato seria posteriormente debatido por Vattel e Bynkershoek, no século XVIII.

Para Vattel (p. 398, 2004): “conceder represálias contra uma Nação em favor de estrangeiros importa em constituir-se juiz entre essa Nação e esses estrangeiros - o que nenhum soberano tem o direito de fazer."

Ainda, para este autor (p. 398, 2004):

Quando a Inglaterra, em 1662, aplicou represálias contra as Províncias Unidas em favor dos cavaleiros de Malta, os Estados da Holanda disseram com razão que, de acordo com o direito das gentes, represálias podiam ser concedidas comente com o intuito de manter os diretos do Estado e não para uma controvérsia, em relação à qual a Nação não tinha nenhum interesse.

Já para Bynkershoek (p. 553-555, 1946, apud DAWIDOWICZ, p. 338, 2006): 
Se você permite represálias em nome dos súditos, não parece haver razão pela qual você deve recusá-las em nome dos estrangeiros. Elas são tanto justas ou injustas; se injustas, concedê-las aos súditos envolve uma injúria; se justas recusá-las aos estrangeiros inevitavelmente resulta em uma injúria; porque em teoria jurídica, não faz diferença se alguém é Troiano ou Tiriano. ${ }^{586}$ (tradução nossa)

Vattel defende a impossibilidade de adoção de represálias por Estados não diretamente lesados tendo em vista a falta de interesse de agir deste, uma vez que seus direitos não forma afetados. Para este autor, uma Nação não poder julgar a relação entre outra Nação e terceiros.

Já Bynkershoek argumenta que, uma vez justas, as represálias devem ser concedidas tanto para os súditos como para os estrangeiros. Ele se baseia no princípio de que, para o Direito, não importa a nacionalidade dos indivíduos. Para este autor, é a justiça das represálias que condiciona a sua validade, e não por quem elas são adotadas.

Phillimore, no século XIX, afirmava (p. 320, 1854):

Intervenção tomada em nome dos interesses gerais da humanidade tem sido frequentemente estimulada, e especialmente no nosso tempo, mas raramente, se alguma vez, sem que outros de maior e mais legítimo peso a apoiem; tal, por exemplo, como o perigo crescente para os outros Estados da continuação de tal estado de coisas, ou o direito de aderir ao requerimento de uma das partes da contenda. ${ }^{587}$

Ainda, para este autor (p. 320, 1854):

Como um acessório a outros, este fundamento pode ser defensível; mas como uma justificação substantiva e solitária da Intervenção nos assuntos de um outro país, ele dificilmente poderia ser admitido no código do Direito Internacional, uma vez que é manifestamente aberto a abusos, tendendo à violação e destruição dos princípios vitais daquele sistema de jurisprudência, - tais abusos como os gerados pelas diversas divisões da Polônia, o grande precedente tão frequentemente citado e tão frequentemente imitado pelos violadores do Direito Internacional. ${ }^{588}$

\footnotetext{
${ }^{586}$ For if you permit reprisals on behalf of subjects, there seems no reason why you should deny them on behalf of foreigners. They are either just or unjust; if just, to grant them to subjects involves an injury; if just, to deny them to foreigners inevitably results in injury; for in legal theory it makes no difference whether one is a Trojan or a Tyrian.

${ }^{587}$ Intervention urged on behalf of the general interests of humanity, has been frequently put forward, and especially in our own times, but rarely, if ever, without others of greater and more legitimate weight to support it; such, for instance, as the danger accruing to other States from the continuance of such a state of things, or the right to accede to an application from one of the contending parties.

${ }^{588}$ As an accessory to others, this ground may be defensible; but as a substantive and solitary justification of Intervention in the affairs of another country, it can scarcely be admitted into the code of International Law, since it is manifestly open to abuses, tending to the violation and destruction of the vital principles
} 
2.2 A legalidade das contramedidas, segundo o anteprojeto de artigos da CDI sobre a responsabilidade internacional do Estado

Tendo em vista a extensiva análise do trabalho realizado pela CDI sobre a responsabilidade internacional do Estado, já realizada em capítulo anterior, não cabe aqui retomar em detalhe toda a evolução da discussão sobre contramedidas no âmbito da Comissão.

Pretendemos apenas resumir a abordagem da CDI e de seus Relatores Especiais sobre a questão da possibilidade de adoção de contramedidas por Estados não diretamente lesados, em especial nos casos de violação a normas visando a proteção dos direitos humanos.

\subsubsection{Subcomitê sobre a responsabilidade do Estado}

Em 1963, após o fim dos trabalhos do Relator Especial Garcia Amador, o subcomitê criado para cuidar do tema da responsabilidade internacional estabeleceu alguns pontos que deveriam ser tratados nos estudos da CDI sobre a matéria. Sobre a questão das sanções, ele considerou que os seguintes aspectos mereciam atenção (ONU, p. 228, 1963): '3) Sanção. Sanções individuais previstas no direito internacional geral. Represálias e seu possível papel como sanção de um ato internacionalmente ilícito. Sanções coletivas." ${ }^{589}$ (tradução nossa)

$\mathrm{Na}$ falta de maiores esclarecimentos, fica a dúvida se o termo "sanções coletivas" teria sido utilizado no sentido de medidas estabelecidas por organizações internacionais, ou se, de forma mais abrangente, ele significaria medidas coercitivas adotadas por diversos Estados.

2.2.2 Os trabalhos realizados por Roberto Ago

of that system of jurisprudence,- - such abuses as generated the several partitions of Poland, the great precedent so often quoted, and so often imitated by the violators of International Law.

${ }^{589}$ (3) Sanction. Individual sanctions provided for in general international law. Reprisals and their possible role as a sanction for an international wrongful act. Collective sanctions. 
A discussão sobre a legalidade das contramedidas por Estados indiretamente lesados só será definitivamente iniciada durante o mandato do Relator Especial Roberto Ago. Este Relator, que, como já mencionado, definiu a estrutura e os principais conceitos do anteprojeto de artigos da CDI sobre a responsabilidade internacional do Estado, tratou do tema em seu oitavo Relatório, de 1979.

Foi com base nos estudos deste Relator que a CDI adota seu artigo 19, que estabelece como crime internacional, inter alia, Ainda, a redação aprovada pela CDI do artigo 19 rezava (ONU, p. $75,1976 a)$ :

Artigo 19 Crimes internacionais e delitos internacionais [...]

b) uma violação séria a uma obrigação internacional de essencial importância para a salvaguarda do direito de autodeterminação dos povos, tais como aquela proibindo o estabelecimento ou a manutenção pela força de dominação colonial.

c) uma grave violação em larga escala de obrigação internacional de essencial importância para a salvaguarda do ser humano, tais como aquelas proibindo a escravidão, o genocídio e o apartheid;

d) uma violação séria de direito internacional de essencial importância para a salvaguarda e preservação do ambiente humano, tais como a proibição à poluição massiva da atmosfera ou dos mares. ${ }^{500}$ (tradução nossa)

$\mathrm{Na}$ definição de crime internacional consagrada no artigo 19, adotado provisoriamente pela CDI, estavam incluídas violações às obrigações internacionais voltadas para a proteção do direito de autodeterminação dos povos, visando a salvaguarda do ser humano (entre elas a proibição da escravidão, do genocídio e do apartheid), e visando a preservação do ambiente humano.

Assim, a violação de ao menos algumas normas protetoras dos direitos humanos poderia ser considerada como um crime internacional.

Já sobre a questão da possibilidade de adoção de contramedidas por Estados não diretamente lesados, embora Ago reconheça que (ONU, p. 43, 1979) “[...] o antigo monopólio do Estado diretamente lesado pelo ato internacionalmente ilícito de outro Estado, em relação à possibilidade de aplicar sanções contra aquele outro Estado que de

\footnotetext{
${ }^{590}$ Article 19. - International crimes and international delicts

(b) a serious breach of an international obligation of essential importance

for safeguarding the right of self-determination of peoples, such as that prohibiting the establishment or maintenance by force of colonial domination;

(c) a serious breach on a widespread scale of an international obligation of essential importance for safeguarding the human being, such as those prohibiting slavery, genocide and apartheid;

(d) a serious breach of an international obligation of essential importance for the safeguarding and preservation of the human environment, such as those prohibiting massive pollution of the atmosphere or of the seas.
} 
outro modo seriam ilícitas, não é mais absoluto no direito internacional moderno"591, o

Relator esclarece que:

Ele [o monopólio] provavelmente ainda subsiste no direito internacional geral, mesmo se, em abstrato, alguns podem achar lógico fazer certas inferências da afirmação progressiva do princípio segundo o qual algumas obrigações - definidas como obrigações erga omnes são de tão grande alcance que a violação de uma delas deve ser considerada como uma ofensa cometida contra todos os membros da comunidade internacional e não simplesmente contra o Estado ou os Estados diretamente afetados pela violação. ${ }^{592}$ (tradução nossa)

A seu ver (ONU, p. 43, 1979):

Em realidade, não se pode subestimar os riscos envolvidos no reconhecimento deste princípio - o principal mérito do qual, seria que este afirma a necessidade de uma solidariedade universal ao tratar das violações mais sérias à ordem internacional - ao ponto onde qualquer Estado estaria automaticamente autorizado a reagir contra uma violação de certas obrigações cometidas contra outro Estado e individualmente tomar medidas punitivas contra o Estado responsável pela violação. ${ }^{593}$ (tradução nossa)

Ainda, para Ago (ONU, p. 43, 1979):

É compreensível, assim, que uma comunidade como a comunidade internacional, procurando uma organização mais estruturada, mesmo se apenas com uma 'institucionalização incipiente, deva ter tomado outra direção, em direção a um sistema encarregando as instituições internacionais, em vez de os Estados, da responsabilidade exclusiva, primeiro, de determinar a existência de uma violação a uma obrigação de importância básica para toda a comunidade internacional, e depois, de decidir quais medidas devem ser tomadas em resposta e como elas devem ser implementadas. ${ }^{594}$ (tradução nossa)

\footnotetext{
591 the former monopoly of the State directly injured by the internationally wrongful act of another State, as regards the possibility of resorting against that other State to sanctions which would otherwise be unlawful, is no longer absolute in modern international law.

${ }_{592}$ It probably still subsists in general international law, even if, in abstracto some might find it logical to draw certain inferences from the progressive affirmation of the principle that some obligations-defined in this sense as obligations erga omnes - are of such broad sweep that the violation of one of them is to be deemed an offence committed against all members of the international community, and not simply against the State or States directly affected by the breach.

593 In reality, one cannot underestimate the risks that would be involved in pressing recognition of this principle - the chief merit of which, in our view, is that it affirms the need for universal solidarity in dealing with the most serious assaults on international order - to the point where any State would be held to be automatically authorized to react against the breach of certain obligations committed against another State and individually to take punitive measures against the State responsible for the breach.

594 It is understandable, therefore, that a community such as the international community, in seeking a more structured organization, even if only an incipient "institutionalization", should have turned in
} 
Assim, Ago, apesar de reconhecer a flexibilização do "antigo monopólio do Estado diretamente lesado", defende que caberia às instituições internacionais, exclusivamente, determinar a existência de uma "obrigação de importância básica para toda a comunidade internacional' assim como as medidas que devem ser tomadas em resposta a ela. Para o Relator, o risco de se reconhecer o direito de qualquer Estado de adotar medidas punitivas no caso da violação de certas obrigações internacionais seria demasiado.

Spinedi ao comentar a posição deste Relator escreve (p. 1122, 2002):

Entretanto, ao menos no que diz respeito ao Relator Especial, um fato é claro para mim: Ago se opunha a dar a possibilidade a estados não diretamente lesados de tomar medidas unilateralmente decididas (exceto em relação a medidas de legítima defesa). Ele previa um sistema de contramedidas coordenadas (se possível no contexto de uma organização internacional), a ser adicionado ao previsto pela Carta. ${ }^{595}$

De fato, parece incongruente com a postura do Relator Especial, grande defensor do conceito de crime internacional, estabelecer consequências mais graves para os "delitos internacionais" do que para os crimes, que seriam por definição, violações mais graves. Imagina-se que Ago planejaria, em relação a estas violações, consequências jurídicas mais severas. Entretanto, na medida em que ele não chegou a desenvolver esta parte do anteprojeto, qualquer conclusão seria apenas especulação.

Portanto, tendo em vista o trabalho realizado por Ago como Relator Especial, devemos concluir que sua posição era contra a possibilidade de adoção de contramedidas por Estados não diretamente lesados, mesmo quando tais violações se referissem a normas elaboradas para proteger os direitos humanos. Ao desconsiderar o instituto em geral, ele também desconsidera sua aplicação específica.

Esta também foi a postura adotada pela CDI em seu Relatório à Assembleia Geral de 1979 (ONU, p. 118-119, 1979) que reproduz, com algumas alterações boa parte dos comentários da $\mathrm{Ago}^{596}$.

another direction, namely towards a system vesting in international institutions other than States the exclusive responsibility, first, for determining the existence of a breach of an obligation of basic importance to the international community as a whole, and thereafter, for deciding what measures should be taken in response and how they should be implemented.

${ }^{595}$ However, at least as regards the Special Rapporteur one fact is clear to me: Ago was opposed to providing the possibility for states not directly injured to take unilaterally decided measures (except in relation to self-defence measures). He envisaged a system of coordinated countermeasures (if possible in the context of an international organization), to be added to the one provided for by the Charter.

596 The progressive affirmation in modern international law of the principle that some obligationstermed obligations erga onmes - are of such broad sweep that a breach of any one of them is to be deemed an offence against all the members of the international community and not simply against the 


\subsubsection{Os trabalhos realizados por Willen Riphagen}

Ao assumir o cargo de Relator Especial em 1980, Riphagen traz uma nova perspectiva sobre a possibilidade de adoção de contramedidas por Estados não diretamente lesados. Já em seu Relatório preliminar, ele admite que os Estados não diretamente lesados (Estados terceiros) gozam de uma posição "não neutra" em relação à violação de determinadas obrigações internacionais (ONU, p. 121, 1980).

Para este Relator, entretanto, (ONU, p. 121, 1980) “uma decisão coletiva é requerida antes que os Estados terceiros possam tomar qualquer ação em relação à 'nova relação jurídica' criada pelo ato ilícito, entre o Estado culpado e o terceiro Estado." ${ }^{597}$ (tradução nossa)

Ainda, para Riphagen, mais que um direito, a nova relação jurídica entre o Estado violador e o Estado não diretamente lesado pode constituir mesmo um dever. Em suas palavras (ONU, p. 122, 1980):

não se pode, parece, excluir a priori um dever dos Estados segundo regras de direito internacional geral de agir (ou de abster-se de atos que de outra forma seriam admissíveis) em resposta a uma violação de uma obrigação internacional, em particular quando esta violação constitui um 'crime internacional' no sentido do artigo 19 do anteprojeto de artigos sobre a responsabilidade do Estado, mesmo se tal violação não envolve, de fato, a paz e segurança internacionais. De novo, uma decisão coletiva pare esse efeito seria um pré-requisito para estabelecer tal dever, e a regra da proporcionalidade deve sempre ser observada. ${ }^{598}$ (tradução nossa)

Assim, para Riphagen, Estados não diretamente lesados podem agir contra determinados atos ilícitos, mas tal ação deve ser precedida de uma "decisão coletiva".

State or States directly affected by the breach, has led the international community to turn towards a system which vests in international institutions other than States exclusive responsibility, first, for determining the existence of a breach of an obligation of basic importance to the international community as a whole, and, thereafter, for deciding what measures are to be taken in response and how they are to be implemented.

597 This, then, rather seems to confirm the statement that a collective decision is required before third States can take any action under a "new legal relationship", created by a wrongful act, between the guilty State and third States.

${ }^{598}$ Be that as it may, one cannot, it would seem, exclude a priori a duty of States under rules of general international law to act (or to refrain from otherwise admissible acts) in response to a breach of an international obligation, in particular when such a breach constitutes an "international crime" in the sense of article 19 of the draft articles on State responsibility, even if such breach does not, in fact, involve international peace and security. Again, a collective decision to that effect would seem to be a prerequisite for establishing such duty, and the rule of proportionality should at all times be observed. 
Durante as discussões da CDI sobre o Relatório, diversos membros posicionam-se contra e a favor da posição do Relator. Destaca-se o comentário de Schwebel, que vai ainda mais longe do que o Relator em relação à possibilidade de aplicação de contramedidas por Estados não diretamente lesados ao afirmar que (CDI. P. 93, 1980b): "Uma decisão coletiva pode ser e provavelmente é necessária para requerer que os Estados terceiros tomem uma ação em resposta, mas se ela é necessária para autorizá-

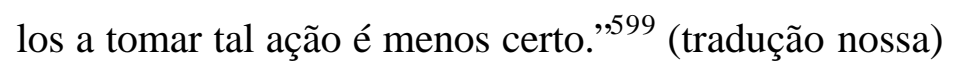

No seu terceiro Relatório, em 1982, o Relator discorre sobre as obrigações de um terceiro Estado a reagir contra uma violação de uma obrigação internacional. Em suas palavras (ONU, p. 38, 1982):

Aqui, novamente, existem vários graus desta obrigação. Pode-se distinguir entre a) uma obrigação de não reconhecer o resultado legal de tal violação pelo Estado autor; b) uma obrigação de aceitar para si alguma consequência lesiva de medidas legais tomadas pelo Estado lesado em resposta a uma violação, e c) uma obrigação de tomar medidas (positivas) de modo a restaurar a situação existente antes da violação, e mesmo, possivelmente, de modo a evitar uma repetição da violação. $^{600}$ (tradução nossa)

Já em relação especificamente ao crime internacional Riphagem escreve (ONU, p. 44, 1982):

Pode ser dito que a noção de 'crime internacional' implica em ao menos um terceiro parâmetro de consequências jurídicas: alguma forma de implementação internacional. Não se pode aceitar esta noção sem ao mesmo tempo prover consequências jurídicas específicas ou os meios de implementação. ${ }^{601}$ (tradução nossa)

Ainda para o Relator (ONU, p. 44, 1982):

\footnotetext{
599 A collective decision might be and probably was needed in order to require third States to take responsive action, but whether it was needed in order to authorize them to take such action was less certain.

600 Here again there are various degrees of such obligation. One may distinguish between $(a)$ an obligation not to recognize as legal the result of such violation by the author State; $(b)$ an obligation to accept for oneself some injurious consequences of measures lawfully taken by the injured State in response to the violation; and (c) an obligation to take (positive) measures in order to restore the situation as it existed before the breach, and possibly even in order to prevent a repetition of the breach.

601 Nevertheless, it may be stated that the notion of "international crime" implies at least a third parameter of legal consequences: some form of international enforcement. One can hardly accept this notion without at the same time providing for its specific legal consequences and the means of "implementation" (mise en oeuvre).
} 
Uma tal consequência jurídica poderia ser a obrigação de todos os Estados de contribuir para a situação na qual o Estado autor de um crime internacional seja compelido a parar a violação. Como um mínimo, tal contribuição incluiria evitar dar apoio $a$ posteriori à conduta constituindo um crime internacional. O segundo grau de contribuição seria dar apoio as contramedidas tomadas por outro Estado ou Estados, e um terceiro grau de seria tomar contramedidas contra o Estado autor. ${ }^{602}$

Tais medidas, como anteriormente defendido por Riphagen, deveriam ser precedidas de uma decisão coletiva. Ele, no entanto, prevê a hipótese de uma exceção a este requisito. Em suas palavras (ONU, p. 45, 1982):

A distinção entre graus de contramedidas pode, talvez, ser aplicada na
questão do direito de um Estado ou Estados de responder ao crime
internacional na ausência de uma decisão coletiva a este respeito do
órgão competente das Nações Unidas. Pode-se tirar a conclusão de
que medidas relativas à retirada de apoio a posteriori e o término ou a
suspensão de relações de tratado com o Estado autor são permitidas,
ao menos até uma decisão do órgão das Nações Unidas competente.
${ }^{603}$ (tradução nossa)

Por fim, Riphagen propõe o seguinte artigo sobre as consequências jurídicas dos crimes internacionais (ONU, p. 48, 1982):

\begin{abstract}
Artigo 6
1. Um ato internacionalmente ilícito de um Estado, que constitui um crime internacional, acarreta uma obrigação para todos os outros Estados:

a) de não reconhecer como legal a situação criada por tal ato; e

b) de não dar ajuda ou assistência ao autor do ato para manter a situação criada por tal ato; e

c) de juntar-se aos outros Estados dando assistência mútua ao executar as obrigações segundo o item a e b.

2. A não ser que de outra forma estabelecido por uma norma aplicável de direito internacional, o cumprimento das obrigações mencionadas no parágrafo lestá sujeito mutatis mutandis aos procedimentos
\end{abstract}

\footnotetext{
602 133. One such specific legal consequence could be an obligation of all States to contribute to a situation in which the author State of an international crime could be compelled to stop the breach. As a minimum, such contribution would include refraining from support a posteriori of the conduct constituting an international crime. A second degree of contribution would be a support of countermeasures taken by another State or States, and a third degree would be the taking of countermeasures against the author State.

603 the distinction between the degrees of countermeasures may perhaps be applied also to the question of the right of a State or States to respond to an international crime in the absence of a collective decision to that effect of the competent United Nations body. One could then draw the conclusion that measures amounting to the withdrawal of support a posteriori and termination or suspension of treaty relationships with the author State are allowed, at least pending a decision of the competent organ of the United Nations.
} 
previstos na Carta das Nações Unidas a respeito da manutenção da paz e segurança internacionais.

3. Sujeito ao artigo 103 da Carta das Nações Unidas, no evento de um conflito entre as obrigações de um Estado segundo os parágrafos 1 e 2 acima, e seus direitos e obrigações segundo qualquer outra norma de direito internacional, as obrigações segundo o presente artigo devem prevalecer. ${ }^{604}$

Embora este artigo não reconheça diretamente as contramedidas como consequências advindas do crime internacional, o parágrafo 3, ao estabelecer que as obrigações estabelecidas no artigo 6 prevalecem em relação as demais obrigações dos Estados decorrente de outras normas do Direito Internacional, indiretamente autoriza os Estados a descumprirem com estas obrigações, i.e. a adotarem contramedidas visando o cumprimento das obrigações estabelecidas neste artigo.

Assim, segundo este artigo, em caso de violações a normas visando a proteção de direitos voltados para a salvaguarda do ser humano, do meio ambiente, ou da autodeterminação dos povos, os Estado teriam não só o direito, mas a obrigação de adotar contramedidas com o objetivo de não reconhecer a situação gerada pelo ato ilícito, não fornecer ajuda ou assistência para a manutenção da situação, e auxiliar os demais Estados a cumprirem com as obrigações anteriores.

A postura do Relator Especial em relação à necessidade de uma decisão coletiva para adoção de contramedidas por Estados não diretamente lesados parece mudar em 1984. No seu quinto Relatório, Riphagen propõe 16 artigos. Dentre eles o artigo 5, que estabelece (ONU, p. 3, 1984):

Artigo 5
Para os propósitos do presente artigo, 'Estado lesado' significa:
a) Se o ato internacionalmente ilícito constitui uma violação de um
direito pertencendo a um Estado em virtude de uma norma
consuetudinária de direito internacional ou a um direito advindo de

604 Article 6

1. An internationally wrongful act of a State, which constitutes an international crime, entails an obligation for every other State:

(a) not to recognize as legal the situation created by such act; and

(b) not to render aid or assistance to the author State in maintaining the situation created by such act; and

(c) to join other States in affording mutual assistance in carrying out the obligations under (a) and (b).

2. Unless otherwise provided for by an applicable rule of international law, the performance of the obligations mentioned in paragraph 1 is subject mutatis mutandis to the procedures embodied in the United Nations Charter with respect to the maintenance of international peace and security.

3. Subject to Article 103 of the United Nations Charter, in the event of a conflict between the obligations of a State under paragraphs 1 and 2 above, and its rights and obligations under any other rule of international law, the obligations under the present article shall prevail. 
uma determinação de um tratado para um Estado terceiro, o Estado cujos direitos foram violados;

b) Se o ato internacionalmente ilícito constitui uma violação de uma obrigação imposta por um julgamento ou outra decisão de solução de disputas vinculante de um tribunal ou uma corte internacional, o outro Estado parte ou Estados partes da disputa;

c) se o ato internacionalmente ilícito constitui uma violação de uma obrigação imposta por um tratado bilateral, o outro Estado parte do tratado;

d) se o ato internacionalmente ilícito constitui uma violação de uma obrigação imposta por um tratado multilateral, um Estado parte daquele tratado, se estabelecido que:

i) a obrigação foi estipulada em seu favor;

ii) a violação da obrigação por um Estado parte necessariamente afeta o exercício de direitos ou o cumprimento de obrigações de todos os outros Estados partes; ou

iii) a obrigação foi estipulada para a proteção dos interesses coletivos dos Estados partes; ou

iv) a obrigação foi estipulada para a proteção de pessoas individuais, independente de sua nacionalidade;

e) se o ato internacionalmente ilícito constitui um crime internacional, todos os outros Estados. ${ }^{605}$ (tradução nossa)

O Relator Especial adota um conceito extremamente amplo de Estado lesado. Por exemplo, no caso dos tratados de direito humanos, que estabelecem "a proteção de pessoas individuais, independente de sua nacionalidade" (artigo 5 ' $d$ ' 'iv'), todos os Estados que fizessem parte do tratado, poderiam ser considerados Estados lesados no caso da violação de uma de suas obrigações.

Já em relação aos crimes internacionais, todos os Estados, como partes da comunidade internacional, seriam considerados Estados lesados.

Esse artigo faz com que a discussão sobre contramedidas por Estados não diretamente lesados ganhe outra dimensão, uma vez que transforma todos os Estados

\section{Article 5}

For the purposes of the present articles, "injured State" means:

(a) if the internationally wrongful act constitutes an infringement of a right appertaining to a State by virtue of a customary rule of international law or of a right arising from a treaty provision for a third State, the State whose right has been infringed;

(b) if the internationally wrongful act constitutes a breach of an obligation imposed by a judgment or other binding dispute-settlement decision of an international court or tribunal, the other State party or States parties to the dispute;

(c) if the internationally wrongful act constitutes a breach of an obligation imposed by a bilateral treaty, the other State party to the treaty;

(d) if the internationally wrongful act constitutes a breach of an obligation imposed by a multilateral treaty, a State party to that treaty, if it is established that:

(i) the obligation was stipulated in its favour; or

(ii) the breach of the obligation by one State party necessarily affects the exercise of the rights or the performance of the obligations of all other States parties; or

(iii) the obligation was stipulated for the protection of collective interests of the States parties; or

(iv) the obligation was stipulated for the protection of individual persons, irrespective of their nationality;

(e) if the internationally wrongful act constitutes an international crime, all other States. 
que poderiam ter interesse de agir em Estados lesados, e não estabelece nenhuma distinção nessa nova categoria, estando assim, todos na mesma situação.

O artigo 5 dá uma nova perspectiva ao artigo 9 proposto (ONU, p. 3, 1984):

\begin{abstract}
Artigo 9
1. Sujeito às determinações dos artigos 10 a 13, o Estado lesado tem o direito de, por meio de represália, suspender o cumprimento de suas outras obrigações em relação ao Estado que cometeu $\mathrm{o}$ ato internacionalmente ilícito.

2. O exercício deste direito pelo Estado lesado não deve, em seus efeitos, ser manifestamente desproporcional a gravidade do ato internacionalmente ilícito cometido. ${ }^{606}$ (tradução nossa)
\end{abstract}

Em conjunto, o artigo 5 e o artigo 9 levam a conclusão de que as contramedidas podem ser adotadas pelos Estados não diretamente lesados, agora incluídos na categoria de Estados lesados. Não é feita nenhuma tentativa de estabelecer condições diferentes para as contramedidas adotadas por Estados lesados definidos nas alíneas (d)(iii), (d)(iv) e (e) do artigo 5. Por outro lado, o artigo 10 estabelece como requisito de todas as contramedidas a exaustão dos procedimentos de solução pacífica de controvérsias disponíveis no Direito Internacional.

Se ainda poderia restar alguma dúvida sobre a posição do Relator Especial, os seus comentários ao artigo 14 no seu sexto Relatório esclarecem (ONU, p. 13-14, 1985):

Sobre as novas obrigações do Estado autor - reparação lato sensu - é difícil imaginar que elas não surgiriam no caso da comissão de um crime internacional, e o mesmo se aplica aos novos direitos de Estado lesado de adotar contramedidas. Em outras palavras, a questão é sobre as consequências jurídicas adicionais. ${ }^{607}$ (tradução nossa)

O Relator, então, reconhece claramente que no caso de crimes internacionais, em relação aos quais todos os Estados seriam considerados Estados lesados de acordo com o artigo 5, os Estados lesados têm o direito de adotar contramedidas.

\title{
606 Article 9
}

1. Subject to articles 10 to 13 , the injured State is entitled, by way of reprisal, to suspend the performance of its other obligations towards the State which has committed the internationally wrongful act.

2. The exercise of this right by the injured State shall not, in its effects, be manifestly disproportional to the seriousness of the internationally wrongful act committed.

607 As to the new obligations of the author State-reparation lato sensu-it is hard to imagine that they would not arise in the case of the commission of an international crime, and the same applies to the new rights of the injured States to take countermeasures. In other words, the question is rather one of additional legal consequences. 
A CDI, em 1985, adota provisoriamente o artigo 5 com a seguinte redação (ONU, p. 25, 1985) :

\section{Artigo 5}

1. Para o propósito dos presentes artigos, 'Estado lesado' significa qualquer Estado cujo direito foi afetado pelo ato de outro Estado, se tal ato constitui, de acordo com a parte 1 dos presentes artigos um ato internacionalmente ilícito daquele Estado.

2. Em particular, 'Estado lesado' significa:

a) se o direito violado pelo ato de um Estado advém de um tratado bilateral, o outro Estado parte do tratado;

b) se o direito violado pelo ato de um Estado advém de um julgamento ou outra decisão vinculante de uma solução de disputas de uma corte ou tribunal internacional, o outro Estado ou Estados partes da disputa e habilitados a se beneficiar daquele direito;

c) se o direito violado pelo ato do Estado advém da decisão vinculante de um órgão internacional outro que não uma corte ou tribunal internacional, o Estado ou Estados que, de acordo com o instrumento constitutivo da organização internacional interessada, estão habilitados a se beneficiar daquele direito;

d) se o direito violado pelo ato do Estado advém de uma determinação de tratado para um Estado terceiro, aquele Estado terceiro;

e) se o direito violado pelo ato do Estado advém de um tratado multilateral ou de uma norma do direito consuetudinário internacional, qualquer outro Estado parte do tratado multilateral ou vinculado pela norma de direito consuetudinário internacional, se estabelecido que:

i) o direito foi criado ou é estabelecido em seu favor.

ii) a violação do direito pelo ato de um Estado necessariamente afe ta o gozo dos direitos ou o cumprimento de obrigações de outros Estados partes do tratado multilateral ou vinculados pela norma de direito consuetudinário, ou

iii) o direito foi criado ou é estabelecido para a proteção de direitos humanos e liberdades fundamentais.

f) se o direito violado pelo ato do Estado advém de um tratado multilateral, qualquer outra parte do tratado multilateral, se ficar estabelecido que o direito foi expressamente estipulado naquele tratado para a proteção dos interesses coletivos dos Estados partes.

3. Também, 'Estado lesado' significa, se o ato internacionalmente ilícito constitui um crime internacional (e no contexto dos direitos e obrigações dos Estados segundo os artigos 14 e 15), todos os outros Estados. ${ }^{608}$ (tradução nossa)

\footnotetext{
608 Article 5

1. For the purposes of the present articles, "injured State" means any State a right of which is infringed by the act of another State, if that act constitutes, in accordance with part 1 of the present articles, an internationally wrongful act of that State.

2. In particular, "injured State" means :

(a) if the right infringed by the act of a State arises from a bilateral treaty, the other State party to the treaty ;

(b) if the right infringed by the act of a State arises from a judgment or other binding dispute-settlement decision of an international court or tribunal, the other State or States parties to the dispute and entitled to the benefit of that right;
} 
Algumas alterações são feitas na redação do artigo, em especial no parágrafo 3, onde é inserida uma "limitação" aos Estados lesados por um crime internacional, restringindo seus direitos e obrigações àqueles estabelecidos nos artigos 14 e 15 da Parte Dois, tal como propostos pelo Relator. Tais artigos se referiam às consequências jurídicas dos crimes internacionais (antigo artigo 6, acima reproduzido) e aos atos de agressão.

Essa limitação, porém, seria apagada pelo Drafting Committee em 1996, tendo em vista a modificação destes artigos.

Em resumo, embora inicialmente Riphagen defendesse que a possibilidade de adoção de contramedidas por Estados não diretamente lesados deveria ser precedida de uma decisão coletiva, ao adotar uma definição ampla de Estados lesados, o Relator Especial altera as bases de discussão. Tendo incluído no conceito de Estados lesados praticamente todos os Estados que teriam interesse de agir no caso de um ilícito internacional, a noção de "Estados terceiros" ou não diretamente lesados deixa de ter relevância.

Essa inclusão ganha uma importância ainda maior tendo em vista que não é feito nenhum tipo de distinção entre os Estados lesados. Embora nas discussões sobre o tema tenha se mencionado uma classificação entre Estados diretamente lesados e Estados não diretamente lesados, tal ideia não chegou a ser incorporada no artigo 5.

(c) if the right infringed by the act of a State arises from a binding decision of an international organ other than an international court or tribunal, the State or States which, in accordance with the constituent instrument of the international organization concerned, are entitled to the benefit of that right;

(d) if the right infringed by the act of a State arises from a treaty provision for a third State, that third State;

(e) if the right infringed by the act of a State arises from a multilateral treaty or from a rule of customary international law, any other State party to the multilateral treaty or bound by the relevant rule of customary international law, if it is established that:

(i) the right has been created or is established in its favour,

(ii) the infringement of the right by the act of a State necessarily affects the enjoyment of the rights or the performance of the obligations of the other States parties to the multilateral treaty or bound by the rule of customary international law, or

(iii) the right has been created or is established for the protection of human rights and fundamental freedoms ;

(f) if the right infringed by the act of a State arises from a multilateral treaty, any other State party to the multilateral treaty, if it is established that the right has been expressly stipulated in that treaty for the protection of the collective interests of the States parties thereto.

3. In addition, "injured State" means, if the internationally wrongful act constitutes an international crime [and in the context of the rights and obligations of States under articles 14 and 15], all other States. 
É com base na definição do artigo 5 que o artigo 9, sobre a possibilidade de adoção de contramedidas é redigido. Segundo este o "Estado lesado" tem o direito a adotar contramedidas.

Diante disso, só se pode concluir que, para o Relator Especial Riphagen, as contramedidas poderiam ser adotadas por Estados não diretamente lesados, sempre que eles se encaixassem na ampla definição de Estados lesados (parte de um tratado de direitos humanos violado ou parte da comunidade internacional no caso de crimes internacionais). Quando não se encaixassem em nenhuma destas categorias, ainda assim, poderiam adotar contramedidas, desde que houvesse uma decisão coletiva anterior aprovando-as.

Já a CDI, num primeiro momento, não admite a adoção de contramedidas por todos os Estados, em caso de crime internacional, a menos que estas medidas sejam tomadas visando cumprir as obrigações estabelecidas nos artigos 14 e 15 da Parte Dois. Por outro lado, ela aceita que nos casos de tratados multilaterais contendo normas de proteção aos direitos humanos, todos os Estados, partes deste tratado, teriam o direito de adotar contramedidas.

\subsubsection{Os trabalhos realizados por Gaetano Arangio-Ruiz}

A posição de Arangio-Ruiz em relação à definição de Estados lesados se assemelha muito com a de seu antecessor. Para este Relator, a diferenciação entre Estados diretamente e indiretamente lesados não tem substância. Um exemplo dado por ele são as normas de proteção de direitos humanos. Em suas palavras (ONU, p. 44, 1992):

Como é geralmente sabido, regras deste tipo [de proteção dos direitos humanos] criam entre os Estados as quais elas se aplicam uma relação jurídica caracterizada pela obrigação de cada Estado de assegurar o gozo dos direitos humanos para todos sob sua jurisdição, independente da nacionalidade. Qualquer violação desta obrigação pelo Estado A constituirá uma violação simultânea do direito correspondente dos Estados B, C, D e E respectivamente. Os direitos de todos os últimos Estados sendo o mesmo - o direito de ter o Estado A respeitando os direitos humanos daqueles sob sua jurisdição - nenhum deles é mais ou menos afetado pela violação que o outro. ${ }^{609}$ (tradução nossa)

609 As generally acknowledged, rules of this kind create among the States to which they apply a legal relationship characterized by each State's obligation to ensure the enjoyment of human rights for everyone under its jurisdiction, irrespective of nationality. Any violation of its obligation by State A will constitute a simultaneous infringement of the corresponding right of States B, C, D and E respectively. The rights of 
Ainda, segundo o Relator (ONU, p. 44-45, 1992):

Pode haver, é claro, uma diferença quando um ou mais Estados lesados se sentem particularmente afetados porque o Estado A violou os direitos humanos de indivíduos com os quais eles tenham uma ligação étnica ou de outro tipo. Isto, entretanto, não faz o dano sofrido por aqueles Estados legalmente mais direto que o sofrido pelos outros Estados. ${ }^{610}$ (tradução nossa)

Já em relação à adoção de contramedidas no caso de obrigações erga omnes, Arangio-Ruiz inicialmente defende (ONU, p. 47-48, 1992):

Qualquer restrição especial da faculdade individual de recorrer a contramedidas da parte do Estado lesado por uma violação a uma obrigação erga omnes não deriva do fato do dano ser indireto. Elas são meramente a consequência da aplicação, em cada situação hipotética ou fática, das regras gerais ou princípios governando as contramedidas, tais como a obrigação de demanda por cessação ou reparação anterior, ou exaustão dos procedimentos de solução de disputas anterior e, claro, do requerimento de proporcionalidade. ${ }^{611}$ (tradução nossa)

Assim, num primeiro momento, Arangio-Ruiz entende que as regras que regulam a adoção de contramedidas por Estados lesados pela violação de uma obrigação erga omnes, i.e. Estados indiretamente lesados, são as mesmas que regulam as contramedidas em geral. Sobre o tema, ele ainda defende (ONU, p. 49, 1992):

De fato, dois aspectos caracterizam as consequências instrumentais de uma violação a uma obrigação erga omnes. A primeira é que o resultado a ser perseguido pelas medidas unilaterais, por causa da identidade do interesse coletivo protegido pela norma, é o mesmo para todas as partes lesadas. O segundo é que este resultado pode ser perseguido solidariamente por uma pluralidade de partes lesadas. A primeira peculiaridade explica porque contramedidas unilaterais por

\footnotetext{
all the latter States being the same-namely the right to have State A respect the human rights of those under its jurisdiction - no one of them is more or less directly affected by the violation than any other.

610 There may, of course, be a difference where one or more of the injured States feel particularly affected because State A has violated the human rights of individuals with whom they have ethnic or other ties. This, however, does not make the injury sustained by those States legally more direct than that suffered by the other States.

611 any special restrictions of the individual faculte of resort to countermeasure on the part of the States injured by the breach of an erga omnes obligation, do not derive from any alleged indirectness of the injury. They are merely the consequence of the application, in each hypothetical or actual situation, of the general rules or principles governing countermeasures, such as the obligation of prior demand for cessation or reparation or prior exhaustion of dispute settlement procedures, and, of course, the requirement of proportionality.
} 
qualquer Estado sozinho são justificadas somente na medida em que elas estão conforme ao interesse comum. Como a norma violada protege um interesse coletivo, quaisquer reações a violação, apesar de numerosas e unilaterais, podem ser legalmente adotadas somente na medida em que elas cumprem a função de garantir a situação legal (primária) representada pelo interesse jurídico comum. Quando quaisquer reações não estão em conformidade com tal função (por exemplo, porque elas visam objetivos individuais de um dado Estado ou fins não protegidos pela norma violada) elas cairiam fora da esfera de consequências (substantivas ou instrumentais) da dada violação erga omnes: na medida em que elas violam obrigações internacionais, elas seriam, por sua vez, ilegais. ${ }^{612}$ (tradução nossa)

Para o Relator, no caso de uma violação a uma obrigação erga omnes diversos Estados podem tomar contramedidas unilaterais legalmente, desde que estas tenham como objetivo proteger o interesse coletivo violado.

Entretanto, uma conceituação mais ampla de Estado lesado e o reconhecimento do direito de todos estes Estados de adotarem contramedidas resulta num endurecimento das regras regulando as condições para a adoção das contramedidas em geral, tornadoas mais rigorosas. Neste sentido, Arangio-Ruiz propõe um novo artigo 12, que estabeleceria como condição para a adoção de contramedidas, a necessidade de exaustão de todos os meios de solução de controvérsias pacíficos disponíveis no Direito Internacional. ${ }^{613}$

612 Indeed, two features characterize the instrumental consequences of a violation of an erga omnes obligation. The first is that the result to be pursued by the unilateral measures, because of the identity of the collective interest protected by the rule, is the same for all the injured parties. The second is that that result may be pursued severally by a plurality of injured parties. The first peculiarity explains why unilateral countermeasures by any single State are justified only in so far as they conform to the common interest. As the infringed rule protects a collective interest, any reactions to the breach, however numerous and unilateral, may be lawfully resorted to only to the extent to which they perform the function of guaranteeing the (primary) legal situation represented by the common legal interest. Were any reactions not to be in conformity with such a function (for example, because they pursue individual aims of a given State or ends otherwise not protected by the infringed rule) they would fall outside the sphere of the consequences (substantive or instrumental) of the given erga omnes breach: to the extent that they were in violation of international obligations, they would in turn be unlawful.

${ }^{613}$ Article 12. Conditions of resort to countermeasures

1. Subject to the provisions set forth in paragraphs 2 and 3, no measure of the kind indicated in the preceding article shall be taken by an injured State prior to:

(a) the exhaustion of all the amicable settlement procedures available under general international law, the Charter of the United Nations or any other dispute settlement instrument to which it is a party; and (b) appropriate and timely communication of its intention.

2. The condition set forth in subparagraph (a) of the preceding paragraph does not apply:

(a) where the State which has committed the internationally wrongful act does not cooperate in good faith in the choice and the implementation of available settlement procedures;

(b) to interim measures of protection taken by the injured State, until the admissibility of such measures has been decided upon by an international body within the framework of a third-party settlement procedure;

(c) to any measures taken by the injured State if the State which has committed the internationally wrongful act fails to comply with an interim measure of protection indicated by the said body. 
Esta disposição sofre diversas críticas dos demais membros da CDI que acaba por adotar, no ano seguinte, uma versão atenuada deste artigo, estabelecendo apenas a necessidade de recurso aos meios de solução de controvérsias no caso da existência de disposições convencionais nesse sentido, vinculando as partes. Na ausência de tais disposições, bastaria a oferta de um procedimento de solução de disputas ao Estado responsável $^{614}$.

Em 1993, no seu quinto Relatório, Arangio-Ruiz escreve mais uma vez sobre as contramedidas no caso de crimes internacionais. Em suas palavras (ONU, p. 51, 1993): "O recurso a medidas sem o uso da força em reação a um crime, ao contrário da adoção de medidas envolvendo o uso da força, não enseja questões de admissibilidade, tais questões sendo geralmente decididas afirmativamente em relação a qualquer violação erga omnes."615 (tradução nossa)

Em comparação com as medidas possíveis de serem adotadas no caso de delitos internacionais, as contramedidas no caso de crimes internacionais poderiam er suas limitações atenuadas nos seguintes casos (ONU, p. 51, 1993):

a) medidas extremas de natureza econômica ou política;

b) medidas afetando a independência, soberania ou jurisdição doméstica do infrator;

c) medidas afetando Estados terceiros;

d) medidas punitivas. ${ }^{616}$ (tradução nossa)

3. The exceptions set forth in the preceding paragraph do not apply wherever the measure envisaged is not in conformity with the obligation to settle disputes in such a manner that international peace and security, and justice, are not endangered.

614 Article 12. Conditions of recourse to countermeasures

1. An injured State may not take countermeasures unless:

(a) It has recourse to a [binding/third-party] dispute settlement procedure which both the injured State and the State which has committed the internationally wrongful act are bound to use under any relevant treaty to which they are parties; or

(b) In the absence of such a treaty, it offers a [binding/ third-party] dispute settlement procedure to the State which has committed the internationally wrongful act.

2. The right of the injured State to take countermeasures is suspended when and to the extent that an agreed [binding] dispute settlement procedure is being implemented in good faith by the State which has committed the internationally wrongful act, provided that the internationally wrongful act has ceased.

3. A failure by the State which has committed the internationally wrongful act to honour a request or order emanating from the dispute settlement procedure shall terminate the suspension of the right of the injured State to take countermeasures.

${ }^{615}$ Resort to measures short of force in reaction to a

crime, unlike the adoption of measures involving force,

does not give rise to questions of admissibility, such questions

being generally settled in the affirmative with respect to any erga omnes breach.

616 (a) Extreme measures of an economic or political nature;

(b) Measures affecting the independence, sovereignty or domestic jurisdiction of the wrongdoer; 
Dois anos, depois, porém, insatisfeito com a posição adotada pela CDI em relação às condições para a adoção de contramedidas em geral, Arangio-Ruiz, no seu sétimo Relatório, propõe um artigo para regular exclusivamente as contramedidas adotadas no caso de crimes internacionais. Estabelece o artigo 17 (ONU, p. 29, 1995):

\begin{abstract}
Artigo 17.
1. Quando o ato internacionalmente ilícito de um Estado é um crime internacional, todo Estado cujas demandas, segundo o artigo 16 não tiveram uma resposta adequada do Estado que cometeu ou esta cometendo o crime é habilitado, sujeito a condição estabelecida no parágrafo 5 do artigo 19 abaixo, a adotar contramedidas de acordo com as condições e restrições estabelecidas nos artigos 11, 13 e 14, como modificadas pelos parágrafos 2 e 3 do presente artigo.

2. A condição estabelecida no parágrafo 5 do artigo 19 , abaixo, não se aplica as medidas urgentes e interinas que são requeridas para proteger os direitos de um Estado lesado ou para limitar o dano causado pelo crime internacional.

3. O requerimento de proporcionalidade estabelecido no artigo 13 deve se aplicar a contramedidas tomadas por quaisquer Estados de modo que a medida não seja fora de proporção com a gravidade do crime internacional. ${ }^{617}$ (tradução nossa)
\end{abstract}

O artigo 17 reconhece claramente o direito de todo o Estado de adotar contramedidas em razão de um crime internacional. Tal direito, no entanto, só pode ser exercido se cumprida a exigência estabelecida no parágrafo 5 do artigo 19, proposto. Tal parágrafo fazia referência a uma sentença da CIJ reconhecendo a existência do crime internacional.

O artigo 19 trazia em seu bojo um elaborado esquema para a determinação da ocorrência de um crime internacional, envolvendo a Assembleia Geral da ONU ou o Conselho de Segurança, num primeiro momento e a CIJ, numa segunda etapa. ${ }^{618}$

(c) Measures affecting "third" States;

(d) "Punitive" measures.

${ }^{617}$ Article 17

1. Where the internationally wrongful act of a State is an international crime, every State whose demands under article 16 have not met with an adequate response from the State which has committed or is committing the crime is entitled, subject to the condition set forth in paragraph 5 of article 19 below, to resort to countermeasures under the conditions and restrictions set forth in articles 11, 13 and 14 o modified by paragraphs 2 and 3 of the present article.

2. The condition set forth in paragraph 5 of article 19 below does not apply to such urgent, interim measures as are required to protect the rights of an injured State or to limit the damage caused by the international crime.

3. The requirement of proportionality set forth in article 13 shall apply to countermeasures taken by any State so that such measures shall not be out of proportion to the gravity of the international crime.

${ }^{618}$ Article 19 
Entretanto, a oposição ao artigo 19 foi tão forte que alguns membros se opuseram ao seu envio ao Drafting Committee. A questão foi decidida por votação na reunião 2406, quando a maioria decidiu pelo envio dos artigos contidos no sétimo Relatório a este órgão (ONU, p. 61, 1995a).

Os artigos 17 e 19, por fim, não foram incluídos no anteprojeto sobre a responsabilidade internacional do Estado, tal como adotado em primeira leitura.

Conclui-se dos trabalhos do Relator Especial Arangio-Ruiz, que este era francamente a favor da adoção de contramedidas por Estados não diretamente lesados. Esta adoção deveria, no entanto, no caso dos crimes internacionais, ser condicionada pelo complexo esquema de determinação da ocorrência de crime internacional elaborado pelo Relator no artigo 19, o que praticamente inviabilizaria a sua utilização. Já em relação à violação de obrigações previstas nos tratados internacionais de direitos humanos, as exigências para que todas as partes deste tratado pudessem adotar as contramedidas seriam as mesmas de qualquer outra contramedida.

2.2.5 $\mathrm{O}$ anteprojeto de artigos sobre responsabilidade internacional adotado em primeira leitura (1996)

1. Any State Member of the United Nations Party to the present Convention claiming that an international crime has been or is being committed by one or more States shall bring the matter to the attention of the General Assembly or the Security Council of the United Nations in accordance with Chapter VI of the Charter of the United Nations.

2. If the General Assembly or the Security Council resolves by a qualified majority of the Members present and voting that the allegation is sufficiently substantiated to justify the grave concern of the international community, any Member State of the United Nations Party to the present Convention, including the State against which the claim is made, may bring the matter to the International Court of Justice by unilateral application for the Court to decide by a judgment whether the alleged international crime has been or is being committed by the accused State.

3. The qualified majority referred to in the preceding paragraph shall be, in the General Assembly, a twothirds majority of the members present and voting, and in the Security Council, nine members present and voting including permanent members, provided that any members directly concerned shall abstain from voting.

4. In any case where the International Court of Justice is exercising its competence in a dispute between two or more Member States of the United Nations Parties to the present Convention, on the basis of a title of jurisdiction other than paragraph 2 of the present article, with regard to the existence of an international crime of State, any other Member State of the United Nations which is a Party to the present Convention shall be entitled to join, by unilateral application, the proceedings of the Court for the purpose of paragraph 5 of the present article.

5. A decision of the International Court of Justice that an international crime has been or is being committed shall fulfil the condition for the implementation, by any Member State of the United Nations Party to the present Convention, of the special or supplementary legal consequences of international crimes of States as contemplated in articles 16, 17 and 18 of the present part. 
Tal como adotado em primeira leitura, o anteprojeto sobre a responsabilidade internacional estatal conceituava de forma extremamente ampla o termo "Estado lesado". O artigo 40, adotado em 1996, retirava do parágrafo 3, qualquer restrição aos Estados lesados por crime internacional.

Seriam Estados lesados assim, entre outros, os Estados parte de um tratado multilateral de proteção aos direitos humanos, no caso de violação de uma obrigação contida neste tratado, e todos os Estados da comunidade internacional no caso de crimes internacionais, incluindo-se nestes aqueles atos contra obrigações voltadas para a salvaguarda do ser humano.

$\mathrm{O}$ artigo 47, antigo artigo 11 da parte 2, foi finalmente adotado com a seguinte redação (ONU, p. 63, 1996a):

Artigo 47. Contramedidas por um Estado lesado

1. Para os propósitos do presente artigo, a tomada de contramedidas significa que um Estado lesado não cumpre com uma ou mais obrigações em relação ao Estado que cometeu o ato internacionalmente ilícito, de modo a induzi-lo a cumprir com suas obrigações segundo os artigos 41 a 46, desde que este não tenha cumprido com estas obrigações e se necessário tendo em vista a sua resposta as demandas feitas pelo Estado lesado.

2. A tomada de contramedidas é sujeita às condições e restrições estabelecidas nos artigos 48 a 50 .

3. Quando uma contramedida contra um Estado que cometeu um ato internacionalmente ilícito envolve a violação de uma obrigação em relação a um terceiro Estado, tal violação não pode ser justificada segundo este capítulo, em relação ao terceiro Estado. ${ }^{619}$ (tradução nossa)

As condições das contramedidas, estabelecidas no artigo 48, se referiam, apenas, à necessidade de negociação com o Estado responsável, e não mais a necessidade de adotar procedimentos de solução de controvérsia ${ }^{620}$.

\footnotetext{
619 Article 47. Countermeasures by an injured State

1. For the purposes of the present articles, the taking of countermeasures means that an injured State does not comply with one or more of its obligations towards a State which has committed an internationally wrongful act in order to induce it to comply with its obligations under articles 41 to 46, as long as it has not complied with those obligations and as necessary in the light of its response to the demands of the injured State that it do so.

2. The taking of countermeasures is subject to the conditions and restrictions set out in articles 48 to 50 .

3. Where a countermeasure against a State which has committed an internationally wrongful act involves a breach of an obligation towards a third State, such a breach cannot be justified under this chapter as against the third State.

${ }^{620}$ Article 48 . Conditions relating to resort to countermeasures
} 
Por outro lado, não foi incluído nenhum artigo regulamentando especificamente as contramedidas adotadas em função de um crime internacional. Pelo contrário, o artigo 51, que se referia às consequências jurídicas dos crimes internacionais foi adotado com a seguinte redação (ONU, p. 64, 1996a): "um crime internacional acarreta todas as consequências jurídicas de outro ato internacionalmente ilícito [...]"621 (tradução nossa)

Assim, um crime internacional acarretaria todas as consequências de um "delito internacional" dentre elas a possibilidade da adoção de contramedidas. Estas também poderiam ser adotadas por todas as partes de um tratado multilateral, nos casos previstos no artigo 40.

Alland escreve sobre o anteprojeto de 1996 (p. 1229-1230, 2002):

Finalmente, na versão de 1996 do anteprojeto, pode-se mais ou menos deduzir o seguinte argumento: contramedidas são uma consequência possível de qualquer ato internacionalmente ilícito; um crime é um ato internacionalmente ilícito que lesa a todos os Estados; mas o artigo 51 estabelece que todas as consequências resultantes de um delito decorrem de um crime; portanto, todos os Estados podem adotar contramedidas em razão de um crime. Mas esta última conclusão não é explicitamente estabelecida. Somos deixados com alguma ambiguidade. ${ }^{622}$ (tradução nossa)

Neste mesmo sentido escreve Sicilianos, segundo o qual (p. 1142, 2002):

Pode-se consequentemente deduzir que, uma vez que as contramedidas constituem uma consequência jurídica dos 'delitos', o

\footnotetext{
1. Prior to taking countermeasures, an injured State shall fulfil its obligation to negotiate provided for in article 54. This obligation is without prejudice to the taking by that State of interim measures of protection which are necessary to preserve its rights and which otherwise comply with the requirements of this chapter.

2. An injured State taking countermeasures shall fulfil the obligations in relation to dispute settlement arising under part three or any other binding dispute settlement procedure in force between the injured State and the State which has committed the internationally wrongful act.

3. Provided that the internationally wrongful act has ceased, the injured State shall suspend countermeasures when and to the extent that the dispute settlement procedure referred to in paragraph 2 is being implemented in good faith by the State which has committed the internationally wrongful act and the dispute is submitted to a tribunal which has the authority to issue orders binding on the parties.

4. The obligation to suspend countermeasures ends in case of failure by the State which has committed the internationally wrongful act to honour a request or order emanating from the dispute settlement procedure.

${ }_{621}$ An international crime entails all the legal consequences of any other internationally wrongful act

622 Finally, in the 1996 version of the Draft, one could more or less derive the following argument: countermeasures are a possible consequence of any wrongful act; a crime is a wrongful act that injuries all states; but article 51 states that all the consequences attaching to a delict follow from a crime; accordingly, all states may take countermeasures following a crime. But this last conclusion is not explicitly stated. We are left with some ambiguity.
} 
Artigo 51 a fortiori reconheceu o poder de qualquer estados 'lesado' por um crime de recorrer a contramedidas. O comentário ao artigo 51, entretanto, cuidadosamente evita se referir às contramedidas. ${ }^{623}$ (tradução nossa)

Apesar da ausência de uma disposição expressa no sentido da possibilidade da adoção de contramedidas por Estados indiretamente lesados, uma interpretação lógica e sistemática dos artigos, tal como adotados em primeira leitura, não deixa dúvida sobre a questão. $\mathrm{O}$ artigo 40 estabelece uma ampla definição de Estados lesados, o artigo 47 determina que os Estados lesados têm o direito de adotar contramedidas e o artigo 51 ainda reforça que todas as consequências jurídicas advindas de um ato internacionalmente ilícito se aplicam a um crime internacional.

A única conclusão a que se pode chegar é que a CDI, nos artigos adotados em primeira leitura, em 1996, reconhecia amplamente o direito dos Estados não diretamente lesados de adotarem contramedidas. Além deste reconhecimento, a CDI não atribuía nenhuma condição específica para a adoção de contramedidas por estes Estados que forma que as regras que regulavam estas medidas seriam as mesmas que regulavam as contramedidas em geral.

Assim, no caso específico da violação a normas de direitos humanos, quando estas estiverem consagradas em um tratado multilateral, todos os Estados partes deste tratado teriam o direito de adotar contramedidas no caso da violação de uma das obrigações nele estabelecidas. Em caso de normas de direitos humanos que, pelo seu amplo reconhecimento, houvessem alcançado o status de normas consuetudinárias, todos os Estados submetidos a esta norma teriam este direito. E em alguns casos mais específicos, quando esta normas forem consideradas de tal importância que a comunidade internacional como um todo teria o interesse na sua proteção, de modo que a sua violação constituiria um crime internacional, todos os Estados da comunidade internacional estariam aptos a adotar contramedidas.

\subsubsection{Os trabalhos realizados por James Crawford}

\footnotetext{
${ }^{623}$ One might accordingly deduce that, since the countermeasures constituted a legal consequence of the 'delicts', Article 51 a fortiori recognized the power of any state 'injured' by a crime to have recourse to countermeasures. The commentary to Article 51, however, carefully avoided referring to countermeasures.
} 
A indicação de James Crawford como Relato Especial sobre a responsabilidade dos Estados resultou em uma verdadeira reviravolta nos trabalhos da CDI. Já no seu Relatório preliminar Crawford defende a exclusão do conceito de crime internacional do anteprojeto. Em suas palavras (ONU, p. 23, 1998):

Recomenda-se que os artigos 19 (e consequentemente, os artigos 51 a 53) sejam apagados do anteprojeto de artigos. No contexto da segunda leitura dos da parte dois, o artigo 40, parágrafo 3, deve ser reconsiderados, inter alia, para lidar com o tema das violações de obrigações erga omnes. Deve se entender que a exclusão do anteprojeto de artigos da noção de 'crimes internacionais' é sem o prejuízo (a) do escopo do anteprojeto de artigos, que continuaria a cobrir todas as violações de obrigações internacionais, qualquer que seja a sua origem, e (b) a noção de 'crime internacional dos Estados' e seu possível desenvolvimento futuro, tanto como um tópico separado ara a Comissão, ou através da prática estatal e da prática das organizações internacionais competentes. ${ }^{624}$ (tradução nossa)

A exclusão dos crimes internacionais dos artigos produz efeitos, em especial na questão das consequências jurídicas dos atos internacionalmente ilícitos.

Crawford, entretanto, reconhece a possibilidade de todos os Estados adotarem contramedidas, de acordo com o anteprojeto da CDI tal como aprovado em primeira leitura (ONU, p. 91, 1999):

É verdade que segundo a definição de 'Estado lesado' no artigo 40, todos os Estados são definidos como lesados pelo crime, e assim, todos os Estados têm o direito individual de procurar reparação e de tomas contramedidas em resposta a um crime. Os projetos de artigos, entretanto, não contêm nenhuma disposição lidando com as possíveis consequências de muitos Estados tomando contramedidas em resposta a um ato ilícito descrito como 'crime' exceto, talvez pelo artigo 53 (d) que prevê que todos Estados devem 'cooperar com outros Estados na aplicação das medidas designadas para eliminar as consequências do crime' ${ }^{625}$ (tradução nossa)

\footnotetext{
624 It is recommended that articles 19 (and, consequently, articles 51 to 53) be deleted from the draft articles. In the context of the second reading of part two, article 40, paragraph 3, should be reconsidered, inter alia, so as to deal with the issue of breaches of obligations erga omnes. It should be understood that the exclusion from the draft articles of the notion of "international crimes" of States is without prejudice (a) to the scope of the draft articles, which would continue to cover all breaches of international obligation whatever their origin; and $(b)$ to the notion of "international crimes of States" and its possible future development, whether as a separate topic for the Commission, or through State practice and the practice of the competent international organizations.

625 It is true that under the definition of. "injured State" in article 40 all States are defined as injured by a crime, and that therefore all States have the individual right to seek reparation for, and to take counter-. measures in response to, a crime. The draft articles, however, contain no provision dealing with the possible consequences of many States taking countermeasures in response to a wrongful act described as
} 
No seu terceiro Relatório, em 2000, este Relator propõe a reformulação do artigo 40, de forma a restringir o conceito de Estado lesado e criando a figura do Estado com interesse jurídico. O novo artigo 40 bis teria a seguinte redação (ONU, p. 54, 2000):

Direito de um Estado de invocar a responsabilidade de outro Estado 1. Para os propósitos deste projeto de artigos, um Estado é lesado pelo ato internacionalmente ilícito de outro Estado se:

a) a obrigação violada é devida individualmente a ele, ou

b) a obrigação em questão é devido à comunidade internacional como um todo (erga omnes), ou a um grupo de Estados dos quais é parte, e a violação da obrigação:

i) afeta especialmente aquele Estado; ou

ii) necessariamente afeta o gozo de seus direitos ou o cumprimento de suas obrigações.

2. Além disso, para os propósitos deste anteprojeto de artigos, um Estado tem um interesse legal no cumprimento de uma obrigação internacional da qual é parte se:

a) a obrigação é devida a comunidade internacional como um todo (erga omnes)

b) a obrigação é estabelecida para a proteção do interesse coletivo de um grupo Estados, incluindo aquele Estado.

3. Este artigo não prejudica nenhum direito, surgido da comissão de um ato internacionalmente ilícito por um Estado, que resulte diretamente a qualquer pessoa ou entidade que não um Estado. ${ }^{626}$ (tradução nossa)

A nova definição de Estado lesado deixaria de fora tanto os Estados, partes de um tratado multilateral, que não tivesse seus interesses afetados especialmente, quanto os Estados da comunidade internacional no caso dos crimes internacionais. Este estados passariam a ser categorizados como Estados com "interesse legal no cumprimento da obrigação".

a "crime", except perhaps for article $53(d)$ which provides that States should "cooperate with other States in the application of measures designed to eliminate the consequences of the crime".

${ }^{626}$ Right of a State to invoke the responsibility of another State

1. For the purposes of these draft articles, a State is injured by the internationally wrongful act of another State if:

(a) the obligation breached is owed to it individually; or

(b) the obligation in question is owed to the international community as a whole (erga omnes), or to a group of States of which it is one, and the breach of the obligation:

(i) specially affects that State; or

(ii) necessarily affects the enjoyment of its rights or the performance of its obligations.

2. In addition, for the purposes of these draft articles, a State has a legal interest in the performance of an international obligation to which it is a party if:

(a) the obligation is owed to the international community as a whole (erga omnes);

(b) the obligation is established for the protection of the collective interests of a group of States, including that State.

3. This article is without prejudice to any rights, arising from the commission of an internationally wrongful act by a State, which accrue directly to any person or entity other than a State. 
As consequências desta nova definição de Estado lesado para o instituto das contramedidas são claras. Reduz-se bastante o seu campo de atuação. O direito de adotar contramedidas passaria a ser restrito aos Estados diretamente lesados.

Para contrabalancear este efeito, o Relator Especial propõe dois novos artigos Segundo estes (ONU, p. 25, 2000b):

Artigo 50A. Contramedidas em nome de um Estado lesado

Qualquer outro Estado habilitado a invocar a responsabilidade de um Estado segundo (o artigo 40 bis 2) pode adotar contramedidas por requerimento e em nome de um Estado lesado, sujeitas a quaisquer condições colocadas por aquele Estado e na medida em que aquele Estado é habilitado a adotar aquelas contramedidas.

Artigo 50B. Contramedidas em caso de violações sérias a obrigações devidas a comunidade internacional como um todo

1) Nos casos referidos no artigo 51 onde nenhum Estado individual é lesado pela violação, qualquer Estado pode adotar contramedidas, sujeito a e de acordo com este Capítulo, de modo a assegurar a cessação da violação da violação e a reparação no interesse das vítimas.

2) Quando mais de um Estado adota contramedidas segundo o parágrafo 1, estes Estados devem cooperar de modo a assegurar que as condições estabelecidas neste Capítulo para a adoção de contramedidas sejam preenchidas. ${ }^{627}$ (tradução nossa)

$\mathrm{O}$ artigo 51, por sua vez, trataria das consequências jurídicas das "violações sérias a obrigações devidas a comunidade internacional como um todo" termo que teria substituído o chamado “crime internacional”. Segundo este artigo (ONU p. 24, 2000b):

Artigo 51. Consequências de violações sérias a obrigações devidas a comunidade internacional como um todo

1) Este Capítulo se aplica a responsabilidade internacional que surge de violações sérias e manifestas pó um Estado de uma obrigação devida a comunidade internacional como um todo.

2) Tal violação acarreta, para o Estado responsável, todas as consequências jurídicas de qualquer outro ato internacionalmente

627 Article 50A Countermeasures on behalf of an injured State

Any other State entitled to invoke the responsibility of a State under [article 40 bis (2)] may take countermeasures at the request and on behalf of an injured State, subject to any conditions laid down by that State and to the extent that that State is itself entitled to take those countermeasures.

Article 50B Countermeasures in cases of serious breaches of obligations to the international community as a whole

(1) In cases referred to in article 51 where no individual State is injured by the breach, any State may take countermeasures, subject to and in accordance with this Chapter, in order to ensure the cessation of the breach and reparation in the interests of the victims.

(2) Where more than one State takes countermeasures under paragraph 1, those States shall cooperate in order to ensure that the conditions laid down by this Chapter for the taking of countermeasures are fulfilled. 
ilícito e, ainda (danos punitivos) (danos refletindo a gravidade da violação).

3) Ela também acarreta, para todos os outros Estados, as seguintes obrigações adicionais:

a) não reconhecer como legal a situação criada pela violação;

b) não prestar ajuda ou assistência ao Estado que cometeu a violação para a manutenção da situação criada;

c) cooperar na aplicação das medidas designadas a trazer um fim a violação e na medida do possível, a eliminar suas consequências.

4) Os parágrafos 2 e 3 são sem prejuízo de consequências adicionais, penais ou outras, que a violação possa acarretar segundo o direito internacional. ${ }^{628}$ (tradução nossa)

Assim, seriam permitidas contramedidas por Estados não diretamente lesados em duas hipóteses: na primeira, a requerimento e em nome de um Estado diretamente lesado; na segunda, no caso de violações sérias às obrigações devidas à comunidade internacional como um todo, quando nenhum Estado individual é lesado pela violação.

A primeira hipótese, adoção de contramedidas a requerimento e em nome de um Estado lesado, seria um paralelo ao instituto de legítima defesa coletiva. Um Estado lesado, tendo em vista um poder econômico ou uma influência política limitados, pode recorrer a Estados mais fortes para tornar efetivas as contramedidas contra o Estado responsável.

$\mathrm{Na}$ segunda hipótese, nos casos "de violações sérias de obrigações devidas à comunidade internacional como um todo", não fica claro se a referência ao artigo 51 se limita a estabelecer que a contramedida só pode ser tomada nos casos de "violações sérias de obrigações devidas à comunidade internacional como um todo" em que não exista um Estado individual diretamente lesado, ou se ela implica em vincular a adoção destas contramedidas exclusivamente ao cumprimento das obrigações estabelecidas no artigo 51 (não reconhecer a situação criada pelo ilícito, não ajudar na manutenção da

${ }^{628}$ Article 51 Consequences of serious breaches of obligations to the international community as a whole (1) This Chapter applies to the international responsibility that arises from the serious and manifest breach by a State of an obligation owed to the international community as a whole.

(2) Such a breach entails, for the State responsible for that breach, all the legal consequences of any other internationally wrongful act and, in addition, [punitive damages] [damages reflecting the gravity of the breach].

(3) It also entails, for all other States, the following further obligations:

(a) not to recognize as lawful the situation created by the breach;

(b) not to render aid or assistance to the State which has committed the breach in maintaining the situation so created;

(c) to cooperate in the application of measures designed to bring the breach to an end and as far as possible to eliminate its consequences.

(4) Paragraphs 2 and 3 are without prejudice to such further penal or other consequences that the breach may entail under international law. 
situação e auxiliar na aplicação de medidas designadas a cessar a violação ou eliminar suas consequências).

De qualquer forma, a terminologia empregada na alínea (c) do parágrafo 3 do artigo 51 é bastante geral, podendo dar margem a interpretações extensivas.

Com base nos artigos propostos por Crawford, o Drafting Committee, sugere alguns novos artigos. Os artigos $41^{629}$ e $42^{630}$, que tratam da violação séria a uma obrigação essencial à comunidade internacional como um todo seriam um desmembramento do artigo 51 proposto pelo Relator; os artigos $43^{631}$, que trata do Estado lesado, e $49^{632}$, que trata da invocação da responsabilidade por Estado outro que não o Estado lesado seriam desmembramentos do artigo 40 bis; e o artigo $54^{633}$, que

${ }^{629}$ Article 41. Application of this chapter

1. This chapter applies to the international responsibility arising from an internationally wrongful act that constitutes a serious breach by a State of an obligation owed to the international community as a whole and essential for the protection of its fundamental interests.

2. A breach of such an obligation is serious if it involves a gross or systematic failure by the responsible State to fulfil the obligation, risking substantial harm to the fundamental interests protected thereby.

${ }^{630}$ Article 42 [51, 53]. Consequences of serious breaches of obligations to the international community as a whole

1. A serious breach within the meaning of article 41 may involve, for the responsible State, damages reflecting the gravity of the breach.

2. It entails, for all other States, the following obligations:

(a) Not to recognize as lawful the situation created by the breach;

(b) Not to render aid or assistance to the responsible State in maintaining the situation so created;

(c) To cooperate as far as possible to bring the breach to an end.

3. This article is without prejudice to the consequences referred to in chapter II and to such further consequences

that a breach to which this chapter applies may entail under international law.

${ }^{631}$ Article 43 [40]. The injured State

A State is entitled as an injured State to invoke the responsibility of another State if the obligation breached is owed to:

(a) That State individually; or

(b) A group of States including that State, or the international community as a whole, and the breach of the obligation:

(i) Specially affects that State; or

(ii) Is of such a character as to affect the enjoyment of the rights or the performance of the obligations of all the States concerned.

632 Article 49. Invocation of responsibility by States other than the injured State

1. Subject to paragraph 2, any State other than an injured State is entitled to invoke the responsibility of another State if:

(a) The obligation breached is owed to a group of States including that State, and is established for the protection of a collective interest;

(b) The obligation breached is owed to the international community as a whole.

2. A State entitled to invoke responsibility under paragraph 1 may seek from the responsible State:

(a) Cessation of the internationally wrongful act, and assurances and guarantees of non-repetition in accordance with article 30 [41, 46];

(b) Compliance with the obligation of reparation under chapter II of Part Two, in the interest of the injured State or of the beneficiaries of the obligation breached.

3. The requirements for the invocation of responsibility by an injured State under articles 44, 45 [22] and 46 apply to an invocation of responsibility by a State entitled to do so under paragraph 1 .

${ }^{633}$ Article 54. Countermeasures by States other than the injured State 
trata das contramedidas por Estados outros que não o Estado lesado funde os artigos 50A e 50B, apresentados pelo Re lator (ONU, p. 68-71, 2000C).

Durante os debates sobre os novos artigos, críticas são feitas ao novo artigo 54, que trataria das contramedidas por Estados não diretamente lesados.

Em defesa deste artigo, Crawford escreve (ONU, p. 29, 2001):

Existe uma dificuldade adicional, que a mera deleção do artigo 54 implicará que contramedidas só possam ser adotadas por Estados lesados, estreitamente definidos. $\mathrm{O}$ atual estado do direito internacional sobre medidas tomadas pelo interesse geral ou comum é, sem dúvida, incerto. Mas não é o caso, na visão do Relator Especial, de que contramedidas em prol da observância do direito internacional sejam limitadas às violações afetando os interesses individuais de Estados poderosos ou seus aliados. Obrigações em relação à comunidade internacional como um todo, ou de outro modo, de interesse coletivo, não são obrigações de 'segunda classe' em comparação com as obrigações previstas em tratados bilaterais. Embora se possa esperar que as organizações internacionais sejam hábeis para resolver crises humanitárias e outras que frequentemente surgem das sérias violações de direito internacional, os Estados não abdicaram de seus poderes de ação individual. Assim, se o artigo 54 for apagado, haverá a necessidade de ao menos uma cláusula de salvaguarda. ${ }^{634}$ (tradução nossa)

Assim, Crawford reconhece à possibilidade da adoção de contramedidas por Estados não diretamente lesados. Para este Relator Especial, entretanto, essa possibilidade é limitada, devendo se encaixar nas hipóteses previstas no artigo 54 (consolidação dos artigos 50.A e 50.B, por ele propostos).

Em relação, exclusivamente, às violações decorrentes de normas voltadas à proteção dos direitos humanos, segundo a proposta do Relator, os demais Estados da

\footnotetext{
1. Any State entitled under article 49, paragraph 1, to invoke the responsibility of a State may take countermeasures at the request and on behalf of any State injured by the breach, to the extent that that State may itself take countermeasures under this chapter.

2. In the cases referred to in article 41 , any State may take countermeasures, in accordance with the present chapter in the interest of the beneficiaries of the obligation breached.

3. Where more than one State takes countermeasures, the States concerned shall cooperate in order to ensure that the conditions laid down by this chapter for the taking of countermeasures are fulfilled.

634 There is a further difficulty, in that the mere deletion of article 54 will carry the implication that countermeasures can only be taken by injured States, narrowly defined. The current state of international law on measures taken in the general or common interest is no doubt uncertain. But it cannot be the case, in the Special Rapporteur's view, that countermeasures in aid of compliance with international law are limited to breaches affecting the individual interests of powerful States or their allies. Obligations towards the international community, or otherwise in the collective interest, are not "second-class" obligations by comparison with obligations under bilateral treaties. While it can be hoped that international organizations will be able to resolve the humanitarian or other crises that often arise from serious breaches of international law, States have not abdicated their powers of individual action. Thus if article 54 were to be deleted, there would at least be a need for some form of saving clause.
} 
comunidade internacional poderiam adotar contramedidas em apoio a um Estado lesado, de acordo com a nova definição estabelecida no artigo 40, a pedido deste. Isto evitaria que em situações onde houvesse um Estado mais afetado pela violação aos direito humanos (por exemplo, Estados fronteiriços que têm que lidar com um grande fluxo de refugiados), outros Estados adotassem medidas sem consultar o referido Estado. Por outro lado, no caso em que estes Estados não tenham interesse em agir, os demais Estados da comunidade internacional ficariam de mão atadas.

Já nos casos de violações sérias a obrigações devidas à comunidade internacional como um todo, quando não houver um Estado diretamente lesado (por exemplo, no caso de um Estado praticando genocídio contra o seu próprio povo em seu próprio território), todos os Estados da comunidade internacional poderiam adotar contramedidas, ao menos para cumprir com as obrigações estabelecidas no artigo 51.

2.2.7 $\mathrm{O}$ anteprojeto de artigos sobre a responsabilidade internacional do Estado

Em 2001 a CDI finalmente adotou a versão definitiva do anteprojeto de artigos sobre a responsabilidade internacional do Estado, após mais de quarenta anos de trabalho.

Nesta versão, o conceito de Estado lesado, tal como proposto pelo por Crawford, fica restrito aos Estados diretamente lesados, conforme a redação do artigo $42^{635}$. Os demais Estados, que Crawford havia denominado "Estados com interesse legal" no cumprimento das obrigações teriam apenas o direito de invocar a responsabilidade internacional do Estado em algumas circunstâncias (artigo 48 ${ }^{636}$ ).

${ }^{635}$ Article 42. Invocation of responsibility by an injured State

A State is entitled as an injured State to invoke the responsibility of another State if the obligation breached is owed to:

(a) that State individually; or

(b) a group of States including that State, or the international commu nity as a whole, and the breach of the obligation:

(i) specially affects that State; or

(ii) is of such a character as radically to change the position of all the other States to which the obligation is owed with respect to the further performance of the obligation.

636 Article 48. Invocation of responsibility by a State other than an injured State

1. Any State other than an injured State is entitled to invoke the responsibility of another State in accordance with paragraph 2 if:

(a) the obligation breached is owed to a group of States including that State, and is established for the protection of a collective interest of the group; or

(b) the obligation breached is owed to the international community as a whole.

2. Any State entitled to invoke responsibility under paragraph 1 may claim from the responsible State: 
Tendo em vista essa definição restrita de Estados lesados, as contramedidas, tal como definidas no artigo 49, só poderiam ser adotadas pelos Estados diretamente lesados.

O artigo 54, porém, adotado no lugar do artigo regulando a adoção de contramedidas por Estados não diretamente lesados, proposto pelo Relator, tem um texto ambíguo. De acordo com este (ONU, p. 137, 2001a):

Art. 54. Medidas tomadas por Estados que não sejam o Estado lesado Este Capítulo não prejudica o direito de qualquer Estado, apto, de acordo com o art. 48, parágrafo 1 , de invocar a responsabilidade de outro Estado para tomar medidas lícitas contra o Estado para assegurar a cessação da viola ção e a reparação no interesse do Estado lesado ou dos beneficiários da obrigação violada. ${ }^{637}$ (tradução nossa)

A CDI, em seus comentários a este artigo, após citar 8 casos de aplicação de contramedidas por Estados não diretamente lesados, ainda assim conclui (ONU, p. 139, 2001a):

Como esta revisão mostra, o presente estado do direito internacional sobre contramedidas tomadas no interesse geral ou coletivo é incerto. A prática estatal é esparsa e envolve um número limitado de Estados. No presente, não parece haver um direito claramente reconhecido dos Estados referidos no artigo 48 de tomarem contramedidas no interesse coletivo. Consequentemente, não é apropriado incluir nos presentes artigos uma provisão relativa à questão se outros Estados, identificados no artigo 48, têm permissão de tomar contramedidas de modo a induzir o Estado responsável a cumprir com suas obrigações. Ao invés disso, o capítulo II inclui uma cláusula de salvaguarda que

(a) cessation of the internationally wrongful act, and assurances and guarantees of non-repetition in accordance with article 30 ; and

(b) performance of the obligation of reparation in accordance with the preceding articles, in the interest of the injured State or of the beneficiaries of the obligation breached.

3. The requirements for the invocation of responsibility by an injured State under articles 43,44 and 45 apply to an invocation of responsibility by a State entitled to do so under paragraph 1.

${ }^{636}$ Article 49. Object and limits of countermeasures

1. An injured State may only take countermeasures against a State which is responsible for an internationally wrongful act in order to induce that State to comply with its obligations under Part Two.

2. Countermeasures are limited to the non-performance for the time being of international obligations of the State taking the measures towards the responsible State.

3. Countermeasures shall, as far as possible, be taken in such a way as to permit the resumption of performance of the obligations in question.

${ }^{637}$ Article 54. Measures taken by States other than an injured State

This chapter does not prejudice the right of any State, entitled under article 48, paragraph 1, to invoke the responsibility of another State, to take lawful measures against that State to ensure cessation of the breach and reparation in the interest of the injured State or of the beneficiaries of the obligation breached. 
reserva a posição e deixa a resolução da matéria para o futuro desenvolvimento do direito internacional. ${ }^{638}$ (tradução nossa)

Ainda, a CDI escreve sobre o artigo 54 (ONU, p. 139, 2001a):

O artigo 54, portanto, prevê que o capítulo sobre contramedidas não prejudica o direito de nenhum Estado, habilitado, segundo o artigo 48, parágrafo 1, a invocar a responsabilidade de outro Estado, de tomar medidas lícitas contra o Estado responsável para assegurar a cessação da violação e a reparação no interesse do Estado lesado ou dos beneficiários da obrigação violada. O artigo fala de 'medidas lícitas' ao invés de 'contramedidas' de modo a não prejudicar qualquer posição relativa a medidas tomadas por Estados outros que não o Estado lesado, em resposta à violação de obrigações para a proteção de um interesse coletivo ou aquelas devidas à comunidade internacional como um todo. ${ }^{639}$ (tradução nossa)

Alland, ao analisar o artigo 54 do anteprojeto e os comentários da CDI, defende (p. 1232-1233, 2002):

Apesar destas formulações da CDI, eu não acredito que o texto seja 'neutro' no ponto que nos interessa aqui, uma vez que os argumentos mencionados não são inteiramente convincentes. Primeiro, em relação ao artigo 54, eu não consigo ver como, sendo restrito às medidas lícitas, este texto poderia não 'prejudicar' a questão do recurso às contramedidas que são por definição intrinsecamente ilícitas. Essa é toda a diferença entre medidas de retorsão que são lícitas per se, e contramedidas que, embora intrinsecamente ilícitas, se tornam lícitas somente porque são justificadas e preenchem certas condições. ${ }^{640}$ (tradução nossa)

\footnotetext{
${ }^{638}$ As this review demonstrates, the current state of international law on countermeasures taken in the general or collective interest is uncertain. State practice is sparse and involves a limited number of States. At present, there appears to be no clearly recognized entitle ment of States referred to in article 48 to take countermeasures in the collective interest. Consequently, it is not appropriate to include in the present articles a provision concerning the question whether other States, identified in article 48, are permitted to take countermeasures in order to induce a responsible State to comply with its obligations. Instead, chapter II includes a saving clause which reserves the position and leaves the resolution of the matter to the further development of international law.

${ }^{639}$ Article 54 accordingly provides that the chapter on countermeasures does not prejudice the right of any State, entitled under article 48, paragraph 1, to invoke the responsibility of another State, to take lawful measures against the responsible State to ensure cessation of the breach and reparation in the interest of the injured State or the beneficiaries of the obligation breached. The article speaks of "lawful measures" rather than "countermeasures" so as not to prejudice any position concerning measures taken by States other than the injured State in response to breaches of obligations for the protection of the collective interest or those owed to the international community as a whole.

${ }^{640}$ Despite this formulations by the ILC, I do not believe the text is 'neutral' on the point that interest us here, since the foregoing arguments are not entirely convincing. First, as regards Article 54, I cannot see how, being confined to lawful measures, this text could not 'prejudice' the question of recourse to countermeasures which are by definition intrinsically wrongful. This is the entire difference between measures of retorsion which are lawful per se, and countermeasures which are, though intrinsically wrongful, become lawful only because they are justified and meet certain conditions.
} 
Assim ele conclui que (ALLAND, p. 1233, 2002) “o Artigo 54 não deixa espaço para a teoria de contramedidas por Estados não diretamente lesados em resposta a uma obrigação erga omnes."641 (tradução nossa)

Algumas críticas podem ser feitas à posição de Alland. A Hermenêutica dispõe de diversos métodos para a interpretação de uma norma (FERRAZ Jr., p. 286, et seq., 1996).

Um desses métodos é a interpretação gramatical. O termo utilizado no artigo 54, "medidas lícitas" (lawful measures), é um termo geral. Não há qualquer referência à necessidade intrínseca ou extrínseca de licitude. Basta que a medida seja lícita.

As contramedidas são medidas que seriam ilícitas se não fossem adotadas em resposta a um ato ilícito internacional e se não seguissem as regras de Direito Internacional que as regulam. Entretanto, uma vez preenchidos todos estes requisitos elas são medidas lícitas. O termo utilizado na versão original em inglês no artigo 22 , que trata das contramedidas como excludentes de ilicitude, foi "precluded", de "preclude", que significa impedir (prevent); tornar impossível (make impossible) (LONGMAN, p. 1034, 1993). Ele se opõe ao termo "preempt", que significa fazer algo não efetivo (LONGMAN, p. 1035, 1993). O texto em francês é ainda mais claro ao utilizar o termo "exclue", de excluir. Assim, segundo o artigo 22, no caso das contramedidas a ilicitude é impedida de ocorrer, é evitada, é excluída. Isso é diferente de afirmar que a contramedida é ilícita, mas os efeitos desta ilicitude são desconsiderados ou anulados. Nesse sentido Ramos (p. 218, 2004): “A aceitação das chamadas excludentes na teoria da responsabilidade internacional do Estado tem o condão de excluir apenas o caráter ilícito da conduta do Estado, de acordo com o projeto da Comissão de Direito Internacional."

Se a ilicitude não ocorre, o ato, por consequência é lícito. Portanto, as contramedidas são medidas lícitas.

Assim, o texto do artigo 54 poderia se referir às contramedidas, desde que elas preencham todos os requisitos estabelecidos para a sua configuração e licitude.

Outro tipo de interpretação é a interpretação histórica. Segundo Ferraz Jr. (p. 290, 1996): "Esta investigação [histórica] leva o intérprete também a buscar - quando

\footnotetext{
${ }^{641}$ Article 54 leaves no room for the theory of countermeasures by states not directly injured in response to a breach of obligations erga omnes.
} 
existem - nos chamados trabalhos preparatórios (discussões parlamentares, emendas preteridas etc.) elementos auxiliares do sentido histórico da norma."

Assim, se levarmos em conta os trabalhos preparatórios da CDI, acima resumidos, perceberemos que embora inicialmente rejeitada (1955-1979), a ideia de contramedidas por Estados não diretamente lesados passou a ser aceita desde os trabalhos do Relator Especial Riphagen (1980-2000), seja através de artigos tratando diretamente deste instituto em si $^{642}$, seja por meio da adoção de um conceito abrangente de Estados lesados $^{643}$.

Desde 1979, todos os Relatores Especiais foram favoráveis a adoção de contramedidas por Estados indiretamente lesados. O anteprojeto de artigos, tal como aprovado em primeira leitura em 1996, por meio de uma interpretação sistemática, permitia a adoção de contramedidas por Estados não diretamente lesados nas mesmas condições que o permitia para os Estados diretamente lesados.

Ainda, o artigo 54 foi adotado em substituição ao antigo artigo 54, proposto pelo Drafting Committee, artigo este que tratava das hipóteses em que as contramedidas poderiam ser adotadas por Estados não diretamente lesados. Analisando a evolução histórica do artigo 54, podemos concluir que ele sempre esteve intimamente ligado ao instituto das contramedidas.

Outro método de interpretação é a interpretação sistemática, que verifica a compatibilidade de uma questão com o todo estrutural (FERRAZ Jr, p. 288, 1996).

Ao analisarmos a estrutura do anteprojeto, o capítulo II da Parte Três, trata exclusivamente das contramedidas, sendo este o seu título. O artigo 54 faz parte deste capítulo. Ainda, em seus comentários a esse capítulo a CDI afirma (ONU, p. 128, 2001a):

Qualquer que seja sua motivação [medidas de retorsão], na medida que tais atos não são incompatíveis com as obrigações internacionais dos Estados que as tomam em relação ao Estado alvo, elas não envolvem contramedidas e estão fora do escopo dos presentes artigos. $^{644}$ (tradução nossa)

\footnotetext{
${ }^{642}$ Artigo 17, proposto por Arangio-Ruiz, Artigos 50.A e 50.B e 54, propostos por Crawford e pelo Drafting Committee.

${ }^{643}$ Artigo 5 proposto por Riphagen, Artigo 5, proposto por Arangio-Ruiz, artigo 40, adotado pela CDI em primeira leitura.

${ }^{644}$ Whatever their [measures of retorsion] motivation, so long as such acts are not incompatible with the international obligations of the States taking them towards the target State, they do not involve countermeasures and they fall outside the scope of the present articles.
} 
Ou seja, para a CDI, as medidas de retorsão, por serem lícitas, estão fora do escopo do anteprojeto, não havendo necessidade de ser reguladas por ele.

Por fim, outro método de interpretação é o método teleológico, que procura determinar o propósito da norma (FERRAZ, p. 291, 1996). Como vimos anteriormente, o artigo 54 foi adotado em substituição ao antigo artigo 54 proposto pelo Drafting Committee, artigo este que tratava das contramedidas a serem adotadas por Estados não diretamente lesados. Crawford, em seu Relatório de 2001 escreveu sobre a deleção do antigo artigo 54 (p. 29, 2001): "se o artigo 54 for apagado, haverá a necessidade de ao menos uma cláusula de salvaguarda.",645

Posteriormente, a própria CDI em seus comentários ao artigo 54, esclareceu (ONU, p. 139, 2001a): “o capítulo II inclui uma cláusula de salvaguarda que reserva a posição [sobre as contramedidas tomadas no interesse geral ou coletivo] e deixa a resolução da matéria para o futuro desenvolvimento do direito internacional." ${ }^{\text {"646 }}$ (tradução nossa)

E ainda (ONU, p. 139, 2001a):

O artigo fala de 'medidas lícitas' ao invés de 'contramedidas' de modo a não prejudicar qualquer posição relativa a medidas tomadas por Estados outros que não o Estado lesado, em resposta à violação de obrigações para a proteção de um interesse coletivo ou aquelas devidas à comunidade internacional como um todo. ${ }^{647}$ (tradução nossa)

Assim, segundo a própria CDI, redatora do artigo, seu objetivo seria de servir de salvaguarda para a posição de Estados agindo em nome do interesse coletivo, e utiliza o termo "medidas lícitas" ao invés de contramedidas, mais restrito, para não prejudicar qualquer posição relativa a medidas tomadas por um Estado não diretamente lesado em defesa deste interesse.

Assim, ao analisarmos sob diversas perspectivas o artigo 54, percebemos que:

a) o artigo 22 exclui a ilicitude das contramedidas, de forma que estas, preenchidas determinadas condições, são medidas lícitas;

b) o artigo 54 foi adotado em substituição a um artigo (antigo artigo 54) que regulava as contramedidas tomadas por Estados não diretamente lesados;

\footnotetext{
645 if article 54 were to be deleted, there would at least be a need for some form of saving clause.

646 chapter II includes a saving clause which reserves the position and leaves the resolution of the matter to the further development of international law

647 The article speaks of "lawful measures" rather than "countermeasures" so as not to prejudice any position concerning measures taken by States other than the injured State in response to breaches of obligations for the protection of the collective interest or those owed to the international community as a whole.
} 
b) o artigo 54 se encontra no capítulo II que trata exclusivamente das contramedidas;

c) este artigo se refere a "medidas lícitas";

d) a CDI considera que medidas de retorsão estão fora do escopo do presente artigo;

e) para a CDI, o objetivo do artigo 54 é servir de cláusula de salvaguarda para a posição dos Estados não diretamente lesados adotando medidas para a preservação de interesses coletivos ou gerais.

Assim, tendo em vista uma interpretação gramatical, histórica, sistemática e teleológica do artigo 54, só podemos conclui que tal artigo se refere às contramedidas, e embora não admita a possibilidade de adoção de contramedidas por Estados não diretamente lesados, adota uma posição no mínimo neutra em relação ao assunto.

Neste sentido, escreve Sicilianos sobre o artigo 54 (p. 1143, 2002):

\begin{abstract}
A ambiguidade está tanto no título, que fala em 'medidas' e não em 'contramedidas', e no texto, que se refere a 'medidas lícitas'. Esta última expressão pode, de fato, ser interpretada de dois modos, de acordo com a posição que se adota na questão das medidas 'coletivas'. Aqueles não favoráveis àquelas medidas provavelmente manterão que 'medidas lícitas' deve se considerar como significando medidas lícitas per se, i.e. atos de retorsão ao invés de contramedidas. Aqueles que adotam o ponto de vista contrário lembrarão que atos de retorsão foram explicitamente excluídos do escopo de aplicação dos Artigos sobre Responsabilidade Internacional; que permitir retorsões e dedicar uma disposição específica com este propósito é sem sentido uma vez que elas são, em todo caso, permitidas; que contramedidas são também "medidas lícitas", tendo em vista que sua ilicitude foi excluída pelo artigo 22 - e pelo direito consuetudinário - na medida em que elas são tomadas de acordo com as condições procedimentais e materiais codificadas essencialmente nos artigos 49-53; e finalmente, que o artigo 54 é uma parte integral do capítulo sobre contramedidas. A segunda interpretação é a legalmente correta, uma vez que é conforme com o espírito e outras disposições dos Artigos sobre a Responsabilidade do Estado. ${ }^{648}$ (tradução nossa)
\end{abstract}

\footnotetext{
${ }^{648}$ The ambiguity lies both in the heading, which talks of 'measures' and not 'countermeasures', and in the text, which refers to 'lawful measures'. This latter expression can in fact be interpreted in two ways, according to the position one takes on the question of 'collective' countermeasures. Those unfavorable to those countermeasures will probably maintain that 'lawful measures' must be taken to mean measures lawful per se, i.e. acts of retorsion rather than countermeasures. Those who take the opposite viewpoint will recall that acts of retorsion were explicitly excluded from the scope of application of the Articles on State Responsibility; that permitting retorsions and devoting a specific provision to the purpose is pointless, since they are in any case permitted; that countermeasures too are 'lawful measures', given that their wrongfulness is precluded by Article 22 - and by customary law - to the extent that they are taken in accordance with the procedural and material conditions codified essentially in Articles 49-53; and finally, that Article 54 is an integral part of the chapter on countermeasures.
} 
Portanto o artigo 54 estabelece que o Capítulo II não prejudica o direito dos Estados que se encaixem nas categorias previstas pelo artigo 48 de tomar contramedidas contra o Estado responsável, visando a cessação e a reparação do ato internacionalmente ilícito.

Outro artigo relevante é o artigo 41, que estabelece:

Art. 41. Consequências particulares da violação séria de uma obrigação de acordo com este Capítulo

1. Os Estados deverão cooperar para pôr fim, através de meios legais, a toda violação séria no sentido atribuído no artigo 40.

2. Nenhum Estado reconhecerá como lícita uma situação criada por uma violação séria no sentido atribuído no artigo 40, nem prestará auxílio ou assistência para manutenção daquela situação.

3. Este artigo não prejudica as outras consequências referidas nesta Parte bem como as demais consequências que uma violação a qual se aplique este Capítulo possa acarretar, de acordo com o Direito Internacional. ${ }^{649}$ (tradução nossa)

Sobre o parágrafo 1 deste artigo a CDI comenta (ONU, p. 114, 2001a):

De acordo com o parágrafo 1 do artigo 41, os Estados têm um dever positivo de cooperar para pôr um fim às violações sérias no sentido do artigo 40. Por causa da diversidade de circunstâncias que poderiam possivelmente estar envolvidas, a disposição não prescreve em detalhes que forma esta cooperação deve ter. A cooperação pode ser organizada no quadro de uma organização internacional competente, em particular as Nações Unidas. Entretanto o parágrafo 1 também prevê a possibilidade de cooperação não institucional. [...] Tal cooperação deve se dar através de meios legais, a escolha dos quais dependerá das circunstâncias de cada situação. Fica, entretanto, claro que a obrigação de cooperar se aplica aos Estados sejam eles individualmente afetados pela violação séria ou não. O que é requerido em face de sérias violações é um esforço conjunto e coordenado de todos os Estados para neutralizar os efeitos destas violações. ${ }^{650}$ (tradução nossa)

\footnotetext{
${ }^{649}$ Article 41. Particular consequences of a serious breach of an obligation under this chapter

1. States shall cooperate to bring to an end through lawful means any serious breach within the meaning of article 40.

2. No State shall recognize as lawful a situation created by a serious breach within the meaning of article 40, nor render aid or assistance in maintaining that situation.

3. This article is without prejudice to the other consequences referred to in this Part and to such further consequences that a breach to which this chapter applies may entail under international law.

${ }^{650}$ Pursuant to paragraph 1 of article 41 , States are under a positive duty to cooperate in order to bring to an end serious breaches in the sense of article 40 . Because of the diversity of circumstances which could possibly be involved, the provision does not prescribe in detail what form this cooperation should take. Cooperation could be organized in the framework of a competent international organization, in particular the United Nations. However, paragraph 1 also envisages the possibility of non-institutionalized cooperation. [...] Such cooperation must be through lawful means, the choice of which will depend on the circumstances of the given situation. It is, however, made clear that the obligation to cooperate applies to
} 
Ainda, em relação à cooperação no âmbito das organizações internacionais a CDI escreve (p. 114, 2001a): "Mas de fato, tal cooperação, especialmente no quadro das organizações internacionais, é realizada já em resposta às mais graves violações do direito internacional e é frequentemente o único modo de conseguir um remédio efetivo." ${ }^{651}$ (tradução nossa)

O parágrafo1 do artigo 41 estabelece um dever de cooperação de todos os Estados para fazer cessar uma violação séria a uma obrigação estabelecida por uma norma imperativa de direito internacional. Tal cooperação deve ocorrer principalmente, mas não exclusivamente, no âmbito de uma organização internacional, em especial a ONU.

Inúmeras questões surgem numa análise detalhada deste parágrafo e de seu comentário. A CDI faz uma ligação deste dever de cooperação com a Organização das Nações Unidas. Entretanto, a ONU não possui nenhum mecanismo para cuidar das "violações sérias a obrigações decorrentes de normas imperativas do direito internacional geral". Vinaixa (p. 615, 2002) se pergunta se a CDI "confunde os mecanismos de segurança coletiva com os de 'resposta a violações mais graves do Direito Internacional'." (tradução nossa) Ainda que a CDI se refira a estes mecanismos de segurança coletiva, cuja competência é exclusiva do Conselho de Segurança, basta uma leitura da Carta das Nações Unidas para perceber que estes somente devem ser utilizados em casos de ameaça a paz e segurança mundiais. Ora, existem diversas violações graves a normas imperativas que não se encaixariam nesta classificação.

Por outro lado, segundo a Carta da ONU (artigo 41), somente o Conselho de Segurança tem competência para adotar medidas coercitivas, ainda que somente de caráter econômico, contra um Estado. Ainda assim, a Assembleia Geral, em algumas ocasiões, como veremos mais detalhadamente a frente, adotou resoluções recomendando aos Estados a adoção de medidas que poderiam se configurar contramedidas de um Estado em relação ao Estado responsabilizado. Nestes casos, seria possível estabelecer que o artigo 41 reconhece não só o direito, mas o dever de alguns Estados de adotar contramedidas em relação ao Estado violador?

States whether or not they are individually affected by the serious breach. What is called for in the face of serious breaches is a joint and coordinated effort by all States to counteract the effects of these breaches.

${ }^{651}$ But in fact such cooperation, especially in the framework of international organizations, is carried out already in response to the gravest breaches of international law and it is often the only way of providing an effective remedy. 
Por fim, a CDI deixa claro que este dever de cooperação pode ser implementado através de cooperação não institucional. Neste caso a cooperação deve se dar pelos "meios legais" disponíveis. Sendo as contramedidas um meio legal, poderiam estas ser utilizadas?

Já sobre o parágrafo 2 do artigo 41 a CDI explica (ONU, p. 115, 2001a):

Ele trata da conduta 'após o fato' que ajuda o Estado responsável a manter a situação 'oponível a todos os Estados no sentido de barrar erga omnes a legalidade da situação que é mantida em violação do direito internacional. Ele se estende além da comissão da violação séria, ela mesma, até a manutenção da situação criada pela violação, e ele se aplica quer a violação seja contínua ou não. ${ }^{652}$ (tradução nossa)

Também a redação do parágrafo 2 do artigo 41 poderia dar margem a interpretações. Ao estabelecer a proibição de prestar auxílio ou assistência ao Estado violador, o artigo não menciona a possibilidade de que tal auxílio ou assistência possa decorrer de uma obrigação internacional de um Estado em relação ao Estado violador. Neste caso, a negação de assistência ou auxílio poderia se configurar em uma contramedida contra este Estado?

Finalmente, a CDI comenta o parágrafo 3. Segundo esta (ONU, p. 116, 2001a):

O parágrafo 3, assim, permite que o direito internacional possa reconhecer consequências jurídicas adicionais derivadas da comissão de uma violação séria no sentido do artigo 40. O fato de que tais demais consequências não estão expressamente referidas no capítulo III não prejudica o seu reconhecimento no direito internacional atual, ou seu futuro desenvolvimento. Além disso, o parágrafo 3 reflete a convicção de que o regime jurídico das violações sérias, esta em estado de desenvolvimento. Ao estabelecer certas consequências jurídicas básicas das violações sérias no sentido do artigo 40, o artigo 41 não pretende impedir o futuro desenvolvimento de um regime mais elaborado de consequências resultantes de tais violações. ${ }^{653}$ (tradução nossa)

\footnotetext{
652 It deals with conduct "after the fact" which assists the responsible State in maintaining a situation "opposable to all States in the sense of barring erga omnes the legality of a situation which is maintained in violation of international law". It extends beyond the commission of the serious breach itself to the maintenance of the situation created by that breach, and it applies whether or not the breach itself is a continuing one.

653 Paragraph 3 accordingly allows that international law may recognize additional legal consequences flowing from the commission of a serious breach in the sense of article 40. The fact that such further consequences are not expressly referred to in chapter III does not prejudice their recognition in presentday international law, or their further development. In addition, paragraph 3 reflects the conviction that the legal regime of serious breaches is itself in a state of development. By setting out certain basic legal consequences of serious breaches in the sense of article 40 , article 41 does not intend to preclude the future development of a more elaborate regime of consequences entailed by such breaches.
} 
O parágrafo 3 do artigo 41 deixa claro que as consequências estabelecidas por este artigo não são exaustivas. Segundo a CDI, o regime de consequências jurídicas das violações sérias está ainda em desenvolvimento, e este parágrafo serviria de salvaguarda para a sua futura evolução. Assim, nada impede que a adoção de contramedidas por Estados não diretamente lesados possa vir a ser considerada uma das consequências jurídicas da responsabilidade internacional do Estado por violações sérias a obrigações decorrentes de normas imperativas do Direito Internacional.

Também o artigo 56 do anteprojeto estabelece (ONU, p. 141, 2001a):

Artigo 56. Questões de responsabilidade do Estado não reguladas por estes artigos

As normas aplicáveis de Direito Internacional continuam a reger as questões relativas à responsabilidade de um Estado por ato internacionalmente ilícito na medida em que tais questões não são reguladas por estes artigos. ${ }^{654}$ (tradução nossa)

A CDI, em seus comentários a este artigo, afirma (ONU, p. 141, 2001a): “Os artigos não pretendem determinar todas as consequências de um ato internacionalmente ilícito mesmo segundo o direito internacional existente e não há intenção de impedir o futuro desenvolvimento do direito sobre a responsabilidade do Estado."655 (tradução nossa)

Assim, a própria CDI admite que os artigos não contêm todas as consequências jurídicas advindas dos atos internacionalmente ilícitos, nem mesmo segundo o Direito Internacional atual.

Uma análise do anteprojeto de artigos sobre a responsabilidade internacional do Estado e dos comentários feitos a ele pela CDI permite extrair as seguintes conclusões:

a) O artigo 54 estabelece que o Capítulo I da Parte III do anteprojeto não prejudica o direito dos Estados não diretamente lesados que se encaixem nas categorias estabelecidas pelo artigo 48 de adotarem medidas lícitas, i.e. contramedidas contra o Estado responsável para assegurar a cessação e a reparação do ato internacionalmente ilícito.

\footnotetext{
${ }^{654}$ Article 56. Questions of State responsibility not regulated by these articles The applicable rules of international law continue to govern questions concerning the responsibility of a State for an internationally wrongful act to the extent that they are not regulated by these articles.

655 the articles do not purport to state all the consequences of an internationally wrongful act even under existing international law and there is no intention of precluding the further development of the law on State responsibility.
} 
b) $\mathrm{O}$ artigo 41.1 estabelece um dever de todos os Estados da comunidade internacional de cooperar dentro e fora das organizações internacionais para a cessação e a reparação de violações sérias a obrigações decorrentes de normas imperativas do Direito Internacional.

b) $\mathrm{O}$ artigo 41.3 afirma que as consequências jurídicas estabelecidas no artigo 41, ou seja, as consequências jurídicas resultantes de uma violação séria a uma obrigação decorrente de uma norma imperativa do Direito Internacional, não são exaustivas, estando ainda em desenvolvimento.

c) $\mathrm{O}$ artigo 56 admite que nem todas as consequências jurídicas advindas dos atos internacionalmente ilícitos estão incorporadas no anteprojeto.

$\mathrm{O}$ artigo 54, lido em conjunto com o artigo 56 e o artigo 41.3, permite concluir que ainda que não expressamente admitidas pelo anteprojeto, as contramedidas adotadas por Estados não diretamente lesados não são proibidas desde que preencham os seguintes requisitos (artigo 48):

a) O Estado que adota a medida é parte do grupo em relação ao qual a obrigação violada foi estabelecida e tal obrigação foi estabelecida para a proteção de um interesse coletivo deste grupo ou;

b) a obrigação violada existe em relação à comunidade internacional como um todo.

Um ponto a ser esclarecido é a relação das contramedidas adotadas por Estados não diretamente lesados com os conceitos de jus cogens e de obrigações erga omnes. A redação do anteprojeto de artigos sobre a responsabilidade internacional do Estado é confusa neste ponto.

Se por um lado ela faz referência a "violações sérias decorrentes de normas imperativas de direito internacional geral ' nos seus artigos 40 e 41, utilizando o conceito de jus cogens para configurar as violações mais graves ao Direito Internacional, por outro lado, o artigo 48.1, se refere a obrigações existentes "em relação à comunidade internacional como um todo", ou seja, obrigações erga omnes. Como visto anteriormente, embora os dois conceitos tenham pontos em comum, eles não se confundem.

Tendo em vista a menção expressa no artigo 54 ao artigo 48.1, deve-se concluir que as medidas previstas neste primeiro artigo têm ligação direta com o conceito de obrigação erga omnes. Portanto, somente diante de violações destas obrigações, estas medidas poderiam ser adotadas. 
Cabe, também, ressaltar a posição de alguns Estados nos debates ocorridos no âmbito da $56^{\mathrm{a}}$ Sessão do $6^{\circ}$ Comitê da Assembleia Geral das Nações Unidas. Para França (ONU, A/C.6/56. SR.11, p. 11), China (ONU, A/C.6/56/SR.11, p 10) e Rússia (ONU, A/C.6/56/SR.14, p 8), o artigo 54 não se resume a uma saving clause, contendo na verdade uma autorização indireta para a adoção de contramedidas por Estados não diretamente lesados. Ainda, segundo a Rússia, tal artigo resultaria em que estas contramedidas tivessem menos restrições do que as contramedidas em geral.

Tal posição, no entanto, não é a que transparece nos comentários da CDI ao artigo, nem é partilhada pelos demais Estados, de modo que a neutralidade do artigo 54 parece ser a interpretação mais correta.

Assim, o anteprojeto de artigos sobre a responsabilidade internacional do Estado não proíbe, no caso de violação a obrigações decorrentes de normas visando à proteção dos direitos humanos, a adoção de contramedidas por Estados partes de um tratado multilateral de proteção a esses direitos, quando uma das obrigações estabelecidas nesse tratado para a proteção dos direitos humanos é violada por outro Estado parte. Neste caso, fica claro que a obrigação é estabelecida em relação a todos os outros Estados partes, e que ela foi estabelecida para a proteção de um interesse coletivo destes Estados, ou seja, a proteção dos direitos humanos previstos no tratado.

Ainda, o anteprojeto, não proíbe contramedidas tomadas por qualquer Estado diante de uma violação de uma obrigação devida à comunidade internacional como um todo. Assim, quando as normas de direitos humanos ensejarem obrigações que se referem à comunidade internacional como um todo (obrigações erga omnes), nenhum Estado estaria proibido de adotar contramedidas no caso de uma violação destas obrigações.

Em resumo, se a CDI, na versão final do anteprojeto de artigos sobre a responsabilidade internacional do Estado, não admite claramente a possibilidade de adoção de contramedidas por Estados não diretamente lesados no caso de violações a obrigações contidas em normas protetoras de direitos humanos, ao menos em alguns casos, ela também não as proíbe, dando ao texto um caráter, no mínimo neutro.

Tendo em vista a falta de uma posição definitiva no anteprojeto, cabe examinar outras fontes do Direito Internacional que possam trazer esclarecimentos sobre a questão, em especial a doutrina a jurisprudência e a prática dos Estados. 


\title{
2.3 Jurisprudência
}

O reconhecimento da capacidade de agir de Estados não diretamente lesados por um ato ilícito internacional já foi objeto de pareceres e decisões dos tribunais internacionais. Embora não se possa falar em um desenvolvimento linear, o estudo desta jurisprudência pode fornecer indicações sobre a legalidade da adoção de contramedidas por Estados não diretamente lesados.

\subsubsection{Corte Permanente de Justiça (CPJI)}

Caso Wimbledon(1923)

A Corte Permanente de Justiça Internacional CPJI) reconheceu a capacidade processual de Estados não diretamente lesados por um ato internacionalmente ilícito no caso Wimbledon, no julgamento de 17 de agosto de 1923. A Alemanha havia impedido a navegação de um navio britânico a cargo de uma companhia francesa no Canal de Kiel. A Grã Bretanha, a França, a Itália e o Japão levaram o caso contra a Alemanha à CPJI, com base em disposições do Tratado de Versailles. Muito embora nem a Itália nem o Japão tivessem sofrido um dano direto pelo ato alemão, ou mesmo tivessem algum direito violado por esta conduta, a Corte considerou que estes tinham direito de figurar no polo ativo da disputa. Em suas palavras (CPJI, p. 20, 1923):

\begin{abstract}
A primeira questão a ser considerada é se os procedimentos poderiam ser instituídos pelos quatro Governos acima mencionados nos termos da Petição apresentada. O Respondente deixou este ponto para a apreciação da Corte.

A Corte não tem dúvida de que pode tomar conhecimento da petição instituindo os procedimentos na forma em que ela foi submetida. Será suficiente observar que, para os propósitos deste caso, cada um dos quatro Poderes requerentes têm um claro interesse na execução das disposições relativas ao Canal de Kiel, uma vez que todos eles têm frotas e navios mercantes navegando sob suas respectivas bandeiras. Eles estão assim, mesmo que sejam incapazes de apresentar um prejuízo a qualquer interesse pecuniário, cobertos pelos termos do Artigo 386, parágrafo I [...]. ${ }^{656}$ (tradução nossa)
\end{abstract}

\footnotetext{
${ }^{656}$ The first question to be considered is whether proceedings could be instituted by the four Governments above mentioned in the terms of the Application filed. The Respondent has left this point to the appreciation of the Court.

The Court has no doubt that it can take cognizance of the application instituting proceedings in the form in which it has been submitted. It will suffice to observe for the purposes of this case that each of the four Applicant Powers has a clear interest in the execution of the provisions relating to the Kiel Canal, since they all possess fleets and merchant vessels flying their respective flags. They are therefore, even though
} 
A Corte reconhece, assim, a capacidade processual ativa da Itália e do Japão, apenas baseada no interesse que estes Estados teriam na implementação das disposições relativas a este Canal. É certo que o artigo 386 menciona que "qualquer Poder interessado pode apelar à jurisdição instituída para este propósito pela Liga das Nações”(p. 20, 1923) ${ }^{657}$, mas o que se destaca neste julgamento é a interpretação do termo "interesse", que não precisa se referir a um dano material ou uma violação substantiva de um direito. Basta um interesse geral, na execução das disposições do tratado para configurar o direito de um Estado não diretamente lesado em acionar a CPJI.

Já no caso Jurisdição Territorial da Comissão Internacional do Rio Oder de 1929, a CPJI reconheceu que um interesse comunitário poderia dar origem a um direito jurídico comum. Em sua s palavras (p. 27, 1929):

Esta comunidade de interesses em um rio navegável se torna a base de um direito jurídico comum, cujas características essenciais são a perfeita igualdade de todos os Estados ribeirinhos no uso de todo o curso do rio e a exclusão de qualquer privilégio especial de um Estado ribeirinho em relação aos outros. ${ }^{6}$

Assim, de um interesse coletivo no rio, nasce um direito coletivo, que atribui a cada Estado, igualdade de condições no uso deste.

\subsubsection{Corte Internacional de Justiça (CIJ)}

Caso reservas à Convenção sobre a prevenção e a punição do Genocídio (1950)

$\mathrm{Na}$ Opinião Consultiva de 1951, quando a Corte se manifestou sobre a possibilidade de reservas à Convenção sobre a prevenção e a punição do Genocídio, esta afirmou (CIJ, p. 23, 1951): "Em tal convenção, os Estados contratantes não têm nenhum interesse próprio; eles têm apenas, cada um e todos, um interesse comum, notadamente,

they may be unable to adduce a prejudice to any pecuniary interest, covered by the terms of Article 386, Paragraph I [...]

657 Any interested Power can appeal to the jurisdiction instituted for the purpose by the League of Nations.

${ }^{658}$ This community of interest in a navigable river becomes the basis of a common legal right, the essential features of which are the perfect equality of all riparian States in the user of the whole course of the river and the exclusion of any privilege of one riparian State in relation to the others. 
a consecução daqueles grandes propósitos que são a razão de ser da convenção." (tradução nossa) ${ }^{659}$

A Corte reconhece, portanto, que em um tratado multilateral cujo objetivo é a proteção de direitos humanos, em particular o direito à vida de um conjunto de pessoas, todos os Estados partes têm um interesse em comum, que é a implementação dos objetivos da convenção, e consequentemente, o respeito às obrigações estabelecidas por esta convenção.

Em sua Opinião Dissidente, os juízes Guerrero, Mc Nair, Read e Hsu Mo vão um pouco mais longe. Para estes (p. 46, 1951):

É um fato inegável que a tendência de todas as atividades internacionais nos tempos recentes tem sido na direção da promoção do bem-estar da comunidade internacional com uma correspondente restrição ao poder soberano dos Estados individuais. Assim, quando um esforço comum é feito para promover um grande objetivo humanitário, como é o caso da Convenção de Genocídio, todo Estado interessado naturalmente espera todo outro Estado interessado a não procurar uma vantagem ou conveniência individual, mas a implementar as medidas decididas de comum acordo. ${ }^{660}$ (tradução nossa)

Para este juízes, assim, a soberania dos Estados, considerados individualmente, poderia ser restringida em função do bem-estar e dos interesses da comunidade internacional como um todo, perdendo seu caráter absoluto.

\section{Caso Monetary Gold (1954)}

No caso Monetary Gold, decidido preliminarmente pela Corte Internacional de Justiça (CIJ) em 1954, a Itália peticionou à Corte contra uma decisão da Comissão Tripartite, formada pelo Reino Unido, França e Estados Unidos, de destinar uma quantidade de ouro, aparentemente pertencente à Albânia, ao Reino Unido a titulo da indenização devida a este pela Albânia, em função da condenação sofrida por esta no caso Canal de Corfu, indenização esta que até então não tinha sido paga. A Itália

\footnotetext{
${ }^{659}$ In such a convention the contracting States do not have any interests of their own ; they merely have, one and all, a common interest, namely, the accomplishment of those high purposes which are the raison d'être of the convention.

${ }^{660}$ It is an undeniable fact that the tendency of all international activities in recent times has been towards the promotion of the common welfare of the international community with a corresponding restriction of the sovereign power of individual States. So, when a common effort is made to promote a great humanitarian object, as in the case of the Genocide Convention, every interested State naturally expects every other interested State not to seek any individual advantage or convenience, but to carry out the measures resolved upon by common accord.
} 
requeria que o ouro fosse entregue a ela para indenizar danos que esta havia sofrido também causados pela Albânia. Embora a Corte finalmente entendesse que, em virtude da recusa da Albânia de submeter a questão a Corte, ela não tinha jurisdição para decidir a questão $^{661}$, teve grande repercussão o discurso de Fitzmaurice, representando o Reino Unido, no qual ele defende o direito de todos os Estados de adotarem medidas para auxiliar na implementação das decisões dos tribunais internacionais. Em suas palavras (p. 126, 1954):

\begin{abstract}
Também deve, num campo mais amplo, ser uma questão de importância para todos os membros da família das nações - cujas relações são regidas pelo Direito internacional - que os julgamentos do mais alto tribunal, na verdade de todos os tribunais, devam ser respeitados e cumpridos. Não pode deixar de ser prejudicial à comunidade internacional e ao estado de direito nas relações internacionais se os julgamentos dos tribunais internacionais, e particularmente de um tribunal tal como a presente Corte, forem infringidos ou desconsiderados. Seria certo dizer, eu acredito, que não só tal ocorrência deve ser motivo de preocupação para todos os membros da comunidade internacional, mas também todos os países estão, se não obrigados, em qualquer caso, habilitados a tomar todas as medidas razoáveis e legítimas, que possam estar disponíveis a eles para evitar tal acontecimento, e tanto individualmente como por ação comum, fazer o que puderem para assegurar que julgamentos, particularmente os desta Corte, sejam devidamente implementados e cumpridos - em qualquer caso, desde que os direitos de terceiros países sejam respeitados. ${ }^{662}$ (tradução nossa)
\end{abstract}

Embora tal discurso não represente o pensamento da Corte, nem de um de seus juízes, ele serve ao menos de indicação sobre a posição do Reino Unido sobre a matéria e teve repercussão na doutrina sobre o tema. Para Akehurst (p. 13, 1970):

O que Sir Gerald Fitzmaurice estava realmente argumentando era que a recusa ilegal da Albânia a pagar os danos concedidos no caso Corfu Channel ao Reino Unido justificava não só o Reino Unido, mas também a França e os Estados Unidos, a cometer o que teria sido

\footnotetext{
661 (CIJ, p. 19, 1954)

662 It must also, on wider grounds, be a matter of importance to all members of the family of nations whose relations are governed by international Law - that the judgments of the highest international tribunal, as indeed of all tribunals, should be respected and carried out. It cannot fail to be prejudicial to the international community and to the rule of law in international relations if the judgments of international tribunals, and particularly of such tribunal as the present Court, are contravened or disregarded. It would be right to say, I think, that not only must such an occurrence be a matter of concern to all members of the international community, but also that all countries are, if not bound, at any rate entitled to take all such reasonable and legitimate steps as may be open to them to prevent such an occurrence, and either individually or by common action to do what they can to ensure that judgments, particularly of this Court, are duly implemented and carried out - at any rate, so long as the rights of third countries are respected.
} 
normalmente um ato internacionalmente ilícito. Este é um caso claro de represálias por Estados terceiros. ${ }^{663}$ (tradução nossa)

Neste mesmo sentido Charney (p. 67, 1989), segundo o qual:

Certamente, se o ouro era da Albânia, os membros da Comissão tinham o dever legal de entregá-lo à Albânia. Um exceção a este dever parece ter sido justificada como represália pela violação da Albânia de seu dever estabelecido em um julgamento anterior de compensar o Reino Unido. A represália dos Estados Unidos e França, como Estados terceiros, parece ter sido baseada num pretenso direito universal de todos os Estados de auxiliar na implementação de julgamentos da CIJ. Ele representa prática estatal em apoio ao direito dos Estados terceiros de implementar os julgamentos da CIJ. ${ }^{664}$ (tradução nossa)

De fato, o Direito Internacional reconhece apenas a competência do Conselho de Segurança (artigo 94 da Carta das Nações Unidas), para assegurar a implementação das decisões da CIJ. A ação dos Estados Unidos, Reino Unido e França, não encontrava amparo em nenhuma norma do Direito Internacional, sendo, assim, ilegal. Ela seria, entretanto, uma resposta a um ato ilícito anterior a Albânia, i.e o descumprimento de uma sentença da CJ. Tal medida foi tomada tanto por um Estado diretamente lesado, como por Estados não diretamente lesados. Embora a Corte não tenha se manifestado sobre a legalidade desta medida, fica ao menos registrado que um Estado defendeu em sua argumentação oral, a possibilidade de adoção de contramedidas por Estados não diretamente lesados perante a CIJ, para a defesa de um interesse coletivo, a dizer, a implementação das decisões da CIJ, e por consequência, a manutenção do "rule of law" no Direito Internacional.

Casos South West Africa (1962-1965)

\footnotetext{
${ }^{663}$ What Sir Gerald Fitzmaurice was really arguing was that Albania's illegal refusal to pay the damages awarded in the Corfu Channel case to the United Kingdom justified not only the United Kingdom, but also France and the United States, in committing what would normally have been an illegal act. This is a clear case of reprisals by third states.

${ }^{664}$ Certainly, if the gold were Albanian, the members of the Commission had a legal duty to deliver it to Albania. An exception to that duty seems to have been justified as a reprisal for the Albanian violation of its own duty established by the earlier Judgment to compensate the United Kingdom. The reprisal by the United States and France, as third states, appears to have been based upon a claimed universal right of all states to assist in the enforcement of judgments of the ICJ. It represents state practice in support of the right of third states to enforce ICJ judgments.
} 
Os casos South West Africa tiveram grande repercussão internacional, em especial por terem sido marcados por uma mudança de posição da CIJ do primeiro, para ao segundo julgamento.

A África do Sul havia recebido da Liga das Nações Mandato para administrar a região sudoeste da África, denominada Namíbia. Em 1960, Etiópia e Libéria entraram com petição perante a CIJ requerendo que esta se manifestasse sobre a continuidade da existência do Mandato em nome da África do Sul, mesmo após a dissolução da Liga das Nações, e sobre os deveres e a atuação da África do Sul. A razão principal da disputa era a violação dos direitos humanos da população negra residente na Namíbia, que estaria sendo submetida a um regime de apartheid pela África do Sul, contrariando os deveres estabelecidos no Mandato, de promover o bem-estar material e moral dos habitantes do território.

Apesar de não terem nenhuma vinculação direta com o sistema de mandato, os dois Estados entraram com o procedimento com base na sua antiga filiação à Liga das Nações e no artigo 7 do Mandato que estabelecia (CIJ, p. 335, 1962):

O Mandatário concorda que, se alguma disputa qualquer surgir entre o Mandatário e outro Membro da Liga das Nações relacionada à aplicação das disposições do Mandato, tal disputa, se não poder ser resolvida em negociação, deve ser submetida à Corte Permanente de Justiça Internacional, prevista pelo artigo 14 do Pacto da Liga das Nações. ${ }^{665}$ (tradução nossa)

Julgamento Preliminar (1962)

A CIJ, em julgamento preliminar realizado em 1962, reconheceu a capacidade processual da Etiópia e da Libéria, embora elas não tivessem vínculo direto com o sistema de mandato. Segundo a CIJ (p. 338, 1962):

A Corte não vê nenhum fundamento válido para se afastar da conclusão chegada na Opinião Consultiva de 1950 no sentido de que a dissolução da Liga das Nações não tornou in operante o Artigo 7 do Mandato. Aqueles Estados que eram membros da Liga das Nações no momento de sua dissolução continuam a ter o direito de invocar a jurisdição compulsória da Corte, assim como tinham o direito antes da dissolução da Liga. $\mathrm{O}$ direito continua a existir enquanto $\mathrm{o}$

\footnotetext{
665 The Mandatory agrees that, if any dispute whatever should arise between the Mandatory and another Member of the League of Nations relating to the interpretation or the application of the provisions of the Mandate, such dispute, if it cannot be settled by negotiation, shall be submitted to the Permanent Court of International Justice provided for by Article 14 of the Covenant of the League of Nations.
} 
Respondente mantém o direito de administrar o território sob Mandato. ${ }^{666}$ (tradução nossa)

A Corte reconhece, portanto, o direito de antigos membros da Liga das Nações, de invocar a jurisdição de CIJ, com base no artigo 7 do Mandato concedido à África do Sul. A votação, entretanto, é apertada, sendo 8 juízes a favor e 7 contra a decisão.

Segunda Fase (1965)

Na segunda fase do julgamento, tendo a composição da Corte sido modificada, ocorre em 1965.

Neste novo julgamento, a CIJ reverte sua decisão anterior. Em suas palavras (p. 25, 1965):

Nenhuma segurança tomando a forma de um direito de todo membro da Liga, separada e individualmente, de requerer dos mandatários o desempenho devido de seus mandatos, ou criando a obrigatoriedade para cada mandatário de ser responsável em relação a eles individualmente, - ainda menos conferindo um direito de recurso à Corte a este respeito - foi previsto pelo Pacto. ${ }^{667}$ (tradução nossa)

Ainda, segundo a CIJ (p. 29, 1965):

A Corte considera que nem mesmo no tempo da Liga, mesmo como membros da Liga quando aquela organização ainda existia, os Aplicantes não tinham, na sua capacidade individual como Estados, qualquer direito independente que eles pudessem reivindicar, independente de, ou adicionalmente ao direito da Liga, na realização da sua atividade institucional coletiva, de requerer o devido desempenho do Mandato, na execução da "sagrada missão".668 (tradução nossa)

\footnotetext{
${ }^{666}$ Court sees no valid ground for departing from the conclusion reached in the Advisory Opinion of 1950 to the effect that the dissolution of the League of Nations has not rendered inoperable Article 7 of the Mandate. Those States who were Members of the League at the time of its dissolution continue to have the right to invoke the compulsory jurisdiction of the Court, as they had the right to do before the dissolution of the League. That right continues to exist for as long as the Respondent holds on to the right to administer the territory under the Mandate.

${ }^{667}$ No security taking the form of a right for every member of the League separately and individually to require from the mandatories the due performance of their mandates, or creating a liability for each mandatory to be answerable to them individually,-still less conferring a right of recourse to the Court in these regards,-was provided by the Covenant.

${ }^{668}$ The Court considers that even in the time of the League, even as members of the League when that organization still existed, the Applicants did not, in their individual capacity as States, possess any separate self contained right which they could assert, independently of, or additionally to, the right of the League, in the pursuit of its collective, institutional activity, to require the due performance of the Mandate in discharge of the "sacred trust".
} 
A CIJ, então, não reconhece a capacidade processual ativa da Etiópia e Libéria, tendo em vista que esta seria exclusiva da extinta Liga das Nações.

Ainda, no julgamento, a CIJ descreve o que seria considerado direito ou interesse jurídico. Em suas palavras (p. 32, 1965):

Em seguida, pode ser dito que um direito ou interesse jurídico não tem necessariamente que se relacional com alguma coisa material ou 'tangível', e pode ser infringido mesmo sem que um prejuízo do tipo material seja sofrido. Neste contexto, as disposições de certos tratados ou outros instrumentos de caráter humanitário, e os termos de várias decisões arbitrais e judiciais, são citados como indicando que, por exemplo, Estados podem ter o direito de defender algum princípio geral, mesmo que a contravenção particular desta alegadamente não tenha afetado seus próprios interesses materiais; - que, novamente, Estados possam ter o interesse jurídico em reivindicar um princípio de direito internacional, mesmo que eles não tenham, no caso dado, sofrido prejuízo material, ou pedido apenas danos simbólicos. ${ }^{669}$ (tradução nossa)

Porém, para a CIJ (p. 32-33, 1965):

A Corte simplesmente sustenta que tais direitos ou interesses, para existirem, devem estar claramente investidos naqueles que $o$ reclamam, por algum texto ou instrumento, ou regra de direito, - e no caso presente, nenhum foi nunca investido nos membros individuais da Liga segundo nenhum instrumento relevante, ou como parte constituinte do sistema de mandato como um todo, ou de outra forma. ${ }^{670}$ (tradução nossa)

A Corte também se manifesta sobre a possibilidade de considerações humanitárias darem origem a certos direito e obrigações. Segundo a CIJ (p. 34, 1965):

Ao longo do caso, foi sugerido, direta ou indiretamente, que considerações humanitárias seriam suficientes, em si mesmas, para

\footnotetext{
${ }^{669}$ Next, it may be said that a legal right or interest need not necessarily relate to anything material or "tangible", and can be infringed even though no prejudice of a material kind has been suffered. In this connection, the provisions of certain treaties and other international instruments of a humanitarian character, and the terms of various arbitral and judicial decisions, are cited as indicating that, for instance, States may be entitled to uphold some general principle even though the particular contravention of it alleged has not affected their own material interests;- that again, States may have a legal interest in vindicating a principle of international law, even though they have, in the given case, suffered no material prejudice, or ask only for token damages.

${ }^{670}$ The Court simply holds that such rights or interests, in order to exist, must be clearly vested in those who claim them, by some text or instrument, or rule of 1aw;-and that in the present case, none were ever vested in individual members of the League under any of the relevant instruments, or as a constituent part of the mandates system as a whole, or 'otherwise
} 
gerar direitos e obrigações legais, e que a Corte pode e deve proceder de acordo. A Corte não pensa assim. Ela é uma corte de direito, e pode levar em conta princípios morais somente na medida em que a estes é dada suficiente expressão na forma jurídica. O direito existe, assim é dito, para servir às necessidades sociais; mas precisamente por esta razão ele só pode o fazer através e dentro dos limites de sua própria disciplina. De outra forma não é um serviço legal que será prestado. ${ }^{671}$ (tradução nossa)

A CIJ ainda continua (p. 34, 1965):

Considerações humanitárias podem constituir a base de inspiração para regras de direito, assim como, por exemplo, as partes preambulares da Carta das Nações Unidas constituem a base moral e política para disposições legais específicas posteriormente estabelecidas. Tais considerações não têm, em si mesmas, o valor de regras de direito. Todos os Estados são interessados - têm um interesse - em tais matérias. Mas a existência de um 'interesse' não implica que este interesse seja especificamente de caráter jurídico. ${ }^{672}$ (tradução nossa)

Aplicando estas considerações ao caso a CIJ afirma (p. 34, 1965):

A sagrada missão, é dito, é uma "sagrada missão da civilização". Assim, todas as nações civilizadas têm um interesse em ver que ela foi cumprida. Um interesse, sem dúvida, - mas para que este interesse tenha um caráter especificamente jurídico, a sagrada missão deve ser ou ter se tornado algo mais que um ideal moral ou humanitário. Para gerar direitos e obrigações jurídicos, a ela deve ser dada expressão jurídica e ser revestida de forma legal. ${ }^{673}$ (tradução nossa)

A Corte reconhece que, em caso de certos tratados ou instrumentos internacionais de proteção aos direitos humanos os "Estados podem ter o direito de defender algum

\footnotetext{
${ }^{671}$ Throughout this case it has been suggested, directly or indirectly, that humanitarian considerations are sufficient in themselves to generate legal rights and obligations, and that the Court can and should proceed accordingly. The Court does not think so. It is a court of law, and can take account of moral principles only in so far as these are given a sufficient expression in legal form. Law exists, it is said, to serve a social need; but precisely for that reason it can do so only through and within the limits of its own discipline. Otherwise, it is not a legal service that would be rendered.

${ }^{672} 50$. Humanitarian considerations may constitute the inspirational basis for rules of law, just as, for instance, the preambular parts of the United Nations Charter constitute the moral and political basis for the specific legal provisions thereafter set out. Such considerations do not, however, in themselves amount to rules of law. All States are interested-have an interest-in such matters. But the existence of an "interest" does not of itself entail that this interest is specifically juridical in character.

${ }^{673}$ The sacred trust, it is said, is a "sacred trust of civilization". Hence all civilized nations have an interest in seeing that it is carried out. An interest, no doubt;-but in order that this interest may take on a specifically legal character, the sacred trust itself must be or become something more than a moral or humanitarian ideal. In order to generate legal rights and obligations, it must be given juridical expression and be clothed in legal form.
} 
princípio geral, mesmo que a contravenção particular desta alegadamente não tenha afetado seus próprios interesses materiais."

Ela entende, entretanto, que para que "considerações humanitárias" possam ser levadas em conta, estas devem ter sido incorporadas em regras jurídicas, deixando de ser unicamente um ideal moral ou humanitário. Somente diante de direitos humanos juridicamente reconhecidos, o interesse dos demais Estados de comunidade internacional se tornaria um interesse jurídico e habilitaria, assim, os Estados a defendêlo no plano internacional.

Nas últimas décadas, numerosos tratados, pactos e convenções foram celebrados. Direitos relevantes para a comunidade internacional como um todo deixaram de ser meros ideais, adquirindo o status de norma jurídica. Assim, segundo as palavras da Corte neste julgado, os Estados partes de tratados multilaterais que os consagrem, ou mesmo todos os Estados da comunidade internacional, quando estes se tornam normas consuetudinárias ou princípios gerais de direito teriam o interesse jurídico na sua preservação.

Por outro lado, a CIJ também se manifesta sobre a existência de uma actio popularis no Direito Internacional. Em suas palavras (p. 47, 1965):

$\mathrm{O}$ argumento se baseia em que a Corte deve permitir o equivalente a uma 'actio popularis', ou o direito de cada membro da comunidade internacional de tomar uma ação legal em reivindicação a um interesse público. Mas embora um direito deste tipo possa ser conhecido em certos sistemas internos de direito, ele não é conhecido no direito internacional como ele se encontra no presente: nem a Corte é capaz de considerá-lo como importado pelos 'princípios de direito' referidos no artigo 38, para grafo 1 (c), de seu Estatuto. ${ }^{674}$ (tradução nossa)

Assim a CIJ claramente nega a existência de uma actio popularis no Direito Internacional, recusando a capacidade processual ativa dos Estados em casos onde se disputam interesses coletivos da comunidade internacional.

Então, embora reconheça a possibilidade de existência de um interesse jurídico dos Estados na preservação, ao menos, de alguns princípios gerais, a CIJ não instrumentaliza a proteção a este interesse.

\footnotetext{
674 the argument amounts to a plea that the Court should allow the equivalent of an "actio popularis", or right resident in any member of a community to take legal action in vindication of a public interest. But although a right of this kind may be known to certain municipal systems of law, it is not known to international law as it stands at present: nor is the Court able to regard it as imported by the "general principles of law" referred to in Article 38, paragraph 1 (c), of its Statute
} 
Por fim, a Corte considera que os Aplicantes não têm o direito legal de apresentar a reclamação diante da CIJ, e rejeita as petições (p. 51, 1965). Vale ressaltar que a decisão da CIJ se deu em votação apertada, sendo desempatada apenas pelo voto decisivo do Presidente.

O Juiz Jessup, em opinião dissidente neste caso, defende o direito dos Estados de agirem em nome do interesse geral, ao menos segundo os Tratados de Paz de Paris. Em suas palavras (JESSUP, p. 374, 1965):

Com certeza, cada área de interesse geral nos Acordos de Paz tinham seu próprio sistema e o papel da Corte era diferente se adequando às necessidades de cada caso. Mas o ponto que se destaca é o reconhecimento do direito dos Estados agindo em nome do interesse geral, e sem a necessidade de declarar sofrimento de dano direto por ele ou por seus nacionais, de recorrer à Corte para uma interpretação obrigatória do significado das obrigações que os Estados assumiram, de modo a que o trabalho, as minorias e os povos dependentes possam gozar de proteção internacional. ${ }^{675}$ (tradução nossa)

Assim, para Jessup (p. 374, 1965): "na era dos Tratados de Paz de Paris, Estados podiam invocar a Corte em nome do interesse geral internacional quando seus próprios interesses não estivessem envolvidos. ${ }^{, 676}$ (tradução nossa)

Sobre a questão da actio popularis, Jessup escreve (p. 387-388, 1965):

Eu concordo que não existe geralmente estabelecida a actio popularis no direito internacional. Mas o direito internacional aceitou e estabeleceu situações nas quais aos Estados foi dado um direito de ação sem nenhuma demonstração de prejuízo individual ou interesse individual substantivo distinta do interesse geral. ${ }^{677}$ (tradução nossa)

Assim, embora este Juiz não reconheça a possibilidade de uma actio popularis, ele reconhece pelo menos a possibilidade, em alguns casos, de atuação do Estado em nome do interesse geral.

\footnotetext{
${ }^{675}$ To be sure, each area of general interest in the Peace Settlements had its own system and the role of the Court was different as suited the needs of each case. But the point which stands out is the recognition of the right of States in the general interest, and without needing to assert direct injury suffered by them or their nationals, to resort to the Court for an authoritative interpretation of the meaning of the obligations which States had assumed in order that labour, and minorities and dependent peoples might enjoy international protection.

${ }^{676}$ in the era of the Paris Peace Treaties, States could invoke the Court in the general international interest when their own particular interests were not involved.

${ }^{677}$ I agree that there is no generally established actio popularis in international law. But international law has accepted and established situations in which States are given a right of action without any showing of individual prejudice or individual substantive interest as distinguished from the general interest.
} 
Opinião Consultiva sobre as consequências jurídicas para os Estados da presença continuada da África do Sul na Namíbia (1970)

O julgamento da CIJ nos casos South West Africa causou forte reação do âmbito da ONU. Segundo Dawindowicz (p. 341, 2006):

No auge do processo de descolonização, o julgamento levantou uma 'tempestade de indignação' na Assembleia Geral da ONU. [...] Em resposta ao clamor causado pelo julgamento, ação institucional foi tomada pelas Nações Unidas: a Assembleia resolveu terminar o Acordo de Mandato. ${ }^{678}$ (tradução nossa)

Essa decisão da Assembleia Geral foi posteriormente ratificada pelo Conselho de Segurança. Apesar destas Resoluções, a África do Sul continuou com a ocupação de Namíbia.

Em 1970, diante desta situação, o Conselho de Segurança requisitou à CIJ Parecer Consultivo sobre as consequências jurídicas para os Estados da presença contínua da África do Sul na Namíbia, tendo em vista a Resolução 276 de 1970, do Conselho de Segurança.

No julgamento, a Corte teve que decidir sobre a obrigatoriedade da Resolução 276 de 1970, do Conselho de Segurança, tendo em vista que esta não faz nenhuma referência a em que artigo da Carta das Nações ela se baseia. Em suas palavras (p. 53, 1970):

A Corte, assim, chegou à conclusão de que as decisões tomadas pelo Conselho de Segurança nos parágrafos 2 e 5 da resolução 276 (1970), como relacionados com o parágrafo 3 da resolução 264 (1969) e parágrafo 5 da resolução 269 (1969), foram adotados em conformidade com os propósitos e princípios da Carta e de acordo com seus artigo 24 e 25 . As decisões são consequentemente obrigatórias para todos os Estados Membros das Nações Unidas, que estão assim, sob a obrigação de aceitá-los e implementá-los. ${ }^{679}$ (tradução nossa)

\footnotetext{
678 At the height of the decolonization process, the judgment raised a 'storm of indignation' in the UN General Assembly. [...] In response to the outcry caused by the judgment, institutional action was taken by the United Nation: the General Assemb ly resolved to terminate the Mandate Agreement.

679 The Court has therefore reached the conclusion that the decisions made by the Security Council in paragraphs 2 and 5 of resolutions 276 (1970), as related to paragraph 3 of resolution 264 (1969) and paragraph 5 of resolution 269 (1969), were adopted in conformity with the purposes and principles of the Charter and in accordance with its Articles 24 and 25. The decisions are consequently binding on all States Members of the United Nations, which are thus under obligation to accept and carry them out.
} 
Ainda, segundo a Corte (p. 55, 1970):

A precisa determinação dos atos permitidos ou autorizados, quais medidas estão disponíveis e são praticáveis, quais delas devem ser selecionadas, qual o escopo que deve ser dado a elas e por quem elas devem ser aplicadas - é uma matéria que está dentro da competência dos órgãos políticos apropriados das Nações Unidas agindo dentro da sua autoridade segundo a Carta. Assim, é o Conselho de Segurança que deve determinar quaisquer outras medidas consequentes das decisões já tomadas por ele na questão da Namíbia. ${ }^{680}$ (tradução nossa)

A CIJ estabelece a obrigatoriedade das Resoluções do Conselho de Segurança, mesmo quando este não faz referência direta a algum dos artigos da Carta da ONU. Tendo determinado a ilicitude da conduta sul africana, cabe ao Conselho de Segurança determinar as medidas a serem tomadas pelos Estados diante da violação da obrigação devida segundo o Direito Internacional.

Tendo em vista a generalidade das disposições deste Conselho em suas Resoluções, a Corte dá algumas indicações das obrigações dos Estados decorrentes do ato ilícito cometido pela África do Sul. Segundo esta (CIJ, p. 54, 1970):

Os Estados membros das Nações Unidas estão, pelas razões dadas no parágrafo 115 acima, obrigados a reconhecer a ilegalidade e invalidade da presença contínua da África do Sul na Namíbia. Eles também estão obrigados a abster-se fornecer qualquer apoio ou qualquer forma de assistência à África do Sul, com referência à sua ocupação da Namíbia, sujeito ao parágrafo 125 , abaixo. ${ }^{681}$ (tradução nossa)

Ainda, segundo a Corte (p. 55, 1970):

Os Estados membros estão obrigados a se abster de entrar em relações convencionais com a África do Sul, em todos os casos em que o Governo da África do Sul alega agir em nome ou em relação à Namíbia. Em relação aos tratados bilaterais existentes, Estados

680 120. The precise determination of the acts permitted or allowed what measures are available and practicable, which of them should be selected, what scope they should be given and by whom they should be applied-is a matter which lies within the competence of the appropriate political organs of the United Nations acting within their authority under the Charter. Thus it is for the Security Council to determine any further measures consequent upon the decisions already taken by it on the question of Namibia.

${ }^{681}$ The member States of the United Nations are, for the reasons given in paragraph 115 above, under obligation to recognize the illegality and invalidity of South Africa's continued presence in Namibia. They are also under obligation to refrain from lending any support or any form of assistance to South Africa with reference to its occupation of Namibia, subject to paragraph 125 below. 
membros devem abster-se de invocar ou aplicar aqueles tratados ou disposições concluídos pela África do Sul em nome ou em relação à Namíbia que envolvam uma cooperação intergovernamental ativa. Em relação aos tratados multilaterais, entretanto, a mesma regra não pode se aplicar a certas convenções gerais tais como àquelas de caráter humanitário, o não cumprimento das quais pode afetar adversamente o povo da Namíbia. Os órgãos competentes internacionais tomarão as medidas específicas a esse respeito. ${ }^{682}$ (tradução nossa)

A Corte determina, ainda, que as resoluções do Conselho de Segurança geram efeitos mesmo para aqueles Estados que não são membros das Nações Unidas, e, portanto, vinculados a Carta das Nações Unidas. Em suas palavras (p. 56, 1970):

$\mathrm{Na}$ visão da Corte, o término do Mandato e a declaração da ilegalidade da presença da África do Sul na Namíbia é oponível a todos os Estados no sentido de barrar erga omnes a legalidade da situação que é mantida em violação do direito internacional; em particular, nenhum Estado que entre em relações com a África do Sul com respeito à Namíbia pode esperar que as Nações Unidas ou seus Membros reconheçam a validade e os efeitos de tal relação, ou das consequências dela. ${ }^{683}$ (tradução nossa)

Finalmente a CIJ decide (p. 58, 1970):

Por 11 votos a 4 ,

2) que os Estados Membros das Nações Unidas estão obrigados a reconhecer a ilegalidade da presença da África do Sul na Namíbia e a invalidade de seus atos em nome e em relação a Namíbia, e a abster-se de qualquer atos e em particular de quaisquer relações com o Governo da África do Sul implicando o reconhecimento da legalidade ou fornecer apoio ou assistência a tal presença e administração;

3) que incumbe aos Estados que não são Membros das Nações Unidas dar assistência, dentro do escopo do parágrafo 2 acima, à ação que foi tomada pelas Nações Unidas em relação à Namíbia. ${ }^{684}$ (tradução nossa)

\footnotetext{
${ }^{682}$ member States are under obligation to abstain from entering into treaty relations with South Africa in al1 cases in which the Government of South Africa purports to act on behalf of or concerning Namibia. With respect to existing bilateral treaties, member States must abstain from invoking or applying those treaties or provisions of treaties concluded by South Africa on behalf of or concerning Namibia which involve active intergovernmental co-operation. With respect to multilateral treaties, however, the same rule cannot be applied to certain general conventions such as those of a humanitarian character, the nonperformance of which may adversely affect the people of Namibia. It will be for the competent international organs to take specific rneasures in this respect.

${ }^{683}$ In the view of the Court, the termination of the Mandate and the declaration of the illegality of South Africa's presence in Namibia are opposable to al1 States in the sense of barring erga omnes the legality of a situation which is maintained in violation of international law: in particular, no State which enters into relations with South Africa concerning Namibia may expect the United Nations or its Members to recognize the validity or effects of such relationship, or of the consequences thereof

${ }^{684}$ by 11 votes to 4 ,
} 
Nesta Opinião Consultiva, a Corte reconhece a obrigatoriedade das Resoluções do Conselho de Segurança, mesmo quando não adotadas expressamente em função do artigo 25 ou do capítulo VII da Carta das Nações Unidas. Estando os Estados obrigados pela Carta a agir de acordo com as determinações do Conselho de Segurança, a ilegalidade das condutas adotadas, mesmo em violação das obrigações existentes para estes Estados em relação à África do Sul é excluída. Esta exclusão se dá, porém, não em virtude do ato internacionalmente ilícito anterior, o que as caracterizaria como contramedidas, mas em função de suas obrigações segundo a Carta da ONU. Estas medidas são, assim, sanções internacionais.

Relevante para o objeto do nosso estudo é o fato de que diversos Estados foram além das medidas determinadas pelo Conselho de Segurança e interpretadas pela CIJ, como veremos mais a frente. As medidas tomadas, extrapolando as determinações do Conselho de Segurança, só podem ser consideradas como contramedidas.

$\mathrm{Na}$ prática, se comprovará que as contramedidas não são incompatíveis com as sanções internacionais. Em alguns casos, elas podem ser mesmo complementares.

\section{Caso Barcelona Traction}

A ideia de interesses jurídicos dos Estados na defesa de princípios gerias, surgida no julgamento de 1965 do caso South West Africa, se desenvolveu no âmbito da CIJ. No caso Barcelona Traction, em 1970, a Corte consagrou o termo obrigações erga omnes, termo este que ganhou reconhecimento internacional. Nos dizeres da Corte (CIJ, p. 32, 1970):

Em particular, uma distinção essencial deve ser feita entre as obrigações de um Estado em relação à comunidade internacional como um todo, e aquelas surgidas somente frente a outro Estado no campo da proteção diplomátic a. Por sua própria natureza, as primeiras dizem respeito a todos os Estados. Tendo em vista a importância dos direitos envolvidos, todos os Estados têm um interesse jurídico na sua proteção; estas são obrigações erga omnes.

(2) that States Members of the United Nations are under obligation to recognize the illegality of South Africa's presence in Namibia and the invalidity of its acts on behalf of or concerning Namibia, and to refrain from any acts and in particular any dealings with the Government of South Africa implying recognition of the legality of, or lending support or assistance to, such presence and administration;

(3) that it is incumbent upon States which are not Members of the United Nations to give assistance, within the scope of subparagraph (2) above, in the action which has been taken by the United Nations with regard to Namibia. 
34. Tais obrigações derivam, por exemplo, no direito internacional contemporâneo, de atos ilegais de agressão e de genocídio, como também de princípios e regras relativos aos direitos básicos da pessoa humana, incluindo proteção contra a escravidão e discriminação racial. Alguns dos direitos de proteção correspondentes entraram no conjunto do direito internacional geral (Reservas à Convenção de Genocídio, Opinião Consultiva, Relatórios da C.I.J.1951, p. 23); outros são conferidos por instrumentos de um caráter universal ou quase universal. (tradução nossa) $)^{685}$

A Corte, assim, reconhece a existência de obrigações de um Estado frente a toda comunidade internacional. Entre tais obrigações, as chamadas obrigações erga omnes estariam inseridos os "direitos básicos da pessoa humana". Destas obrigações nasce o interesse jurídico de todos os Estados no cumprimento de tais obrigações. A Corte, entretanto, mais uma vez, não instrumentaliza estes interesses jurídicos, apenas reconhecendo a sua existência.

\section{Caso Atividade Militares e Paramilitares na e contra a Nicarágua (1986)}

Já na decisão sobre as Atividades Militares e Paramilitares na e contra a Nicarágua, em 1986, a Corte examina a possibilidade de adoção de contramedidas de caráter militar por um Estado terceiro, os Estados Unidos. Nessa decisão a CIJ determina (p. 127, 1986):

Enquanto um ataque armado poderia dar origem ao direito a uma legítima defesa coletiva, o uso da força em um grau menor não pode, como a Corte já observou (parágrafo 211 acima), produzir nenhum direito a tomar contramedidas coletivas envolvendo o uso da força. Os atos dos quais da Nicarágua é acusada, mesmo assumindo que tenham estabelecidos e imputáveis àquele Estado, poderiam apenas justificar contramedidas proporcionais da parte do Estado que foi vítima destes atos, notadamente, El Salvador, Honduras ou Costa Rica. Eles não poderiam justificar contramedidas tomadas por outro Estado, os

\footnotetext{
685 In particular, an essential distinction should be drawn between the obligations of a State towards the international community as a whole, and those arising vis -à-vis another State in the field of diplomatic protection. By their very nature the former are the concern of all States. In view of the importance of the rights involved, all States can be held to have a legal interest in their protection; they are obligations erga omnes.

34. Such obligations derive, for example, in contemporary international law, from the outlawing of acts of aggression, and of genocide, as also from the principles and rules concerning the basic rights of the human person, including protection from slavery and racial discrimination. Some of the corresponding rights of protection have entered into the body of general international law (Reservations to the Convention on the Prevention and Punishment of the Crime of Genocide, Advisory Opinion, I.C.J. Reports 1951, p. 23); others are conferred by international instruments of a universal or quasiuniversal character.
} 
Estados Unidos, e particularmente não poderiam justificar uma intervenção envolvendo o uso da força ${ }^{686}$ (tradução nossa)

A Corte rejeita, neste caso, a aplicação de contramedidas pelos Estados Unidos, tendo em vista este não ter sido diretamente lesado pela conduta da Nicarágua.

A redação da sentença, entretanto, pode dar margem a interpretações. Ao afirmar que "Eles [os atos dos quais a Nicarágua é acusada] não poderiam justificar contramedidas tomadas por outro Estado, os Estados Unidos, e particularmente não poderiam justificar uma intervenção envolvendo o uso da força”, ela não é taxativa no sentido de proibir contramedidas por Estados não diretamente lesados. O Corte afirma somente, que estes atos, imputados à Nicarágua, não as justificam. Uma interpretação a este enunciado poderia considerar que outros atos, de natureza mais grave, poderiam justificar este tipo de contramedidas.

Nesse sentido segue Charney segundo o qual (p. 74, 1989)

Ela concluiu a discussão com uma afirmação que também proíbe contramedidas de estados terceiros na ausência de um requerimento do estado vítima, quando outro estado fornece suporte sem o uso da força armada para grupos revolucionários operando no estado vítima. Ela na proibiu as contramedidas de estados terceiros em outras situações não envolvendo a força. ${ }^{687}$

Ainda sob a questão exclusiva de violações aos direitos humanos, alegada pelos Estados Unidos para justificar as medidas adotadas contra a Nicarágua a Corte escreve (p. 134, 1986): "Entretanto, quando os direitos humanos são protegidos por convenções internacionais, esta proteção toma a forma de tais regimes para monitorar ou assegurar o respeito aos direitos humanos como provido pela própria convenção." ${ }^{988}$

Para Ramos isso significa que (p. 380, 2004): "Com efeito, a existência de procedimentos próprios de solução de controvérsias em tratados de direitos humanos

\footnotetext{
${ }^{686}$ While an armed attack would give rise to an entitlement to collective self-defence, a use of force of a lesser degree of gravity cannot. as the Court has already observed (paragraph 211 above), produce any entitlement to take collective countermeasures involving the use of force. The acts of which Nicarágua is accused, even assuming them to have been established and imputable to that State, could only have justified proportionate counter-measures on the part of the State which had been the victim of these acts, namely El Salvador, Honduras or Costa Rica. They could not justify counter-measures taken by a third State, the United States, and particularly could not justify intervention involving the use of force.

${ }^{687}$ It concluded the discussion of this matter with dicta that also forbid third state counter-measure in the absence of a request from the victim state when another state provides support short of armed force for revolutionary groups operating in the victim state. It did not foreclose third state counter-measure in other situations not involving the use of force.

${ }^{688}$ However, where human rights are protected by international conventions, that protection takes the form of such arrangements for monitoring or ensuring respect for human rights as are provided for in the conventions themselves.
} 
impede o exercício de contramedidas sem que seja esgotada esta fase de busca de reparação da violação de direitos humanos."

Os direitos humanos, seriam, assim um regime de autocontenção que só permitiriam o uso de contramedidas uma vez esgotados os recursos internos. Resta lembrar que a CDI retirou qualquer referência expressa aos regimes de autocontenção do texto final do anteprojeto de artigos sobre a responsabilidade do Estado. Por outro lado, para que um regime de autocontenção possa ser considerado como tal, há necessidade de que os mecanismos que ele preveja para lidar com violações a obrigações nele previsto sejam efetivos. Embora este possa ser o caso de alguns tratados de proteção aos direitos humanos, especialmente os celebrados em escala regional, ele não é o caso de todos os tratados de proteção a estes direitos, o que veremos na análise do sistema global de proteção aos direitos humanos.

\section{Caso Timor Leste (1991)}

No caso Timor Leste, Portugal entrou com ação contra a Austrália tendo em vista tratado internacional celebrado por esta com a Indochina, alegadamente desrespeitando o direito de autodeterminação do povo timorense e seus direitos sobre os recursos naturais da região.

Segundo a Corte (p. 102, 1991):

Ele mantém, em efeito, que os direitos que a Austrália alegadamente violou eram direitos erga omnes e que, consequentemente, Portugal poderia requerer, individualmente, a ela que os respeitasse independentemente se outro Estado se conduziu, similarmente, de maneira ilícita. Na visão da Corte, a afirmação de Portugal de que o direito dos povos à autodeterminação, como desenvolvido pela Carta e pela prática das Nações Unidas, tem um caráter erga omnes, é irrepreensível. O princípio da autodeterminação dos povos tem sido reconhecido pela Carta das Nações Unidas e na jurisprudência do Corte [...]; é um dos princípios essenciais do direito internacional contemporâneo. Entretanto, a Corte considera que o caráter erga omnes de uma norma e a regra de consentimento de jurisdição são duas coisas diferentes. Qualquer que seja a natureza das obrigações invocadas, a Corte não poderia pronunciar-se sobre a legalidade da conduta de um Estado quando este julgamento implicaria na avaliação da legalidade da conduta de outro Estado que não é parte no caso. Quando é assim, a Corte não pode agir, mesmo se o direito em questão é um direito erga omnes. ${ }^{689}$ (tradução nossa)

\footnotetext{
${ }^{689}$ It maintains, in effect, that the rights which Australia allegedly breached were rights erga omnes and that accordingly Portugal could require it, individually, to respect them regardless of whether or not another State had conducted itself in a similarly unlawful manner. In the Court's view, Portugal's assertion
} 
A Corte, então reconhece o direito à autodeterminação dos povos como um direito erga omnes. Entretanto, não reconhece que este direito erga omnes gera a todos os Estados da comunidade internacional um direito de ação na CIJ contra esta violação.

Em opinião dissidente, o Juiz Weeramentry afirma que todo direito erga omnes deve gerar consequências. Para este juiz (WEERAMENTRY, p. 215, 1991):

Entretanto, este caso salientou o aspecto reverso dos direitos oponíveis erga omnes -, a dizer, o direito erga omnes do povo de Timor Leste ao reconhecimento da sua autodeterminação e soberania permanente sobre seus recursos naturais. Esta reclamação é baseada na oponibilidade do direito em relação à Austrália [...]

O caso presente é um onde claramente as consequências do princípio erga omnes levam à sua conclusão lógica - que a obrigação que é o corolário deste direito pode ter sido violada. Isto levaria, na minha visão, à garantia do remédio judicial pela violação do direito. ${ }^{690}$ (tradução nossa)

Weeramentry, entretanto, reconhece que esta não é a posição dominante na Corte (p. 215, 1991):

Eu sou consciente, ao chegar a esta conclusão, que a violação de um direito erga omnes não foi, até agora, base para o remédio ju dicial perante esta Corte. Ainda, o principio é claro, e a necessidade é manifesta para o reconhecimento que o direito, como todos os direitos, gera deveres correspondentes. ${ }^{691}$ (tradução nossa)

O Juiz, ainda, conclui (p. 216, 1991):

\footnotetext{
that the right of peoples to self-determination, as it evolved from the Charter and from United Nations practice, has an erga omnes character, is irreproachable. The principle of self-determination of peoples has been recognized by the United Nations Charter and in the jurisprudence of the Court [...]; it is one of the essential principles of contemporary international law. However, the Court considers that the erga omnes character of a norm and the rule of consent to jurisdiction are two different things. Whatever the nature of the obligations invoked, the Court could not rule on the lawfulness of the conduct of a State when its judgment would imply an evaluation of the lawfulness of the conduct of another State which is not a party to the case. Where this is so, the Court cannot act, even if the right in question is a right erga omnes.

${ }^{690}$ However, this case has stressed the obverse aspect of rights opposable erga omnes - namely, the right erga omnes of the people of East Timor to the recognition of their self-determination and permanent sovereignty over their natural resources. The claim is based on the opposability of the right to Australia.[...] The present case is one where quite clearly the consequences of the erga omnes principle follow through to their logical conclusion - that the obligation which is a corollary of the right may well have been contravened. This would lead, in my view, to the grant of judicial relief for the violation of the right.

${ }^{691} \mathrm{I}$ am conscious, in reaching this conclusion, that the violation of an erga omnes right has not thus far been the basis of judicial relief before this Court. Yet the principles are clear, and the need is manifest for a recognition that the right, like al1 rights, begets corresponding duties.
} 
O conceito erga omnes tem estado às portas desta Corte por muitos anos. Um descumprimento de obrigações erga omnes faz um sério rasgo na teia das obrigações internacionais, e o Estado corrente do dire ito internacional requer que violações ao conceito sejam seguidas de sua consequência lógica e jurídica. ${ }^{692}$ (tradução nossa)

A conclusão que se pode tirar da jurisprudência da CIJ, em relação aos direitos dos Estados não diretamente lesados é que esta é incongruente. Se por um lado ela reconhece a existência de direitos e obrigações erga omnes, e a existência de um interesse jurídico de todos os Estados da comunidade internacional na proteção destes, por outro a Corte nega que tal interesse jurídico possa ensejar uma capacidade processual ativa para os Estados interessados na proteção e passiva para Estados violadores de obrigações erga omnes. Utilizando a terminologia adotada pelo juiz Weeramentry, a CIJ não reconhece as consequências jurídicas lógicas dos conceitos que ela mesma ajudou a consagrar.

Por outro lado, embora reconheça claramente a inexistência de um direito de ação, a Corte não é tão taxativa em relação à possibilidade de adoção de contramedidas pelos Estados com interesse jurídico. Embora seja clara ao reconhecer que o direito a uma actio popularis "não é conhecido no direito internacional como ele se encontra no presente" (CIJ, p. 47, 1965), ela afirma apenas, no caso das atividades militares e paramilitares na Nicarágua que os atos a esta imputados "não poderiam justificar contramedidas tomadas por outro Estado" (CIJ, p. 127, 1986). Não se afirma que contramedidas não podem, em nenhuma circunstância, ser adotadas por outros Estados, i.e. Estados não diretamente lesados. Nem que outras violações, mais graves, não possam ensejar este direito.

Assim, concluirse que a jurisprudência da CIJ também não é definitiva sobre a legalidade da adoção de contramedidas por Estados não diretamente lesados. Ela reconhece claramente a existência de interesse jurídico por parte destes Estados. Também, no único caso em que teve que se confrontar diretamente com a questão, ela restringiu sua decisão a estabelecer esta impossibilidade somente em um caso específico, não utilizando linguagem mais geral.

Cabe aqui observar, em relação à questão da existência da actio popularis, que tendo em vista o artigo 48 do anteprojeto sobre a responsabilidade internacional do Estado, estabelecendo o direito de Estados não diretamente lesados de invocar a responsabilidade internacional de um Estado em casos em que estes teriam um interesse jurídico, a posição da CIJ pode vir a mudar.

\footnotetext{
${ }^{692}$ The erga omnes concept has been at the door of this Court for many years. A disregard of erga omnes obligations makes a serious tear in the web of international obligations, and the current state of international law requires that violations of the concept be followed through to their logical and legal conclusion.
} 
Embora este artigo não faça nenhuma referência específica à Corte, vai caber a ela definir o significado da expressão "invocar a responsabilidade de outro Estado".

\title{
2.4 Doutrina
}

A doutrina geral não se dedicou muito ao tema das contramedidas adotadas por Estados não diretamente lesados. Nquyên e Dinh (p. 900, 1999) escrevem:

\begin{abstract}
Além desta relativa não diferenciação das 'contramedidas', duas tendências notáveis (e interdependentes) podem ser demonstradas na prática atual dos Estados: sua globalização e sua utilização como substitutas das sanções previstas pela Carta das Nações. ${ }^{693}$ (tradução nossa)
\end{abstract}

Ainda, para estes autores (NQUYÊN E DINH, p.900, 1999):

Ao mesmo tempo, o caráter de 'substituição' [...] destas medidas concertadas às snções que pode decidir o Conselho de Segurança aparece claramente: seus autores se colocam como defensores da legalidade internacional, que este, paralisado pelo direito a veto, não pode fazer respeitar. [...] Também é notável que as contramedidas estatais intervenham frequentemente em seguida às recomendações do Conselho de Segurança ou da Assembleia Geral, ou mesmo da simples constatação de uma violação por estes órgãos. ${ }^{64}$ (tradução nossa)

Estes autores franceses destacam, assim, o papel das contramedidas de substituição das sanções institucionais estabelecidas na Carta da ONU, no caso de paralisação do Conselho de Segurança, ou de complementação destas, no caso de serem posteriores a resoluções dos principais órgãos da ONU.

Já Cassese, ao tratar da comunidade internacional, reconhece a existência não só de obrigações comunitárias, mas também de direitos. Segundo este (p. 16-17, 2005):

\footnotetext{
693 Outre cette relative indifférenciation des 'contre-mesures', deux tendances très remarcaquables (et interdépendantes) peuvet être relevées dans la pratique qu'en font actuellement les États: leur globalisation et leur utilisation en tant que substituts aux sanctions prévues par la Charte des Nations Unies.

${ }^{694} \mathrm{Du}$ meme coup le caractère de 'substitution' [...] de ces measures concertées aux sanctions que peut décider le Conseil de sécurité apparaît clairement : leurs auteurs se posent en défenseurs de la légalité internationale que celui-ci, paralysé par le droit de veto, ne peut faire respecter [...]. Il est du reste remarquable que les contre-meures étatiques interviennent souvent à la suite de recommandations du Conseil de sécurité ou de l'Assemblée géneérale ou même de la simple constatation d'une violation du droit par ces organes.
} 
Como podem os direitos comunitários que estamos discutindo ser exercidos? As regras consuetudinárias não preveem nenhum mecanismo em particular. Conclui-se que é possível recorrer aos meios tradicionais de reparação (medidas diplomáticas, pressão diplomática, contramedidas pacíficas; $[. .].) .{ }^{695}$ (tradução nossa)

Cassese reconhece, assim, o direito dos Estados de adotarem contramedidas em defesa de interesses comunitários.

Ainda para este autor (p. 271, 2005): “quando uma obrigação comunitária é seriamente violada, para a CDI qualquer outro Estado ‘não especialmente afetado' não tem o direito de recorrer a contramedidas. Isto, novamente, parece estar em conflito com a prática estatal. ${ }^{9696}$ (tradução nossa)

Cassese também dá uma ampla interpretação ao que seria um Estado especialmente afetado. Para ele (p. 271, 2005):

Assim, por exemplo, se um Estado maltrata, devido às suas crenças religiosas, todos os seus nacionais que são muçulmanos, qualquer outro país muçulmano poderia se considerar 'especialmente afetado' e teria o direito de adotar contramedidas; tal direito adviria par o Estado mesmo que o maltrato seja esporádico e irrele vante. ${ }^{697}$ (tradução nossa)

Assim, para este autor, a CDI vai contra a prática estatal ao não reconhecer a possibilidade de contramedidas por Estados não diretamente afetados. Também, ao dar uma interpretação ampla do que seriam Estados "especialmente afetados”, este autor estende a possibilidade de adoção de contramedidas, mesmo diante das regras estabelecidas pela CDI no anteprojeto sobre a responsabilidade do Estado, a Estados que poderiam ser considerados Estados não diretamente lesados (Estados em defesa de pessoas de sua religião ou de sua etnia).

Já a doutrina especializada, voltada à responsabilidade internacional do Estado ou às contramedidas, é mais prolixa. Segundo Zoller (p. 117, 1984):

\footnotetext{
${ }^{695}$ How can the 'community rights' we are discussing be exercised? Customary rules do not provide for any particular mechanism. It follows that it is possible to resort to traditional means of redress (diplomatic steps, diplomatic pressure, peaceful countermeasures; [...]

${ }^{696}$ When a community obligation is seriously breached, for the ILC any other State not 'specially affected' is not entitled to resort to countermeasures. This, again, seems to be in conflict with the international practice.

${ }^{697}$ Thus, for instance, if a State ill-treats, on account of their religious beliefs, all its nationals that are Muslim, any other Muslim country might consider itself as 'specially affected' would be entitled to adopt countermeasures; such right would accrue to the State even of the ill-treatment is sporadic and inconspicuous.
} 
Uma regra que retire dos estados terceiros de qualquer capacidade legal de recorrer às contramedidas no caso de uma violação flagrante e patente das regras fundamentais enfraqueceriam $o$ direito internacional. É claro, se esta capacidade jurídica for admitida, haverá um grande perigo de abuso. Entretanto, este medo, que é legítimo, não leva em conta o fato de que contramedidas não permitem que os aplicadores fazerem o que eles quiserem. Não apenas existem regras humanitárias às quais estes Estados devem obedecer, mas a medida não pode nunca ser de caráter punitivo. ${ }^{698}$ (tradução nossa)

Para esta autora, não só estes Estados têm o direito de adotar contramedidas, como a seu ver eles deveriam ter também a obrigação. Em suas palavras: 'De lege ferenda, seria certamente desejável que em tais situações [resoluções não vinculantes], terceiros Estados sejam compelidos a participar de uma ação coletiva."699 (tradução nossa)

Leben, por sua vez, escreve (p. 76, 1982):

Àqueles que são conscientes dos inconvenientes e dos perigos que as contramedidas fazem correr a sociedade internacional, este estudo não vem trazer a sustentação de uma condenação, no direito, de seu uso. Ao contrário, ela afirma sua licitude e seu caráter inevitável, no estado atual da sociedade internacional. ${ }^{700}$ (tradução nossa)

Ainda para esse autor (p. 76, 1982):

Porém, para os outros fenômenos da força, o caráter aleatório da implementação do mecanismo da responsabilidade internacional, e a fraqueza das garantias ofertadas pelas organizações internacionais, somente podem forçar os Estados a adotarem, por eles mesmos, as medidas assegurando uma certa repressão daquilo que eles consideram ser violações flagrantes ao direito internacional. ${ }^{701}$ (tradução nossa)

\footnotetext{
698 A rule which would deprive third states of any legal capacity to resort to countermeasures in case of a gross and patent violation of fundamental rules would emasculate international law. Of course, should a legal capacity to intervene be admitted, there would be a real danger of abuse. However, this fear, which is quite legitimate, does not take into account the fact that countermeasures do not allow enforcers to do whatever they want. Not only are there humanitarian rules which these states have to comply with, but the measure must never be punitive in character.

${ }^{699}$ De lege ferenda, it would certainly be desirable that in such situations third states could be compelled to participate in a joint action.

${ }^{700}$ A ceux qui sont conscients des inconvénients et des dengers que font courir les contre-mesures à la société internationale, cette étude ne vient pas apporter le souiten d'une condemnation, en droit, de leur usage. Au contraire, elle affirme leur licéité et leur caractère inévitable, dans l'état actuel de la société internationale.

701 Mais pour les autres phénomènes de force, le caractère aléatoire de la mise en jeu du mécanime de la responsabilité internationale, et la faiblesse des garanties offertes par les organisations internationales, ne peuvent que pousser les Etats à dopter par eux-mêmes les mesures assurant une certaine répression de ce qu'ils considèrent être des vioaltions flagrantes du droit international.
} 
Leben, então, reconhece a legalidade das contramedidas e sua necessidade, no caso de violações flagrantes ao Direito Internacional, tendo em vista a ausência de mecanismos efetivos das organizações internacionais para lidar com tais violações.

Elagab também escreve sobre o tema. Em suas palavras (p. 59, 1988):

Para concluir, a longa posição doutrinária que advoga o direito de qualquer Estado de retaliar contra um crime internacional não tem apoio na prática estatal. Entretanto, o princípio erga omnes pode ser aplicado para ampliar a categoria de 'uma parte ofendida' de modo a incluir todos os Estados quando a dbrigação violada tem um caráter erga omnes. Assim, todos os Estados, incluindo aqueles que não forma diretamente lesados, serão considerados como tendo o direito de impor contramedidas contra o perpetrador da violação. Isto dito, deve ser, entretanto, reconhecido que medidas adotadas em tais circunstâncias podem exceder os limites da proporcionalidade. Consequentemente, assim, dificuldades surgiriam quando a legalidade de tais medidas fosse considerada. ${ }^{702}$

Assim, para Elagab, a prática estatal não apoiaria o direito de Estados não lesados de retaliarem contra "crimes internacionais". No entanto, com a expansão da categoria de "parte agravada" pelo princípio erga omnes, todos os Estados poderiam adotar contramedidas no caso de violação a obrigações erga omnes. Tais medidas, entretanto, poderiam enfrentar dificuldades em relação à proporcionalidade.

Alland, em sua obra de 1994, afirma (p. 370, 1994):

Não se deve deixar entender que a existência de um poder de sanção individual dos Estados, universalmente distribuído como reação específica à violação de uma obrigação erga omnes, é adequado à defesa de uma 'ordem pública internacional' fundada sobre a importância de certos princípios: ela é ao contrário, a negação. ${ }^{703}$ (tradução nossa)

\footnotetext{
${ }^{702}$ To conclude, the long doctrinal view which advocates the right of any State to retaliate against an international crime has no support in State practice. None the less, the erga omnes principle may be applied to widen the category of 'an aggrieved party' so as to include all State where the violated obligation has an erga omnes character. Accordingly, all States, including those which have not been injured directly, will be deemed to have the right to impose counter-measures against the perpetrator of the breach. That said, it needs however, to be recognized that measures taken in such circumstances might exceed the limits of proportionality. It follows, therefore, that difficulties would arise when the legality of such measures is being considered.

${ }^{703}$ Il ne faut pas laisser entendre que l'existence d'un pouvoir de sanction individual des Etats, universellement distribué comme réaction spécifique à la violation d'une obligation erga omnes est adéquat à la défense d'un 'ordre publique international' fondé sur l'importance de certains principes : il en est au contraire la négation.
} 
Entretanto, ainda, para este autor (p. 370, 1994): "É justo dizer que uma prática consolidada poderia conduzir ao reconhecimento do caráter justificável das contramedidas adotadas por Estados terceiros, mas seria necessário precisar a natureza deste poder."704 (tradução nossa)

Assim, embora Alland afirme, em sua obra de 1994, que o poder de sanção dos Estados seria a negação de uma ordem internacional pública, ele reconhece que uma prática consolidada tornaria as contramedidas por Estados não diretamente lesados justificável.

Já em obra mais recente, este mesmo autor afirma (ALLAND, p. 1239, 2002):

no presente estado de coisas, nós não podemos eliminar o problema criado pelo caso onde nenhum estado é diretamente lesado no sentido da responsabilidade clássica (genocídio perpetrado por um estado contra parte da população em seu próprio território); se, por uma razão ou outra, a resposta institucional não funciona, nós temos que escolher entre o subjetivismo de uma resposta descentralizada em defesa do interesse geral, ou a ausência de qualquer consequência para os atos ilícitos mais sérios. ${ }^{705}$ (tradução nossa)

Para Hoogh (p. 246, 1996):

Violações de obrigações para a proteção de direitos humanos de indivíduos, independente de sua nacionalidade, não precisam afetar nenhum Estado especialmente. Por esta razão o status de Estado lesado abrange todos aqueles Estados vinculados pela norma de direito convencional ou consuetudinário relevante. Na medida em que tais violações de obrigações são o resultado do comportamento negligente dos Estados, não parece haver nenhum receio que eles recusem a remediar seus atos. Especialmente no caso de violações de obrigações de direitos humanos, os Estados devem ter recurso aos mecanismos de supervisão contidos nos tratados dos quais eles são partes. O mesmo não pode ser dito quando as violações são intencionais ou premeditadas e de natureza séria. Nesses casos todos os Estados lesados podem adotar contramedidas contra o Estado autor. $^{706}$ (tradução nossa)

\footnotetext{
${ }^{704}$ Il est juste de dire qu'une pratique consolidée pourrait conduire à reconaître le caractère justifiable des contre-mesures adoptées par des Etat tiers, mas il faut préciser la nature de ce pouvoir.

${ }^{705}$ In the present state of affairs, we cannot eliminate the problem raised by the case where no state is directly injured in the sense of classical responsibility (genocide perpetrated by a state against part of the population on its own territory); if, for one reason or another institutional response do not work, we have to choose between the subjectivism of a decentralized response in defense of general interest of the absence of any consequences for the most serious wrongful acts.

${ }^{706}$ Breaches of obligations for the protection of human rights of individuals irrespective of nationality need not affect any State specifically. For that reason injured State status results for all those States bound by the relevant rule of conventional or customary law. To the extent that such breaches of obligations are the result of negligent behavior of States, there would not seem to be any fear that they refuse to remedy
} 
Este autor, assim, reconhece o direito de adotar contramedidas no caso de violações a obrigações estabelecidas para a proteção dos direitos humanos à todos os Estados vinculados pela norma infringida, quando estas violações são intencionais ou premeditadas e de natureza séria.

Lloret também trata do tema. Para ele (p. 273-274, 1998):

\begin{abstract}
A aplicação de medidas de retorsão ou represálias consistentes com a cessação ou a diminuição da cooperação da cooperação econômica ou comercial, a cooperação ao desenvolvimento, a venda de armas ou a não concessão de empréstimos por mecanismos internacionais, constituem os principais meios de aplicação forçosa do direito internacional, a margem das sanções internacionais [...] e do uso descentralizado da força [...]. Estas medidas constituem o único meio de pressão que dispõe um Estado para compelir a outro para que se respeite os direitos humanos de seus próprios nacionais, se deixamos de lado, claro está, as simples condenações verbais. ${ }^{707}$
\end{abstract}

Ainda, para este autor (p. 274, 1998):

Portanto, entendemos que esta necessidade dos mecanismos descentralizados de aplicação de normas deve conjugar-se com a finalidade que persegue a normativa dos direitos humanos, que não é outra que garantir um conjunto de direitos humanos ao particular qualquer que seja sua nacionalidade. $^{708}$

Assim, para Lloret, as represálias ou contramedidas seriam mecanismos descentralizados de aplicação das normas do Direito Internacional, necessários para a proteção dos direitos humanos.

Pellet (p. 20, 2002), escreve sobre o artigo 54 do anteprojeto sobre a responsabilidade do Estado:

their ways. Especially in case of breaches of human rights obligations States ought to have recourse to the supervision mechanisms contained in treaties to which there are parties. The same cannot be said where the breaches are intentional or premeditated and of a serious nature. In such case, all injured States can adopt countermeasures towards the author State.

${ }^{707} \mathrm{La}$ aplicación de medidas de retorsión o represalia consistentes en el cese o la disminución de la cooperación económica o comercial, la cooperación al desarrollo, la venta de armas o la no concesión de préstamos por organismos internacionales, constituyen los principales medios de aplicación forzosa del derecho internacional, al margen de las sanciones internacionales [...] y del uso descentralizado de la fuerza [...] Estas medidas constituyen el único instrumento de presión de que dispone un Estado para compeler a otro Estado para que respete los derechos humanos de sus propios nacionales, si dejamos de lado, caro está, las simples condenas verbales.

${ }^{708}$ Por lo tanto, entendemos que esta necesidad de los mecanis mos descentralizados de aplicación de normas debe conjugarse con la finalidad que persigue la normativa sobre derechos humanos, que no es otra que garantizar un conjunto de derechos humanos al particular cualquiera que sea su naciolalidad. 
No entanto, o novo artigo 54 constitui uma cláusula de salvaguarda que, não somente não exclui esta possibilidade [de adoção de contramedidas por todos os Estados no caso de uma obrigação grave a uma obrigação essencial devida à comunidade internacional], mas que é mesma redigida de tal maneira que ela parece a consagrar.

Paradoxalmente, aquilo que era estreitamente enquadrado pelas regras bastante precisas na versão de 2000 , se encontra, em realidade, ao mesmo tempo consagrado de fato e largamente desregulamentado pelo projeto definitivo. Deve-se sem dúvida se alegrar de que em caso de violação (não necessariamente grave) uma faculdade de reação seja, de fato, reconhecida a todos os Estados interessados no respeito de uma obrigação mesmo quando eles não são 'lesados' no sentido do projeto. Deve-se lamentar que o regime destas 'medidas' (que a CDI quis distinguir das contramedidas abertas aos Estados lesado) seja mais impreciso, mais incerto que aquele que tinha sido previsto no ano anterior. $^{709}$ (tradução nossa)

Para Pellet, portanto, o artigo 54 do anteprojeto consagraria, de fato, o direito dos Estados não diretamente lesados de adotarem contramedidas no caso de violações às obrigações devidas à comunidade internacional. Tais medidas, entretanto, estariam desregulamentadas devido à falta de disposições mais precisas.

Ramos, por seu lado, entende que as contramedidas feririam os direitos humanos da população do Estado infrator (p. 381-382, 2004), e enfraqueceriam o Direito Internacional (p. 383, 2004). Por isto, para este autor (p. 386, 2004):

o uso das contramedidas deve ser cada vez mais raro e utilizado como exceção às regras coletivas de aplicação de sanção a Estados violadores de direitos humanos. $\mathrm{O}$ futuro da contramedida deve ser o mesmo da possibilidade do uso da força para o exercício da própria razão no Direito interno: raramente utilizado, pois sujeito a uma série de requisitos de legalidade.

Já para Tams (p. 250, 2005): “À luz destas evidências, parece justificado concluir que o direito internacional atual reconhece um direito a todos os Estados, independente

\footnotetext{
709 Toutefois, le nouvel article 54 constitue une clause de sauvegarde qui, non seulement, n'exclut pas cette possibilité mais qui est même rédigée de telle manière qu'elle paraît la consacrer.

Paradoxalment ce qui était très étroitement encadré par des règles fort précises dans la version de 2000 se trouve en réalité à la fois consacré de facto et largement déréglementé dans le projet définitif. On doit sans doute se réjouir qu'en cas de violation (pas forcément grave) une faculté de réaction soit, en fait, reconnue à tous les États intérressés par le respect d'une obligation quand bien même ils ne sont pas 'lésés' au sens du projet. On peut regretter que le régime de ces 'mesures' (que la CDI a vuoulu distinguer des contre-mesures ouvertes aux États lésés) soit plus flou, plus incertain que celui qui avait été envisagé l'année précédente.
} 
de dano individual, de adotar contramedidas em resposta a violações em larga escala ou sistemáticas, às obrigações erga omnes. ${ }^{710}$ (tradução nossa)

Neste mesmo sentido Dawidowicz (p. 418, 2006): “O estudo acima apoia fortemente a conclusão de que contramedidas individuais de terceiras partes são lícitas segundo o direito internacional geral."711 (tradução nossa)

Por fim, Proukaki afirma (p. 209, 2010):

\begin{abstract}
A analise nas seções precedentes demonstrou que uma norma consuetudinária relacionada ao direito a contramedidas de Estados não diretamente lesado para a proteção de interesses coletivos se desenvolveu no direito internacional. Isto foi conseguido através de uma prática geral, consistente e contínua, acompanhada da necessária opinio juris, abrindo o caminho para a efetiva implementação de interesses jurídicos coletivos fundamentais. ${ }^{712}$
\end{abstract}

Assim, para esta autora, existe uma norma consuetudinária garantindo o direito dos Estados não diretamente lesados a adotarem contramedidas na defesa de interesses coletivos.

Percebe-se deste apanhado geral que a maioria da doutrina especializada reconhece a legalidade da adoção de contramedidas por Estados não diretamente lesados.

Para estes autores, seja em função de uma norma consuetudinária decorrente da prática estatal, seja devido à implementação do conceito de obrigações erga omnes, ou mesmo de uma interpretação extensiva do artigo 54 do anteprojeto da CDI sobre a responsabilidade do Estado, os Estados não diretamente lesados têm o direito de aplicar contramedidas em defesa dos interesses da comunidade internacional.

Ciente da possibilidade de abusos, alguns doutrinadores entendem que a regulamentação do instituto, que segue as regras gerais relativas à proporcionalidade, às limitações e objetivos, seria suficiente para evitar abusos.

\footnotetext{
${ }^{710}$ In the light of this evidence, it seems justified to conclude that present-day international law recognises a right of all States, irrespective of individual injury, to take countermeasures in response to large-scale or systematic breaches of obligations erga omnes.

711 The above survey strongly supports the conclusion that individual third-party countermeasures are lawful under general international law.

712 The analysis in the preceding sections has demonstrated that a customary rule concerning a right to countermeasures by not directly injured states for the protection of collective interests has evolved in international law. This has been achieved through general, consistent and continuous practice, accompanied by the necessary opinio juris, opening the way for the effective enforcement of fundamental collective legal interests.
} 
Nessa perspectiva, mais importante que o risco corrido, é a implementação do Direito Internacional, impedindo que graves violações a obrigações relevantes para toda a comunidade internacional ocorram sem maiores consequências.

\subsection{A prática dos Estados} da ONU

2.5.1 A posição dos Estados durante os debates do $6^{\circ}$ Comitê da Assembleia Geral

2.5.1.1 Debates anteriores à adoção do anteprojeto de artigos em primeira leitura

Durante os debates anteriores a adoção dos artigos em primeira leitura, ocorrida em 1996, alguns Estados já haviam expressado sua posição em relação à adoção de contramedidas por Estados não diretamente lesados.

O Japão, em 1976, deixava clara sua posição a respeito. Em relação ao crime internacional, ele alegava (ONU, A/C.6/31/SR.21, p.3): “se se confiasse aos Estados esta função de órgão judicial, se correria o risco de abusos de poder, sobretudo por parte das grandes potências, na aplicação das sanções ou penas que voltariam a colocar em causa o sistema político e jurídico em vigor."713 (tradução nossa)

A Indonésia, por outro lado, reconhecia este direito (ONU, A/C.6/31/SR.30, p. 9). Para esta: "Em caso de crime internacional, o Estado lesionado não só tem o direito a uma reparação ou a uma indenização; pode exercer represálias, e os demais Estados podem atuar de igual maneira." ${ }^{, 714}$ (tradução nossa)

Em 1982, durante os debates sobre o conceito de Estados lesados, Portugal defendia (ONU, A/C.6/37/SR.46, p. 8): “é também necessário definir os direitos dos Estados que sofreram danos e de outros Estados e os meios para conseguir o respeito a estes direitos." ${ }^{, 715}$ (tradução nossa)

\footnotetext{
${ }^{713} \mathrm{Si}$ se confiara a los Estados está función de órgano judicial, se correría el riesgo de abusos de poder, sobre todo por parte de las grandes Potencias, en la aplicación de las sanciones o las penas que volverían a poner en tela de juicio el sistema político y jurídico internacional en vigor.

${ }^{714}$ En caso de crimen internacional, el Estado lesionado no sólo tiene derecho a una reparación o a una indemnización; puede ejercer represalias, y los demás Estados pueden actuar de igual manera.

${ }^{715}$ Es también necesario definir los derechos de los Estados que han sufrido un daño y de otros Estados y los medios para lograr el respecto a esos derechos.
} 
Já para Madagascar (ONU, A/C.6/37/SR.46, P. 30): seria "difícil imaginar que direitos podem resultar de um ato internacionalmente ilícito para um Estado que não é o Estado afetado." ${ }^{, 116}$ (tradução nossa)

A discussão continua em 1984 e 1985. A Argélia defende que (ONU, A/C.6/39/SR.39, p. 7) "o conceito de represália deveria ser utilizado com o máximo de circunspeção." 717 (tradução nossa)

Para a Jamaica (ONU, A/C.6/40/SR.24, p. 10): "Em relações às ditas obrigações [erga omnes] pode existir um direito correspondente de qualquer membro da comunidade internacional que lhes faculte tomar medidas em defesa de um interesse público."718 (tradução nossa)

Já a Etiópia tem dúvidas (ONU, A/C.6/40/SR.27, p. 12) "se todos os demais Estados podem atuar individualmente com respeito a um crime internacional da mesma maneira que o fariam se tivessem tido seus direitos particulares violados."719 (tradução nossa)

A questão neste período é controversa, com Estados se manifestando contra e a favor.

2.5.1.2 Debates após a adoção dos artigos em primeira leitura (51 ${ }^{\text {a }}$ Sessão, 1996)

O anteprojeto sobre a responsabilidade do Estado tal como aprovado em primeira leitura trazia um conceito amplo de Estados lesado, de modo que muito da discussão sobre a adoção de contramedidas por Estados não diretamente lesados se deu dentro dos debates das contramedidas em geral.

Alguns Estados fizeram críticas à regulamentação das contramedidas em geral no anteprojeto (Brasil, Marrocos e Sri Lanka). Outros expressaram a aprovação das regras sobre contramedidas, entendidas em função da definição ampla de Estados lesados adotadas (Reino Unido, Argentina, Camarões)

Apesar disto, alguns Estados expressaram a sua opinião em relação especificamente às contramedidas adotadas por Estados não diretamente lesados.

\footnotetext{
${ }^{716}$ Difícil imaginar qué derechos puede entrañar un hecho internacionalmente ilícito para un Estado que no sea el Estado afectado.

${ }^{717}$ No debería utilizarse el concepto de represalia sino con un máximo de circunspección.

${ }^{718}$ En relación con dichas obligaciones, puede existir un derecho correspondiente en cualquiera miembro de la comunidad internacional que le faculte para tomar medidas en defesa de un interés público.

${ }^{719} \mathrm{Si}$ todos los demás Estados pueden actuar individualmente con respecto a un crimen internacional de la misma manera que lo harían si hubieran visto violados sus derechos particulares.
} 
Para o Brasil (ONU, A/C.6/51/SR.34, p. 15): "Parece improvável que contramedidas, um remédio altamente individualizado voltado aos delitos, fossem também apropriadas num caso em que toda a comunidade internacional foi lesada., ${ }^{, 720}$ (tradução nossa)

Também a França (ONU, A/C.6/51/SR.36, p. 7) afirma que tais medidas seriam de difícil implementação tendo em vista que só o Conselho de Segurança teria a competência para adotá- las.

Neste mesmo sentido o Irã (ONU, A/C.6/51/SR.36, p. 16), segundo o qual: "enquanto todos os Estados foram considerados como lesados pela comissão de um ato internacionalmente ilícito, somente a 'vítima efetiva' tem o direito de recurso às contramedidas."721 (tradução nossa)

Já para a Bulgária (ONU, A/C.6/51/SR.36, p. 16):

Em relação às contramedidas, sua delegação também concorda que todos os Estados têm o direito de tomar medidas imediatas para obter a cessação do ato ilícito e evitar danos irreparáveis, mas somente os Estados mais diretamente afetados deveriam ser capazes de tomar medidas urgentes interinas. ${ }^{722}$ (tradução nossa)

A discussão sobre o tema, no entanto, ficou prejudicada pelo amplo conceito de Estado lesado. Alguns Estados, em suas considerações, fizeram referência a este termo, incluindo dentre os Estados lesados os Estados não diretamente lesados. Pode-se ter ideia mais clara da posição dos Estados após o início dos trabalhos do Relator Crawford, quando a CDI aprovou nova definição de Estados lesados, mais restrita. 2000)

2.1.5.3 Debates anteriores á adoção final dos anteprojeto de artigos (55 ${ }^{\mathrm{a}}$ Sessão,

Em 2000, o Relator Especial Crawford, após a redução do conceito de Estados lesados, propôs os artigos 50 A e 50 B, fundidos pelo Drafting Committee no artigo

\footnotetext{
${ }^{720}$ It seemed unlikely that countermeasures, the highly individualized remedy provided for delicts, would also be appropriate in a case where the entire international community had been injured.

${ }^{721}$ While all States were regarded as injured by the commission of an international crime, only the "effective victim" was entitled to recourse to countermeasures.

${ }^{722}$ Concerning countermeasures, his delegation also agreed that all States were entitled to take immediate measures to obtain cessation of a wrongful act and avoid irreparable damage but that only the most directly concerned States should be able to take urgent interim measures.
} 
$54^{723}$, que tratava da possibilidade de contramedidas por Estados não diretamente lesados, ou contramedidas coletivas.

Nos debates do $6^{\circ}$ Comitê da Assembleia Geral da ONU, diversos Estados se manifestaram a respeito.

Alguns Estados (África do Sul, em nome da Comunidade de Desenvolvimento Sul Africano $\left(\mathrm{SADC}^{724}\right)$, Argentina, Espanha, Austrália, Costa Rica e Grécia) aprovaram o artigo 54 e, consequentemente, a adoção de contramedidas por Estados não diretamente lesados, individualmente ou de maneira genérica, fazendo referência a um conjunto de artigos (50 a 54, conjunto de artigos que regula as contramedidas ou artigos $34,41,42,49$ e 54, que se referem às consequências das violações sérias a obrigações decorrentes de normas imperativas).

Outros foram expressamente contra a adoção deste artigo (China, Cuba, Camarões e Tanzânia), ou manifestaram dúvidas a respeito da sua adequação (Brasil e Japão). Dentre os motivos apresentados estão o risco de abuso de tal direito pelos Estados mais fortes (China e Japão), a possibilidade das contramedidas acirrarem ainda mais o conflito (Tanzânia) ou mesmo de desestabilizarem as Nações Unidas e marginalizarem o Conselho de Segurança (Camarões e Israel).

Um terceiro gupo reconheceu a possibilidade da adoção de contramedidas por Estados não diretamente lesados, mas não exatamente nos termos do artigo 54.

O Reino Unido (ONU, A/C.6/55/SR.14, p. 7) expressou dificuldade em aceitar a possibilidade de Estados adotarem contramedidas no interesse dos beneficiários da obrigação e sugeriu que o parágrafo 2 do artigo 54 fosse substituído por uma saving clause, reservando a posição na matéria ${ }^{725}$.

\footnotetext{
${ }^{723}$ Article 54. Countermeasures by States other than the injured State

1. Any State entitled under article 49, paragraph 1, to invoke the responsibility of a State may take countermeasures at the request and on behalf of any State injured by the breach, to the extent that that State may itself take countermeasures under this chapter.

2. In the cases referred to in article 41 , any State may take countermeasures, in accordance with the present chapter in the interest of the beneficiaries of the obligation breached.

3. Where more than one State takes countermeasures, the States concerned shall cooperate in order to ensure that the conditions laid down by this chapter for the taking of countermeasures are fulfilled.

${ }^{724}$ Organização de integração econômica composta por 15 Estados africanos, fundada pelo Tratado da Comunidade de Desenvolvimento Sul Africano em 1992. Disponível em: http://www.sadc.int/index/browse/page/120, Acesso em: 22 out. 2010.

${ }^{725}$ Chapter III of Part Two and draft article 54, paragraph 2, could be replaced by a clause to the effect that the draft articles were without prejudice to any regime that might be established to deal with serious breaches of obligations erga omnes.
} 
Já a Alemanha objetou a possível interpretação do parágrafo 1 deste artigo, que poderia resultar em medidas unilaterais desproporcionais, disfarçadas de contramedidas (ONU, A/C.6/55/SR.14, p. 10) ${ }^{726}$.

O Irã, modificando sua posição anterior, contrária, defendeu a individualização do parágrafo 2 do artigo 54 em um artigo separado e a subordinação destas medidas à coordenação das Nações Unidas (ONU, A/C.6/55/SR.15, p. 3) ${ }^{727}$.

Já Botsuana, entendeu os artigos 23 e 50 a 55 como uma limitação ao direito de legítima defesa de um Estado de seus interesses, defendendo assim, uma maior possibilidade de adoção de contramedidas por Estados não diretamente lesados (ONU, A/C.6/55/SR. 15 , p. 10$)^{728}$

A Itália, embora demonstrasse surpresa com a proposição do parágrafo 2 do artigo 54, aprovou seu parágrafo 3, uma tentativa de preservar a proporcionalidade (ONU, A/C.6/55/SR.16, p. 5) ${ }^{729}$.

O Chile, por sua vez, sugeriu que a redação do artigo fosse mais precisa em relação à proporcionalidade no caso de vários Estados adotando contramedidas (ONU, A/C.6/55/SR.17, p. 8) ${ }^{730}$.

A Áustria, apesar de reconhecer a melhora do anteprojeto em relação às contramedidas por Estados não diretamente lesados, considerou o parágrafo 2 do artigo 54 confuso (ONU, A/C.6/55/SR.17, p. 13) ${ }^{731}$.

\footnotetext{
${ }^{726}$ article 54, paragraph 1, must be interpreted cautiously. Pursuant, to that article, beneficiaries of the obligation breached could be either States or non-States; accordingly, there was a danger that disproportional unilateral acts, which in reality were not justified by the interest they sought to protect, might be disguised countermeasures

${ }^{727}$ It would be better to devote a separate article to the current draft article 54, paragraph 2, as the Special Rapporteur had originally proposed, and to state that where there had been a serious breach of an essential obligation owed to the international community as a whole, countermeasures must be coordinated by the United Nations.

${ }^{728}$ According to his understanding, the State referred to in article 49, paragraph 1, was injured in the sense that the breached obligation protected a collective interest or the interest of the international community. [...]

When a State's interests were injured, it would want to protect its interests and should be allowed to do so. Draft articles 23 and 50 to 55 , however, attempted to restrict the right to act in self-defence.

${ }^{729}$ In the case of draft article 54, he was surprised at the proposal to allow third States to take countermeasures on behalf of the State injured by the breach rather than in cases where no State was the victim of the breach, as the Special Rapporteur had proposed. However, in light of the rapid developments in international law and in the interests of proportionality, he welcomed the flexibility of paragraph 3, which called on States to cooperate in the implementation of countermeasures.

730 . Where more than one State was entitled to use countermeasures, it was necessary to decide whether the concept of proportionality applied to the measures employed by each State separately against the violator, or to all the countermeasures taken together. Draft article 54 appeared to opt for the latter solution, but the principle should be expressed more clearly in order to avoid future problems of interpretation of what was an extremely significant rule.
} 
A Jordânia, embora reconhecesse a possibilidade de adoção de contramedidas por Estados não diretamente lesados a pedido do Estado lesado, destacou algumas dificuldades em relação à proporcionalidade e a efetividade de contramedidas tomadas no caso de violações sérias a obrigações decorrentes de normas imperativas (ONU, A/C.6/55/SR.18, p. 4) ${ }^{732}$.

A Eslovênia, embora entendendo que, em alguns casos, a adoção de contramedidas poderia ser justificada, considerou que o amplo escopo das regras propostas poderiam dar lugar a abusos (ONU, A/C.6/55/SR.18, p. 6) ${ }^{733}$.

A Polônia considerou que a CDI deveria fornecer maiores esclarecimentos em relação ao parágrafo 2 do artigo 54. Para esta, a função primária das contramedidas por Estados não diretamente lesados seria a cessação do ato e não a reparação (ONU, A/C.6/55/SR.18, p. 9) ${ }^{734}$.

Já a Rússia não reconheceu o direito de Estados não diretamente lesados adotarem medidas a requerimento dos Estados lesados, mas admite a adoção de tais medidas no caso de violação séria a obrigação decorrente de norma imperativa (ONU, A/C.6/55/SR.18, p. 9) ${ }^{735}$.

\subsubsection{Debates após a adoção final dos artigos pela CDI (56 ${ }^{\mathrm{a}}$ Sessão, 2001)}

\footnotetext{
731 In the case of serious breaches as defined in article 41, however, under article 54, paragraph 2, any State might take countermeasures in the interest of the beneficiaries of the obligation breached. The provision was confusing, because it covered two different situations. $\mathrm{f}$ the serious breach met the conditions of article 43 (b), any State concerned was an injured State and entitled as such to take countermeasures, but not, as the draft articles stood, to make requests in the interest of the beneficiaries. 732 While it was acceptable to take collective countermeasures in the context of an initiative undertaken at the request of or on behalf of an "injured State", the issue of whether to authorize "any" State to take countermeasures against the author of a serious breach of the essential obligations owed to the international community needed to be studied further. It was hard to envisage how the principle of proportionality could be respected if "any" State was authorized to take countermeasures, as it deemed appropriate. Moreover, such countermeasures could well provoke an escalation, instead of restoring legality.

733 In certain circumstances, such as in the case of serious and systematic human rights violations, the proposed rules could certainly be justified but, because of its broad scope, risked at the same time giving rise to abuses

734 Paragraph 2 of article 54 would thus authorize each State to have recourse to countermeasures in consultation with the other States involved. Although there was a trend in that direction, it hardly reflected the general practice of States. The question should therefore be clarified by the International Law Commission before the draft was adopted in its final version. Lastly, he said that the countermeasures adopted by third (indirectly injured) States should be aimed primarily at the cessation of the internationally wrongful act rather than at obtaining reparation for the directly injured State.

${ }^{735}$ It would be unacceptable for any State to take countermeasures at the request of any injured State, because that would give the big Powers the opportunity to play the role of international policemen. The only exception concerned the acts referred to in article 41 . There were cases where such relations between States might also fall under the jurisdiction of international organizations responsible for security matters.
} 
Após os debates sobre o artigo 54 na $55^{\mathrm{a}}$ Sessão do Sexto Comitê das Nações Unidas, embora a ampla maioria dos Estados tenha apoiado ao menos parcialmente este artigo, a CDI decidiu substituí-lo por uma saving clause, reservando a posição sobre a adoção das contramedidas para o desenvolvimento futuro do Direito Internacional.

Alguns Estados se manifestaram sobre o novo artigo 54 na $56^{a}$ Sessão do Sexto Comitê.

Dentre estes, Japão, Singapura, Itália, Mali e Serra Leoa demonstraram seu apoio ao artigo 54, considerando-o como uma saving clause.

Nova Zelândia e Mongólia expressaram sua aprovação pelo novo artigo, apesar de apoiarem também o artigo anterior.

A Finlândia, porém, falando em nome dos países nórdicos, lamentou a substituição do artigo 54 e embora entendesse que o novo artigo iria em direção ao reconhecimento do princípio de que todos os Estados têm o direito de adotar contramedidas no caso de violação a uma obrigação devida à comunidade internacional como um todo, mencionou a necessidade de esclarecimentos em relação às normas imperativas de Direito Internacional (ONU, A/C.6/56/SR.11, p. 6)

Já China (ONU/ A/C.6/56/SR.11, p. 10) ${ }^{737}$, França (ONU, A/C.6/56/SR.11, p. $11)^{738}$ e México (ONU, A/C.6/56/SR.14, p. 4) ${ }^{739}$ foram contra o artigo por considerar que este não contém uma saving clause e sim uma autorização indireta para a adoção de contramedidas.

Neste mesmo sentido discursou a Rússia, que embora a favor do antigo artigo 54, considerou que a nova redação implicaria em menor regulação do direito de adoção de contramedidas por Estados não diretamente lesados (A/C.6/56/SR.14, p. 8) ${ }^{740}$.

\footnotetext{
736 Less fortunately, the wording of article 54 seemed to exclude the possibility of collective countermeasures in case of a breach of a jus cogens obligation unless it was simultaneously a bre ach of an obligation erga omnes, or at any rate to leave the matter open to dispute. To clarify the discrepancy between the two regimes, a link should be created between articles 41,48 and 54, perhaps through a less restrictive wording of paragraph 3 of article 41

${ }^{737}$ However, the new article failed to define "lawful measures". If they included countermeasures, the new provision would have the same effect as the old one.

${ }^{738}$ As for measures taken by States other than an injured State, he did not accept that draft article 54 was a "saving clause", since it implied that a State having only a legal interest in the matter could take countermeasures against the responsible State, for the sake of obtaining cessation or reparation in the interest of the injured State. That question should be explored in much greater detail.

${ }^{739}$ His delegation had reservations about the inclusion of draft article 54, since it seemed to invite States other than the injured State to take countermeasures against a responsible State and was silent on other mechanisms that existed in the organized international community for dealing with breaches of international law

${ }^{740}$ The new article 54 had not preserved all its good points, however. The right of States other than the injured State to take countermeasures was now derived from only one criterion - that the measures
} 
Também o Barein se posicionou contra o artigo 54.

A República da Coreia, por seu lado, apresentou comentário ao antigo artigo 54 em resposta ao pedido da CDI (A/CN.4/515, p. 89, 2001). Neste comentário, ela admite em princípio a possibilidade de contramedidas por Estados não diretamente lesados, ressaltando, porém que o parágrafo 2 deveria implementar mecanismos de controle da arbitrariedade na utilização destas medidas.

Conclui-se dos debates ocorridos no âmbito do $6^{\circ}$ Comitê da Assembleia Geral da ONU, que embora a posição inicial dos Estados em relação à questão da possibilidade de adoção de contramedidas por Estados não diretamente lesados tenha sido recalcitrante, alguns Estados mudaram a sua posição no decorrer dos trabalhos e, ao final, uma ampla maioria apoiava ao menos algumas hipóteses em que esta adoção seria permitida.

Numa análise da posição dos Estados sobre o tema, temos:

a) Estados que reconheceram a possibilidade da adoção de contramedidas por Estados não diretamente lesados em ao menos alguns casos: Indonésia (1978), Jamaica (1985), Bulgária (1996), África do Sul, e demais países da SADC (2000), Alemanha (2000), Argentina (2000), Austrália (2000), Áustria (2000), Botsuana (2000), Chile (2000), Costa Rica (2000), Eslovênia (2000), Espanha (2000), Grécia (2000), Irã (2000), Jordânia (2000), Polônia (2000), Rússia (2000), Finlândia e demais países nórdicos (2001) e Mongólia (2001), República da Coreia (2001);

b) Estados a favor de uma saving clause deixando a matéria reservada para o desenvolvimento futuro do direito internacional: Reino Unido (2000), Itália (2001), Japão (2001), Mali (2001), Serra Leoa (2001), Singapura (2001);

c) Estados contra a adoção de contramedidas por Estados não diretamente lesados em qualquer hipótese: Madagascar (1982), Brasil (2000), Camarões (2000), Cuba (2000), Israel (2000), Tanzânia (2000), Barein (2001), China (2001), França (2001), México (2001)

Em relação especificamente às contramedidas adotadas em razão de uma violação a normas de direitos humanos, dos Estados favoráveis a adoção de contramedidas por Estados não diretamente lesados, somente o Reino Unido e a Jordânia foram expressamente contra a adoção de contramedidas no caso de violações sérias a

should be lawful - whereas the previous draft article 54 stated that such a State could take countermeasures only to the extent that it would itself be entitled to take them. The new wording therefore gave such a State greater rights than the injured State. 
obrigações decorrentes de norma imperativa. A Polônia reconheceu a possível necessidade da regra, porém requereu esclarecimentos à CDI sobre a prática geral relativa à questão.

Dos Estados a favor de uma saving clause, a Itália, embora tenha demonstrado surpresa em relação ao parágrafo 2 do artigo 54, não foi taxativamente contra, e mesmo elogiou o parágrafo 3.

Assim, do grupo de Estados favoráveis às "contramedidas coletivas", somente Reino Unido e Jordânia não reconheceriam o direito dos Estados de adotarem contramedidas no caso de violações a direitos humanos consagrados em normas imperativas. Eles reconheceriam, porém, o direito dos Estados atuarem a requerimento de um Estado lesado em qualquer caso.

Embora a prática de contramedidas por Estados não diretamente lesados seja alegadamente Ocidental (afirmação que pretendemos refutar adiante), podemos verificar que dentre os Estados que reconheceram este direito nos debates do $6^{\circ}$ Comitê, encontramos representantes das mais diversas regiões (Caribe, África, América do Sul, Oceania, Oriente Médio, Europa do Leste, Ásia). Os Estados ocidentais (WEOC ${ }^{741}$ ) não podem nem mesmo ser considerados maioria neste grupo.

Por outro lado, dentre os Estados que recusam terminantemente a possibilidade de adoção de contramedidas por Estados não diretamente lesados, temos vários Estados que já as utilizaram, como veremos mais a frente. Um exemplo é a França, franca opositora das contramedidas em geral, mas que já as utilizou em alguns casos, tanto em conjunto, no âmbito da União Europeia, quanto individualmente.

Assim, a posição de um Estado sobre a questão da legalidade das contramedidas adotadas por Estados não diretamente lesados deve ser estudada não só com base no seu discurso dentro da Assembleia Geral, mas também levando em conta a prática destes Estados nas suas relações internacionais.

2.5.2 Casos de adoção de contramedidas por Estados não diretamente lesados

Casos de adoção de contramedidas por Estados não diretamente lesados diante de violações a obrigações em geral

\footnotetext{
${ }^{741}$ Western Europe and Other Countries, grupo regional atuante nas Nações Unidas.
} 
Estados Unidos contra China e Coreia do Norte (1950)

Em junho de 1950 a Coreia do Sul é invadida pela Coreia do Norte, com apoio da China. Embora a invasão tenha sido considerada um ato de agressão, e repudiada por diversas Resoluções do Conselho de Segurança (e.g. Security Council Res 82, 25 de junho de 1950) e da Assembleia Geral (e.g. AG Res 377 (V)) das Nações Unidas, o Conselho de Segurança, paralisado pela ameaça de veto da União Soviética não adotou nenhuma Resolução autorizando sanções a esta ação. A Assembleia Geral adotou, em maio de 1951, Resolução recomendando a imposição de um embargo à China e Coreia, referente a materiais militares e produtos úteis para a produção destes materiais (AG Res. $500(\mathrm{v}))$.

Os Estados Unidos, em 16 de dezembro de 1950, adotaram medidas unilaterais congelando os bens da China ${ }^{742}$ e da Coreia do Norte ${ }^{743}$. O congelamento dos bens de um Estado é contra as regras de Direito Internacional geral ${ }^{744}$, caracterizando as medidas tomadas como contramedidas. $\mathrm{O}$ ato internacionalmente ilícito que a originou, a agressão da Coreia do Norte e China, foi tomado contra a Coreia do Sul, sendo os Estados Unidos, assim, um Estado não diretamente lesado.

Segundo o Governo dos Estados Unidos (Dep of State Bulletin, p. 1004, dec 1950):

Esta ação foi forçada pela intervenção das forças comunistas chinesas militares na Coreia. Tendo em vista o comprometimento dos recursos chineses com esta agressiva atividade não provocada, este Governo não pode permitir que os Comunistas Chineses tenham acesso aos suprimentos e bens nos Estados Unidos, uso dos quais de acordo com as presentes circunstâncias claramente vai contra os interesses e objetivos das Nações Unidas na crise do Oriente. ${ }^{75}$ (tradução nossa)

\footnotetext{
${ }^{742}$ The United States Government is taking measures today to place under control all Chinese Communist assets within United States jurisdiction (Dept of State Bulletin (25 december 1950))

${ }^{743}$ Proclamation 2914 of December 16, 1950, "The same controls also are being applied to North Korean assets at this time" (Dept of State Bulletin (25 december 1950))

${ }_{744}$ Neste sentido Dawidowicz (p. 353, 2006), Prokauki, (p. 114, 2010)

745 This action has been forced upon us by the intervention of Chinese Communist military forces in Korea. In view of the commitment of Chinese resources in this unprovoked aggressive activity, this Government cannot permit the Chinese Communists to have access to United States supplies or assets in the United States, the use of which under present circumstances clearly runs counter to the interests and objectives of the United Nations in the Far Eastern crisis.
} 
Em explicação à medida adotada, os Estados Unidos não fazem qualquer referência à legítima defesa coletiva. Também fica claro que, embora baseada nos interesses das Nações Unidas, a medida é adotada independente de qualquer autorização neste sentido.

Assim, para Dawidowicz (p. 354, 2006) “a justificação dos EUA pode ser interpretada como contramedidas de Estados terceiros." ${ }^{, 746}$ (tradução nossa)

OEA contra República Dominicana (1960)

Em resposta a uma suposta tentativa de assassinato do Presidente da Venezuela pela República Dominicana, então sob a ditadura de Trujillo, a OEA adotou em 1960 Resolução adotando as seguintes medidas:

a) O rompimento de relações diplomáticas de todos os estados membros com a República Dominicana;

b) Interrupção parcial das relações econômicas de todos os Estados membros com a República Dominicana começando com a suspensão imediata do comércio de armas e implementos de guerra de qualquer tipo. O Conselho da Organização dos Estados Americanos, de acordo com as circunstâncias e com a devida consideração com as limitações constitucionais ou legais de cada um dos seus estados membros deve estudar a viabilidade e o desejo de estender a suspensão de comércio com a República Dominicana a outros artigos. ${ }^{747}$ (tradução nossa)

O embargo posteriormente se estendeu ao petróleo e seus derivados e a caminhões $^{748}$.

Na data, a República Dominicana era membro do GATT, Acordo Geral sobre Tarifas Aduaneiras e Comércio. Também, o Brasil, Haiti, Nicarágua e Estados Unidos eram membros deste tratado, que em como objetivo facilitar o comércio entre os Estados. O embargo econômico poderia ser considerado uma violação ao artigo XI do GATT, que proíbe a imposição de restrições ou proibições para a importação ou exportação de produtos originários dos países membros.

\footnotetext{
${ }^{746}$ The US justification may be interpreted as third-party countermeasures.

747 a) breaking of diplomatic relations of all the member states with the Dominican Republic

b) partial interruption of economic relations of all member states with the Dominican Republic, beginning with the immediate suspension of trade in arms and implements of war of any kind. The Council of the Organization of the American States in accordance with the circumstances and with due consideration for the constitution and legal limitations of each and every one of the member states, shall study the feasibility and desirability of extending the suspension of trade with the Dominican Republic to other articles.

${ }^{748}$ Prokauki (p. 115, 2010).
} 
Por outro lado, o artigo 53 da Carta das Nações Unidas proíbe a adoção de medidas coercitivas no âmbito dos acordos ou organizações regionais sem a autorização do Conselho de Segurança. Embora os Estados Unidos tenham alegado que o dispositivo se referia apenas às ações com o uso da força, a União Soviética afirmou que, na ausência de autorização do Conselho de Segurança, a OEA não tinha competência para adotar tais medidas. Esta também não foi a posição adotada pelos Estados Unidos durante a elaboração da Carta das Nações Unidas (PROKAUKI, p. 115, 2010).

Assim, a Resolução da OEA não tinha o condão de excluir a ilicitude das medidas tomadas pelos seus membros. Tendo em vista que as medidas foram adotas em resposta a um ato ilícito anterior da República Dominicana contra a Venezuela, nenhum dos Estados pode alegar ter sido diretamente lesado. As medidas, então, podem ser caracterizadas como contramedidas adotadas por Estados não diretamente lesados.

Países Árabes contra Israel e demais países ocidentais (1973)

Após o fracasso das negociações posteriores a guerra de expansão Israelense em 1967, diversos países árabes tais como Egito, Síria, Algéria, Barein, Iraque, Kuwait, Líbia, Qatar e Arábia Saudita decidiram reduzir a exportação de petróleo para Es tados que direta e indiretamente apoiaram Israel ${ }^{749}$.

Tendo em vista que o Kuwait era parte do GATT e que a Arábia Saudita tinham um acordo comercial válido, as medidas adotadas por Estados dois Estados estavam desacordo com suas obrigações internacionais e podem ser consideradas como contramedidas adotadas por Estados não diretamente lesados. Resta a discussão sobre a possibilidade de adoção de contramedidas contra Estados que não atuaram diretamente na violação internacional. $\mathrm{O}$ anteprojeto sobre responsabilidade internacional, entretanto, estabelece no seu artigo 16 que o auxílio ou assistência a um ato internacionalmente ilícito (a invasão militar de Israel) gera responsabilidade também para o Estado que auxiliou. Desta forma, também os demais Estados podem ser considerados como Estados responsáveis e passíveis de contramedidas lícitas.

Estados ocidentais contra URSS (1980)

\footnotetext{
${ }^{749}$ Keesing's, p. 26224, 1973..
} 
Em dezembro de 1979 as forças armadas da URSS invadiram o Afeganistão. A alegação russa de que a intervenção ocorreu a pedido do Afeganistão para repelir uma intervenção armada dos países ocidentais demonstrou-se falsa (ONU, UNYB, p. 296, 1980).

Em Resolução da Assembleia Geral (A/RES/35/37) foi reconhecido que a intervenção militar estrangeira no Afeganistão contrariava direito de autodeterminação dos povos e se requereu "a imediata retirada das tropas estrangeiras do Afeganistão"750

Entretanto nenhuma sanção foi recomendada.

Em resposta a invasão inúmeras medidas de retorsão foram tomadas. Em especial os Estados Unidos adotaram medidas de suspensão de exportação de bens de alta tecnologia, de fosfato para fertilizantes, boicote as Olimpíadas de Moscou e mesmo um embargo de Grãos em relação à URSS. Essas medidas, porém, tendo em vista que o respeito ao Acordo de Grãos entre Estado Unidos e URSS, só podem ser caracterizadas como medidas de retorsão (DAWIDOWICZ, p. 364, 2006).

Outros Estados, entretanto, tomaram medidas que forma além da simples ação inamistosa. Em 11 de janeiro de 1980, o Canadá suspendeu os direitos de pesca da URSS (ROUSSEAU, p. 837, 1980), direitos estes garantidos pelo Acordo sobre Relações Mútuas de Pesca de 1976 (UNTS, Vol. 1132, p. 139). Ocorre que tal acordo, no seu artigo VII.2 prevê que o término do mesmo somente poderia ocorrer após seis anos da sua entrada em vigor e com uma notificação prévia de as menos 12 meses. ${ }^{751}$ Assim, a suspensão dos direitos estabelecidos neste tratado são uma violação das obrigações do Canadá em relação à URSS. Tal medida, assim, tendo em vista que foi tomada em razão da invasão russa a um Estado estrangeiro, pode ser considerada como uma contramedida por Estado não diretamente lesado.

Também a Nova Zelândia suspendeu em 23 de fevereiro os direitos de pesca da URSS (ROUSSEAU, p. 837, 1980) segundo o Acordo de Pesca de 1978 (UNTS, vol.

\footnotetext{
${ }^{750}$ Calls upon the immediate withdrawal of the foreign troops from the Afghanistan.

751 2. The present Agreement shall be subject to review by the two Governments after a period of two years or at any time following ratification, acceptance or approval by both Parties of a future multilateral Convention dealing with the same substantive matters. It may be terminated by either Party at the conclusion of any six-year period from the date of its entry into force, provided that notice of termination is given not less than twelve months before the expiry of such period. (UNTS, p. 142, Vol. 1132)
} 
1151, p. 278). Este acordo, no seu artigo VII.2 também continha disposição requerendo uma notificação anterior de 12 meses para a efetivação do término do tratado $^{752}$.

Portanto, também esta medida pode ser considerada uma contramedida adotada por um Estado não diretamente lesado.

Países Ocidentais contra a Argentina (1982)

Em 2 de abril de 1982 a Argentina invadiu as Malvinas. No dia seguinte o Conselho de Segurança adotou resolução condenado o fato e declarando a ação como uma violação à paz (SC Res 502). Tal resolução, porém, não estabeleceu nenhuma sanção a este Estado.

Entretanto, a Comunidade Europeia, a pedido do Reino Unido, declarou um embargo total de importação aos produtos argentinos ${ }^{753}$. Tal embargo, além de ser uma violação às obrigações dos Estados europeus partes do GATT em relação à Argentina, violaram as obrigações destes em relação a dois acordos setoriais. Um voltado a produtos têxteis (OJ 1979, L/298/2), outro voltado a carneiros e cordeiros (OJ 1980, $\mathrm{L} / 275 / 14)$.

Também a Austrália ${ }^{754}$ e o Canadá ${ }^{755}$ estabeleceram embargos econômicos. A Nova Zelândia estabeleceu embargos de importação e exportação e suspendeu o tratado bilateral de aviação ${ }^{756}$.

Os Estados que adotaram embargos alegaram estar agindo de acordo com o artigo XXI do GATT, ou seja, a exceção relativa à segurança. Entretanto, os acordos setoriais entre os países membros da Comunidade Europeia e a Argentina não possuíam nenhuma cláusula neste sentido. Sua violação, assim, pode ser considerada como contramedidas adotadas por Estados não diretamente lesados.

Estados Unidos contra Nicarágua (1981-1985)

Diante da aproximação da Nicarágua com Cuba e a União Soviética, os Estados Unidos acusaram este Estado de apoiar movimentos de insurreição em El Salvador. Em

\footnotetext{
752 (2) This Agreement will remain in force until 30 June 1982 unless terminated by either Government by giving notification of such termination twelve months in advance. (UNTS, p. 142, vol. 1151)

${ }^{753}$ ILM, p. 547, 1982.

${ }^{754}$ AYIL, p. 573,1983

${ }^{755}$ CYIL, p.337, 1983.

${ }^{756}$ Keesing's, p. 31533, 1982.
} 
1985 os Estados Unidos impõem um embargo total contra Nicarágua, contra suas obrigações perante o GATT, e suspende os direitos de aviação e navegação garantidos por tratado bilateral ${ }^{757}$. Apesar da alegação estadunidense de que estaria agindo com base na exceção prevista no artigo XXI do GATT, a atuação da Nicarágua não configurou uma ameaça à segurança dos Estados Unidos nem uma grave tensão internacional, como deixou claro o julgamento da CIJ sobre a questão. Assim, estas medidas podem ser consideradas contramedidas adotadas por um Estado não diretamente lesado.

Diversos Estados contra o Iraque (1990)

Em 2 de agosto de 1990 as forças militares iraquianas invadiram o Kuwait. Diante desta invasão, diversos Estados adotaram medidas unilaterais antes da adoção de Resolução SC Res 611 que adota sanções coletivas. Dentre estes Estados os Estados Unidos congelam os bens do Kuwait em 2 de agosto (BETHLEHEM, p.429, 1991). Também bloquearam os bens do Iraque e decretaram um embargo total a este país (Executive Order 12.722 apud NASH, p. 903-905, 1990)

Entre 4 e 5 de agosto os 12 membros da Comunidade Europeia e o Japão adotaram sanções contra o Iraque.

Dentre as medidas tomadas pelos membros da Comunidade Europeia estão (ONU, S/21444):

a) um embargo à importação de petróleo do Kuwait e do Iraque;

b) medidas congelando os bens do Iraque no território dos Estados membros;

c) um embargo a venda de armas e outros equipamentos militares para o Iraque;

d) a suspensão de qualquer cooperação na esfera militar com o Iraque;

e) a suspensão da cooperação técnica e científica com o Iraque;

f) a suspensão da aplicação do Sistema Geral de Preferência ao Iraque. $^{758}$ (tradução nossa)

\footnotetext{
${ }^{757}$ ILM, p. 811-816, 1985.

758 a) An embargo on oil imports from Iraq and Kuwait;

b) Appropriate measures aimed at freezing Iraqi assets in the territory of member States;

c) An embargo on sales of arms and other military equipment to Iraq;

d) The suspension of any co-operation in the military sphere with Iraq;

e) The suspension of technical and scientific co-operation with Iraq;

f) The suspension of the application to Iraq of the System of Generalized Preferences.
} 
O Japão também adotou medidas que iam do embargo de importação de petróleo à suspensão de transações econô micas com Iraque e Kuwait (ONU, S/21449).

O congelamento de bens de um estado estrangeiro, como já mencionado é uma violação das normas de Direito Internacional Geral. Diante da falta de autorização do Conselho de Segurança para a adoção de tais medidas, elas podem ser consideradas como contramedidas adotadas por estados não diretamente lesados. Também segue a mesma linha os embargos decretados, que vão contra as obrigações destes países segundo o GATT.

Estados Unidos contra a Síria (2003-2004)

Em dezembro de 2003, tendo em vista o alegado suporte da Síria a terroristas, os Estados Unidos estabeleceram um embargo econômico e o congelamento dos bens sírios (Public Law 108-175 759 ). Embora o embargo, na ausência de tratados comerciais, seja uma medida de retorsão, o congelamento de bens de um Estado é contra as normas do Direito Internacional geral e pode ser considerado como contramedidas adotadas por estados terceiros.

Casos de adoção de contramedidas por Estados não diretamente lesados diante de violações a obrigações decorrentes de normas de proteção aos direitos humanos

Países em Desenvolvimento contra a África do Sul (1960-1964)

Os casos de maior repercussão internacional de adoção de contramedidas por Estados não diretamente lesados talvez sejam aqueles envolvendo a África do Sul.

759 (1) the President shall prohibit the export to Syria of any item, including the issuance of a license for the export of any item, on the United States Munitions List or Commerce Control List of dual-use items in the Export Administration Regulations (15 CFR part 730 et seq.); and

(2) the President shall impose two or more of the following sanctions:

(A) Prohibit the export of products of the United States (other than food and medicine) to Syria. (B) Prohibit United States businesses from investing or operating in Syria.

(C) Restrict Syrian diplomats in Washington, D.C., and at the United Nations in New York City, to travel only within a 25-mile radius of Washington, D.C., or the United Nations headquarters building, respectively.

(D) Prohibit aircraft of any air carrier owned or controlled by Syria to take off from, land in, or overfly the United States.

(E) Reduce United States diplomatic contacts with Syria (other than those contacts required to protect United States interests or carry out the purposes of this Act).

(F) Block transactions in any property in which the Government of Syria has any interest, by any person, or with respect to any property, subject to the jurisdiction of the United States. 
Em função da sua política contínua de apartheid, este Estado foi alvo de embargo econômico por diversos países em diferentes ocasiões.

Em junho de 1960 a Segunda Conferência dos Estados Africanos Independentes adota a Resolução sobre a África do Sul, na qual "insta todos os povos africanos e sindicatos, assim como os Governos dos Estados Independentes Africanos a organizar um boicote contra mercadorias da África do Sul e África Sudoeste., ${ }^{, 760}$

Em cumprimento a esta resolução, Gana, em 6 de julho, Malásia, em $1^{\circ}$ de agosto e Tanzânia em $1^{\circ}$ de setembro impõem um embargo comercial contra a África do Sul em 1960 (Rousseau, 1960, p. 804-806).

Em 1962 a Assembleia Geral da ONU adota a Resolução 1761 (XVII) na qual requer que os Estados adotem uma série de medidas contra a África do sul (ONU, 1962):

Requer que os Estados Membros adotem as seguintes medidas, separadamente ou coletivamente, em conformidade com a Carta, para levar ao abandono destas políticas:

a) o rompimento das relações diplomáticas com o Governo da Repúblic a da África do Sul, ou se abster de estabelecer tais relações;

b) o fechamento de seus portos para todos os navios navegando sob a bandeira sul-africana;

c) a adoção de legislação proibindo seus navios de entrarem nos portos sul-africanos;

d) boicote a todas as mercadorias sulafricanas e abster-se de exportar mercadorias, inclusive armas e munição para a África do Sul;

e) recusar aterrissagem e instalações de passagem para todas as aeronaves pertencentes ao Governo da África do Sul e companhias registradas sob as leis da África do Sul. ${ }^{761}$ (tradução nossa)

\footnotetext{
760 The Second All-African Peoples Conference, having examined the situation in South Africa which has only worsened, urges the African peoples and Trade Unions as well as the Governments of the Independent African States to organize a boycott of goods from South Africa and South-West Africa Instructs the Secretariat of the Conference to take all effective measures for the practical application of this decision. (Resolution on South Africa, Tunis, 1960, disponível em: http://publishing.cdlib.org/ucpressebooks/view?docId=ft5x0nb3tg\&chunk.id=d0e14659\&toc.depth=100\& toc.id=d0e14599\&brand=ucpress. Acesso em: 20 out. 2010.

761 4. Requests Member States to take the following measures, separately or collectively, in conformity with the Charter, to bring about the abandonment of those policies:

a) Breaking off diplomatic relations with the Government of the Republic of South Africa or refraining from establishing such relations;

b) Closing their ports to all vessels flying the South African flag;

c) Enacting legislation prohibiting their ships from entering South African ports;

d) Boycotting all South African goods and refraining from exporting goods, including all arms and ammunition to South Africa;

e) Refusing landing and passage facilities to all aircraft belonging to the Government of South Africa and companies registered under the laws of South Africa;
} 
Também, a primeira Conferência de Chefes de Estados e Governos Independentes Africanos, que criou a Organização da União Africana, adotou Resolução que:

Requer um efetivo boicote ao comércio externo de Portugal e África do Sul:

a) Proibindo a importação de bens destes dois países;

b) fechando portos e aeroportos africanos aos seus navios e aviões;

c) proibindo os aviões destes dois países de sobrevoar seus territórios ou todos os Estados Africanos. ${ }^{762}$ (tradução nossa)

Seguindo estas recomendações, diversos Estados impuseram embargos comerciais à África do Sul nos anos seguintes. Dentre eles Indonésia ${ }^{763}$, Kuwait ${ }^{764}$, Nigéria ${ }^{765}$, Paquistão $^{766}$, Serra Leoa ${ }^{767}$, Tanzânia ${ }^{768}$, Uganda $^{769}$.

Ocorre que a África do Sul é parte originária do GATT, Acordo Geral sobre Tarifas Aduaneiras e Comércio, sendo vinculada a este desde 1947. Gana, Malásia, Indonésia, Kuwait, Nigéria, Paquistão, Serra Leoa, Tanzânia e Uganda também são partes do mesmo acordo, que tem como objetivo facilitar o comércio entre as nações. A adoção de um embargo econômico vai contra as obrigações assumidas por estes Estados segundo este tratado, em especial seu artigo XI.

Nenhum destes Estados invocou alguma das exceções previstas nos artigos XIX a XXI do GATT. Também, segundo o artigo 53 da Carta das Nações Unidas, nenhuma ação coercitiva poderá ser tomada no âmbito dos acordos ou entidades regionais sem a autorização do Conselho de Segurança. A Resolução da OUA não poderia servir, portanto, de excludente de ilicitude para as condutas adotadas.

Por outro lado, as Resoluções da Assembleia Geral da ONU, nestes casos, não têm caráter vinculante ${ }^{770}$.

Para Frowein (p. 383, 1994):

\footnotetext{
762 ASKS FOR AN EFFECTIVE BOYCOTT of the foreign trade of Portugal and South Africa by:

(a) prohibiting the import of goods from those two countries;

(b) closing African ports and airports to their ships and planes;

(c) forbidding the planes of those two countries to overfly the territories or all African States (Etiópia, 1963, disponível em http://www.africa-union.org/root/AU/Documents/Decisions/decisions fr.htm. Acesso em 22 out. 2010.

${ }^{763}$ Keesing's, p. 19757, 1963-1964

${ }^{764}$ Keesing's p. 19757, 1963-1964

765 Keesing's p. 18027,1964

766 Keesing's p. 20421, 1961-1962

${ }^{767}$ Keesing's p. 18186, 1963-1964

768 Keesing's p. 19699, 1963-1964

${ }^{769}$ Keesing's p. 19699, 1963-1964

${ }^{770}$ Arangio-Ruiz, p. 48, 1993
} 
A Assembleia Geral da ONU não tem possibilidade de adotar decisões vinculantes a este respeito. Entretanto, uma recomendação a um boicote econômico pela Assembleia Geral pode criar uma presunção de que essas medidas de boicote são lícitas segundo o direito internacional. ${ }^{771}$ (tradução nossa)

Entretanto, uma vez que tais resoluções não são vinculantes e ne nhuma disposição da Carta das Nações Unidas autoriza a Assembleia Geral a adotar medidas coercitivas contra os Estados Membros, não haveria como uma simples recomendação, ainda que emanada pela Assembleia Geral da ONU, excluísse a ilegalidade de uma conduta contrária as obrigações internacionais de um Estado. $\mathrm{O}$ anteprojeto sobre responsabilidade internacional do Estado, aprovado por meio de Resolução pela própria Assembleia Geral não prevê, dentre as excludentes de ilicitude, medidas adotadas em cumprimento a uma Resolução da Assembleia Geral.

Ainda na Opinião Consultiva de 1970 sobre a Namíbia, a CIJ declarou que (p. 50, 1970) "a Assembleia Geral é principalmente inve stida de poderes de recomendação"772. Embora a Corte reconheça que em alguns casos específicos a Assembleia Geral pode adotar Resoluções que "estabelecem determinações", ela claramente afirma a falta de poderes da Assembleia Geral para assegurar a retirada da África do Sul do território da Namíbia, ou seja, a falta de poderes da Assembleia Geral para adotar medidas coercitivas contra um Estado membro, mesmo quando este domina ilegalmente um território (CIJ, p.51, $1970^{773}$ ).

Portanto, as Resoluções da Assembleia Geral da ONU não têm o condão de excluir a legalidade da conduta dos Estados.

Estes embargos, assim, foram adotados contra as obrigações estabelecidas pelo GATT, em relação a um ato internacionalmente ilícito anterior (a política de apartheid da África do Sul). Nenhum destes Estados pode alegar terem sido diretamente lesados de forma que estas medidas se caracterizam como contramedidas adotadas por Estados não diretamente lesados.

\footnotetext{
771 The General Assembly has no possibility to take binding decisions in that respect. Nevertheless, a recommendation as to economic boycott by the General Assembly may create a presumption that these boycott measures are lawful under international law.

772 the General Assembly is in principle vested with recommendatory powers

773 By resolution 2145 (XXI) the General Assembly terminated the Mandate. However, lacking the necessary powers to ensure the withdrawal of South Africa from the Territory, it enlisted the co-operation of the Security Council
} 
Comunidade Europeia contra Grécia (1969-1970)

A Comunidade Europeia e seus Estados partes haviam assinado em 1963 um Acordo de Associação com o Estado grego ${ }^{774}$. Neste mesmo ano, foi celebrado também um Protocolo de Ajuda Financeira ${ }^{775}$.

Após o golpe militar de 21 de abril de 1967, a Grécia foi acusada de perseguição política. Tendo em vista várias reclamações à Comissão Europeia de Direitos Humanos e o receio de ser suspensa, a Grécia se retira do Conselho da Europa em 2 de dezembro de $1970^{776}$.

Em 1967 o Parlamento Europeu adota Resolução afirmando:

1. Constata que o acordo de associação entre a Comunidade Europeia e a Grécia, que prevê a adesão ulterior deste país à Comunidade, só poderá ser aplicado nas suas diferentes fases se as estruturas democráticas e as liberdades políticas forem restabelecidas na Grécia. ${ }^{777}$

Em 16 de abril de 1973, devido ás persistentes violações da Grécia aos direitos humanos, a Comunidade Europeia decide suspender em parte o Acordo de Associação, em particular a ajuda financeira devida à Grécia ${ }^{778}$. Tendo em vista que tais acordos não possuem nas cláusulas operativas uma vinculação ao cumprimento aos direitos humanos, somente uma breve referência aos "ideais subjacentes ao Tratado estabelecendo a Comunidade Econômica Europeia"779, a suspensão deste não encontra justificativa nos textos dos tratados. Tendo em vista que foras signatários do tratado não só o Conselho da Comunidade Econômica Europeia, mas também seus Estados partes (Bélgica, Holanda, Alemanha, França, Itália e Luxemburgo), a suspensão parcial deste tratado pode ser considerada como uma contramedida adotada por todos estes Estados, além daquela organização internacional.

Estados Unidos contra Uganda (1971-1978)

\footnotetext{
774 OJ 1963 294/63.

775 OJ 1963 340/63.

${ }^{776}$ Keesing's p. 23773, 1970.

777 1. Constate que l'accord d'association entre la Communauté européenne et la Grèce, qui prévoit l'adhésion ultérieure de ce pays à la Communauté, ne pourra être appliqué dans ses différentes phases que si les structures démocratiques et les libertés politique et syndicale sont rétablies en Grèce; (UE, Parliament Resolution, disponível em: http://www.ena.lu/. Acesso em 22 out. 2010

${ }^{778}$ Keesing's, p. 24170, 1969-70.

${ }^{779}$ Ideals underlying the Treaty establishing the European Economic Community
} 
Em 1971, Idi Amin tomou o poder em Uganda através de um golpe de Estado. Durante este período 75.000 asiáticos foram expulsos, e cerca de 300 mil pessoas morreram (DAWIDOWICZ, p. 356, 2006).

Em 10 de Outubro de 1978 os Estado Unidos adotam o Ato de Embargo a Uganda, "Uganda Embargo Act". De acordo com esta lei (Pub. L 95-435 Stat. 1051):

(a) O Congresso dos Estados Unidos entende que:

(1) O Governo de Uganda, segundo o regime do General Idi Amin cometeu genocídio contra os Ugandenses; [...]

(b) É opinião do Congresso que o Governo dos Estados Unidos deve tomar medidas para se desassociar de qualquer governo estrangeiro que comente o crime internacional de genocídio.

(c) Independente de qualquer outra provisão de direito, depois da data de entrada em vigor desta seção, nenhuma corporação, instituição, grupo ou indivíduo pode importar, direta ou indiretamente, para os Estados Unidos ou seus territórios ou possessões qualquer artigo criado, produzido ou manufaturado em Uganda até que o Presidente determine e certifique ao Congresso que o Governo de Uganda não mais comete um padrão consistente de flagrantes violações de direitos humanos. ${ }^{780}$

Tendo em vista que tanto Uganda quanto os Estados Unidos eram partes do GATT, Acordo Geral de Tarifas Aduaneira e Comércio, na época do embargo, e que os Estados Unidos não alegaram nenhuma das exceções previstas neste acordo, apenas justificando sua ação devido ao genocídio cometido pelo governo da Uganda, o embargo pode ser considerado uma violação ao artigo XI deste tratado, sendo, portanto, uma contramedida adotada por um Estado não diretamente lesado.

Comunidade Europeia contra Uganda (1971-1978)

Em 1975 os países da Comunidade Europeia assinaram a Convenção de Lomé (UE, OJ 1976 L/25/1) com os países da África, Caribe e Pacífico. Este tratado continha

\footnotetext{
${ }^{780}$ SEC. 5. (a) The Congress finds that-

(1) the Government of Uganda, under the regime of General Idi Amin, has committed genocide against Ugandans ; [...]

(b) It is the sense of the Congress that the Government of the United

States should take steps to disassociate itself from any foreign government which engages in the international crime of genocide.

(c) Notwithstanding any other provision of law, after date of enactment of this section, no corporation, institution, group or individual may import, directly or indirectly, into the United States or its territories or possessions any article grown, produced, or manufactured in Uganda until the President determines and certifies to the Congress that the Government of Uganda is no longer committing a consistent pattern of gross violations of human rights.
} 
disposições de cooperação comercial (Título I) e disposições de cooperação técnica e financeira (Titulo IV), dentre outras, segundo as quais assistência financeira seria fornecida para os países menos desenvolvidos, entre eles a Uganda (artigo 48).

No entanto, devido às graves violações aos direitos humanos cometidas durante o governo de Idi Amin na Uganda, o Conselho Europeu adotou as Diretrizes de Uganda ou "Uganda Guidelines" (EC Bull, 1977, n.6 parag. 2.2.59) nas quais afirmava:

O Conselho deplora a consistente denegação de direitos humanos básicos ao povo de Uganda. O Conselho concorda em adotar medidas dentro do quadro das suas relações com Uganda segundo a Convenção de Lomé, para assegurar que qualquer assistência dada pela Comunidade a Uganda não tenha, de maneira renhuma como seus efeitos o reforço ou o prolongamento da denegação dos direitos básicos de seu povo. ${ }^{781}$

$\mathrm{Na}$ prática, essa declaração levou à suspensão quase total da ajuda ao desenvolvimento devida a este país segundo a Convenção de Lomé. Essa convenção, por outro lado, não possuía em seus parágrafos operativos, qualquer vinculação à aplicação do tratado com os respeitos aos direitos humanos ${ }^{782}$. A simples menção no preâmbulo afirmando que os Estados signatários estão: "Resolvidos a intensificar seus esforços conjuntos para o desenvolvimento econômico e progresso social dos países da ACP"783 e do artigo 40 afirmando que "tal desenvolvimento deve consistir, em particular, no maior bem estar da população" 784 não fornecem base jurídica suficiente para que se suspenda as disposições deste tratado em razão de violações aos direitos humanos.

Destaca-se também que o tratado não foi ratificado pela Comunidade Europeia como uma organização internacional, e sim por todos os seus Estados partes (Bélgica, Dinamarca, Alemanha, Holanda, França, Itália, Irlanda, Luxemburgo e Reino Unido).

Portanto, a suspensão de fato da Convenção de Lomé (DAWIDOWICZ, p. 359, 2006) por não se basear em nenhuma disposição deste tratado, pode ser considerada como uma contramedida adotada por Estados terceiros (Bélgica, Dinamarca, Alemanha,

\footnotetext{
${ }^{781}$ The Council deplores the consistent denial of basic human rights to the people of Uganda. The Council agrees to take steps within the framework of its relationships with Uganda under the Lomé Convention to ensure that any assistance given by the Community to Uganda does not in any way have as its effect a reinforcement or prolongation of the denial of basic human rights to its people

${ }^{782}$ Tal cláusula só foi inserida posteriormente, em outra Convenção de Lomé, justamente devido a este e outros casos.

${ }^{783}$ RESOLVED to intensify their efforts together for the economic development and social progress of the ACP States

${ }^{784}$ Such development shall consist in particular in the greater wellbeing of the population
} 
Holanda, França, Itália, Irlanda, Luxemburgo e Reino Unido), diante das violações de direitos humanos ocorridas em Uganda.

Comunidade Europeia contra República Centro Africana (1979)

Em $1^{\circ}$ de Janeiro de 1966 o Coronel Bokassa assumiu o poder na República Centro Africana após um golpe militar. Durante seu governo diversas violações graves e sistemáticas aos direitos humanos ocorreram.

Ainda assim, em 1975 os países da Comunidade Europeia assinaram a Convenção de Lomé (UE, OJ 1976 L/25/1), com os países da África, Caribe e Pacífico. A República Centro Africana era um dos Estados partes.

Porém, após o massacre de cerca de 100 crianças e estudantes de 8 a 16 anos, ocorrido entre 18 e 21 de abril de 1979 com a alegada participação pessoal do Imperador Bokassa ${ }^{785}$, a Comunidade Europeia decidiu agir.

A assistência para o desenvolvimento devida segundo o artigo 48 da Convenção foi suspensa ${ }^{786}$. Assim como no caso da Uganda, tendo em vista que o tratado não continha cláusulas vinculando esta assistência ao respeito aos direitos humanos, esta suspensão pode ser considerada como uma violação das obrigações dos Estados da Comunidade Europeia em relação ao tratado. Portanto, esta conduta pode ser considerada uma contramedida adotadas pelos Estados membros da Comunidade Europeia (Bélgica, Dinamarca, Alemanha, Holanda, França, Itália, Irlanda, Luxemburgo e Reino Unido) contra a República Centro Africana, devido à grave violação dos direitos humanos cometido por este Estado.

\section{França contra República Centro Africana (1979)}

Em $1^{\circ}$ de Janeiro de 1966 o Coronel Bokassa assumiu o poder na República Centro Africana após um golpe militar. Durante seu governo diversas violações graves e sistemáticas aos direitos humanos ocorreram. Apesar deste fato, a França, antiga potência dominante, continuou a manter relações com o país, fornecendo apoio financeiro e militar. Após o massacre de crianças acorrido em 1979, a posição da França mudou radicalmente. Neste mesmo ano ela suspendeu o Acordo relativo à Assistência

\footnotetext{
${ }^{785}$ Keesing's, p. 29750, 1979.

${ }^{786}$ Dawidowicz p. 360, 2006, Proukaki, p. 132, 2010.
} 
Técnica Militar (UNTS, vol. 821, p. 266) ${ }^{787}$. Diante da ausência de disposições neste acordo condicionando essa assistência ao respeito aos direitos humanos, tal suspensão se deu em desacordo com as obrigações da França nele estabelecidas.

Em novembro deste mesmo ano Bokassa foi retirado do poder. A França teve participação indireta neste golpe de estado ${ }^{788}$

Comunidade Europeia contra Libéria (1980)

Na noite de 12 a 13 de abril de 1984, o sargento Samuel Doe chegou ao poder na Libéria por meio de um golpe de Estado. Em 27 de abril os membros da Comunidade Econômica dos Estados do Oeste Africano (ECOWAS) não permitiram a participação do Presidente Doe na $5^{\text {a }}$ Conferência Anual da organização. Embora parte da doutrina (DAWIDOWICZ, p. 362, 2006, PROUKAKI, p. 135, 2010), considerem tal ação como uma contramedida, uma vez que a Libéria teria direito, como membros da organização, de atender a reunião, consideramos que, tendo em vista o não reconhecimento do novo governo pelos Estados membros da ECOWAS (ROUSSEAU, p. 1144-1145, 1980), faz com que sua conduta não seja voltada contra o Estado da Libéria, mas apenas contra um governo recém formado de forma violenta. Em face ao não reconhecimento deste novo governo, a recusa da participação de Doe não poderia ser considerada contra as obrigações dos Estados membros diante do tratado constitutivo da organização.

Por outro lado, os Estados membros da Comunidade Europeia, decidiram suspender a assistência para o desenvolvimento devida a Libéria segundo a Convenção de Lomé. Como já mencionado, este tratado não tem clausula vinculando esta assistência ao respeito aos direitos humanos. Esta suspensão, a exemplo do ocorrido nos casos da Uganda e República Centro Africana, pode ser considerada como uma contramedida adotada pelos Estados membros da Comunidade Europeia (Bélgica, Dinamarca, Alemanha, Holanda, França, Itália, Irlanda, Luxemburgo e Reino Unido) contra a Libéria em razão da situação dos direitos humanos neste país.

Países Ocidentais contra a Polônia e URSS (1981)

\footnotetext{
${ }^{787}$ Keesing's, p. 29750, 1979.

${ }^{788}$ Keesing's, p. 29933, 1979
} 
Em 3 de dezembro de 1981 o Governo polonês impôs a lei marcial e deu início a perseguição de milhares de ativistas políticos. Mais de 6 mil ativistas foram presos e postos em campos de internamento sem julgamento (ROUSSEAU, p. 603-604, 1982).

Em discurso do Presidente Reagan o Governo dos Estados Unidos responsabilizou a URSS pelos acontecimentos ocorridos na Polônia (Nash, p. 380, 1982). Segundo este “A União Soviética, através das suas ameaças e pressões, merece a maior parte da culpa pelos desenvolvimentos na Polônia.",789

Assim os Estados Unidos adotaram medidas contra a Polônia e a URSS.

Em 23 de Dezembro de 1981 os Estados Unidos anunciaram a suspensão (US, Dep. of State Bulletin, p. 2-3, Fev. 1982) do Acordo relativo à Pesca nas Costas dos Estados Unidos com a Polônia (UNTS, vol. 1068, p. 3). Esta suspensão era contrária ao artigo 16.1 que estabelecia a necessidade de notificação com 12 meses de antecedência para o término do tratado ${ }^{790}$.

Também foi suspenso (NASH, p. 380, 1982) o tratado bilateral de aviação civil de 1972 com a Polônia (UNTS, p. 206, vol. 1279). Este tratado também possuía cláusula estabelecendo que seu término só poderia se dar após uma notificação com um ano de antecedência (artigo XV). ${ }^{791}$

Os Estados Unidos suspenderam, ainda, (NASH, p. 382, 1982) o tratado bilateral de aviação civil com a União Soviética de 1966 (ILM, p. 82, 1967). Tendo em vista a justificativa destes atos seria a violação dos direitos humanos do povo polonês, estas medidas podem ser consideradas contramedidas por Estado terceiro.

Diante das mesmas circunstâncias, diversos Estados europeus suspenderam os direitos de aterrissagem da companhia aérea nacional polonesa (Rousseau, p. 607, 1982). Deste Estados ao menos a Suíça suspendeu os direitos contrariando as cláusulas de denúncia do tratado entre os dois países.

\footnotetext{
${ }^{789}$ The Soviet Union, through its threats and pressures, deserves a major share of the blame for the developments in Poland.

790 Article XVI. 1. This Agreement shall enter into force on a date to be mutually agreed by exchange of notes following the completion of the internal procedures of both Parties, and shall remain in force until July 1, 1982, unless terminated sooner by either Party after giving written notification of such termination one year in advance. (UNTS, p.8, Vol. 1068)

${ }^{791}$ Article 15. Either Contracting Party may at any time notify the other of its intention to terminate this Agreement. Such notice shall be sent simultaneously to the International Civil Aviation Organization. This Agreement shall terminate one year from the last day of the month in which the notic e of termination is received by the other Contracting Party, unless withdrawn before the end of this period by agreement between the Contracting Parties. (UNTS, p. 211, Vol. 1279)
} 
Países Ocidentais contra a URSS (1983)

Em $1^{\circ}$ de setembro de 1983 um jato soviético abateu um avião da linha aérea sul coreana causando a morte de 269 pessoas.

Diante deste fato, diversos Estados suspenderam seus tratados bilaterais de aviação com a URSS. ${ }^{792}$ Dentre eles Finlândia, França, Alemanha, Espanha e Suíça, Estados não diretamente lesados, agiram em desacordo com suas obrigações internacionais segundo estes tratados (DAWIDOWICZ, p. 375, 2006). Essa suspensão se caracteriza, assim como contramedidas por Estados terceiros.

Estados Ocidentais contra África do Sul (1985-1986)

Na década de 80 a áfrica do Sul continuava sua política de apartheid. Diante desta condutas, novas Resoluções da Assembleia Geral da ONU foram adotadas recomendando a adoção de medidas coletivas. Dentre elas a Resolução A/RES/36/172 estabelecia:

5. Comenda todos os Governos que tomaram medidas para romper, ou se abster de quaisquer relações com o regime de apartheid da África do Sul;

6. Urge todos os Estados que ainda não tenham o feito, a adotarem medidas de sanção separadas ou coletivas, na pendência da ação do Conselho de Segurança. ${ }^{793}$

O Conselho de Segurança, em 1985 adota Resolução recomendando medidas unilaterais coercitivas. Tal Resolução, entretanto não tinha caráter obrigatório, não podendo portanto, impedir a ilegalidade da conduta dos Estados que adotassem medidas contrárias a suas obrigações internacionais.

A Commonwealth recomendou a aplicação de medidas unilaterais contra a África do Sul (Rousseau, p. 948-949, 1986) Tal recomendação foi seguida pelos Estados membros que suspenderam imediatamente seus acordos bilaterais de aviação em 1986.

A Dinamarca e a Noruega Estabeleceram embargos a produtos sul africanos em desacordo com sua obrigações diante do GATT (ROUSSEAU, p. 950-951, 1986)

\footnotetext{
${ }^{792}$ Keesing's p. 32516, 1983.

793 5. Commends all Governments that have taken action to break off, or to refrain from, any relations with the apartheid régime of South Africa;

6. Urges all States that have not yet done so to adopt separate and collective measures for comprehensive sanctions against South Africa, pending action by the Security Council;
} 
Os Estados Unidos adotaram o Ato Anti-Apartheid "Anti-Apartheid Act" (NASH, p. 201-215, 1987) contrário a suas obrigações segundo o GATT. Também suspenderam o tratado bilateral de aviação de 1947 (UNTS, p. 233, Vol. 66) em desacordo com as disposições do tratado de renúncia.

\section{Estados Unidos Contra Panamá (1988)}

O General Noriega chega o poder no Panamá através de um golpe de Estado em 26 de fevereiro de 1988.

Visando a restauração da democracia e o fim das violações aos direitos humanos os Estados Unidos congelam todos os bens do Panamá e suspendem o pagamento de 7 milhões de dólares devidos à Comissão do Canal do Panamá (NASH, p. 571-573, 1988). O congelamento dos bens do Panamá é uma violação das regras de Direito Internacional Geral, e a suspensão do pagamento uma violação às obrigações dos Estados Unidos segundo o Tratado do Canal do Panamá (UNTS, p. 3, 1280).

Tendo em vista que os Estados Unidos não formas diretamente lesados, as medidas se caracterizam como contramedidas de Estados terceiros.

Estados africanos contra o Burundi (1996)

Depois de um golpe militar de Pierre Buyoya, antecedido por anos de instabilidade política e desrespeito aos direitos humanos, Etiópia, Quênia, Ruanda, Tanzânia, Uganda e Zaire, durante a Segunda Cúpula de Arusha, em 32 de julho de 1996, impuseram um embargo comercial total contra o Burundi (A/51/264 $\left.{ }^{794}\right)$. Um mês depois a Zâmbia também seguiu a mesma medida ${ }^{795}$.

Com exceção da Etiópia e do Zaire, todos os outros Estados eram partes do GATT. Assim tais embargos, contrários as obrigações destes Estados segundo este tratado, podem ser consideradas contramedidas adotadas por Estados terceiros.

Estados Unidos contra o Sudão (1997-2005)

\footnotetext{
794 11. The Regional Summit decided to exert maximum pressure on the regime in Bujumbura, including the imposition of economic sanctions in order to bring about conditions which are conducive to a return to normalcy in Burundi. In this regard, the Summit strongly appeals to the international community to support the efforts and measures taken by the countries of the region.

795 Keesing's p. 41214, 1996.
} 
Em 3 de novembro de 1997 os Estado Unidos adotaram uma série de medidas unilaterais contra o Sudão tendo em vista o apoio a grupos rebeldes na Uganda e às graves violações aos direitos humanos (Exec. Order 13067 $7^{796}$ ). Dentre estas medidas estabeleceu-se um embargo econômico e financeiro, que na ausência de tratados comerciais e financeiros se caracterizava como medidas de retorsão e o congelamento dos bens do governo da Uganda, o que como mencionado é contrário as normas de Direito Internacional Geral. O congelamento, ocorrido antes da Resolução do Conselho de Segurança autorizando medidas coercitivas, é assim uma contramedida de um Estado não diretamente lesado.

Estados Europeus e Estados Unidos contra Mianmar/Burma (1997-2005)

Mianmar tem estado sob uma ditadura militar desde 1962. Em outubro de 2007 os Membros da Comunidade Europeia impuseram diversas medidas unilaterais contra este Estado. Em 1997 os Estado Unidos impuseram o congelamento de investimentos em Mianmar (Exec. Order 13047). Em 24 de maio de 2000 a Comunidade Europeia congelou os bens do governo de Mianmar (OJ L 122/29797). Já em 2003 os Estados Unidos adotaram o Ato de Liberdade e Democracia burmesa "Burmese Freedom and Democracy Act” ampliando as sanções unilaterais (Public Law 108-61 ${ }^{798}$ ). Dentre as sanções previstas estava o congelamento de bens do governo de Mianmar.

Ao menos o congelamento dos bens do governo de Mianmar pode ser considerado como contramedidas adotadas por Estados indiretamente lesados, como anteriormente visto.

Estados da Comunidade Europeia contra Iugoslávia (1998)

\footnotetext{
${ }^{796}$ Section 1. Except to the extent provided in section 203(b) of IEEPA (50 U.S.C. 1702(b)) and in regulations, orders, directives, or licenses that may be issued pursuant to this order, all property and interests in property of the Government of Sudan that are in the United States, that hereafter come within the United States, or that hereafter come within the possession or control of United States persons, including their overseas branches, are blocked.

${ }_{797}$ (iii) funds held abroad by persons referred to in (i) will be frozen

${ }^{798}$ SEC. 4. FREEZING ASSETS OF THE BURMESE REGIME IN THE UNITED STATES.

(a) REPORTING REQUIREMENT.- Not later than 60 days after the date of enactment of this Act, the President shall take such action as is necessary to direct, and promulgate regulations to the same, that any United States financial institution holding funds belonging to the SPDC or the assets of those individuals who hold senior positions in the SPDC or its political arm, the Union Solidarity Development Association, shall promptly report those funds or assets to the Office of Foreign Assets Control.
} 
Em 7 de maio e 29 de junho de 1998, devido ao conflito armado em Kosovo, os Estados membros da Comunidade Europeia impuseram o congelamento de bens da Iugoslávia (OJ L 143/1 ${ }^{799}$ de 1998) e o imediato fim dos direitos de voo. (OJ L 190/3 ${ }^{800}$ DE 1998)

Como já mencionado, o congelamento de bens de um Es tado estrangeiro é contra o Direito Internacional Geral. Já o fim dos direitos de voo, ao menos para França e Reino Unido, violou aos acordos bilaterais de aviação destes países com a Iugoslávia, sendo considerados contramedidas por terceiros Estados.

Países Europeus e Estados Unidos contra o Zimbábue (2002)

Diante de sérias violações de direitos humanos ocorridas em 2002 no Zimbábue, os Membros da Comunidade Europeia decidiram congelar os bens de membros do Governo de Zimbábue (OJ L 50/4 ${ }^{801}$ de 2002). Um mês depois, 12 Estado Europeus decidiram implementar as medidas decididas em fevereiro, ou seja, o congelamento dos bens de Zimbábue (EC BULL 2002, N.3 , para 1.6.22)

Em março de 2003 os Estados Unidos decidiram tomar a mesma medida, i.e. congelar os bens de membros do governo de Zimbábue (Exec. Order $13288^{802}$ ).

Como já mencionado o congelamento de bens de Estados estrangeiros e seus governantes é contra as normas de direito Internacional geral, podendo ser consideradas contramedidas adotas por Estados não diretamente lesados.

\footnotetext{
${ }^{799}$ Funds held abroad by the Federal Republic of Yugoslavia and Serbian Governments will be frozen.

800 Flights by Yugoslav carriers between the Federal Republic of Yugoslavia and the European Community will be banned.

801 All funds, other financial assets or economic resources belonging to individual members of the Government of Zimbabwe and to any natural or legal persons, entities or bodies associated with them as listed in Annex I, shall be frozen.

802 Section 1. Except to the extent provided in section 203(b) of IEEPA (50 U.S.C. 1702(b)), and in regulations, orders, directives, or licenses that may be issued pursuant to this order, and notwithstanding any contract entered into or any license or permit granted prior to the effective date of this order, all property and interests in property of the following persons that are in the United States, that hereafter come within the United States, or that are or hereafter come within the possession or control of United States persons, including their overseas branches, are blocked and may not be transferred, paid, exported, withdrawn, or otherwise dealt in:

(a) the persons listed in the Annex to this order; and

(b) any person determined by the Secretary of the Treasury, in consultation with the Secretary of State, to be owned or controlled by, or acting or purporting to act directly or indirectly for or on behalf of, any of the persons listed in the Annex to this order.
} 
Estado Unidos contra Belarus (2004-2006)

Diante de diversas violações dos Direitos Humanos na Belarus os Estado Unidos, em 16 de junho de 2006 congelaram os bens do Presidente Lukashenko e dos seus principais assessores (Executive Order $13405^{803}$ de 2006). Também a União Europeia (OJ L 134/2 ${ }^{804}$ de 2006) tomou medida semelhante. Como visto anteriormente, o congelamento de bens, inclusive de Chefes de Estado é contra as normas de direito Internacional geral, podendo ser consideradas contramedidas adotas por Estados não diretamente lesados.

Dos casos práticos analisados duas importantes conclusões podem ser tiradas. A primeira, que as contramedidas, embora em alguns casos consistam em embargos econômicos, em diversos outros se referem a direitos dos Estados em relação a acordos de aviação, de navegação, de pesca, de assistência militar, etc. Outras medidas também muito comuns são o congelamento dos bens dos Estados estrangeiros e de seus governantes.

Tais medidas, dificilmente podem ser consideradas como violando os direitos humanos fundamentais da população do Estado afetado, crítica comum feita ao instituto das contramedidas.

${ }^{803}$ Section 1. (a) Except to the extent provided in section 203(b)(1), (3), and (4) of IEEPA (50 U.S.C. 1702(b)(1), (3), and (4)), or in regulations, orders, directives, or licenses that may be issued pursuant to this order, and notwithstanding any contract entered into or any license or permit granted prior to the effective date of this order, all property and interests in property that are in the United States, that hereafter come within the United States, or that are or hereafter come within the possession or control of any United States person, including any overseas branch, of the following persons are blocked and may not be transferred, paid, exported, withdrawn, or otherwise dealt in:

(i) the persons listed in the Annex to this order; and

(ii) any person determined by the Secretary of the Treasury, after consultation with the Secretary of State: (A) to be responsible for, or to have participated in, actions or policies that undermine democratic processes or institutions in Belarus;

(B) to be responsible for, or to have participated in, human rights abuses related to political repression in Belarus;

(C) to be a senior-level official, a family member of such an official, or a person closely linked to such an official who is responsible for or has engaged in public corruption related to Belarus;

(D) to have materially assisted, sponsored, or provided financial, material, or technological support for, or goods or services in support of, the activities described in paragraphs (a)(ii)(A) through (C) of this section or any person listed in or designated pursuant to this order; or

(E) to be owned or controlled by, or acting or purporting to act for or on behalf of, directly or indirectly, any person listed in or designated pursuant to this order.

${ }^{804}$ All funds and economic resources belonging to, owned, held or controlled by President Lukashenko as well as those belonging to owned, held or controlled by certain other officials of Belarus who are responsible for the violations of international electoral standards in the Presidential elections in Belarus on 19 March 2006 and the crackdown on civil society and democratic opposition, and those natural or legal persons, entities or bodies associated with them, as listed in Annex I shall be frozen. 
A segunda conclusão, é que a prática de contramedidas por Estados não diretamente lesados, embora majoritariamente ocidental, também é adotada por Estados de outras regiões geográficas como África, América Latina, Ásia, Oriente Médio e Oceania.

2.6 A configuração de uma norma consuetudinária reconhecendo a legalidade das contramedidas adotadas por violação a normas protetoras de direitos humanos

O artigo 38 do Estatuto da Corte Internacional de Justiça descreve o costume como: "b) o costume internacional, como prova de uma prática geral aceita como sendo o direito;"

Percebe-se pelo estabelecido no artigo a necessidade de dois elementos para a formação do costume. O primeiro, o elemento material, é uma prática geral. O segundo, um elemento psicológico, é que esta prática seja aceita como Direito.

Quanto ao elemento material, a prática, quer se constitua por meio de uma ação ou omissão, deve ser comum, ou seja, que tenha precedentes; uniforme, ou ao menos concordante; e evolutiva, ou seja, mais flexível em relação a mudanças. (ROUSSEAU, 1970, p. 309-310).

Como demonstrado acima, a prática dos Estados em relação à adoção de contramedidas por Estados não diretamente lesados é extensa, tendo ainda se intensificado nas últimas décadas.

Em relação à uniformidade, comprovoutse também que, embora tal prática seja predominantemente dos países ocidentais, ela não é exclusiva destes, havendo uma importante contribuição de países das mais diversas regiões do globo ${ }^{805}$. Por outro lado, a generalidade da prática, geralmente requerida para a configuração do costume, não se confunde com a unanimidade. Para Rousseau (1970, p. 319): "a doutrina afasta ordinariamente a exigência de unanimidade por entender que basta o consentimento dos Estados que se encontram em situação de ter que a aplicar e a ausência de protesto dos outros." (tradução nossa) ${ }^{806}$

Neste sentido também Salcedo (p. 106, 1984):

\footnotetext{
${ }^{805}$ Neste sentido Tams (p. 250, 2005) e Dawidowicz $(417,2006)$

${ }^{806}$ la doctrine écarté ordinairement l'exigence d'unanimité pour retenir que ls seul consentement des Etats qui se trouvés en situation d'avoir á appliquer et l'absence de protestation des autres.
} 
A exigência de uma aceitação geral, efetivamente, não quer dizer unanimidade, senão a aceitação geral por uma ampla maioria dos Estados, representativa de todos os diferentes sistemas sociais e econômicos, quer dizer, dos distintos grupos de Estados existentes na sociedade internacional. ${ }^{807}$

Como demonstrado nos casos analisados, a prática da adoção de contramedidas por Estados não diretamente lesados, apesar de consistente, raramente foi questionada pelos demais Estados da comunidade internacional. Ainda, como mencionado acima, ela foi adotada por Estados de diversas regiões geográficas, não sendo exclusivamente ocidental.

Ainda, a não necessidade de unanimidade da prática estatal é demonstrada, pela figura do protesto reiterado, reconhecida no Direito Internacional. Nas palavras de Rousseau (1970, p. 320): "É certo, entretanto, que uma regra costumeira não pode obrigar um Estado que manifestou de maneira constante e inequívoca sua recusa a aceitar." (tradução nossa) ${ }^{808}$

Esta manifestação em contrário, entretanto, embora tenha o condão de isentar o Estado protestante da norma consuetudinária, não impede a formação desta.

Assim, conclui-se que a prática estatal de adoção de contramedidas por Estados não diretamente lesados preenche os requisitos do exigidos para a configuração do elemento objetivo do costume.

Resta a comprovação do elemento subjetivo, ou seja, a opinio juris.

Tams, Dawidowicz e Proukaki, que em seus trabalhos analisam a prática dos Estados em relação a contramedidas adotadas por Estados não diretamente lesados, defendem que esta prática, embora não acompanhada de declarações expressas dos Estados, é acompanhada de opinio juris.

Dawidowicz escreve sobre a opinio juris (p. 414-415, 2006):

Da sua parte, a CIJ desenvolveu duas abordagens distintas para provar a existência da opinio juris relevante. Na maioria dos casos, na ausência de quaisquer antecedentes em contrário, a Corte presumiu que uma conduta uniforme dos Estados é acompanhada pela opinio juris relevante. Entretanto, em uma importante minoria de casos a

\footnotetext{
${ }^{807}$ La exigencia de una aceptación general, efectivamente, no quiere decir unanimidad sino aceptación general por una amplia mayoría de los Estados, representativa de los diferentes sistemas sociales y económicos, es decir, de los distintos grupos de Estados existentes en la sociedad internacional.

${ }^{808} \mathrm{Il}$ est certain toutefois qu'une règle coutimière ne peut lier un Etat qui a manifesté d'une manière constante et non equivoque son refus de l'accepter.
} 
Corte adotou uma abordagem mais estrita, requerendo uma evidência mais positiva da opinio juris $^{809}$ (tradução nossa)

Neste mesmo sentido, segue Tams (p. 238, 2005): "Esta abordagem é baseada na presunção de que, na ausência de indicações específicas em contrário, a conduta dos Estados será acompanhada de uma convicção legal; a opinio juris, assim, pode geralmente ser inferida da prática dos Estados. ${ }^{\Perp 10}$

De fato, a CIJ, no caso do Golfo do Maine estabelece (CIJ, p. 299, 1984):

Um corpo de normas detalhadas não deve ser procurado no direito consuetudinário internacional que de fato compreende um conjunto limitado de normas assegurando a coexistência e a cooperação vital dos membros da comunidade internacional, junto com um conjunto de regras consuetudinárias cuja presença na opinio juris dos Estados pode ser testada pela indução baseada na análise de uma prática suficientemente extensiva e convincente, e não pela dedução de ideias preconcebidas. ${ }^{811}$ (tradução nossa)

A CIJ parece, neste caso, ter modificado seu entendimento anterior, demonstrado no caso Plataforma Continental do Mar do Norte, onde escreve (CIJ, p. 44, 1969):

Não só os atos concernidos devem significar uma prática estabelecida, mas eles também devem ser tais, ou serem praticados de tal forma a serem evidência de que esta prática é considerada obrigatória pela existência de uma regra de direito a requerendo. A necessidade de tal crença, i.e. a existência de um elemento subjetivo, é implícita à própria noção de opinio juris sive necessitatis. ${ }^{812}$ (tradução nossa)

Tal entendimento já teria sido questionado no voto dissidente dos juízes Tanaka e Sorensen.

Para Tanaka (CIJ, p. 176, 1969):

\footnotetext{
${ }^{809}$ For its part, the ICJ has developed two distinct approaches to proving the existent of the relevant opinio juris. In most cases, in the absence of any antecedents to the contrary, the Court has presumed that a uniform conduct of States is accompanied by the relevant opinio juris.

810 This approached is based on the assumption that in the absence of specific indications to the contrary, the conduct of the States will be based on an accompanying legal conviction; opinion juris thus can usually be inferred by the State practice.

811 A body of detailed rules is not to be looked for in customary international law which in fact comprises a limited set of norms for ensuring the co-existence and vital co-operation of the members of the international community, together with a set of customary rules whose presence in the opinio juris of States can be tested by induction based on the analysis of a sufficiently extensive and convincing practice, and not by deduction fro $\mathrm{m}$ preconceived ideas.

812 Not only must the acts concerned amount to a settled practice, but they must also be such, or be carried out in such a way, as to be evidence of a belief that this practice is rendered obligatory by the existence of a rule of law requiring it. The need for such a belief, ie., the existence of a subjective element, is implicit in the very notion of the opinio juris sive necessitatis.
} 
Em segundo lugar, em relação ao fator qualitativo, nomeadamente, a opinio juris sive necessitatis, é extremamente difícil conseguir evidência de sua existência nos casos concretos. Este fato, relacionado à motivação interna e sendo de natureza psicológica, não pode ser apurado facilmente, particularmente quando diversos órgãos legislativos e executivos de um governo participam de um processo de decisão a respeito da ratificação ou de outros atos. Não há outro modo além de apurar a existência da opinio juris do fato da existência externa de um certo costume e de sua necessidade sentida na comunidade internacional, ao invés de procurar evidência dos motivos subjetivos para cada exemplo de prática dos Estados, o que é algo impossível de conseguir. ${ }^{813}$ (tradução nossa)

Já para Sorensen (CIJ, p. 244, 1969): "A possibilidade foi, assim, reservada de reconhecer a rápida emergência de uma nova norma do direito consuetudinário baseada na prática recente dos Estados.",814

Também no caso dos pesqueiros Ingleses e Noruegueses (CIJ, p. 128, 1951) e no caso Barcelona Traction (CIJ, p. 70, 1970), a simples prática dos Estados foi considerada para estabelecer critérios válidos.

A posição da Corte, no entanto, parece ser errática, pois em 1986, no caso relativo a atividades militares e paramilitares na e contra a Nicarágua, a CIJ novamente faz menção à necessidade da convicção de que existe uma norma que requer a conduta, ao mencionar o julgamento de 1969 (CIJ, p. 108-109, 1986).

Já para Proukaki (p. 203, 2010):

A CIJ definiu o elemento psicológico como a crença dos Estados de que uma certa prática é 'obrigatória pela existência de uma regra do direito a exigindo'. Dificuldades podem surgir com relação a provar a existência da opinio juris, ou seja, a crença de que certa atividade estatal esta de acordo com a lei. Por razões práticas, o requerimento da opinio juris foi expandido para incluir não só a crença de que certa conduta é requerida pelo direito, mas também, que ela está se tornando direito. $^{815}$ (tradução nossa)

\footnotetext{
${ }^{813} \mathrm{Next}$, so far as the qualitative factor, namely opiniojuris sive necessitates is concerned, it is ext remely difficult to get evidence of its existence in concrete cases. This factor, relating to internal motivation and being of a psychological nature, cannot be ascertained very easily, particularly when diverse legislative and executive organs of a government participate in an internal process of decision-making in respect of ratification or other State acts. There is no other way than to ascertain the existence of opinio juris from the fact of the external existence of a certain custom and its necessity felt in the international community, rather than to seek evidence as to the subjective motives for each example of State practice, which is something which is impossible of achievement.

${ }^{814}$ The possibility has thus been reserved of recognizing the rapid emerg ence of a new rule of customary law based on the recent practice of States.

${ }^{815}$ The ICJ has defined the psychological element as the belief of states that certain practice 'is obligatory by the existence of a rule of law requiring it'. Difficulties may arise in relation to proving the existence of opinio juris, that is, the belief that a certain state activity is in accordance with the law. For practical
} 
Independente do critério adotado, Tams, Dawidowicz e Proukaki entendem que a prática estatal foi acompanhada da opinio juris.

Para Proukaki (p. 203, 2010):

Esta última consideração lidou com um número de casos que, na opinião da autora, estabelecem que a questão das medidas de solidariedade não é um tema concebido recentemente na prática internacional e que tal prática e opinio juris apoiam a existência de uma regra consuetudinária que permite a implementação dos interesses coletivos e da comunidade por tais meios. ${ }^{816}$ (tradução nossa)

Ainda, segundo Tams (p. 250, 2005):

Também foi demonstrado que, tanto durante a primeira quanto na segunda leitura dos trabalhos da Comissão, a maioria dos governos expressou apoio à substância do artigo 54 (2000). [...] Finalmente, esta opinião é fortemente apoiada pela real conduta dos Estados em disputas específicas envolvendo violações sérias à obrigações erga omnes. Como foi demonstrado, Estados não diretamente lesados têm afirmado e exercido o direito a adotar contramedidas em uma variedade de instâncias. Contrário à opinião sustentada por comentadores, a prática não é nem exclusivamente ocidental, nem falta à requerida opinio juris, nem, de fato, é muito seletiva. À luz destas evidências, parece justificado concluir que o direito internacional atual reconhece um direito a todos os Estados, independente de dano individual, de adotar contramedidas em resposta a violações em larga escala ou sistemáticas, às obrigações erga omnes. ${ }^{817}$ (tradução nossa)

Também, para Dawidowicz (p. 417, 2006):

\footnotetext{
reasons, the opinio juris requirement has been expanded to include not only the belief that a certain conduct is required by law but, also, that it is becoming law.

816 This last consideration has dealt with a number of cases that, in the author's opinion, establish that the question of solidarity measures is not a newly conceived issue in the practice of international law and that such practice and opinio juris support the existence of a customary rule that permits enforcement of collective and community interests by such means.

${ }^{817}$ It has also been shown that, both during the first and the second reading of the Commission's work, a majority of governments expressed support for the substance of article 54 (2000). [...] Finally, this view is strongly supported by actual conduct of States in specific disputes involving serious breaches of obligations erga omnes. As has been shown, States not individually injured have asserted and exercised a right to take countermeasures in a variety of instances. Contrary to views held by commentators, practice is neither exclusively western, nor lacks the required opinio juris, nor indeed too selective. In the light of this evidence, it seems justified to conclude that present-day international law recognises a right of all States, irrespective of individual injury, to take countermeasures in response to large-scale or systematic breaches of obligations erga omnes.
} 
Este estudo demonstrou que a extensão e a amplitude geográfica da prática estatal de contramedidas de terceira parte no período moderno tem frequentemente sido subestimada pela CDI e Estados igualmente. Nós avaliamos 22 casos relevantes para o conceito de contramedidas de terceira parte. Em todos estes casos, com exceção do embargo comercial contra a Nicarágua, um grande número de Estados não individualmente lesados adotaram contramedidas de terceira parte em resposta a violações anteriores sérias das mais fundamentais obrigações internacionais, cometidas por outro Estado. Em ao menos sete outros casos (incluindo Nigéria e Belarus), embora não adotando realmente contramedidas de terceira parte um grande número de Estados não individualmente lesados reclamaram o direito de fazê-lo. Enquanto Estados desenvolvidos são responsáveis pela maioria desta extensiva prática em contramedidas de terceira parte, uma significante minoria foi adotada por Estados em desenvolvimento. Além disso, não há evidência para apoiar a alegação de que esta prática deve ser considerada predominantemente politicamente motivada. Existe, assim, forte apoio na prática internacional à posição de que Estados tem o direito de adotar contramedidas de terceira parte para a proteção dos interesses comunitários. [...]

O estudo acima, assim, apoia fortemente a conclusão de que contramedidas individuais de terceira parte são lícitas segundo o direito internacional geral. ${ }^{818}$ (tradução nossa)

A grande questão que se coloca, neste estudo, é se a opinio juris deve ser a convicção de que uma conduta é obrigatória segundo o direito internacional, ou se basta a convicção de que a conduta é lícita segundo este direito. Há uma grande diferença entre a obrigatoriedade de uma conduta e a sua legalidade. O primeiro caso implica em que a norma consuetudinária consagre sempre uma obrigação. O segundo caso implica que esta mesma norma também possa consagrar um direito.

A jurisprudência da CIJ, como acima destacado, não é unânime a respeito. Em alguns casos ela requer claramente a prática seja "considerada obrigatória pela existência de uma regra de direito a requerendo" (CIJ, p. 44, 1969), em outros, a prática

\footnotetext{
${ }^{818}$ This study has demonstrated that the extent and geographical spread of State practice on third-party countermeasure in the modern period has often been underestimated by the ILC and States alike. We have assessed 22 relevant cases relevant to the concept of third-party countermeasures. In all these cases, with the exception of the US trade embargo against Nicarágua, a very large number of States not individually injured have taken third-party countermeasures in response to previous serious breaches of the most fundamental international obligations committed by another State. In at least seven other cases (including Nigeria and Belarus), while not actually adopting third-party countermeasures, a very large number of States not individually injured have claimed a right to do so. While developed States account for most of this extensive practice on third-state countermeasures, a significant minority has been adopted by developing States. Moreover, there is no evidence to support the claim that this practice should be considered as pre-dominantly politically motivated. There is therefore strong support in the international practice for the view that States are entitled to take third-party countermeasure in order to protect commu nity interests. [...]

The above survey thus strongly supports the conclusion that individual third-party countermeasures are lawful under general international law.
} 
estatal seria suficiente (CIJ, p. 299, 1984), da onde se infere que basta que ela tenha sido considerada legal pelo Estado que atuou.

De fato, o artigo 38 do Estatuto da CIJ, acima citado, menciona apenas que a prática geral deve ser "aceita como direito".

Não há nenhuma referência à necessidade da conduta ser considerada obrigatória. Esta interpretação do artigo 38 conduziria a ideia de que o conteúdo das normas consuetudinárias deve ser sempre impositivo, determinando obrigações. Não seria possível a existência de normas consuetudinárias reconhecendo direitos, que seriam, assim, uma faculdade, e não uma obrigação.

A melhor interpretação, tanto por ser conforme a letra do artigo 38 do Estatuto da CIJ, como por ser mais coerente com o conteúdo real do direito consuetudinário é aquela que entende que basta a convicção de que a conduta é legal para que se considere formada a opinio juris. Assim, não há necessidade de que esta conduta seja considerada obrigatória pelo Estado, basta que este a considere lícita.

$\mathrm{Na}$ prática referente à adoção de contramedidas por Estados não diretamente lesados, como demonstrado pelos casos acima estudados, muitas vezes estas medidas são adotadas mediante pronunciamentos públicos, e mesmo são incorporadas em documentos e Resoluções de organizações internacionais ou de conferências de Estados. O caráter público destes pronunciamentos e documentos permite inferir que os Estados acreditavam na legalidade das medidas adotadas e no seu direito de adotá-las. Neste sentido escreve Tams, acima citado (p. 238, 2005), para quem na ausência de indicações em contrário, a conduta dos Estados deve ser considerada como acompanhada da convicção da sua legalidade.

Embora não haja nenhuma declaração expressa de que tais medidas sejam adotadas na forma de contramedidas, não há, na praxe do Direito Internacional, necessidade de caracterização jurídica de todos os atos dos Estados no momento em que estes são adotados. Também, na ausência de qualquer outra justificativa legal possível, os atos devem ser considerados como contramedidas. Assim, para Dawidowicz (p. 415, 2006): "na ausência de indicações de total ilegalidade ou de justificações legais alternativas, um determinado ato foi presumido lícito como contramedida de terceira parte." 819

\footnotetext{
${ }^{819}$ In the absence of indications of outright illegality or alternative legal justifications, a particular act has been presumed lawful as a third-party countermeasure.
} 
Portanto, a prática estatal de adoção de contramedidas por Estados não diretamente lesados deve ser considerada como acompanhada da devida opinio juris.

Fator que reforça a existência de uma opinio juris subjacente à prática estatal apresentada é o reconhecimento, no âmbito dos debates do $6^{\circ}$ Comitê da Assembleia Geral da ONU, pela ampla maioria dos Estados de um direito a adoção de contramedidas por Estados não diretamente lesados. A existência de uma minoria de Estados contrária a este direito não teria o condão de impedir a formação desta opinio juris. Como mencionado acima, a prática estatal deve ser geral, mas não precisa ser unânime. As manifestações contrárias dos Estados poderiam impedir que estes ficassem vinculados a uma norma consuetudinária, mas não impedir a sua formação. Deve-se destacar também que alguns Estados que manifestaram sua desaprovação a este direito já o utilizaram diversas vezes, de modo que diante de condutas contraditórias, nem mesmo a isenção em relação a uma norma consuetudinária poderia ser alegada ${ }^{820}$.

Assim, pode-se conclui que a prática estatal, ao contrário do alegado pela CDI (p. 137, 2001) não é nem limitada, nem embrionária, nem esparsa. É uma prática contínua, consistente e geral. Tendo em vista ser acompanhada da devida opinio juris, pode-se considerar que esta demonstra a existência de uma norma consuetudinária, reconhecendo o direito dos Estados não diretamente lesados de adotarem contramedidas no caso de violações devidas à comunidade internacional como um todo. Em outras palavras, a legalidade destas medidas seria reconhecida devido à existência de uma regra consuetudinária as permitindo.

A existência desta norma consuetudinária, portanto, autoriza a adoção de contramedidas por Estados não diretamente lesados diante de violações de direitos humanos, sempre que estas violações afetem obrigações voltadas à proteção de direitos humanos fundamentais.

\footnotetext{
${ }^{820}$ Dentre eles Brasil, Tanzânia e França, além do Reino Unido em relação a contramedidas no caso de obrigações devidas a comunidade internacional como um todo
} 


\section{CAPITULO III: A NECESSIDADE DAS CONTRAMEDIDAS ADOTADAS POR ESTADOS NÃO DIRETAMENTE LESADOS DIANTE DE VIOLAÇÃO ÀS NORMAS PROTETORAS DE DIREITOS HUMANOS}

Uma vez comprovada a legalidade da adoção de contramedidas por Estados não diretamente lesados, legalidade esta garantida pela existência de uma norma consuetudinária reconhecendo este direito, devemos demonstrar que estas contramedidas não somente são lícitas, mas são necessárias para a proteção efetiva dos direitos humanos no estado atual do Direito Internacional

3.1 O sistema da ONU de proteção dos direitos humanos

O sistema global de proteção dos direitos humanos se desenvolve, sobretudo, no âmbito da Organização das Nações Unidas.

Embora ele seja composto, também, por diversos tratados e pelos mecanismos por eles criados, são órgãos como o Conselho de Direitos Humanos e o Alto Comissariado para Direito Humanos, entre outros, que fornecem suporte e coordenam os trabalhos destes órgãos de monitoramento.

O sistema da ONU de proteção dos direitos humanos, assim, é formado pelos órgãos e agências desta organização internacional, além dos oito órgãos instituídos com base nos tratados de proteção aos direitos humanos.

\subsubsection{Principais órgãos encarregados da proteção dos direitos humanos}

A base jurídica do sistema de proteção de direitos humanos da ONU é o seu próprio tratado constitutivo, a Carta das Nações Unidas de 1948. No seu artigo $1^{\circ}$ este texto normativo estabelece como um dos propósitos das Nações Unidas:

Conseguir uma cooperação internacional para resolver os problemas internacionais de caráter econômico, social, cultural ou humanitário, e para promover e estimular o respeito aos direitos humanos e às liberdades fundamentais para todos, sem distinção de raça, sexo, língua ou religião. 
A proteção internacional dos direitos humanos no âmbito da Organização das Nações Unidas se dá de maneira difusa. Segundo Lewandowski (p. 109, 1984): “De um ponto de vista abrangente, todos os órgãos da ONU encontram-se, em termos práticos, comprometidos com a promoção e defesa dos direitos humanos, podendo oferecer, no exercício de suas atribuições regulares, importantes contribuições nesse campo."

Dos órgãos principais, a Assembleia Geral e o Conselho Econômico e Social (ECOSOC) realizam um importante trabalho na proteção dos direitos humanos.

Também o Conselho de Segurança cuida da proteção dos direitos humanos, embora de maneira incidental, tendo em vista que sua principal função é proteção da paz e segurança mundiais.

Atualmente, o ECOSOC vem sendo substituído pelo Conselho de Direitos Humanos, criado em 2006, num processo de reestruturação dos mecanismos de proteção dos direito humanos da ONU.

Este órgão passou a ser, então, o principal órgão da ONU voltado exclusivamente à proteção destes direitos.

Uma análise do sistema da ONU de proteção aos direitos humanos, não pode prescindir assim, do estudo deste novo órgão.

\subsubsection{O Conselho de Direito Humanos (CDH)}

O Conselho de Direitos Humanos foi criado pela Resolução A/RES/60/251 ${ }^{821}$ da Assembleia Geral da ONU, de 15 de março de 2006, para suceder a Comissão de Direitos Humanos, criada com base no artigo 68 da Carta das Nações Unidas ${ }^{822}$, pela Resolução 5 (I) do Conselho Econômico e Social (ECOSOC) em 1946.

O Conselho de Direitos Humanos sucede a Comissão de Direitos Humanos na tarefa de proteger os direitos do ser humano. Ele é baseado em Genebra e ao invés de ser órgão subsidiário do ECOSOC, como sua antecessora, passa a ser um órgão subsidiário da própria Assembleia Geral. ${ }^{823}$

\footnotetext{
${ }^{821}$ Resolution A/RES/60/251. Disponível em: http://www2.ohchr.org/english/bodies/hrcouncil/docs/A.RES.60.251_En.pdf . Acesso em 5 de jun. 2008. ${ }^{822}$ Artigo 68 - O Conselho Econômico e Social criará comissões para os assuntos econômicos e sociais e a proteção dos direitos humanos assim como outras comissões que forem necessárias para o desempenho de suas funções.

${ }^{823}$ (...) 1. Decides to establish the Human Rights Council, based in Geneva, in replacement of the Commission on Human Rights, as a subsidiary organ of the General Assembly; (Resolution
} 
Sobre a composição do Conselho a Resolução estabelece:

7. Decide também que o Conselho deve consistir de quarenta e sete Estados-Membros, os quais devem ser eleitos diretamente e individualmente por votação secreta pela maioria dos membros da Assembleia Geral, a composição dos membros deve ser baseada numa distribuição geográfica equitativa, e as cadeiras devem ser distribuídas como se segue entre os grupos regionais: Grupo dos Estados Africanos, treze; Grupo dos Estados Asiáticos, treze; Grupo dos Estados da Europa do Oriental, seis; Grupo da dos Estados da América Latina e Caribe, oito e Grupo da Europa Ocidental e outros Estados, sete; os membros do Conselho devem servir por um período de três anos e não serão elegíveis para reeleição imediata após dois mandatos consecutivos. (tradução nossa) ${ }^{824}$

A nova composição reduz o número de Estados da antiga Comissão de 53 para 47 e aumenta a representação da Ásia (de 12 para 13) e da Europa Oriental (de 5 para 6) e diminui a da África (de 15 para 13), a da Europa Ocidental e outros países (de 10 para 7) e da América Latina e Caribe (de 11 para 8).

A Resolução também determina que:

6. Decide também que o Conselho deve assumir, revisar e, onde necessário, melhorar e racionalizar todos os mandatos, mecanismos, funções e responsabilidades da Comissão de Diretos Humanos de forma a manter o sistema de procedimentos especiais, consulta especializada e procedimento de reclamações; o Conselho deve completar esta revisão passado um ano da sua primeira sessão. (tradução nossa) $^{825}$

\footnotetext{
$\mathrm{A} / \mathrm{RES} / 60 / 251$. Disponível

em:

http://www2.ohchr.org/english/bodies/hrcouncil/docs/A.RES.60.251_En.pdf . Acesso em 5 de jun. 2008.)

${ }^{824}$ 7. Decides further that the Council shall consist of forty-seven Member States, which shall be elected directly and individually by secret ballot by the majority of the members of the General Assembly; the membership shall be based on equitable geographical distribution, and seats shall be distributed as follows among regional groups: Group of African States, thirteen; Group of Asian States, thirteen; Group of Eastern European States, six; Group of Latin American and Caribbean States, eight; and Group of Western European and other States, seven; the members of the Council shall serve for a period of three years and shall not be eligible for immediate re-election after two consecutive terms; (Resolution A/RES/60/251. Disponível

em:

http://www2.ohchr.org/english/bodies/hrcouncil/docs/A.RES.60.251_En.pdf . Acesso em 5 de jun. 2008.) ${ }^{825}$ 6. Decides also that the Council shall assume, review and, where necessary, improve and rationalize all mandates, mechanisms, functions and responsibilities of the Commission on Human Rights in order to maintain a system of special procedures, expert advice and a complaint procedure; the Council shall complete this review within one year after the holding of its first session; (Resolution A/RES/60/251. Disponível em: http://www2.ohchr.org/english/bodies/hrcouncil/docs/A.RES.60.251_En.pdf . Acesso em 5 de jun. 2008.)
} 
Assim, o Conselho de Direitos Humanos não só sucede a Comissão, mas também assume seus mecanismos de proteção aos direitos humanos, devendo, entretanto, fazer uma revisão dos mesmos para melhorá-los e racionalizá-los no prazo de um ano.

A Resolução da Assembleia Geral ainda estabelece as diretrizes que devem reger a atuação do Conselho (parágrafo, 12):

12. Decide também que os métodos de trabalho do Conselho devem ser transparentes, justos e imparciais e devem possibilitar o diálogo genuíno, ser orientado para a busca de resultados, permitir para o acompanhamento subsequente discussões das recomendações e sua implementação e também permitir uma interação substantiva com os procedimentos especiais e mecanismos. (tradução nossa) ${ }^{826}$

Procura-se, assim, dar uma resposta às críticas feitas, em especial ao procedimento relativo ao exame de violações cometidos por Estados específicos, a respeito da imparcialidade política das decisões sobre as investigações.

O Conselho de Direitos Humanos, seguindo as determinações da Assembleia Geral da ONU, adotou a Resolução 5.1, contendo o chamado "institution building package", ou pacote de construção institucional. Esta Resolução estabelece, assim, as normas de funcionamento e procedimento do Conselho de Direitos Humanos, e faz uma revisão dos mecanismos desenvolvidos no âmbito da Comissão de Direitos Humanos, sua sucessora.

Para uma melhor análise desta revisão, é necessário primeiro um breve apanhado sobre o desenvolvimento destes mecanismos, também conhecidos como mecanismos extra-convencionais, ou procedimentos especiais.

3.1.1.1.1 Desenvolvimento dos procedimentos especiais no âmbito da Comissão de Direitos Humanos

Tendo funcionado de 1946 até 2006, é impossível falar do desenvolvimento dos mecanismos de proteção aos direitos humanos no âmbito da ONU sem mencionar um pouco da história da Comissão de Direitos Humanos.

\footnotetext{
${ }^{826}$ 12. Decides also that the methods of work of the Council shall be transparent, fair and impartial and shall enable genuine dialogue, be resultsoriented, allow for subsequent follow-up discussions to recommendations and their implementation and also allow for substantive interaction with special procedures and mechanisms;
} 
"De caráter governamental e subordinada ao ECOSOC, a CDH teve, originalmente, dezoito Estados-membros. A composição foi aumentada em 1961 para 21; em 1966, para 43; em 1990, para 53.” (ALVES, p. 73, 1994)

Esses membros eram eleitos para mandatos de 3 anos, e que eram distribuídos de forma a assegurar uma representação geográfica equilibrada das diferentes regiões do planeta. Os representantes eram 15 da África, 12 da Ásia, 11 do grupo de Estados latino-americanos e caribenhos, 10 do grupo da Europa Ocidental e outros (em que se incluem os EUA, o Canadá, a Austrália e a Nova Zelândia) e 5 da Europa Central e Oriental.

Segundo Alves (p. 6, 1994) a evolução dos trabalhos da CDH pode ser dividida em 3 fases:

a de redação de normas gerais, de 1947 a 1954; a de 'promoção' dos valores (através de seminários, cursos, publicações etc.), de 1955 a 1966; a de iniciativas para a proteção dos direitos, a partir de 1967. As duas primeiras correspondem ao extenso período 'abstencionista'; a terceira, que prossegue no presente, constitui, em contraposição aos vinte primeiros anos, o período 'intervencionista'.

Sobre o primeiro período este mesmo autor esclarece (p.7, 1994): “O período 'abstencionista' foi extremamente útil e prolífico no estabelecimento de normas, consubstanciadas em declarações, convenções e pactos." Dentre estes se destacam os dois Pactos Internacionais, um sobre Direitos Civis e Políticos e outro sobre os Direitos Econômicos, Sociais e Culturais que juntamente com a Declaração Universal dos Direitos do Homem constituem a "Carta Internacional dos Direitos Humanos", espinha dorsal da proteção internacional dos direitos humanos no âmbito global.

Estes dois Pactos possuíam originalmente, um mecanismo de implementação diferente para cada um. O Pacto sobre Direitos Civis e Políticos institui no seu artigo $28^{827}$ um Comitê de Direitos Humanos, que não se confunde com o Comitê de Direitos Humanos da ONU, encarregado de receber os relatórios e reclamações dos Estados signatários, além de receber as petições de particulares sujeitos a jurisdição dos Estados signatários do Protocolo Facultativo anexo a este Pacto. (LEWANDOWSKI, p. 92-93, 1984)

\footnotetext{
827 Artigo 28 - 1.Constituir-se-á um Comitê de Direitos Humanos (doravante denominado 'Comitê' no presente Pacto). O Comitê será composto de dezoito membros e desempenhará as funções descritas adiante
} 
Já o Pacto sobre Direitos Econômicos, Sociais e Culturais estabelece no artigo $16^{828}$ um sistema de relatórios a ser enviado pelos Estados ao ECOSOC, que podia remetê-los à Comissão de Direitos Humanos. (LEWANDOWSKI, p. 95, 1984)

Por outro lado, neste período a Comissão, respaldada pelo Conselho Econômico e Social (Resolução 75 (V) de 1947), entende que não teria competência para agir em relação às mais de 65 mil petições recebidas pela ONU só no período de 1947 a 1957 (BUERGENTHAL e KISS, p. 47, 1991).

A atuação da Comissão de Direitos Humanos sofre importante modificação em 1967, a partir da chamada de atenção do Comitê de Descolonização sobre as violações de direitos humanos ocorridas na África do Sul, à qual o Conselho Econômico e Social reagiu recomendando à Comissão de Direitos Humanos que considerasse urgentemente sobre o assunto. (ALVES, p.8, 1994)

Assim, segundo Alves (p. 8, 1994):

O período 'intervencionista' da CDH começa, pois, em 1967, por impulsão dos países do Terceiro Mundo de independência recente, mobilizados pela luta contra o apartheid e o colonialismo, será estendido, em 1969, ao caso dos territórios árabes ocupados por Israel, e romperá a auto-restrição da $\mathrm{CDH}$ a respeito de sua competência para atuar a propósito das comunicações recebidas sobre violações de direitos humanos em qualquer parte do mundo, com a adoção, pelo ECOSOC, das Resoluções 1235, de 1967, e 1503, de 1970.

Passa a Comissão, assim, a ter atribuição para examinar situações de violações de direitos humanos de modo a ter uma atuação mais incisiva na proteção destes direitos, razão pela qual se denomina este período de "Intervencionista".

Segundo Steiner e Alston (p. 611, 2000):

Em termos gerais existem atualmente três diferentes procedimentos usados pela Comissão para encaminhar as violações. Eles são: (1) consideração confidencial de uma situação sob o procedimento 1503; (2) debate público sob o procedimento 1235, que pode levar a designação de um Relator Especial da Comissão, um Representante Especial do Secretário-Geral, ou outro indivíduo ou grupo designado para investigar a situação; e (3) a designação de um relator ou Grupo de Trabalho temático para considerar violações em qualquer lugar

\footnotetext{
${ }^{828}$ Artigo 16 - 1.Os Estados Signatários do presente Pacto se comprometem a apresentar, de acordo com esta parte do Pacto, informes sobre as medidas que tenham adotado e sobre os progressos realizados a fim de garantir o respeito aos direitos reconhecidos no mesmo.

2.a) Todos os relatórios serão apresentados ao Secretário Geral das Nações Unidas, que enviará cópias ao Conselho Econômico e Social para que sejam examinadas conforme o disposto no presente Pacto.
} 
relacionadas a um tema específico (como a tortura, desaparecimentos, ou detenção arbitrária). (tradução nossa) ${ }^{829}$

\subsection{O Procedimento da Resolução 1235}

O procedimento da Resolução 1235, também chamado Controle Ostensivo de Situações (ALVES, p. 11, 1994) tem base jurídica nesta Resolução de 1967 do ECOSOC. A Resolução 1235 do Conselho Econômico e Social das Nações Unidas sobre "Questão da violação dos diretos humanos e liberdades fundamentais, incluindo políticas de discriminação racial e segregação e de apartheid em todos os países, com referência particular aos países e territórios coloniais e dependente" autoriza a Comissão de Direitos Humanos e a Subcomissão de Prevenção de Discriminação e de Proteção de Minorias "a examinar as informações atinentes a violações flagrantes de direitos humanos e liberdades fundamentais, como exemplificadas pela política de apartheid praticada na República da África do Sul (...)”. (parágrafo 2, apud, TRINDADE, p. 120, 1991)

Ela também: "Decide que a Comissão de Direitos Humanos poderá, (...) realizar um estudo completo das situações que revelem um padrão consistente de violações de direitos humanos, (...) e relatar, com recomendações a respeito, ao Conselho Econômico e Social” (parágrafo 3, apud, TRINDADE, p. 120, 1991)

Sobre esta Resolução, Ramos comenta (p. 152, 2002):

Nasce o chamado 'procedimento 1235 ', inicialmente limitado a praticantes do colonialismo e do apartheid. Neste procedimento cabe a Comissão de Direitos Humanos a decisão de estabelecer ou não um órgão especial de investigação da pretensa situação de violação sistemática dos direitos humanos.

Segundo Alves (p. 12, 1994):

\footnotetext{
${ }^{829}$ In broad terms there are now three different procedures used by the Commission to address violations. They are: (1) confidential consideration of a situation under the 1503 procedure; (2) public debate under the 1235 procedure, which may lead to the appointment of a Special Rappouteur of the Commission, a Special Representative of the Secretary-General, or some other designated individual or group to investigate a situation; and (3) the designation of a 'thematic' rapporteur or Working Group to consider violations anywhere relating to a specific theme (such as torture, disappearances, or arbitrary detention).
} 
$\mathrm{O}$ primeiro instrumento ostensivo criado pela $\mathrm{CDH}$, a partir da Resolução 1235 do ECOSOC, para examinar situação concreta de violações maciças e sistemáticas foi o Grupo Especial de Peritos sobre a Situação dos Direitos Humanos na África Austral. (...)

Em 1969, um segundo Grupo Especial de Peritos, integrado pelos mesmos componentes do primeiro foi estabelecido pela $\mathrm{CDH}$ para investigar alegações de violações por Israel da Convenção de Genebra de 1949 sobre o tratamento de civis em tempo de guerra nos territórios árabes ocupados.

O Grupo de Trabalho Especial sobre a Situação dos Direitos Humanos no Chile de 1975 é um marco na evolução dos mecanismos de proteção da CDH. Em primeiro lugar porque é o primeiro caso de investigação ostensiva de uma situação de violação grave e sistemática de direitos humanos ocorrido fora do âmbito do tema da colonização e do apartheid, que era inicialmente o mandato previsto na Resolução 1235. Em segundo, porque se passou a adotar, a partir da Resolução 33/176 de 1978 da Assembleia Geral a figura do Relator Especial, para acompanhar a evolução da situação no Chile. (nesse sentido RAMOS, p. 152-153, 2002, ALVES, p. 12-14, 1994)

Com base neste precedente a Comissão de Direitos Humanos passou a enviar Relatores Especiais, Representantes e Enviados Especiais para a realização de estudos sobre a situação dos direitos humanos em diversos Estados.

Essa prática, embora atualmente plenamente aceita, não escapa de algumas críticas. Segundo (ALVES, p. 16, 1994):

\begin{abstract}
A instituição dos Relatores Especiais para situações é mecanismo de controle polêmico. Por seu caráter inevitavelmente seletivo, que se presta à manipulação política, o mecanismo tem sua eficiência e validade muitas vezes questionadas tanto pelos Estados-alvos e seus aliados quanto por alguns ativistas autenticamente devotados à causa dos direitos humanos.
\end{abstract}

De toda forma o procedimento criado pela Resolução 1235 se desenvolveu. Segundo Steiner e Alston (p. 620, 2000):

Este procedimento [da Resolução 1235] agora opera para fornecer fundamento para dois tipos de atividades. A primeira, de acordo com o mandato, envolve a manutenção de um debate público anual durante a sessão anual da Comissão no qual governos e ONGs tem a oportunidade de identificar publicamente aquelas situações específicas em Estados que eles consideram merecer a atenção da Comissão. O segundo envolve o estudo e a investigação de situações particulares (ou casos individuais) através do uso de quaisquer técnicas que a Comissão considere adequadas. Essa atividade de investigação só é 
autorizada em relação a uma pequena proporção das situações identificadas durante o debate anual. (tradução nossa) ${ }^{830}$

Assim, o procedimento da Resolução 1235 do ECOSOC mudou radicalmente as atribuições da Comissão Direitos Humanos, ampliando-as de forma a abranger uma atuação mais incisiva deste órgão ante a violações de direitos humanos, dotando-a de capacidade investigativa. Se inicialmente surge voltado a questões de segregação racial e colonialismo, desenvolve-se posteriormente alargando seu escopo de forma que passa a ser um mecanismo de proteção de direitos humanos que abrange diversos temas e se preocupa não só com violações maciças de direitos humanos, mas também com a proteção de indivíduos específicos (nesse sentido RAMOS, p. 155, 2002)

As principais características deste procedimento eram a publicidade dos debates sobre a situação dos direitos humanos em diversos Estados e a ausência da necessidade de anuência por parte do Estado interessado para sua instauração, sendo irrelevante seu consentimento (RAMOS, p. 154, 2002).

Segundo Steiner e Alston eram diversos os possíveis resultados deste procedimento. Em suas palavras, a Comissão poderia (p. 621, 2000):

Decidir que o país interessado deveria receber 'serviços consultivos' evitando, assim, a condenação, mas deixando clara a sua preocupação; Adotar uma resolução pedindo que toda a informação disponível seja submetida a ela com o objetivo de considerar o assunto em uma sessão posterior;

Pedir ao governo para responder às alegações em detalhe e em escrito antes da próxima sessão;

Adotar uma resolução criticando o governo (para cada propósito, linguagem, variando de diplomática à altamente crítica pode ser usada) e requerendo que o governo tome medidas específicas;

Indicar um Relator Especial ou outro indivíduo ou grupo para examinar a situação e submeter um relatório à Comissão com base numa visita (se possível) ao país;

Pedir ao Secretário-Geral que indique um Representante Especial para realizar a mesma função; ou

Pedir ao Conselho de Segurança para se dedicar ao assunto, visando considerar a adoção de sanções ou outra medida punitiva. ${ }^{831}$

\footnotetext{
${ }^{830}$ That procedure now operates to provide the foundation for two types of activity. The first, in ccordance with the mandate, involves the holding of an annual public debate during the Commission's annual session in which governments and NGOs are given an opportunity to identify publicly those country-specific situations that they consider to merit the Commission's attention. The second involves studying and investigating particular situations (or individual cases) through the use of whatever techniques the Commission deems appropriated. Such investigative activity is only authorized in relation to a small proportion of the situations identified during the annual debate.

831 Decide that the country concerned should be provided with 'advisory services', thus avoiding condemnation but making clear its concern;
} 
Dos resultados possíveis, os mais graves seriam a adoção de uma Resolução pela Comissão, criticando o Governo e a submissão do assunto ao Conselho de Segurança. Cabe ressaltar, porém, que as Resoluções da Comissão, assim, como as do atual Conselho de Direito Humanos, não têm natureza vinculante, sendo apenas recomendações.

\subsection{O Procedimento da Resolução 1503}

O procedimento da Resolução 1503, também chamado de Controle Confidencial de Situações tinha como fundamento jurídico a Resolução 1503 de 1970 do ECOSOC intitulada "Procedimento para lidar com comunicações relativas a violações de direitos humanos e liberdades fundamentais".

Considerada inovadora por criar o "direito individual de petição às Nações Unidas" (ALVES, p.10, 1994) não é de se estranhar que tenha sido aprovada numa votação difícil.

A Resolução no seu parágrafo 1 autoriza va a Subcomissão de Prevenção de Discriminação e de Proteção de Minorias a nomear um grupo de trabalho com não mais que 5 membros para se reunir uma vez ao ano para considerar todas as comunicações recebidas pelo Secretário-Geral, com vistas a trazer a atenção aquelas comunicações "que pareçam revelar um padrão consistente de violações flagrantes e seguramente comprovadas de direitos humanos e liberdades fundamentais nos termos de referência da Subcomissão." 832

\footnotetext{
Adopt a resolution calling for all available information to be submitted to it with a view to considering the matter at a latter session;

Call upon the government to respond to the allegations in detail and in writing before its next session; Adopt a resolution criticizing the government (for which purpose, language ranging from diplomatic to the highly critical might be used) and calling upon the government to take specific measures;

Appoint a Special Rapporteur or other individual or group to examine the situation and submit a report to the Commission on the basis of a visit (if possible to the country;

Call upon the Secretary-General to appoint a Special Representative to perform a similar function; or

Call upon the Security Council to take up the issue, with a view to considering the adoption of sanctions or some other punitive measure.

${ }^{832}$ Authorizes the Sub-Commission on Prevention of Discrimination and Protection of Minorities to appoint a Working Group consisting of not more than five of its members, with due regard to geographical distribution, to meet once a year in private meetings for a period not exceeding ten days immediately before the sessions of the Sub-Commission to consider all communications, including replies of Governments thereon, received by the Secretary-General under Council resolution 728F
} 
Em seu parágrafo 5 também encarregava a Subcomissão de determinar "se encaminhará à Comissão de Direitos Humanos determinadas situações que pareçam revelar um padrão consistente de violações flagrantes e seguramente comprovadas de direitos humanos que requeiram a consideração da Comissão." ${ }^{, 833}$

A Comissão então deveria determinar sobre a situação, de acordo com o parágrafo 6 da Resolução: “(a) Se ela requer um estudo completo da Comissão e um relatório e recomendações a respeito ao Conselho, de acordo com o parágrafo 3 da Resolução 1235 (XLII) do Conselho." ${ }^{, 34}$; ou "(b) Se ela é passível de uma investigação por um comitê ad hoc, a ser nomeado pela Comissão, que só a efetuará com o consentimento expresso do Estado em questão [...]",835.

Assim a Resolução 1503 permitia que órgãos da ONU, a Subcomissão e a Comissão, atuassem com base em reclamações que poderiam advir de indivíduos ou de ONGs e atribuía à Comissão competência para decidir qual procedimento adotar. Se o previsto na Resolução 1235, ou o criado por esta mesma Resolução.

O procedimento da Resolução 1503 previa a possibilidade da criação de um comitê ad hoc com o consentimento do Estado para realizar a investigação. O processo do Comitê deveria ser confidencial, este deveria se empenhar em encontrar soluções amistosas e encaminhará um relatório à Comissão de Direitos Humanos com observações e sugestões.

Por fim a Resolução estabelecia:

8. Decide que todas as providências previstas na implementação da presente resolução pela Subcomissão de Prevenção de Discriminação e de Proteção de Minorias ou pela Comissão de Direitos Humanos deverão permanecer confidenciais até o momento em que a Comissão decida fazer recomendações ao Conselho Econômico e Social. ${ }^{836}$

\footnotetext{
(XXVIII) of 30 July 1959 with a view to bringing to the attention of the Sub-Commission those communications, together with replies of Governments, if any, which appear to reveal a consistent pattern of gross and reliably attested violations of human rights and fundamental freedoms within the terms of reference of the Sub-Commission; (ECOSOC, Resolution 1503, 1970, disponível em: ap.ohchr.org/documents/E/ECOSOC/resolutions/1970-1503.doc. Acesso em: 22 out 2010.

833 whether to refer to the Commission on Human Rights particular situations which appear to reveal a consistent pattern of gross and reliably attested violations of human rights requiring consideration by the Commission.

${ }^{834}$ (a) Whether it requires a thorough study by the Commission and a report and recommendations thereon to the Council in accordance with paragraph 3 of Council resolution 1235 (XLII);

${ }^{835}$ (b) Whether it may be a subject of an investigation by an ad hoc committee to be appointed by the Commission which shall be undertaken only with the express consent of the State concerned [...]

836 8. Decides that all actions envisaged in the implementation of the present resolution by the SubCommission on Prevention of Discrimination and Protection of Minorities or the Commission on Human
} 
Para Alves (p. 10, 1994): “A maior sanção prevista pela resolução 1503 consiste, pois, na publicidade."

Segundo Ramos (p. 156, 2002):

O objetivo desse procedimento é identificar as comunicações que indiquem a existência de um quadro persistente de violações manifestas de direitos humanos e liberdades fundamentais. A violação manifesta consiste em uma situação que afete um grande número de pessoas por um período dilatado de tempo.

A Subcomissão de Prevenção de Discriminação e de Proteção de Minorias, por sua vez definiu as regras a serem seguidas para a admissão das recomendações por meio da Resolução I (XXIV) de 1971. No seu artigo 1.b estabelecia (parágrafo 1.b, apud, TRINDADE, p. 128, 1991):

As comunicações serão admissíveis somente se, após consideração das mesmas, juntamente com as respostas, se existentes, dos Governos em questão, houver fundamentos razoáveis para crer que possam revelar um padrão consistente de violações flagrantes e seguramente comprovadas dos direitos humanos e liberdades fundamentais (...)

Para Trindade (p. 50, 1997):

O novo mecanismo [da Resolução 1503], voltado a situações prevalecentes (afetando grupos de indivíduos ou coletividades), além de independer da ratific ação dos Estados membros das Nações Unidas, cumpriu o papel histórico de acelerar a cristalização, a um tempo, da capacidade processual internacional dos indivíduos e da capacidade de agir dos órgãos de supervisão internacionais na era das Nações Unidas.

Apesar do entusiasmo inicial causado pela Resolução, e da sua importância histórica por regular a possibilidade de petição direta dos indivíduos e ONGs no âmbito dos mecanismos de proteção dos direitos humanos da $\mathrm{CDH}$, a verdade é que o Procedimento por ela criado possui 3 principais deficiências.

A primeira seria a morosidade do procedimento. Segundo Ramos (p. 157, 2002): "O procedimento 1503 é considerado lento, pois dura um ano para que se complete a análise de quatro órgãos da Comissão de Direitos Humanos.” A Comunicação era

Rights shall remain confidential until such a time as the Commission may decide to make recommendations to the Economic and Social Council; 
recebida pela Secretária, que encaminhava para o Estado requerido para instrução do processo e elaborava uma lista mensal que era enviada para o Grupo de Trabalho. O Grupo de Trabalho verificava a admissibilidade e a enviava para o plenário da Subcomissão. A Subcomissão envia va um relatório ao Grupo de Trabalho, que por sua vez envia va um informe final ao plenário da Comissão, que só então decidiria sobre a possibilidade de exercer bons ofícios, realizar um estudo sobre a matéria ou designar um Comitê especial de investigação. Nas palavras de Ramos (p. 158, 2002): "a Comissão de Direitos Humanos tem optado por suspender o exame da questão no procedimento confidencial para dar início ao estudo no procedimento público regido pela Resolução 1235."

Outra falha no procedimento 1503 é que tendo em vista que todos os atos, relatórios e decisões eram sigilosos até o final do procedimento, os responsáveis não tinham o peso da opinião pública para fiscalizar suas ações, sentindo somente a pressão do Estado, de forma que considerações e cautelas políticas poderiam ser levadas em consideração devido à falta de transparência desse procedimento.

Outro ponto a ser levantado também tem relação com a ausência de publicidade. Uma vez que não temia a exposição pública, o Estado podia cooperar muito pouco ou mesmo atrapalhar o procedimento, o que acabava por esvaziar este mecanismo. De acordo com Ramos (p. 158, 2002): “A publicidade é ainda arma na busca da responsabilidade internacional do Estado por violação de direitos humanos."

Assim, embora este procedimento tenha sido inovador em alguns aspectos, foi apenas mais um passo no caminho da plena efetivação dos direitos humanos na esfera internacional. Foi revisto pela Resolução 2000/3 de junho de 2000 e agora, com a criação do Conselho de Direitos Humanos ele esta sendo revisado novamente, como veremos mais adiante.

\subsection{O Procedimento de Proteção Temático}

Um outro procedimento de proteção dos direitos humanos desenvolvido no âmbito da Comissão de Direitos Humanos foi o chamado procedimento temático ou controle temático de proteção.

Segundo Ramos (p. 153, 2002): 
A quarta etapa [do desenvolvimento dos mecanismos de proteção aos direitos humanos da CDH] inicia-se em 1980, quando a Comissão de Direitos Humanos incorpora outra novidade no procedimento 1235, que foi a criação de órgãos especiais de investigação por temas especificos. De fato, em 1980, criou-se o Grupo de Trabalho sobre desaparições forçadas ou involuntárias e desde então, foram estabelecidos vários grupos temáticos.

Assim a base jurídica deste novo procedimento era a Resolução 1235, e também, por seu caráter universal e não seletivo, podem ser considerados elementos de desenvolvimento da cooperação determinada no Artigo 56 para a promoção universal do respeito e da observância dos direitos humanos, prevista no Artigo 55.c, ambos da Carta das Nações Unidas. (ALVES, p. 20, 1994)

O procedimento em linhas gerais se baseava na criação de Grupos de Trabalho ou designação de Relatores Especiais ou equivalentes, com mandato por tempo determinado ou indeterminado para o estudo de um tema específico de direitos humanos. Após a recepção de uma denúncia pelo Grupo ou Relator esta era comunicada aos governos para a instrução do processo. Tal procedimento obedecia aos princípios do contraditório, da ampla defesa e da confidencialidade até a divulgação do Relatório final. (RAMOS, p. 159-160, 2002)

O principal diferencial deste procedimento em termos de processo internacional era a possibilidade, dependendo do mandado concedido ao Grupo de Trabalho ou Relator Especial, das chamadas "medidas urgentes" que, segundo Ramos (p. 160, 2002), seriam verdadeiras medidas com caráter cautelar, visando a proteção de um direito humano ameaçado.

Conforme Alves (p. 19, 1994): "Vencidas as resistências iniciais a seu estabelecimento e funcionamento, os Relatores Especiais e Grupos de Trabalho temáticos constituem hoje instrumentos regulares do trabalho de proteção dos direitos humanos das Nações Unidas, (...)".

Este tem sido um dos principais instrumentos usados pelo atual Conselho de Direitos Humanos da ONU, como veremos a seguir. O fato de tratar da violação dos direitos humanos de forma geral, sem focar em um Estado específico, faz com que este mecanismo sofra menos as críticas relacionadas à manipulação política que o procedimento voltado a um único Estado sofre. 
3.1.1.1.2 A Revisão dos Procedimentos Especiais pelo Conselho de Direito Humanos

Visando cumprir a missão destinada pelo parágrafo 6 da Resolução A/RES/60/251, que o criou, o Conselho adota na Resolução $5 / 1^{837}$ o texto de seu Presidente "UN Human Rights Council: Institution Building".

Esse texto trata, inter alia, da revisão dos chamados "procedimentos especiais", nos quais se incluem tanto o procedimento de proteção temático, quanto o procedimento desenvolvido a partir da Resolução 1235, que examina a situação específica de um país. De fato, como esclarece o Projeto de Manual dos Procedimentos Especiais das Nações Unidas $^{838}$ :

1. O termo Procedimentos Especiais tem sido desenvolvido à luz da prática da Comissão de Direitos Humanos, do Conselho Econômico e Social (ECOSOC) e da Assembleia Geral, para descrever um diverso número de procedimentos estabelecidos para promover os direitos humanos em relação a temas ou assuntos específicos, ou para examinar a situação em países específicos. Enquanto os mandatos e métodos de trabalho de vários Procedimentos Especiais difere, existem muitas similaridades nos modos de trabalho. (tradução nossa $)^{839}$

A Resolução 5/1 do Conselho estabelece critérios precisos para a seleção e nomeação dos mandatários (mandate-holders) da ONU com base nesses procedimentos e para a renovação, racionalização e melhora destes mandatos.

O texto trata também da revisão do procedimento da Resolução 1503, ou o chamado Procedimento de Reclamações (Complaint Procedure). Foram criados dois grupos de trabalho (CDH, p. 11, 2007), o "Working Group on Communications" e o "Working Group on Situations".

O "Working Group on Communications" é composto por 5 membros, um de cada grupo regional, apontados pelo "Human Rights Council Advisory Committee", com mandato de 3 anos, renováveis uma vez. Este grupo é o responsável pela

\footnotetext{
${ }^{837}$ Disponível em: http://ap.ohchr.org/documents/E/HRC/resolutions/A HRC RES 5 1.doc. Acesso em 5 de jun. 2008.

${ }^{838}$ Disponível em: http://www2.ohchr.org/english/bodies/chr/special/docs/Manual English 23jan.doc. Acesso em 5 de jun. 2008.

${ }^{839}$ 1. The term Special Procedures has been developed in light of the practice of the Commis sion on Human Rights, the Economic and Social Council (ECOSOC) and the General Assembly to describe a diverse range of procedures established to promote human rights in relation to specific themes or issues, or to examine the situation in specific countries. While the specific mandates and methods of work of the various Special Procedures differ, there are a great many commonalities in the ways in which they work.
} 
admissibilidade das reclamações e seus méritos, transmitindo para o "Working Group on Situations" um arquivo com todas as reclamações admitidas assim como com recomendações a respeito destas.

O "Working Group on Situations" é composto por 5 membros indicados pelos grupos regionais dentre os representantes dos Estados-membros do Conselho. Seu mandato é de um ano renovável uma vez. Este grupo tem a função de apresentar um relatório, geralmente na forma de um projeto de resolução ou decisão, sobre um padrão consistente de maciças e seguramente comprováveis violações de direitos humanos e liberdades fundamentais, contendo recomendações ao Conselho sobre as ações a serem tomadas. Após isto, cabe ao Conselho tomar a decisão sobre que medidas adotar.

Em relação às críticas feitas ao Procedimento 1503, não há grandes modificações no novo procedimento. Apesar da instituição de um prazo para a resposta dos Estados, (3 meses após a requisição de informações, com possibilidade de extensão), o procedimento ainda parece ser demasiadamente lento. Também continua sendo confidencial, o que como já mencionado diminui a pressão da opinião pública e a transparência do procedimento. Ainda assim pode ser considerado um avanço, ao simplificar a tramitação.

A Resolução 5.1 também criou o Mecanismo de Revisão Periódica Universal (Universal Periodical Review Mechanism), considerado um dos maiores avanços realizado pelo Conselho de Direitos Humanos. Por este mecanismo, todos os Estados membros das Nações Unidas serão avaliados em relação à situação dos direitos humanos em seu território. No primeiro ciclo, que erá a duração de 4 anos, serão analisados, anualmente, 48 Estados durante três sessões do Grupo de Trabalho, cada qual com duas semanas de duração. ${ }^{840}$

Já em relação aos Procedimentos Especiais o Conselho tem trabalhado bastante no sentido de delimitar regras mais claras para a sua aplicação. Não só o Projeto de Manual dos Procedimentos Especiais das Nações Unidas foi elaborado, como também um Código de Conduta para os Mandatários dos Procedimentos Especiais do Conselho de Segurança entre outros regulamentos estão em fase de elaboração ou aperfeiçoamento.

\footnotetext{
${ }^{840} 14$. The periodicity of the review for the first cycle will be of four years. This will imply the consideration of 48 States per year during three sessions of the working group of two weeks each. (CDH, Resolution 5.1)
} 
3.1.1.1.3 A eficácia dos mecanismos e procedimentos do Conselho de Direitos Humanos

A Comissão de Direitos Humanos e o atual Conselho de Direitos Humanos desenvolveram, ao longo dos seus trabalhos, diversos mecanismos de monitoramento, investigação e mesmo determinação da ocorrência de violações de direito humanos. Pela estrutura criada, todos os Estados membros da ONU são monitorados em relação à situação dos direitos humanos em seus territórios, diversos temas são estudados e monitorados em escala global e alguns Estados sofrem uma avaliação mais específica de sua conduta.

A grande questão que se coloca diante toda esta estrutura é que o Conselho de Direitos Humanos não tem mandato para adotar Resoluções vinculantes, ou seja, obrigatórias para os Estados membros ${ }^{841}$. Embora ele funcione como um grande foro de discussão e tenha a capacidade de exercer uma grande pressão política sobre os Estados, na prática, ele não tem o poder de implementar suas recomendações, de forma que qualquer Estado pode ignorá-las sem que nenhuma consequência jurídica advenha deste fato.

O Conselho de Direito Humanos pode chamar a atenção da Assembleia Geral da ONU sobre determinado assunto, mas esta, como veremos adiante, também não têm competência para editar Resoluções vinculantes sobre a matéria, tendo que recorrer ao Conselho de Segurança, para que este analise a propriedade da adoção de medidas coercitivas.

A incapacidade de adotar decisões vinculantes, também se reflete em seus mecanismos e procedimentos especiais. Por exemplo, a doutrina destaca a capacidade do Relator Especial sobre Execuções Sumárias de adotar medidas urgentes que teriam, mesmo, um caráter cautelar. Destaca-se também a atuação do Grupo de Trabalho sobre Detenção Arbitrária, que poderia adotar medidas consideradas como um "habeas corpus internacional" (RAMOS, p. 160-161, 2002).

Entretanto, de fato, tais medidas nada mais são do que apelos e requerimentos feitos aos Governos para que modifiquem sua conduta.

A Resolução 8/6 do Conselho de Direito Humanos determina que o Relator Especial sobre Execuções Sumárias deve: "Responder efetivamente à informação que chega a ele, em particular quando uma execução extrajudicial, sumária ou arbitrária é

\footnotetext{
${ }^{841}$ Resolução A/RES/60/251, parágrafo 5.i.
} 
iminente ou quando esta execução já ocorreu;". Para tanto, ele pode enviar ao governo apelos urgentes (urgent appeals), requerendo medidas para prevenção ou investigação e punição dos fatos. ${ }^{842}$

Também cabe ao Grupo de Trabalho sobre Detenção Arbitrária segundo o parágrafo 1.c da Resolução 6/4 do CDH: “Agir sobre a informação submetida à sua atenção relacionada a casos alegados de detenção arbitrária através do envio de apelos urgentes e comunicações aos governos interessados para esclarecer e para chamar sua atenção para estes casos" $" 843$

Estes mandatários, assim, podem apenas fazer requerimentos aos Estados, que podem atendê-los ou não. No caso de não atendimento, cabe somente ao mandatário levar ao conhecimento do Conselho de Direitos Humanos esta conduta. O Conselho de Direitos Humanos pode, então, adotar uma Resolução não vinculante sobre a questão, ou recorrer à Assembleia Geral, que por seu turno pode recorrer ao Conselho de Segurança para a adoção de medidas coercitivas.

Outra consequência do caráter não obrigatório das Resoluções do Conselho é que um Estado pode se recusar a cooperar com os mecanismos e procedimentos estabelecidos por este. Os Relatores Especiais devem receber um convite para que possam ingressar nos Estados que serão avaliados. No caso do Estado recusar o convite, o estudo da situação pelo Relator Especial deve ser realizado sem uma visita de campo.

Para Lloret (p. 51, 1998):

A eficácia do sistema se centra principalmente na publicidade do próprio procedimento de controle. Publicidade que pode ser seguida de pressões que de forma individual - outros Estados - ou coletiva organizações internacionais - levem a cabo os sujeitos do ordenamento jurídico internacional para que o Estado afetado se acomode a normativa internacional sobre direitos humanos. ${ }^{844}$

\footnotetext{
${ }^{842}$ To respond effectively to information which comes before him or her, in particular when an extrajudicial, summary or arbitrary execution is imminent or threatened or when such an execution has occurred;

843 (c) To act on information submitted to its attention regarding alleged cases of arbitrary detention by sending urgent appeals and communications to concerned Governments to clarify and to bring to their attention these cases;

${ }^{844}$ La eficacia del sistema se centra principalmente en la publicidad del propio procedimiento de control. Publicidad que puede ir seguida de presiones que de forma individual -otros Estados - o colectiva organizaciones internacionales - lleven a cabo los sujetos del ordenamiento internacional para que el Estado afectado se acomode a la normativa internacional sobre derechos humanos.
} 
Ainda, apesar da reforma dos procedimentos realizada pelo Conselho de Segurança, a burocracia institucional ainda faz com que a resposta às violações aos direitos humanos seja relativamente lenta na maioria dos casos.

Assim, embora a atuação do Conselho de Direito Humanos seja eficaz na consolidação dos direitos humanos e no monitoramento, investigação e determinação da existência de violações aos direitos humanos, a proteção efetiva dos direitos humanos por este órgão em casos em que um Estado se recusa a cooperar ou de graves crises humanitárias, encontra grandes barreiras institucionais.

\subsubsection{Os mecanismos convencionais de proteção aos direitos humanos}

Como já mencionado, a internacionalização dos direitos humanos, desenvolvida a partir do fim da Segunda Guerra Mundial, resultou na celebração de diversos tratados internacionais para a proteção dos direitos humanos. Destes, nove são considerados os principais tratados de proteção aos direitos humanos no sistema ONU. São eles o Pacto internacional sobre direitos civis e políticos (ICCPR); o Pacto internacional sobre direitos econômicos, sociais e culturais (ICESCR); a Convenção para a eliminação de todas as formas de discriminação racial (ICERD); a Convenção contra a tortura e outros tratamentos ou penas cruéis, desumanos ou degradantes (CAT); a Convenção sobre a eliminação de todas as formas de discriminação contra as mulheres (CEDAW); a Convenção sobre os direitos da criança (CRC); a Convenção para a proteção dos direitos de todos os trabalhadores migrantes e suas famílias (ICRMW); a Convenção para a proteção de todas as pessoas dos desaparecimentos forçados (CPED); e a Convenção sobre o direito das pessoas portadoras de deficiência (CRPD).

Destes, a Convenção para a proteção de pessoas do desaparecimento forçado ainda não entrou em vigor.

Todos estes tratados estabelecem, em seus textos, a criação de um órgão técnico, encarregado do monitoramento do cumprimento das obrigações decorrentes do tratado.

Atualmente existem oito órgãos convencionais em funcionamento ${ }^{845}$. São eles o Comitê de direitos humanos; o Comitê sobre direitos econômicos, sociais e culturais; o Comitê sobre a eliminação de discriminação racial; o Comitê sobre a eliminação de discriminação contra a mulher; o Comitê contra a tortura; o Comitê sobre os direitos das

\footnotetext{
${ }^{845} \mathrm{O}$ Comitê sobre desaparecimento forçado ainda não entrou em funcionamento.
} 
crianças; o Comitê sobre trabalhadores migrantes; e o Comitê sobre os direitos das pessoas com deficiência. Há também um subcomitê sobre a prevenção de tortura. ${ }^{846}$

A principal função destes órgãos convencionais, como mencionado, é monitorar o cumprimento das obrigações estabelecidas pelos tratados internacionais pelos Estados membros destes tratados. Segundo Lloret (p.47, 1998): “As técnicas utilizadas para levar a cabo esta atividade de controle são três: a obrigação de apresentar informes pelos Estados partes; as demandas interestatais, e - como maior novidade - as demandas ou denúncias individuais." ${ }^{\circ 47}$

A função de receber e analisar os relatórios enviados pelos Estados sobre a situação dos direitos protegidos pelo tratado internacional em seu território é a mais usual, sendo comum a todos os órgãos convencionais. Segundo Trindade (p.87, 1997):

O sistema de relatórios constitui um dos métodos de implementação internacional dos direitos humanos mais frequentemente utilizados. Abarca uma diversidade de relatórios, requeridos pelos tratados e instrumento de direitos humanos como procedimento para verificar o seu cumprimento.

Por este sistema de relatórios, os Estados parte de uma convenção internacional se comprometem a enviar relatórios periódicos, fornecendo dados da situação dos direitos humanos protegidos em seus território.

A crítica que se faz a este sistema, é que com o grande número de instrumentos internacionais criando órgãos de monitoramento (9 atualmente em funcionamento), os Estados, em especial os de menor desenvolvimento, encontram dificuldade para lidar com toda esta burocracia. Os diferentes critérios utilizados para a elaboração de cada relatório, a periodicidade variável e a falta de assistência técnica faz com que muitos Estados não consigam enviar os relatórios no prazo. Ciente destes problemas, em 2002 o Secretário-Geral da ONU propôs mudanças para melhorar o sistema. Segundo o seu Relatório (A/57/387, p. 11-12):

Duas medidas podem ajudar a aliviar os problemas do sistema atual. Primeiro, os comitês devem elaborar uma abordagem mais coordenada de suas atividades e padronizar os requerimentos dos relatórios. Segundo deve ser permitido a cada Estado elaborar um

\footnotetext{
${ }^{846}$ Dados disponíveis em: http://www.ohchr.org/EN/Pages/WelcomePage.aspx Acesso em: 22 nov. 2010.

${ }^{847}$ Las técnicas utilizadas para llevar a cabo esta actividad de control son principalmente tres: la obligación de presentar informes por los Estados partes: las demandas interestatales, y -como mayor novedad - las demandas o denuncias individuales.
} 
único relatório, sumarizando sua aderência a todo o conjunto de tratados internacionais de direitos humanos do qual ele é parte. ${ }^{848}$

Estas mudanças estão, atualmente, sendo incorporadas ao sistema ONU.

O segundo método de monitoramento dos órgãos convencionais é o recebimento e a investigação de demandas ou petições por parte dos Estados partes do tratado.

Segundo Ramos (p. 131, 2002):

Este procedimento torna possível a um Estado apresentar uma petição pugnando pela constatação de violação de direitos humanos protegidos em uma convenção internacional, baseado em dispositivo convencional, em geral, de adesão facultativa. A actio popularis, então, é aceita por essas Convenções internacionais.

Dos principais tratados de direitos humanos, atualmente quatro preveem em seus textos um procedimento para processar as petições recebidas pelos Estados parte do tratado. São eles a Convenção contra a tortura e outros tratamentos ou penas cruéis, desumanos ou degradantes (CAT, artigo 21); a Convenção sobre trabalhadores migrantes (ICRMW, artigo 74); a Convenção sobre a eliminação de todas as formas de discriminação racial (ICERD, artigos 11-13); e o Pacto Internacional sobre direitos civis e políticos (ICCPR, artigos 41-43).

Enquanto os dois primeiros preveem que cabe ao Comitê criado analisar as petições provenientes dos tratados, os dois últimos contêm um sistema mais elaborado, com a criação de uma Comissão de Conciliação ad hoc para solucionar a disputa (ICCPR artigo 42, ICERD artigo 12).

O terceiro método de monitoramento é o recebimento e investigação das petições apresentadas pelos indivíduos. Atualmente, cinco tratados preveem a possibilidade de seus órgãos de monitoramento receberem e agirem em relação à petições apresentadas diretamente por indivíduos. São eles o Pacto internacional sobre direitos civis e políticos (OP1-ICCPR); a Convenção sobre eliminação de todas as formas de discriminação racial (CERD, artigo 14); a Convenção contra a tortura e outros tratamentos ou penas cruéis, desumanos ou degradantes (CAT, artigo 22); a Convenção

\footnotetext{
${ }^{848}$ Two measures may help to alleviate the shortcomings of the current system. First, the committees should craft a more coordinated approach to their activities and standardize their varied reporting requirements. Second, each State should be allowed to produce a single report summarizing its adherence to the full range of international human rights treaties to which it is a party.
} 
sobre a eliminação de todas as formas de discriminação contra as mulheres (OPCEDAW); e a Convenção sobre o direito das pessoas com deficiência (OP-CRPD).

A Convenção sobre trabalhadores migrantes também contém disposições sobre do direito de petição dos indivíduos (ICRMW, artigo 77). Tais disposições se tornarão operativas assim que dez Estados parte fizerem a declaração prevista no artigo 77.

Ramos (p. 133, 2002) esclarece que o procedimento no caso de petições de indivíduos tem pontos em comum. Em suas palavras:

Em primeiro lugar, o Estado parte deve ter aceito expressamente a competência do Comitê respectivo em receber as petições de particulares. Em segundo lugar, o procedimento é confidencial e obrigatório, sendo ainda informado pelos princípios da ampla defesa e contraditório. Sobre a questão de mérito, o Comitê delibera e fixa a existência ou não de violação de direito protegido pela Convenção. Em caso positivo, deve ainda fixar as medidas de reparação que o Estado infrator deverá adotar.

Ainda, dois destes órgãos convencionais têm competência para agir de ofício investigando por sua própria iniciativa casos de violações graves ou sistemáticas aos direitos protegidos nos tratados que os criaram. São eles o Comitê contra a tortura (CAT, artigo 20) e o Comitê sobre a eliminação de discriminação contra a mulher (OPCEDAW, artigos 8 a 10).

Os comitês internacionais, criados para realizar o monitoramento do cumprimento das obrigações assumidas pelos Estados segundo os principais tratados internacionais de direitos humanos têm, assim, a competência para investigar e determinar a existência de violações a estes tratados e mesmo de determinar medidas a serem adotadas pelos Estados no caso destas violações. No entanto, existem debates a respeito da natureza das recomendações feitas por estes comitês. Segundo Ramos (p. 305, 2002) existem duas correntes sobre a força vinculante destas deliberações. Em suas palavras:

Com efeito, percebe-se a existência de duas correntes. De um lado, os defensores do caráter não-vinculante destas deliberações enfatizam a ausência de disposição expressa nos tratados internacionais. Apontam, também, o estágio atual do Direito Internacional dos Direitos Humanos, que exigiria a cooperação dos Estados para o cumprimento de suas normas. Essa cooperação seria mais facilmente obtida através da ausência de coerção e da prevalência do convencimento.

Ainda para este autor (p. 306, 2002): 
A segunda corrente, por seu turno, indica que a interpretação sistemática e finalística dos tratados de direitos humanos deve ser feita em prol do aumento da carga protetiva, já que os mesmos foram celebrados justamente para proteger o indivíduo e não para dar vantagens materiais aos Estados contratantes.

Independente da questão da obrigatoriedade das decisões, interessa mais a este trabalho a questão da sua efetividade.

No Relatório de Comitê de Direitos Humanos (A/52/40 [VOL.1], p. 94), este Comitê analisou os resultados dos trabalhos ocorridos entre 1979 e 1997 . Neste período, o Comitê determinou a existência de 199 casos de violações às disposições do tratado. Destes 199 casos, apenas $30 \%$ receberam uma resposta adequada por parte dos Estados. O Relatório do Comitê de 2009 revela números ainda piores. Dos casos analisados (mais de 385), somente cerca de 58 receberam uma resposta adequada dos Estados, totalizando aproximadamente $15 \%$ de respostas satisfatórias (A/64/40 [VOL.1], p. 125168).

Segundo Lloret (p. 49-50, 1998):

O cumprimento das decisões do Comitê se produz, no geral, em caso de violações de direitos humanos não contidos em um padrão único de tratamento e cometidas em países com estruturas de governo democráticas nos quais se garante o império do direito como por exemplo, Canadá, Itália, Noruega ou Dinamarca. Pelo contrário, em Estados não democráticos responsáveis por violações do direito à vida ou à integridade física, por norma se tem ignorado as decisões do Comitê; [...]. Esta problemática também afeta em todo seu alcance as medidas de caráter cautelar que o Comitê solicita em um bom número de ocasiões aos Estados que foram denunciados antes de adotar uma decisão, medidas não cumpridas frequentemente na prática. ${ }^{849}$

Assim, independente do debate a cerca da obrigatoriedade das decisões destes órgãos convencionais, a questão que se coloca, em relação à proteção dos direitos humanos, é a sua efetividade.

\footnotetext{
${ }^{849}$ El cumplimiento de las decisiones del Comité sí produce, por lo general, en el caso de violaciones de los derechos humanos no contenidos en el estándar único de trato y cometidas en países con estructuras de gobierno democráticas en los que se garantiza el imperio del derecho, como, por ejemplo, Canadá, Italia, Noruega o Dinamarca. Por el contrario, en Estados no democráticos responsables de violaciones del derecho a la vida o a la integridad física, por norma se ha hecho caso omiso a las decisiones del Comité; [...] Esta problemática también afecta en todo su alcance a las medidas de carácter cautelar que el Comité solicita en un buen número de ocasiones a los Estados que han sido denunciados antes de adoptar una decisión, medidas incumplidas frecuentemente en la práctica.
} 
Outros pontos devem ser destacados. Ramos escreve sobre o Comitê de Direito Humanos (p. 135, 2002):

Assim, procedimento sofre de desequilíbrio crônico em prol do Estado. De fato, o Estado possui tempo e diversas possibilidades de extinguir $\mathrm{o}$ feito sem julgamento de mérito. Além disso, o procedimento se prolonga por um prazo médio de quatro anos, o que significa o aumento da impunidade dos Estados.

Outra crítica, é que o sistema de petições individuais, por exemplo, só é obrigatório para os Estados que assinaram os protocolos, se submetendo voluntariamente. Ainda, como um tratado internacional, ele pode ser denunciado, ainda que a denúncia não deva gerar efeitos em relação aos casos que já estão sendo analisados.

Não há duvida, a exemplo do que ocorre com os mecanismos extra-convencionais acima descritos, que estes órgãos são eficazes no monitoramento, investigação e constatação de existência de violações de direitos humanos. Estes dois sistemas de proteção, entretanto, padecem do mesmo problema. Devido à ausência de capacidade de implementação das decisões que emanam, eles pouco podem fazer para que esta violação ocorra ou continue ocorrendo de fato, em especial em Estados que não tem compromisso com a democracia ou que não se importam com a pressão sofrida no plano internacional.

Embora a publicidade e a pressão política sejam armas eficazes para que os Estados com relações complexas na comunidade internacional, ou que respondam a uma opinião pública interna atuante, corrijam a sua conduta em relação a violações aos direitos humanos, elas são ineficazes em casos de Estados cujo governo que tem maior preocupação em consolidar seu poder interno do que estabelecer boas relações internacionais e em Estados passando por graves crises políticas e sociais.

Ainda a lentidão do procedimento faz com que este seja inadequado no caso de crises graves de direitos humanos, que exigem a tomada de medidas imediatas.

Assim, a eficácia destes mecanismos, convencionais e extra-convencionais é limitada.

\subsubsection{A Assembleia Geral da ONU (AG)}


A competência da Assembleia Geral da ONU para tratar da questão dos direitos humanos advém da própria Carta de São Francisco. Segundo o artigo 10 da Carta das Nações Unidas (ONU, 1945, p. 645, apud SALIBA):

A Assembleia Geral poderá discutir quaisquer questões ou assuntos que estiverem dentro das finalidades da presente Carta ou que se relacionarem com as atribuições e funções de qualquer dos órgãos nela previstos e, com exceção do estipulado no artigo 12, poderá fazer recomendações aos Membros das Nações Unidas ou ao Conselho de Segurança ou a estes e àqueles, conjuntamente, com referência a qualquer daquelas questões ou assuntos.

Também, o artigo 13 da Carta estabelece (ONU, 1945, p. 675, apud SALIBA):

1. A Assembleia Geral iniciará estudos e fará recomendação, destinados a: $[\ldots]$

b) promover cooperação internacional nos terrenos econômico, social, cultural, educacional e sanitário e favorecer o pleno gozo dos direitos humanos e das liberdades fundamentais, por parte de todos os povos, sem distinção de raça, sexo, língua ou religião.

Apesar da menção expressa da competência da AG para a promoção dos direitos humanos na Carta das Nações, a atuação deste órgão no monitoramento do respeito a estes direitos foi bastante limitada nos primeiros anos.

Nas palavras de Tomuschat (p. 115, 2003): "De fato, durante os primeiros anos após 1945 não havia espaço na agenda da Assembleia Geral para alegações de que um dado estado havia violado obrigações devidas por ele de respeitar e observar os direitos humanos. $" 850$

Este período foi marcado pela incerteza das consequências legais advindas do Artigo 1.3 da Carta das Nações. Argumentava-se que este dispositivo "estabelecia nada mais que uma obrigação de promoção para a própria organização, enquanto se abstinha de impor um verdadeiro compromisso legal para os Estados membros." ${ }^{, 851}$ (TOMUSCHAT, p. 115, 2003)

\footnotetext{
${ }^{850}$ Indeed, during the first years after 1945 there was no room on the agenda of the General Assembly for allegations that a given state has breached obligations incumbent upon it to res pect and observe human rights.

${ }^{851}$ established no more than a promotional obligation for the organization itself, while refraining from imposing a true legal commitment on Member States.
} 
De fato, segundo o Anuário das Nações Unidas de 1954 (ONU, UN YEARBOOK, p. 87, 1954) relata a posição de alguns Estados em relação à questão do tratamento dos indivíduos de origem indiana na África do Sul:

\begin{abstract}
Alguns representantes, incluindo aqueles da Austrália, Bélgica, França, Holanda, Nova Zelândia e Reino Unido, afirmaram que embora eles se opusessem fortemente contra qualquer política de discriminação racial, eles não eram capazes de tomar uma posição em relação a este tema. Eles tinham grandes dúvidas sobre a competência das Nações Unidas na matéria e não poderiam concordar que as negociações diretas, sugeridas no projeto de resolução, devessem ser tomadas dentro do quadro das Nações Unidas. ${ }^{852}$
\end{abstract}

Assim, em 1954, diversos Estados membros, mesmo sendo contrários a ação da África do Sul, relutavam em reconhecer a competência das Nações Unidas e da AG para atuar diante de violações de direitos humanos de um Estados em relação à sua própria população sob a alegação de que tal ação seria uma interferência nos assuntos domésticos de um Estado.

Apesar disto, a atuação da AG no monitoramento das violações de direitos humanos foi se desenvolvendo ao longo de seus trabalhos.

Para Rowe (p. 431, 1970):

Essencialmente o que aconteceu durante os anos anteriores a 1960 foi o desenvolvimento de um acordo quase unânime de que era legítimo para a Assembleia Geral considerar primeiro o tratamento das pessoas de origem indiana na África do Sul, e depois a situação racial em geral. Junto com isso desenvolveu-se um desejo geral de condenar a apartheid e apelar à África do Sul para mudar suas políticas para torná-las de acordo com a Carta da ONU e a Declaração Universal dos Direitos Humanos. Uma significante proporção dos membros da ONU não desejavam ir além disso. ${ }^{853}$

\footnotetext{
852 Some representatives, including those of Australia, Belgium, France, the Netherlands, New Zealand and the United Kingdom, stated that although they were strongly opposed to any policy of racial discrimination, they were unable to take a stand on this item. They had strong doubts concerning the competence of the United Nations in the matter and could not agree that the direct negotiations suggested in the draft resolution should be undertaken within the framework of the United Nations.

853 Essentially what happened during the years before 1960 was the development of nearly unanimous agreement that it was legitimate for the General Assembly to consider first the treatment of people of Indian origin in South Africa and later the racial situation there in general. Along with this developed a general willingness to condemn apartheid and to call upon South Africa to change her policies to bring them into accord with the UN Charter and the Universal Declaration of Human Rights. Beyond this, a significant proportion of UN members were unwilling to go.
} 
Outras questões de direitos humanos também foram discutidas no âmbito da AG, como a questão da recusa da URSS a deixar esposas russas casadas com estrangeiros saírem de seu território, ou a supressão das liberdades políticas no Leste Europeu. Porém, segundo Tomuschat (p. 116, 2003):

Essas primeiras medidas não eram generalizadas, entretanto, para formar um sistema coerente de acordo com o qual a Assembleia Geral e possivelmente a Comissão de Direitos Humanos pudessem intervir em todas as situações que parecesse revelar padrões de flagrantes violações dos direitos humanos. ${ }^{854}$

A posição da AG sobre a questão das violações aos direitos humanos começou a mudar nos anos 60, tanto devido à entrada de novos membros nas Nações Unidas, o que alterou a composição de votos na $\mathrm{AG}$, quanto devido à mudança de posição dos antigos membros (ROWE, p. 435, 1970). Ainda assim, segundo Tomuschat (p. 121, 2003) “antes de 1974 a Assembleia Geral focava sua atenção exclusivamente na África do Sul e Israel".

Este quadro mudou na final dos anos 70 e início dos anos 80 , devido às situações na Bolívia (A/RES/35/185), Guatemala (A/RES/37/184) e El Salvador (A/RES/37/185).

Atualmente, a atuação da Assembleia Geral diante de violações de direitos humanos é usual, não sendo mais questionada. Esta atuação, entretanto, embora seja um importante instrumento de pressão política, também é limitada pela arquitetura institucional das Nações Unidas. Isso ocorre porque mesmo as Resoluções da Assembleia Geral não tem caráter vinculante.

Já a CIJ na Opinião Consultiva sobre a Namíbia, em 1970, declarou que (p. 50, 1970) "a Assembleia Geral é principalmente investida de poderes de recomendação" 855 .

Neste sentido escrevem Steiner e Alston (p. 600, 2000): "Suas resoluções [da AG] não são por si, legalmente vinculantes, mas elas são um importante reflexo da vontade da comunidade internacional." ${ }^{\circ 56}$

Também para Arangio-Ruiz (ONU, p. 48, 1993): “a Assembleia não pode ir além de declarações não vinculantes da ilegalidade e atribuição e recomendações não vinculantes de reação aos Estados e ao Conselho de Segurança." 857 (tradução nossa)

\footnotetext{
${ }^{854}$ These first steps were not generalized, however, to form a coherent system according to which the General Assembly and possibly the HRCion would intervene in all situations which seemed to reveal patterns of gross violations of human rights.

855 the General Assembly is in principle vested with recommendatory powers

${ }^{856}$ Its resolutions are not per se legally binding but they are an important reflection of the will of the world community.
} 
Por isso para Tomuschat (p. 124, 2003):

Embora resoluções da Comissão de Direitos Humanos e da Assembleia Geral sejam ferramentas importantes de uma política mundial de proteção aos direitos humanos, elas certamente não são uma panaceia para curar todos os males concebíveis. Seu peso moral é considerável. $^{858}$

Tomuschat (p. 125, 2003) conclui:

Entretanto, mesmo se a desaprovação de certas práticas atinja os mais altos graus de intensidade, isso não leva a nenhum salto quântico que capacitaria a Assembleia Geral a se livrar das restrições às suas competências. Seu julgamento continua essencialmente político, tendo o caráter geral de uma recomendação. ${ }^{859}$

Assim, mesmo a Assembleia Geral da ONU, um dos principais órgãos desta organização internacional e o mais democrático, tendo em vista que dele participam todos os Estados membros em pé de igualdade, não tem competência para adotar decisões vinculantes diante de violações aos direitos humanos. Portanto, também o seu papel na proteção dos direitos humanos tem uma eficácia limitada.

Para que medidas obrigatórias sejam tomadas, a Assembleia Geral deve cha mar a atenção do Conselho de Segurança sobre determinado assunto. Entretanto, cabe discricionariamente ao Conselho de Segurança decidir se e como agir sobre a questão.

\subsubsection{O Conselho de Segurança da ONU}

O único órgão com competência para adotar decisões obrigatórias e mesmo medidas coercitivas no quadro das Nações Unidas é o Conselho de Segurança (ONU, artigo 25, 1945).

A função precípua deste órgão, entretanto, não é a proteção dos direitos humanos e sim a manutenção da paz e segurança mundiais (ONU, artigo 24, 1945). Por isso não é

\footnotetext{
${ }^{857}$ the Assembly cannot go beyond non-binding declarations of unlawfulness and attribution and nonbinding recommendations of reaction by States or by the Security Council.

${ }^{858}$ Although resolutions of the HRCion and the General Assembly are important tools of a world policy for the protection of human rights, they are certainly no panacea to cure any conceivable ills. Their moral weight is considerable.

${ }^{859}$ However, even if the disapproval of certain practices reaches its highest degree of intensity, this does not lead to any quantum leap that would empower the General Assembly to free itself from the constraints of its competences. Its judgment remains essentially a political one, having the legal character of a recommendation.
} 
de se estranhar a relutância deste órgão da ONU de lidar com questões relacionadas à proteção dos direitos humanos.

Segundo Bailey: "Infelizmente, por mais de quatro décadas o Conselho de Segurança fez o seu melhor para evitar lidar com assuntos de direitos humanos, e ainda não desenvolveu procedimentos consistentes para lidar com estas matérias." 860

Para este autor a posição do Conselho de Segurança em relação aos direitos humanos pode ser divida em duas fases. Na primeira, de 1946 e 1989, a atuação deste órgão foi cautelosa. Na segunda, a partir de 1989, ele começa a agir na área dos direitos humanos.

Tendo em vista que não há previsão expressa na Carta das Nações da competência do Conselho de Segurança para agir na proteção dos direitos humanos, esta proteção tem se dado com base na expansão do conceito de paz e segurança. Segundo Ramcharan (p. 18, 2002):

De fato, a Carta das Nações Unidas vê a paz e a segurança internacional sendo construídas nas fundações da justiça econômica e social, do respeito aos direitos humanos e as liberdades fundamentais, do respeito às regras do direito internacional da resolução pacífica de disputas e da segurança coletiva. Este é o conceito de paz e segurança sob o qual o Conselho de Segurança atua. ${ }^{861}$

Neste sentido o discurso feito pelo Presidente do Conselho de Segurança no encerramento da reunião de janeiro de 1992 deste órgão (ONU, S/23500):

Os membros do Conselho notam que as tarefas de manutenção de paz das Nações Unidas aumentaram e se ampliarem consideravelmente nos anos recentes. O monitoramento de eleições, a verificação dos direitos humanos e a repatriação de refugiados têm, na solução de conflitos regionais, a pedido ou com a anuência das partes interessadas, sido partes integrais dos esforços do Conselho de Segurança para manter a paz e segurança mundiais. ${ }^{862}$

\footnotetext{
${ }^{860}$ Unfortunately, for more than four decades, The Security Council did its best to avoid taking up human rights issues, and it has not yet developed consistent procedures for dealing with such matters.

${ }^{861}$ Indeed, the Charter of the United Nations sees international peace and security being built on the foundations of economic and social justice, respect for human rights and fundamental freedoms, respect for the rules of international law, the peaceful settlement of disputes and collective security. This is the peace and security concept over which the Security Council presides.

862 The members of the Council note that United Nations peace-keeping tasks have increased and broadened considerably in recent years. Election monitoring, human rights verification and the repatriation of refugees have in the settlement of some regional conflicts, at the request or with the agreement of the parties concerned, been integral parts of the Security council's effort to maintain international peace and security.
} 
Esta atuação, entretanto, não ocorre sem críticas. Para Ramos (p. 178, 2002):

Caso a segunda corrente doutrinária prevaleça [interpretação ampliativa do conceito de paz e egurança mundiais], então, nada pode impedir o Conselho de Segurança de considerar qualquer fato como ameaça à paz e à segurança mundial, transformando-se na Guarda Pretoriana contemporânea.

Além das críticas a respeito da competência do Conselho de Segurança para atuar nas questões de direitos humanos, existem críticas em relação à qualidade desta atuação.

Em 1999 o Secretário-Geral da ONU, com a aprovação do Conselho de Segurança instaurou uma investigação independente (Independent Inquiry) para verificar a atuação das Nações Unidas no caso do genocídio ocorrido em Ruanda, em 1994. O relatório desta investigação foi altamente crítico, tanto em relação à atuação das Nações Unidas como um todo, quanto em relação à atuação do Conselho de Segurança (ONU, S/1999/1257). Segundo este (S/1999/1257, p. 3):

A falha pelas Nações Unidas de prevenir e, subsequentemente, de parar o genocídio em Ruanda foi uma falha do sistema das Nações Unidas como um todo. A falha fundamental foi a falta de recursos e de comprometimento político devotado aos acontecimentos em Ruanda e à presença das Nações Unidas lá. Houve uma persistente falta de vontade política dos Estados membros em agir, ou de agir com a assertividade necessária. ${ }^{863}$

Ainda, segundo este Relatório (S/1999/1257, p. 37): 'O Conselho de Segurança tem a responsabilidade por sua falta de vontade política de fazer mais para parar a matança."

Também, de acordo com este documento (S/1999/1257, p. 38):

A demora em identificar os eventos em Ruanda como um genocídio foi uma falha do Conselho de Segurança. A relutância de alguns Estados de usar o termo genocídio foi motivada pela falta de vontade de atuar, o que é deplorável. Se for para existir uma ação efetiva internacional contra o genocídio, os Estados devem estar preparados para identificar

\footnotetext{
863 The failure by the United Nations to prevent, and subsequently, to stop the genocide in Rwanda was a failure by the United Nations system as a whole. The fundamental failure was the lack of resources and political commitment devoted to developments in Rwanda and to the United Nations presence there. There was a persistent lack of political will by Member States to act, or to act with enough ass ertiveness. ${ }^{864}$ The Security Council bears a responsibility for its lack of political will to do more to stop the killing.
} 
as situações como tal, e assumir a responsabilidade de agir que acompanha esta definição. ${ }^{865}$

Assim, para este Relatório, o sistema de proteção de direitos humanos da ONU falhou como um todo. Em especial, o Conselho de Segurança falhou em identificar os fatos como um genocídio e em tomar medidas para parar as mortes. Tal falha se deu, em grande parte, pela falta de vontade dos Estados membros do Conselho de Segurança de agir naquela situação.

As críticas feitas pelo Relatório expõem, de fato, os problemas que surgem ao encarregar o Conselho de Segurança de um papel relevante no sistema de proteção dos direitos humanos da ONU. Isso porque o Conselho não é um órgão democrático. Ele é formado por apenas quinze membros. Destes, cinco membros têm assento permanente, sendo eles: Estados Unidos, Rússia, China, França e Reino Unido (ONU, artigo 23, 1945). Este cinco membros permanentes ainda gozam do chamado direito a veto, pois as decisões de matérias consideradas relevantes só podem ser aprovadas pó nove votos, incluindo o voto afirmativo de todos os membros permanentes (ONU, artigo 27.3, 1945). Assim, os membros permanentes têm o poder de barrar qualquer decisão do Conselho que contrarie seus interesses, a não ser quando estiver em curso um procedimento pacífico de solução de disputas do qual eles são partes.

Para Arangio-Ruiz, Relator Especial sobre a Responsabilidade dos Estados (ONU, p. 50, 1993):

O Conselho de Segurança é um órgão político encarregado de uma função essencialmente política de manutenção da paz. Isto resulta em algumas consequências que podem ser sumarizadas como segue:

a) O Conselho opera numa base altamente discricionária. Ele não age nem necessariamente nem regularmente em todas as situações que poderiam aparentemente demandar o exercício de sua competência. Ele opera, pelo contrário, de maneira seletiva;

b) O Conselho não é obrigado a usar um critério uniforme nas situações que podem parecer bem similares. Consequentemente, crimes do mesmo tipo e gravidade podem ser considerados de forma diferente ou mesmo não considerados;

c) A própria natureza das determinações do Conselho parecem excluir qualquer dever da sua parte de substanciar suas decisões, ações ou inações. $\mathrm{O}$ caráter discricionário e possivelmente arbitrário das suas escolhas é, assim, agravado pelo fato de que a falta de justificação

\footnotetext{
${ }^{865}$ The delay in identifying the events in Rwanda as a genocide was a failure by the Security Council. The reluctance by some States to use the term genocide was motivated by a lack of will to act, which is deplorable. /if there is ever to be effective international action against genocide, States must be prepared to identify situations as such, and to assume the responsibility to act that accompanies that definition.
} 
impede a presente ou futura verificação de legitimidade das suas escolhas. ${ }^{866}$

Nesse sentido também escreve Lloret (p. 392-393, 1998):

[...] a prática desenvolvida pelo Conselho de Segurança nos últimos anos é esporádica, seletiva e imperfeita. É esporádica porque se ocupa somente de algumas situações de violações graves de direitos humanos e em especial nas que se vulnera a normativa sobre o direito internacional humanitário. É seletiva porque depende da vontade política dos Estados membros que compõem o Conselho de Segurança, sem que se apreciem a aplicação de critérios uniformes a situações aparentemente similares. E é imperfeita porque a proteção dos direitos humanos não é uma das prioridades do Conselho de Segurança, inclusive depois do fim da guerra fria; por isto, este órgão se mostra muito mais preocupado com a manutenção da paz e segurança internacionais e, por regra geral, somente aborda a problemática dos direitos humanos no contexto das violações do direito humanitário cometidas no marco de um conflito armado quer seja interno ou internacional. ${ }^{867}$

Realmente, a estrutura institucional do Conselho de Segurança resultou na sua paralisação em diversos casos. O seu caráter político resulta não só na discricionariedade de suas decisões, mas na verdadeira arbitrariedade, principalmente quando estão envolvidos os interesses dos cinco membros permanentes.

Embora seja o único órgão competente para fazer efetiva a proteção dos direitos humanos, a ausência de uma vocação exclusiva para lidar com a matéria faz com que fatores estranhos ao Direito Internacional dos Direitos Humanos informem as decisões

\footnotetext{
${ }^{866}$ The Security Council is a political body entrusted with the essentially political function of maintaining peace. This entails a number of consequences which may be summarized as follows:

(a) The Council operates on a highly discretionary basis. It acts neither necessarily nor regularly in all situations that would seemingly call for the exercise of its competence. It operates on the contrary in a selective manner;

(b) The Council is not bound to use uniform criteria in situations which may seem to be quite similar. Consequently, crimes of the same kind and gravity may be dealt with differently or not at all;

(c) The very nature of the Council's determinations seems to exclude any duty on its part to substantiate its decisions, its action or its inaction. The discretionary and possibly arbitrary character of its choices is thus aggravated by the fact that the lack of substantiation precludes present or future verification of the legitimacy of its choices.

${ }^{867}$ La práctica desarrollada por el C. de S. en los últimos años es esporádica, selectiva e imperfecta. Es esporádica, porque se ocupa solamente de algunas situaciones de violaciones graves de los derechos humanos y en especial en las que se vulnera la normativa sobre derecho internacional humanitario. Es selectiva, porque depende de la voluntad política de los Estados miembros que componen el C. de S., sin que se aprecie la aplicación de criterios uniformes a situaciones aparentemente similares. Y es imperfecta, porque la protección de los derechos humanos no es una de las prioridades del C. de S., ni mucho menos, incluso después del fin de la guerra fría; por ello, este órgano se muestra mucho más preocupado por el mantenimiento de la paz y seguridad internacionales, y por regla general solamente aborda la problemática de los derechos humanos en el contexto de violaciones del derecho humanitario cometidas en el marco de un conflicto armado ya sea interno o internacional.
} 
do Conselho de Segurança, impedindo-o de tomar as medidas adequadas para este proteção

Ainda para Lloret (p. 393, 1998):

Não obstante as críticas ao funcionamento do Conselho de Segurança em relação à seletividade que possui este órgão, esta assunção de competências por parte do principal órgão institucional de aplicação de sanções que existe no ordenamento internacional merece uma valoração positiva já que, por regra geral, este protagonismo do Conselho de Segurança é preferível às atuações absolutamente unilaterais das grandes potências. ${ }^{868}$

De fato, o que se pretende mostrar com este estudo do mecanismo de proteção dos direitos humanos no âmbito das Nações Unidas não é que as medidas unilaterais dos Estados sejam preferíveis que as medidas coletivas adotadas por esta organização internacional.

Pelo contrário, as medidas de proteção aos direitos humanos adotadas pelo sistema de proteção de direitos humanos da ONU gozam de muito mais legitimidade do que qualquer medida unilateral jamais poderia ter. Os mecanismos convencionais e extra-convencionais da ONU tem um papel imprescindível no monitoramento, investigação e constatação das violações de direitos humanos.

Entretanto, diante da eficácia limitada destes mecanismos de pressão política e da discricionariedade do Conselho de Segurança, as medidas unilaterais podem complementar ou substituir a atuação dos órgãos internacionais, garantindo que violações graves aos direitos humanos resultem em consequências reais para os Estados violadores.

Como destacam Nquyên e Dinh (p. 900, 1999) as contramedidas unilaterais muitas vezes são tomadas após resoluções do Conselho de Segurança ou da Assembleia Geral, atuando de forma complementar ao sistema onusiano quando este já reconheceu a ocorrência da violação.

Elas também foram tomadas antes destas Resoluções ou da determinação da ocorrência de uma violação por parte dos órgãos de monitoramento, uma vez que os

\footnotetext{
${ }^{868}$ No obstante las críticas al funcionamiento del C. de S. en atención a la 'selectividad' de la que hace gala este órgano, esta asunción de competencias por parte del principal órgano institucional de aplicación de sanciones que existe en el ordenamiento internacional, merece una valoración positiva, ya que, por regla general, este protagonismo del C. de S. es preferible a las actuaciones absolutamente unilaterales de las grandes potencias.
} 
procedimentos estabelecidos podem ser lentos e a situação fática pode exigir ação imediata.

Em outras palavras, as contramedidas adotadas por Estados não diretamente lesados, obviamente, não devem tomar o lugar das medidas coletivas. Na verdade, seria desejável a criação de um sistema global de proteção dos direitos humanos ágil e dotado de capacidade para implementar as suas próprias decisões. No entanto, pela própria arquitetura institucional das Nações Unidas e dada a relutância dos Estados em reconhecer limitações ainda maiores à sua soberania, a possibilidade de criação de tal sistema a curto e médio prazo é bastante remota.

Assim, resta consolidar, neste sistema imperfeito, as regras que podem propiciar um mínimo de eficácia real na proteção dos direitos humanos, se não impedindo a ocorrência de violações, ao menos permitindo, na medida mais ampla possível, que estas violações gerem consequências para os Estados violadores.

A utilização das contramedidas por Estados não diretamente lesados é necessária quando os mecanismos de proteção dos direitos humanos, seja devido a entraves políticos, ou devido a entraves burocráticos, deixam de funcionar no momento necessário. Como veremos adiante, a proteção dos direitos humanos é o objetivo e fundamento do Direito Internacional dos Direitos Humanos e dos seus mecanismos de proteção.

Assim, desde que o meio utilizado seja lícito, deve ser aplicado ao caso concreto a medida que melhor garanta a proteção aos direitos humanos, ou seja, aquela mais efetiva para impedir a continuidade da violação das normas protetoras e aquelas que garantam, por meio da atribuição de consequências à esta violação, que tal conduta não voltará a se repetir.

\subsection{O Princípio Pro Homine}

O Manual de terminologia dos direitos humanos internacionais contém um verbete tratando do Hominum Causa Omne Jus Constitutum Est, ou Princípio de interpretação e aplicação dos tratados. Este seria, segundo esta obra (CONDÉ, p. 108, 2004):

O princípio de todo o direito, incluído os tratados de direitos humanos, que diz que toda a lei é criada para o benefício/bem dos serem humanos. Segundo este princípio todos os instrumentos legais de 
direitos humanos e normas consuetudinárias devem ser interpretadas e aplicadas da maneira mais protetora da dignidade humana dos seres humanos, não da maneira que é melhor para o Estado.

Ele também é conhecido como princípio Pro Homine ${ }^{869}$

Este mesmo manual possui um verbete que trata especificamente do princípio pro homine, segundo o qual (CONDÉ, p. 207, 2004):

Um princípio do direito internacional dos direitos humanos que requer que as normas de direitos humanos internacionais devem sempre ser interpretadas $\mathrm{e}$ aplicadas na maneira que mais completa $\mathrm{e}$ adequadamente proteja os seres humanos. E quando mais de uma norma ou instrumento de direitos humanos se aplica a uma situação em particular, aquele que dá maior proteção à liberdade do indivíduo deve prevalecer sobre aqueles que oferecem menos. Qualquer que seja a aplicação e interpretação de tais normas, é a mais favorável ao ser humano individual e protetora da dignidade humana que deve prevalecer. $^{870}$

Diversos tratados de proteção aos direitos humanos do sistema da ONU possuem disposições estabelecendo que os princípios nele estabelecidos não podem ser restringidos, nem mesmo pelas disposições do próprio tratado (ICPPR, artigo 5.2; Convenção Relativa ao Estatuto dos Refugiados, artigo 5; Convenção sobre o Estatuto dos Apátridas, artigo 5; CEDAW, artigo 23; CRC, artigo41).

Também nos sistemas regionais, o Pacto de San José da Costa Rica no seu artigo $29 . b^{871}$ e a Convenção para a Proteção dos Direitos Humanos e Liberdades Fundamentais do Conselho da Europa (artigo $53^{872}$ ) contém previsões semelhantes.

\footnotetext{
${ }^{869}$ The principle of all law, including human rights treaties, that says that all law is created for the benefit/sake of human beings. Under this principle all human rights legal instruments and customary norms must be interpreted and applied in the manner most protective of the human dignity of human beings, not the manner that is best for the state. It is also known as the principle of Pro Homine

${ }^{870}$ A principle of international law of human rights that requires that international human rights norms must always be interpreted and applied in a way that most fully and adequately protects human beings. And where more than one human rights norm or instrument applies to a particular situation, the one that gives the most protection of freedom to the individual should prevail over those offering less. Whatever application and interpretation of such norms is most favorable to the individual human being and protective of human dignity should prevail.

${ }^{871}$ Nenhuma disposição desta Convenção pode ser interpretada no sentido de:

b) Limitar o gozo e exercício de qualquer direito ou liberdade que possam ser reconhecidos de acordo com as leis de qualquer dos Estados -Partes ou de acordo com outra convenção em que seja parte um dos referidos Estados;

${ }^{872}$ Nothing in this Convention shall be construed as limiting or derogating from any of the human rights and fundamental freedoms which may be ensured under the laws of any High Contracting Part or under any other agreement to which it is a Party.
} 
A doutrina também reconhece este princípio. Segundo Lauterpacht e Greenwood (p. 372, 1989):

Neste respeito, parece que o critério fundamental que cria a própria natureza dos direitos humanos requer que normas que garantam ou estendam os direitos humanos sejam amplamente interpretadas e aquelas que limitam ou restringem direitos humanos sejam restritivamente interpretadas. Este critério fundamental, o princípio pro homine do Direito dos Direitos Humanos leva a conclusão de que aplicabilidade imediata e incondicional é a regra e que aplicação condicional é a exceção. ${ }^{873}$

Já para Trindade (p. 434, 1997): "No presente contexto, a primazia é da norma mais favorável às vítimas, que melhor as proteja, seja ela norma de direito internacional ou norma de direito interno."

Também para Ramos (p. 280-281, 2002):

A régle d'or de interpretação das normas de proteção internacional dos direitos humanos é a primazia da norma mais favorável ao indivíduo. Esta busca da maior proteção possível consta explicitamente dos tratados, na medida em que nos mesmos é mencionada a impossibilidade de interpretação do próprio tratado que exclua ou revogue proteção normativa maior já alcançada.

A jurisprudência da Corte Interamericana já reconheceu expressamente este princípio no Parecer Consultivo 5/85 de 13 de novembro de 1985, sobre a filiação obrigatória de jornalistas. Segundo esta Corte (CIDH, parag. 52, 1985):

Em consequência, se a uma mesma situação são aplicáveis a Convenção Americana e outro tratado internacional, deve prevalecer a norma mais favorável à pessoa humana. Se a própria Convenção estabelece que suas regulamentações não têm efeito restritivo sobre outros instrumentos internacionais, menos ainda poderão trazer-se restrições presentes nestes outros instrumentos, porém não na Convenção, para limitar o exercício dos direitos e liberdades que esta reconhece. ${ }^{874}$

\footnotetext{
${ }^{873}$ In this respect, it appears that the fundamental criterion which creates the very nature of human rights requires that the norms which guarantee or extend the human rights be broadly interpreted and those that limit or restrict human rights be narrowly interpreted. This fundamental criterion, the pro homine principle of the Law of Human Rights leads to the conclusion that immediate and unconditional enforceability is the rule and that conditional enforcement is the exception.

${ }^{874}$ En consecuencia, si a una misma situación son aplicables la Convención Americana y otro tratado internacional, debe prevalecer la norma más favorable a la persona humana. Si la propia Convención establece que sus regulaciones no tienen efecto restrictivo sobre otros instrumentos internacionales, menos aún podrán traerse restricciones presentes en esos otros instrumentos, pero no en la Convención, para limitar el ejercicio de los derechos y libertades que ésta reconoce.
} 
Neste mesmo sentido segue o voto em separado do Juiz Trindade no caso Blake Vs Guatemala, de 22 de janeiro de 1999, segundo o qual (CIDH, TRINDADE, parag. 7 , 1999):

7. Distintamente Direito Internacional Público, oDireito Internacional dos Direitos Humanos não rege as relações entre iguais; opera precisamente na defesa dos ostensivamente mais fracos e vulneráveis (as vítimas das violações dos direitos humanos). Nas relações entre desiguais, se posiciona na defesa dos mais necessitados de proteção. Não busca obter um equilíbrio abstrato entre as partes, mas sim remediar os efeitos do desequilíbrio e das disparidades na medida em que afetam os direitos humanos. Não se nutre das condições de reciprocidade, senão se inspira melhor nas considerações de ordem pública em defesa dos interesses comuns superiores. É um verdadeiro direito de proteção, marcado por uma lógica própria, e dirigida à salvaguarda dos direitos dos seres humanos e não dos Estados. ${ }^{875}$

Ainda para Trindade (CIDH, TRINDADE, parag. 8, 1999):

8. É este o sentido próprio do Direito Internacional dos Direitos Humanos, cujas normas jurídicas são interpretadas e aplicadas tendo sempre presentes às necessidades urgentes de proteção das vítimas, e reclamando, desse modo, a humanização dos postulados do Direito Internacional Público clássico. Não há razão para que a já mencionada tensão entre os postulados do Direito Internacional Público e do Direito Internacional dos Direitos Humanos perdure sempre, pelo contrário: o grande desafio que se apresenta é precisamente no sentido da superação daquela tensão. ${ }^{876}$

Assim, o principio pro homine é um princípio do Direito Internacional dos Direitos Humanos, segundo o qual a norma mais favorável à proteção dos direitos

\footnotetext{
875 7. Distintamente del Derecho Internacional Público, el Derecho Internacional de los Derechos Humanos no rige las relaciones entre iguales; opera precisamente en defensa de los ostensiblemente más débiles y vulnerables (las víctimas de violaciones de los derechos humanos). En las relaciones entre desiguales, se posiciona en defensa de los más necesitados de protección. No busca obtener un equilibrio abstracto entre las partes, sino más bien remediar los efectos del desequilibrio y de las disparidades en la medida en que afectan los derechos humanos. No se nutre de las concesiones de la reciprocidad, sino se inspira más bien en las consideraciones de ordre public en defensa de intereses comunes superiores. Es un verdadero derecho de protección, marcado por una lógica propia, y dirigido a la salvaguardia de los derechos de los seres humanos y no de los Estados.

${ }^{876}$ 8. Es este el sentido propio del Derecho Internacional de los Derechos Humanos, cuyas normas jurídicas son interpretadas y aplicadas teniendo siempre presentes las necesidades apremiantes de protección de las víctimas, y reclamando, de ese modo, la humanización de los postulados del Derecho Internacional Público clásico. No hay razón para que la ya mencionada tensión entre los postulados del Derecho Internacional Público y los del Derecho Internacional de los Derechos Humanos perdure siempre, sino todo lo contrario: el gran desafío que se nos presenta es precisamente en el sentido de la superación de aquella tensión.
} 
humanos deve ser empregada. Ele é reconhecido em diversos tratados internacionais, na jurisprudência dos tribunais especializados e pela doutrina.

Embora este princípio seja usualmente utilizado na interpretação de normas protetoras de direitos internacionais conflitantes, o objetivo nele consubstanciado é claro: a proteção dos direitos humanos deve nortear não só a interpretação, mas também a aplicação das normas de direitos humanos.

E não só as normas de direitos humanos previstas nos tratados estão submetidas a este princípio. As normas consuetudinárias, assim como as demais normas e regulamentos que formam o complexo sistema de proteção internacional dos direitos humanos devem ser aplicadas sempre visando a maior efetividade desta proteção.

Ainda, mesmo as normas do Direito Internacional "clássico", como afirma o Juiz Trindade, acima mencionado, devem ser vistas segundo uma perspectiva humanizada.

Portanto, a proteção, a aplicabilidade e a implementação dos direitos humanos são a prioridade no Direito Internacional dos Direitos Humanos, um dos campos do Direito onde fica mais evidente a prevalência do conteúdo sobre a forma.

3.3 A necessidade das contramedidas adotadas por estados não diretamente lesados por violação a normas protetoras de direitos humanos

Ficou comprovada, no capítulo anterior, a existência de uma norma consuetudinária reconhecendo o direito de Estados não diretamente lesados de adotarem contramedidas no caso de violações de normas que protejam interesses da comunidade internacional como um todo.

Ficou comprovado na primeira parte deste capítulo que o complexo sistema de proteção global dos direitos humanos, organizado no âmbito da Organização das Nações Unidas, apesar de efetivo no monitoramento, investigação e determinação das violações de direitos humanos, não possui os instrumentos adequados para lidar com graves crises humanitárias, seja devido á burocracia e a falta de capacidade coercitiva dos órgãos técnicos ou em razão do caráter político dos órgãos principais.

Resta comprovar que, ao menos em alguns casos, as contramedidas adotadas por Estados não diretamente lesados são a melhor norma para garantir a proteção dos direitos humanos.

Lloret, acima citado (p. 49, 1998) revela que "em Estados não democráticos responsáveis por violações do direito à vida ou à integridade física, por norma se tem ignorado 
as decisões do Comitê [de Direitos Humanos]”. Essa afirmação é verdadeira não somente para os mecanismos convencionais de proteção aos direitos humanos. Ela também espelha a realidade dos mecanismos extra-convencionais e das Resoluções da Assembleia Geral, que por não terem caráter vinculante, causam apenas embaraço internacional a Estados com pouca preocupação com sua imagem externa.

No caso destes Estados, a forma de pressão mais eficaz são medidas coercitivas que saiam do campo moral e atinjam efetivamente os interesses dos Estados violadores.

Um exemplo é o caso da apartheid na África do Sul. Como mencionado anteriormente, diversos Estados adotaram contramedidas contra a África do Sul, como forma de pressão para que esta abandonasse sua política discriminatória, antes das Resoluções do Conselho de Segurança determinando medidas coercitivas.

Este caso em específico, devido ao papel que teve no desenvolvimento da proteção dos Direitos Humanos no sistema ONU, deve ser mais bem examinado.

Já em sua primeira Sessão, em 1946, a Assembleia Geral adotou Resolução (A/RES/44(I)) sobre o tratamento de indianos na África do Sul, instando os dois Estados a relatarem as medidas adotadas para o cumprimento de suas obrigações mútuas.

A Assembleia Geral continuou tratando do assunto nas Sessões seguintes (A/RES/265(III); A/RES/395(V); A/RES/511(VI); A/RES/616(VII)).

Nas Resoluções 395 (V) ${ }^{877}$ e 511 (VI), a Assembleia Geral também se manifestou sobre a questão da apartheid, afirmando que a política de segregação racial (Apartheid) seria necessariamente baseada em doutrinas de discriminação racial. Porém, tal manifestação foi somente incidental, sem nenhuma condenação dos fatos.

Somente em 1952 a Assembleia Geral adota Resoluções exclusivas sobre a questão da apartheid, muito embora esta política tenha se iniciado na África do Sul em 1948. Na Resolução 616 A (A/RES/616(VII)[A]) ela estabelece a criação de uma comissão de três membros para estudar a situação racial na África do Sul; e na Resolução 616 B (A/RES/616(VII)[B]) ela:

Afirma que políticas governamentais dos Estados Membros que não
são direcionadas em relação a estes objetivos [igualdade perante a lei
do todas as pessoas], mas que são designadas para perpetuar ou
aumentar a discriminação racial são inconsistentes com os
compromissos dos Membros segundo o Artigo 56 da Carta. ${ }^{878}$

${ }^{877}$ Considering that a policy of "racial segregation" (Apartheid) is necessarily based on doctrines of racial discrimination (A/RES/395(V))

${ }^{878}$ Affirms that governmental policies of Member States which are not directed towards these goals, but which are designated to perpetuate or increase discrimination, are inconsistent with the pledges of the Members under the Article 56 of the Charter; 
A Resolução 616 B, assim, afirma indiretamente que as políticas raciais adotadas pela África do Sul são uma violação das suas obrigações decorrentes da Carta das Nações Unidas. Apesar deste reconhecimento, somente é instaurada uma Comissão de investigação dos fatos.

Nos anos seguintes a Assembleia Geral continua tratando da questão (A/RES/1302(XIII); A/RES/1460(XIV); A/RES/1597 (XV); (A/RES/1662(XVI)).

Porém é somente em 1962, após a Segunda Conferência dos Estados Africanos Independentes adotar a Resolução sobre a África do Sul instado todos os Governos dos Estados Independentes Africanos a organizar um boicote contra mercadorias da África do Sul e África Sudoeste, que a Assembleia Geral adota a Resolução 1761 (XVII) na qual requer que os Estados adotem uma série de medidas contra a África do sul (ONU, 1962):

Requer que os Estados Membros adotem as seguintes medidas, separadamente ou coletivamente, em conformidade com a Carta, para levar ao abandono destas políticas:

a) o rompimento das relações diplomáticas com o Governo da República da África do Sul, ou se abster de estabelecer tais relações;

b) o fechamento de seus portos para todos os navios navegando sob a bandeira sul-africana;

c) a adoção de legislação proibindo seus navios de entrarem nos portos sul-africanos;

d) boicote a todas as mercadorias sulafricanas e abster-se de exportar mercadorias, inclusive armas e munição para a África do Sul;

e) recusar aterrissagem e instalações de passagem para todas as aeronaves pertencentes ao Governo da África do Sul e companhias registradas sob as leis da África do Sul. ${ }^{879}$ (tradução nossa)

No entanto, com já mencionado, as Resoluções da Assembleia Geral não têm caráter obrigatório. As medidas tomadas pelos Estados em cumprimento a esta Resolução, contrárias as suas obrigações internacionais em relação á África do Sul só podem ser consideradas como contramedidas.

\footnotetext{
879 4. Requests Member States to take the following measures, separately or collectively, in conformity with the Charter, to bring about the abandonment of those policies:

a) Breaking off diplomatic relations with the Government of the Republic of South Africa or refraining from establishing such relations;

b) Closing their ports to all vessels flying the South African flag;

c) Enacting legislation prohibiting their ships from entering South African ports;

d) Boycotting all South African goods and refraining from exporting goods, including all arms and ammunition to South Africa;

e) Refusing landing and passage facilities to all aircraft belonging to the Government of South Africa and companies registered under the laws of South Africa;
} 
Diante da manifestação da Assembleia Geral recomendando um embargo à África do Sul, o Conselho de Segurança também se manifestou sobre a questão, porém em termos bem mais suaves. Na sua Resolução 181 de 1963 (S/5386), este órgão recomendou um embargo de arma, munição e veículos militares em relação à África do $\mathrm{Sul}^{880}$. Pelos termos utilizados nesta Resolução, entretanto, fica claro que a medida é apenas uma recomendação, e não uma decisão obrigatória.

Essa inércia do Conselho de Segurança foi indiretamente criticada pela Assembleia Geral que na Resolução 2054 de 1965 (A/RES/2054(XX)[A]) afirma:

6. Chama a atenção do Conselho de Segurança para o fato de que a situação na África do Sul constitui uma ameaça a paz e segurança internacionais, que uma ação segundo o Capítulo II da Carta é essencial para resolver o problema da apartheid e que sanções universalmente aplicadas são o único modo de conseguir uma solução pacífica. ${ }^{881}$

Diante da continuidade da inércia do Conselho de Segurança, a Assembleia Geral adotou Resolução nos mesmos termos no ano seguinte (A/RES/2202(XXI0[A]) e nos posteriores.

Apesar desta pressão, somente em 1977 o Conselho de Segurança estabelece um embargo de armas obrigatório contra a África do Sul (SC Res 418 de 1977). Esse embargo, porém, estava longe do embargo econômico requerido pela Assembleia Geral.

Esta, portanto, continua sua campanha de pressão política. Em 1981, adota extensa Resolução sobre a questão, declarando o ano de 1982 o "Ano Internacional de Mobilização para Sanções Contra a África do Sul” (A/RES/36/172).

A sessão D desta Resolução também é controversa. Sob o título de "Sanções compreensivas e mandatórias contra a África do Sul", a Assembleia Geral insta os Estados a adotarem extensas medidas de sanção, incluindo embargos econômicos e financeiros.

A redação é confusa, uma vez que a Assembleia afirma: "Reconhecendo que sanções compreensivas e mandatórias segundo o Capítulo VII da Carta das Nações Unidas são essenciais para evitar a grave ameaça à paz e segurança internacionais

\footnotetext{
${ }^{880}$ Solemnly calls upon all States to cease forthwith the sale and shipment of arms, ammunition of all types and military vehicles to South Africa. (ONU, S/5396)

${ }^{881}$ Draws the attention of the Security Council to the fact that the situation in South Africa constitutes a threat to international peace and security, that action under the Chapter VII of the Charter is essential in order to solve the problem of apartheid ant that universally applied economic sanctions are the only means of achieving a peaceful solution
} 
resultante das políticas e ações do regime de apartheid da África do Sul [...]" $(\mathrm{A} / \mathrm{RES} / 36 / 172)^{882}$

E ainda: "Deplorando a atitude daqueles membros ocidentais permanentes do Conselho de Segurança que até então impediram o Conselho de adotar sanções compreensivas contra o regime segundo o Capitulo VII da Carta." ${ }^{, 83}$

$\mathrm{Na}$ sequência, a Assembleia Geral recomenda uma série de medidas, deixando dúvidas quando a natureza das mesmas. Porém, tendo em vista que nenhuma disposição da Carta autoriza este órgão a adotar medidas coercitivas obrigatórias, mesmo diante da inação do Conselho de Segurança, conclui- se que tais são somente recomendações.

Nesta mesma Resolução a Assembleia Geral ainda:

5. Comenda todos os Governos que tomaram medidas para romper, ou se abster de quaisquer relações com o regime de apartheid da África do Sul;

6. Urge todos os Estados que ainda não tenham o feito, a adotarem medidas de sanção separadas ou coletivas, na pendência da ação do Conselho de Segurança. ${ }^{884}$

O regime de apartheid na África do Sul prosseguiu até 1994 com a ocorrência de eleições multirraciais e democráticas.

Do caso relatado destacam-se as seguintes conclusões: as limitações à capacidade do Conselho de Segurança de agir como um órgão de proteção dos direitos humanos devido à sua estrutura institucional e o seu caráter político.

$\mathrm{Na}$ ausência da atuação do Conselho de Segurança, a conduta adotada pela Assembleia Geral, órgão composto por todos os Estados membros da ONU, boa parte da comunidade internacional foi norteada pelo seguinte entendimento: "sanções universalmente aplicadas são o único modo de conseguir uma solução pacífica". Na ausência da possibilidade de tais sanções "medidas de sanção separadas ou coletivas" não só podem como devem ser utilizadas para remediar a situação.

\footnotetext{
${ }^{882}$ Recognizing that comprehensive and mandatory sanctions under Chapter VII of the Charter of the United Nations are essential to avert the grave threat to international peace and security resulting from the policies and actions of the apartheid régime of South Africa.

${ }^{883}$ Deploring the attitude of those Western permanent members of the Security Council that have so far prevented the Council from adopting comprehensive sanctions against that régime under the Chapter VII of the Charter.

${ }^{884}$ 5. Commends all Governments that have taken action to break off, or to refrain from, any relations with the apartheid régime of South Africa;

6. Urges all States that have not yet done so to adopt separate and collective measures for comprehensive sanctions against South Africa, pending action by the Security Council;
} 
É verdade que a posição da Assembleia Geral parece ter mudado posteriormente.

Em Resolução de 1996 (A/RES/52/120), este órgão:

1.Urge a todos os Estados abster-se de adotarem ou implementarem medidas unilaterais em desacordo com o direito internacional e a Carta das Nações Unidas, em particular aquelas de natureza coercitiva com todos os seus efeitos extraterritoriais, que criem obstáculos às relações comerciais entre Estados, impedindo, assim, a plena realização dos direitos estabelecidos na Declaração Universal dos Direitos Humanos e outros instrumentos internacionais, em particular o direito de indivíduos e povos ao desenvolvimento;

2. Rejeita medidas coercitivas unilaterais com todos os seus efeitos extraterritoriais como ferramentas para pressão política ou econômica contra qualquer país, em particular contra países em desenvolvimento, por causa de seus efeitos negativos na realização dos direitos humanos de vastos setores de suas populações, em particular crianças, mulheres, e idosos. ${ }^{885}$

Essa mudança de posição também pode ser sentida em outros instrumentos internacionais. A Declaração de Viena a Programa de Ação de 1993 (A/CONF.157/23) estabelece no seu item 31:

31. A Conferência Mundial sobre Direitos Humanos insta os Estados a se absterem de qualquer medida unilateral em desacordo com o direito internacional e a Carta das Nações Unidas que criem obstáculos às relações comerciais e que impeçam a realização pela dos direitos humanos estabelecidos na Declaração Universal dos Direitos Humanos e instrumentos internacionais de direitos humanos, em particular os direitos de todos a um padrão de vida adequado para sua saúde e bem-estar, incluindo alimento e cuidado médico e os serviços sociais adequados. A Conferência Mundial dos Direitos Humanos

\footnotetext{
885 1. Urges all States to refrain from adopting or implementing any unilateral measure not in accordance with international law and the Charter of the United Nations, in particular those of a coercive nature with all their extraterritorial effects, which create obstacles to trade relations among States, thus impeding the full realization of the rights set forth in the Universal Declaration of Human Rights8 and other international human rights instruments, in particular the right of individuals and peoples to development; 2. Rejects unilateral coercive measures with all their extraterritorial effects as tools for political or economic pressure against any country, in particular against developing countries, because of their negative effects on the realization of all the human rights of vast sectors of their populations, in particular children, women and the elderly;
} 
afirma que alimento não deve ser usado como ferramenta de pressão política. $^{886}$

Também a Resolução 11 de 1998 da antiga Comissão de Direito Humanos de 1998 declara:

1. Insta mais uma vez todos os Estados a se absterem de adotar ou implementar medidas unilaterais em desacordo com o direito internacional e a Carta das Nações Unidas, em particular aquelas de natureza coercitiva com efeitos extraterritoriais, que criem obstáculos às relações comerciais entre Estados, impedindo, assim, a pela realização dos direitos estabelecidos na Declaração Universal dos Direitos Humanos e outros instrumentos internacionais de direitos humanos, em particular o direito dos indivíduos e dos povos ao desenvolvimento. ${ }^{887}$

Todos estes textos, de redação bem similar, possuem dois pontos em comum. Eles rejeitam a aplicação de medidas em desacordo com o Direito Internacional, ou seja, medidas ilícitas. Como ficou demonstrado em capítulo anterior, as contramedidas adotadas por Estados não diretamente lesados no caso de violações graves a interesses da comunidade internacional com um todo são lícitas, tendo em vista a existência de uma norma consuetudinária reconhecendo este direito.

Também, eles se referem a medidas de coerção econômica que afetem os direitos e o bem-estar da população do Estado violador. Como os casos estudados demonstram, as contramedidas não se limitam a medidas de caráter comercial ou econômico. Em diversas ocasiões, as ações adotadas atingiram direitos do Estado em relação a acordos internacionais de aviação, de pesca, de participação em organizações internacionais. Mesmo medidas de caráter econômico, como o confisco de bens dos Estados, de seus dirigentes ou embargos proibindo a venda de armas, munição e material militar dificilmente podem ser consideradas como medidas afetando os direitos humanos das populações destes Estados. Pelo contrário, a proibição de venda de material bélico para

\footnotetext{
886 31. The World Conference on Human Rights calls upon States to refrain from any unilateral measure not in accordance with international law and the Charter of the United Nations that creates obstacles to trade relations among States and impedes the full realization of the human rights set forth in the Universal Declaration of Human Rights and international human rights instruments, in particular the rights of everyone to a standard of living adequate for their health and well-being, including food and medical care, housing and the necessary social services. The World Conference on Human Rights affirms that food should not be used as a tool for political pressure.

887 1. Calls once again upon all States to refrain from adopting or implementing unilateral measures not in accordance with international law and the Charter of the United Nations, in particular those of a coercive nature with extraterritorial effects, which create obstacles to trade relations among States, thus impeding the full realization of the rights set forth in the Universal Declaration of Human Rights and other international human rights instruments, in particular the right of individuals and peoples to development;
} 
Estados que violam sistematicamente o direito à vida, à integridade física e à liberdade de sua própria população só pode ser vista como uma medida visando justamente a garantia destes direitos.

Por outro lado, como claramente estabelecido pelo anteprojeto de artigos sobre a responsabilidade do Estado da CDI, as contramedidas possuem diversas limitações. Não somente elas devem ser proporcionais à violação cometida (artigo 51, como elas também não podem afetar "obrigações estabelecidas para a proteção de direitos fundamentais" (artigo 50.b) ou "obrigações de caráter humanitário proibindo represálias" (artigo50.a).

Assim, a própria regulamentação das contramedidas afirma que estas não podem ferir direitos humanos.

As críticas que se fazem a sanções econômicas, ou ao menos a determinados tipos de sanções econômicas, assim, se referem somente a alguns tipos de contramedidas. Também, as regras que regulam este instituto proíbem que este seja utilizado de forma a prejudicar, de qualquer forma, os direitos humanos.

A utilidade de um instituto, portanto, não pode ser julgada pela má aplicação de apenas um aspecto do mesmo.

Determinadas situações de violações graves e sistemáticas dos direitos humanos muitas vezes exigem medidas que vão além da esfera política. Isto se demonstra pela própria atuação do Conselho de Segurança. Se até 1990 ele havia aplicado sanções apenas duas vezes (Rodésia do Sul e África do Sul), de 1990 a 2000 ele aplicou sanções em 11 situações (STEINER, ALSTON, p. 662, 2000).

A própria Declaração de Viena de 1993 afirma que faltam remédios e instrumentos efetivos para a proteção dos direitos humanos. Em suas palavras (A/CONF.157/23):

29. A Conferência Mundial dos Direitos Humanos expressa grave preocupação com as contínuas violações de direitos humanos em todas as partes do mundo em desrespeito aos padrões contidos nos instrumentos internacionais de direitos humanos e direito humanitário internacional e com a falta de remédios sufic ientes e efetivos para as vítimas. ${ }^{888}$

\footnotetext{
${ }^{888}$ 29. The World Conference on Human Rights expresses grave concern about continuing human rights violations in all parts of the world in disregard of standards as contained in international human rights instruments and international humanitarian law and about the lack of sufficient and effective remedies for the victims.
} 
Por outro lado, a crescente importância dos direitos humanos no plano internacional tem justificado, para alguns, não só a mitigação da soberania do Estado, mas mesmo uma mitigação do princípio da proibição do uso da força.

A intervenção da OTAN no Kosovo é um exemplo. Diante da inação do Conselho de Segurança devido ao veto, ou ameaça de veto da China e Rússia, a OTAN realizou uma intervenção militar sem a permissão do Conselho de Segurança. Apesar de críticas da comunidade internacional, houve aqueles que apoiassem a medida. O próprio Secretário-Geral da ONU, Kofi Annan embora rão apoiando a ação adotada afirmou (SG/SM/7136):

Foi colocado em grande realce o dilema do que tem sido chamado intervenção humanitária: de um lado, a questão da legitimidade da ação tomada por uma organização regional sem o mandato das Nações Unidas; de outro, o imperativo universalmente reconhecido de evitar efetivamente violações flagrantes e sistemáticas dos direitos humanos com graves consequências. ${ }^{889}$

Ainda segundo Annan (SG/SM/7136): “A Carta é um documento vivo, cujos altos princípios ainda definem as aspirações dos povos de todos os lugares por vidas com paz, dignidade e desenvolvimento. Nada na Carta impede um reconhecimento de que existem direitos além das fronteiras.

Por fim o Secretário-Geral conclui (SG/SM/7136): "A Carta requer que o Conselho seja o defensor do interesse comum, e a não ser que ele seja visto assim numa era de direitos humanos, interdependência, e globalização - há o perigo de que outros procurem tomar o seu lugar.,

Assim o Secretário-Geral da ONU, embora não defenda a atitude tomada pela OTAN, reconhece que esta adveio de uma falha das Nações Unidas em tomar medidas apropriadas diante da situação.

Cassese também escreve sobre a intervenção no Kosovo (p. 25, 1999):

\footnotetext{
${ }^{889}$ It has cast in stark relief the dilemma of what has been called humanitarian intervention: on one side, the question of the legitimacy of an action taken by a regional organization without a United Nations mandate; on the other, the universally recognized imperative of effectively halting gross and systematic violations of human rights with grave humanitarian consequences.

890 The Charter is a living document, whose high principles still define the aspirations of peoples everywhere for lives of peace, dignity and development. Nothing in the Charter precludes a recognition that there are rights beyond borders.

${ }^{891}$ The Charter requires the Council to be the defender of the common interest, and unless it is seen to be so - in an era of human rights, interdependence, and globalization - there is a danger that others could seek to take its place.
} 
Diante de uma enorme tragédia feita por humanos e dada a inação do Conselho de Segurança da ONU devido a recusa da Rússia e da China de apoiar qualquer envolvimento significante da comunidade internacional para parar os massacres e expulsões deves-se sentar indolentemente e assistir milhares de pessoas serem massacradas ou brutalmente perseguidas? Deve-se permanecer silente e inativo somente porque o órgão existente de direitos internacional se prova incapaz de remediar tal situação? Ou, pelo contrário, deve o respeito pelo Estado de direitos ser sacrificado no altar da compaixão humana? $?^{892}$

Ainda para Cassese (p. 29, 1999):

Este caso particular de violação de direito internacional pode levar, gradualmente, à cristalização de uma regra geral de direito internacional autorizando contramedidas armadas com o propósito exclusivo de por fim à atrocidade em larga escala resultando em crimes contra a humanidade e constituindo uma ameaça à paz. Tal regra, caso eventualmente se desenvolva na comunidade internacional, constitui uma exceção ao sistema da Carta da ONU de aplicação coletiva baseada na autorização do Conselho de Segurança. ${ }^{893}$

Não cabe, em sede deste trabalho, discutir a legalidade das medidas de intervenção humanitária ocorridas sem a autorização do Conselho de Segurança. Sua base legal, se existir, é diferente da base legal das contramedidas pacíficas adotadas por Estados não diretamente lesados.

O ponto que deve ser ressaltado é que, se em alguns casos de violações graves aos direitos humanos, se considera a possibilidade de medidas coercitivas militares, tendo em vista a importância dos valores a serem preservados, os mesmos argumentos servem para reforçar a necessidade da adoção de contramedidas por Estados não diretamente lesados.

O próprio Secretário-Geral da ONU reconhece o imperativo universal de "évitar efetivamente violações flagrantes e sistemáticas dos direitos humanos com graves consequências". Ele também entende que a Carta das Nações Unidas não impede o reconhecimento de "direitos além das fronteiras".

\footnotetext{
${ }^{892}$ Faced with such an enormous human made tragedy and given the inaction of the UN Security Council due to the refusal of Russia and China to countenance any significant involvement by the international community to stop the massacres and expulsions should one sit idly by and watch thousands of human beings being slaughtered or brutally persecuted? Should one remain silent and inactive only because the existing body of international hw proves incapable of remedying such a situation? Or rather, should respect for the Rule of Law be sacrificed on the altar of the human compassion?

${ }_{893}$ This particular instance of breach of international law may gradually lead to the crystallization of a general rule of international law authorizing armed countermeasures for the exclusive purpose of putting an end to large scale atrocities amounting to crimes against humanity and constituting a threat to the peace. Such a rule, should it eventually evolve in the world community would constitute an exception to the UN Charter system of collective enforcement based on the authorization of the Security Council.
} 
Assim, se se reconhece a necessidade moral da adoção de medidas militares em alguns casos de graves violações de direitos humanos, com mais razão se deve reconhecer a necessidade de medidas lícitas, coercitivas, porém que não implicam o uso da força, visando a cessação destas violações.

É evidente que tais medidas, voltadas à preservação dos direitos humanos, não podem ser tomadas de modo a violá-los. Neste sentido Lloret, já citado (p. 274, 1998):

esta necessidade dos mecanismos descentralizados de aplicação de normas deve conjugar-se com a finalidade que persegue a normativa dos direitos humanos, que não é outra que garantir um conjunto de direitos humanos ao particular qualquer que seja sua nacionalidade. ${ }^{894}$

No entanto, o próprio Comitê de direito econômicos, sociais e culturais, duro crítico das sanções econômicas, afirma no seu Comentário Geral nº 8 (E/C.12/1997/8):

15. Antecipando a objeção de que as sanções devem, quase que por definição, resultar em graves violações graves aos direitos econômicos, sociais e culturais se elas quiserem atingir seus objetivos, o Comitê nota a conclusão de um grande estudo das Nações Unidas no sentido de que 'decisões para reduzir o sofrimento das crianças ou minimizar outras consequências adversas podem ser tomadas sem por em risco o objetivo político das sanções". Isto se aplica igualmente à situação de todos os grupo vulneráveis. ${ }^{895}$

Também o Relatório do Comitê de Relações Econômicas Externas da Comunidade Europeia do ano de 1982-1983, conhecido como Relatório Seller (Document 1-83/82, p. 36, 1982-83) que afirma que: "sanções [econômicas], como regra, não atingem o seu objetivo político e são geralmente não efetivas", admite que em determinados casos (sanções voltadas a determinados produtos, sanções financeiras, etc.) estas sanções podem ser efetivas (Document 1-83/82, p. 38-39, 1982-83).

Assim, conclui-se que grande parte das críticas sofridas pelas contramedidas, quer sejam adotadas individualmente por Estados não diretamente lesados ou não, diz

\footnotetext{
${ }^{894}$ Por lo tanto, entendemos que esta necesidad de los mecanismos descentralizados de aplicación de normas debe conjugarse con la finalidad que persigue la normativa sobre derechos humanos, que no es otra que garantizar un conjunto de derechos humanos al particular cualquiera que sea su nacionalidad.

895 15. In anticipating the objection that sanctions must, almost by definition, result in the grave violations of economic, social and cultural rights if they are to achieve their objectives, the Committee notes the conclusion of a major United Nations study to the effect that "decisions to reduce the suffering of children or minimize other adverse consequences can be taken without jeopardizing the policy aim of sanctions". This applies equally to the situation of all vulnerable groups
} 
respeito a medidas econômicas, geralmente embargos comerciais abrangentes, que incidentalmente acabam por ferir os direitos humanos da população dos Estados.

Como demonstra a prática estatal, estas medidas são apenas uma parte das contramedidas adotadas. Contramedidas revogando direitos estabelecidos em acordos de aviação, de assistência militar, congelando bens dos Estados, de seus dirigentes, revogando direitos dos Estados diante de organizações comerciais são bastante comuns e não parecem atingir os direitos humanos fundamentais da população.

Também, mesmo medidas de caráter comercial como boicotes de mercadorias específicas, em especial aqueles proibindo a venda de armamento e produtos militares para Estados violadores dos direitos humanos, não só não prejudicam como mesmo asseguram os direitos essenciais da população do Estado atingido.

Outro ponto a ser esclarecido, é se os sistemas de proteção de direitos humanos seria um regime de autocontenção, possuindo no seu interior regras específicas a serem aplicadas no caso de violações das obrigações nele estabelecidas. Neste caso, se aplicaria o disposto no artigo 55 do anteprojeto sobre a responsabilidade internacional dos Estados, tratando da Lex especialis.

Para Ramos (p. 380, 2004): “Com efeito, a existência de procedimentos próprios de solução de controvérsias em tratados de direitos humanos impede o exercício de contramedidas sem que seja esgotada esta fase de busca de reparação da violação de direitos humanos."

De fato no caso das operações militares e paramilitares na e contra a Nicarágua, de 1986, já citado a CJ estabelece (p. 134, 1986): "Entretanto, quando os direitos humanos são protegidos por convenções internacionais, esta proteção toma a forma de tais regimes para monitorar ou assegurar o respeito aos direitos humanos como provido pela própria convenção." ${ }^{896}$

Porém, para Zoller (p. 92, 1984): 'Mas o caráter de 'autocontenção' de um sistema depende da eficiência dos meios que ele contém para restabelecer a equivalência das condições entre as partes. ${ }^{897}$ (tradução nossa)"

Como demonstramos acima, o sistema ONU de proteção aos direito humanos possui uma eficácia limitada no caso de graves crises de direitos humanos. Exigir que

\footnotetext{
${ }^{896}$ However, where human rights are protected by international conventions, that protection takes the form of such arrangements for monitoring or ensuring respect for human rights as are provided for in the conventions themselves.

${ }^{897}$ But the 'self-contained' character of a system hinges on the efficiency of the means it contains in order to re-establish the equivalence of conditions between the parties.
} 
um Estado esgote os procedimentos de monitoramento e investigação de ocorrência de violação de direitos humanos, pode significar exigir que este Estado permaneça quatro anos ou mais assistindo a violação flagrante e sistemática dos direitos humanos por outro Estado sem poder tomar nenhuma atitude. Tendo em vista que o princípio fundamental do Direito Internacional dos Direitos Humanos é a efetiva proteção dos direitos humanos, fica óbvio que esta não é a norma que melhor protege estes direitos.

Assim, quando a violação grave e sistemática dos direitos humanos for de tal natureza que exija uma resposta imediata e contundente para a cessação e a reparação desta violação, diante da ineficácia ou inação dos mecanismos internacionais de proteção, podem os Estados agir unilateralmente através de contramedidas para proteger os direitos violados.

O imperativo universal de evitar estas violações é um princípio do próprio sistema de proteção aos direitos humanos e está acima de considerações formais.

A jurisprudência da CIJ sobre o caso da Nicarágua, acima citada, se refere não ao sistema global de proteção de direitos humanos, mas ao sistema interamericano de proteção.

Este sistema regional, assim como o sistema europeu de proteção de direitos humanos são sistemas mais robustos, possuindo mesmo tribunais especializados com competência para adotar decisões vinculantes nas questões de violações de direitos humanos. Estes sistemas, porém, possuem algumas restrições. Ambos são sistemas regionais, não atingindo todos os Estados da comunidade internacional por sua própria definição. O segundo ponto, é que eles são baseados em tratados internacionais, ou seja, eles podem ser denunciados a qualquer tempo, como ocorreu, por exemplo, com a Grécia, após o golpe de Estado de 1967. Esta denuncia, embora não gere efeito nos processos que já estão em andamento, faz com que tais sistemas não possam mais considerar as violações cometidas por Estados que deixaram de ser parte.

Outro aspecto a ser ressaltado é a efetividade das decisões destas Cortes de Direitos Humanos. O artigo 50 da Convenção Europeia de Direitos Humanos estabelece que caso esta decisão entenda que uma decisão ou medida as autoridades das Partes Contratantes esteja em contradição com as obrigações desta mediante o tratado e o direito interno da dita parte só permite uma reparação parcial "a decisão da Corte deve, se necessário, dar apenas satisfação à parte lesada." $\$ 98$

\footnotetext{
${ }^{898}$ If the Court finds that a decision or a measure taken by a legal authority or any other authority of a High Contracting Party, is completely or partially in conflict with the obligations arising from the present
} 
Assim para Ramos (p. 209, 2002):

Portanto, as sentenças da Corte são, em parte, meramente declaratórias. Quando condenatórias, só a indenização pecuniária é oferecida. Condena-se o Estado a uma obrigação de dar some em dinheiro somente. Para todo o resto a Corte tem se considerado incompetente, pois avalia que o cumprimento da Convenção é tarefa do Estado, sob o controle político do Conselho da Europa, que é o órgão em cujo seio foi concebida a Convenção.

Já a Corte Interamericana de Direitos Humanos, embora tenha competência para emanar sentenças que vinculam as partes, deve recorrer a Assembleia Geral da OEA, para que esta aja em caso de descumprimento destas sentenças (OEA, artigo 65,1969). Segundo Ramos (p. 244, 2002): "Entretanto, até o momento, esse mecanismo político de coerção dos Estados para o cumprimento de sentença da Corte tem se mostrado insuficiente." Ainda, no sistema interamericano de proteção aos direitos humanos, um caso pode demorar anos no âmbito da Comissão Interamericana de Direitos Humanos.

Assim, mesmo os dois sistemas de proteção de direitos humanos regionais mais desenvolvidos têm problemas com a eficácia de suas decisões. Em casos em que esta eficácia também é limitada, recusar a possibilidade de adoção de contramedidas por Estados não diretamente lesados seria conferir menor proteção aos direitos humanos nestes sistemas do que a garantida pelo Direito Internacional Geral.

Assim, embora a proteção internacional dos direitos humanos tenha evoluído muito nas últimas décadas, violações graves e sistemáticas a esses direitos ainda ocorrem diariamente no mundo inteiro. Os mecanismos de proteção, ainda em desenvolvimento, não possuem, por hora, a eficácia necessária para lidar com crises graves de direitos humanos de exijam uma resposta imediata e contundente. A pressão política, embora seja eficaz para corrigir a conduta de Estados com participação ativa na comunidade internacional e com uma opinião pública interna atuante, é insuficiente para lidar com Governos mais preocupados com a consolidação de seu poder interno do que com a sua imagem exterior. Por outro lado, o único órgão internacional com competência para adotar sanções coletivas em relação a este Estado pode ser paralisado por interesses políticos estranhos à proteção dos direitos humanos

convention, and if the internal law of the said Party allows only partial reparation to be made for the consequences of this decision or measure, the decision of the Court shall, if necessary, afford just satisfaction to the injured party. 
Nestes casos, diante do imperativo universal de evitar violações graves e sistemáticas aos direitos humanos, e do princípio geral de aplicação da regra mais favorável à proteção destes direitos, as contramedidas adotadas por Estados não diretamente lesados são necessárias por serem a única forma de atribuir consequências reais às mais graves violações do Direito Internacional.

Assim a adoção de contramedidas por Estados não diretamente lesados é lícita quando tais violações se referem a direitos humanos fundamentais. Elas são necessárias, quando os mecanismos coletivos de proteção internacional são ineficazes para impedir a ocorrência, a continuidade, ou a reparação destas violações internacionais. 


\section{CONSIDERAÇÕES FINAIS}

A internacionalização dos direitos humanos causou profundas mudanças no Direito Internacional Contemporâneo. O reconhecimento da importância do ser humano e da dignidade humana trouxe novos valores a um sistema que durante séculos foi norteado pelos interesses individuais dos Estados.

Estes novos valores, aliados à consolidação do conceito de comunidade internacional, modificaram o papel dos Estados no Direito Internacional.

Neste trabalho pretendeutse, num primeiro momento, definir qual é esse novo papel dos Estados tanto em relação aos seus deveres quanto em relação aos seus direitos.

$\mathrm{O}$ anteprojeto de artigos sobre a responsabilidade internacional dos Estados elaborado pela CDI e adotado através de Resolução pela Assembleia geral da ONU estabelece que toda a violação a uma obrigação internacional acarreta a responsabilização do Estado violador. Ele estabelece também a existência de um tipo mais grave de violação ao direito internacional, as chamadas "violações graves decorrentes de normas imperativas de direito internacional geral”. Destas violações decorrem, além das consequências jurídicas previstas para as violações ordinárias, outras consequências específicas, que afetam não só o Estado violador, mas todos os Estados da comunidade internacional.

Por outro lado, o mesmo anteprojeto estabelece que qualquer Estado pode invocar a responsabilidade internacional de um outro Estado, mesmo não sendo diretamente lesado, se a obrigação violada existir em relação à comunidade internacional como um todo, ou se a obrigação violada existe em relação a um grupo de Estados e é estabelecida para a proteção de um interesse coletivo deste grupo.

Assim, na mesma medida em que se reconhece novos deveres aos Estados, também se reconhece novos direitos a eles.

A base fundamental destes novos direitos e deveres, como mencionado, é o surgimento de valores e interesses que dizem respeito não ao Estado individualmente, mas à comunidade internacio nal como um todo.

Estes valores e interesses foram consubstanciados em normas que, devido à importância do seu conteúdo, possuem um caráter diferenciado das demais normas de direito internacional. Num segundo momento, estudou-se a natureza destas normas, e 
concluiu-se que um conteúdo em comum tanto das normas imperativas de direito internacional geral ou jus cogens, quanto das obrigações devidas à comunidade internacional como um todo ou obrigações erga omnes, é a proteção dos direitos humanos básicos ou fundamentais.

Portanto, as normas protetoras de direitos humanos fundamentais possuem uma natureza diferenciada, pois, por um lado, seu cumprimento diz respeito à comunidade internacional como um todo, e por outro, elas só podem ser derrogadas por outras normas imperativas de direito internacional.

Num terceiro momento, estudou-se uma das consequências jurídicas instrumentais da responsabilidade internacional do Estado, o instituto das contramedidas. Este instituto, cuja origem remonta à antiguidade, foi reconhecido e regulamentado no anteprojeto de responsabilidade internacional mesmo diante das críticas alegando que as contramedidas seriam um instrumento arcaico que privilegiaria os Estados mais poderosos. Isto porque sua necessidade foi reconhecida, tendo em vista o caráter descentralizado do Direito Internacional.

Outra razão para a sua inserção no anteprojeto foi a importância da regulamentação deste instituto. Assim, o anteprojeto estabelece as condições e os limites das contramedidas. Dentre estes, podemos destacar a necessidade de proporcionalidade da contramedida com a violação da obrigação internacional, e a proibição de contramedidas que afetem os direitos humanos fundamentais e as obrigações decorrentes do direito humanitário. Esta regulamentação tem o objetivo de evitar uso abusivo do direito de adotar contramedidas. Quaisquer medidas tomadas em desrespeito a estas regras perdem a natureza de contramedida, tornando-se, então, um ato internacionalmente ilícito passível de responsabilização.

Após o estudo da responsabilidade internacional do Estado, da natureza jurídica das normas protetoras de direitos humanos e do instituto das contramedidas em geral, passou-se á efetiva discussão da tese proposta neste trabalho.

Para verificar a aplicabilidade das contramedidas adotadas por Estados não diretamente lesados diante de violações às normas protetoras de direitos humanos primeiro investigou-se a legalidade das referidas contramedidas. Uma análise literal, sistemática, histórica e teleológica das disposições a respeito das contramedidas por Estados não diretamente lesados no anteprojeto de artigos sobre a responsabilidade internacional revelou que este documento adota uma posição neutra em relação a possibilidade da adoção destas contramedidas, ao estabelecer uma cláusula de 
salvaguarda, reservando a matéria para o desenvolvimento futuro do direito internacional. A pesquisa jurisprudencial também não revelou uma posição definitiva dos tribunais internacionais sobre o tema. Embora a CIJ reconheça a existência de obrigações erga omnes que são devidas à comunidade internacional como um todo, esta mesma Corte não reconheceu que tais obrigações resultam num direito de ação dos Estados da comunidade internacional perante este tribunal no caso de sua violação.

A pesquisa bibliográfica demonstrou que boa parte da doutrina especializada reconhece em pelo menos algumas hipóteses a possibilidade de adoção de contramedidas por Estados não diretamente lesados.

Por outro, lado, a doutrina é apenas uma fonte subsidiária de Direito Internacional, não podendo criar, por si só, normas de direito internacional.

Por fim, realizourse um estudo da prática dos Estados em relação ao tema. Esta prática foi analisada de duas formas distintas. Compilaram-se os comentários e declarações feitas pelos Estados no âmbito das discussões do $6^{\circ}$ Comitê da Assembleia Geral da ONU a respeito da possibilidade da adoção de contramedidas por Estados não diretamente lesados. Esta compilação demonstrou que a grande maioria dos Estados que se manifestaram era a favor, em princípio, do direito de adoção de contramedidas por Estados terceiros em pelo menos algumas hipóteses. Destes Estados, apenas dois seriam contrários à aplicação de contramedidas no caso de violações a obrigações devidas a comunidade internacional com um todo, ou seja, contrários a adoção de contramedidas no caso de violações de normas protegendo os direitos humanos fundamentais.

A maioria que reconhecia esse direito era composta por Estados das mais diferentes regiões geográficas, representando diferentes sociedades, culturas e sistemas jurídicos.

A prática estatal também foi analisada através do levantamento de casos em que os Estados adotaram contramedidas apesar de não terem sido diretamente lesados.

Esta análise demonstrou a ocorrência de diversos casos de adoção de contramedidas por Estados não diretamente lesados. Embora na maioria dos casos estas medidas tenham sido tomadas pelos Estados ocidentais, uma importante minoria foi adotada por Estados de diversas regiões geográficas como África, América Latina, Oceania e Ásia. A análise dos casos também demonstrou que mesmo Estados que se manifestaram abertamente contra o direito de adoção de contramedidas por Estados não diretamente lesados já haviam utilizado, alguns repetidamente, este tipo de medidas. 
Diante desta extensa prática estatal, examinou-se se tal prática seria consistente o suficiente para configurar o elemento objetivo das normas consuetudinárias, i.e. prática constante, consistente e geral; e se tal prática viria acompanhada do elemento subjetivo das normas consuetudinárias, i.e. a opinio juris.

Em relação ao elemento objetivo, constatourse que a prática estatal era numerosa, tendo, ainda, se intensificado nas últimas décadas. Apesar da sua consistência, em poucos casos, Estados, que não o Estado afetado, manifestaram repúdio a esta medidas. Os Estados que as adotaram também eram representantes das diversas regiões geográficas, de modo que se comprovou a generalidade desta prática. Demonstroutse, também, que a generalidade exigida para a configuração do costume não se confunde com unanimidade. Esta não é necessária para a formação de uma norma consuetudinária.

Quanto ao elemento subjetivo, demonstrourse que este requer que a prática estatal seja acompanhada da convicção de sua legalidade. Em diversos dos casos analisados, as medidas foram tomadas mediante declarações públicas ou mesmo incorporadas em documentos resultantes de convenções internacionais. Diante desta publicidade e de quaisquer outros indícios em contrário, considerou-se que os Estados que as adotaram acreditavam na sua licitude. Outro fato que reforça a existência de uma opinio iuris reconhecendo a legalidade das contramedidas adotadas por Estados não diretamente lesados é o reconhecimento deste direito pela grande maioria dos Estados que se manifestaram nos debates ocorridos no $6^{\circ}$ Comitê da Assembleia Geral das Nações Unidas.

Assim, diante da configuração do elemento objetivo e do elemento subjetivo formadores do costume internacional, concluiu-se que existe uma norma consuetudinária reconhecendo a existência do direito de Estados não diretamente lesados de adotarem contramedidas diante de violações a interesses da comunidade internacional como um todo.

Portanto, contramedidas adotadas por Estados não diretamente lesados são lícitas sempre que ocorra uma violação a direitos humanos fundamentais.

Uma vez determinada a legalidade da adoção de contramedidas por Estados não diretamente lesados, partiu-se para o exame da sua necessidade, tendo em vista o Direito Internacional dos Direitos Humanos.

Numa análise do sistema global de proteção dos direitos humanos, constatou-se que os diversos mecanismos, órgãos e procedimentos de proteção dos direitos humanos, 
embora importantes no monitoramento, investigação e determinação de existência de violações, tem eficácia limitada uma vez que, por regra geral, não têm competência para dotar decisões obrigatórias para os Estados.

A única exceção a regra, o Conselho de Segurança da ONU, é um órgão político cujo objetivo principal é a manutenção da paz e segurança mundiais e não a proteção dos direitos humanos. Seu procedimento de decisão é discricionário e pouco democrático, o que muitas vezes resulta na sua paralisação diante de graves crises humanitárias.

Assim, a efetividade do sistema global de proteção dos direitos humanos se baseia, na imensa maioria dos casos, na pressão política exercida pela comunidade internacional em relação ao Estado violador.

Porém, como já mencionado, embora este tipo de pressão seja eficaz no caso de Estados com relações internacionais complexas e que tenham uma opinião pública interna atuante, o mesmo não pode ser dito em relação a Estados cujos Governos estão mais preocupados com a consolidação de seu poder interno do que com sua imagem internacional.

Por outro lado um dos princípios que norteia o Direito Internacional dos Direitos Humanos é o princípio Pro Homine. Este princípio, embora geralmente utilizado para solucionar conflitos entre normas protetoras de direitos humanos, consubstancia claramente aquele que deve ser o objetivo principal deste ramo do Direito Internacional: a norma que forneça a proteção mais efetiva dos direitos humanos deve ser utilizada não só na interpretação dos casos judiciais, mas também na aplicação concreta deste direito em caso de violação.

Portanto, diante da efetividade limitada do sistema coletivo de proteção internacional dos direitos humanos, e tendo em vista o princípio segundo o qual deve prevalecer sempre a norma que garanta maior proteção aos direitos humanos, a necessidade das contramedidas adotadas por Estados não diretamente lesados para a proteção destes direitos resta demonstrada.

Pretendeu-se neste estudo analisar a aplicação das contramedidas por Estados não diretamente lesados diante de violação das normas protetoras de direitos humanos. Através de pesquisa documental, jurisprudencial e bibliográfica, demonstrou-se a existência de uma norma consuetudinária reconhecendo o direito dos Estados a adotar contramedidas, ainda que não tenham sido diretamente lesados, no caso de violações a normas devidas a comunidade internacional como um todo. Esta norma, assim, garante 
a legalidade das contramedidas tomadas por Estados não diretamente lesados no caso de violações a direitos humanos fundamentais.

Demonstrou-se ainda, que no atual estágio de desenvolvimento do Direito Internacional, os mecanismos coletivos de proteção aos direitos humanos têm uma eficácia limitada em algumas situações. Nestes casos, diante do princípio de prevalência da regra mais protetora dos direitos humanos, fica comprovada a necessidade destas contramedidas.

A proteção dos direitos humanos é cada vez mais uma preocupação central no âmbito do Direito Internacional. Diante da perspectiva remota do desenvolvimento a curto ou médio prazo de um sistema robusto de proteção coletiva dos direitos humanos, dotado de competência para implementar decisões obrigatórias estabelecendo esta proteção, só nos resta tentar encontrar no sistema imperfeito dos dias de hoje instrumentos que garantam a proteção mais efetiva possível destes direitos.

Se a adoção de contramedidas por Estados indiretamente lesados não é a melhor saída para a proteção dos direitos humanos, no Direito Internacional atual, ela pode ser a única saída em alguns casos. 


\title{
REFERÊNCIAS
}

REFERÊNCIAS BIBLIOGRÁFICAS

\author{
OBRAS GERAIS
}

ALLAND. Justice privée et ordre juridique international : étude théorique des contre-mesures en droit international public. Paris: A Pedone, 1994.

ALVES, J. A. Lindgren. Os direitos humanos como tema global. São Paulo: Perspectiva, 1994.

ANZILOTTI, Dionísio. Teoria general della responsabilità dello stato nel diritto internazionale. Firenze: F. Lumachi Libraio-Editore, 1902.

BAILEY, Sydney. The UN Security Council and Human Rights. New York: St. Martin's Press, 1994.

BETHLEHEM, D. Kuwait Crisis: Basic Documents. Cambridge: Burlington Press, 1991.

BRIERLY, J.L. The law of nations. Oxford: Claredon Press, 1963.

BROWNLIE, Ian. Principles of public international law. 4 Ed. Oxford: Clarendon press, 1995.

BUERGENTHAL, Thomas. International human rights in a nutshell. St. Paul: West Publishing CO, 1988.

BUERGENTHAL, Thomas. KISS, Alexandre. La protection international des droits de l'homme. Arlington: N.P. Engel, 1991.

CASSESE, A. International Law. 2 ed. Oxford: Oxford University Press: 2005.

CHASOURNES, L. B. Les contre-mesures dans les relations internationales économiques. Paris : A. Pedone, 1992

COMPARATO, F. K. A Afirmação Histórica dos Direitos Humanos. São Paulo: Ed. Saraiva, 2007.

CONDÉ, V. A Handbook of International Human Rights Terminology. Nebrasca:

University of Nebrasca Press, 2004.

ELAGAB. O.Y. The legality of non-forcible counter-measures in international law. Oxford : Clarendon Press, 1988. 
FERRAZ Jr, Tercio F. Introdução ao Estudo do Direito. 2 ed. São Paulo: Atlas, 1996 GROTIUS, Hugo. The rights of war and peace. Vol. III. London: Boothroyd, 1814. . O direito da guerra e da paz. Vol. 1. Ijuí: Editora Unijuí, 2004.

HOOGH, André. Obligations erga omnes and international crimes. New York : Springer Publishers, 1996.

LAUTERPACHT, GREENWOOD. International Law Reports. Llandysul: Gomer Press, 1989.

LLORET, J.F. Responsabilidad Internacional Del Estado y Derechos Humanos: Estudios de La Práctica Relacional. Madrid: Editorial Tecnos, 1998.

LONGMAN. Dictionary of English Language and Culture. Harlow: Clays, 1993. MELLO, Celso D. de Albuquerque. Curso de direito internacional público. Rio de Janeiro: Renovar, 1992

LEWANDOWSKI, Enrique R. Proteção dos Direitos Humanos na Ordem Interna e Internacional. Rio de Janeiro: Forense, 1984.

NICOLOUDIS, E. P. La nullité de jus cogens et le développement contemporain du droit international public. Atenas: Ed. Papazissi, 1974.

NQUYÊN. DINH. Droit International Public. 6 ed. Paris: LGDJ, 1999.

NYS, E. Les origines du droit international. Bruxelle: A. Castaigne, 1894.

OPPENHEIM. Tratado de direito internacional. Barcelona: Basch Casa Editorial, 1961.

PHILLIMORE. Commentaries upon International Law. Vol I. Philadelphia :

Johnson Law Booksellers, 1854.

PILLET, A. Les fondateurs du droit international. Paris: V.Giard \& E. Brière, 1904.

PROUKAKI, E. K. The problem of Enforcement in International Law. New York, Routledge, 2010.

PUFENDORF. Of the Law of Nature and Nations . London: Waltor, Wilkin, Ward, Osborne, 1729.

RAMCHARAN, B.G. The Security Council and the Protection of Human Rights. Hague: Kluwer Law International, 2002.

RAMOS, André de Carvalho. Direitos humanos em juízo. São Paulo: Max Limonad, 2001. 
. Responsabilidade Internacional por Violação de Direitos Humanos. São

Paulo: Renovar, 2004.

Teoria Geral dos direitos humanos na ordem internacional. São Paulo:

Renovar, 2005.

REUTER. Paul. Droit international public. 6 Ed. Paris: Presses Universitaires de France, 1983.

REZEK, J. Francisco . Direito Internacional Público. São Paulo: Editora Saraiva, 1995.

ROUSSEAU, Charles. Droit international public. Paris: Editions Sirey, 1970.

SALCEDO, Carrillo.El derecho Internacional en un Mundo en Cambio. Madrid:

Tecnos, 1984.

SHAW, M.V. International law. 5 ed. Cambridge: Cambridge University Press, 2005.

SICILIANOS, L.A. Les réactions décentralisées à l'illicite. Des contre-mesures à la

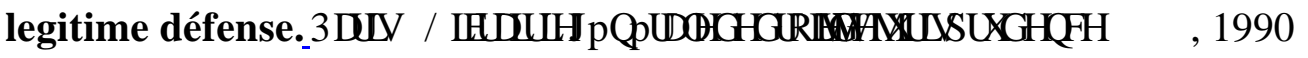

SOARES, Guido Fernando Silva. Curso de direito internacional público. São Paulo: Editora Atlas, 2002.

STEINER, H. e ALSTON, P. International human rights in context. Oxford: Oxford Univertity Press, 2000.

SZTUCKI, Jerzy. Jus Cogens and the Vienna Convention on the Law of Treaties.

Viena : Ed. Springer-Verlag, 1974.

TAMS, C. Enforcing obligations erga omnes in international law. Cambridge:

Cambridge University Press, 2005.

TOMUSCHAT,C. Human Rights: between Idealism and Realism Oxford: Oxford University Press, 2003.

TRINDADE, A. A. Cançado. A proteção internacional dos Direitos Humanos. Fundamentos Jurídicos e Instrumentos Básicos. São Paulo: Saraiva, 1991.

Tratado de direito internacional dos direitos humanos. Vol. I. Porto

Alegre: Fabris Editor, 1997.

VATTEL, Emerich de. O direito das gentes. Brasília: Editora UNB, 2004.

VERDROSS, Alfred. Derecho internacional publico. $4^{\circ}$ Ed. Madri: Aguilar, 1967.

ZOLLER, E. Peacetime Unilateral Remedies: An analyzis of Coutermeasures. New York, Transnational Publishers, 1984. 
AGO, Roberto. Le délit international. In Recueil des Cours de L'Académie de Droit International T. 69. Vol. 2. Paris: Librairie du Recueil Sirey, 1939.

AKEHURST. Reprisals by Third States. In British Yearbook of International Law, 1970.

ALEXIDZE, Levan. Legal nature of Jus Congens in contemporary international law. In Recueil de Cours de L’Académie de Droit International. 172. t. III, 1981

ALLAND, D. Countermeasures of General Interest. In European journal of International Law, Vol. 13 n. 5, 2002.

BENNOURA, M. Le règlements des différends peut-il limiter le droit de se faire justice à soi-même. In European Journal of International Law, n.5, 1994.

CANIZZARO, E. The role of Proportionality in the Law of International

Countermeasures. In European journal of International Law, Vol. 12 n. 5, 2001.

CASSESE. A. Ex iniuria ius oritur: Are We Moving towards International Legitimation of Forcible Humanitarian Countermeasures in the World Community? In European journal of International Law, Vol. 10, 1999.

CHARNEY, J.I. Third State Remedies in International Law. In Michingan Journal of International Law, 57, 1989.

CRAWFORD, James. Countermeasures as Interim Measures. In European Journal of International Law, n.5, 1994.

DAMROSCH. Retaliation or arbitration-or both? The 1978 United States-France aviation dispute. In American Journal of International Law, 74, 1980.

DAWIDOWICZ, M. Public Law Enforcement without Public Safeguards? An Analysis of State Practice on Third-Party Countermeasures and their Relationship to the UN Security Council. In British Yearbook of International Law, 2006.

DUPUY, Pierre-Marie. Le fait générateur de la responsabilité internationale des États. In Recueil des Cours de L'Académie de Droit International. T. 188. Vol. 5. Dordrecht: Martinus Nijhoff Publishers, 1984.

FASSÒ. Jusnaturalismo. In Dicionário de política. BOBBIO, N. MATTEUCCI, N. PASQUINO, G. Brasília: Ed UNB, 1994.

FROWEIN, J.A. Reactions by not directly affected States to breaches of public international law. In Recueil des Cours de L'Académie de Droit International. T. 248. Dordrecht: Martinus Nijhoff Publishers, 1994.

GAJA, G. Jus Cogens Beyond the Vienna Convention. In Recueil de Cours de L’Académie de Droit International. 172. t. III, 1981. 


\section{AMERICAN SOCIETY OF INTERNATIONAL LAW. International Legal} Materials. 1967. International Legal Materials. 1983. . International Legal Materials. 1985.

KEESING. Keesing's Comtemporay Archives. 1961-1962. . Keesing’s Comtemporay Archives. 1963-1964. . Keesing's Comtemporay Archives. 1964. . Keesing's Comtemporay Archives. 1969-1970. . Keesing’s Comtemporay Archives. 1970. . Keesing's Comtemporay Archives. 1979. . Keesing's Comtemporay Archives. 1983.

LA BRIÈRE. Evolution de la doctrine et de la pratique en matière de représailles. In Recueil de Cours de L'Académie de Droit International. T. 22. 1928.

LAFER, Celso. Prefácio. In ALVES, Lindgren. Os direitos humanos como tema global. São Paulo: Perspectiva, 1994.

LEBEN, C. Le contre-mesures inter-étatiques et les réactions à l'illicite dans la societé internationale. In Annuaire Française de Droit International, 1982.

NASH. Contemporay practice of the United States relating to international law. In American Journal of International Law, 1982.

Contemporay practice of the United States relating to international law. In American Journal of International Law, 1987.

Contemporay practice of the United States relating to international law. In American Journal of International Law, 1988.

PELLET, Allan. Les articles de la C.D.I. sur la responsabilité de l'état pour fait internationalement illicite suite - et fin? In Annuaire Français de droit international. T. 48. Paris: CNRS Editions, 2002.

ROBLEDO, A. Gómez. Le jus cogens international. In Recueil de Cours de L'Académie de Droit International. 172. t. III, 1981.

ROSENNE, Shabtai. Codification Revisited after 50 years. In Max Planck yearbook of United Nations law, 1998 Disponível em < www.mpil.de/shared/data/pdf/pdfmpunyb/rosenne_2.pdf > Acesso em 20 out. 2006.

ROUSSEAU, C. Chronique des faits internationaux. In Revue Générale de Droit International Public, 1960. 
Public, 1980.

Chronique des faits internationaux. In Revue Générale de Droit International Chronique des faits internationaux. In Revue Générale de Droit International Public, 1982.

Public, 1986.

Chronique des faits internationaux. In Revue Générale de Droit International

ROWE, E. T. Human Rights Issues in the UN General Assembly, 1946-1966. In The

Journal of Conflict Resolution. Vo91. 14, n. 4 Dec. 1970.

SICILIANOS, L.A.The classification of obligations and the multilateral dimensions of the relations of international responsibility. In European journal of International Law, Vol. 13 n. 5, 2002.

SIMMA, B. From bilateralism to Community Interest. In Recueil de Cours de L’Académie de Droit International. T. 250. Vol. VI, 1994.

SPINEDI, M. From One Codification to Another: bilateralism and Multilateralism in the Genesis of the Codification of the Law of Treaties and the Law of State

Responsibility. In European Journal of International Law, Vol. 13 n. 5, 2002.

TAMS, C. All's well that ends well: Comments on the ILC's articles on International Responsibility. In Zeitschrift fur auslandishes offentliches Recht und Volkerrecht, 2002.

VASAK, Karel. Le droit international des droits de l'homme. In Recueil de Cours de L'Académie de Droit International. T. 140. Vol. IV, 1974.

VINAIXA, Rosário Huesa. El derecho de la responsabilidad internacional y la Carta de las Naciones Unidas: consideraciones desde la perspectiva de las relaciones entre sistemas. In Revista Española de Derecho Internacional. Vol. 54. nº 2. Madrid: Boletín Oficial del Es tado, 2003.

\section{REFERÊNCIAS DOCUMENTAIS}

\section{LIGA DAS NAÇÕES}

LIGA DA NAÇÕES, document C.275.192.V. In p. 14 American Journal of International Law, Special Supplement, Vol. 20, 1926

LIGA DAS NAÇÕES, document C.46.M.23.1926.V. In p. 19 American Journal of International Law, Special Supplement, Vol. 20, 1926 
LIGA DAS NAÇÕES, document C.196.M.70.1927.V, in p. 15-21, American Journal of International Law, Special Supplement, Vol. 22, 1928

LIGA DAS NAÇOES, document C.75.M.69.1929.V. In ONU, Yearbook of International Law Commission, p. 223-225, 1956

LIGA DAS NAÇÕES, document C.351(c)M.145(c).1930.V. In ONU, Yearbook of International Law Commission, p. 178, 1956

ORGANIZAÇÃO DAS NAÇÕES UNIDAS (ONU)

COMISSÃO DE DIREITO INTERNACIONAL (CDI)

ONU. Document A/CN.4/ 96: International Responsibility: Report by F.V. Garcia Amador, Special Rapporteur. In Yearbook of International Law Commission, Vol. II, Nova Iorque: ONU, 1956. Disponível em <http://www.un.org/law/ilc/> Acesso em 1 de set. 2007.

ONU. Yearbook of International Law Commission, Vol. I, Nova Iorque: ONU, 1956a. Disponível em <http://www.un.org/law/ilc/> Acesso em 1 de set. 2007.

ONU. Document A/CN.4/ 106: International Responsibility: Second Report by F.V. Garcia Amador, Special Rapporteur. In Yearbook of International Law Commission, Vol. II, Nova Iorque: ONU, 1957. Disponível em <http://www.un.org/law/ilc/> Acesso em 1 de set. 2007.

ONU. Yearbook of International Law Commission, Vol. I, Nova Iorque: ONU, 1957a. Disponível em <http://www.un.org/law/ilc/> Acesso em 1 de set. 2007.

ONU. Document A/CN.4/ 111: International Responsibility: Third Report by F.V. Garcia Amador, Special Rapporteur. In Yearbook of International Law Commission, Vol. II, Nova Iorque: ONU, 1958. Disponível em <http://www.un.org/law/ilc/> Acesso em 1 de set. 2007.

ONU. Document A/CN.4/ 119: International Responsibility: Fourth Report by F.V. Garcia Amador, Special Rapporteur. In Yearbook of International Law Commission, Vol. II, Nova Iorque: ONU, 1959. Disponível em <http://www.un.org/law/ilc/> Acesso em 1 de set. 2007.

ONU. Document A/CN.4/ 125: International Responsibility: Fifth Report by F.V. Garcia Amador, Special Rapporteur. In Yearbook of International Law Commission, Vol. II, Nova Iorque: ONU, 1960. Disponível em <http://www.un.org/law/ilc/> Acesso em 1 de set. 2007.

ONU. Yearbook of International Law Commission, Vol. I, Nova Iorque: ONU, 1960a. Disponível em <http://www.un.org/law/ilc/> Acesso em 1 de set. 2007. 
ONU. Document A/CN.4/ 134: International Responsibility: Sixth Report by F.V. Garcia Amador, Special Rapporteur. In Yearbook of International Law Commission, Vol. II, Nova Iorque: ONU, 1961. Disponível em <http://www.un.org/law/ilc/> Acesso em 1 de set. 2007.

ONU. Yearbook of International Law Commission, Vol. I, Nova Iorque: ONU, 1961a. Disponível em <http://www.un.org/law/ilc/> Acesso em 1 de set. 2007.

ONU. Document A/CN.4/ 165:Summary of the discussions in various United Nations organs and the resulting decisions: working paper prepared by the Secretariat. In Yearbook of International Law Commission, Vol. II, Nova Iorque: ONU, 1964. Disponível em <http://www.un.org/law/ilc/> Acesso em 1 de set. 2007.

ONU. Document A/CN.4/ 169: Digest of the decisions of the international tribunals relating to State responsibility, prepared by the Secretariat. In Yearbook of International Law Commission, Vol. II, Nova Iorque: ONU, 1964. Disponível em <http://www.un.org/law/ilc/> Acesso em 1 de set. 2007.

ONU. Document A/CN.4/ 196: State Responsibility: note by Mr. Roberto Ago, Special Rapporteur. In Yearbook of International Law Commission, Vol. II, Nova Iorque: ONU, 1967. Disponível em <http://www.un.org/law/ilc/> Acesso em 1 de set. 2007.

ONU. Document A/CN.4/ 209: Supplement, prepared by the Secretariat to the "Digest of the decisions of the international tribunals relating to State responsibility". In Yearbook of International Law Commission, Vol. II, Nova Iorque: ONU, 1969. Disponível em <http://www.un.org/law/ilc/> Acesso em 1 de set. 2007.

ONU. Document A/CN.4/ 209: Proposals submitted to, and decisions of, various United Nations organs relating to the question of State responsibility: supplement prepared by the Secretariat to the Document A/CN.4/165. In Yearbook of International Law Commission, Vol. II, Nova Iorque: ONU, 1969. Disponível em <http://www.un.org/law/ilc/> Acesso em 1 de set. 2007.

ONU. Document A/CN.4/217 and Add. 1: First Report on State responsibility, by Mr. Robert Ago, Special Rapporteur - Review of previous work on codification of the topic of international responsibility of States. In Yearbook of International Law Commission, Vol. II, Nova Iorque: ONU, 1969. Disponível em <http://www.un.org/law/ilc/> Acesso em 1 de set. 2007.

ONU. Document A/CN.4/233: Report on State responsibility, by Mr. Robert Ago, Special Rapporteur - The origin of international responsibility. In Yearbook of International Law Commission, Vol. II, Nova Iorque: ONU, 1970. Disponível em <http://www.un.org/law/ilc/> Acesso em 1 de set. 2007.

ONU. Yearbook of International Law Commission, Vol. I, Nova Iorque: ONU, 1970a. Disponível em <http://www.un.org/law/ilc/> Acesso em 1 de set. 2007.

ONU. Document A/CN.4/217 and Add. 2: First Report on State responsibility, by Mr. Robert Ago, Special Rapporteur - Review of previous work on codification of the topic of international responsibility of States: Addendum - Annex XXIV (Restatement of the law, by the American Law Institute) In Yearbook of 
International Law Commission, Vol. II, Nova Iorque: ONU, 1971. Disponível em <http://www.un.org/law/ilc/> Acesso em 1 de set. 2007.

ONU. Document A/CN.4/246 and Add. 1-3: Third Report on State responsibility, by Mr. Robert Ago, Special Rapporteur - The internationally wrongfull act of the State, source of international responsibility. In Yearbook of International Law Commission, Vol. II, Nova Iorque: ONU, 1971. Disponível em <http://www.un.org/law/ilc/> Acesso em 1 de set. 2007.

ONU. Document A/CN.4/264 and Add. 1: Fourth Report on State responsibility, by Mr. Robert Ago, Special Rapporteur - The internationally wrongfull act of the State, source of international responsibility (continued). In Yearbook of International Law Commission, Vol. II, Nova Iorque: ONU, 1972. Disponível em <http://www.un.org/law/ilc/> Acesso em 1 de set. 2007.

ONU. Document A/10010/Rev.1: Report of the International Law Commission. In Yearbook of International Law Commission, Vol. II, Nova Iorque: ONU, 1975. Disponível em <http://www.un.org/law/ilc/> Acesso em 17 de set. 2007.

ONU. Document A/CN.4/291 and Add. 1 and 2: Fifth Report on State responsibility, by Mr. Robert Ago, Special Rapporteur - The internationally wrongfull act of the State, source of international responsibility (continued). In Yearbook of International Law Commission, Vol. II, Nova Iorque: ONU, 1976. Disponível em <http://www.un.org/law/ilc/> Acesso em 17 de set. 2007.

ONU. Yearbook of International Law Commission, Vol. I, Nova Iorque: ONU, 1976a. Disponível em <http://www.un.org/law/ilc/> Acesso em 17 de set. 2007.

ONU. Document A/CN.4/302 and Add. 1-3: Sixth Report on State responsibility, by Mr. Robert Ago, Special Rapporteur - The internationally wrongfull act of the State, source of international responsibility (continued). In Yearbook of International Law Commission, Vol. II, Nova Iorque: ONU, 1977. Disponível em <http://www.un.org/law/ilc/> Acesso em 17 de set. 2007.

ONU. Yearbook of International Law Commission, Vol. I, Nova Iorque: ONU, 1977a. Disponível em <http://www.un.org/law/ilc/> Acesso em 17 de set. 2007.

ONU. Document A/CN.4/307 and Add. 1 and 2: Seventh Report on State responsibility, by Mr. Robert Ago, Special Rapporteur - The internationally wrongfull act of the State, source of international responsibility (continued). In Yearbook of International Law Commission, Vol. II, Parte I. Nova Iorque: ONU, 1978. Disponível em <http://www.un.org/law/ilc/> Acesso em 17 de set. 2007.

ONU. Yearbook of International Law Commission. Vol. I, Nova Iorque: ONU, 1978a. Disponível em <http://www.un.org/law/ilc/> Acesso em 17 de set. 2007.

ONU. Yearbook of International Law Commission, Vol. II. Parte II. Nova Iorque: ONU, 1978b. Disponível em <http://www.un.org/law/ilc/> Acesso em 17 de set. 2007.

ONU. Document A/CN.4/318 and Add. 1-4: Eighth Report on State responsibility, by Mr. Robert Ago, Special Rapporteur. The internationally wrongfull act of the State, source of international responsibility (continued). In Yearbook of 
International Law Commission, Vol. II, Parte I. Nova Iorque: ONU, 1979. Disponível em <http://www.un.org/law/ilc/> Acesso em 17 de set. 2007.

ONU. Document A/CN.4/330: Preliminary Report on the content, forms and degrees of international responsibility (Part 2 of the draft articles on State responsibility) by William Riphagen, Special Rapporteur . In Yearbook of International Law Commission, Vol. II, Parte I. Nova Iorque: ONU, 1980. Disponível em <http://www.un.org/law/ilc/> Acesso em 17 de set. 2007.

ONU. Document A/35/10: Report of the International Law Commission. In Yearbook of International Law Commission, Vol. II, Parte II. Nova Iorque: ONU, 1980a. Disponível em <http://www.un.org/law/ilc/> Acesso em 17 de set. 2007.

ONU. Document A/CN.4/328 and Add. 1-4 : Observations and comments of Governments on chapters I, II and III of Part 1 of the draft articles on State responsibility for internationally wrongfull acts. In Yearbook of International Law Commission, Vol. II, Parte I. Nova Iorque: ONU, 1980b. Disponível em <http://www.un.org/law/ilc/> Acesso em 17 de set. 2007.

ONU. Document A/CN.4/344: Second report on the content, forms and degrees of international responsibility (part 2 of the draft articles) by Willem Riphagen, Special Rapporteur . In Yearbook of International Law Commission, Vol. II, Parte I. Nova Iorque: ONU, 1981. Disponível em <http://www.un.org/law/ilc/> Acesso em 17 de set. 2007.

ONU. Document A/CN.4/342 and Add. 1-4 : Comments of Governments on Part 1 of the draft articles on State responsibility for internationally wrongfull acts. In Yearbook of International Law Commission, Vol. II, Parte I. Nova Iorque: ONU, 1981a. Disponível em <http://www.un.org/law/ilc/> Acesso em 17 de set. 2007.

ONU. Document A/CN.4/354 and Add. 1 and 2: Third report on the content, forms and degrees of international responsibility (part 2 of the draft articles) by Willem Riphagen, Special Rapporteur . In Yearbook of International Law Commission, Vol. II, Parte I. Nova Iorque: ONU, 1982. Disponível em <http://www.un.org/law/ilc/> Acesso em 17 de set. 2007.

ONU. Yearbook of International Law Commission, Vol. II, Parte II. Nova Iorque: ONU, 1982. Disponível em <http://www.un.org/law/ilc/> Acesso em 17 de set. 2007.

ONU. Document A/CN.4/366 and Add. 1: Fourth report on the content, forms and degrees of international responsibility (part 2 of the draft articles) by Willem Riphagen, Special Rapporteur . In Yearbook of International Law Commission, Vol. II, Parte I. Nova Iorque: ONU, 1983. Disponível em <http://www.un.org/law/ilc/> Acesso em 17 de set. 2007.

ONU. Yearbook of International Law Commission, Vol. II, Parte II. Nova Iorque: ONU, 1983a. Disponível em <http://www.un.org/law/ilc/> Acesso em 17 de set. 2007.

ONU. Document A/CN.4/380: Fifth report on the content, forms and degrees of international responsibility (part 2 of the draft articles) by Willem Riphagen, Special Rapporteur . In Yearbook of International Law Commission, Vol. II, Parte I. 
Nova Iorque: ONU, 1984. Disponível em <http://www.un.org/law/ilc/> Acesso em 17 de set. 2007.

ONU. Yearbook of International Law Commission, Vol. II, Parte II. Nova Iorque: ONU, 1984a. Disponível em <http://www.un.org/law/ilc/> Acesso em 17 de set. 2007.

ONU. Document A/CN.4/389: Sixth report on the content, forms and degrees of international responsibility (part 2 of the draft articles), and "Implementation" (mise en ouvre) of international responsibility and the settlement of the disputes (part 3 of the draft articles) by Willem Riphagen, Special Rapporteur . In Yearbook of International Law Commission, Vol. II, Parte I. Nova Iorque: ONU, 1985. Disponível em <http://www.un.org/law/ilc/> Acesso em 17 de set. 2007.

ONU. Yearbook of International Law Commission, Vol. II, Parte II. Nova Iorque: ONU, 1985a. Disponível em <http://www.un.org/law/ilc/> Acesso em 17 de set. 2007.

ONU. Document A/CN.4/397 and Add. 1: Seventh report on State responsibility, by Willem Riphagen, Special Rapporteur . In Yearbook of International Law Commission, Vol. II, Parte I. Nova Iorque: ONU, 1986. Disponível em <http://www.un.org/law/ilc/> Acesso em 17 de set. 2007.

ONU. Document A/CN.4/416 and Add.l. Preliminary report on State responsibility, by Mr. Gaetano Arangio-Ruiz, Special Rapporteur. In Yearbook of International Law Commission, Vol. II, Parte I. Nova Iorque: ONU, 1988. Disponível em <http://www.un.org/law/ilc/> Acesso em 17 de set. 2007.

ONU. Yearbook of International Law Commission, Vol. II, Parte II. Nova Iorque: ONU, 1988a. Disponível em <http://www.un.org/law/ilc/> Acesso em 17 de set. 2007.

ONU. Document A/CN.4/414: Comments and observations of Governments on part 1 of the draft articles on State responsibility for internationally wrongfull acts. In Yearbook of International Law Commission, Vol. II, Parte I. Nova Iorque: ONU, 1988b. Disponível em <http://www.un.org/law/ilc/> Acesso em 17 de set. 2007.

ONU. Document A/CN.4/425 and Add.1 Second report on State responsibility, by Mr. Gaetano Arangio-Ruiz, Special Rapporteur. In Yearbook of International Law Commission, Vol. II, Parte I. Nova Iorque: ONU, 1989. Disponível em <http://www.un.org/law/ilc/> Acesso em 17 de set. 2007.

ONU. Document A/CN.4/440 and Add. 1. Third report on State responsibility, by Mr. Gaetano Arangio-Ruiz, Special Rapporteur. In Yearbook of International Law Commission, Vol. II, Parte I. Nova Iorque: ONU, 1991. Disponível em <http://www.un.org/law/ilc/> Acesso em 17 de set. 2007.

ONU. Document A/CN.4/444 and Add. 1-3. Fourth report on State responsibility, by Mr. Gaetano Arangio-Ruiz, Special Rapporteur. In Yearbook of International Law Commission, Vol. II, Parte I. Nova Iorque: ONU, 1992. Disponível em <http://www.un.org/law/ilc/> Acesso em 17 de set. 2007.

ONU. Yearbook of International Law Commission, Vol. II, Parte II. Nova Iorque: ONU, 1992a. Disponível em <http://www.un.org/law/ilc/> Acesso em 17 de set. 2007. 
ONU. Document A/CN.4/453 and Add. 1-3. Fifth report on State responsibility, by Mr. Gaetano Arangio-Ruiz, Special Rapporteur. In Yearbook of International Law Commission, Vol. II, Parte I. Nova Iorque: ONU, 1993. Disponível em <http://www.un.org/law/ilc/> Acesso em 17 de set. 2007.

ONU. Yearbook of International Law Commission, Vol. II, Parte II. Nova Iorque: ONU, 1993a. Disponível em <http://www.un.org/law/ilc/> Acesso em 17 de set. 2007.

ONU. Document A/CN. 4/461 and Add. 1-3. Sixth report on State responsibility, by Mr. Gaetano Arangio-Ruiz, Special Rapporteur. In Yearbook of International Law Commission, Vol. II, Parte I. Nova Iorque: ONU, 1994. Disponível em <http://www.un.org/law/ilc/> Acesso em 17 de set. 2007.

ONU. Yearbook of International Law Commission, Vol. II, Parte II. Nova Iorque: ONU, 1994a. Disponível em <http://www.un.org/law/ilc/> Acesso em 17 de set. 2007.

ONU. Document A/CN.4/469 and Add.1 and 2. Seventh report on State responsibility, by Mr. Gaetano Arangio-Ruiz, Special Rapporteur. In Yearbook of International Law Commission, Vol. II, Parte I. Nova Iorque: ONU, 1995. Disponível em <http://www.un.org/law/ilc/> Acesso em 17 de set. 2007.

ONU. Yearbook of International Law Commission, Vol. II, Parte II. Nova Iorque: ONU, 1995a. Disponível em <http://www.un.org/law/ilc/> Acesso em 17 de set. 2007.

ONU. Document A/CN.4/476 and Add.1. Eighth report on State responsibility, by

Mr. Gaetano Arangio-Ruiz, Special Rapporteur. In Yearbook of International Law Commission, Vol. II, Parte I. Nova Iorque: ONU, 1996. Disponível em <http://www.un.org/law/ilc/> Acesso em 17 de set. 2007.

ONU. Document A/51/10: Report of the International Law Commission. In Yearbook of International Law Commission, Vol. II, Parte II. Nova Iorque: ONU, 1996a. Disponível em <http://www.un.org/law/ilc/> Acesso em 10 de set. 2006.

ONU. Yearbook of International Law Commission, Vol. II, Parte II. Nova Iorque: ONU, 1996b. Disponível em <http://www.un.org/law/ilc/> Acesso em 17 de set. 2007.

ONU. Document A/CN.4/490 and Add.1-7. First report on State responsibility, by. Mr. James Crawford, Special Rapporteur. In Yearbook of International Law Commission, Vol. II, Parte I. Nova Iorque: ONU, 1998. Disponível em <http://www.un.org/law/ilc/> Acesso em 17 de set. 2007.

ONU. Yearbook of International Law Commission, Vol. II, Parte II. Nova Iorque: ONU, 1998a. Disponível em <http://www.un.org/law/ilc/> Acesso em 17 de set. 2007.

ONU. Document A/CN.4/488 and Add.1-3. In Yearbook of International Law Commission, Vol. II, Parte I. Nova Iorque: ONU, 1998b. Disponível em <http://www.un.org/law/ilc/> Acesso em 17 de set. 2007.

ONU. Document A/CN.4/498 and Add.1-4. Second report on State responsibility, by. Mr. James Crawford, Special Rapporteur. In Yearbook of International Law 
Commission, Vol. II, Parte I. Nova Iorque: ONU, 1999. Disponível em <http://www.un.org/law/ilc/> Acesso em 17 de set. 2007.

ONU. A/CN.4/507/Add.3. Nova Iorque: ONU, 2000a. Disponível em: < http://daccessdds-ny.un.org/doc/UNDOC/GEN/N00/540/05/PDF/N0054005.pdf?OpenElement> Acesso em 17 de set. 2007

ONU. Document A/CN.4/507/Add.4. Nova Iorque: ONU, 2000b. Disponível em: $<$ http://daccess-dds-

ny.un.org/doc/UNDOC/GEN/N00/592/24/PDF/N0059224.pdf?OpenElement> Acesso em 17 de set. 2007

ONU. Yearbook of International Law Commission, Vol. II, Parte II. Nova Iorque: ONU, 2000c. Disponível em <http://www.un.org/law/ilc/> Acesso em 17 de set. 2007.

ONU. A/CN.4/517. Nova Iorque: ONU, 2000b. Disponível em: < http://daccess-ddsny.un.org/doc/UNDOC/GEN/N01/316/56/PDF/N0131656.pdf?OpenElement> Acesso em 17 de set. 2007.

ONU. Document A/56/10: Report of the International Law Commission. In Yearbook of International Law Commission, Vol. II, Parte II. Nova Iorque: ONU, 2001a. Disponível em <http://www.un.org/law/ilc/> Acesso em 10 de set. 2006.

\section{ASSEMBLEIA GERAL}

Resoluções

ONU. A/RES/44(I). Disponível em < http://www.un.org/documents/resga.htm> . Acesso em 30 jun. 2010.

ONU. A/RES/174(II). Disponível em < http://www.un.org/documents/resga.htm>. Acesso em 30 jun. 2010.

ONU. A/RES/265(III). Disponível em < http://www.un.org/documents/resga.htm>. Acesso em 30 jun. 2010.

ONU. A/RES/377 (V). Disponível em < http://www.un.org/documents/resga.htm>. Acesso em 30 jun. 2010.

ONU. A/RES/395(V). Disponível em < http://www.un.org/documents/resga.htm $>$. Acesso em 30 jun. 2010.

ONU. A/RES/500 (V). Disponível em < http://www.un.org/documents/resga.htm Acesso em 30 jun. 2010.

ONU. A/RES/511(VI). Disponível em < http://www.un.org/documents/resga.htm $>$. Acesso em 30 jun. 2010. 
ONU. A/RES/616(VII)[A]. Disponível em < http://www.un.org/documents/resga.htm $>$. Acesso em 30 jun. 2010.

ONU. A/RES/616(VII)[B]. Disponível em < http://www.un.org/documents/resga.htm> Acesso em 30 jun. 2010.

ONU. A/RES/799(VIII). Disponível em < http://www.un.org/documents/resga.htm>. Acesso em 30 jun. 2010.

ONU. A/RES/1302(XIII). Disponível em < http://www.un.org/documents/resga.htm>. Acesso em 30 jun. 2010.

ONU. A/RES/1460(XIV). Disponível em < http://www.un.org/documents/resga.htm>. Acesso em 30 jun. 2010.

ONU. A/RES/1505(XV). Disponível em < http://www.un.org/documents/resga.htm $>$. Acesso em 30 jun. 2010.

ONU. A/RES/1597 (XV). Disponível em < http://www.un.org/documents/resga.htm>. Acesso em 30 jun. 2010.

ONU. A/RES/1662(XVI). Disponível em < http://www.un.org/documents/resga.htm>. Acesso em 30 jun. 2010.

ONU. A/RES/1686(XVI). Disponível em < http://www.un.org/documents/resga.htm>. Acesso em 30 jun. 2010.

ONU. A/RES/1761(XVII). Disponível em < http://www.un.org/documents/resga.htm $>$. Acesso em 30 jun. 2010.

ONU. A/RES/1765(XVII). Disponível em < http://www.un.org/documents/resga.htm>. Acesso em 30 jun. 2010.

ONU. A/RES/1902(XVIII). $\quad$ Disponível em http://www.un.org/documents/resga.htm>. Acesso em 30 jun. 2010.

ONU. $\quad$ A/RES/2054(XX)[A]. $\quad$ Disponível em http://www.un.org/documents/resga.htm>. Acesso em 30 jun. 2010.

ONU. A/RES/2202(XXI[A]). $\quad$ Disponível em http://www.un.org/documents/resga.htm>. Acesso em 30 jun. 2010.

ONU. A/RES/2400(XXIII). Disponível em http://www.un.org/documents/resga.htm>. Acesso em 30 jun. 2010.

ONU. A/RES/32/151. Disponível em < http://www.un.org/documents/resga.htm>. Acesso em 30 jun. 2010.

ONU. A/RES/35/37. Disponível em < http://www.un.org/documents/resga.htm> Acesso em 30 jun. 2010. 
ONU. A/RES/35/185. Disponível em < http://www.un.org/documents/resga.htm $>$. Acesso em 30 jun. 2010.

ONU. A/RES/36/39 . Disponível em < http://www.un.org/documents/resga.htm> Acesso em 30 jun. 2010.

ONU. A/RES/36/172. Disponível em < http://www.un.org/documents/resga.htm $>$. Acesso em 30 jun. 2010.

ONU. A/RES/37/184. Disponível em < http://www.un.org/documents/resga.htm>. Acesso em 30 jun. 2010.

ONU. A/RES/37/185. Disponível em < http://www.un.org/documents/resga.htm>. Acesso em 30 jun. 2010.

ONU. A/RES/52/120. Disponível em < http://www.un.org/documents/resga.htm> Acesso em 30 jun. 2010.

ONU. A/RES/56/83. Disponível em < http://www.un.org/documents/resga.htm $>$. Acesso em 30 jun. 2010.

ONU. A/RES/60/251. Disponível em < http://www.un.org/documents/resga.htm> Acesso em 30 jun. 2010.

ONU. A/RES/65/19. Disponível em < http://www.un.org/documents/resga.htm>. Acesso em 30 dez. 2010.

Demais Documentos

ONU. A/51/264. Disponível em < http://www.un.org/en/documents/> Acesso em 30 jun. 2010.

ONU. A/57/387. Disponível em < http://www.un.org/en/documents/> Acesso em 30 jun. 2010.

ONU. A/52/40 [VOL.1]. Disponível em < http://www.un.org/en/documents/> Acesso em 30 jun. 2010.

ONU. A/64/40 [VOL.1]. Disponível em < http://www.un.org/en/documents/> Acesso em 30 jun. 2010.

ONU.A/C.6/236

ONU. A/C.6/31/SR.21

ONU. A/C.6/31/SR.30

ONU. A/C.6/37/SR.46

ONU. A/C.6/37/SR.46 


\section{ONU. A/C.6/39/SR.39}

ONU. A/C.6/40/SR.24

ONU. A/C.6/40/SR.27

ONU. A/C.6/51/SR.34. Disponível em < http://www.un.org/en/documents/> Acesso em 30 jun. 2010.

ONU. A/C.6/51/SR.36 Disponível em < http://www.un.org/en/documents/> Acesso em 30 jun. 2010.

ONU. A/C.6/55/SR.14 Disponível em < http://www.un.org/en/documents/> Acesso em 30 jun. 2010.

ONU. A/C.6/55/SR.15 Disponível em < http://www.un.org/en/documents/> Acesso em 30 jun. 2010.

ONU. A/C.6/55/SR.16 Disponível em < http://www.un.org/en/documents/> Acesso em 30 jun. 2010.

ONU. A/C.6/55/SR.17 Disponível em < http://www.un.org/en/documents/> Acesso em 30 jun. 2010.

ONU. A/C.6/55/SR.18 Disponível em < http://www.un.org/en/documents/> Acesso em 30 jun. 2010.

ONU. A/C.6/56. SR.11 Disponível em < http://www.un.org/en/documents/> Acesso em 30 jun. 2010.

ONU. A/C.6/56/SR.14 Disponível em < http://www.un.org/en/documents/> Acesso em 30 jun. 2010.

ONU. A/CN.4/515 Disponível em < http://www.un.org/en/documents/> Acesso em 30 jun. 2010.

ONU. A/CONF.157/23 Disponível em < http://www.un.org/en/documents/> Acesso em 30 jun. 2010.

\section{CONSELHO DE SEGURANÇA}

Resoluções

ONU. Security Council Resolution 82 (1950). S/1501. Disponível em: http://www.un.org/Docs/sc/unsc_resolutions.html. Acesso em 30 jun. 2010.

ONU. Security Council Resolution 418 (1977). Disponível em: http://www.un.org/Docs/sc/unsc_resolutions.html. Acesso em 30 jun. 2010.

ONU. Security Council Resolution 181(1963). S/5386. Disponível em: http://www.un.org/Docs/sc/unsc_resolutions.html. Acesso em 30 jun. 2010. 
Demais Documentos

ONU. S/1999/1257. Disponível em < http://www.un.org/en/documents/> Acesso em 30 jun. 2010.

ONU. S/21444. Disponível em < http://www.un.org/en/documents/> Acesso em 30 jun. 2010.

ONU. S/21449. Disponível em < http://www.un.org/en/documents/> Acesso em 30 jun. 2010.

ONU. S/23500. Disponível em < http://www.un.org/en/documents/> Acesso em 30 jun. 2010.

ONU. SG/SM/7136 Disponível em < http://www.un.org/en/documents/> Acesso em 30 jun. 2010.

\section{DEMAIS ÓRGÃOS}

ONU. Economic and Social Council Resolution 1985-17. Disponível em: http://ap.ohchr.org/documents/E/ECOSOC/resolutions/E-RES-1985-17.doc. Acesso em: 15 jun. 2008.

ONU. Resolução 1235 de 1967 do Conselho Econômico e Social das Nações Unidas. apud, TRINDADE, A proteção internacional dos Direitos Humanos. Fundamentos Jurídicos e Instrumentos Básicos. São Paulo: Saraiva, 1991.

ONU. Economic and Social Council Resolution 1503, 1970. Disponível em: ap.ohchr.org/documents/E/ECOSOC/resolutions/1970-1503.doc. Acesso em: 22 out 2010

ONU. Resolution 5/1 of the Human Rights Council. Disponível em:

http://ap.ohchr.org/documents/E/HRC/resolutions/A_HRC_RES_5_1.doc. Acesso em 5 de jun. 2008.

ONU. Resolution 6/4 of the Human Rights Council. Disponível em:

http://www2.ohchr.org/english/bodies/hrcouncil/. Acesso em 5 de jun. 2010.

ONU. Manual of the United Nations Human Rights Special Procedures. Disponível em: http://www2.ohchr.org/english/bodies/chr/special/docs/Manual_English_23jan.doc. Acesso em 5 de jun. 2008.

\section{ONU. Human Rights Commission Resolution 1998-11.}

ONU. E/C.12/1997/8. Disponível em < http://www.un.org/en/documents/> Acesso em 30 jun. 2010. 
ONU. United Nations Yearbook, 1954. Disponível em < http://unyearbook.un.org/> Acesso em: 11 set. 2010.

ONU. United Nations Yearbook, 1980. Disponível em < http://unyearbook.un.org/> Acesso em: 11 set. 2010.

\section{DEMAIS ORGANIZAÇÕES INTERNACIONAIS}

\section{ORGANIZAÇÃO DOS ESTADOS AMERICANOS (OEA)}

Segunda Conferência Internacional dos Estados Americanos. Convenção relativa ao Direito dos Estrangeiros de 1902. apud ONU, Yearbook of the International Law Commission, 1956.

Sétima Conferência Internacional dos Estados Americanos. Resolução sobre "Responsabilidade internacional do Estado" de 1933. apud ONU, Yearbook of the International Law Commission, 1956.

OEA. Resolução sobre "Princípios do Direito Internacional regendo a Responsabilidade do Estado" de 1954. apud ONU, Yearbook of the International Law Commission, p. 179, 1956

OEA. Resolução sobre "Principles of International Law governing the Responsibility of the State", OEA, Caracas, 1954, apud ONU, Yearbook of the International Law Commission, p. 179, 1956

OEA. Principles of international law that govern the responsibility of the State in the opinion of the United States of America, OEA, Washington, 1965, apud ONU, Yearbook of the International Law Commission, p. 154, 1969

OEA. Principles of international law that govern the responsibility of the State in the opinion of Latin American countries, OEA, Washington, 1962, apud ONU, Yearbook of the International Law Commission, p. 153, 1969

OEA. Resolução sobre a República Dominicana de 1947. Disponível em: http://www.oas.org/consejo/MEETINGS\%200F\%20CONSULTATION/Actas/Acta\%2 06.pdf. Acesso em: 30 ago. 2010.

\section{OUTRAS ORGANIZAÇÕES}

SECOND ALL-AFRICAN PEOPLES CONFERENCE. Resolution on South Africa, Tunis, 1960, disponível em: http://publishing.cdlib.org/ucpressebooks/view?docId=ft5x0nb3tg\&chunk.id=d0e14659 \&toc.depth=100\&toc.id=d0e14599\&brand=ucpress. Acesso em: 20 out. 2010 
OUA. Resolução sobre a África do Sul e Portugal. Disponível em http://www.africaunion.org/root/AU/Documents/Decisions/decisions_fr.htm. Acesso em 22 out. 2010.

UE. EC Bull, 1977, n.6

UE. EC BULL, 2002, n. 3

UE. OJ L 122/29. Disponível em: http://eur-lex.europa.eu/en/index.htm. Acesso em 22 out. 2010.

UE. OJ L 134/2 Disponível em: http://eur-lex.europa.eu/en/index.htm. Acesso em 22 out. 2010

UE. OJ L 143/1 Disponível em: http://eur-lex.europa.eu/en/index.htm. Acesso em 22 out. 2010.

UE. OJ L 190/3 Disponível em: http://eur-lex.europa.eu/en/index.htm. Acesso em 22 out. 2010.

UE. Relatório do Comitê de Relações Econômicas Externas da Comunidade Europeia do ano de 1982-1983, conhecido como Relatório Seller (Document 1-83/82, 1982-83)

UE. 2002/145/CFSP

ESTADOS UNIDOS (US)

US. Dep. of State Bulletin, p. 1004, dec. 1950

US. Dep. of State Bulletin, p. 2-3, fev. 1982

US. Executive Order 12.722

US. Executive Order 13047

US. Executive Order 13067

US. Executive Order 13288

US. Public Law 95-435 Stat. 1051

US. Public Law 108-61.

US. Public Law 108-175.

INSTITUIÇÕES PRIVADAS 
AMERICAN INSTITUTE OF INTERNATIONAL LAW. Project no. 15: Responsibility of Governments apud ONU, Yearbook of the International Law Commission, p. 227, 1956

AMERICAN INSTITUTE OF INTERNATIONAL LAW. Project no. 16: Diplomatic Protection apud ONU, Yearbook of the International Law Commission, p. 227, 1956

DEUTSCHE GESELLSCHAFT FUR VOLKERRECHT. Draft convention on the responsibility of States for injuries caused in their territory to the person or property of aliens. apud ONU, Yearbook of the International Law Commission, p. 149, 1969

HARVARD. Draft convention on "responsibility of States for da mage done in their territory to the person or property of foreigners" 1929

HARVARD. Draft convention on "responsibility of States for damage done in their territory to the person or property of foreigners" 1969

INSTITUT DE DROIT INTERNATIONAL, Resolução de 1927 sobre a "Responsabilidade Internacional dos Estados em razão dos danos causados em seu território às pessoas e aos bens estrangeiros Lausanne, 1927, disponível em : http://www.idi-iil.org/idiF/resolutionsF/1927_lau_05_fr.pdf

INSTITUT DE DROIT INTERNATIONAL, Resolução sobre represálias de 1934, disponível em: http://www.idi-iil.org/idiF/resolutionsF/1934_paris_03_fr.pdf. Acesso em: 23 out. 2010

INSTITUTO HISPANO-LUSO-AMERICANO DE DERECHO INTERNACIONAL. Resolution La Responsabilidad del Estado en los daños causados a extranjeros, Quito, 1957, disponível em: http://www.ihladi.org/resoluciones_III.pdf

JAPANESE BRANCH OF THE INTERNATIONAL LAW ASSOCIATION. KOKUSAIHO GAKKWAI. Draft code of international law. apud ONU, Yearbook of the International Law Commission, p. 141, 1969

JURISPRUDÊNCIA

CORTE PERMANENTE DE JUSTIÇA INTERNACIONAL

CPJI. Sentença do Caso Wimbledon de 1923. Disponível em: http://www.icj-cij.org/. Acesso em 23 ago. 2010.

CPJI. Sentença do Caso da Usina Chorzow de 1927. Disponível em: http://www.icjcij.org/. Acesso em 23 ago. 2010.

CPJI. Sentença do caso Jurisdição Territorial da Comissão Internacional do Rio Oder de 1929. Disponível em: http://www.icj-cij.org/. Acesso em 23 ago. 2010. 
CPJI. Sentença do Caso sobre o Tráfico Ferroviário entre Lituânia e Polônia de 1931. Disponível em: http://www.icj-cij.org/. Acesso em 23 ago. 2010.

CPJI. Sentença do Caso Fosfatos em Marrocos de 1938. Disponível em: http://www.icj-cij.org/. Acesso em 23 ago. 2010.

\section{CORTE INTERNACIONAL DE JUSTIÇA}

CIJ. Sentença do Caso Estreito de Corfu de 1949. Disponível em: http://www.icjcij.org/. Acesso em 23 ago. 2010.

CIJ. Parecer Consultivo de 18 de julho de 1950, sobre os Tratados de paz entre Bulgária, Hungria e Romênia Disponível em: http://www.icj-cij.org/. Acesso em 23 ago. 2010.

CIJ. Parecer Consultivo a respeito da possibilidade de reservas à Convenção de Genocídio de 1949 de 1951. Disponível em: http://www.icj-cij.org/. Acesso em 23 ago. 2010.

CIJ. Opinião Dissidente dos juízes Guerrero, Mc Nair, Read e Hsu Mo no Parecer Consultivo a respeito da possibilidade de reservas à Convenção de Genocídio de 1949 de 1951. Disponível em: http://www.icj-cij.org/. Acesso em 23 ago. 2010.

CIJ. Sentença do caso dos pesque iros Ingleses e Noruegueses de 1951. Disponível em: http://www.icj-cij.org/. Acesso em 23 ago. 2010.

CIJ. Sentença do Caso Monetary Gold de1954. Disponível em: http://www.icjcij.org/. Acesso em 23 ago. 2010.

FITZMAURICE. Discurso representando o Reino Unido no Caso Monetary Gold (Oral Proceedings) de1954. Disponível em: http://www.icj-cij.org/. Acesso em 23 ago. 2010.

CIJ. Sentença Preliminar do Caso South West Africa de 1962. Disponível em: http://www.icj-cij.org/. Acesso em 23 ago. 2010.

CIJ. Sentença do Caso South West Africa de 1965. Disponível em: http://www.icjcij.org/. Acesso em 23 ago. 2010.

CIJ. Voto Dissidente do juiz Jessup no Caso South West Africa de 1965. Disponível em: http://www.icj-cij.org/. Acesso em 23 ago. 2010.

CIJ. Sentença do Caso Plataforma Continental do Mar do Norte de 1969. Disponível em: http://www.icj-cij.org/. Acesso em 23 ago. 2010.

CIJ. Voto Dissidente dos juízes Tanaka e Sorensen no Caso Plataforma Continental do Mar do Norte de 1969. Disponível em: http://www.icj-cij.org/. Acesso em 23 ago. 2010 .

CIJ. Sentença do Caso Barcelona Traction, 1970. Disponível em: http://www.icjcij.org/. Acesso em 23 ago. 2010. 
CIJ. Parecer Consultivo sobre as consequências jurídicas para os Estados da presença continuada da África do Sul na Namíbia de 1970. Disponível em: http://www.icj-cij.org/. Acesso em 23 ago. 2010.

CIJ. Sentença do Caso sobre os funcionários diplomáticos e consulares dos Estados Unidos no Teerã de 1980. Disponível em: http://www.icj-cij.org/. Acesso em 23 ago. 2010 .

CIJ. Sentença do caso do Golfo do Maine de 1984. Disponível em: http://www.icjcij.org/. Acesso em 23 ago. 2010.

CIJ. Sentença do caso sobre as Atividades Militares e Paramilitares na e contra a Nicarágua de 1986. Disponível em: http://www.icj-cij.org/. Acesso em 23 ago. 2010.

CIJ. Sentença do Caso Timor Leste de 1991. Disponível em: http://www.icj-cij.org/. Acesso em 23 ago. 2010.

CIJ. Voto Dissidente do Juiz Weeramentry no Caso Timor Leste de 1991. Disponível em: http://www.icj-cij.org/. Acesso em 23 ago. 2010.

CIJ. Sentença do Caso do Projeto Gabcíkovo-Nagymaros de 1997. Disponível em: http://www.icj-cij.org/. Acesso em 23 ago. 2010.

\section{CORTE INTERAMERICANA DE DIREITOS HUMANOS}

CIDH. La Colegiación Obligatoria de Periodistas (Arts. 13 y 29 Convención Americana sobre Derechos Humanos). Opinión Consultiva OC-5/85 del 13 de noviembre de 1985. Serie A No. 5. Disponível em: <http://www.corteidh.or.cr/> Acesso em 23 ago. 2010.

CIDH. Voto separado Cançado Trindade Corte IDH. Caso Blake Vs. Guatemala. Reparaciones y Costas. Sentencia de 22 de enero de 1999. Serie C No. 48 Disponível em: <http://www.corteidh.or.cr/> Acesso em 23 ago. 2010.

\section{TRIBUNAIS ARBITRAIS}

TRIBUNAL ARBITRAL. Sentença do Caso da Pesca no Atlântico Norte de 1910. In UNRIAA, Vol. IX, p. 186. Disponível em: <http://www.un.org/law/riaa/> Acesso em 23 ago. 2010.

TRIBUNAL ARBITRAL. Sentença do Caso Naulilaa de 1928. In UNRIAA, Vol. IV, p. 1026. Disponível em: <http://www.un.org/law/riaa/> Acesso em 23 ago. 2010.

TRIBUnAl ARBITRAL. Sentença do Caso Cysne de 1930. In UNRIAA, Vol. IV, p. 1057. Disponível em: <http://www.un.org/law/riaa/> Acesso em 23 ago. 2010. 
TRIBUNAL ARBITRAL. Sentença do Caso do Acordo sobre Serviço Aéreo de 27 de março de 1946, de 1978. In UNRIAA, Vol. XVIII p. 483. Disponível em: <http://www.un.org/law/riaa/> Acesso em 23 ago. 2010.

TRIBUNAL ARBITRAL. Sentença do caso Rainbow Warrior, entre França e Nova Zelândia de 1990. InUNRIAA, Vol XX, p. 251. Disponível em: <http://www.un.org/law/riaa/> Acesso em 23 ago. 2010.

TRIBUNAL ARBITRAL. Sentença do Caso sobre os bens britânicos no Marrocos espanhol de 1925. In UNRIAA, Vol. II, p. 641. Disponível em: <http://www.un.org/law/riaa/> Acesso em 23 ago. 2010.

TRIBUNAL ARBITRAL. Sentença do Caso Dickson Car Wheel Company de 1931. In UNRIAA, Vol. IV, p. 678. Disponível em: <http://www.un.org/law/riaa/> Acesso em 23 ago. 2010.

TRIBUNAL ARBITRAL. Sentença do Caso International Fisheries Company de 1931. In UNRIAA, Vol. IV, p. 701. Disponível em: <http://www.un.org/law/riaa/> Acesso em 23 ago. 2010.

Tribunal ARBITRAL. Sentença do Caso Armstrong Cork Company de 1953. In UNRIAA, Vol. XIV, p. 163. Disponível em: <http://www.un.org/law/riaa/> Acesso em 23 ago. 2010.

\section{TRATADOS INTERNACIONAIS}

TRATADOS BILATERAIS

CANADÁ.URSS. Acordo sobre Relações Mútuas de Pesca de 1976. In UNTS, Vol. 1132, p. 139.

NOVA ZELÂNDIA. URSS. Acordo de Pesca de 1978. In UNTS, vol. 1151, p. 278.

ARGENTINA. COMUNIDADE EUROPEIA. Acordo relativo a produtos têxteis. In OJ 1979, L/298/2.

ARGENTINA. COMUNIDADE EUROPEIA. Acordo relativo a carneiros e cordeiros. In OJ 1980, L/275/14

FRANÇA. REPÚBLICA CENTRO AFRICANA. Acordo relativo à Assistência Técnica Militar. In UNTS, vol. 821, p. 266.

US. POLÔNIA. Acordo relativo à Pesca nas Costas dos Estados Unidos. In UNTS, vol. 1068 , p. 3.

US. POLÔNIA. Tratado bilateral de aviação civil de 1972. In UNTS, p. 206, Vol. 1279.

US.URSS. Tratado bilateral de aviação civil de 1966. In ILM, p. 82, 1967. 
US. ÁFRICA DO SUL. Tratado bilateral de aviação de 1947. In UNTS, p. 233, Vol. 66.

US. PANAMÁ. Tratado do Canal do Panamá. In UNTS, p. 3, Vol. 1280.

TRATADOS MULTILATERAIS

ACP. COMUNIDADE EUROPEIA. Convenção de Lomé. In OJ 1976 L/25/1.

COMUNIDADE EUROPEIA. GRÉCIA. Acordo de Associação com o Estado grego. In OJ 1963 294/63.

COMUnidade EUROPEIA. GRÉCIA. Protocolo de Ajuda Financeira. In OJ 1963 $340 / 63$

CONSELHO DA EUROPA. Convenção para a proteção dos Direitos do Homem e das Liberdades Fundamentais, 1959. Disponível em: http://conventions.coe.int/. Acesso em 15 jun. 2009

GENEBRA. Acordo Geral sobre Tarifas Aduaneiras e Comércio.

GENEBRA. Convenção relativa ao Tratamento dos Prisioneiros de Guerra de 1929. Disponível em: http://www.icrc.org/ihl.nsf/FULL/305?OpenDocument. Acesso em: 22 out 2010

GENEBRA. Protocolo Adicional à Convenção de Genebra de 1949 (Protocolo I de 1977 Genebra, 1977. Disponível em: http://www.icrc.org/ihl.nsf/7c4d08d9b287a42141256739003e636b/f6c8b9fee14a77fdc1 25641e 0052b079. Acesso em: 22 out 2010.

OEA. Carta da Organização dos Estados Americanos. . In SALIBA, A. Legislação de Direito Internacional. São Paulo: Editora Rideel, 2006.

OEA. Convenção Americana sobre Direitos Humanos. . In SALIBA, A. Legislação de Direito Internacional. São Paulo: Editora Rideel, 2006.

ONU. Carta das Nações Unidas. In SALIBA, A. Legislação de Direito Internacional. São Paulo: Editora Rideel, 2006.

ONU. Convenção contra a tortura e outros tratamentos ou penas cruéis, desumanos ou degradantes.

ONU. Convenção de Viena sobre o Direito dos Tratados. In SALIBA, A. Legislação de Direito Internacional. São Paulo: Editora Rideel, 2006.

ONU. Convenção sobre a eliminação de todas as formas de discriminação contra as mulheres. Disponível em: <http://www2.ohchr.org/english/law/index.htm\#core> Acesso em: 20 set. 2010. 
ONU. Convenção sobre a eliminação de todas as formas de discriminação racial. Disponível em: <http://www2.ohchr.org/english/law/index.htm\#core> Acesso em: 20 set. 2010.

ONU. Convenção sobre a proteção dos direitos de todos os trabalhadores migrantes e fuas famílias. Disponível em: <http://www2.ohchr.org/english/law/index.htm\#core> Acesso em: 20 set. 2010.

ONU. Convenção sobre a proteção de todas as pessoas dos desaparecimentos forçados. Disponível em: <http://www2.ohchr.org/english/law/index.htm\#core> Acesso em: 20 set. 2010.

ONU. Convenção sobre os direitos das crianças. Disponível em: <http://www2.ohchr.org/english/law/index.htm\#core> Acesso em: 20 set. 2010.

ONU. Convenção sobre o direito das pessoas portadoras de deficiência. Disponível em: <http://www2.ohchr.org/english/law/index.htm\#core> Acesso em: 20 set. 2010.

ONU. Pacto Internacional sobre Direitos Civis e Políticos. In SALIBA, A. Legislação de Direito Internacional. São Paulo: Editora Rideel, 2006.

ONU. Pacto Internacional sobre Direitos Econômicos, Sociais e Culturias. In SALIBA, A. Legislação de Direito Internacional. São Paulo: Editora Rideel, 2006.

BIBLIOGRAFIA CONSULTADA

OBRAS GERAIS

ACCIOLY, Hildebrando. Tratado de direito internacional público. São Paulo: IBGE, 1956.

AL-HIL ÃLI, M.T. KHÃN, M.M. Interpretation of the meanings of the noble Qur'an in the English language. Riyadh, Darussalam, 1996.

ANZILOTTI, Dionísio. Corso di diritto internazionale. Vol. 1. Roma: Athenaeum. 1928.

ARANGIO-RUIZ, Vincenzo. Instituzioni di Diritto Romano. Napoles: Casa Editrice Dott. Eugenoi Jovene, 1952.

ARISTÓTELES. Política. São Paulo: Ed. Martin Claret, 2004.

AZEVEDO, Álvaro Villaça. Teoria geral das obrigações. $4^{\mathrm{a}}$ ed. São Paulo: Editora Revista dos Tribunais, 1987.

BEDERMAN, David J. International law in antiquity. Cambridge: Cambridge University Press, 2001. 
BOBBIO, Norberto. A era dos direitos. Rio de Janeiro: Editora campus, 1996.

CHENG, Bin. General Principles of as applied by international courts and and tribunals. Cambridge: Grotius Publications limited, 1987.

CICERO. Da República. in Os Pensadores. São Paulo: Abril, 1985.

COLOMBO, Leonardo A. Culpa aquiliana. T.1 e 2. $3^{\text {a }}$ ed. Buenos Aires: La ley, 1965. CONFÚCIO. Os analectos. Porto Alegre: L\&PM, 2007.

CORRAL, D. Ildefonso L. Garcia. Cuerpo del derecho civil romano. Barcelona: Jaime Molinas Editor, 1889.

CUQ, Édouard. Les Institutions Juridiques des Romains. T. I. Paris: Librairie générale de droit e jurisprudence, 1904.

DIAS, José de Aguiar. Da responsabilidade civil. Vol. 1.10 ed. Rio de Janeiro: Editora Forense, 1997.

DIPLA, Haritini. La responsabilité de l'état pour violation des droits de l' homme:problèmes d'imputation. Paris: Pédone, 1994.

DOXEY, M. Economic Sanctions ans international enforcement. Oxford: Oxford University Press, 1971.

DUNHAM, S. A. History of Spain and Portugal. Vol. IV. Londres: John Taylor, 1832.

DUPUY, Pierre-Marie. Droit international public. Paris: Dalloz, 2000.

FERRARI Bravo. L. Responsabilità civile e diritto internazionale privado. Napole: Jovene, 1973.

FERREIRA FILHO, M. G. Direitos Humanos Fundamentais. São Paulo: Ed. Saraiva, 2007.

FIGUEIREDO, A.P. A Santa Bíblia. Londres: Bagster e thoms, 1828.

FORCHIELLI, Paolo. Responsabilitá Civile. Padova: Antonio Milani, 1968.

GAIUS. Gaius institutes. Paris: Société d'édition Les belles lettres, 1950.

GENTILI, Alberico. O direito de guerra. Ijuí: Editora Unijuí, 2005.

GIBON, Edward. The history of the decline and fall of the Roman Empire. Londres: T. Caldell, Strand, 1917.

GIRARD, Paul Frédéric. Manuel Élémentaire de Droit Romain. Paris: Librairie nouvelle de droit e jurisprudence, 1906.

GOMES, Máximo Pacheco. El Concepto de Derechos Fundamentales de la Persona Humana. Liber Amicorum, Héctor Fix-Zamudio / Corte Interamericana de Derechos 
Humanos, presentado por César Gaviria -Volumen I. - San José, Costa Rica: Corte Interamericana de Derechos Humanos, Unión Europea, 1998.

GUGGENHEIM, Paul. Traité de Droit international public. Gèneve: Librairie de l'Université, Georg e Cie S. A., 1954.

HEDEMANN, J. W. Derecho de obligaciones. Vol. 3. Madrid: Editorial Revista de Derecho Privado, 1958.

ISHAY, Micheline R. The history of human rights: from ancient times to the globalization era. Berkley: University of California Press, 2004.

JENKS, Edouard. Digeste de Droit Civil Anglais. Paris: Librairie Générale de Droit et de Jurisprudence, 1923.

JESSUP, Philip C. A modern law of nations. Nova Iorque: The Macmillian Company, 1948.

JHERING, R. Von. Études complementaires de l"esprit du droit romain. Vol. I. De la faute en Droit Privé. Paris: A. Maresc, Aîne, Éditeur, 1880.

JORGENSEN, N. The responsibility of States for international crimes. Oxford: Oxford University Press, 2003.

JOURDAIN, Patrice. Les principes de la responsabilité civile. Paris: Daloz, 1996.

JUSTINIANO, Flavius P. S. Institutas do Imperador Justiniano. Bauru: EDIPRO, 2001.

KELSEN, Hans. Princípios de derecho internacional público. Buenos Aires: El Atheneo, 1965.

LAFER,C. A reconstrução histórica dos direitos humanos:um diálogo com o pensamento de Hannah Arendt. São Paulo: Companhia das Letras, 2001.

LOPES, Othon de Azevedo. Responsabilidade Jurídica: Horizontes, Teoria e Linguagem. São Paulo: Quartier Latin, 2006.

LEHR, Ernest. Éléments de droit civil anglais. Paris: Laros et Foral, 1885.

LIMA, Alvino. Culpa e risco. $2^{\text {a }}$ ed. São Paulo: Editora Revista dos Tribunais, 1998.

MANN, F. A. Studies in international law. Oxford: Clareton Press, 1973.

MARTON, G. Les fondements de la responsabilité civile. Paris: Recueil de Sirey, 1938.

MAZEAUD, Henri. MAZEAUD, Leon. Traité théorique et pratique de la responsabilité civile délictuelle et contractuelle. T. 1. Paris: Recueil de Sirey, 1938.

MIRANDA, Pontes de. Tratado de Direito Privado. Parte Especial. T. 53. Rio de Janeiro: Editor Borsoi, 1972. 
PLATÃO. Diálogos. Rio de Janeiro: Ediouro,s.d.

PRADIER-FODÉRÉ. Traité de Droit international public. Paris: G. Pedone-Lauriel, 1885.

RICUPERATI,G. Cosmopolitismo. In. BOBBIO, N. MATTEUCCI, N., PASQUINO, G. Dicionário de Política. Brasília: Ed. UNB, 1994.

ROBERT, J. Droits de l'homme et libertés fondamentales. Paris : Montchrestien, 1993.

ROTONDI, Giovanni. Scritti Giuridici. Vol. II. Milão: Ulrico Hoelpli, 1922.

SAVATIER, Rene. Traité de la responsabilité civile en droit français. T.1. Paris: Librairie Générale de Droit et de Jurisprudence, 1939.

SAVIGnY, M. F. C. Traité de Droit Romain. T. 5. Paris: Librairie de Firmin Didot Frères, 1858.

SHELTON, Dinah. Remedies in International Human Rights Law. Oxford: Oxford University Press, 2006.

SICILIANOS. FORLATI, L.P. Economic Sanctions in International Law. Leiden: M. Nijhoff, 2004.

SOARES, Guido Fernando Silva. As responsabilidades no Direito Internacional do Meio Ambiente. Campinas: Komedi Editores, 1995.

SÓFOCLES. Antígona. Porto Alegre: L\&PM, 2009.

SPINEDI, M. SIMMA, Bruno. United Nations Codification of State Responsability. Nova Yorque: Oceana Public., 1987.

TYTLER, A. F. NARES, E. Elements of general history, ancient and modern. New Hamshire: John F. Brown, 1839.

TRUYOL. Los Derechos Humanos. Madri : Editorial Tecnos, 1974.

TUNKIN, G. I. Droit international public:problèmes théoriques. Paris: A. Pédone, 1965.

WEILER, J. CASSESE, A. SPINEDI, M. International Crimes of States - A Critical Analysis of the ILC's draft article on State Responsibility. Berlin:Gruyter, 1989.

WEILER, CASSESE, SPINEDI, International crimes of State : a critical analysis of the ILC's draft article 19 on State responsibility. New York : W. de Gruyter, 1989.

WENGLER, Wilhelm. Responsabilidades por acto ilícito em direito internacional privado:tentativa. Coimbra: Atlântida, 1974. 
ACCIOLY, Hildebrando. Principes Généraux de la responsabilité internatinale d'après la doctrine et la jurisprudence. In Recueil des Cours. T.96. Vol. I. Leyde: A.W. Sijthoff, 1960.

ALLAND, D. Countermeasures of General Interest. In European journal of International Law, Vol. 13 n. 5, 2002.

ARANGIO-RUIZ, Gaetano. State fault and the forms and degrees of interntional responsibility: Questions of attribution and relevance. In Le droit international au service de la paix, de la justice et du développement. Mélanges Michel Virally. Paris: Editons. A. Pedone, 1991.

Counter-measures and dispute Settlement. The current debate within the ILC. In European Journal of International Law, n. 5, 1994.

BOWET, Derek William. Treaties and State responsibility. In Le droit international au service de la paix, de la justice et du développement. Mélanges Michel Virally. Paris: Editons. A. Pedone, 1991.

CASSESE. A. A Follow-Up: Forcible Humanitarian Countermeasures and Opinio Necessitatis. In European journal of International Law, Vol. 10, n.4, 1999

COHN. G. Responsabilité internationale. In Recueil des Cours. T. 68. Vol. 2. Paris: Librairie du Recueil Sirey, 1939.

CONDORELLI, Luigi. Imputation à l'Etat d'un fait internationalement illicite. In Recueil des Cours. T. 189. Vol. 6. Dordrecht: Martinus Nijhoff Publishers, 1984.

Les règlements des différends en matière de responsabilité internationale des Etats : quelques remarques candides sur le débat à la CDI. In European Journal of International Law, n.5, 1994.

CRAWFORD, James. The ILC's Draft Articles on State Responsibility: Toward Completion of a Second Reading. In American Journal of International Law, 2000.

PEEL, Jacqueline. OLLESON, Simon. The ICL's Articles on Responsibility of States for Internationally Wrongful Acts: Completion of the Second Reading. In European Journal of International Law, vol. 12, 2001. Disponível em < http://lcil.law.cam.ac.uk/ILCSR/Statresp.htm> Acesso em 20 set. 2006.

CZAPLINSKI, W. UN Codification of Law of State Responsibility. In Archiv des Völkerrechts, Bd. 41, 2003.

DAMROSCH. Enforcing International Law through Nonforcible Measures. In Recueil des Cours. T. 269. Dordrecht: Martinus Nijhoff Publishers, 1997.

DAVIS, L. ENGERMAN, S. Sanctions: Neither war nor peace. in The Journal of Economic Perspectives, Vol. 17, No. 2, 2003. 
DE GUTTRY, A. Some recent cases of unilateral countermeasures an the problem of their lawfulness in international law. In Italian Yearbook of International Law, vol. 7, 1986-1987.

DOMINICE, Christien. De la réparation constructive du préjudice immateriel souffert par un État. In El derecho internacional en un mundo en transformation. En homenaje al professor Eduardo Jimenez de Aréchaga. Montevideo:Fundacion de Cultura Universitaria, 1992.

DUPUY, Pierre-Marie. Observations sur la pratique récente des «sanctions' de l'illicite. In Revue Général de Droit International Publique, 1983.

FOCARELLI. Le contremesure Pacifiche Colletive e la Nozione de Oblighi Erga Omnes. In Rivista di diritto internazionale, 1993.

FRANK, T.M. On Proportionality of Countermeasures in International Law. In American Journal of International Law, 102, 2008.

FREEMAN. A.V. Responsability of States for Unlawful Acts of their Armed Forces. In Recueil des Cours. T. 88 Leyde: A.W. Sijthoff, 1956.

GARCIA AMADOR, Francisco. State Responsability. In Recueil des Cours. T. 94. Vol. 2. Leyde: A.W. Sijthoff, 1958.

GARCIA, Márcio P.P. Responsabilidade internacional do Estado: atuação da CDI. In Revista de Informação Legislativa. n 162. Brasília: Senado Federal, 2004.

HUTCHINSON. Solidarity and Breaches of Multilateral Treaties. in British Yearbook of International Law, 1989.

ITO, M. Le problème des droits de l'homme dans les autres traditions asiatiques. In Enseignement des droits de l'homme. Vol. IV. Unesco : Paris, 1985.

KATSELLI, Elena. Countermeasures and the Non-Injured State in International Law. In 2004 Florence Founding Conference of European Society of international law. Disponível em: http://www.esil-sedi.eu/fichiers/en/Katselli_874.pdf. Acesso em: 03.03, 2009.

KOSKENNIEMI. Solidarity measures: State Responsibility as a New International order? In British Yearbook of International Law, 2001.

LO. Chung-Shu. Le droits de l'homme dans La tradition chinoise. In Enseignement des droits de l'homme. Vol. IV. Unesco : Paris, 1985.

MARTÍN, Dolores. Problemática en torno a las fuentes en el derecho romano clásico. Referencia especial a Publio Iuvencio Celso-Hijo. In Anales de Derecho. $\mathrm{n}^{\circ}$ 23, Murcia: Universidade de Murcia, 2005.

PUGLIESE, G. Appunti per una storia della protezione dei diritti umani.in Rivista trimestrale di diritto e procedura civile. Ano 43 n.3. Milão: Dott. A. Giuffrè, 1989. 
PUNTAMBEKAR, S. V. La conception hindoue des droits de l'homme. In Enseignement des droits de l'homme. Vol. IV. Unesco : Paris, 1985.

REED, K.D. Reviving the Doctrine of Non-Forcible Countermeasures: Resolving the Effect of Third Party Injuries. In Virginia Journal of International Law, Vol. 29, 1988-1989.

REUTER, Paul. Trois observations sur la codification de la responsabilité internationale des Etats pour fait illicite. In Le droit international au service de la paix, de la justice et du développement. Mélanges Michel Virally. Paris: Editons. A. Pedone, 1991.

ROSENNE, Shabtai. League of Nations Conference for the Codification of International Law (1930). In American Journal of International Law, Vol. 70, 1976.

SICILIANOS, L.A. The relationship between Reprisals and Denunciation or Suspension of a Treaty. In European Journal of International Law, n.5, 1994.

SIMMA, B. Counter-measures and Dispute Settlement: A Plea for a different Balance. In European Journal of International Law, n.5, 1994.

THAPAR, R. Le problème des droits de l'homme dans le traditons hindoue et bouddhique. In Enseignement des droits de l'homme. Vol. IV. Unesco : Paris, 1985.

TOMUSCHAT, C. Are Counter-measures Subject to Prior Recourse to Dispute Settlement Procedures? In European Journal of International Law, n.5, 1994.

WEIL, P. Judaisme et développement Du droit international. In Recueil des Cours. T.151. Vol. III. Leyde: A.W. Sijthoff, 1976.

Droit des traités et droit de la responsabilité. In El derecho internacional en un mundo en transfornation. En homenaje al professor Eduardo Jimenez de Aréchaga. Montevideo:Fundacion de Cultura Universitaria, 1992.

WOUNTERS, J. VERHOEVEN, S. The prohibition of Genocide as a Norm of Ius Cogens and its Implications for the Enforcement of the Law of Genocide. In International Criminal Law Review, n. 5, 2005.

WYLER, E. From 'State Crime' to Responsibility for Serious Breaches of Obligations under Peremptory Norms of General International Law. In European Journal of International Law, Vol. 13 n. 5, 2002. 
